\title{
Sciencestudies
}

THOMAS GONDERMAN N

\section{Evolution und Rasse}

Theoretischer und institutioneller Wandel

in der viktorianischen

Anthropologie 
Thomas Gondermann

Evolution und Rasse 
Thomas Gondermann (MA Sociology) arbeitet zur Wissenschafts- und Ressentimentforschung. 
Thomas Gondermann

\section{Evolution und Rasse}

Theoretischer und institutioneller Wandel

in der viktorianischen Anthropologie

[transcript $]$ 
Die Drucklegung dieser Publikation wurde durch die Hans-Böckler-Stiftung gefördert.

Bibliografische Information der Deutschen Bibliothek

Die Deutsche Bibliothek verzeichnet diese Publikation in der Deutschen Nationalbibliografie; detaillierte bibliografische Daten sind im Internet über http://dnb.ddb.de abrufbar.

(C) 2007 transcript Verlag, Bielefeld

\section{(c) $\$($ This work is licensed under a Creative Commons BY NC ND Attribution-NonCommercial-NoDerivatives 3.0 License.}

Umschlaggestaltung: Kordula Röckenhaus, Bielefeld Lektorat \& Satz: Thomas Gondermann

Druck: Majuskel Medienproduktion $\mathrm{GmbH}$, Wetzlar ISBN 978-3-89942-663-2

Gedruckt auf alterungsbeständigem Papier mit chlorfrei gebleichtem Zellstoff.

Besuchen Sie uns im Internet: http://www.transcript-verlag.de

Bitte fordern Sie unser Gesamtverzeichnis und andere Broschüren an unter: info@transcript-verlag.de 


\section{Inhalt}

$1 \quad$ Einleitung 9

1.1 Evolutionstheorie und X-Club. Der Stand der Forschung 26

1.2 Monogenismus und Polygenismus.

Die Krise der Rassentheorien 32

2 Evolution und X-Club 42

2.1 "Wire-Pullers“ und „Bigwigs“. Der X-Club als
wissenschaftspolitisches Organisationsinstrument

2.2 Adaption und Selektion. Darwins Evolutionstheorie 70

2.3 Menschen und Mammuts. Das Alter der Menschheit 77

$\begin{array}{ll}2.4 & \text { Fortschritt und Wachstum. Spencers organische } \\ \text { Evolutionslehre } & 81\end{array}$

2.5 Archetypen und Transmutation. Huxleys Rezeption der Evolutionstheorie $\quad 87$

2.6 Metamorphosen, Essays and Reviews. Lubbocks Rezeption der Evolutionstheorie $\quad 93$

$\begin{array}{lll}2.7 & \text { Zusammenfassung } & 96\end{array}$

$3 \quad$ X-Club und Anthropologie 98

3.1 Skandalisierung. Evolution und die Stellung des Menschen in der Natur $\quad 100$

3.1.1 „Ape-Theory“. Huxley contra Wilberforce 100

3.1.2 „Hippocampus minor“. Huxley contra Owen 105

3.2 Rationalisierung. Evolution und Monogenismus 117

3.2.1 „Missing Links“. Die Neandertaler-Debatte 118

3.2.2 „True Savages“. Kontroversen über Degenerationstheorien 128

3.3 Institutionalisierung. Evolution und Polygenismus 136

3.3.1 „Nest of Impostors“. Die Anthropological Society 138 
3.3.2 „Our prognathous relative“. Anthropologische Kontroversen $\quad 150$

3.4 Zusammenfassung 172

4 Evolution und Rassentheorien 175

4.1 „Widely Contrasted Forms of the Human Cranium“. Der Rassenbegriff in der Anthropologie Thomas Henry Huxleys 176

4.2 „Anthropology, properly so termed“. Rassendimensionen in der Anthropometrie George Busks 200

4.3 „Extremes of a series“. Rassenkonzepte in John Lubbocks Theorie sozialer Evolution 209

4.4 „From the smallest and rudest up to the largest and most civilized“. Rassen und soziale Evolution bei Herbert Spencer 231

4.5 Zusammenfassung

5 Schluß. Theoretischer und institutioneller Wandel in Anthropologie und Rassentheorien

Anhang

WULF D. HUND

Nachwort: Evolution und Extinktion. Die darwinistische Modernisierung des Rassismus 


\section{Vorbemerkung}

An dieser Stelle möchte ich all jenen danken, die die Entstehung dieser Arbeit unterstützt haben. Zunächst gilt mein Dank Professor Wulf D. Hund am Department für Wirtschaft und Politik der Universität Hamburg, dessen Anregungen und Kommentare wesentlich zu ihrer Entstehung beitrugen. Danken möchte zudem Professor Peter Weingart vom Institut für Wissenschafts- und Technikforschung (IWT) der Universität Bielefeld für hilfeiche und weiterführende Anmerkungen und für die Möglichkeit, am IWT in einer inspirierenden Arbeitsumgebung zu arbeiten. Ruth Barton und Mark Patton, University of Westminster, gebührt Dank für die Überlassung teilweise unveröffentlichter Manuskripte, Tina Craigh am Royal College of Surgeons und Sarah Walpole am Royal Anthropological Institute für die Unterstützung bei meinen Recherchen.

Ermöglicht wurde die Arbeit an dieser Studie durch ein Stipendium der Hans-Böckler-Stiftung, die darüber hinaus einen wesentlichen Beitrag zu den Kosten der Drucklegung getragen hat. 



\section{Einleitung}

Rassentheorien stellten einen besonderen Aggregatzustand des Rassismus dar: die Verbindung seiner Ressentiments mit dem Rationalitätsanspruch wissenschaftlichen Wissens. Die wissenschaftliche Fundierung des Rassismus wurde erforderlich, als die modernen Wissenschaften zunehmend Autorität in Erkenntnisfragen beanspruchten, denn der Rassismus zog zur Begründung sozialer Ungleichheit den menschlichen Körper als biologisches Substrat heran und rekurrierte damit auf einen Gegenstand, der sukzessive unter wissenschaftliche Beobachtung gestellt wurde. ${ }^{1}$ Dabei war der Körper nicht unmittelbares Indiz der sozialen Differenz, sondern

„das Material, mit dessen Hilfe der Rassismus seine herrschaftlich bestimmte Entmenschlichung als Reaktion auf natürliche Unterlegenheit auszugeben und damit zu legitimieren trachtete. Nicht weil die anderen körperlich defizitär waren, wurden sie sozial degradiert, sondern weil sie sozial ausgeschlossen wurden, schrieb man ihrer Natur Defizite zu, die ihren Körpern angesehen werden sollten“. ${ }^{2}$

1 Vgl. Wolfgang Krohn (1976) „Zur soziologischen Interpretation der neuzeitlichen Wissenschaft". In: Edgar Zilsel: Die sozialen Ursprünge der neuzeitlichen Wissenschaft. Frankfurt: Suhrkamp, S. 7-43, S. 13; Steve Woolgar (1993) Science. The Very Idea. London: Routledge, S. 19; Werner Rammert (1999) „Weder festes Faktum noch kontingentes Konstrukt: Natur als historisches Resultat experimenteller Interaktivität zwischen menschlicher und nicht-menschlicher Natur". In: IWT-Paper 23 - Workshop „Die Natur der Natur“. S. 184-205. http://uni-bielefeld.de/iwt/general /iwtpapers/rammert.pdf, S. 187; allgemein Edgar Zilsel (1976) Die sozialen Ursprünge der neuzeitlichen Wissenschaft. Frankfurt: Suhrkamp.

2 Wulf D. Hund (2006) Negative Vergesellschaftung. Dimensionen der Rassismusanalyse. Münster: Westfälisches Dampfboot, S. 120. 
Dieser definitorische Zugriff auf den Körper mußte sich den Modalitäten naturwissenschaftlicher Wissensproduktion anpassen und war deshalb zu beständigen Modifikationen gezwungen. Außerdem waren Rassentheorien aufgrund ihrer legitimatorischen Funktion für die Praxis rassistischer Diskriminierung einem andauernden Veränderungsdruck ausgesetzt und reagierten auf die veränderten Beziehungen zwischen den definitionsmächtigen Europäern und den rassifizierten Nicht-Europäern. Im Kontext expandierender territorialer und politischer Herrschaftsansprüche konstruierte das rassistische Denken die Fremden zu Rassen, denen distinkte Körpermerkmale zugeschrieben wurden. ${ }^{3}$ Theorien über Menschenrassen entstanden so an der Schnittstelle von Wissenschaft und Politik. Sie waren hybrid und stets Einflüssen von zwei Seiten ausgesetzt. Die Kontinuität der Einschreibung rassischer Unterschiede, die Howard Winant als „racial longue durée“ bezeichnet, wurde immer wieder von Momenten durchbrochen, in denen die Logik der rassischen Differenz mit einer aktualisierten Rationalität versehen wurde. ${ }^{4}$

\section{Evolution und Rassentheorien}

In der Mitte des neunzehnten Jahrhunderts wurde durch die Etablierung der Evolutionstheorien einer der nachhaltigsten Umbrüche in der Geschichte der Rassentheorien und der Anthropologie ausgelöst. Er wird in der Regel auf Charles Darwins Origin of Species (1859) zurückgeführt. ${ }^{5}$

3 Vgl. Wulf D. Hund (1999) Rassismus. Die soziale Konstruktion natürlicher Ungleichheit. Münster: Westfälisches Dampfboot, S. 15-53.

4 Howard Winant (2002) Racial Conditions. Politics, Theory, Comparisons. Minneapolis, London: University of Minnesota Press, S. 21.

5 In vielen Periodisierungen der Anthropologiegeschichte markiert das Jahr 1859 den Beginn einer neuen Epoche (vgl. Wilhelm Mühlmann (1968) Geschichte der Anthropologie. Bonn: Athenaeum; Thomas Kenneth Penniman (1974) A Hundred Years of Anthropology. New York: Morrow; George W. Stocking (1987) Victorian Anthropology. New York: Free Press; Uwe Hoßfeld (2005) Geschichte der biologischen Anthropologie in Deutschland. Stuttgart: Steiner, S. 28). Vgl. bspw. Douglas A. Lorimer (1978) Colour, Class and Victorians: English Attitudes to the Negro in the Mid-Nineteenth Century. Leicester: Leicester University Press, S. 15-16; Robert Miles (1989) Racism. London u.a.: Routledge, S. 36-37; Elazar Barkan (1996) The Retreat of Scientific Racism. Changing Concepts of Race in Britain and the United States Between the World Wars. Cambridge: Cambridge University Press, S. 15; Michael Banton (1998) Racial Theories. Cambridge: Cambridge University Press, S. 81-116; Achim Barsch, Peter M. Hejl (2000) „Zur Verweltlichung und Pluralisierung des Menschenbildes im 19. Jahrhundert: Einleitung“. In: Dies. (Hrsg.): Menschenbilder. Zur Pluralisierung der Vorstellung von der menschlichen Natur (1850-1914). Frankfurt: Suhrkamp, S. 7-90, S. 13. 
Die bis zu jenem Zeitpunkt dominierenden rassentheoretischen Ansätze des Polygenismus, der verschiedene Arten und Ursprünge der Menschen annahm, und des Monogenismus, der von einer gemeinsamen Abkunft der Menschen ausging, wurden von der auf das Soziale angewandten Evolutionstheorie abgelöst. ${ }^{6}$

Doch obwohl mittlerweile die Durchsetzung der Evolutionslehre in den Naturwissenschaften sozialgeschichtlich als „Resultat eines Komplexes von Verhandlung, Ausschluß und rhetorischem Blendwerk“ gilt, ${ }^{7}$ wird die Transformation der Anthropologie oft bloß ideengeschichtlich als Folge einer Anlehnung der Anthropologie an die Naturwissenschaften dargestellt. ${ }^{8}$ Die Anthropologie und die Rassentheorien hätten sich an den Evolutionstheorien ausgerichtet, weil diese im Referenzsystem Naturwissenschaften ebenso wie im öffentlichen Diskurs dominant geworden seien. Dabei wird der Ausgangspunkt des neuen anthropologischen Rassenverständnisses regelmäßig in Werken wie Edward Burnett Tylors Early History of Mankind (1865), John Lubbocks Origin of Civilization (1870), Darwins Descent of Man (1871) oder Lewis Henry Morgans Ancient Society (1877) vermutet. ${ }^{9}$

6 Vgl. Nancy Stepan (1982) Idea of Race in Science. Great Britain 18001960. Houndsmill, London: Macmillan, S. 49.

7 Adrian Desmond (2001) „Redefining the X Axis: ,Professionals, ,Amateurs" and the Making of Mid-Victorian Biology - A Progress Report". In: Journal of the History of Biology 34, S. 3-50, S. 40: ,outcome of a complex piece of social negotiation, exclusion and rhetorical posturing".

8 Vgl. Ashley Montagu (1972) Statement on Race. An Annotated Elaboration and Expostion of the Four Statements on Race Issued by the United Nations Educational, Scientific, and Cultural Organization. Oxford: Oxford University Press, S. 14-33; Banton 1998, S. 88-89; Joseph L. Graves (2002) The Emperor's New Clothes. Biological Theories at the Millennium. New Brunswick: Rutgers University Press, S. 53 und S. 62-73. Für einen Überblick über die Forschung zur Rolle von Analogien in den Naturwissenschaften vgl. Sabine Maasen, Everett Mendelsohn, Peter Weingart (1995) „Metaphors: Is there a bridge over troubled waters?“. In: Dies. (Hrsg.): Biology as Society, Society as Biology: Metaphors. Yearbook of the Sociology of the Sciences. Dordrecht u.a.: Kluwer, S. 1-8.

9 Vgl. Franz Boas (1914) Kultur und Rasse. Leipzig: Veit, S. 142; Irving Goldman (1959) „Evolution and Anthropology“. In: Victorian Studies 3, S. 55-75; Lucy Mair (1965) An Introduction to Social Anthropology. Oxford: Clarendon, S. 18; John S. Haller (1970) „The Species Problem: Nineteenth-Century Concepts of Racial Inferiority in the Origin of Man Controversy“. In: American Anthropologist 172, S. 1319-1329, S. 1326; Peter J. Bowler (1987) Theories of Human Evolution: A Century of Debate, 1844-1944. Oxford: Basil Blackwell, S. 52; Anthony Leeds (1988) „Darwinian and ,Darwinian“ Evolutionism in the Study of Society and Culture“. In: Thomas F. Glick (Hrsg.): The Comparative Reception of Darwinism. Chicago: University of Chicago Press, S. 437-477, S. 437477; Graves 2002, S. 64-65. 
Die meisten Überblicke zur Rassismusgeschichte gehen grundsätzlich von einer diskursiven Verkopplung von Naturwissenschaften und Anthropologie aus. Zudem spannen sie einen derart großen Bogen, daß ihnen die Prozesse der evolutionstheoretischen Transformation des viktorianischen Rassendenkens und die Bedingungen des Wissenstransfers zwischen den Naturwissenschaften und der Anthropologie entgehen. ${ }^{10}$ Die bisherige Forschung zur Geschichte des Rassismus läßt die Modalitäten und den Verlauf der Transformation des wissenschaftlichen Wissens über Rassen und des angenommenen Wissenstransfers zwischen Naturwissenschaft und Rassenthorien im Dunkeln. Sie bleibt eine Berücksichtigung der sozialen Dimension, der Akteure, ihrer Motive und ihrer Kommunikationsstrukturen schuldig und impliziert, daß naturwissenschaftliche Konzeptionen ohne weiteres in beliebige theoretische Kontexte integriert werden könnten. Deshalb wird dieser Transfer oft als ein interessengeleiteter Zugriff bereits etablierter Anthropologen oder gar nicht-naturwissenschaftlicher, primär politisch motivierter Autoren dargestellt. $^{11}$

10 Robert Miles etwa sieht die postdarwinianischen Rassentheorien im Widerspruch mit der Lehre Darwins, bezeichnet sie als Sozialdarwinismus und übergeht so völlig die Konstruktion der evolutionären Rassentheorien in der Mitte des neunzehnten Jahrhunderts (vgl. Miles 1989, S. 36-37). Nach Michael Banton setzt die Anwendung der darwinschen Evolutionslehre auf den Menschen neben Darwins Descent of Man erst mit Autoren wie John Beddoe (Races of Britain, 1885) oder Otto Ammon (Die Gesellschaftsordnung und ihre natürlichen Grundlagen, 1896) ein (vgl. Banton 1998, S. 86-91). George Mosse beschreibt den Einfluß des Darwinismus auf die Rassentheorien anhand der Schriften Francis Galtons ab 1872 (vgl. George Mosse (1978) Toward the Final Solution. A History of European Racism. New York: Fertig, S. 72-73). Mosse, Banton und Miles springen gewissermaßen von den frühen Polygenisten wie Robert Knox über James Hunt direkt zur postdarwinianischen Applikation der Evolutionslehre auf die Rassentheorien. Christine Bolt hat die Auseinandersetzung innerhalb der viktorianischen Anthropologie nur schemenhaft skizziert (vgl. Christine Bolt (1971) Victorian Attitudes to Race. London: Routledge and Paul). John Haller diskutiert zwar die Entwicklung der physischen Anthropologie im Kontext der Professionalisierung der Wissenschaft. Da er die physische Anthropologie aber am Beispiel der französischen Anthropologen darstellt, entgeht ihm der unmittelbare Einfluß der Evolutionisten um Darwin auf die Entwicklung dieser Disziplin (vgl. John S. Haller (1971) Outcasts from Evolution. Scientific Attitudes of Racial Inferiority 18591900. Urbana: University of Illinois Press).

11 Bspw. Peter J. Bowler (1988) The Non-Darwinian Revolution. ReInterpreting a Historical Myth. Baltimore: Johns Hopkins University Press, S. 157: ,[T] $]$ he concept of a racial hierarchy was so popular that many biological theories [...] were used to justify it". Karin Priester beispielsweise geht davon aus, daß „Rassenideologen” sich „die passenden Versatzstücke herausgriffen und auf die Gesellschaft übertrugen“ (Karin 
Allein die Chronologie der Ereignisse stellt solche Vorstellungen einer einfachen Übertragung stabiler naturwissenschaftlicher Konzepte in Rassentheorien und Theorien sozialer Evolution in Frage. Zum einen wurde die Evolutionslehre erstmals auf sozialwissenschaftliche Problemstellungen angewandt, als sie selbst noch im Zentrum heftiger Kontroversen um ihre eigene Anerkennung stand. Zum anderen war diese erste Anwendung der Evolutionstheorie im rassentheoretischen Kontext nicht das Resultat eines externen Zugriffs auf einen als gesichert geltenden naturwissenschaftlichen Wissensbestand, nicht das Ergebnis einer legitimationsheischenden Nutzbarmachung durch Akteure des anthropologischen oder ethnologischen Diskurses. Vielmehr waren es die in den Naturwissenschaften beheimateten Evolutionstheoretiker selbst, die die Evolutionslehre in die physische Anthropologie und in die Rassentheorien einführten. Dabei handelte es sich um Mitglieder aus dem engsten sozialen und wissenschaftlichen Umfeld Charles Darwins, ${ }^{12}$ um Thomas Henry Huxley, John Lubbock und George Busk sowie um einen Philosophen und Theoretiker der Evolutionslehre, der zu ihren Lebzeiten Darwin in seinem Ruhm kaum nachstand: Herbert Spencer. Zwar hatte Spencer seine Evolutionstheorie bereits einige Jahre vor Darwins Origin of Species entworfen, doch erst mit dessen Veröffentlichung dynamisierte sich die naturwissenschaftliche Debatte - und die Evolutionstheorie, unter der die Ansätze Spencers und Darwins trotz ihrer Verschiedenheiten subsumiert wurden, konnte ihren Siegeszug antreten. ${ }^{13}$ Dabei war es vor allem Huxley, der nach Erscheinen von Darwins Abhandlung den Part der öffentlichen Verteidigung und Interpretation übernahm, während dieser sich selbst im Hintergrund hielt. Huxley, Lubbock und auch Busk wurden in der Folge dem Lager der Darwinianer zugeordnet und Spencer als ihr engster Verbündeter betrachtet. ${ }^{14}$

Doch sie einte nicht nur eine evolutionstheoretische Orientierung, sie hatten zudem einen Club von hoher Exklusivität gegründet, der als eine einflußreiche pressure group in der viktorianischen scientific community

Priester (2003) Rassismus. Eine Sozialgeschichte. Leipzig: Reclam, S. 222).

12 Vgl. Adam Kuper (1988) The Invention of Primitive Society: Transformations of an Illusion. London: Routledge, S. 2.

13 Vgl. Donald MacRae (1969) „Introduction“. In: Ders. (Hrsg.): Herbert Spencer: The Man Versus The State. Harmondsworth: Penguin, S. 7-54, S. 22; Valerie A. Haines (1991) „Spencer, Darwin, and the Question of Reciprocal Influence“. In: Journal of the History of Biology 24, S. 409-431.

14 Der Bruch zwischen Spencer und Huxley trat erst Mitte der siebziger Jahre zutage, Spencers offen ausgetragener Konflikt mit dem (Neo)-Darwinismus datiert aus den achziger und neunziger Jahren des neunzehnten Jahrhunderts. 
gilt, den X-Club. Diese Gruppierung, die neben Spencer, Huxley, Lubbock und Busk nur noch fünf weitere Mitglieder von vergleichbar wissenschaftlichem Format zählte, war für mehrere Jahrzehnte ein wichtiges Instrument zur Orchestrierung der wissenschaftspolitischen ${ }^{15}$ Eingriffe ihrer Mitglieder.

\section{Paradigmawechsel und Modernisierung}

Die Transformation der Rassentheorien fand im Kontext jenes elementaren Theorieumbruchs in den Naturwissenschaften statt, der lange als Darwinianische Revolution bezeichnet wurde. Diese Bezeichnung ist vor allem deshalb umstritten, weil Darwins Theorie auch von seinem unmittelbaren wissenschaftlichen Umfeld nur gebrochen rezipiert wurde und ihre breite Anerkennung in keinem zeitlichen Zusammenhang mit ihrer Veröffentlichung stand. ${ }^{16}$ Dennoch besteht kein Zweifel, daß sie von zentraler Bedeutung für den revolutionären Umbruch in den Naturwissenschaften war, durch den nicht nur ihre theoretischen Grundlagen, sondern ein ganzes Weltbild umgestürzt wurden. ${ }^{17} \mathrm{Zu}$ diesem Prozeß trugen neben Darwin, der zu seiner Ikone wurde, aber auch andere Positionen in den Naturwissenschaften, wie die durch Herbert Spencer prominent vertretene Lehre Jean Baptiste Lamarcks bei. Was sich in der Mitte des neunzehnten Jahrhunderts in relativ kurzer Zeit in den Naturwissenschaften etablieren konnte, war folglich weniger die reine Theorie

15 Mit dem Begriff der Wissenschaftspolitik wird im folgenden politisches, also auf soziale Zusammensetzung und institutionelle Beschaffenheit der Wissenschaften abzielendes, Handeln innerhalb der scientific community bezeichnet (vgl. Alvin I. Goldman (1999) Knowledge in a Social World. Oxford: Clarendon Press, S. 225-230; Philip Kitcher (1993) The Advancement of Science. Science without Legend, Objectivity without Illusions. New York, Oxford: Oxford University Press, S. 203-204).

16 Vgl. allgemein Michael Ruse (1979) The Darwinian Revolution. Science Red in Tooth and Claw. Chicago, London: Chicago University Press; Michael Ruse (2005) „The Darwinian Revolution, as seen in 1979 and as seen Twenty-Five Years Later in 2004". In: Journal of the History of Biology 38, S. 3-17; sowie Bowler 1988; Peter J. Bowler (2005) „Revisiting the Eclipse of Darwinism”. In: Journal of the History of Biology 38, S. 1932; Vassiliki Betty Smocovitis (2005) , It Ain't Over ,til it's Over“: Rethinking the Darwinian Revolution“. In: Journal of the History of Biology 38, S. 33-49.

17 Vgl. Ruse 1979, S. ix; John C. Greene (1981a) „The Kuhnian Paradigm and the Darwinian Revolution in Natural History". In: Ders.: Science, Ideology, and World View. Essays in the History of Evolutionary Ideas. Berkeley: University of California Press, S. 30-59, S. 33, S. 51. 
Darwins, als eine breiter gefasste, grundsätzlich evolutionstheoretische Orientierung. ${ }^{18}$

Der evolutionstheoretische Wandel stellte die bis dahin weitgehend anerkannten Überzeugungen der Naturphilosophen über die Entstehung der Arten in Frage. Zudem stand er im deutlichen Widerspruch zu den theologischen Interpretationen der Naturgeschichte. Deshalb war er auch innerhalb der scientific community anfangs starkem Widerstand ausgesetzt und seiner Durchsetzung gingen heftige Kontroversen voraus. Der Umbruch war auch Ausdruck einer gegen die klerikale Dominanz Oxfords und Cambridges gerichteten Säkularisierungsbestrebung, die mitunter zu einem Krieg zwischen „Wissenschaft und Religion“, oder, pointierter, zwischen ,evolutionärer Wissenschaft und traditioneller Religion" stilisiert wurde. ${ }^{19}$

Wissenschaftliche Revolutionen stellen substanzielle Umbrüche in Theoriebildung und wissenschaftlicher Praxis dar. Als einflussreichste theoretische Schrift zur Problematik wissenschaftlicher Revolutionen kann Thomas S. Kuhns Klassiker The Structure of Scientific Revolutions gelten. Kuhn stellt die bis dahin vorherrschende kumulative Konzeption wissenschaftlicher Entwicklung in Frage. Er gilt zudem als einer der ersten Wissenschaftstheoretiker, der sich mit einer Integration der bis dahin getrennten Dimensionen von inhaltlicher Entwicklung und organisatorischer Struktur von Wissenschaft befaßt haben. ${ }^{20}$ Die soziale Di-

18 Greene 1981c.

19 Vgl. Neal C. Gillespie (1977) „,The Duke of Argyll, Evolutionary Anthropology, and the Art of Scientific Controversy“. In: Isis 68, S. 40-54, S. 40: „evolutionary science and traditional religion“; Getrude Himmelfarb (1959) Darwin and the Darwinian Revolution. London: Chatto and Windus; A. O. J. Cockshut (1964) The Unbelievers. English Agnostic Thought, 1840-1890. London: Collins; Anthony Symondson (1970) The Victorian Crisis of Faith. London: Society for Promoting Christian Knowledge; Frank M. Turner (1974) Between Science and Religion: The Reaction to Scientific Naturalism in Late Victorian England. New Haven, Conn.: Yale University Press; Bernhard Lightman (1987) The Origins of Agnosticism. Baltimore: John Hopkins University Press; George Levine (1990) „Scientific Discourse as an Alternative to Faith“. In: Richard J. Helmstadter, Bernhard Lightman (Hrsg.): Victorian Faith in Crisis. Essays on Continuity and Change in Nineteenth-Century Religious Belief. Stanford, Cal.: Stanford University Press, S. 225-261; Peter Addinall (1991) Philosophy and Biblical Interpretation: A Study in Nineteenth-Century Conflict. Cambridge: Cambridge University Press.

20 Vgl. Peter Weingart (1974b) „On a sociological theory of scientific change“. In: Richard Whitley (Hrsg.): Social Processes of Scientific Development. London: Routledge, S. 45-68; Ian Hacking (1981) „Introduction“. In: Ders. (Hrsg.): Scientific Revolutions. Oxford: Oxford University Press, S. 1-5, S. 1; Bruno Latour, Steve Woolgar (1986) Laboratory Life. The Construction of Scientific Facts. Princeton: Princeton University 
mension der Wissenschaft bedeutet dabei nicht einfach, wie Steve Woolgar erklärt, „daß Wissenschaft ihre sozialen Aspekte hat“, was „,impliziert, daß ein Rest, ein harter Kern der Wissenschaften unberührt von belanglosen nicht-wissenschaftlichen (d.h. ,sozialen') Faktoren fortbestehen kann, sondern daß Wissenschaft von ihrer Beschaffenheit her sozial ist". 21

Zentrale Annahme Kuhns ist, daß wissenschaftliche Entwicklung generell zwei äußerst unterschiedlich charakterisierbare Formen annimmt, die sogenannte normale und die als außerordentlich oder revolutionär bezeichnete Wissenschaft. Im Normalzustand orientiere sich der Wissenschaftsbetrieb an Paradigmen, in Momenten der ,revolutionären Wissenschaft" hingegen würde ein bestehendes Paradigma durch ein neues abgelöst. ${ }^{22}$ Kuhns Definition des Paradigmabegriffs bleibt zwar mehrdeutig, nicht zuletzt, weil er selbst ihn später praktisch wieder aufgibt. ${ }^{23}$ Dennoch hat sich eine an Structure of Scientific Revolutions orientierte Standardlesart etabliert. Derzufolge kennzeichne die Existenz von Paradigmen die ,reifen“ Wissenschaften ab dem achtzehnten Jahrhundert. ${ }^{24}$ Wo zuvor eine Vielzahl von konträren und miteinander unvereinbaren Theorien oder Erklärungsmodellen bestanden habe, hätte die Etablierung eines Paradigmas den Diskurs in einem Wissenschaftsfeld vereinheitlicht. Ein Paradigma entwickele sich aus einer der konkurrie-

Press, S. 275; Peter Weingart (2003) Wissenschaftssoziologie. Bielefeld: Transcript, S. 18; Barry Barnes (2003) „Thomas Kuhn and the Problem of Social Order in Science“. In: Thomas Nickles (Hrsg.): Thomas Kuhn. Cambridge: Cambridge University Press, S. 122-141, S. 122; Martin Carrier (2006) Wissenschaftstheorie zur Einführung. Hamburg: Junius, S. 143f. Andere Ansätze, die die sozialen Strukturen als wesentliche Elemente wissenschaftlichen Wissens schon vor Kuhn diskutiert haben, beschäftigen sich hingegen nicht mit der Frage der Determinanten und Dimensionen seines Wandels. Hier ist vor allem an Ludwig Fleck zu denken (vgl. Lugwig Fleck (1980) Entstehung und Entwicklung einer wissenschaftlichen Tatsache. Einführung in die Lehre vom Denkstil und Denkkollektiv. Frankfurt: Suhrkamp).

21 Woolgar 1993, S. 13: „It is not that science has its ,social aspects, " thus implying that a residual (hard core) kernel of science proceeds untainted by extraneous non-scientific (i.e. ,social') factors, but that science is itself constitutively social“.

22 Vgl. Thomas S. Kuhn (1996) The Structure of Scientific Revolutions. Chicago, London: University of Chicago Press, S. 10, S. 92, S. 94.

23 Vgl. Margaret Masterman (1970) „The Nature of a Paradigm“. In: Imre Lakatos, Alan Musgrave (Hrsg.): Criticism and the Growth of Knowledge. Cambridge: Cambridge University Press, S. 68-76; Weingart 2003, S. 44. Vgl. Kuhn (1978b) „Neue Überlegungen zum Begriff des Paradigma“. In: Ders.: Die Entstehung des Neuen Studien zur Struktur der Wissenschaftsgeschichte. Frankfurt: Suhrkamp, S. 389-420.

24 Kuhn 1996, S. 12: „mature science“. 
renden Theorien heraus, bestehe aber ebenso aus konkreten Beispielen der Theorieanwendung und Problemlösung, ,aus denen eine bestimmte kohärente Forschungstradition entsteht". ${ }^{25}$ Aufgrund dieser Strukturmerkmale muß unter einem Paradigma im kuhnschen Sinne ein ,vortheoretischer Orientierungskomplex ${ }^{6}$ verstanden werden. ${ }^{26}$ Ein Paradigma biete „Handlungsnormen“, die die Interaktions- und Verkehrsformen innerhalb der scientific community strukturierten. ${ }^{27}$

Da der Normalbetrieb der Wissenschaften an derart normgebenden Paradigmen ausgerichtet sei, würden in ihm, so Kuhn, nur jene Probleme gelöst, die sich in seinem Kontext formulieren lassen. Treten im Verlauf der normalen Wissenschaft Anomalien auf, leiteten sie eine krisenhafte Phase des Theorienpluralismus ein, in der verschiedene Ansätze um eine probate und allgemein anerkennbare Erklärung ringen und die erst durch die Errichtung eines neuen Paradigmas wieder aufgelöst werden könne. ${ }^{28}$

Kuhn erklärt, daß die scientific community in solchen Situationen ,,in miteinander konkurrierende Lager [...] gespalten“ sei, ,,von denen das eine versucht, die alte institutionelle Konstellation zu bewahren und das andere, eine neue zu installieren“. ${ }^{29}$ Er weist explizit auf die soziale Dimension des wissenschaftlichen Wandels hin, ein neues Paradigma müsse ,zunächst eine Gruppe von Unterstützern um sich sammeln, [...] die es soweit entwickeln, daß nüchterne Argumente entworfen und ausgetauscht werden können“ ${ }^{30}$ Zudem setzten sich Paradigmen auch des-

25 Vgl. Kuhn 1996, S. 17; Kuhn 1996, S. 10: „from which spring particular coherent traditions of scientific research".

26 Vgl. Weingart 1974b, S. 49.

27 Peter Weingart (1974a) „Wissenschaftlicher Wandel als Institutionalisierungsstrategie“. In: Ders. (Hrsg.): Wissenschaftssoziologie II. Determinanten wissenschaftlicher Entwicklung. Frankfurt: Athenäum, S. 11-35, S. 33; vgl. M. D. King (1974) „Vernunft, Tradition und Fortschrittlichkeit der Wissenschaft“. In: Weingart (Hrsg.): Wissenschaftssoziologie II, S. 3975.

28 Vgl. Kuhn 1996, S. 68, S. 82f, S. 92.

29 Kuhn 1996, S. 93: „At that point the society is devided into competing camps or parties, one seeking to defend the old institutional constellation, the other seeking to institute some new one".

30 Kuhn 1996, S. 158: But if a paradigm is ever to triumph it must gain some first supporters, men who will develop it to the point where hardheaded arguments can be produced and multiplied“; vgl. Bernard Barber (1973) „Der Widerstand von Wissenschaftlern gegen wissenschaftliche Entdeckungen“. In: Peter Weingart (Hrsg.): Wissenschaftssoziologie I. Wissenschaftliche Entwicklung als sozialer Prozeß. Frankfurt: Athenäum, S. 205221; Peter Weingart (1976) Wissensproduktion und soziale Struktur. Frankfurt: Suhrkamp, S. 34-35. 
halb nicht selbsttätig durch, weil sie nicht nur eine Theorie, sondern sämtliche Facetten wissenschaftlicher Praxis umfaßten.

Deshalb führe ein Paradigmawechsel zugleich einen sozialen Ablösungsprozeß herbei. Die Wahl zwischen „konkurrierenden Paradigmen ist auch eine Wahl zwischen inkommensurablen Formen des gemeinschaftlichen Seins. Weil sie diesen Charakter hat, ist und kann die Wahl nicht durch bloße evaluative Prozeduren determiniert werden, die die normale Wissenschaft charakterisieren“. ${ }^{31}$ Durch das neue Paradigma entstünde nicht nur eine neue Sicht auf die Erkenntnisobjekte, die Wissenschaftler seien, so Kuhn, sogar in die Lage versetzt, neue und andere Dinge zu sehen. ${ }^{32}$ Er beschreibt diesen veränderten Blick auf die Welt mit einer Metapher der Psychologie, es käme zu einem ,Gestaltswitch ${ }^{33}$

Kuhns Modell der Wissenschaftsentwicklung ist mittlerweile nicht mehr unumstritten. Neben der Unschärfe seines Paradigmabegriffs ist für die vorliegende Untersuchung vor allem die Kritik an seiner Diskussion der sozialen Dimension von Wissenschaft relevant. So moniert Barry Barnes, daß Kuhn die differenzierte Struktur der Wissenschaften und den Aspekt des Wettbewerbs zwischen verschiedenen Schulen nicht ausreichend berücksichtigt habe. ${ }^{34}$ Ian Hacking führt diese Kritik weiter. Er betont die Bedeutung der Beziehung und der Kommunikation zwischen Disziplinen und weist auf den Umstand hin, daß Kuhn die Auswirkung eines Paradigmawechsels auf andere oder benachbarte Disziplinen vernachlässigt hat. ${ }^{35}$

31 Kuhn 1996, S. 94: „Like the choice between competing political institutions, that between competing paradigms proves to be a choice between incommensurable modes of community life. Because it has that character, the choice is not and cannot be determined merely by the evaluative procedures characteristic of normal science".

32 Kuhn bleibt unklar in Hinblick auf die Substanz dieses Wandels. Er schreibt ebenso davon, daß die Wissenschaftler dieselbe Welt nur anders sehen (Kuhn 1996, S. 150), wie davon, daß sie nun in einer anderen Welt arbeiten würden (ebd. S. 135), vgl. Paul Hoyningen-Huene (1989) Die Wissenschaftsphilosophie Thomas S. Kuhns. Rekonstruktion und Grundlagenprobleme. Braunschweig, Wiesbaden: Vieweg, S. 161-199.

33 Vgl. Kuhn 1996, S. 111; Steven Shapin (1996) The Scientific Revolution. Chicago, London: University of Chicago Press, S. 2-3.

34 Vgl. Barry Barnes (1974) T. S. Kuhn and Social Science. London, Basingstoke: Macmillan, S. 95-96.

35 Vgl. Ian Hacking (1993) „Working in a New World: The Taxonomic Solution“. In: Paul Horwich (Hrsg.): Thomas Kuhn and the Nature of Science. Cambridge, Mass.: MIT Press, S. 275-310, S. 298. 
Die unmittelbare Relevanz der Evolutionstheorie für außernaturwissenschaftliche Kontexte war augenscheinlich. Darwin hatte in Origin of Species noch versucht, der Diskussion um sein Buch die Schärfe zu nehmen, indem er Implikationen für die naturwissenschaftliche Interpretation des Menschen auswich. Dies war weitsichtig, denn gerade sie wurde zum Prüfstein der Evolutionslehre. Die brisanteste Frage überhaupt war, ob sich die traditionelle Sonderstellung des Menschen in der Natur aufrechterhalten ließe. John C. Greene schreibt, daß für Spencer und Huxley die Evolutionslehre der Schlüssel zu ihren Theorien über den Menschen war. ${ }^{36}$ In paradigmatheoretischer Hinsicht ließe sich diese Feststellung aber auch umkehren: Der Mensch war für sie der Schlüssel zur Evolutionstheorie und seine evolutionstheoretische Interpretation die Vorbedingung für den hegemonialen Status der Evolutionstheorien in den Naturwissenschaften, weil die Etablierung eines Paradigma zugleich seine, wenn auch nicht uneingeschränkte, so doch breite Anerkennung bedeutet. Hier zeichnet sich eine vielschichtige Wechselbeziehung zwischen der sogenannten darwinianischen Revolution in den Naturwissenschaften und der Etablierung evolutionstheoretischer Ansätze in Anthropologie und Rassentheorien ab.

Vielfach wurde auf das Problem der Theoriewahl oder der Entscheidung für ein bestimmtes Paradigma aufmerksam gemacht, deren Modalitäten Kuhn offen gelassen habe. ${ }^{37}$ Selbst die wohlmeinende KuhnInterpretion Paul Hoyningen-Huenes erklärt, daß das Konzept des Gestalt-switches ,die Mikroprozesse, durch die die Veränderung realisiert wird“ außer Acht lasse. ${ }^{38}$ Kuhn hat wissenschaftliche Entwicklung letzlich nach dem Muster antiteleologischer Evolutionstheorien als eine intentions- und ziellose Entwicklung beschrieben. ${ }^{39}$ Auch der Arbeitstitel seines unvollendeten Projekts zeigt, daß der Autor der Structure of

36 Vgl. Greene (1981d) „From Huxley to Huxley: Transformations in the Darwinian Credo“. In: Ders. (Hrsg.): Science, Ideology, and World View. Essays in the History of Evolutionary Ideas. S.158-193, S. 167.

37 Vgl. Imre Lakatos (1970) „Falsifikation and the Methodology of Scientific Research Programmes“. In: Imre Lakatos, Alan Musgrave (Hrsg.): Criticism and the Growth of Knowledge. Cambridge: Cambridge University Press, S. 91-195, S. 93; Gunnar Andersson (1988) Kritik und Wissenschaftsgeschiche. Kuhns, Lakatos' und Feyerabends Kritik des kritischen Rationalismus. Tübingen: Mohr, S. 37; Steve Fuller (2003) Kuhn vs Popper. Cambridge: Icon Books, S. 64.

38 Hoyningen-Huene 1989, S. 200.

39 Vgl. Steve Fuller (2000) Thomas Kuhn. A Philosophical History for Our Times. Chicago, London: University of Chicago Press, S. 7, S. 18. 
Scientific Revolutions eigentlich an einer Evolutionary Theory of Scientific Development arbeitete. ${ }^{40}$

Aufgrund der berechtigten Einwände gegen Kuhns Theorie einerseits und andererseits aufgrund des Umstandes, daß dennoch keine alternative tragfähige Theorie zum Verständnis der Prozesse wissenschaftlicher Revolutionen existiert, werden die Begriffe Paradigma und Paradigmawechsel nur in ihrer landläufigen Bedeutung in das analytische Vokabular dieser Arbeit aufgenommen. Für die Untersuchung der evolutionstheoretischen Transformation der Rassentheorien müssen sie analytisch ergänzt und weiter gefaßt werden. Besonderes Augenmerk wird dabei auf die wissenschaftsinternen Kommunikationsprozesse zu legen sein, über die sich die Errichtung des Evolutionsparadigmas vollzog. ${ }^{41}$ Nicholas Mullins zur Folge korrelieren theoretische Orientierungen wissenschaftlichen Arbeitens mit sozialen Strukturen von unterschiedlichen Integrations- und Kohäsionspotentialen. Mullins geht davon aus, daß Vertreter neuer theoretischer Ansätze sich ausgeprägtere Kommunikationsnetze schaffen, als dies im Normalbetrieb der Wissenschaften der Fall sei. ${ }^{42}$ Durch eine sukzessive Verdichtung der internen Kommunikation unter den Vertretern einer bestimmten Schule entstünden feste Gruppenstrukturen, aus denen sogar komplexe und eigenständige Spezialgebiete hervorgehen können. Hierbei lassen sich verschiedene Strategien der Institutionalisierung beobachten. ${ }^{43}$

Jüngst hat Steve Fuller auf Kuhns mangelnde Berücksichtigung der Einflüsse außerwissenschaftlicher Faktoren hingewiesen. Kuhn hat die Entwicklung der Wissenschaften ausschließlich wissenschaftsimmanent diskutiert und politische wie soziale Variablen als mögliche Einflußfaktoren dieser Entwicklung nicht erörtert. ${ }^{44}$ Eine Untersuchung der theoretischen und institutionellen Transformation in Anthropologie und Rassendenken impliziert zwar ohnehin eine Analyse der wissenschaftlichen

40 Vgl. Paul Hoyningen-Huene (2001) „Thomas S. Kuhn 1922-96“. In: International Encyclopedia of the Social \& Behavioral Sciences, Bd. 12, Amsterdam: Elsevier, S. 8171-8176, S. 8172. Der vollständige Arbeitstitel des von Kuhn nicht mehr vollendeten Werks lautet nach HoyningenHuene The Plurality of Worlds: An Evolutionary Theory of Scientific Development.

41 Vgl. Weingart 2003, S. 30.

42 Vgl. Nicholas C. Mullins (1973) Theories and Theory Groups in Contemporary American Sociology. New York: Harper and Row, S. 18-25; Belver C.Griffith; Nicholas C. Mullins (1974) „Kohärente soziale Gruppen im wissenschaftlichen Wandel“. In: Peter Weingart (Hrsg.): Wissenschaftssoziologie II. Determinanten wissenschaftlicher Entwicklung. Frankfurt: Athenäum, S. 223-238.

43 Vgl. Weingart 1974a, S. 22-33.

44 Vgl. Fuller 2000, S. 10. 
Entwicklung im Kontext der politischen Diskurse, dennoch operationalisiert diese Studie den Einwand Fullers dadurch, daß sie die Transformation der Wissenschaft noch im Licht eines anderen Konzeptes betrachtet, dem der Modernisierung. Diese Transformation nicht nur als wissenschaftliche Revolution sondern auch als Prozeß der Modernisierung zu diskutieren, liegt allein schon aufgrund der sozialen Umstrukturierungen im Zeitalter der Industrialisierung nahe, die auch die soziale Basis der Wissenschaften betraf. Zwar stellte die Einführung des Evolutionsparadigmas primär einen theoretischen Wandel der wissenschaftlichen Wissensproduktion dar. Doch dieser Prozeß fiel mit elementaren Veränderungen in den sozialen Strukturen der viktorianischen scientific community zusammen, die auf ihre Modernisierung und Professionalisierung zielten. Im Zusammenspiel mit dem evolutionstheoretischen Paradigmawechsel führte diese Konstellation auch zu einer beschleunigten Transformation der sozialen Strukturen der Wissenschaften.

Besonders im Zusammenhang mit der Auseinandersetzung um die Säkularisierung der Wissenschaften, um die Interpretationshoheit über die Natur, zeigte sich deutlich die Konvergenz von evolutionstheoretischem Paradigmawechsel und Modernisierung der Wissenschaften. Im Sinne Max Webers stellte sich die Modernisierung des Wissens im wesentlichen als seine Rationalisierung und als eine „Entzauberung der Welt" dar. ${ }^{45}$ Die modernen Wissenschaften verstanden sich als Suche „,nach dem wahren Sein“,46 und dem sinnhaften Aufbau der Welt. Bedeutungen waren nicht mehr vorgegeben, sondern mußten der Welt abgelesen werden. ${ }^{47}$ Das wissenschaftliche Wissen versuchte so, sich der Totalität wahrnehmbarer objektiver Realität anzunähern. ${ }^{48}$

45 Max Weber (1988) „Wissenschaft als Beruf“ [1919]. In: Johannes Winckelmann (Hrsg.): Max Weber. Gesammelte Aufsätze zur Wissenschaftslehre. Tübingen: Mohr, S. 586-613, S. 594; vgl. Johannes Winckelmann (1980) „Die Herkunft von Max Webers ,Entzauberungs'-Konzeption. Zugleich ein Beitrag zu der Frage, wie gut wir das Werk Max Webers kennen können“. In: Kölner Zeitschrift für Soziologie und Sozialpsychologie 32, S. 12-53, S. 18; Robert K. Merton (1996) „The Rise of Modern Science“. In: Piotr Sztompka (Hrsg.): Robert K. Merton. On Social Structure and Science. Chicago, London: University of Chicago Press, S. 223-240.

46 Weber 1988, S. 595.

47 Vgl. Stewart R. Clegg (1994) „Max Weber and contemporary sociology of organisations“. In: Larry J. Ray; Michael Reed (Hrsg.): Organizing Modernity. New Weberian Perspectives on Work, Organization and Society. London, New York: Routledge, S. 46-80, S. 53.

48 Vgl. Talcott Parsons (1968) The Structure of Social Action. A Study in Social Theory with Special Reference to a Group of Recent European Writers. New York: Free Press, S. 601. 
Diese Rationalisierung verband sich mit einem strukturellen Wandel der Wissenschaften, der den Wissenschaftsbetrieb als institutionalisierten Ort der Wissensgenerierung hervorbrachte und von anderen Formen der Wissensproduktion abgrenzte. In ihrer sozialen Dimension führte die Modernisierung dabei zu einer Marginalisierung der alten, am klerikalen Dogma orientierten Eliten. Nicht nur in den Naturwissenschaften, auch in der Anthropologie vollzog sich dieser Ablösungsprozeß unter maßgeblicher Mitwirkung des X-Clubs.

Der Autoritätsanspruch der Wissenschaften basiert auf einer strukturellen Entkopplung von Wissenschaft und Ethik, durch die eine distinkte Systemrationalität der Wissenschaften erst entstehen konnte. ${ }^{49}$ Indem sich das Wissenschaftssystem, so Niklas Luhmann, auf die Generierung objektivierbarer Wahrheitssätze ausrichtet, enthält es sich der Erörterung ethischer und politischer Fragen, die damit exklusiv in die Hoheitsbereiche der sozialen und politischen Kommunikation fallen. ${ }^{50}$ Diese Trennung ist jedoch nicht vollständig, weil ungeachtet ihrer epistemologischen Autonomie die „Wissenschaft ihre Legitimationsmuster den herrschenden Wertvorstellungen anpassen" muß.$^{51}$ Zudem wird, wie Steven Shapin schreibt, ein Wissensbestand für die Verwendung in politischen Kontexten um so interessanter, je mehr er seine Rationalität und Objektivität hervorhebt. ${ }^{52}$ Dies gilt insbesondere für ethisch und politisch umstrittene Themen, was eine beständige Grenzziehung zur Absicherung der Wissenschaftssphäre erfordert. Diese Markierung wissenschaftlichen Wissens ist ein integraler Bestandteil des Diskurses der modernen Wissenschaften. Auch die Evolutionstheoretiker des X-Clubs praktizierten eine solche Grenzziehung, um die konservative und klerikale Oligarchie Oxbridges als unwissenschaftlich delegitimieren zu können.

In der sozialen Dimension des evolutionstheoretischen Paradigmawechsels verband sich der theoretische Umbruch zudem mit einem Professionalisierungsimpuls, der die Wissenschaften im neunzehnten Jahrhundert erfaßt hatte. Ökonomische und soziale Veränderungen hatten eine größer werdende Mittelschicht hervorgebracht, die wegen berufli-

49 Vgl. Peter Weingart (1983) „Verwissenschaftlichung der Gesellschaft Politisierung der Wissenschaft". In: Zeitschrift für Soziologie 12, S. 225241, S. 225.

50 Vgl. Niklas Luhmann (1969) Soziologische Aufklärung. Aufsätze zur Theorie sozialer Systeme. Köln, Opladen: Westdeutscher Verlag, S. 159; Niklas Luhmann (1991) Die Wissenschaft der Gesellschaft. Frankfurt: Suhrkamp, S. 622.

51 Peter Weingart; Jürgen Kroll; Kurt Bayertz (1996) Rasse, Blut und Gene. Geschichte der Eugenik und Rassenhygiene in Deutschland. Frankfurt: Suhrkamp, S. 25.

52 Vgl. Shapin 1996, S. 164. 
cher Aspirationen eine Hochschulausbildung anstrebte. Solche Professionalisierung der Wissenschaften schuf nicht nur eine andere Form des Wissenschaftsbetriebes, der durch rasch wachsender Ausdifferenzierung, Institutionalisierung und Spezialisierung gekennzeichent war. ${ }^{53} \mathrm{Sie}$ erzeugte auch einen neuen sozialen Akteur, den Wissenschaftler, der, anders als der Amateurforscher und Gentleman-Gelehrte, mit seiner wissenschaftlichen Tätigkeit sein Einkommen zu bestreiten hatte. Dieser soziale Ablösungsprozeß muß bei der Bewertung von Modernisierungsbestrebungen und wissenschaftspolitischen Konflikten berücksichtigt werden. Durch die Hinzuziehung der Analysekategorie der Modernisierung versucht diese Untersuchung aber nicht nur, dem historischen Kontext gerecht zu werden. Durch sie soll vor allem die von Fuller bei Kuhn diagnostizierte Leerstelle der Zielgerichtetheit wissenschaftlicher Entwicklungen geschlossen werden. Mithilfe des Konzeptes der Modernisierung können die Austauschbeziehung zwischen innerwissenschaftlichen beziehungsweise innerdisziplinären Entwicklungen und wissenschafts- und disziplinen-externen Faktoren analysiert werden.

\section{Fragestellung}

Die vorliegende Arbeit untersucht die Dynamik der Rassentheorien in der Mitte des neunzehnten Jahrhunderts. Sie geht der Frage nach, welche sozialen Prozesse zur Etablierung der Evolutionstheorien in den anthropologischen Rassentheorien führten. Sie analysiert die Beziehung dieses Prozesses zum evolutionstheoretischen Paradigmawechsel in den $\mathrm{Na}$ turwissenschaften und $\mathrm{zu}$ den sozialen Veränderungen der Wissenschaften, die mit den Stichworten der Modernisierung und Professionalisierung beschrieben werden.

Hierfür wird der X-Club ${ }^{54}$ als eine Akteursgruppe im Diskursfeld der viktorianischen Rassentheorien betrachtet. Es werden die Faktoren untersucht, die zu seiner Formierung und seinen wissenschaftspolitischen

53 Vgl. Rudolf Stichweh (1984) Zur Entstehung des modernen Systems wissenschaftlicher Disziplinen. Frankfurt: Suhrkamp; Rudolf Stichweh (1988) „Differenzierung des Wissenschaftssystems“. In: Renate Mayntz (Hrsg.): Differenzierung und Verselbständigung: zur Entwicklung gesellschaftlicher Teilsysteme. Frankfurt u.a.: Campus, S. 45-115; Weingart 1976, S. 52-57.

54 Zwar arbeiteten von den insgesamt neun Mitgliedern des X-Clubs nur vier anthropologisch beziehungsweise sozialwissenschaftlich (Spencer, Huxley, Lubbock und Busk) und beteiligten sich an den wissenschaftspolitischen Kontroversen innerhalb der Anthropologie vor allem drei von ihnen (Huxley, Lubbock und Busk). Dennoch wird in dieser Arbeit vom X-Club die Rede sein, auch wenn nur die Aktivitäten eines Teils seiner Mitglieder diskutiert werden. 
Interventionen führten. Der X-Club wird ins Verhältnis zur scientific community gesetzt und nach den wechselseitigen Abhängigkeiten zwischen anthropologischen und naturwissenschaftlichen Wissensbeständen und ihren Dynamiken gefragt. Dies zielt auf die zentrale Bedeutung der Motive der wissenschaftlichen Akteure ab, und stellt die zunächst trivial erscheinende Frage, warum die X-Club-Mitglieder überhaupt eine evolutionstheoretische Transformation der Rassentheorien anstrebten.

Angesichts der historischen Kontinuität rassistischer Konstruktionen und ihrer gleichzeitigen Plastizität geht diese Arbeit nicht nur der Frage nach, welche Faktoren die evolutionstheoretische Transformation der Rassentheorien beeinflussten. Ebenso wird sie herausarbeiten, wie sich diese Transformation auf theoretischer Ebene gestaltete, welchen Effekt sie auf das wissenschaftliche Menschenbild hatte und wie sie sich insbesondere auf die Repräsentation der im Rassendiskurs traditionell als primitiv charakterisierten Menschen niederschlug. Nancy Stepan liefert den wichtigen Hinweis, daß der evolutionstheoretische Paradigmawechsel im wissenschaftlichen Rassendiskurs nur begrenzte Veränderungen bedingte:

„Bereits Ende der sechziger Jahre des neunzehnten Jahrhunderts hatten Wissenschaftler, die die Evolutionstheorie akzeptierten, erkannt, daß das evolutionäre Denken ungeachtet der Neuerung des Darwinschen Antikreationismus mit der Idee der Unveränderbarkeit [...] und der Hierarchie menschlicher Rassen kompatibel war. Die Evolutionstheorie war weit davon entfernt, die alten Rassenkonzepte auszuhebeln, sie stärkte sie und versah sie mit einem neuen wissenschaftlichen Vokabular des Kampfes und des Überlebens““. ${ }^{55}$

Diese Einsicht verlangt eine differenzierte Betrachtung der Transformation der Rassentheorien, die Veränderungen auf den Ebenen der Theoriebildung, der Methodologie und der Gegenstandsbeschreibung, also der Repräsentation der vermeintlich primitiven Rassen, berücksichtigt. Darüber hinaus rechnet zu einer differenzierten Analyse der Transformation der Rassentheorien die Betrachtung ihrer institutionellen und sozialen Basis.

Zur Untersuchung der Transformation der Rassentheorien zählt auch die Analyse ihrer Voraussetzungen. Kuhn nimmt als Vorbedingung für eine wissenschaftliche Revolution die Krisenhaftigkeit einer Disziplin

55 Stepan 1982, S. 48-49: „By as early as the late 1860s, scientists embracing evolution found that, despite the novelty of Darwin's anti-creationism, evolutionary thought was compatible with the idea of the fixity, antiquity, and hierarchy of human races. Far from dislodging old racial ideas, evolution strengthened them, and provided them with a new scientific vocabulary of struggle and survival"“. 
an. Barnes, Bloor und Henry heben hervor, daß Wissenschaftler erst in Phasen der Krise explizite Wissenschaftspolitik betrieben, hingegen erfolge die politische Grenzziehung in nicht-krisenhaften Ruhephasen innerhalb der wissenschaftlichen Praxis. ${ }^{56}$ Eine Situation, die von einem krisenhaften Verlust tradierter Deutungsmuster gekennzeichnet war, wurde Mitte des neunzehnten Jahrhunderts für viele Naturwissenschaftler eben durch die Evolutionstheorien geschaffen. Dies galt auch für die Anthropologie und den rassentheoretischen Diskurs. Während ihre Dynamik zudem durch neue Erkenntnisse in der Archäologie, durch Funde wie den Neandertaler oder durch die Debatten um die Beziehung des Menschen zu den Primaten beeinflußt war, manifestierte sich die Krisenhaftigkeit der Anthropologie in der Abspaltung der Anthropological Society von der Ethnological Society, die für mehrere Jahre die wissenschaftliche Öffentlichkeit beschäftigte. ${ }^{57}$

\section{Aufbau des Buchs}

Diese Studie gliedert sich in drei analytische Abschnitte, die diesem einleitenden Abschnitt folgen. Im anschließenden zweiten Abschnitt werden der X-Club und sein wissenschaftspolitisches Wirkungsfeld diskutiert, die Entstehung der Evolutionstheorie bei Darwin und Spencer dargestellt, sowie ihre Rezeption durch Lubbock und Huxley skizziert. Diese Diskussion beleuchtet zum einen den Kontext der Durchsetzung der Evolutionstheorie, zum anderen bereitet sie die Einschätzung der evolutionären Rassentheorien der hier untersuchten X-Club-Mitglieder vor.

Im darauf folgenden dritten Abschnitt werden die wissenschaftspolitischen Kampagnen und Interventionen des X-Clubs in der damaligen Anthropologie untersucht. Hier geht es darum, an ebenso konkreten wie markanten Problemstellungen und Fragen dieses Wissenschaftsfeldes zu zeigen, auf welche Weise und aus welchen Gründen sich ein evolutionstheoretisches Menschenbild herausbildete und wie die XClub-Mitglieder in diesen Kampagnen ihre evolutionären Rassentheo-

56 Vgl. Barry Barnes, David Bloor, John Henry (1996) Scientific Knowledge. A Sociological Analysis. London: Athlone, S. 155.

57 Die Auseinandersetzung zwischen diesen beiden Gesellschaften ist am ausführlichsten vom Anthropologiehistoriker George W. Stocking diskutiert worden (Stocking (1971) „What's in a Name? The Origins of the Royal Anthropological Institute (1837-71)“. In: Man. The Journal of the Royal Anthropological Institute. New Series 6, S. 369-390; Stocking 1987, S. 248-273). Stocking hat zwar die evolutionstheoretische Wende in der Anthropologie als Überwindung der alten Ansätze von Monogenismus und Polygenismus beschrieben, ist dabei jedoch nur am Rande auf das Wirken des X-Clubs in dieser Entwicklung eingegangen. 
rien entwickelten. In diesem Abschnitt wird außerdem untersucht, wie sich im Kontext der Etablierung der Evolutionstheorien die Umorientierung im Diskursfeld der Rassentheorien vollzog und wie durch wissenschaftspolitische Kampagnen und Kontroversen die Dominanz der evolutionären Rassentheorien hergestellt sowie Gegenpositionen marginalisiert wurden. Hier wird vor allem die soziale Ebene der Modernisierung der Rassentheorien herausgearbeitet.

Im vierten Abschnitt schließt sich eine Analyse der Theorien über Rassen und soziale Evolution bei Huxley, Busk, Lubbock und Spencer an. Um die theoretische Ebene und die des Erkenntnisgegenstandes zu untersuchen, wird hier auf eine diskursanalytische Perspektive umgeschaltet. Dieser Teil der Studie beschäftigt sich gewissermaßen mit der Theorieentwicklung im Ruhezustand, im Gegensatz zu der auf die soziale Dynamik fokussierenden Untersuchungsperspektive des dritten Abschnitts. Dabei geht es um die theoretische Dimension der Modernisierung der Rassentheorien. In den hier herangezogenen Werken wird die innere Logik der evolutionären Rassentheorien, ihr Umgang mit empirischem Material und ihre Konstruktion von Rassenidentitäten untersucht.

\subsection{Evolutionstheorie und X-Club. Der Stand der Forschung}

Neue theoretische Ansätze werden häufig von alten Wissenschaftseliten abgelehnt. Auch Darwin erging es so. Die Verbindung mit der gleichzeitigen Professionalisierung der Naturwissenschaften weist nicht nur auf die soziale Dimension der wissenschaftlichen Revolution hin, sondern auch auf den Umstand, daß sich massiver Widerstand auf verschiedenen Ebenen gegen die Evolutionstheorie formierte. Führende Mitglieder des X-Clubs, vor allem Huxley, Lubbock und Busk, starteten eine Reihe von Kampagnen und beeinflußten die Wissenschaftspolitik zentraler wissenschaftlicher Körperschaften wie der Royal Society oder der British Association for the Advancement of Science (im weiteren: British Association), um die Anerkennung der Evolutionstheorie zu befördern. Die Wissenschaftsgeschichte hat die Rolle des X-Clubs detailliert beschrieben und seine Modernisierungsbestrebungen herausgehoben. Weitaus weniger wurden seine Kampagnen zur Etablierung der Evolutionslehre im Kontext anthropologischer Kontroversen beachtet. ${ }^{58}$

58 Vgl. Ruth Barton (1998b) „,Huxley, Lubbock, and Half a Dozen Others“. Professionals and Gentlemen in the Formation of the X-Club, 1851 1864“. In: Isis 89, S. 410-444; Desmond 2001; Andrew John Harrison (1988) Scientific Naturalists and the Government of the Royal Society. 
Nur wenige haben die rassentheoretischen Darstellungen und Konstruktionen in den Werken von Huxley ${ }^{59}$, Spencer ${ }^{60}$, Lubbock ${ }^{61}$ und

1850-1900. Unveröffentlichte PhD-Thesis, Milton Keynes: Open University; J. Vernon Jensen (1970) „The X-Club Fraternity of Victorian Scientists“. In: British Journal for the History of Science 5, S. 63-72; Roy M. MacLeod (1969) „The X-Club. A Social Network of Science in LateVictorian England“". In: Notes and Records of the Royal Society of London 24, S. 305-322.

59 Thomas Henry Huxley wird als einer der herausragenden Persönlichkeiten des Viktorianischen Zeitalters behandelt (vgl. Adrian Desmond (1998) Huxley. From Devil's Disciple to Evolution's High Priest. Harmondsworth, London: Penguin; Paul White (2003) Thomas Huxley: Making the ,Man of Science'. Cambridge: Cambridge University Press), weshalb es eine große Zahl an biographischen Werken und Reminiszenzen an ihn gibt (vgl. Charles Blinderman, James Paradis (Internetquelle) Huxley Files: http://aleph0.clarku.edu/huxley/index.html; Huxleys Bedeutung für die Wissenschaft wird vor allem in seiner Rolle als Popularisierer der Lehre Darwins gesehen. Ungeachtet dieses großen Interesses an Huxley hat sein Beitrag zur Anthropologie kaum Aufmerksamkeit erhalten.

60 Trotz einer äußerst umfangreichen Forschung zu Spencer (über 1.500 Einträge zählte Robert Perrins Sekundärbibliographie zu Spencer, vgl. Robert G. Perrin (1993) Herbert Spencer. A Primary and Secondary Bibliography. New York: Garland) wurde der seiner Theorie sozialer Evolution immanente Rassenbegriff nur unzulänglich problematisiert. Da die Auseinandersetzung mit Spencer vornehmlich auf theoretischer Ebene vollzogen wird, Evolutionstheorie und Individualismus sind hier die Anknüpfungspunkte, werden die Darstellungen der sogenannten Wilden faktisch als wissenschaftsexterne Ideologie ausgeklammert. Robert L. Carneiro beschreibt sein Verfahren wie folgt: „When Spencer went beyond the bounds of science and introduced considerations of ethics or values, such passages have generally been deleted. Occasional passages in which Spencer proposed racial explanations for certain cultural features have also been omitted“ (Robert L. Carneiro (1967a) „Editor's Introduction“. In: Ders. (Hrsg.): The Evolution of Society. Selections from Herbert Spencer's „Principles of Sociology“. Chicago: University of Chicago Press, S. ixlvii, S. v). Autoren wie Valerie Haines oder Antonello La Vergata haben sich in jüngerer Zeit mit Spencers Theorien der Evolution und der sozialen Evolution befaßt. Doch haben weder sie (Valerie A. Haines (1988) „Is Spencer's Theory an Evolutionary Theory?"“. In: American Journal of Sociology 93, S. 1200-1223; Antonello La Vergata (1995) „Herbert Spencer: Biology, Sociology, and Cosmic Evolution“. In: Maasen, Mendelsohn, Weingart: Biology as Society, Society as Biology. S. 193-229), noch John Offer (John Offer (1994) „Introduction“. In: Ders. (Hrsg.): Herbert Spencer. Political Writings. Cambridge: Cambridge University Press, S. viixxxix), noch Tim Gray (Tim S. Gray (1996) Political Philosophy of Herbert Spencer. Aldershot: Avebury), noch Michael Taylor (Michael W. Taylor (1992) Men versus the State. Oxford: Clarendon), noch Robert Perrin (1993) und auch nicht Carneiro und Perrin (Robert L. Carneiro; Robert G. Perrin (2002) „Herbert Spencer's Principles of Sociology: A Centennial Retrospective and Appraisal“". In: Annals of Science 59, S. 221-261) von 
Busk $^{62}$ analysiert. ${ }^{63}$ Wenn ihre Werke unter diesem Gesichtspunkt beleuchtet wurden, dann fanden weder die Bedeutung der Rassenkonzeption für ihre Theorien sozialer Evolution, noch ihre Definitionsarbeit am Rassenbegriff, noch ihre wissenschaftspolitischen Interventionen in die Debatten um die Rassentheorien Beachtung. Statt dessen wurde mehr oder weniger explizit auf einen Niederschlag vermeintlich unausweichbarer kultureller Einflüsse, auf einen „viktorianischen Rassismus“, abgestellt. $^{64}$

den rassistischen Konstruktionen bei Spencer und von ihrer Rolle für seine Soziologie Kenntnis genommen.

61 Auf John Lubbock wird in verschiedenen Werken der Evolutionsgeschichte und Rassismusgeschichte als einer der Urheber der komparativen Methode in der Ethnologie hingewiesen, allerdings ohne daß sein Rassenkonzept näher untersucht würde (vgl. Maurice Mandelbaum (1971) History, Man, \& Reason. A Study in Nineteenth-Century Thought. Baltimore: Johns Hopkins University Press; Stepan 1982; Peter J. Bowler (1989) The Invention of Progress: The Victorians and the Past. Oxford: Basil Blackwell). Eingehender befaßte sich John Clark mit Lubbocks Entomologie und deutete an, Lubbock habe ein psychisches Kontinuum von den Insekten bis hin zum Menschen konstruiert (J. F. M. Clark (1997) ,,The ants were duly visited': making sense of John Lubbock, scientific naturalism and the senses of social insects“. In: British Journal for the History of Science 30, S. 151-176; J. F. M. Clark (1998) „John Lubbock and mental evolution". In: Endeavour 22, S. 44-47).

62 George Busk ist bislang in nur einem Aufsatz biographisch gewürdigt worden (vgl. G. C. Cook (1997) „George Busk FRS (1807-1886), nineteenth-century polymath: surgeon, parasitologist, zoologist and palaeontologist“. In: Journal of Medical Biography 5, S. 88-101). In der Sekundärliteratur der einschlägigen Felder wurde Busks Beitrag zu Archäologie und Anthropologie nur am Rande, und dann nicht mit Blick auf seine anthropometrischen und kraniometrischen Methoden untersucht.

63 Nach wie vor hat Nancy Stepans Einschätzung von 1982 Gültigkeit, daß die Rassentheorien der wesentlichen evolutionären Naturwissenschaftler des neunzehnten Jahrhundert keiner Analyse unterzogen worden sind (vgl. Stepan 1982, S. 49).

64 Etwa Stocking 1987, S. 252: „True, like most Victorians, they [die „ethnologicals", T.G.] tended to regard a darker skin as sign of both physical and cultural inferiority”. Oder Di Gregorio: „In reply to the objection that Huxley was more of a racist than a racial anthropologist, one should not forget that the idea of the cultural superiority of the European races was commonplace in nineteenth-century Europe, even among the most liberal minds" (Mario A. Di Gregorio (1984) Thomas Henry Huxley's Place in Natural Science. New Haven, London: Yale University Press, S. 168). Und Rick Rylance schreibt über Spencers Rassentheorie, sie „,were tainted by a not wholly untypical Victorian racism“ (Rick Rylance (2000) Victorian Psychology and British Culture, 1850-1880. Oxford: Oxford University Press, S. 221). 
Nur wenige Ausnahmen sind in dieser Hinsicht zu verzeichnen. So erhob 1969 der Anthropologiehistoriker Marvin Harris gegen Spencer den Vorwurf, sein biologischer Reduktionismus habe die Erklärungskraft seiner Theorie sozialer Evolution eingeschränkt. ${ }^{65}$ Die Spencerforschung hat diese Überlegungen als denunziatorischen Angriff abgetan. ${ }^{66}$ Deshalb erkennen Carneiro und Perrin noch 2002 die tragende Funktion des Datenmaterials in Spencers Principles of Sociology, ohne es einer kritischen Analyse zu unterziehen. ${ }^{67}$

Spencer wird gemeinsam mit Darwin als ein wesentlicher Urheber des sozialdarwinistischen Denkens betrachtet. ${ }^{68}$ Der Sozialdarwinismus

65 Vgl. Marvin Harris (1969) The Rise of Anthropological Theory. A History of Theories of Cultures. London: Routledge, Kegan Paul, S. 123-131.

66 Vgl. J. D. Y. Peel (1971) Herbert Spencer. The Evolution of an Evolutionist. New York: Basic Books. Peel unterstellt Harris eine Freude am Rassismusverdacht (vgl. S. 143: „Harris [...] evidently derives a certain sombre satisfaction from pointing out the racism of much nineteenth-century anthropology"). David Wiltshire pflichtet Peel bei (vgl. David Wiltshire (1978) The Social and Political Thought of Herbert Spencer. Oxford: Oxford University Press, S. 209). Robert Carneiro weist den Vorwurf des Rassismus an Spencer ebenfalls zurück. Er begründet seinen Einwand damit, daß Spencer ein erklärter Gegner des europäischen Imperialismus und Liberaler gewesen sei (vgl. Robert L. Carneiro (1981) „Herbert Spencer as an Anthropologist“". In: The Journal of Libertarian Studies 5, S. 153-210, S. 179).

67 Carneiro, Perrin 2002, S. 235: „The Principles of Sociology [...] is sober, non-polemical, and at pains to arrive at ,empirical generalizations" and explications of them by specific causal propositions, all of which are supported by concrete historical and comparative data". Auch der Spencerianer Andreski betont die Bedeutung des Datenmaterials für Spencers Darstellung sozialer Evolution (vgl. Stanislav Andreski (1971) Herbert Spencer: Structure, Function, and Evolution. London: Joseph, S. 16).

68 Vgl. Robert C. Bannister (1979) Social Darwinism, Science and Myth in Anglo-American Social Thought. Philadelphia: Temple University Press; Raymond Williams (2000) „Social Darwinism“ [1973]. In: Offer: Herbert Spencer. Critical Assessments. London, New York: Routledge, Bd. 2, S. 186-197; Mike Hawkins (1997) Social Darwinism in European and American thought, 1860-1945. Nature as model and nature as threat. Cambridge: Cambridge University Press, S. 82; Michael Ruse (1982) „Social Darwinism: Two Sources“. In: Rivista di Filosofia 73, S. 36-52, S. 47. Bannister bemängelt allerdings selbst (S. 5), daß manche Studien zum Sozialdarwinismus (bspw. Richard Hofstadter (1955) Social Darwinism in American Thought. Boston: Beacon Press) diesen gar nicht mehr unabhängig von Spencer definieren können. In der jüngeren Literatur wird regelmäßig darauf hingewiesen, daß Spencer bereits lange vor Darwins Origin begonnen hatte, über soziale Evolution zu schreiben und daß er bis zuletzt an seinen lamarckschen Grundannahmen festhielt (vgl. allgmein Greta Jones (1980) Social Darwinism and English Thought. Brighton: Harvester Press). 
ist tief in den sozialphilosophischen Traditionen verwurzelt, und Darwins Mechanik wurde diesem Denken einverleibt. Vor diesem geschichtlichen Hintergrund ist es erklärlich, daß der Sozialdarwinismus ein ideologisch flexibles Konstrukt darstellte, auf das verschiedenste politische Lager zugreifen konnten. ${ }^{69}$ Seine Anpassungsfähigkeit ist in seinen Entstehungsbedingungen begründet, denn der Sozialdarwinismus war keine nachträgliche Verformung des Darwinismus, sondern zeitgleich aus derselben wissenschaftlich-sozialen Konstellation heraus entstanden. ${ }^{70}$ Zwar haben Historiker des Sozialdarwinismus immer wieder geschrieben, daß seine Konzeption auf biologischen und rassentheoretischen Annahmen aufbaute, doch wurde diese analytische Verbindung erst im Kontext sozialdarwinistischer Ansätze der Rassenhygiene hergestellt. ${ }^{71}$ Für den frühen und liberalen Sozialdarwinismus Spencers ist die Forschung zum Sozialdarwinismus den Nachweis einer solchen Verbindung schuldig geblieben, da Rassen als intergesellschaftliche Kategorie, der Sozialdarwinismus aber als innergesellschaftlich ansetzende Ideologie verstanden wurde. Spencers Rassentheorie wurde auch deshalb keiner intensiven Untersuchung unterzogen, weil die kritische Forschung zu Spencer hauptsächlich seinen Beitrag zum Sozialdarwinismus untersuchte.

Auch in der Forschung zu Huxley stellt sein Beitrag zur Entwicklung der Rassentheorie eine beachtliche Leerstelle dar. Einzig Douglas Lorimer und Frank Spencer beschäftigen sich mit Huxleys methodologischen Innovationen in der Rassenforschung. ${ }^{72}$ Die Diskussion seines

69 Vgl.: Gertrude Himmelfarb (1968) Victorian Minds. London: Weidenfeld, Nicolson, S. 327; R. J. Halliday (2000) „Social Darwinism: A Definition“ [1971]. In: John Offer (Hrsg.): Herbert Spencer: Critical Assessments of Leading Sociologists. London, New York: Routledge, Band 2, S. 133-148; Ted Benton (1982) ,Social Darwinism and Socialist Darwinism in Germany: 1860 to 1900“. In: Rivista di Filosofia 73, S. 79-121.

70 Steven Shapin; Barry Barnes (1979) „Darwin and Social Darwinism: Purity and History“. In: Dies. (Hrsg.): Normal Order: Historical Studies of Scientific Culture. Beverly Hills: Sage, S. 125-142, S. 126.

71 Vgl. allgemein Markus Vogt (1997) Sozialdarwinismus. Wissenschaftstheorie, politische und theologisch-ethische Aspekte der Evolutionstheorie. Freiburg: Herder.

72 Lorimer etwa schreibt, daß Huxley die Rahmenbedingungen des anthropologischen Diskurses und die anthropologische Forschungsagenda in den siebziger Jahren des neunzehnten Jahrhunderts geprägt habe, doch mit der Phase davor befaßt er sich nicht (vgl. Douglas A. Lorimer (1988) „Theoretical Racism in Late-Victorian Anthropology, 1870-1900“. In: Victorian Studies 32, S. 405-430, S. 412 ); vgl. Frank Spencer (1994) „Some Notes on the Attempt to Apply Photography to Anthopometry during the Second Half of the Nineteenth Century“. In: Elizabeth Edwards (Hrsg.): 
Anteils an den Kontroversen innerhalb der Anthropologie Mitte des neunzehnten Jahrhunderts erschöpft sich in der Regel mit einer vagen Beschreibung seiner Rolle, stellt hingegen keine Verbindung zu seiner Definition von sozialer Evolution und Menschenrassen her. Auf Huxleys epochales Werk Man's Place in Nature wird in rassismustheoretischer Hinsicht nicht analytisch eingegangen und die darin von ihm vorgenommene zoologische Einordnung des Menschen und seine Begriffsbestimmung von Menschenrassen wird nicht analysiert. ${ }^{73}$ Patrick Brantlingers Auseinandersetzung mit Huxleys Rassenkonstruktionen hat einen Aufsatz aus dem späten neunzehnten Jahrhunderts zum Gegenstand und zieht Huxleys frühe anthropologische Schriften nicht hinzu. ${ }^{74}$

Anthropology and Photography 1860-1920. New Haven: Yale University Press, S. 99-107.

73 Mario Di Gregorio unterzieht zwar Huxleys Anthropologie einer quellenreichen Untersuchung, macht aber den viktorianischen Rassismus für rassistische Erklärungen bei Huxley verantwortlich (vgl. Di Gregorio 1984, S. 166: „Of course, Huxley must pay lip service to the typical prejudice of Victorian anthropology").

Cyril Bibby behandelt Huxleys geographische Verteilung der Rassen auf dem Globus als eine sehr moderne und vom Rassismus höchst unterschiedliche Ansicht der menschlichen Variationen und behauptet, Huxley hätte die „Attributierung angeborener mentaler, emotionaler und moralischer Eigenschaften zu verschiedenen sogenannten ,Rassen“" abgelehnt. (vgl. Cyril Bibby (1972) Scientist Extraordinary. The Life and Scientific Work of Thomas Henry Huxley, 1825-1895. Oxford: Pergamon Press, S. 142: ,very modern view of human variation, so unlike the racialist theorising of many scientists during succeeding decades“, 143: „,suspicious of the attribution of inborn mental, emotional and moral characteristics to various so-called ,races“"). Gänzlich unkritisch liest auch Albert Ashforth Huxleys Man's Place in Nature (vgl. Albert Ashforth (1969) Thomas Henry Huxley. New York: Twayne). Vollständig an der Problematik vorbei argumentiert Sherrie Lyons, die zwar schreibt, daß Huxley, von Darwins Origin of Species inspiriert, Man's Place in Nature verfaßte, um zu demonstrieren, daß auch der Mensch den evolutionären Gesetzmäßigkeiten der Natur unterworfen sei, doch welche Auswirkung diese Applikation des Darwinismus auf seine Darstellung verschiedener menschlicher Rassen hatte, läßt Lyons unberücksichtigt (vgl. Sherrie Lynne Lyons (1999) Thomas Henry Huxley: The Evolution of a Scientist. New York: Prometheus Books, S. 189-193).

74 Vgl. Patrick Brantlinger (1997) „Thomas Henry Huxley and the Imperial Archive" In: Alan P. Barr (Hrsg.): Thomas Henry Huxley's Place in Science and Letters: Centenary Essays. Athens, Georgia: University of Georgia Press, S. 259-276; auch Michael S. Helfand stellt fest, daß für Huxley die Wilden Teil einer amoralischen Natur gewesen wären und daß ihre koloniale Unterwerfung, wie im Beispiel Tasmaniens, zu ihrer Vernichtung führen würde (vgl. Michael S. Helfand (1977) „T. H. Huxley's ,Evolution and Ethics": The Politics of Evolution and the Evolution of Politics“. In: Victorian Studies 20, S. 159-177). 
Lubbock wird zwar von Idus L. Murphee als einer der evolutionstheoretischen Urheber der modernen Anthropologie diskutiert, doch seine Rassenkonstruktionen bleiben unbehandelt. ${ }^{75}$ Das gilt auch für die Arbeit Janet Owens, die sich mit Lubbocks Sammlung ethnologischer Artefakte beschäftigt, und Neill Gillespie, der Lubbocks Auseinandersetzung mit dem Duke of Argyll über soziale Degeneration untersucht. ${ }^{76}$

Es ist sicherlich nicht falsch, beispielsweise Huxley, ,gemessen an den Standards seiner Zeit“, als „,moderaten Rassisten“ zu bezeichnen. ${ }^{77}$ Doch wenn sich Huxley und mit ihm die anderen prominenten Evolutionstheoretiker des X-Clubs in die Debatten in Human- und Sozialwissenschaften einschalteten, ging es nicht mehr nur um eine Reproduktion tradierter Vorstellungen über Rassen, sondern um den Versuch, die Grundlagen dieser Rassentheorien neu zu definieren. Douglas Lorimer faßt das in dem Bild vom rassistischen Erbe der Wissenschaftler, das diese angenommen und ,weiterentwickelt“" hätten. ${ }^{78}$

\subsection{Monogenismus und Polygenismus. Die Krise der Rassentheorien}

Durch die von der Evolutionstheorie ausgelösten theoretischen wie sozialen Veränderungen im Wissenschaftssystem wurde die Krisenhaftigkeit der Anthropologie und der Rassentheorien offengelegt und in der Folge

75 Vgl. Idus L. Murphee (1961) „The Evolutionary Anthropologists: The Progress of Mankind. The Concepts of Progress and Culture in the Thought of John Lubbock, Edward B. Tylor, and Lewis H. Morgan“. In: Proceedings of the American Philosophical Society 105, S. 265-300, S. 273.

76 Vgl. Janet Owen (2000) The Collecting Activities of Sir John Lubbock (1834-1913). Unveröffentlichte Ph.D. Thesis, Durham: University of Durham; Gillespie 1977.

77 Stephen J. Gould (1998) „A Seahorse for All Races“. In: Ders.: Leonardo's Mountain of Claims and the Diet of Worms. London: Jonathan Cape, S. 119-140, S. 135: ,a liberal racist by the standards of his time“; vgl. Douglas A. Lorimer (1996) „Race, science and culture: historical continuities and discontinuities, 1850-1914“. In: Shearer West (Hrsg.): The Victorians and Race. Aldershot, Scolar Press, S. 12-33.

78 Douglas A. Lorimer (1997), ,Science and the Secularization of Victorian Images of Race“. In: Bernhard Lightman (Hrsg.): Victorian Science in Context. Chicago: University of Chicago Press, S. 213-235, S. 228: „In assessing the influence of science in effecting this regressive change in Victorian attitudes to race, it needs to be recognized both that the community of scientists inherited the racism of the common context and that, as science gained greater intellectual authority and institutional and professional status, it came to reshape that inheritance". 
öffentlich thematisiert. Als Darwin 1871 in Descent of Man den Stand der vorevolutionären Rassentheorien zusammenfaßte, fiel seine Bilanz ernüchternd aus:

„Der Mensch wurde genauer als jedes andere Lebewesen studiert, und dennoch besteht die größtmögliche Unentschiedenheit unter den Gelehrten, ob er als eine Art oder Rasse zu klassifizieren sei oder als zwei (Virey), als drei (Jacquinot), als vier (Kant), fünf (Blumenbach), sechs (Buffon), sieben (Hunter), acht (Agassiz), elf (Pickering), fünfzehn (Bory St. Vincent), sechzehn (Desmoulins), zweiundzwanzig (Morton), sechzig (Crawfurd) oder als dreiundsechzig, wie Burke meint" ${ }^{79}$

Die Evolutionstheoretiker fanden den Diskurs der Rassentheorien in einem Zustand der Uneindeutigkeit vor. ${ }^{80}$ Dessen institutionelle Trägerschicht war in erster Linie die Anthropologie. In ihr fielen verschiedene Denktraditionen zusammen. Eine der traditionsreichsten war der Diskurs über die vermeintlich Wilden, der bis in die Antike zurückreicht und sich in der Anthropologie der Aufklärung verwissenschaftlichte. Schon den Entwicklungsmodellen der Philosophen der Gesellschaftsvertragstheorie war die Rassendimension implizit. Sie griffen, so Charles W. Mills, gleich auf zwei Urzustände zurück: „Der eigentliche Naturzustand ist den Nichtweißen vorbehalten, für die Weißen ist der Naturzustand nur hypothetisch“. ${ }^{81}$ Der soziale Urzustand, aus dem diese philosophische Schule ihr Gleichheitspostulat ableiteten, war hypothetisch - doch immer, wenn die Trope des Kampfes zwischen Mensch und Mensch aufgegriffen und das Bestialische oder das Müßiggängerische am Naturzustand betont wurde, zog sie die Erzählungen über die vermeintlich wirklichen Wilden heran.

Die verbreitete Vorstellung sozialer Entwicklung ging von einem Verlauf über bestimmte Entwicklungsstufen aus, und nahm eine Abfolge von nomadischer, pastoraler, landwirtschaftlicher und schließlich kom-

79 Charles Darwin (1998b) The Descent of Man and Selection in Relation to Sex. [1874] New York: Prometheus Books, S. 181: „Man has been studied more carefully than any other animal, and yet there is the greatest possible diversity amongst capable judges whether he should be classed as a single species or race, or as two (Virey), as three (Jacquinot), as four (Kant), five (Blumenbach), six (Buffon), seven (Hunter), eight (Agassiz), eleven (Pickering), fifteen (Bory St. Vincent), sixteen (Desmoulins), twenty-two (Morton), sixty (Crawfurd), or as sixty-three, according to Burke“.

80 Vgl. Barkan 1992, S. 17-18.

81 Charles W. Mills (1997) The Racial Contract. Ithaca, London: Cornell University Press, S. 66: ,[T] he literal state of nature is reserved for nonwhites; for whites the state of nature is hypothetical" (Hervorh. im Original, T.G.). 
merzieller Gesellschaftsform an. ${ }^{82}$ Hierbei sei der Mensch durch die Arbeit aus seinem Naturzustand herausgetreten. Die angenommene Entwicklung war voluntaristisch konzipiert und basierte auf dem Postulat der Perfektibilität, ein dem Menschen eigener Drang zur Selbstverbesserung. Vor allem aber war der Fortschritt in diesem Verständnis regelhaft, er war Ausdruck einer immanenten Tendenz und verlief deshalb nicht nur stetig sondern „ereignislos“, wie Kenneth Bock schreibt. ${ }^{83}$ Sozialevolutionäre Theorien standen zum einen in der Tradition dieses Fortschrittsdenkens, zum anderen waren sie von der Erfahrung wirtschaftlicher Prosperität inspiriert. ${ }^{84}$ In England wurde dieser Diskurs in erster Linie durch Adam Ferguson und Adam Smith verkörpert, doch auch Rousseaus Spekulationen über den Urzustand des Menschen und die Entwicklung des Sozialen wurden hier rezipiert. ${ }^{85}$

\section{Traditionen der Anthropologie}

Im anthropologischen Diskurs des späten achtzehnten und frühen neunzehnten Jahrhunderts entwickelten sich mit dem Monogenismus und dem Polygenismus zwei konträre Deutungsmuster sozialer Entwicklung, die sich deutlich vom aufklärerischen Modell unterschieden. Der Ausgangspunkt der monogenistischen Rassentheorien war das Modell der Verkettung allen Lebens (,great chain of being“"). ${ }^{86}$ Es ging von einer göttlichen Schöpfung des Lebens aus und brachte es in eine hierarchische Ordnung. Dieses Modell markiert den Beginn der Systematisierung eines Wertigkeitsgefälles zwischen Europäern und Afrikanern. ${ }^{87}$

Die Monogenisten gingen von einer Sonderstellung des Menschen in der Natur, von der genealogischen Einheit der Menschheit und von einer einheitlichen, hierarchischen Ordnung der Menschenrassen aus. Johann

82 Vgl. Hund 2006, S. 54-55; Ronald L. Meek (1976) Social science and the ignoble savage. Cambridge: Cambridge University Press, S. 5.

83 Kenneth Bock (1980) Human Nature and History. A Response to Sociobiology. New York: Columbia University Press, S. 39: „eventless“.

84 Vgl. Geoffrey Best (1990) Mid-Victorian Britain 1851-75. London: Fontana Press, S. 19; Robert A. Nisbet (1970) The Sociological Tradition. London: Heinemann, S. 160; Mandelbaum 1971.

85 Vgl. allgemein David Kettler (1965) The Social and Political Thought of Adam Ferguson. Ohio: Ohio State University Press; Stephen K. Sanderson (1990) Social Evolutionism. A Critical History. London: Basil Blackwood.

86 Vgl. allgemein Arthur O. Lovejoy (1936) The Great Chain of Being. The Study of an History of an Idea. Cambridge Mass.: Harvard University Press.

87 Vgl. Miles 1989, S. 28f. 
Friedrich Blumenbach etwa berief sich auf die Sprachbefähigung des Menschen als Anhaltspunkt ihrer gemeinsamen Abkunft, Immanuel Kant nahm in seinen anthropologischen Schriften an, das für ihn wesentliche physische Unterscheidungskriterium, die Hautfarbe, sei einem irreversiblen, primären Akklimatisierungsprozeß geschuldet. ${ }^{88}$ Auch wenn den Kern der monogenistischen Rassentheorien die Annahme eines gemeinsamen Ursprungs der Menschenrassen bildete; sie waren von der Ungleichwertigkeit dieser Rassen überzeugt, die sowohl ästhetisch als auch kulturell konstruiert wurde. Der Körper der vermeintlich Wilden wurde zum bedeutungstragenden Zeichen, das die Primitivität der Individuen samt ihrer Kultur auswies.

Der Monogenismus trat in zwei Spielarten auf, die die Annahme eines gemeinsamen Ursprung aller Rassen teilten. Eine noch im neunzehnten Jahrhundert verbreitete Erklärung verstand die verschiedenen Rassen als Abkömmlinge der Söhne Noahs, die die verschiedenen Erdregionen bevölkerten. ${ }^{89}$ Diese christliche Lesart interpretierte die verschiedenen Körpermerkmale als Ausdruck einer göttlichen Vorsehung oder eines göttlichen Fluchs, manche hielten die Afrikaner für die Nachfahren Hams. ${ }^{90}$ Eine andere Variante des Monogenismus basierte nicht auf der biblischen Erzählung. Dieser säkularisierte Monogenismus vermutete den Ursprung der Menschheit in Asien und führte die physischen Unterschiede auf die Akklimatisierung der in verschiedene Regionen Eingewanderten zurück. Er ging dabei von einem Degenerationsprozeß aus, durch den die nicht-weißen Rassen entstanden seien. ${ }^{91}$ Die unterstellte zivilisatorische Degeneration wurde zuweilen damit begründet, daß allzu günstige Umweltbedingungen das Überleben auch ohne Arbeit und Innovation ermöglicht hätten, zwei Werte, die im aufgeklärten europäischen Denken zu den Voraussetzungen eines zivilisatorischen Prozesses gerechnet wurden.

88 Vgl. Frank W. P. Dougherty (1990) „Christoph Meiners und Johann Friedrich Blumenbach im Streit um den Begriff der Menschenrasse“. In: Gunter Mann, Franz Dumont (Hrsg.): Die Natur des Menschen. Probleme der Physischen Anthropologie und Rassenkunde (1750-1850). Stuttgart, New York: Fischer, S. 89-111; Alex Sutter (1989) „Kant und die ,Wilden“. Zum impliziten Rassismus in der Kantischen Geschichtsphilosophie“. In: Prima Philosophia 2, S. 241-265, S. 241-265; Robert Bernasconi (2001) „Who invented the Concept of Race? Kant's Role in the Enlightenment Construction of Race“. In: Ders. (Hrsg.): Race. Oxford: Basil Blackwell, S. 11-36.

89 Vgl. Stepan 1982, S. 1.

90 Vgl. Banton 1998, S. 37.

91 Vgl. Stephen J. Gould (1981) The Mismeasure of Man. New York: Norton, S. 39. 
Die monogenistischen Ansätze wurden in erster Linie von Naturalisten der Aufklärung und Anfang des neunzehnten Jahrhunderts von Naturwissenschaftlern entwickelt, die ebenfalls an der Errichtung und Modifikation von Taxonomien der organischen Welt arbeiteten. $\mathrm{Zu}$ ihnen zählten im achtzehnten Jahrhundert Carl von Linné und George Buffon sowie im frühen neunzehnten Jahrhundert George Cuvier. ${ }^{92}$ Ihre Rassentheorien waren Teil jener naturgeschichtlichen Tradition, die die Naturwissenschaften noch zu Zeiten des jungen Darwin prägten.

Linnés Einordnung des Menschen in die Gruppe der Primaten wurde von vielen als eine unerhörte Profanisierung empfunden und rief die Erwiderungen Buffons und Blumenbachs hervor, die verschiedene Kriterien heranzogen, um die taxonomische Sonderstellung des Menschen zu unterstreichen. Buffon hatte grundsätzlich die Bedingung der Fruchtbarkeit als Indikator der Zugehörigkeit zu einer Art aufgestellt, Rassen waren für ihn miteinander fruchtbare Varietäten einer Art. Er hatte damit eine Definition des Rassebegriffs in Abgrenzung zum Begriff der Art vorgenommen, die für nachfolgende Generationen in den Naturwissenschaften normgebend war.

Der Polygenismus ging im Unterschied zu den monogenistischen Theorien von verschiedenen Ursprüngen der Menschheit aus. Im Kontext der Buffonschen Unterscheidung von Rasse und Art verstanden Polygenisten die Menschheit als Konglomerat verschiedener Arten des Menschen. Der Polygenismus hatte eine ebenso lange Tradition wie der Monogenismus. ${ }^{93}$ Die Polygenisten des achtzehnten Jahrhunderts stellten die monogenistische Hypothese der Akklimatisierung als Ursache für die phänotypische Varianz der Menschen in Frage. Sie hielten Buffons Kriterium der Fertilität als Anhaltspunkt für die Unterscheidung von Rasse und Art für schwächer als die physischen oder physiognomischen Unterschiede, die sie den Menschenrassen attestierten. Dabei lehnten die frühen Polygenisten das Fertilitätskriterium nicht rundweg ab, sahen in ihm aber keinen hinlänglichen Beweis für die monogenistische Interpretation eines gemeinsamen Ursprungs der Menschenrassen.

Samuel Thomas Soemmering in Deutschland oder Lord Kames in England unterteilten als Vertreter eines wissenschaftlichen Polygenismus die Menschen in verschiedene Arten; ihren Abgrenzungspunkt konstruierten sie dabei über anatomische Vergleiche mit Primaten, vor allem der Orang-Utan wurde im späten achtzehnten Jahrhundert als der nächs-

92 Vgl. Stepan 1982, S. 10-12; Banton 1998, S. 20f; Graves 2002, S. 38-40.

93 Vgl. Stepan 1982, S. 32. 
te Verwandte der Menschen betrachtet. ${ }^{94}$ Dabei muß berücksichtigt werden, daß diese frühen Auseinandersetzungen um eine polygenistische oder monogenistische Interpretation der Menschheitsentwicklung im Kontext einer humanistisch motivierten Kritik an der Sklaverei entstand und daß Soemmering, ganz im Unterschied zu Kames etwa, die Sklaverei strikt ablehnte. ${ }^{95}$ Diese frühen Kontroversen zwischen Polygenisten und Monogenisten zeigen, daß bereits hier ein Konfliktpotential in der Beziehung zwischen Wissenschaft und Politik vorlag und die Grenzziehung zwischen diesen distinkten Systemrationalitäten immer wieder zur Disposition stand.

Als Gegenposition zum Emanzipationsdiskurs, der sich vor allem auf die monogenistische Rassentheorie stützte, lebte in der ersten Hälfte des neunzehnten Jahrhunderts in Amerika und Großbritannien der Polygenismus durch eine Vielzahl von Schriften wieder auf. ${ }^{96}$ Der politische Diskurs über die Emanzipation und die Befreiung der Sklaven verband sich wegen der Argumentation der Philanthropen mit einer rassentheoretischen Debatte. Dies wird vor allem an der Losung der Emanzipationsbewegung „Am I not a man and a brother?“ deutlich. Der Emanzipationsdiskurs pochte auf die Gleichheit im Menschsein - nichtsdestoweniger ging er von der Existenz der Rassen aus und legte die Taxonomien der monogenistischen Naturphilosophen an. An diesem Rekurs aufs wissenschaftliche Wissen setzte die Kritik der Gegner der Sklavenbefreiung an. Die monogenistische Erklärung phänotypischer Unterschiede durch Akklimatisierung wurde in Frage gestellt. Die Erfahrung, daß auch nach vielen Generationen die aus Afrika nach Nordamerika verschleppten Sklaven keine Änderung der Hautfarbe aufwiesen und die hohe Krankheitsanfälligkeit der europäischen Kolonialtruppen in tropischen Gefilden zeigten die Grenzen der Akklimatisierungstheorie auf. ${ }^{97}$

Die Polygenisten betonten demgegenüber die Beständigkeit der rassischen Merkmale und leiteten daraus die Zivilisationsunfähigkeit der als primitiv geltenden Gesellschaften ab. 1837 war infolge philanthropi-

94 Vgl. Georg Lilienthal (1990) „Samuel Thomas Soemmering und seine Vorstellung über Rassenunterschiede“. In: Gunter Mann, Franz Dumont (Hrsg.): Die Natur des Menschen. Probleme der physischen Anthropologie und Rassenkunde. Stutgart: Fischer, S. 31-55; Sigrid Oehler-Klein (1998) „Einleitung“. In: Dies. (Hrsg.): Samuel Thomas Soemmering. Anthropologie: Über die körperliche Verschiedenheit des Negers vom Europäer (1785). Stuttgart, New York: Fischer, S. 89-142.

95 Vgl. Samuel Thomas Soemmering (1785) Ueber die körperliche Verschiedenheit des Negers vom Europäer. Frankfurt, Mainz: Warrentrapp, Wenner, S. VII-VIII.

96 Vgl. Stepan 1982, S. 20-46.

97 Vgl. Banton 1998, S. 33. 
scher Kampagnen die Sklaverei auch in den britischen Kronkolonien abgeschafft worden. Diese Entwicklung hatte dem polygenistischen Diskurs einen enormen Auftrieb verschafft. Anders als in der Mitte des achtzehnten Jahrhunderts, als polygenistische Anthropologen annahmen, $\mathrm{da}$ die physischen Merkmale der Menschenrassen graduell in einander übergingen, wurde nun die Abgrenzung zum Monogenismus schärfer konturiert. Gegen dessen wahlweise Berufung auf die Akklimatisierungsthese oder auf eine angenommene sprachliche Verwandtschaft zwischen den Menschenrassen beriefen sich Polygenisten auf eine Unveränderlichkeit physischer Rassenmerkmale, auf eine durch bestimmte Resistenzen gegen Krankheiten dokumentierte Gebundenheit des Menschen an ein bestimmtes Klima und auf eine Unfruchtbarkeit der Nachkommen von Menschen verschiedener Rassen. Neben diesen vermeintlichen Belegen, daß die Rassen eigentlich verschiedene Arten des Menschen seien, führten Polygenisten physische Unterschiede zwischen den Menschen an, die ihre verschiedenen Abstammungen belegen sollten, wie etwa die Differenz der Schädelvolumina oder die Beschaffenheit der Haut. $^{98}$

$\mathrm{Zu}$ den in England prominentesten Vertretern der polygenistischen Position gehörten neben dem Amerikaner Samuel George Morton, Autor von Crania Americana (1839), dem Standardwerk der amerikanischen Polygenisten, vor allem der Londoner Chirurg William Lawrence und der schottische Anatom Robert Knox. ${ }^{99}$ Bei den Akteuren des polygenistischen Diskurses handelte es sich nur teilweise um einschlägig gebildete Akademiker, viele hatten bloß eine medizinische Ausbildung. Aufgrund der aus universitärer Sicht in den ersten Jahrzehnten des neunzehnten Jahrhunderts noch eher randständigen akademischen Ausbildung der Chirurgen, konnten sie zumeist nicht mit der gleichen wissenschaftlichen Autorität sprechen, wie die prominenten Monogenisten, von denen viele dem Milieu der Gentlemen-Gelehrten entstammten. Diese soziale Dimension beeinflußte die Rezeption der beiden rivalisierenden Parteien maßgeblich. Während die philanthropischen Monogenisten vor allem bei liberalen und bürgerlichen Kreisen Zuspruch fanden, repräsentierten die Polygenisten eher die Ansichten der Straße.

Robert Knox brachte 1850 in The Races of Men die polygenistische Überzeugung auf den Punkt, als er schrieb, die Menschenrassen wiesen seit Beginn der geschichtlichen Aufzeichnung unveränderte körperliche

98 Vgl. Graves 2002, S. 43-51.

99 Vgl. Hannah Franziska Augstein (1996) „Introduction“. In: Dies.: Race. The Origin of an Idea, 1760-1850. Bristol: Toemmes, S. ix-xxxiii, S. xxxxxxi. 
Unterschiede auf und seien miteinander unfruchtbar. ${ }^{100}$ Sein berühmtes Diktum, „Rasse ist alles“ („Race is everything“) behandelte die Rasse als elementare biologische Basis der Nation. ${ }^{101}$ Er entwickelte diese Sicht im Kontext der populären Debatte über die Rasse der Sachsen und ihre Rolle für die englische Gesellschaft - eine in der ersten Hälfte des neunzehnten Jahrhunderts geführte Diskussion, die nicht unwesentlich von Walter Scotts Roman Ivanhoe angestoßen wurde, der in romantischer Manier einen Gegensatz von Angelsachsen und Normannen erst konstruierte und dann zur Versöhnung führte. ${ }^{102}$

Aus dem politischen Streit um Emanzipation und Sklaverei war so ein breit angelegter Diskurs geworden, der die Frage der Rassentheorie im Ganzen betraf und die Berechtigung der politischen Forderung von der wissenschaftlichen Beweisführung der Einheit der Menschheit abhängig machte. Der Wissenschaftlichkeit dieses Nachweises kam dehalb innerhalb des Rassendiskurses immer größere Bedeutung zu.

\section{Methodologie der Anthropologie}

Bereits im achtzehnten Jahrhundert gab es Ansätze für ein einheitliches rassentaxonomisches System. Sie basierten vor allem auf einer zunehmend regelhaften Zuschreibung körperlicher Eigenschaften, die als ursächlich für kulturelle Differenzen gehalten wurden. Die Aufklärung brachte, wie George Mosse schreibt, die Anthropologie als Wissenschaft vom Menschen hervor, die sich anschickte, dessen ,Stellung [...] in der Natur durch Beobachten, Messen und Vergleichen zwischen Menschenund Tiergruppen exakt zu bestimmen““. ${ }^{103}$ Diese physisch-anthropologische Tradition wurde durch die Schriften Petrus Campers, Soemmerings oder Blumenbachs begründet. Aus ihrem wissenschaftlichen Streben nach exaktem Erfassen gingen die Messverfahren der Anthropometrie

100 Knox 1862. Zitiert nach: Banton 1998, S. 72: „[T] [The races of men differ from each other, and have done so from the earliest historic period, as proved -1 . By their external characters, which have never altered during the last six thousand years. 2. By anatomical differences in structure. 3 . By the infertility of the hybrid product, originating in the intermingling of two races. 4. By historic evidence, which shows that no distinct hybrid race can ever be shown to exist anywhere".

101 Robert Knox (1850) The Races of Man. A Fragment. Philadelphia: Lea, Blachard, S. 7.

102 Vgl. Bowler 1989, S. 17; vgl. allgemein Alexander Welsh (1968) The Hero of the Waverley Novels. New York: Athenaeum; Kurt Gamerschlag (1978) Sir Walter Scott und die Waverley Novels. Darmstadt: Wissenschaftliche Buchgesellschaft.

103 Mosse 1978, S. 2. 
und der Kraniometrie hervor. ${ }^{104}$ Neben dieser physischen Anthropologie existierte eine ethnologische ausgerichtete, vornehmlich an kulturellen Merkmalen arbeitende Forschungstradition. Zu ihr zählten auch linguistische Theorien. Ungeachtet der methodischen Unterschiede dieser Schulen versuchten viele Ansätze, eine Korrelationen zwischen den verschiedenen Untersuchungsgegenständen, zwischen Körper und Kultur, herzustellen.

Doch die messtechnische, mit wissenschaftlicher Methodik betriebene Erfassung sozialer Differenz erwies sich, schon wegen steigender Ansprüche an wissenschaftliche Präzision und Verlässlichkeit als problematisch, denn Anthropologen wurden auch durch Kritik und Falsifikation im Diskurs der Rassentheorien beständig zu methodischen Neuerungen gezwungen. Deutlich wird die Verunsicherung an der wiederholten Ablehnung von Methoden zur Bestimmung von Rassen: Orientierte man sich im achtzehnten Jahrhundert zunächst an der Hautfarbe, bezogen spätere Rassentheorien andere Körpermerkmale oder Körperteile ein, an denen sie diskretere Eigenschaften, wie die Nervendicke oder die Haarbeschaffenheit zu identifizieren hofften. Doch keines der Verfahren führte $\mathrm{zu}$ anfechtungsresistenten Ordnungs- und Bestimmungskriterien. Deshalb konzentrierten sich die Versuche auf die Vermessung des Schädels. Damit wurde die Verbindung von Körper und Kultur enger gestaltet, denn die Größe des Gehirns galt zunehmend als Gradmesser der zivilisatorischen Leistungsfähigkeit. ${ }^{105}$

Die Anthropometrie kannte um die Mitte des neunzehnten Jahrhunderts drei wesentliche Maße am Schädel, die klassifikatorische Rückschlüsse erlauben sollten. Das älteste Maß war der Gesichtswinkel. Es wurde vom niederländischen Anatom Petrus Camper entworfen. ${ }^{106}$ Der Gesichtswinkel wurde aus zwei auf das Profil konstruierten Achsen gebildet und gestattete die Klassifikation des Schädels entweder als orthognathisch, wenn die Front des Gesichtes für senkrecht gehalten wurde, oder als prognathisch, wenn die Kieferpartie für vorstehend gehalten wurde. Der Gesichtswinkel war vor allem ein ästhetisches Maß, dessen Signifikanz deshalb oft durch den Vergleich eines Orang-Utans mit einer griechischen Büste illustriert wurde. Das zweite Maß war die Opera-

104 Vgl. Harry L. Shapiro (1959), ,The History and Development of Physical Anthropology“. In: American Anthropologist 61, S. 371-379, S. 376.

105 Vgl. Banton 1998, S. 44-80.

106 Vgl. Antonie M. Luyendijk-Elshout (1989) „Petrus Camper als antropoloog”. In: J. Schuller tot Persum-Meijer, W.R.H. Koops (Hrsg.): Petrus Camper (1722-1789): onderzoeker van nature. Groningen: Universiteitsmuseum, S. 57-72; Miriam Claude Meijer (1999) Race and Aesthetics in the anthropology of Petrus Camper (1722-1789). Amsterdam, u.a.: Rodopi, S. 167-177. 
tionalisierung des gängigen Stereotyps, daß die Kulturleistung ihre Entsprechung im Gehirnvolumen finden müßte. Ab der Mitte des achtzehnten Jahrhunderts wurden Methoden der Bestimmung des Kranialvolumens entwickelt, wobei sich das Auslitern mit bestimmtem Füllmaterial durchgesetzt hatte. Das dritte hier relevante Maß war der sogenannte kephalische Index, den der schwedische Anatom Anders Retzius 1842 entworfen hatte. Der kephalische Index unterschied zwischen breiten brachykephalischen und langen dolichokephalischen Schädeln, die verschiedene Rassen repräsentierten und denen bestimmte Charaktereigenschaften zugeschrieben wurden.

Allen drei Maßen war gemein, daß jedes einzelne Mitte des neunzehnten Jahrhunderts bereits in Zweifel gezogen worden war. Dies lag vor allem daran, daß Gegendarstellungen glaubhaft machen konnten, daß ihre Rassen-Klassifikationen bruchstückhaft waren. Der Gesichtswinkel, das Gehirnvolumen und der Schädelindex waren nicht als komplementäre Bestimmungsmethoden, sondern alternativ und sogar gegeneinander entworfen worden. Retzius' Behauptung, die nordischen, brachykephalischen Schädel seien eine höhere Entwicklung als die südländischen dolichokephalischen Schädel, wurde vom französischen Anthropologen Paul Broca heftig zurückgewiesen. Neben Broca und Busk kritisierte in England auch der Mediziner und Anthropologe John Thurnam Retzius kephalischen Index als ein ungenaues Maß. ${ }^{107}$ Schon 1836 hatte der deutsche Anatom Friedrich Tiedemann im Journal der Linnéan Society dargelegt, daß das Schädelvolumen der von ihm vermessenen Afrikaner nicht vom Volumen europäischer Schädel abweiche. ${ }^{108} \mathrm{We}$ gen solcher methodischen Unklarheiten konnten die anthropometrischen Maße ihren Universalitätsanspruch nicht einlösen. Mit steigender Zahl an Meßverfahren entfernte sich die Anthropologie von ihrem damals vorrangigen Ziel, eine meßbare Korrelation zwischen Körper und sozialem Sein herzustellen. Nicht nur theoretisch, sondern auch methodisch war sie in eine heillose Konfusion geraten.

107 John Thurnam (1810-1873) war mit John Barnard Davis Autor das einflußreiche Werks Crania Britannica (1856).

108 Frederick Tiedemann (1836) „On the Brain of a Negro, Compared with That of the European and the Orang-Utang“. In: Philosophical Transactions of the Royal Society of London 126, S. 497-527. 


\section{Evolutionstheorie und X-Club}

„Es gibt Perioden - die ausgeprägtesten und am leichtesten erkennbaren Beispiele sind das Auftreten der Kopernikanischen, der Darwinianischen oder der Einsteinschen Theorie -, in denen eine wissenschaftliche Gemeinschaft ein altehrwürdiges Weltbild und eine altehrwürdige Wissenschaftsform aufgibt und zu einem anderen, gewöhnlich damit unvereinbaren Ansatz übergeht" (Thomas S. Kuhn). ${ }^{1}$

Dieser Abschnitt behandelt die wissenschaftlich-theoretische und die soziale Dimension des evolutionstheoretischen Paradigmawechsels, der für die evolutionstheoretische Transformation der Rassentheorien die Rahmenbedingungen bildete. Bei der Diskussion der sozialen Dimension der evolutionstheoretischen Wende wird vor allem das wissenschaftliche Umfeld Darwins untersucht, durch das seine Theorie popularisiert und in den Naturwissenschaften etabliert wurde. Bei dieser Etablierung spielte der X-Club eine zentrale Rolle. Sein Entstehen und seine soziale Architektur werden deshalb ebenso analysiert, wie die wissenschaftspolitischen Maßnahmen, mit denen seine Mitglieder die Etablierung der Evolutionstheorie verfolgten. Im X-Club verbanden sich evolutionäre Überzeugungen mit wissenschaftspolitischen Modernisierungsambitionen.

Der naturwissenschaftliche Diskurs wurde im neunzehnten Jahrhundert aber nicht nur durch Darwins Origin of Species, sondern auch durch die Ausweitung der geologischen und archäologischen Zeitrechnung revolutioniert. Sie öffnete die historischen Räume, durch die erst die evolutionäre Mechanik plausibilisiert werden konnte. Zum theoriebil-

1 Thomas S. Kuhn (1978) „Die grundlegende Spannung: Tradition und Neuerung in der wissenschaftlichen Forschung“. In: Ders.: Die Entstehung des Neuen. S. 308-326, S. 309. 
denden Kontext gehören auch die Schriften Spencers, der für den viktorianischen Evolutionsdiskurs kaum weniger bedeutend war als Darwin. Etliche Jahre vor Origin of Species hatte Spencer seine Theorie organischer Evolution aus seinem radikalen Liberalismus entwickelt, woran sich die politische Dimension der Evolutionstheorie ablesen läßt. Dieser Abschnitt schließt mit einer Diskussion der Darwinrezeption bei Lubbock und Huxley, die beide zwar bei ihren Zeitgenossen als Darwinianer galten, in ihr Evolutionsverständnis aber auch andere, undarwinianische Ansätze integrierten. ${ }^{2}$ Auch für Huxley hatte die Evolutionstheorie eine explizit politische Komponente. Der Paradigmawechsel der sogenannten darwinianischen Revolution setzte sich aus sozialen, politischen und theoretischen Komponenten zusammen - Komponenten, die auch die Einführung des Evolutionsparadigmas in der Anthropologie und den anthropologischen Rassentheorien kennzeichneten.

\section{1 "Wire-Pullers“ und „Bigwigs“. Der X-Club als wissenschaftspolitisches Organisationsinstrument}

Im November 1864 wurde bei einem Dinner in einer Hotellobby, strategisch günstig gelegen zwischen den tragenden Säulen der viktorianischen scientific community, der Royal Institution und der Royal Society, eine der einflußreichsten pressure groups in der Geschichte der Wissenschaften gegründet: der X-Club. ${ }^{3}$ Anwesend waren neben Huxley, Lubbock, Spencer und Busk noch Edward Frankland (Chemiker, Royal Institution), Thomas Archer Hirst (Mathematiker, University College London), Joseph Dalton Hooker (Botaniker, Kew Gardens) und John Tyndall (Physiker, Royal Institution); William Spottiswoode (Verleger und Mathematiker) stieß als neuntes Mitglied bei der zweiten Sitzung hinzu. Auf ein ursprünglich vorgesehenes zehntes Mitglied konnten sich diese neun nicht mehr verständigen.

Der Kreis ist trotz jeweiliger Ausnahmen in mehrfacher Hinsicht homogen, was Alter, Herkunft oder berufliche Position anbelangt. Busk, Jahrgang 1807, war der älteste, Lubbock, 1834 geboren, der jüngste, die Geburtsjahrgänge häuften sich zwischen 1820 und 1825. Außer Spottis-

2 Obwohl George Busk (als Sekretär der Linnéan Society) das Darwin-Wallace Papier vorgetragen hatte, hat er selbst keine nachvollziehbare Diskussion der Evolutionslehre geführt und überhaupt eine Positionierung in dieser Frage nicht geleistet, er fällt deshalb aus der Analyse in Hinblick auf das Evolutionsverständnis heraus.

3 Vgl. JTAH, Bd. 9, S. 163. 
woode und Lubbock waren alle X-Club Mitglieder auf den Broterwerb durch ihre wissenschaftlichen Tätigkeiten angewiesen. Alle außer Spencer waren anerkannte Naturwissenschaftler und Mitglieder der Royal Society. ${ }^{4}$ Gemeinsam repräsentierten sie eine neue soziale Trägerschicht der Wissenschaften, deren theoretische Orientierung und beruflichen Aspirationen eine Kampfansage an die etablierten Gentleman-Wissenschaften waren - besonders vor dem Hintergrund ihrer sozialen Herkunft und ihrer Bildungswege. Ausgehend von Spencer, Huxley, Lubbock und Busk, den für die Entwicklungen im Diskurs der Rassentheorien relevanten Autoren des X-Clubs, wird im folgenden sein Entstehen, sein Wirken und sein Niedergang diskutiert.

\section{Herbert Spencer}

Herbert Spencer wurde am 27. April 1820 in Derby geboren. Der Vater war Lehrer, der Haushalt methodistisch. In seiner Jugend besuchte Spencer für drei Jahre eine Privatschule, der er aber rasch entwuchs, denn bereits mit elf Jahren hörte er öffentlich gehaltene Vorträge und Lesungen. ${ }^{5}$ Die Eltern hatten an klassischen Bildungsinhalten wenig Interesse. Statt dessen wurde anwendungsbezogene Kenntnisse in den Naturwissenschaften geschätzt. Der religiöse Nonkonformismus, der sich von der anglikanischen Kirche abgewandt hatte, war bis weit ins neunzehnte Jahrhundert von den traditionellen englischen Universitäten ausgeschlossen und hatte daraufhin eigene Bildungskodizes entwickelt. ${ }^{6}$ Obgleich es zu Lebzeiten Spencers Nonkonformisten wieder möglich war, am Londoner University College oder an einer der renommierten schottischen Universitäten zu studieren, wurde als angemessenste Ausbildung für ihn die Unterrichtung durch seinen Onkel, Reverend Thomas Spencer, erachtet. Dieser unterwies ihn in Sprachen, Mathematik und Zeichnen - Kenntnisse, die Spencer für eine Ingenieurslaufbahn qualifi-

4 Vgl. Ruth Barton (1990) „An Influential Set of Chaps““. In: British Journal for the History of Science 23, S. 53-81, S. 54-56.

5 Die Schilderung des Lebens und des Werdeganges Herbert Spencers auf den kommenden Seiten stützt sich auf folgende Werke, die im weiteren Verlauf nicht mehr als Quellen angeführt werden: David Duncan (1908) Life and Letters of Herbert Spencer. London: Methuen; Herbert Spencer (1904b) An Autobiography. London: Williams \& Norgate, 2 Bde.; Hugh Samuel Roger Elliot (1917) Herbert Spencer. London: Constable; James G. Kennedy (1978) Herbert Spencer. Boston: Twayne; Beatrice Webb (1926) My Apprenticeship. London: Longmans, Green; Wiltshire 1978, S. 3-131.

6 Vgl. allgemein Rupert E. Davies (1963) Methodism. Harmondsworth, London: Penguin. 
zierten, welche er im November 1837 auch mit einem Engagement bei der London and Birmingham Railways begann.

Der Eisenbahnbau jener Jahrzehnte war eine der Triebfedern der Industrialisierung Großbritanniens, und das Streckennetz wurde in die entlegensten Gegenden ausgeweitet. 1843 gab Spencer aber das Ingenieurswesen wieder auf und versuchte sein Glück als Journalist in London. Dabei interessierte er sich insbesondere für Fragen der Sozialpolitik und der Armengesetzgebung. ${ }^{7} 1851$ erschien Spencers erstes Buch, Social Statics, in dem er sein stark individualistisch gefärbtes Verständnis des Liberalismus entwickelte: „Jeder Mann hat die Freiheit alles zu tun was ihm beliebt, vorausgesetzt, er verletzt nicht die gleiche Freiheit eines anderen". 8

In den fünfziger Jahre baute Spencer ein soziales Netzwerk auf, aus dem zum Teil lebenslange Freundschaften hervorgehen sollten. Bei Soireen im Haus seines Verlegers John Chapman mischte er sich unter das radikal-liberale London und traf auf so profilierte Köpfe wie den Philosophen und Literaten George Henry Lewes oder Marian Evans, Herausgeberin des Westminster Review, die später unter dem Pseudonym George Eliot literarischen Ruhm erlangen sollte. Hier begegnete er zum ersten Mal Huxley, den er zuvor schriftlich um Details zu dessen Weichtierforschung gebeten hatte - Kenntnisse, die er für seine werdende Evolutionstheorie benötigte.

\section{Thomas Henry Huxley}

Thomas Henry Huxley wurde am 4. Mai 1825 in Ealing, damals noch ein Dorf westlich Londons, geboren. ${ }^{9}$ Sein Vater war dort als Lehrer an

7 Bereits 1836 hatte er einen Leserbrief zu den damals gerade verabschiedeten und reformierten Poor Laws verfaßt (vgl. Herbert Spencer (1836) „Poor Laws: Reply to ,T.W.S.“.. In: The Bath and West of England Magazine 3, S. 81-83). Für den Nonconformist schrieb er unter anderem über die sogenannten Rebecca Riots in Wales. Als ,Rebecca Riots“ wurden Unruhen in Süd-Wales der Jahre 1839 bis 1842 bezeichnet, die sich konkret an Wegenutzungsgebühren entzündeten, aber grundsätzlich auf eine angespannte Situation für die verarmte Landbevölkerung und den Unmut über das 1834 verschärfte Armengesetz zurückgeführt wurden.

8 Herbert Spencer (1851) Social Statics: or, the Conditions Essential to Human Happiness Specified and the First of them Developed. London: Chapman, S. 103: „Every man has the freedom to do all that he wills, provided he infringes not the equal freedom of any other man".

9 Die Darstellung beruht auf folgenden Werken und Aufsätzen: Thomas H. Huxley (1890) „Autobiography“. In: [L. Engel (Hrsg.): From Handel to Halle: Biographical Sketches with Autobiographies of Professor Huxley and Professor Herkomer. 1890] Collected Essays, Bd. 1, S. 1-17; Leonard Huxley (1900) Life and Letters of Thomas Henry Huxley. 2 Bde. London: 
der örtlichen Public School beschäftigt. Sinkende Schülerzahlen veranlaßten ihn allerdings, mit seiner Familie nach Coventry umzusiedeln. Bescheidener finanzieller Verhältnisse wegen konnte der junge Huxley seinen in Ealing begonnenen Schulbesuch nicht fortsetzen. Statt dessen begann er eine Medizinerausbildung, die er ab 1841 bei einem Arzt im Londoner Elendsquartier Rotherhithe fortsetzte, wo er das ganze Ausmaß der städtischen Armut erlebte. 1845 wurde er Bachelor of Medicine an der Medical School des Charing Cross Hospitals.

Wie vor ihm bereits Charles Darwin, heuerte Huxley als Assistenzarzt bei der Royal Navy an. Sein Schiff, die HMS Rattlesnake, verließ Plymouth 1846 mit Kurs auf Australien. ${ }^{10}$ Seine naturwissenschaftliche Arbeit an Bord wurde allerdings nicht mit der gleichen Großzügigkeit wie die Darwins auf der Beagle behandelt, mehrfach beförderte die Besatzung die Kadaver seiner Sektionen ins Meer. ${ }^{11}$ Dennoch kehrte er im Oktober 1850 mit zahllosen konservierten Proben und Notizen im Gepäck nach London zurück. Er hatte von Übersee aus Forschungsberichte und Aufsätze nach England geschickt und sich durch ihre Veröffentlichung erste wissenschaftliche Anerkennung verdient. ${ }^{12}$

Auf diesem Grundstein galt es, eine Karriere aufzubauen. Huxley war in den folgenden Jahren zunächst vergeblich bemüht, auf eine wissenschaftliche Position berufen zu werden, die ihm ausreichende finanzielle Sicherheiten hätte bieten können. Seine Umtriebigkeit führte ihn in der Londoner scientific community mit gestandenen Naturwissenschaftlern wie dem Naturkundler Edward Forbes oder dem Geologen und Vertrauten Darwins, Charles Lyell, zusammen. Im Red Lions Club, dem Dining Club der British Association, traf er auf George Busk, mit dem gemeinsam er 1852 Albert von Köllikers Handbuch der Gewebe-

Macmillan; Ashforth 1969; William Irvine (1963) Apes, Angels, and Victorians. Darwin, Huxley, and Evolution. New York: Time; Desmond 1998; White 2003. Auf diese Quellen wird in diesem Kapitel nicht gesondert verwiesen.

10 Vgl. Desmond, Moore 1994; Leonard Huxley (1921) Life and Letters of Sir Joseph Dalton Hooker. 2. Bde. London: Macmillan; Julian Huxley (1936) T. H. Huxley's Diary of the Voyage of H.M.S. Rattlesnake. Garden City, New York: Doubleday, Doran.

11 Vgl. Joel S. Schwartz (1997) „,A Good Impudent Faith in My Own Star“. Thomas Henry Huxley's Odyssey in the South Seas“. In: Alan P. Barr (Hrsg.): Thomas Henry Huxley's Place in Science and Letters: Centenary Essays. Athens, Georgia: University of Georgia Press, S. 67-94, S. 71.

12 Vgl. Thomas H. Huxley (1850) „Notes on Medusæ and Polypes”. In: Annals and Magazine of Natural History 6, S. 66-67; Thomas H. Huxley (1852) „Upon Animal Individuality“. In: [Proceedings of the Royal Institution of London 1, 1852, S. 184-189] The Scientific Memoirs of Thomas Henry Huxley, Bd. 1, S. 146-151. 
lehre des Menschen übersetzte. Der Royal Society, die gerade ihre Mitgliederstruktur zugunsten aktiver Wissenschaftler verändert hatte, trat Huxley im Mai 1851 bei. Noch im selben Jahr machte er Bekanntschaft mit John Tyndall und Joseph Dalton Hooker. Gerade weil Huxley zunächst der finanzielle Erfolg verwehrt blieb, spannte er ein Netz von Bekanntschaften und Allianzen, das er bei der Verfolgung seiner Aspirationen wirkungsvoll einzusetzen wußte.

\section{John Lubbock}

John Lubbock wurde am 30. April 1834 in London geboren. ${ }^{13}$ Sein Vater, Sir John William Lubbock, war Inhaber eines Londoner Bankhauses, Mitglied der Royal Society, erster Vize-Präsident der London University und hatte einige Schriften zu Astronomie und Mathematik veröffentlicht. John Lubbock wuchs auf dem Landsitz der Familie in High Elms bei Farnborough südlich von London auf. Lubbocks Eltern hatten zwar liberale Bildungsideale, betonten aber dennoch die Notwendigkeit einer klassischen Ausbildung. Vor allem durch die Mutter lernte er Geographie und Bibelkunde. Hierbei entstand eine dezente Religiosität, die Lubbock Zeit seines Lebens nicht aufgab. Vom neunten Lebensjahr an besuchte er die Eliteschule in Eton. Die Nachbarschaft Charles Darwins, der über das Bankhaus Lubbock seine Geschäfte abwickelte und 1842 nur wenige Meilen südlich von High Elms in Down seinen Landsitz bezogen hatte, sollte sein Leben nachhaltig verändern. Denn Darwin nahm den interessierten Lubbock unter seine Fittiche und unterwies ihn regelrecht in der Methodik naturwissenschaftlichen Arbeitens. Im Alter von sechzehn Jahren stieg Lubbock als Mitinhaber in das väterliche Bankgeschäft ein. Doch die beruflichen Verpflichtungen hinderten ihn nicht daran, seine naturwissenschaftlichen Interessen weiter zu verfolgen. Ab 1853 erschienen erste Aufsätze von Lubbock, in denen er neue Erkenntnisse seiner mikroskopischen Studien präsentierte. ${ }^{14}$ Diese waren über-

13 Ich stütze mich im Wesentlichen auf folgende Quellen: Ursula Grant Duff (1924) The Life Work of Lord Avebury (Sir John Lubbock) 1834-1913. London: Watts; Horace G. Hutchinson (1914) Life of Sir John Lubbock, Lord Avebury. 2 Bde. London: Macmillan; Ruth Barton (2004) „Lubbock, Sir John, Lord Avebury (1834-1913)“. In: Bernard Lightman (Hrsg.): The Dictionary of Nineteenth-Century British Scientists. Bristol: Thoemmes; Patton (im Erscheinen); R. Pumphrey (1958) „The Forgotten Man - Sir John Lubbock, F.R.S.“ In: Notes and Records of the Royal Society of London 13, S. 49-58.

14 John Lubbock (1853a) „Description of a New Genus of Calanidae“. In: The Annals and Magazine of Natural History 11, S. 25; John Lubbock (1853b) „On two new Subgenera of Calanidæ“. In: The Annals and Magazine of Natural History 11, S. 202-209; John Lubbock (1857) „Description 
zeugend genug, so daß er von Darwin in die scientific community eingeführt werden konnte. Darwin stellte ihn verschiedenen späteren Mitgliedern des X-Clubs wie Huxley, Busk und Hooker vor, und als sein Mentor ermöglichte er 1856 seine Aufnahme in die Royal Society als eines ihrer jüngsten Mitglieder überhaupt.

\section{George Busk}

George Busk wurde am 12. August 1807 als Sohn eines Kaufmanns in Sankt Petersburg geboren. ${ }^{15}$ Er studierte Medizin an den Londoner Hospitälern St Thomas's und Bartholomew's. Ab 1830 bekleidete er verschiedene Positionen bei der Marine in Greenwich, die längste Zeit diente er dort als leitender Arzt auf Lazarettschiffen, die als Quarantänestationen in der Themse lagen. In dieser Funktion befaßte sich Busk mit der Behandlung von Erkrankungen der inneren Organe. Eine seiner ersten großen Arbeiten war ein Bericht über den Ausbruch der Cholera an Bord eines der Lazarettschiffe, mit dem Busk und sein Partner Budd wichtige Impulse für die Verbesserung der sanitären Bedingungen in den urbanen Elendsquartieren der Zeit gaben. ${ }^{16}$ Von 1842 an war als er Mitherausgeber für das Microscopical Journal verantwortlich. Im Jahr darauf wurde Busk Mitglied am Royal College of Surgeons of London, an dem er in den Jahren zuvor Vorlesungen gehört hatte. 1845 übersetzte er das damals einflußreiche Buch Steenstrups On the Alternation of Generations und begann 1852 mit der Katalogisierung der zoologischen Sammlung des Britischen Museums.

\section{Die viktorianische Scientific Community}

Die scientific community Englands befand sich in den fünfziger Jahren in einem Umwälzungsprozeß, den 1831 ein Reformgesetz ausgelöst hatte. Bis weit ins neunzehnte Jahrhundert hinein war der Wissen-

of eight new species of Entomostraca found at Weymouth“. In: The Annals and Magazine of Natural History 20, S. 401-410; John Lubbock (1862b) „On two Aquatic Hymenoptera“. In: Report British Association 32, S. 110.

15 Die Quellenlage zu George Busk ist erheblich dünner als die bei den anderen X-Club Mitgliedern. Ich stütze mich im Wesentlichen auf zwei Quellen. Einen unbekannten Autor (Anon. (1901) „Busk, George (18071886)“. In: Dictionary of National Biography. Supplement 1, London: Smith and Elder, S. 357-358) und Cook 1997.

16 Vgl. George Busk; G. Budd (1838) „Report of twenty cases of malignant cholera that occurred in the Seamen's Hospital, Dreadnought, between the 8th and 28th of October, 1837“". In: Medico-Chirurgical Transactions 21, S. $152-186$. 
schaftsbetrieb neben etlichen Gesellschaften von Amateurwissenschaftlern auf einige wenige Universitäten und die Royal Society beschränkt. ${ }^{17}$ Die Reformen zielten auf eine Pluralisierung der akademischen Bildungslandschaft. Durch die von ihnen initiierte Gründung der British Association wurden die außerakademischen Wissenschaften nachhaltig stimuliert, die sich vor allem in Gelehrten-Gesellschaften organisierten. ${ }^{18}$ Doch während die Anzahl solcher Gesellschaften nach 1830 rapide in die Höhe schnellte, litten die universitären Neugründungen erst einmal unter Studentenmangel. ${ }^{19}$

Eine Wiederbelebung des Reformprozesses ging 1851 von der Great Exhibition in London aus, einem Vorläufer späterer Weltausstellungen. Sie stellte die technischen Errungenschaften der Zeit einem breiten Publikum zur Schau, und löste eine intensive Debatte über den Stand der technischen und wissenschaftlichen Ausbildungen aus, denn England attestierte sich eine alarmierende Rückständigkeit in Hinblick auf technische Innovationen. ${ }^{20}$ Diese Debatte korrespondierte mit dem wachsenden sozialen Stellenwert nicht nur technischer, sondern überhaupt moderner, wissenschaftlicher Ausbildung, im Gegensatz zur konservativen, altsprachlich orientierten Oxbridge-Qualifikation: Wissenschaft war für die aufstrebende industrielle, kommerzielle und professionelle Mittelklasse attraktiv, da sie aufgrund religiöser Orientierung, sozialer Herkunft oder geringen Vermögens von den traditionell einflußreichen Kreisen Oxfords oder Cambridges ausgeschlossen war. ${ }^{21}$

17 Vgl. hierzu: Ernest Barker (1946) British Universities. London: Longmans, Green; Henry Lyons (1944) The Royal Society 1660-1940. A History of its Administration under its Charters. Cambridge: Cambridge University Press; George Bassalla, William Coleman, Robert H. Kargon (1970) „Introduction“. In: Dies. (Hrsg.): Victorian Science. A Self-Portrait from the Presidential Addresses of the British Association for the Advancement of Science. Garden City, New York: Doubleday, S. 3-21; allgemein R. D. Anderson (1995) Universities and elites in Britain since 1800. Cambridge: Cambridge University Press.

18 Vgl. zur British Association: Jack Morrell; Arnold Thackray (1981) Gentlemen of Science. Early Years of the British Association for the Advancement of Science. Oxford: Clarendon; A. D. Orange (1981) „The Beginnings of the British Association, 1831-1851“. In: Roy MacLeod, Peter Collins (Hrsg.): The Parliament of Science. Northwood, Midx.: Science Reviews, S. 43-64; Negley Harte (1986) The University of London. 18361986. London: Athlone.

19 Vgl. Anderson 1995, S. 6.

20 Vgl. Bassalla, Coleman, Kargon 1970, S. 12-15.

21 Steven Shapin; Arnold Thackray (1974) „Prosopography as a Research Tool in History of Science: The British Scientific Community 17001900“. In: History of Science 7, S. 1-28, S. 7: „Science could and did appeal to legions of the ascending industrial, commercial and professional 
Ein anderer Indikator dieser Entwicklung war das Anwachsen der wissenschaftlichen Kommunikation über Veröffentlichungen und Journale. $^{22}$ Die Veränderungen in den Wissenschaften, die auf eine Verweltlichung der universitären Ausbildung zielten, wurden nun auch durch die stetig steigende Zahl Studierender verstärkt, die ab den sechziger Jahren eine Steigerung bei den Neugründungen von Universitäten und anderen akademischen Einrichtungen herbeiführte. ${ }^{23}$ In diesem Klima des Aufbruchs kreuzten sich die Wege der späteren Mitglieder des X-Clubs.

\section{"Scientific Young England“. Die Entwicklung des X-Club Netzwerks}

In den frühen fünfziger Jahren begann sich das Netz von Bekanntschaften zwischen den Akteuren des späteren X-Clubs zu entwickeln. Es basierte dabei zum Teil auf bereits bestehenden Cliquen, wie etwa dem Trio John Tyndall, Thomas Archer Hirst und Edward Frankland oder dem Kreis von Huxley, Busk und Joseph Dalton Hooker. Diese Freundschaften knüpften an gemeinsamen Studienzeiten in Deutschland an, oder waren das Resultat beruflicher Kontakte. ${ }^{24}$

Doch es war vor allem die schmerzliche Erfahrung, daß wissenschaftliches Arbeiten im damaligen England noch kaum zum gesicherten Broterwerb taugte, die sie einander näherbrachte und die wesentlich den Korpsgeist des späteren X-Clubs prägte. Ungeachtet ihrer wissenschaftlichen Qualifikationen, erworben auf Forschungsreisen oder an deutschen Universitäten, die als vorbildlich für die englische Wissenschaft galten, hatten Tyndall, Frankland, Hirst und Huxley gleichermaßen Schwierigkeiten, in den Wissenschaften eine Anstellung zu erhalten. Sie erklärten sich ihre Lage mit der hermetischen Abschließung des Wissenschaftsbetriebes durch die etablierten ,Gentleman-Wissenschaftler', die ,gentleman-scientists‘. Denen gegenüber entwarfen sie deshalb ein Selbstbild des mittelständischen ,Mannes der Wissenschaften“, des ,man of science'.

Spencers berufliche Lage war kaum weniger prekär. Er arbeitete bereits an seiner Theorie organischer Evolution und nahm deshalb 1852 mit Huxley Kontakt auf. Huxley fand an Spencers Evolutionsgedanken

middle-classes who, because of religion, social origin, wealth, or personal disposition, were excluded from the traditional socializing influences of Oxford, Cambridge and other lairs of polite learning".

22 Vgl. Ruth Barton (1998a) „Just before Nature: The Purposes of Science and the Purposes of Popularization in some English Popular Science Journals of the 1860s". In: Annals of Science 55, S. 1-33.

$23 \mathrm{Vgl}$. Anderson 1995, S. 14.

24 Vgl. Barton 1998b, S. 416-420. 
Gefallen und stellte ihn Hooker als einen „Kerl der spekuliert“ vor. ${ }^{25}$ Darwin wiederum, der in Down in relativer Abgeschiedenheit lebte, nahm zu jener Zeit den Kontakt mit Huxley auf und stellte die Verbindung zu Lubbock über Fragen ihrer mikroskopischen Anatomiestudien her. ${ }^{26}$ Er lud beide zu sich nach Down ein. ${ }^{27}$ Dies drückt nicht nur die Würdigung der wissenschaftlichen Arbeit Huxleys durch den Gentleman-Wissenschaftler Darwin aus, es zeigt zugleich, daß für Huxley die Frontstellung von ,gentleman-scientist" und ,man of science ' durchlässig war, denn seine eigene Lage als Berufswissenschaftler war durchaus verschieden vom amateurwissenschaftlichen Arbeiten Lubbocks und auch Darwins. $^{28}$

Huxley erhielt erst 1854 seine erste Anstellung als Dozent der Naturgeschichte an der Government School of Mines. Das Problem eines geregelten Einkommens war damit nur unzulänglich behoben. Doch auf die Anerkennung für seine Forschungsleistung mußte Huxley nicht länger warten. Er, Tyndall und Hooker, das Dreigespann des wissenschaftlichen Nachwuchses, in seinen Worten das ,wissenschaftliche Young England“ (,scientific Young England“), erhielten nacheinander in den Jahren 1852 bis 1854 die begehrte Medaille der Royal Society. ${ }^{29}$ Dies war auch ein Indiz für ein zunehmend meritokratisches Verfahren in den viktorianischen Wissenschaften, das seine Anerkennungen nun nicht mehr vorrangig dem sozialen Titel, sondern auch wissenschaftlichen Verdiensten zollte.

Auch Spencers Bestreben, von der Wissensproduktion seinen Lebensunterhalt $\mathrm{zu}$ bestreiten, blieb lange der Erfolg verwehrt. Um sich

25 Vgl. Duncan 1908, S. 65.

26 Vgl. Adrian Desmond; James Moore (1994) Darwin. Reinbek: Rowohlt, S. 460-461; Darwin an Huxley, 17. Juli 1851. In: CCD, Bd. 6, S. 49.

27 Vgl. Darwin an Lubbock, 24. April 1856. In: CCD Bd. 6, S. 87; Darwin an Huxley, 09. Dezember 1856. In: CCD Bd. 6, S. 301; Darwin an Lubbock, 30. März 1858. In: CCD Bd. 7, S. 58.

28 Vgl. White 2003, S. 4.

29 Huxley an Elizabeth Huxley, 27. März 1858. In: HP 31.24. Mit dem Terminus „Scientific Young England“ ruft Huxley eine Analogie zur ,Young England“ Bewegung der vierziger Jahre des neunzehnten Jahrhunderts auf, die von Benjamin Disraeli, zu jener Zeit gerade ins Unterhaus gewählter Literat und anderen, jungen Aristokraten und Eton-Absolventen gegründet wurde. Das ,Young England“ wird als romantisierende Variante eines sozialen Toryismus verstanden, die Bewegung hatte sich ebenso der Rekonstitution einer Staatskiche wie der Kritik an den sozialen Verwerfungen der Industrialisierung verschrieben (vgl. Louis Cazamian (1973) The Social Novel in England 1830-1850. London, Boston: Routledge and Kegan Paul; John Morrow (1999) „Introduction“. In: Ders. (Hrsg.): Young England: The New Generation: A Selection of Primary Texts. London: Continuum, S. 1-28). 
eine finanziell solide Arbeitsgrundlage zu schaffen, wandte er sich im Frühjahr 1860 mit einem Entwurf seines System of Synthetic Philosophy und der Bitte um Subskription an die renommiertesten Vertreter der britischen Wissenschaften und Philosophie. Bereits wenige Monate später bilanzierte er seinen Erfolg und ging davon aus, 350 namhafte Subskribenten allein in Europa gewinnen zu können.

Lubbock teilte die pekuniären Sorgen Huxleys, Spencers und der meisten der späteren X-Club Mitglieder nicht. Er und William Spottiswoode lebten in finanziell abgesicherten Verhältnissen. Auch wenn sie eher als Gentleman-Wissenschaftler betrachtet werden müssen, rechneten sie dennoch zur Garde der wissenschaftlichen Modernisierer, zu deren Ikone der umtriebige Huxley wurde. Dessen ,Mann der Wissenschaften" definierte sich folglich weniger von seinem sozialen Status als von seinem Wissenschaftsverständnis her.

Die Geschicke der zukünftigen X-Club-Gefährten ähnelten sich zunehmend. Schon 1855 hatte sich Busk aus dem Dienst in Greenwich zurückgezogen, um sich ausschließlich der Wissenschaft zuzuwenden. In der scientific community war er zu diesem Zeitpunkt bereits etabliert, ein Mitglied der British Association und der Linnean Society. 1856 wurde ihm die Hunterian-Professur am Royal College of Surgeons übertragen. Huxley und Tyndall lehrten zur gleichen Zeit an der Royal Institution. Das ,scientific Young England“ hatte zwar erfolgreich nach Posten gegriffen, doch seine Aspirationen reichten bereits weiter, denn die Diskurshoheit wurde immer noch vom konservativen Oxbridge ausgeübt und die Londoner Naturwissenschaften von Richard Owen dominiert. Der Anatom und Paläontologe Owen war ein erklärter Gegner des Lamarckismus und transmutativer Theorien in den Naturwissenschaften. Da er die Fuller Professur für Anatomie an der Royal Institution bekleidete und Direktor der naturwissenschaftlichen Abteilung des British Museums war, konnte er den naturwissenschaftlichen Diskurs auf mehreren Ebenen steuern.

Zwar hatten Huxley und die anderen jungen Wissenschaftler im Wissenschaftsbetrieb Fuß fassen können, doch angesichts der konservativen Dominanz in den Naturwissenschaften war die weitere Entwicklung fraglich. Die zur Dynamisierung der Situation notwendige revolutionäre Theorie war jedoch in der Abgeschiedenheit Downs bereits im Entstehen begriffen. Darwin war sich der Brisanz seiner Ergebnisse bewußt und suchte die Nähe zu den aufstrebenden Londoner Wissenschaftszirkeln, weil er in ihnen wichtige Bündnispartner vermutete. Darwin war insbesondere an der Zustimmung des streitbaren Huxley interessiert, der sich mit Owen bereits befehdete, seinem, wie Darwin ver- 
mutete, bedeutendsten Widersacher. ${ }^{30}$ Im April 1856 lud er Huxley und Hooker nach Down zu intensiven Arbeitssitzungen ein. ${ }^{31}$ Ihnen ging es um die Frage, inwieweit aus den fossilen Funden eine Theorie der Transmutation entwickelt werden könne. Darwin, Hooker und Huxley stellten den inner circle der Darwinianer dar, der nicht nur von einem gemeinsamen wissenschaftlichen Projekt, sondern auch von einer „Kameraderie" getragen wurde, wie sie sich Darwin sonst keinem seiner Kollegen gegenüber leistete. ${ }^{32}$

In den fünfziger Jahren schärfte Huxley sein Profil in der scientific community auch dadurch, daß er in öffentlichen Vorlesungen heftige Kritik an Owen und seiner Theorie der Parthenogenese, der eingeschlechtlichen Fortpflanzung, übte. ${ }^{33}$ Die Heftigkeit wurde von einigen seiner Biographen auf einen persönlichen Groll zurückgeführt, seine Verbündeten waren darüber keinesfalls glücklich. ${ }^{34}$ Zwar wurde der Schaden begrüßt, den der Widersacher Owen nahm, doch gleichzeitig befürchteten sie, Huxley und mit ihm der Kreis von ambitionierten Wissenschaftlern könne an Ansehen verlieren. So riet Darwin Hooker sogar davon ab, Huxley für den erlesenen Athenaeum Club zu nominieren, da er den Codex des Gentlemans nicht beherrsche. ${ }^{35}$

Seine vehemente Anfeindung Owens hatte Huxley für eine kurze Zeit den Zugang zu Kreisen der Gesellschaft versperrt. Erst 1858 verwendete sich Hooker erfolgreich für Huxleys Aufnahme in den erlesenen Londoner Club und gemeinsam bereiteten sie danach Busk und Tyndall den Weg. ${ }^{36}$ Lubbock war ebenso Mitglied wie Spencer, der aber erst 1868 aufgenommen wurde. ${ }^{37}$ Der Athenaeum Club pflegte eine exklusive und zugleich diskrete Atmosphäre, in der die Prominenz aus

30 Vgl. Desmond, Moore 1994, S. 466, 488-490; James Moore (1991) „Deconstructing Darwinism: The Politics of Evolution in the 1860s“. In: Journal of the History of Biology 24, S. 353-408, S. 367.

31 Vgl. Joseph Dalton Hooker an Huxley, 4. April 1856. In: HP 3.24: „I am glad that we shall meet at Darwins. I wish that we could there discuss some plan that would bring about more unity in our efforts to advance science“; Desmond, Moore 1994, S. 490-495.

32 Moore 1991, S. 367.

33 Vgl. Adrian Desmond (1982) Archetypes and Ancestors. Palaeontology in Victorian London, 1850-1875. London: Blond, Briggs, S. 22-37; Huxley an W. Macley, 9. November 1851. In: LLTHH, Bd. 1, S. 94: „Owen [...] can only work in the concrete from bone to bone, in abstract reasoning he becomes lost - witness ,Partenogenesis' which he told me he considered one of the best things he had done".

34 Vgl. Desmond 1982, S. 20-29.

35 Vgl. White 2003, S. 48-50.

36 Vgl. White 2003, S. 48; Desmond 1998. S. 241-242; Humphrey Ward (1926) History of the Athenaum. 1824-1925. London: Athenaeum.

37 Vgl. Spencer 1904b, Bd. 2, S. 177. 
Politik, Kultur und Wissenschaft abgeschirmt von der Öffentlichkeit miteinander Kontakt hielt. Er wurde zu einem wichtigen infrastrukturellen Stützpunkt des X-Clubs, denn man traf sich hier nicht nur regelmäßig zum Dinner, später wurden hierhin oft auch einflußreiche Gäste zu gemeinsamen Besprechungen eingeladen.

Darwins Sorge um die Etikette war nicht mehr zeitgemäß. Dies zeigt der stetige Reputationsgewinn Huxleys und die wachsende Zahl seiner öffentlichen Vorlesungen. Als ihm 1858 die Ehre zukam, die Croonian Lecture der Royal Society halten zu dürfen, hatte dies keines besonderen Protegierens bedurft. Seine Vorlesung hatte aufgrund des erlesenen und zahlreichen Publikums das Format eines Galaabends. Huxley behandelte die Frage der Herkunft des Schädels, und er nutzte diese Gelegenheit, die von Lorenz Oken herrührende Überzeugung Owens, der Schädel habe sich aus der Wirbelsäule herausgebildet, in das Reich der Mythen zu verweisen. ${ }^{38}$

Die Akklamation der im wissenschaftlichen Rahmens versammelten Elite stand im Kontrast zu ihrer reservierten Haltung, wenn es um Aufnahme in einen elitären, sozialen Kreis ging. An dieser unterschiedlichen Haltung des Establishments gegenüber Huxley zeigt sich bereits, daß das von der Royal Society verkörperte Wissenschaftssystem nach anderen Maßgaben strukturiert war als das politische System, dem der Diskurs des Athenaeum Clubs zuzurechnen ist.

\section{Origin of Species}

Die Geschichte der Entstehung von Darwins Origin of Species ist hinlänglich bekannt. Aufgeschreckt durch einen Brief von Alfred Russell Wallace, in dem dieser eine der Darwinschen Überlegung sehr ähnliche Theorie entwarf, beschloß Darwin, die langwierigen Arbeiten an seinem eigentlich größer geplanten Werks abzukürzen. Nachdem ein gemeinsames Papier von Wallace und Darwin im Juli 1858 von George Busk vor der Linnéan Society verlesen worden war, erschien On the Origin of Species im November 1859. Das Buch erregte unmittelbar nach Veröffentlichung die Gemüter der konservativen und klerikalen Kreise, die nicht nur den Vorwurf des Nihilismus erhoben, sondern vor allem gegen die befürchtete Naturalisierung des Menschen wetterten: Darwins Theorie wurde als ,Affen-Theorie' diffamiert. ${ }^{39}$

38 Vgl. Lyons 1999, S. 199; Lorenz Oken (1779-1851), romantischer Naturphilosoph und Mediziner, Professuren der Philosophie in Jena, München und Zürich.

39 Vgl. Stocking 1987, S. 146. 
In die aufbrandende Debatte um Darwins Origin griff Huxley so entschieden ein, daß er sich den Titel „Darwin's Bulldog“ verdiente. Zwar war er kein restlos überzeugter Vertreter der Darwinschen Lehre und machte aus seinem Zweifel auch keinen Hehl, in der Öffentlichkeit galt er dessenungeachtet als das Zugpferd des Darwinianischen Lagers. ${ }^{40}$ Nach einer Reihe von äußerst konträren Rezensionen ergab sich bei der Jahreskonferenz der British Association im Sommer 1860 in Oxford die erste Gelegenheit, vor größerem Publikum die Bedeutung des Origin of Species zu diskutieren. Huxley, Lubbock und Hooker verteidigten die Theorie Darwins gegen heftige Kritiken. Besonders die Auseinandersetzung zwischen Huxley und Bischof Samuel Wilberforce wurde in der Presse skandalisiert, da sie über die brisante Frage der Bedeutung der Lehre Darwins für die Rolle des Menschen in der Natur geführt wurde. ${ }^{41}$ Durch diese Konfrontation gewann das ,scientific Young England“ weiter an Reputation. Huxleys Aufstieg wurde dadurch zusätzlich befördert. $^{42}$ Zugleich ging der durch Wilberforce verkörperte klerikale Einfluß auf die wissenschaftlichen Diskurse zurück.

Spencer beschritt zu dieser Zeit eigene Wege. Mit Darwin verband ihn nie mehr als ein distanzierter Austausch von Höflichkeiten. An der Debatte um dessen Buch beteiligte er sich nicht, überhaupt trat er in den frühen sechziger Jahren kaum an die Öffentlichkeit, er schien völlig von der Arbeit an seinem System der Synthetic Philosophy in Beschlag genommen gewesen zu sein. Daß er dennoch ein integraler Teil des sich langsam zum X-Club auswachsenden Netzwerkes von Freundschaften zählte, lag neben persönlichen Affinitäten auch daran, daß das ,scientific Young England' große Hoffnungen in seine Evolutionstheorie und ihre öffentliche Rezeption investierte.

\section{"Plastically minded young men". Aktivitäten des X-Club-Netzwerkes}

Zur Stärkung ihrer Position in den wissenschaftlichen Auseinandersetzungen über Evolutionstheorien und den Origin of Species hatte Huxley

40 Vgl. Robert J. Richards (1992) The Meaning of Evolution: The Morphological Construction and Ideological Reconstruction of Darwin's Theory. Chicago: University of Chicago Press, S. 159-160.

41 Vgl. J. Vernon Jensen (1988) „Return to the Wilberforce-Huxley Debate“. In: British Journal for the History of Science 21, S. 161-179; Edward Caudill (1994) „The Bishop-Eaters: The Publicity Campaign for Darwin and the Origin of Species“. In: Journal of the History of Ideas 55, S. 441460.

42 Huxley wurde 1861 Vize-Präsident der Zoological Society und ein Jahr später Sekretär der Geological Society. 
1860 ein Quartals-Journal übernommen, den Natural History Review. ${ }^{43}$ Er erklärte Hooker wenige Wochen nach seiner Auseinandersetzung mit Wilberforce, was ihn zu diesem Schritt bewogen hatte:

„Bedenkt man die gegenwärtigen Situation und die schlechte Versorgungslage mit naturgeschichtlichen Journalen [...] in diesem Land, scheint dies eine günstige Gelegenheit für einen gestalterisch veranlagten jungen Mann [...]. Um das Maß dieser zusätzlichen Arbeit zu begrenzen, brauche ich jedoch Mitherausgeber und ich habe Lubbock und Rolleston geschrieben (auch gestalterisch veranlagte junge Männer), um zu sehen, ob sie sich beteiligen“. ${ }^{44}$

Die Stoßrichtung des Natural History Review unterstrich er noch, indem er erklärte, das Blatt würde „mild episcophagus“ ausgerichtet sein, ein wenig bischof-verspeisend. ${ }^{45}$ Darwin warnte sowohl Huxley als auch Lubbock vor dem Umfang dieser zusätzlichen Arbeit, doch beide ignorierten seine Bedenken und bildeten gemeinsam mit Busk, William B. Carpenter und George Rolleston die Redaktion des Natural History Review. ${ }^{46}$ Für einige Jahre hielten sie so ein effektives Sprachrohr der wissenschaftspolitischen Intervention in den Händen. Die Mehrzahl der Beiträge widmete sich den damals aktuellen naturwissenschaftlichen Debatten und einen besonderen Schwerpunkt bildeten die anthropologischen und archäologischen Fragen, zu denen Huxley und Lubbock selbst viele Stellungnahmen beisteuerten.

Obwohl die Auflagenzahl mit rund eintausend eher durchschnittlich war, sind Historiker des X-Clubs und Biographen seiner Mitglieder nur am Rande auf die Beweggründe für dieses arbeitsintensive und wirtschaftlich riskante Unterfangen eingegangen. ${ }^{47}$ An den Natural History

43 Schon 1858, so Ruth Barton, hätten Hooker, Tyndall, Huxley und Frankland sich mit dem Gedanken getragen, ein wissenschaftliches Magazin aufzulegen (vgl. Barton 1998b, S. 428-429).

44 Huxley an Hooker, 17. Juli 1860. In: LLTHH Bd. 1, S. 209: ,[C]onsidering the state of the times, and the low condition of natural history journalisation [...] in this country this seems to me to be a fine opening for a plastically minded young man [...]. To limit the amount of this extra work, however, I must get co-editors, and I have written to Lubbock and to Rolleston (also plastically minded young men) to see if they will join".

45 Ebd.

46 Vgl. Barton 1998b, S. 433. William Benjamin Carpenter (1813-1885) hatte sich durch sein Buch Principles of general and comparative physiology (London 1839) als Physiologe etabliert, George Rolleston (18291881) war Naturwissenschaftler.

47 Vgl. W. H. Brock (1980) „The Development of Commercial Science Journals in Victorian Britain“. In: Arthur Jack Meadows (Hrsg.): Development of Science Publishing in Europe. Amsterdam u.a.: Elsevier, S. 95-122, S. 
Review knüpften seine Herausgeber großer Erwartungen. Er war nicht nur ein Mittel, direkt und ungefiltert für die Etablierung der darwinschen Lehre streiten zu können, er erlaubte auch, auf den von vielen Magazinen nur vorsichtig behandelten Feldern der Anthropologie und Ethnologie evolutionstheoretische Interpretationen $\mathrm{zu}$ veröffentlichen (s.u.). Doch die Hoffnung, die Mehrarbeit problemlos bewältigen zu können, erfüllte sich nicht. Und so gab der X-Club den Natural History Review 1865 wieder auf.

Zur konstituierenden Zusammenkunft des X-Clubs im November 1864 war es dann Spencer, der den Erwerb eines weiteren Journals vorschlug. ${ }^{48}$ The Reader hatte ein entschieden anderes Format als der Natural History Review. War letzterer ausschließlich der Wissenschaft verschrieben, versuchte der zudem wöchentlich erscheinende Reader, sich als Organ der Avantgarde in einem Spektrum von Politik, Literatur und Wissenschaft zu etablieren. Huxley und Lubbock waren begeistert, sie zeichneten gemeinsam mit Tyndall, Spottiswoode und Darwin Anteile. ${ }^{49}$ Die redaktionelle Verantwortung trugen sie nicht mehr selbst, hierfür wurden Redakteure engagiert, unter ihnen Norman Lockyer, der das Wissenschaftsressort leitete. Doch weil sich einerseits die finanzielle Lage des Readers nicht konsolidierte und er andererseits kein evolutionäres Profil annahm, wurde auch dieses Projekt 1865 wieder eingestellt. Diese Episoden zeigen, daß der X-Club versuchte, auf verschiedenen Wegen die Evolutionstheorie zu verbreiten. Doch der Reader stellte aufgrund seiner thematischen Bandbreite eine Ausnahme im vornehmlich wissenschaftlichen Betätigungsfeld des X-Clubs dar.

Etwas später entstand ein neuer Kanal der wissenschaftlichen Publikation und Kommunikation. 1869 startete Norman Lockyer mit Nature das wohl erfolgreichste Magazin an der Schnittstelle von Wissenschaft und Öffentlichkeit - und der X-Club nahm auf seine Einladung hin beratend auf die inhaltliche Ausgestaltung des Magazins Einfluß. ${ }^{50}$ Spencer organisierte darüber hinaus für einige Jahre eine Art wissenschaftlichen Beirat aus X-Club-Mitgliedern für die von Edward Livingston

109; Bspw. Patton (im Erscheinen). Kap. 3; Barton 1998b; Desmond 1998.

48 Vgl. JTAH, Bd. 9, S. 164; Spencer 1904b, Bd. 2, S. 119; Spencer an Lubbock, 12. September 1864, In: HSP, ADD 49640, f. 174.

49 Vgl. Barton 1998b, S. 439.

50 Vgl. David A. Roos (1981) „The ,Aims and Intentions“ of Nature“. In: James Paradis, T. Postlewait (Hrsg.): Victorian Science and Victorian Values: Literary Perspectives. New York: New York Academy of Science, S. 159-180; Arthur Jack Meadows (1980) „Access to the Results of Scientific Research: Developments in Victorian Britain“. In: Ders.: Development of Science Publishing. Amsterdam: Elsevier, S. 43-62, S. 54. 
Youmans beim amerikanischen Verlagshaus Appleton herausgegebene Schriftenreihe International Scientific Series. ${ }^{51}$ Gemeinsam mit Tyndall und Huxley beriet Spencer Youmans über potentielle Autoren und stellte Kontakte zu europäischen Verlagshäusern her. So konnte die International Scientific Series in insgesamt vier Ländern erscheinen, neben Amerika und Groß-Britannien auch in Frankreich und Deutschland. ${ }^{52}$ Mit ihren eigenen Journalen, ihrem direkten Zugriff auf Nature in dessen ersten Jahren, ihrer Zusammenarbeit mit der International Scientific Series und nicht zuletzt einer Vielzahl öffentlich gehaltener Vorlesungen nutzten die Akteure des X-Clubs fast über die gesamten sechziger Jahre hinweg bedeutende und einflußreiche Kommunikationskanäle mit teilweise internationaler Reichweite, um innerhalb der scientific community und in der wissenschaftsinteressierten Öffentlichkeit den evolutionären Standpunkt zu festigen und auszubauen.

Diesen Einfluß versuchte der X-Club auch im sogenannten ,Parlament der Wissenschaften`, der British Association, auszuüben. 1864 waren ihr alle Mitglieder, mit Ausnahme Spencers, beigetreten. ${ }^{53}$ Als 1868 die British Association eine Kommission ins Leben rief, um die Möglichkeiten staatlicher Regulierung der akademischen, technischen Ausbildung auszuloten, stellte der X-Club vier ihrer sechs Mitglieder: Huxley, Tyndall, Frankland und Hirst. ${ }^{54}$ In den Jahren danach saßen regelmäßig X-Club-Mitglieder der British Association oder einigen ihrer Sektionen vor. ${ }^{55}$

\section{Royal Society}

Der Einfluß, des X-Clubs auf die Royal Society war in den sechziger Jahren noch gering, gleichwohl immer mehr seiner Mitglieder im Lei-

51 Vgl. John Offer (1980) „Interpreting Spencer“. In: Sociology 14, S. 131140, S. 132.

52 Vgl. John Fiske (1894) Edward Livingston Youmans. Interpreter of Science for the People. New York: Appleton, S. 266-294; Spencer 1904b, Bd. 2, S. 231-232; Roy M. MacLeod (1980) „Evolutionism, Internationalism and Commercial Enterprise in Science: The International Scientific Series 1871-1910“. In: A. J. Meadows: Development of Science Publishing. Amsterdam u.a.: Elsevier, S. 63-93, S. 68.

53 Vgl. J. Vernon Jensen (1991) Thomas Henry Huxley: Communicating for Science. Newark: University of Delaware Press, S. 156.

54 Vgl. Roy M. MacLeod (1971) „The Support of Victorian Science: The Endowment of Research Movement in Great Britain, 1868-1900“. In: Minerva 9, S. 197-230, S. 202-203.

55 Vgl. O. J. R. Howarth (1922) The British Association for the Advancement of Science - a Retrospect 1831-1931. London: The Association, S. 298299; Jensen 1991, S. 156-157; Jensen 1970, S. 66-67. 
tungsgremium vertreten waren. Sie versuchten, die Aufnahme neuer Mitglieder und den Modus der Vergabe von Ehrenmedaillen zu beeinflussen, vor allem ging es ihnen um die Ausweitung meritokratischer Strukturen in einer noch stark von Gentleman-Wissenschaftlern bestimmten Organisation. Eine der ersten Kampagnen des X-Clubs innerhalb der Royal Society erwuchs 1864 aus der Empörung Huxleys und Hookers über die Begründung für die Ehrung Darwins mit der CopleyMedaille. Edward Sabine, der Präsident der Royal Society, hatte in seiner Würdigung Origin of Species explizit ausgeschlossen. ${ }^{56}$ Doch der Versuch des X-Clubs, daraufhin die Vergabekriterien für die CopleyMedaille zu verändern, ging im Kompetenzgerangel zwischen Vorstand und Präsident unter. ${ }^{57}$

Erst einige Jahre später gelang dem X-Club der Durchbruch bei der Einflußnahme auf die Politik der Royal Society. Ab 1871 begann eine knapp fünfzehnjährige Epoche, in der die zentralen Ämter der Royal Society ununterbrochen von X-Club Mitgliedern besetzt waren. ${ }^{58}$ Spottiswoode als Schatzmeister der Royal Society war der erste, den der XClub erfolgreich aus seinen Reihen installierte. ${ }^{59}$ Auch bei der Ernennung des Astronomen George Biddell Airy zum Präsidenten der Gesellschaft und bei der Besetzung weiterer Posten gab es im Vorwege entsprechende Absprachen zwischen den X-Club-Mitgliedern. ${ }^{60}$

$\mathrm{Ob}$ die jeweiligen Ernennungen aber tatsächlich von derartigen Beeinflussungsversuchen abhängig waren, oder ob sie sich nicht auch auf das wissenschaftliche Ansehen des jeweiligen Kandidaten zurückführen ließen, ist nicht mit letzter Sicherheit zu bestimmen. Sicher ist allerdings, daß der X-Club an einer Reform und Modernisierung der Royal Society mitgewirkt hatte, die gleichzeitig eine Reaktion auf veränderte soziale Rahmenbedingungen, besonders auf die fortschreitende Professionalisierung der Wissenschaften, war. ${ }^{61}$ Das Renommee des X-Clubs

56 Vgl. Frederick H. Burkhardt (2001) „Darwin and the Copley Medal“. In: Proceedings of the American Philosophical Society 145, S. 510-518.

57 Vgl. Barton 1998b, S. 61.

58 Vgl. Barton 1998b, S. 60-63.

59 Vgl. Barton 1998b, S. 64-66. Zwischen Huxley und Tyndall war es über die Besetzung des Postens des Schatzmeisters zu einer Meinungsverschiedenheit gekommen, denn Huxley favorisierte Lubbock, doch Tyndall konnte seinen Kandidaten, Spottiswoode, durchsetzen. Ein Vorgang, der zeigt, daß Desmonds Darstellung des X-Clubs als ein Instrument Huxleys zu einseitig ist (vgl. Barton 1998b, S. 60-63; Tyndall an Huxley, 3. Oktober 1870. In: Tyndall Papers, Bd. 9, S. 2938 und Huxley a Tyndall, 4. Oktober 1870. In: Tyndall Papers, Bd. 9, S. 2939).

60 Vgl. Barton 1998b, S.67.

61 Vgl. E. N. da C. Endrade (1960) A Brief History of the Royal Society. London: The Royal Society, S. 14; Marie Boas Hall (1984) All Scientists Now. 
wie auch die Anerkennung seiner einzelnen Mitglieder muß zwischen 1864 und 1871, zwischen dem ersten gescheiterten Versuch der Einflußnahme und dem Beginn jener langen Phase, in der sie die wesentlichen Posten der Royal Society besetzt hielten, einen enormen Auftrieb erhalten haben. Es liegt nahe, das veränderte wissenschaftspolitische Gewicht des X-Clubs, das in dieser Entwicklung zum Ausdruck kommt, mit der einzigen Kampagne, die in jenen Jahren vom ihm ausging, in Verbindung zu bringen: mit seinem Engagement in der britischen Anthropologie, das in die Gründung des Anthropological Institutes mündete, in dem sich seine evolutionäre Anthropologie institutionalisierte. Das Ende der Krise der Anthropologie wurde dem Wirken Huxleys, Lubbocks und Busks zugeschrieben.

\section{"Govern scientific affairs". Struktur und Funktion des X-Clubs}

Wissenschaftshistoriker beschreiben den X-Club häufig als bedeutsame pressure group. Viele zitieren die begeisterte Einschätzung eines Zeitgenossen, des Harvard Professors und Spencer-Freundes John Fiske, nach der der X-Club „,der einflußreichste und mächtigste wissenschaftliche Klüngel in England" gewesen sei. ${ }^{62}$ Doch war diese Ansicht bei weitem nicht repräsentativ für die Außenwahrnehmung des X-Clubs, denn nicht wenige zeitgenössische Wissenschaftler haben sein Wirken schlicht nicht registriert. $^{63}$

Auch über die Beweggründe, die zur Gründung des X-Clubs führten, besteht in der Wissenschaftsgeschichte keine Einigkeit. Zwei grundsätzlich verschiedene Ansätze stehen sich gegenüber. Der eine vermutet als Kernmotiv die Bündelung der Kräfte zur wissenschaftspolitischen Machtausübung, der andere versteht den Club als einen primär freundschaftlichen Zusammenschluß. Für beide Interpretationsrichtungen liegen ernstzunehmende Anhaltspunkte vor.

Für Adrian Desmond handelte es sich beim X-Club um eine Initiative Huxleys, der „eine robuste Gruppe“ zusammengestellt hätte, in der alle „einer Meinung über den Darwinismus“ gewesen wären. Sie hätte

The Royal Society in the nineteenth century. Cambridge: Cambridge University Press, S. 92-119.

62 John Fiske an seine Frau, 8. Dezember 1873, zitiert nach MacLeod 1969. S. 305: ,the most powerful and influential scientific coterie in England“. Vgl. auch Jensen 1991, S. 165.

63 Vgl. Harrison 1988, S. 179-181. 
den Charakter eines „Kaders“ und einer „Elite“ gehabt. ${ }^{64}$ Desmond beschreibt Huxley als die zentrale Figur des Ringens zwischen Wissenschaft und Religion. ${ }^{65}$ James Moore sieht im X-Club eine pressure group, die nicht einfach Darwins Theorie verteidigt, sondern eine ,aggressive Kampagne“ organisiert hätte, ,um die Natur von der Theologie zurückzufordern“. ${ }^{66}$ Diese politische Dimension betont auch Ruth Barton, die zudem hervorhebt, daß es den Mitgliedern dabei auch um ihre professionelle Anerkennung gegangen sei: ${ }^{67}$

„Sie trachteten nicht nur danach, Wissenschaft als eine Profession unter anderen zu etablieren, sondern forderten vielmehr jenen Berufsstand heraus, der eine einzigartige kulturelle Vorherrschaft ausübte, der die öffentliche Meinung prägte, der die öffentliche Moral leitete und der die soziale Ordnung legitimierte“. 68

Auf der anderen Seite leitet Roy MacLeod die spätere Bedeutung des XClubs aus der seiner Mitglieder selbst $a b,{ }^{69}$ und auch J. Vernon Jensen hält ihn zuallererst für einen Freundeskreis. ${ }^{70}$ Diese Überlegungen basieren vor allem auf einer Chronologie der Besetzung von Positionen in der Royal Society durch X-Club-Mitglieder oder deren Kandidaten. Aktivitäten des X-Club-Netzwerkes, also gemeinsame Anstrengungen und Interventionen, wie der Natural History Review oder ihre Politik in der Anthropologie, bleiben hierbei unberücksichtigt. Doch gerade diese Vorgeschichte des X-Clubs zeigt, daß er durchaus als ein ambitioniertes Projekt angelegt war.

Eine Reihe von Anhaltspunkten sprechen dafür, im X-Club vor allem ein privates Freundschaftsnetzwerk zu sehen. Gemeinsame Neujahrsfeiern, Dinnerparties, Urlaube und fest installierte, jährliche Ausflüge belegen, daß die persönlichen Affinitäten nicht zu gering bewertet

64 Desmond 1998, S. 327-328: „He brought together a robust group, all of a mind on Darwinism [...]. He needed to pull his cadre together. [...] [T]his was an elite".

65 Vgl. Jensen 1991, S. 127.

66 Moore 1991, S. 376: „they plotted an aggressive campaign to reclaim nature from theology".

67 Vgl. Barton 1998b, S. 413.

68 Barton 1998b, S. 414: ,[M]ore than professional recognition was at stake. They were not merely aiming to establish science as one profession among others; rather, they were challenging the profession that had the unique role of cultural leadership, educating the public mind, guiding public morals, and legitimating the social order".

69 Vgl. MacLeod 1969, S. 305-322.

70 Vgl. Jensen 1970. 
werden dürfen. ${ }^{71}$ Freundschaft und gemeinsame Interessen spielten gleichermaßen konstituierende Rollen für den X-Club. Ohne miteinander vereinbare Interessen und Bewußtseinslagen, die sich an die wissenschaftliche Betätigung und berufliche Ziele knüpften, wäre schon das dem Club vorausgegangene Netzwerk nicht entstanden. Für das Verständnis des X-Clubs und seiner Bedeutung für die jeweiligen Mitglieder ist es unabdingbar, anzuerkennen, daß beide Faktoren gleichbedeutend nebeneinander stehen. Ihre Beziehung läßt sich an den Aussagen der Mitglieder über ihren Club deutlich ablesen: Spencer beschrieb ihn rückblickend als eine harmlose freundschaftliche Zusammenkunft, bei der wissenschaftliche Diskussionen zwar aufgekommen seien, aber nicht im Vordergrund gestanden hätte. Gleichwohl habe man nach dem Dinner „die Angelegenheiten der wissenschaftlichen Gesellschaften“ besprochen. ${ }^{72}$ Huxley stellte den X-Club in einem Nachruf auf John Tyndall 1894 folgendermaßen dar:

„Im Laufe der Zeit, als die Arbeit schwerer wurde, und die Ablenkungen des Lebens einen mehr in Beschlag nahmen, stellten ein paar von uns, die seit langem befreundet waren, fest, daß wir auseinanderdriften, und wir beschlossen, um dem entgegenzuwirken, einmal im Monat miteinander zu Abend zu essen. [...] Ich glaube, daß der , $x^{\prime}$ von einigen Leuten als wissenschaftlicher Klüngel oder Kreis angesehen wurde. In der Tat, zwei ausgezeichnete wissenschaftliche Kollegen von mir führten einst im Raucherkabinett des Athenaeum ein Gespräch über meinen Kopf hinweg (das ich gelassen ignorierte) in etwa folgenden Inhalts: ,Sag mal A, weißt Du irgend etwas über den x Club?` ,Aber ja, B, ich habe davon gehört. Was machen die?' ,Nun, sie lenken wissenschaftliche Angelegenheiten, und wirklich, alles in allem, sie machen es nicht schlecht "“. 73

71 Vgl. J. Vernon Jensen (1981) „Tyndall's Role in the ,X Club““. In: W. H. Brock, N. D. McMillan, R. C. Mollan: John Tyndall. Essays on a Natural Philosopher. Dublin: Royal Society, S. 157-168, S.161; Spencer 1904b Bd. 2, S. 117; Spencer an Huxley, 23. April 1872. In: HP 7, f. 131; Spencer an Huxley, 31. Dezember 1877. In: HP 7, f. 141-142.

72 Spencer 1904b, Bd. 2, S. 116: „There did, however, grow up something like a function. It became the custom to discuss, after dinner, the affairs of the scientific societies: sometimes those of the British Association, but more frequently those of the Royal Society. These consultations had their effects, though in what exact way I do not know".

73 Thomas H. Huxley (1894) „Professor Tyndall“. In: The Nineteenth Century 35, S. 1-11, S. 10: „As time went on, as the work became harder, and the distractions of life more engrossing, a few of us, who had long been intimate, found we were drifting apart; and, to counteract that tendency, we agreed to dine together once a month“; S. 11: „I believe that the ,X' had the credit of being a sort of scientific caucus, or ring with some people. In fact, two distinguished scientific colleagues of mine once carried on a 
Angesichts der Umstände, unter denen die freundschaftlichen Beziehungen entstanden waren, auf die Spencer wie auch Huxley als Motiv für die gemeinsamen Abendessen abstellten, sind ihre Darstellungen nachträgliche Banalisierungen. Ihre Beziehungen beruhten von Beginn an auf gemeinsamen wissenschaftspolitischen Interessen. Huxley und Hooker hatten bereits seit 1856 die Gründung einer pressure group ins Auge gefaßt, deren Aufgabe nichts geringeres als die Beförderung der Wissenschaften („to advance science") hätte sein sollen. ${ }^{74}$ Ihr gemeinschaftliches Tafeln sollten deshalb nicht nur ihren sozialen Zusammenhalt, sondern auch die Gemeinsamkeit ihrer Interessen festigen. Deshalb enthält Spencers Ansicht, dem Club sei nachgesagt worden, mehr Macht ausgeübt zu haben, als er tatsächlich getan habe, eine gehörige Portion Understatement. ${ }^{75}$ Huxley zeichnete ein besonders bescheidenes Bild von einem bloß freundschaftlichen Zusammenschluß, in dem der wissenschaftliche Einfluß allein in den Karrieren ihrer Mitglieder bestand:

„Es passierte halt, daß diese Busenfreunde sich zu großen Tieren entwickelten, und deshalb hat der Club nebenbei, ich möchte sagen zufällig, einen gehörigen Einfluß in der Wissenschaftswelt gehabt" ${ }^{* 76}$

Natürlich schrieb hier die Eitelkeit Huxleys mit, der seinen persönlichen Erfolg nicht dem Umstand eines sozialen Netzwerkes zuschreiben wollte. Es ist zudem nicht unerheblich, daß seine Einschätzungen aus einer Zeit stammten, in der der X-Club faktisch zu existieren aufgehört hatte. Rückblickend nahm Huxley ihn nun als einen Freundeskreis wahr, dem von seiner Umwelt vielleicht zuviel Bedeutung zugeschrieben worden sei. Allerdings hatte es ihm früher selbst gefallen, den X-Club als ein geheimnisumwittertes Machtzentrum der Wissenschaften darzustellen:

„Als ich Sekretär [der Royal Society, T.G.] war, versuchte ich, den Anschein sorgfältig zu vermeiden, irgendeinen bestimmten Einfluß ausüben zu wollen. Aber es gab da eine Eifersucht gegenüber dem $x$ Club und gerade gestern

conversation (which I gravely ignored) across me, in the smoking room of the Athenaeum, to this effect: ,I say, A, do you know anything about the $\mathrm{x}$ Club?' ,Oh yes, B, I have heard of it. What do they do?' ,Well, they govern scientific affairs; and really, on the whole, they don't do it badly"“.

74 Hooker an Huxley, 1856. In: HP 3, f. 23.

75 Vgl. Spencer 1904b, Bd. 2, S. 116: ,supposed to exercise more power than it did".

76 Huxley an Hooker, 1888. In: LLTHH, Bd. 1, S. 261: „,it has happened that these cronies had developed into bigwigs of various kinds, and therefore the club has incidentally - I might say accidentally - had a good deal of influence in the scientific world". 
sprach ich zu meiner großen Belustigung mit einem einflußreichen Mitglied des Royal Society Clubs über die Möglichkeit, diesen mit dem Phil. Club zu fusionieren. Er sagte, und vergaß dabei, daß ich Mitglied des letzteren bin: ,Oh! Wir wollen keinen dieser Drahtzieher! ““. ${ }^{77}$

Doch die Stimmung und Intention, mit der 1864, also zwanzig bis dreiBig Jahre vor den hier zitierten Aussagen, der X-Club gegründet wurde, lassen sich anhand zeitnaher Dokumente zuverlässiger einschätzen. ${ }^{78}$ Hirst beispielsweise hielt den Club von Beginn an für eine politische Mission auf der Basis freundschaftlicher Beziehungen. Er schrieb in seinem Notizbuch über die Gründung:

„Neben persönlicher Freundschaft war das Band, das uns vereinte, die Hingabe an die Wissenschaft, rein und frei, ungehemmt durch religiöse Dogmen. Unter uns herrscht absolute Offenheit, und zweifelsohne werden sich Gelegenheiten ergeben, bei denen konzertierte Aktionen unsererseits hilfreich sein werden". ${ }^{79}$

Spencer berichtete seinem Vater von diesem Ereignis: „Eine lang verschobene Absicht verfolgend, haben sich einige der fortgeschrittensten Männer der Wissenschaft zusammen getan, um einen kleinen Club zu bilden und gelegentlich miteinander zu Abend zu essen“. ${ }^{80}$ Aus beiden Dokumenten geht die Bedeutung des Aspekts des wissenschaftlichen Hintergrundes hervor. Hirst beschrieb den erwarteten Nutzen gegensei-

77 Huxley an Foster, 17. September 1885. In: LLTHH, Bd. 2, S. 112: „When I was secretary the one thing I was most careful to avoid was the appearance of desiring to exert any special influence. But there was a jealousy of the $\mathrm{x}$ Club, and only the other day, to my great amusement, I was talking to an influential member of the Royal Society Club about the possibility of fusing it with the Phil. Club, and he said, forgetting I was a member of the latter: ,Oh! We don't want any of those wire-pullers! ““.

78 Harrison vertritt, entgegen der Interpretationen Bartons und anderer, die im X-Club ein politisches Projekt ausgemacht haben, die Ansicht, daß die Darstellungen Huxleys, die das Freundschafts-Modell unterstützen, ganz einfach als die Wahrheit begriffen werden sollten (vgl. Harrison 1988, S. 179).

79 Thomas Archer Hirst in: JTAH, Bd. 4, f. 1702: „Besides personal friendship, the bond that united us was devotion to science, pure and free, untrammelled by religious dogmas. Amongst ourselves there is perfect outspokenness, and no doubt opportunities will arise when concerted action on our part may be of service“.

80 Spencer an George Spencer, 07. November 1864. In: Spencer 1904b, Bd. 2, S. 115: „In persuance of a long-suspended intention, a few of the most advanced men of science have united to form a small club to dine together occasionally“. 
tiger Hilfe und Unterstützung, aus Spencers Darstellung sprach der Korpsgeist der wissenschaftlichen Modernisierer.

Vor dem Hintergrund der heftigen Auseinandersetzungen um die Evolutionstheorie, an denen die meisten der in diesem Club versammelten Wissenschaftler unmittelbar beteiligt waren, und auch unter Anrechnung der Beteiligung von vier Mitgliedern dieses Zirkels an der Kontroverse zwischen der Anthropological und der Ethnological Society, kann Hirsts Darstellung als eine authentische Beschreibung der Motivlage der treibenden Kräfte bei der Clubgründung angesehen werden. Daß Huxley dreißig Jahre später nur noch das private Moment anführte, liegt an der historischen Entwicklung, die der X-Club selbst durchlaufen hat. Er war in umgekehrt reziprokem Verhältnis zum Ansehen der einzelnen Mitglieder einem langsamen Zerfallsprozeß ausgesetzt gewesen, der seine wissenschaftspolitische Bedeutung nicht nur faktisch, sondern auch in der Erinnerung der Beteiligten hatte schwinden lassen. Deshalb ist Bartons oder Desmonds Betonung der wissenschaftspolitischen Steuerungsambitionen allemal zutreffender als eine Reduktion des X-Clubs auf eine gesellige Runde.

Eine solche Heraushebung der politischen Programmatik verlangt aber zugleich nach der Identifikation der konsensualen Basis, des gemeinsamen Nenners. Dieser bestand in der Präferenz für die inhaltliche Orientierung an Evolutionstheorien und Liberalismus. Spencers Evolutionstheorie war dabei offenbar koalitionsfähig mit der Lehre Darwins, zumindest mit dem, was deren Interpreten im X-Club darunter verstanden. Dies äußert sich auch darin, daß Spencer trotz seines weniger naturwissenschaftlichen und eher philosophischen Ansatzes in diesem Kreis von Wissenschaftlern ein anerkanntes Mitglied war, dessen Arbeit nicht nur geschätzt, sondern auch für nutzbringend erachtet wurde. ${ }^{81}$ Spencer repräsentierte den breiteren Kontext der Evolutionslehre auch in der außerwissenschaftlichen Öffentlichkeit, die für Huxley ja stets eine große Rolle spielte. ${ }^{82}$ So sandte Huxley etwa das Manuskript der First Principles mit einem Lob zurück: „Arbeite weiter, hervorragender Seiler, und fertige uns Seile, die uns Halt geben gegen den Teufel und den Pfarrer". 83

81 Vgl. Tyndall an Spencer, Weihnachten 1864. In: Tyndall Papers Bd. 3, f. 1030.

82 Vgl. Barton 1998b, S. 432-433; Hooker an Darwin, 18. Januar 1869. In: Leonard Huxley 1921, Bd. 1, S. 120.

83 Huxley an Spencer, 3. September 1860. In: LLTHH, Bd. 1, S. 213: „Work away, then, excellent rope-maker, and make us more ropes to hold on against the devil and the parsons"; vgl. Spencer (1904a) First Principles. [1864] New York: Appleton. 
Jenseits von Modellen, die den X-Club entweder als Einrichtung eines Freundeskreises oder als Instrument wissenschaftspolitischer Ambitionen betrachteten, stellt Colin Russell eine alternative Deutung vor. Er hält ihn für

„eine flexible Einrichtung, die durch das Band der Freundschaft zusammengehalten wurde (wie Huxley behauptete), aber für eine, die gleichgesinnten Männern eine gesellschaftliche Machtbasis für ihre individuellen Angriffe auf das Establishment war". ${ }^{84}$

Russell hat mit dieser mehrschichtigen Interpretation einen wertvollen Hinweis geliefert, denn die Verhältnisse der Mitglieder zu ihrem Club waren bei weitem nicht identisch und sie veränderten sich mit den Jahren. Die unterschiedlichen sozialen Lagen der Mitglieder unterlaufen eine historische Rekonstruktion einheitlicher Ambitionen. Eine Kampagne zur Professionalisierung der Wissenschaften stellte letztlich auch Lubbocks und Spottiswoodes Status als Amateurwissenschaftler und ,gentleman-scientists“ in Frage, ${ }^{85}$ Huxleys Wutreden gegen die Kommerzialisierung der Wissenschaften galten auch Franklands Geschäft mit Expertisen zu Wasserqualitäten. ${ }^{86}$ Am Sozialmeliorismus eines Lubbock oder Huxley konnte der radikalliberale Spencer keinen Gefallen gefunden haben, und bei einer späteren Kontroverse mit Huxley brach dieser Dissens offen aus: ${ }^{87}$ Bereits 1871 war Huxley in „Administrative Nihilism“ mit Spencers laissez faire Liberalismus hart ins Gericht gegangen, doch da betonten beide noch, die persönliche Beziehung werde aus der politischen Querele herausgehalten. ${ }^{88}$ So stilvoll ließ sich jedoch nicht jede Kontroverse beherrschen: Ende der achtziger Jahre stritt sich Huxley in der Öffentlichkeit mit Spencer über dessen radikalen Liberalis-

84 Colin Archibald Russell (1996) Edward Frankland: chemistry, controversy, and conspiracy in Victorian England. Cambridge: Cambridge University Press, S. 323: ,a flexible institution held together by the bond of friendship (as Huxley maintained), but as one which gave like-minded men a social power-base for individual assaults on the establishment".

85 Aufgrund der verschiedenen Bildungshintergründe der Mitglieder des XClubs erklärt Desmond, daß der X-Club nicht primär eine Professionalisierungskampagne in den Wissenschaften betrieben habe (vgl. Desmond 2001, S. 3-50).

86 Vgl. Russell 1996, S. 327-328.

87 Vgl. MacLeod 1969, S. 315.

88 Vgl. Huxley an Anton Dohrn, 03. Januar 1872. In: LLTHH, Bd. 1, S. 368; Spencer 1904b, Bd. 2, S. 232. 
mus. Diese Kontroverse führte zu einem Bruch, der erst einige Jahren später gekittet wurde. ${ }^{89}$

Neben einigen abgekühlten freundschaftlichen Beziehungen führten auch wissenschaftliche Umorientierung und zeitintensive politische Engagements zur Lockerung der Kohäsionskräfte des Clubs. Lubbock war bereits 1870 ins Unterhaus eingezogen, ab 1880 vertrat er dort die University of London. Als seine größte politische Errungenschaft gilt der Bank Holiday Act von 1871, die Einführung eines gesetzlichen Feiertags, der als ,,St. Lubbocks-Day“ bejubelt wurde..$^{90}$

Huxley war an den Planungen für die Errichtung der Science School in South Kensington beteiligt und bezog 1871 dort seine Arbeitsräume. ${ }^{91}$ Neben etlichen wissenschaftlichen Ehrenämtern, wie dem Posten des Sekretärs der Royal Society, der ihm ebenfalls 1871 übertragen wurde, war die Präsidentschaft der Royal Society im Jahr 1883 die Krönung seiner wissenschaftlichen Karriere. ${ }^{92}$ Aber auch politische Fragen beschäftigten Huxley. Neben regelmäßigen Vorlesungen an Londoner Working-Men's Colleges wurde er 1870 in das soeben eingerichtete London School Board berufen. Er verband nun seinen Einsatz für die Bildung der breiten Masse mit einem bildungspolitischen Reformprogramm zur Förderung der Wissenschaften. Er forderte vermehrte Anstrengungen in der technischen und naturwissenschaftlichen Ausbildung mit dem expliziten Verweis auf die Bedeutung des industriellen Wachstums Deutschlands für den imperialen Wettlauf. Als 1888 eine königliche Kommission installiert wurde, um Empfehlungen für die Reform der Hochschulen zusammenzutragen, wurde Huxley in diese Kommission berufen. ${ }^{93}$

89 Vgl. Spencer an Joseph Dalton Hooker, 05.12.1889 (Handschriftliche Kopie Huxleys). In: HP 7, f. 243; Huxley an Spencer, 24. Oktober 1893; Spencer an Huxley, 26. Oktober 1893, beide in: Duncan 1908, S. 337.

90 Vgl. Sir Bernhard Mallet (1924) „Political and Economic“. In: Grant Duff 1924, S. 35-66, S. 40.

91 Vgl. Desmond 1998, S. 395-396; Sophie Forgan; Graeme Gooday (1997) „Constructing South Kensington: the buildings and politics of T. H. Huxley's working environment". In: British Journal for the History of Science 29, S. 435-468.

92 Zudem war Huxley Präsident der Geological Society (1869-1871), Trustee beim British Museum (ab 1887), Präsident der Palaeontological Society (ab 1890). Den Vorsitz der Royal Society wie auch alle anderen Ämter legte er aus gesundheitlichen Gründen 1885 nieder.

93 Vgl. Cyril Bibby (1958) „Thomas Henry Huxley and University Development“. In: Victorian Studies 2, S. 97-116, S. 114. 


\section{"The Skeleton in the Club's Closet". Das Ende des X-Clubs}

Schon Mitte der siebziger Jahre des neunzehnten Jahrhunderts war der Bedeutungsverlust des X-Clubs unverkennbar. Er wurde durch den Fortzug etlicher Mitglieder aus London (Spencer kurte ab den achtziger Jahren regelmäßig in Brighton, Frankland zog 1885 nach Reigate, Tyndall 1890 in den Lake District, Huxley im gleichen Jahr nach Bournemouth), die schlechte Gesundheit einiger und der Tod anderer (Spottiswoode starb 1883, Busk 1886) später noch verstärkt. ${ }^{94}$ Dennoch kam es erst 1893 zur letzten Sitzung des Clubs.

Der angesichts seiner Langlebigkeit frühe Bedeutungsverlust des XClubs ging auf mehrere Ursachen zurück. Zunächst einmal war eine Phase der wissenschaftspolitischen Auseinandersetzungen beendet, in der der offene Widerstand gegenüber der Evolutionslehre gebrochen worden und aus der die Akteure des X-Clubs als etablierte Wissenschaftler hervorgegangen waren - als Wissenschaftler, die in der scientific community und in der Öffentlichkeit den wissenschaftlichen Diskurs bestimmten. Damit hatte der X-Club als Koordinationsinstrument wissenschaftspolitischer Kampagnen gegen das System der alteingesessenen Amateur- und Gentleman-Wissenschaften ausgedient. Mit der Gründung des Anthropological Institutes war Anfang der siebziger Jahre die letzte Schlacht des X-Clubs erfolgreich geschlagen worden.

Die Bedeutung des Clubs stand im umgekehrten Verhältnis zum Einfluß und Status der einzelnen Mitglieder. Im gleichen Maße, wie ihre gemeinsam verfolgten Ziele zugunsten zunehmend unterschiedlicher persönlicher Aspirationen an Bedeutung verloren, nahmen auch die

94 Vgl. X-Club Notebook, Royal Institution, JT/3/50; MacLeod 1969, S. 316. Huxley verstarb am 29. Juni 1895. Spencer verlebte seine letzten Jahre in Brighton, dort starb er am 8. Dezember 1903. Der Versuch, seine Beisetzung in der Westminster Abbey zu veranlassen, der von etlichen namhaften Prominenten aus Wissenschaft und Politik getragen wurde, war nicht erfolgreich. Als Unterstützer dieser Initiative unterzeichneten eine entsprechende Petition an den Dean of Westminster Abbey u.a.: Lord Avebury, Lord Hobhouse, Francis Galton, R. B. Haldane, J. D. Hooker, Norman Lockyer, James Ward (vgl. Duncan 1908, S. 485-486). Nach seinem Tod wurde der sogenannte Spencer Trust ins Leben gerufen, dessen Aufgabe die Vollstreckung des letzten Willens Spencers war, der in erster Linie auf die Vollendung der Descriptive Sociology und die Veröffentlichung seiner Autobiographie abzielte (vgl. Alfred W. Tillett (1939) Herbert Spencer Betrayed. London: King \& Sons). Lubbock verbrachte seine letzten Jahre abwechselnd in London, zur Parlamentssaison, oder auf Kingsgate Castle, seinem zweiten Landsitz an der Küste Kents, wo er am 28. Mai 1913 starb. 
freundschaftlichen Kohäsionskräfte ab. Lubbock etwa entfernte sich mit den Jahren nicht nur aus einem gemeinsamen Interessenfeld, seine persönlichen Bindung zu anderen X-Club-Mitgliedern wurde zudem von Konflikten getrübt. Mit Darwin stritt er um einen Streifen Land, seine zweite Ehefrau wurde nicht in die X-Club-Gemeinschaft aufgenommen und privat pflegte er, wie auch Spencer, Umgang mit dem damaligen liberalen Premier William Gladstone, der von Huxley, Hooker und vor allem Tyndall wegen seiner Home-Rule-Politik der irischen Selbstverwaltung angefeindet wurde. ${ }^{95}$ Vergleichbare Entfremdungsprozesse sind auch zwischen Huxley und Hooker auf der einen und Frankland und Hirst auf der anderen Seite auszumachen. Selbst gegenüber Tyndall, schreibt Andrew Harrison, wuchs aufgrund dessen Drogenkonsums der Mißmut bei den alten Weggefährten. ${ }^{96}$ Und während der Auseinandersetzung zwischen Spencer und Huxley urteilte Hooker in einem Brief an Huxley über Spencer:

„Bei mir zu Haus in Kew war er immer ein Langweiler. So umfassend sein Verstand auch ist, seine Ansichten sind so eingeengt und begrenzt, daß du dich bei einer Unterhaltung mit ihm nicht bewegen konntest, und sein Ego ist derart überwältigend, daß ich es vorziehe, ihm aus dem Weg zu gehen: Kurz, ich schätzte ihn nie. [...] [D]er Thron, auf dem er sich wähnt, hoch über jedem Weisen, der jemals lebte, ich fühle eher ein grundsätzliches Mitleid [...] als Geringschätzung. Es ist nun mal so, er ist die Leiche im Keller des Clubs und ich hatte meine Schwierigkeiten, die Tür über ihm zuzuhalten“. ${ }^{97}$

Neben allen förmlichen Erklärungen sind Dokumente des intimen Meinungsaustauschs wie diese eindeutige Hinweise auf das definitive Ende des Zusammenhalts des Clubs. Die Anerkennung, die beide der Arbeit Spencers noch ganz zu Anfang ihrer Beziehung entgegengebracht hatten, ${ }^{98}$ war durch einen Prozeß der Selbst-Professionalisierung dieser Wissenschaftsikonen vollständig aufgebraucht. Und Spencers unverän-

95 Vgl. Desmond, Moore 1994, S. 684.

96 Vgl. Harrison 1988, S. 205-207.

97 Hooker an Huxley, 02. Juni 1890. In: HP 3, f. 360: „At my house at Kew, he was always a damper. Comprehensive as his intellect or capacity is, his views are so cribbed, cabined and confined that you have no freedom of motion in conversing with him, and his ego is so crushing that I prefer getting out of his way: in short I never esteemed him. [...] the throne he fancies he occupies, high above that of any sage that ever lived, I rather feel a profound pity (far indeed from love) than even contempt. As it is he is the skeleton in the club's closet and I have had difficulty in keeping the door shut upon it".

$98 \mathrm{Zu}$ Hookers frühen Meinung über Spencer vgl. Peel 1971, S. 5; Duncan 1908, S. 90, S. 151. 
derte politische Haltung erschien im Kontext der veränderten sozialpolitischen Koordinaten im letzten Drittel des neunzehnten Jahrhunderts als ein ärgerlicher Anachronismus, als eine Altlast, die den Club beschädigte, wie es Hooker empfand. Anfang und Niedergang des Clubs waren gleichermaßen von der Wechselwirkung freundschaftlicher Beziehungen und gemeinsamer Interessen geprägt.

So reduziert sich die Zeitspanne, in der der X-Club tatsächlich für seine Mitglieder die Funktion einer pressure group hatte, auf die ersten zehn Jahre seines Bestehens - und die fünf Jahre vor seiner Gründung. Für die wissenschaftspolitische Intervention dieses Kreises ist die Epoche des X-Club-Netzwerkes nicht weniger entscheidend als die der institutionalisierten sozialen Beziehungen im bestehenden Club. Ohne daß konkrete Anhaltspunkte dafür existierten, kann angenommen werden, daß die Kontroversen in den Jahren vor 1864 jenen Korpsgeist des ,scientific Young England' entscheidend geprägt hatten, aus dem der XClub schließlich hervorging. Eine der geschlagenen Schlachten, und vielleicht die, deren Erfolg sich am deutlichsten niederschlug, war die Auseinandersetzung zwischen der Anthropological und der Ethnological Society. Ihr Ausgangspunkt ging der Gründung des Clubs unmittelbar voran und nach ihrem erfolgreichen Ende war ab 1871 den X-Club Mitgliedern der Weg zu begehrten Posten wie denen in der Royal Society geebnet.

\subsection{Adaption und Selektion. Darwins Evolutionstheorie}

Als das zentrale wissenschaftliche Ereignis des neunzehnten Jahrhunderts und als das Kernstück der viktorianischen Evolutionstheorie gilt Charles Darwins Origin of Species, ein Buch, das 1859 eine sprunghafte Verschiebung im naturwissenschaftlichen Diskurs markierte. Ob es sich dabei allerdings tatsächlich um eine Darwinian Revolution (Michael Ruse) oder eher um eine Non-Darwinian Revolution (Peter J. Bowler) handelte, ist weiterhin umstritten. Ebenso besteht Unklarheit über die Rezeption der Lehre Darwins durch sein unmittelbares wissenschaftliches Umfeld, wie Lubbock und Huxley. Bevor Darwins Theorie in ihren wesentlichen Grundzügen dargestellt wird, beginnt dieses Kapitel mit einer kurzen Zusammenfassung jener Theorien, die John C. Greene als ,statische Naturgeschichte" bezeichnet. Sie bildeten den epistemischen Rahmen der europäischen Naturwissenschaften vor 1859 - spielten aber auch noch danach eine Rolle. Sie waren deshalb das allgegenwärtige 
Objekt inhaltlicher, aber auch wissenschaftspolitischer Abgrenzung durch die Evolutionstheoretiker in dieser Zeit.

\section{Vorläufer der Evolutionstheorien}

Der Begriff der Evolution als Beschreibung für die Entstehung und Entwicklung des Lebens nahm erst im neunzehnten Jahrhundert jene Bedeutung an, mit der er heute immer noch verwendet wird. ${ }^{99}$ Die Geschichte der Naturwissenschaften hat evolutionstheoretische Ansätze avant la lettre bis zu den Naturalisten der Aufklärung, Carl von Linné, George Buffon, George Cuvier oder Jean Baptiste Lamarck zurückverfolgt. 100

Linnés Systema Naturae (1735) stellte für weit über hundert Jahre die Standard-Taxonomie der Arten dar, die für ihn als Schöpfungsprodukte eine Hierarchie der Komplexität bildeten. Buffon hatte auf der Fruchtbarkeit von Kreuzungen beruhende Definitionen für die Begriffe Art und Rasse geliefert, Cuvier ging als Katastrophist von einem göttlichen Plan aus, den die Natur nach alles Leben vernichtenden Katastrophen immer von neuem, aber mit leichten Abweichungen exekutiert habe. Lamarck schließlich erklärte die Entstehung der unterschiedlichen Arten durch die Anpassung einzelner Organismen an Veränderungen der Umweltbedingungen. Dabei würden, je nach ihrem Einsatz und Gebrauch, Teile des Organismus gestärkt oder geschwächt. Durch die Vererbbarkeit derart erworbener Eigenschaften entstünden dann, vorausgesetzt, es handele sich nicht um isolierte Vorgänge, neue Arten. ${ }^{101}$ Sein berühmtes Beispiel führte den langen Hals der Giraffe auf die wiederholte Streckbewegung einzelner Giraffen zurück.

Geoffroy Saint-Hilaire stützte die Vermutung eines entwicklungsgeschichtlichen Zusammenhangs der Organismen auf sein aus anatomischen Studien gewonnenes Konzept der „Einheit des Aufbaus“. Sein Postulat der Ähnlichkeit der Organismen und Lamarcks Mechanismus

99 Vgl. Peter J. Bowler (1975) „The Changing Meaning of ,Evolution““. In: Journal for the History of Ideas 36, S. 95-114, S. 95; Michael Ruse (2001) Mystery of Mysteries: is evolution a social construction? Cambridge, Mass.: Harvard University Press, S. 54-80.

100 Vgl. Richards 1992.

101 Vgl. allgemein Ernst Mayr (1972) „Lamarck Revisited“. In: Journal of the History of Biology 5, S. 55-94; Richard W. Burkhardt (1977) The Spirit of System: Lamarck and Evolutionary Biology. Cambridge, Mass.: Harvard University Press; Ludmilla Jordanova (1989) „Nature's powers: A reading of Lamarck's distinction between creation and production“. In: James R. Moore (Hrsg.): History, Humanity, and Evolution: Essays for John C. Greene. Cambridge: Cambridge University Press, S. 71-98. 
der Veränderung waren die Elemente, aus denen sich ein evolutionäres Bild der organischen Welt zusammenfügte, das eine serielle Abfolge der Organismen unterstellte, die sich durch Transformationen bildeten. Dieses Modell trachtete die traditionelle Schöpfungslehre, die ja auf der Idee der jeweiligen Erschaffung durch Gottes Hand basierte, entscheidend $\mathrm{zu}$ modifizieren. Die Werke der frühen Verfechter dieses Entwicklungsmodells waren an einer religiösen Letztbegründung ihrer Auffassungen interessiert. Deshalb suchten sie in der Natur nach den Regeln und Mustern der göttlichen Schöpfung.

Neben der französischen Schule der Anatomie war vor allem die Arbeit Karl Ernst von Baers von großer Bedeutung für die wissenschaftlichen Debatten in England. Der Embryologe von Baer hatte 1827 die bis dahin verbreitete rekapitulationistische Ansicht verworfen, daß Embryonen in ihren Entwicklung Phasen durchliefen, in denen sie verschiedenen, jeweils taxonomisch niedrigeren Arten glichen. Entgegen dieser Kontinuitätsvermutung behauptete er nun, es gäbe vier fundamental unterschiedliche Haupttypen, in die sich die Organismen einteilen ließen. Diese Haupttypen könnten nicht mehr in eine Entwicklungsreihenfolge gebracht werden, doch in jeder einem Haupttyp zugeordneten Gruppe bestünde eine Hierarchie der Komplexität der Organismen. Von Baer verband sein Postulat der Haupttypen mit der epigenetischen Hypothese des Entwicklungsverlaufes vom Einfachen zum Komplexen. ${ }^{102}$ Mit dieser Erkenntnis modifizierte er wesentlich die Vorstellung von der Einheit des Aufbaus, wie sie noch Geoffroy vertreten hatte.

In den dreißiger Jahren des neunzehnten Jahrhunderts stieg Richard Owen in England zur dominierenden Figur in den Naturwissenschaften auf. Sein Kerngedanke war das Konzept der Archetypen. Im Gegensatz zu Naturalisten wie Cuvier oder Lamarck ging er davon aus, daß alle existierenden und vergangenen Formen des Lebens um idealtypisch konstruierbare Archetypus gruppiert werden könnten, zwischen denen es keine Übergangsformen oder mutativen Verbindungen gäbe. ${ }^{103}$ Owen führte das Phänomen von funktionslosen und rudimentären Körperpartien, die dennoch Ähnlichkeiten mit wichtigen Gliedern verwandter Arten aufwiesen, auf einen gemeinsamen sogenannten Archetypen zurück. In ihm sah er aber weniger eine gemeinsame Abstammung als einen idealen Plan, an dem sich der organische Aufbau all jener Arten orientierte, die er ihm zuordnete. ${ }^{104}$ Seine Auseinandersetzung mit den führenden

102 Vgl. Richards 1992, S. 55-61.

103 Vgl. Adrian Desmond (1989) The Politics of Evolution. Morphology, Medicine, and Reform in Radical London. Chicago: University of Chicago Press, S. 335-372.

104 Vgl. Ruse 1979, S. 116-125. 
französischen Morphologen brachte ihm die Anerkennung der nationalistisch gesinnten Elite ein, die damals noch die wissenschaftlichen Gesellschaften dominierte. ${ }^{105}$

Doch nicht allein Owens Kritik marginalisierte Mitte des neunzehnten Jahrhunderts transmutative Entwicklungstheorien. Auch die 1844 vom schottischen Verleger Robert Chambers anonym verfaßte, enorm populäre Schrift Vestiges of Natural History diskreditierte innerhalb der scientific community solche Ansätze, weil sie als wissenschaftlich unseriös empfunden wurde. ${ }^{106}$ Chambers hatte im Rahmen eines universellen Progressivismus eine fortschreitende Perfektionierung des Menschen postuliert und wurde dafür aus wissenschaftlichen wie politischen Kreisen heftig attackiert. ${ }^{107}$ In den Reihen der radikalen Arbeiter-Eliten und des Chartismus wurde zur gleichen Zeit beharrlich auf die Evolutionslehre Lamarcks zurückgegriffen, da man diese als Argument für die Möglichkeit des Aufstiegs aus eigenem Antrieb las. ${ }^{108}$ Owens Kritik an den Transmutationstheorien Chambers oder Lamarcks hatte daher eine besondere politische Dimension, an die sich die Hoffnungen der Konservativen auch aus innenpolitischen Erwägungen knüpften. Der Diskurs, in den Darwin sein Werk plazierte, war ein konfliktreiches Milieu, dessen Ebenen kontrovers aufgeladen und eng miteinander verbunden waren. Die Kontingenz politischer Implikationen von naturwissenschaftlichen Theorien war allen Beteiligten der Darwinianischen Revolution deshalb bewußt.

\section{Darwin}

Als Darwins On the Origin of Species by Means of Natural Selection or, the Preservation of Favoured in the Struggle for Life im November 1859 erschien, war die erste Auflage binnen weniger Tage vergriffen. ${ }^{109}$ Dieser große Erfolg ist sowohl auf die wissenschaftliche Reputation Darwins innerhalb der scientific community zurückzuführen als auch auf die erwartete Brisanz des Buches, das sich, wie Darwin eingangs erklärte, mit nichts geringerem als dem "Geheimnis der Geheimnisse“ befaßt. ${ }^{110}$ Vor dem Hintergrund seiner Beziehung zu den Vorgängern bei der Be-

105 Vgl. Desmond 1989, S. 296.

106 Vgl. Barnes, Bloor, Henry 1996, S. 140-168.

107 Vgl. Desmond 1989, S. 176-177.

108 Vgl. Desmond 1989, S. 60.

109 Darwin 1998a. Alle weitere Zitate und Verweise beziehen sich auf diese Ausgabe. Vgl. Desmond, Moore 1994, S. 541.

110 Charles Darwin (1998a) On the Origin of Species by Means of Natural Selection or, the Preservation of Favoured in the Struggle for Life. [1859] Ware: Wandsworth, S. 3: „mystery of mysteries“. 
antwortung gerade dieser Frage haben jüngere Studien die alte Behauptung relativiert, allein mit Darwin habe ein radikaler Wechsel des wissenschaftlichen Paradigmas eingesetzt, eben die vielbeschworene Darwinsche Revolution. Vielmehr wird Darwin mittlerweile als Teil einer großen wissenschaftlichen Debatte über die Evolution betrachtet, die sich nicht nur eine naturalistische Sichtweise auf die Welt, das Leben und den Menschen zueigen machte, sondern die sich darüber hinaus in ihrem Denken durchaus von sozialen und ökonomischen Überlegungen wie denen Robert Malthus' inspirieren ließ. ${ }^{111}$ Doch für seine Zeitgenossen war Origin of Species einfach ein die naturwissenschaftliche Diskussion umwälzendes Ereignis. Der revolutionäre Effekt dieser Schrift war in der Mechanik angelegt, die er hinter der Entstehung der Arten vermutete. $^{112}$

Seine Überlegung setzte bei einem seinerzeit allgemein akzeptierten Axiom an, bei Thomas Robert Malthus' Theorie von der ständigen Knappheit der Nahrungsgrundlage. Der Ökonom Malthus hatte angenommen, daß die Bevölkerung immer stärker zunehme, als die verfügbare Nahrungsgrundlage. ${ }^{113}$ Darwin vermutete seinerseits, daß aufgrund dieser Knappheit ein andauernder Überlebenskampf (,struggle for existence“) geführt würde. ${ }^{114}$ In diesem Kampf überlebten jene Arten und Individuen, die sich aufgrund ihrer Eigenheiten als überlegen erwiesen:

„Diese Erhaltung günstiger Variationen und die Ablehnung schädlicher Variationen nenne ich Natürliche Auslese. Variationen, die weder nützlich noch nachteilig sind, würden durch die Natürliche Auslese nicht betroffen“. ${ }^{115}$

111 Vgl. Robert M. Young (1985b) „The Impact of Darwin on Conventional Thought“. In: Ders. (Hrsg.): Darwin's Metaphor. S. 1-22, S. 1-4; Bowler 1988; Greene1981a.

112 Thomas S. Kuhn hat Darwins Aufgabe einer teleologischen Theorie der Evolution als das wissenschaftlich Revolutionäre am Origin of Species ausgewiesen (vgl. Kuhn 1996, S. 171-172).

113 Vgl. Thomas Robert Malthus (1890) An Essay on the Principle of Population or a View of its Past and Present Effects on Human Happiness. [1803] London: Johnson, S. 2; vgl. auch Donald Winch (1987) Malthus. Oxford: Oxford University Press; Robert M. Young (1985a) „Malthus and the evolutionists: the common context of biological and social theory“. In: Ders. (Hrsg.): Darwin's Metaphor. Cambridge: Cambridge University Press, S. 23-55.

114 Vgl. Darwin 1998a, S. 50-51.

115 Darwin 1998a, S. 64: „This preservation of favourable variations and the rejection of injurious variations, I call Natural Selection. Variations neither useful nor injurious would not be affected by natural selection". 
Anpassung und natürliche Auslese sind die Kernannahmen Darwins. Darüber hinaus entwickelte er seine Theorie auch unter Verwendung lamarckscher Elemente. So ging er beispielsweise davon aus, daß die adaptiven Mechanismen zu vererbbaren Eigenschaften führten. Grundsätzlich maß er jedoch traditionellen Ansätzen wie dem Lamarckismus nur eine marginale Bedeutung für die Erklärung der Entstehung der Arten bei. ${ }^{116}$ Dies lag nicht zuletzt an seiner Lektüre Henry Milne-Edwards. ${ }^{117}$ Darwin übertrug, wie Sylvan Schweber erkannte, durch eine ebenso simple wie effektive Veränderung der Wortstellung Milne-Edwards' Prinzip der Teilung der physiologischen Arbeit in eine physiologische Teilung der Arbeit. ${ }^{118}$ Im Origin stand ihm damit eine naturwissenschaftliche Quelle für das Zusammenwirken von Adaption und Spezialisierung zur Verfügung, die ihm das Gewicht der malthusianischen Arithmetik, d.h. des notwendigen und selektiven Bevölkerungsdrucks, in der Bilanz seiner theoretischen Anleihen auszubalancieren ermöglichte.

Der Überlebenskampf war zwar ein wesentliches Element in Darwins Theorie, doch die Vorstellung, daß ein besser angepaßter Organismus einen Wettbewerbsvorteil darstelle, war selbst nicht neu. Allerdings war seine Begründung für die Variation ein Novum seines Ansatzes. Variation wäre in der Natur ein ubiquitäres Phänomen, das auf zufälligen und minimalen Mutationen beruhe, die den Ursprung der Differenzierung der Arten bildeten:

„Ich betrachte individuelle Unterschiede, die für den Taxonomen nur von geringer Bedeutung sind, als höchst wichtig für uns, als ersten Schritt hin zu Varietäten, die so klein sind, daß sie kaum eines Eintrags in Arbeiten zur Naturgeschichte Wert gehalten werden“. ${ }^{119}$

Diese Betonung der permanenten und minimalen Mutationen als Grundlage der Entstehung der Arten implizierte die Anerkennung des Lehrsatzes natura non facit saltum. ${ }^{120}$ Der Grund, warum dennoch nicht unendlich viele Übergangsformen vorzufinden seien, läge darin, daß sie selbst

116 Vgl. Darwin 1998a, S. 104-111.

117 Henry Milne-Edwards (1800-1885), französischer Zoologe und Entomologe.

118 Vgl. Sylvan S. Schweber (1980) „Darwin and the Political Economists: Divergence of Character". In: Journal of the History of Biology 13, S. 195-289, S. 212-213, S. 250-256.

119 Darwin 1998a, S. 42: „I look at individual differences, though of small interest to the systematist, as of high importance to us, as being the first step towards such slight varieties as are barely thought worth recording in work on natural history".

120 Vgl. Darwin 1998a, S. 132-133, S. 355. 
nur unvollkommene Anpassung an zudem räumlich wie zeitlich stark begrenzte Umweltbedingungen darstellten und deshalb von späteren, besser angepaßten Variationen rasch verdrängt worden sein müßten. ${ }^{121}$

Darwin hatte die Frage nach dem Platz des Menschen aus Origin of Species bewußt herausgehalten. ${ }^{122}$ Ursprünglich jedoch war in dem zunächst ja umfangreicher geplanten Werk ein Kapitel über den Menschen vorgesehen, was Greene anhand von Korrespondenzen, Manuskripten und Annotationen Darwins darlegt. ${ }^{123}$ Diese Fragmente zeigen, daß Darwin nach Anhaltspunkten für Parallelen zwischen der organischen und der sozialen Evolution suchte. Anders als Spencer, hielt er diese Vermutungen aber zurück. Doch sie belegen, daß die Frage der Entwicklung des Menschen bei jedem theoretischen Versuch, die Entwicklung und Entstehung des Lebens generell zu rekonstruieren, mitgedacht wurde. Gerade deshalb erfüllte sich Darwins Hoffnung nicht, die Rezeption des Origins könnte durch das Aussparen einer Diskussion dieses heiklen Punkts begünstigt werden.

In Origin of Species hatte Darwin ein für die Entstehung eines evolutionstheoretischen Rassenbildes bedeutendes Element entwickelt, denn er betonte die Relativität der Anpassungsleistung und ihre Abhängigkeit von der Umwelt. Fremde Organismen genössen oft einen Vorteil, trotz einer Umwelt, an die sie nicht angepaßt seien:

„Da die natürliche Auslese durch Wettbewerb wirkt, paßt sie die Bewohner eines Landes nur in Relation zum Grad der Perfektion ihrer Gefährten an; so brauchen wir nicht überrascht zu sein, wenn die Bewohner irgend eines Landes von den naturalisierten Geschöpfen eines anderen Landes besiegt und verdrängt werden, obwohl es vordergründig so scheint, als wären sie speziell für dieses Land geschaffen und an es angepaßt“. ${ }^{124}$

Die Anpassung noch an die unwirtlichsten Bedingungen stellte für Darwin also keinen Wert an sich dar. Diese Überlegung entfaltet ihre volle

121 Vgl. Darwin 1998a, S. 133-138; Ruse 1979, S. 192.

122 Darwin hatte seinen Verleger explizit darauf hingewiesen, daß die kontroverse Frage zur Rolle des Menschen ausgespart bliebe (vgl. Desmond, Moore 1994, S. 538).

123 Vgl. John C. Greene (1981b) „Darwin as a Social Evolutionist“. In: Ders.: Science, Ideology, and Worldview. Essays in the History of Evolutionary Ideas. S. 95-127, S. 98-101.

124 Darwin 1998a, S. 35: „As natural selection acts by competition, it adapts the inhabitants of each country only in relation to the degree of perfection of their associates; so that we need feel no surprise at the inhabitants of any one country, although on the ordinary view supposed to have been specially created and adapted for that country, being beaten and supplanted by the naturalized productions from another land“". 
Bedeutung im imperialen Kontext, in dem sie den kontingenten Relativismus der Adaptionshypothese durch das Motiv des Wettbewerbs entkräftet. Darwin mag nicht nur an die Berichte über Pflanzen- und Tierarten gedacht haben, die europäische Kolonisatoren eingeführt hatten und die die endemischen Arten verdrängten, sondern sich auch seines Überlegenheitsgefühls bei seiner Begegnung mit den Feuerländern erinnert haben. ${ }^{125}$ Er selbst stellte an dieser Stelle keine Verbindung zur anthropologischen Diskussion her. Seine Argumentation war trotzdem relevant für den entschieden nicht-kulturrelativistischen Diskurs der evolutionären Anthropologie, der eine Parallelstruktur aufwies. In ihm führte der Topos der kulturellen Überlegenheit der Europäer zu keinem Konflikt mit der Vorstellung, vermeintlich Wilde seien besonders angepaßt an ihre Umwelt gewesen, da die Anpassung zwar als Mechanismus von zentraler Bedeutung war, an sich aber kein normatives Element darstellte.

Darwin hatte also eine Theorie entworfen, die einerseits von einer hierarchischen Ordnung der Organismen ausging und die andererseits noch nicht gänzlich frei von teleologischen Annahmen war. In ihr wurden dennoch die progressivistischen und Perfektionierungs-Vermutungen verworfen und an deren Stelle eine evolutionäre Mechanik der Entstehung der Arten gestellt, die auf einem Zusammenspiel des inneren Faktors der zufälligen Mutation mit äußeren Faktoren wie Ressourcenknappheit und natürlicher Auslese basierte.

\subsection{Menschen und Mammuts. Das Alter der Menschheit}

$\mathrm{Zu}$ den epistemischen Vorbedingungen der Darwinianischen Revolution rechnete die Ausweitung der geologischen Zeitrechnung, die auf den britischen Geologen Charles Lyell zurückzuführen ist. Di damals noch gültige, traditionelle Zeitrechnung, die seit James Usshers Kalkulation im siebzehnten Jahrhundert für die Erde ein Alter von ungefähr sechstausend Jahren annahm, war unvereinbar mit der Vorstellung, daß die Vielfalt der Arten in einem von der Natur selbst initiierten Prozeß unendlicher Mutationen und gradueller Veränderungen entstanden sei. ${ }^{126}$

125 Vgl. Charles Darwin (1989) Voyage of the Beagle. [1839] London: Penguin, S. 171-184.

126 James Ussher (1581-1656) war Prälat der anglikanischen Kirche und Professor am Trinity College in Dublin (vgl. allgemein Claude C. Albritton (1980) The Abyss of Time, Changing Conceptions of the Earth's Antiquity After the Sixteenth Century. San Francisco: Freeman, Cooper). 
Eine Vorbedingung für die Einführung des Evolutionsparadigmas in den anthropologischen Diskurs war mit dieser Wende in der Geologie verbunden. Sie revolutionierte auch die Archäologie, denn durch das modifizierte Verständnis des Alters der Erde konnte auch das Verständnis des Alters der Menschheit verändert werden. Im achtzehnten Jahrhundert hatte man Usshers Zeitrechung mit dem Cuvierschen Katastrophismus dahingehend kombiniert, daß die Erdgeschichte zwar unterschiedliche Epochen durchlaufen habe, die Geschichte des Menschen selbst aber auf die letzte, die moderne Welt beschränkt sei, die eben vor ungefähr sechstausend Jahren entstanden sei. ${ }^{127}$

Die britische Archäologie und Geschichtswissenschaft kannte vor der Zeit der Römer nur noch die keltische Epoche, der alle Ausgrabungs-Fundstücke zugeordnet wurden, die sich nicht als römisch interpretieren ließen. Megalithische Anlagen wie Stonehenge wurden deshalb für „druidische Tempelstätten“ der Kelten gehalten. ${ }^{128}$ Durch den Dänen Christian Thomsen wurde Anfang des neunzehnten Jahrhunderts die Unterscheidung von Stein-, Bronze- und Eisenzeit eingeführt. ${ }^{129}$ Diese relative Unterteilung hatte jedoch zunächst keinen Einfluß auf die Bestimmung des absoluten Alters des Menschen. ${ }^{130}$ Für eine präzise Altersbestimmung war in der damaligen Methodologie die kombinierte Anwendung von Stratigraphie und Paläontologie erforderlich; erstere, um die Lage eines Fundes in einer bestimmten Schicht zu bestimmen,

127 Bis dahin hatten Geologen angenommen, jede dieser vormodernen Epochen des Erdzeitalters hätte eine jeweils besondere Fauna und Flora hervorgebracht. Sie erklärten sich damit die in unteren, also älteren, Ablagerungsschichten gefundenen Spuren von Tieren und Pflanzen, die zwar Ähnlichkeiten mit heute lebenden Formen aufwiesen, aber doch nicht identisch waren.

128 Vgl. Guy Freeland (1983) „Evolutionism and Arch(a)eology“. In: David Roger Oldroyd, Ian Langham: The Wider Domain of Evolutionary Thought. Dordrecht u.a.: Reidel, S. 175-219, S. 183; Fernand Niel (1977) Auf den Spuren der Großen Steine. Stonehenge, Carnac und die Megalithen. München: List, S. 244-250.

129 Vgl. Judith Rodden (1981) „The development of the Three Age System: Archaeology's first paradigm“. In: Glyn Daniel (Hrsg.): Towards a History of Archaeology. Being the Papers Read at the First Conference on the History of Archaeology in Aarhus, 29 August - 2 September 1978. London: Thames, Hudson, S. 51-68; Geoffrey Bibby (1960) Faustkeil und Bronzeschwert. Frühzeitforschung in Nordeuropa. Berlin, Darmstadt, Wien: Dt. Buchgemeinschaft, S. 26-32. Thomsens Werk wurde 1848 ins Englische übersetzt.

130 Für Thomsen beispielsweise begann die Steinzeit gerade einmal vor ca. 3000 Jahren (vgl. Graham Clark (1972) Aspects of Prehistory. Berkeley: University of California Press, S. 9). 
letztere, um in derselben Schicht abgelagerte fossile Reste von Tieren zu identifizieren.

1858 wurden in Nordfrankreich und in England Steinwerkzeuge gefunden, die eine Wende in der Archäologie einleiteten. Diese Funde bewiesen, daß Menschen zeitgleich mit Mammuts gelebt hatten, sie wurden deshalb auf eine Zeit datiert, die weit vor der bis dahin anerkannten Zeitrechnung gelegen haben mußte. ${ }^{131}$ Mitte 1859 wurden diese Erkenntnisse der britischen scientific community auf Versammlungen der Royal Society und der British Association kommuniziert. Auch Charles Lyell, seinerzeit der renommierteste Geologe Englands, bekräftigte den Befund, daß die alte Zeitrechnung nun keinen Bestand mehr haben konnte. ${ }^{132}$ Dieser Paradigmawechsel in der Archäologie fand also in beachtlicher zeitlicher Nähe zur der Debatte statt, die Darwins Buch nur wenige Monate später auslösen sollte. ${ }^{133}$

Dennoch war ein wesentliches Problem nicht gelöst, nämlich die Bestimmung des absoluten Alters menschlicher Artefakte und Überreste. Diese Frage wurde Gegenstand der Debatten, die sich in der Folge anschlossen. ${ }^{134}$ Prominente Evolutionisten und Darwinianer schalteten sich in diese Diskussionen ein. Lubbock und Busk besuchten archäologische Fundstellen in Nordfrankreich, Dänemark und der Schweiz, um sich ein Bild von den prähistorischen Hinterlassenschaften in situ zu machen. ${ }^{135}$

131 Vgl. Glyn Daniel (1952) A Hundred Years of Archaeology. London: Duckworth, S. 58-61.

132 Charles Lyell hatte sich in den 1830er Jahren durch die Veröffentlichung seiner Principles of Geology (1830-32) einen Namen als Geologe gemacht. Sein Konzept des Uniformitarismus, das von der Annahme ausging, daß die gegenwärtigen physischen, geologischen Prozesse auch in der Vergangenheit gewirkt haben müssen, stand der damals etablierten Lehrmeinung des Katastrophismus entgegen, die vor allem auf den Franzosen George Cuvier zurïckging und fossile Funde heute nicht mehr lebender Tiere als Spuren früherer Zeitalter, die durch Katastrophen ausgelöscht worden seien, deutete (vgl. Daniel 1952, S. 33-38; vgl. allgemein L. G. Wilson (1972) Charles Lyell. The Years to 1841: The Revolution in Geology. New Haven, Conn.: Yale University Press).

133 Vgl. A. Bowdoin Van Riper (1993) Men Among the Mammoths. Victorian Science and the Discovery of Human Prehistory. Chicago: University of Chicago Press, S. 115-116.

134 Vgl. Van Riper 1993, S. 155. In den Jahren nach 1859 hatte man sich zunächst unspezifisch auf eine ,große Zeitspanne“ geeinigt. Erst 1863 taxierte Lyell in Antiquity of Man dessen Alter auf hunderttausend Jahre und gab damit als erster eine Einschätzung in absoluten Zahlen ab.

135 In Dänemark wurden sie unter anderem vom dänischen Biologen Johan Steenstrup begleitet, dessen wichtige Monographie Alternation of Generations George Busk 1848 übersetzt hatte, was mit ziemlicher Sicherheit den Kontakt zwischen Lubbock und den dänischen Archäologen hergestellt haben dürfte. 
Von Lubbock stammte dann auch die Unterscheidung zwischen Alt- und Jungsteinzeit, mit der er Thomsens Zeitunterteilung modifizierte. Die unterschiedlichen Fertigungsweisen der steinzeitlichen Werkzeuge verlangten nach einer differenzierten Betrachtung dieser Epoche und Lubbock unterschied die gröber gearbeiteten, frühsteinzeitlichen Funde aus Abbeville, die er den Ablagerungen in Flußbetten (,drift“) zuordnete, von den polierten, jungsteinzeitlichen Werkzeugen, die in Hügelgräbern oder bei den schweizer Pfahlbauten gefunden worden waren. ${ }^{136}$ Er war damit an der Begründung einer Schule der Archäologie beteiligt, die sich als Prähistorische Archäologie bezeichnete. Sie wurde von einer jüngeren Archäologen-Generation gebildet, deren Karrieren erst nach 1860 begannen, und denen es deshalb erheblich leichter fiel, die neue Zeitrechnung zu akzeptieren. ${ }^{137}$

Der Paradigmawechsel in der Archäologie schloß einen sozialen Ablösungsprozeß ein, denn die neuen Erkenntnissen führten zu einer veränderten Forschung, an der sich die große Mehrzahl der Vertreter der alten Archäologie nicht mehr beteiligten. Sie grub nicht mehr nach den Spuren einer idealisierten Antike, sondern suchte in Nord- und Mitteleuropa nach den Spuren vorzeitlicher Gesellschaften, deren kulturelle Leistung nicht für bewundernswert sondern für primitiv gehalten wurde.

136 Vgl. Lubbock (1862a) „On the Ancient Lake Habitations of Switzerland“. In: The Natural History Review 2, S. 26-51, S. 27; Lubbock (1865) „On Mr. Bateman's Researches in Ancient British Tumuli“. In: Transactions of the Ethnological Society of London. n.s. 3, S. 307-321; Solche archäologische Forschung betrieb Lubbock noch für längere Zeit weiter. Dabei befaßte er sich oft mit Detailstudien, die er nicht zum Anlaß theoretischer Erörterungen nahm (vgl. Lubbock (1868b) „Stone Implements from the Cape“. In: Journal of the Ethnological Society of London, n.s. 1, S. 51-53; Lubbock (1872b) „Note on Some Stone Implements from Africa and Syria“. In: Journal of the Anthropological Institute 1, xcii-xcvii; Lubbock (1875) „Notes on the Discovery of Stone Implements in Egypt“. In: Journal of the Anthropological Institute 4, S. 215-222; Lubbock (1881) „Note on a Stone Implement of Palaeolithic Type found in Algeria“. In: Journal of the Anthropological Institute 10, S. 316-319).

137 Vgl. Thomas Trautmann (1987) Lewis Henry Morgan and the Invention of Kinship. Berkeley: University of California Press, S. 220. 


\subsection{Fortschritt und Wachstum. Spencers organische Evolutionslehre}

Es war Herbert Spencer, der in den fünfziger Jahren des neunzehnten Jahrhunderts den Begriff der Evolution systematisch aus der Kombination verschiedener naturwissenschaftlicher Ansätze gewann. ${ }^{138}$ Dabei verband er diesen Begriff mit seinem Verständnis sozialer Entwicklung, das sich ab den vierziger Jahren im Rahmen seiner radikalliberalen Kritik an der Sozialpolitik Englands herausbildete. ${ }^{139}$ Er behauptete, daß die Ursache für die Armut bei den Verarmten selbst läge:

„In neun von zehn Fällen kommt solches Elend vom Fehlverhalten des Einzelnen oder seiner Eltern. [...] Die Eltern können an ihr Kind entweder eine schlechte Moral weitergeben oder einen krankhaften Zug oder sie können es im Zustand großer Not zurücklassen“. ${ }^{140}$

Indem er die Armut als selbstverschuldet darstellte, griff er ein tradiertes Motiv auf, das schon zu Zeiten der Elizabethanischen Armengesetzgebung zu unterscheiden trachtete, wer der Zuwendung wert und wer ihrer nicht wert wäre. Spencer schilderte die hinter der Armut vermutete Ten-

138 Vgl. Robert L. Carneiro (2003) Evolutionism in Cultural Anthropology: A Critical History. Boulder, Colorado: Westview Press, S. 3; Bereits 1851 hatte Spencer den Begriff der Evolution mit der sozialen Entwicklung verbunden, allerdings noch nicht im Sinne eines theoretischen Konzeptes (vgl. Spencer 1851, S. 440: ,what we call the moral law - the law of equal freedom, is the law under which individuation becomes perfect; and [the] ability to recognize and act up to this law, is the final endowment of humanity - an endowment now in process of evolution“). Vgl. auch Richards 1992, S. 73.

139 Am Umstand, daß Spencer anfangs kein Naturwissenschaftler sondern ein politischer Philosoph gewesen war, hat die Forschung zur Evolutionsgeschichte großes Interesse gezeigt. David Wiltshire betont, Spencer sei zunächst Individualist und erst später Evolutionist gewesen (vgl. Wiltshire 1978, S. 135). Andere wiederum meinen, Spencer habe das Soziale biologisiert, da er seine evolutionäre Mechanik aus der Biologie heraus entwickelt habe (vgl. J.D.Y. Peel (1972) „Introduction“. In: Ders. (Hrsg.): Herbert Spencer on Social Evolution. Selected Writings. Chicago: University of Chicago Press, S. vii-li).

140 Spencer (1994) „The Proper Sphere of Government“. In: [The Nonconformist 2 und 3, 1842-43] John Offer (Hrsg.): Herbert Spencer: Political Writings. Cambridge: Cambridge University Press, S. 3-57, S. 17f: „In nine cases out of ten, such miseries result from the transgressions of the individual or his parents [...]. The parent may either transmit to the child bad moral tendencies, a constitutional taint, or may leave it in circumstances of great misery". 
denz zur Immoralität als eine vererbbare „moralische Krankheit“. ${ }^{141}$ Wirksame Abhilfe könne nur durch die ungeschönte Armutserfahrung initiiert werden, als Anstoß zur Selbsthilfe. Doch die Armengesetzgebung lindere die Übel der Armut und hebele so eine natürliche Wirkungskette aus.

Später modifizierte Spencer seine Analyse sozialer Not. In Social Statics führte er sie auf eine defizitäre Anpassung zurück, faßte dieses Anpassungsdefizit jedoch als den Motor immer weiterer Entwicklung auf. $^{142}$ Jede Schmerzensregung und alles Leiden sei Ausdruck einer gestörten Harmonie zwischen einem Organismus und den Umweltbedingungen, für die er nur unzureichend angepaßt sei - eine Modifikation halte deshalb solange an, bis die Anpassung vollständig sei. ${ }^{143}$ Es fände also ein progressiver Adaptionsprozeß statt: „Fortschritt ist deshalb kein Zufall, sondern eine Notwendigkeit. Zivilisation ist nicht künstlich, sondern Teil der Natur“. ${ }^{144}$ Er argumentierte lamarckistisch und subsumierte organische wie soziale Entwicklungen unter einer Gesetzmäßigkeit.

141 Spencer 1994, S. 18: ,the same tendency to immorality, which characterised the parent is bequeathed to the offspring - the moral disease requires a cure - under a healthy social condition that cure will be found in the poverty which has followed in its train".

142 Vgl. Spencer 1851, S. 59: „All evil results from the non-adaptation of constitution to conditions". Ernest Albee nimmt wegen dieser Formulierung an, daß Spencers Ausgangspunkt in der Biologie liegt, allerdings habe Spencer noch nicht ,in the light of modern evolutionary thought“ geschrieben und hätte auch keine Faktoren benannt, die die Anpassung an die Verhältnisse bewirkten (Ernest Albee (1957) A History of English Utilitarianism. London: Allen and Unwin, S. 277). John C. Greene schreibt dagegen, daß Spencers ,social ideal had never really been grounded in biological science“ (John C. Greene (1969) „Biology and Social Theory in the Nineteenth Century: Auguste Comte and Herbert Spencer". In: Marshall Clagett (Hrsg.): Critical Problems in the History of Science. Madison, Milw., London: University of Wisconsin Press, S. 419-446, S. 440). Spencer habe in jugendlichem Optimismus den Fortschritt der Natur auf die historische und soziale Entwicklung übertragen, aber „both history and biology betrayed him“ (ebd.). Auf die sozialpolitischen Implikationen dieser Passage gehen weder Albee noch Greene ein. Sie befassen sich mit den nur als wechselseitiges Verhältnis zu begreifenden Austauschbedingungen von natur- und sozialwissenschaftlicher Theoriebildung im neunzehnten Jahrhundert (und bei Spencer im besonderen), und sehen in der Anleihe bei der Biologie ein Hindernis für die Entwicklung der sozialen Theorie bei Spencer.

143 Spencer 1851, S. 60: ,and modification [...] continues until the adaptation is complete".

144 Spencer 1851, S. 65: „Progress, therefore, is not an accident, but a necessity. Instead of civilization being artificial, it is part of nature“. 
Nach Spencer ging der Prozeß der Zivilisation mit einem individuellen Freiheitsverlust einher, denn das größte Maß an Individuation würde unweigerlich von der ,größten wechselseitigen Abhängigkeit“ begleitet. ${ }^{145}$ Nur mittels der „Aneignung einer selbstbeschränkenden Kraft“" wäre der Mensch befähigt, ,in Harmonie mit seinen Mitmenschen zu leben“. ${ }^{146}$ Spencers Vorstellung sozialer Entwicklung setzte von Beginn an eine Anpassung mentaler Eigenschaften der Menschen an den sozialen Zustand voraus.

\section{Theorien organischer Evolution}

Die dynamische Entwicklung der naturwissenschaftlichen Wissensbestände wurde in den fünfziger Jahren des neunzehnten Jahrhunderts mit großem Interesse vom Londoner Bildungsbürgertum verfolgt. Unter dem Eindruck dieser Diskussionen richtete Spencer seinen Ansatz zunehmend naturwissenschaftlich aus und bekannte sich unmißverständlich zur Hypothese natürlicher und naturbedingter Entwicklung. Es wäre irrig ,anzunehmen, daß irgendeine Art jemals geschaffen worden sei“. ${ }^{147}$ Seine Evolutionstheorie bestand in der Annahme einer Entwicklung von „den einfachsten zu den komplexesten Formen“ des Lebens, „durch kleine Zuwächse an Veränderung kann jede Summe von Veränderungen im Laufe der Zeit hervorgerufen werden“. ${ }^{148}$

Spencer nahm an, daß die evolutionäre Höherentwicklung der Organismen mit einer Differenzierung ursprünglich homogener Funktionen einhergehe und den „Fortschritt der Organisation“ bedinge. ${ }^{149}$ Diese Tendenz zu Heterogenität selbst begründete er nicht im Bezugssystem

145 Spencer 1851, S. 441: „,must this highest individuation be joined with the greatest mutual dependence".

146 Spencer 1851, S. 198: „by the acquirement of self-restraining power, becomes fitted to live in harmony with his fellow".

147 Vgl. Spencer (1908) „The Filiation of Ideas“. In: Duncan 1908. S. 533576, S. 543; Spencer (1852b) „The Development Hypothesis“. In: [The Leader 3 (20. März), S. 280-281] Essays. Bd. 1, S. 1-7, S. 1: ,assume that any species ever had been created".

148 Spencer 1852b, S. 4: „by small increments of modification, any amount of modification may in time be generated"; Peter J. Bowler weist darauf hin, daß Spencer als einer der ersten den Begriff der Evolution in einem naturwissenschaftlichen Kontext verwendet habe. Für das, was Spencer mit Theorie der Evolution meinte, seien damals vorwiegend die Begriffe „Development“ oder „Transmutation“ verwendet worden (vgl. Bowler 1975, S. 104).

149 Spencer (1852a) „A Theory of Population. Deduced from Animal Fertility“. In: The Westminster Review, New Series 1, S. 468-501, S. 488: ,change from homogeneity of function to heterogeneity of function“, ,progress of organization“. 
der Biologie, sondern mit einem Rückgriff auf die Physik, denn „,der Zustand der Homogenität ist ein Zustand instabilen Gleichgewichts" und könne deshalb, Gesetz der Mechanik, nicht aus sich heraus aufrecht erhalten werden, woraus der „erste Schritt seines Hinstrebens zum Heterogenen" resultiere. ${ }^{150}$ Die Ausdifferenzierung der Funktionssysteme in einem Organismus könne nur bei gleichzeitiger Herausbildung einer Koordinierungsstruktur erfolgen, dem Nervensystem. ${ }^{151}$ Dessen sich bei den höheren Lebewesen herausbildende zentrale Einrichtung, das Gehirn, war für Spencer zugleich Voraussetzung und Ausdruck stetig steigender Individualisierung und stetig steigender Intelligenz. ${ }^{152} \mathrm{Er}$ betrachtete Intelligenz als ein Mittel der Anpassung eines Organismus an seine Umwelt. Da er deren individuelle Entwicklung als einen Prozeß der Entfaltung von Anlagen beschrieb, ${ }^{153}$ ging er notwendigerweise von ihrer Vererbbarkeit aus. ${ }^{154}$ Wenn sich ein Verhalten verstetige, dann würde auch die dahinterliegende psychische Disposition verstetigt und als Anlage vererbt. ${ }^{155}$

Spencer hatte bisher zwar von der Anpassung eines Organismus an seine Umweltbedingungen gesprochen und diesen Anpassungsprozeß als einen Generationen und Zeitalter überdauernden Vorgang begriffen, doch erst in „Transcendental Physiology“ (1857) entwickelte er einen spezifischen Mechanismus für diesen Prozeß. Hier führte er die wesentlichen Elemente seiner Lamarckrezeption ein, schrieb von der „Bezie-

150 Spencer (1857b) „Transcendental Physiology“. In: [,,The Ultimate Law of Physiology”. In: National Review 5, S. 332-355] Essays. Bd. 1, S. 63107, S. 81: "the condition of homogeneity is a condition of unstable equilibrium“, vgl. S. 82: ,the first step in its gravitation towards the heterogeneous". Spencer beruft sich auf die Theorie der physischen Arbeitsteilung von Milne-Edwards, wobei interessant ist festzuhalten, daß nicht nur Milne-Edwards damit eine soziale Metapher in die organische Biologie eingeführt hat, sondern daß auch Spencer bereits in Social Statics die aus der sozialen Arbeitsteilung erwachsene, wechselseitige Abhängigkeit diskutierte und daß deshalb der Aspekt der „Verbindung der Teile" ebenfalls von der Beobachtung der sozialen Arbeitsteilung inspiriert ist. Peel fragt völlig zu Recht nach dem Mechanismus, der diese Arbeitsteilung antreibe, und stellt fest, daß sie, wie jegliche Differenzierung oder Spezialisierung von Spencer allein über ihr adaptives Potential begründet wird (vgl. Peel 1971, S. 139).

151 Vgl. Spencer 1852a, S. 485-486.

152 Vgl. Spencer 1852a, S. 495.

153 Vgl. Spencer (1855) The Principles of Psychology. London: Longmans, S. 349: „from the simple reflex action by which the infant sucks, up to the elaborate reasonings of the adult man, the progress is by infinitisemal steps [...] Here intelligence begins“".

154 Vgl. Spencer 1855, S. 526: „Hereditary transmission [...] applies not only to physical but to psychical peculiarities".

155 Vgl. Spencer 1855, S. 526. 
hung zwischen der Aktivität eines Organs und seinem Wachstum“ und nahm eine ,erbliche Übertragung“ der so erworbenen Eigenschaften an. ${ }^{156}$

Darwin spielte bei der Entwicklung von Spencers Evolutionstheorie nur eine Nebenrolle. Spencer kündigte seinem Vater die Principles of Biology mit der Einschätzung an: „Ich bin an einem Punkt angelangt, von dem aus erkannt werden kann, wie Darwins Doktrin der ,Natürlichen Auslese، von der grundsätzlichen Theorie der Evolution, wie ich sie interpretiere, absorbiert wird“. ${ }^{157}$ Doch zumindest hatte ihm Darwins Kritik an Lamarck die Notwendigkeit einer eigenen Bewertung Lamarcks vor Augen geführt. Lamarck seien zwar Fehler unterlaufen, so sein Befund, dennoch tauge sein Ansatz als theoretisches Fundament:

„Zu sagen, daß funktionale Anpassung an die Verhältnisse grundsätzlich Evolution schaffe [...] wirft weitere Fragen auf. Diese biologische Ableitung muß selbst interpretiert werden. Nur wenn der Evolutionsprozeß von Organismen in den generellen Prozeß der Evolution eingeordnet wird, kann von seiner wirklichen Erklärung gesprochen werden. Was notwendigerweise gezeigt werden muß ist, daß seine verschiedenen Ergebnisse Folgen erster Prinzipien sind". 158

Grundsätzlich entwickelte Spencer hier eine Evolutionstheorie, die versuchte, Darwins Theorie der natürlichen Auslese zu integrieren, ohne dabei die lamarckistische Perspektive zu verlassen. ${ }^{159}$ Andererseits war er einer der wenigen Viktorianer, die umgehend Darwins Theorie akzeptierten, wenn er dafür auch nicht seine eigenen Konzepte aufzugeben bereit war. ${ }^{160}$ Er erklärte, natürliche Auslese würde die Anpassung der

156 Spencer 1857b, S. 63: „relation between the activity of an organ and its growth“, S. 64: ,heredity transmission“.

157 Spencer 1904b, Bd. 2, S. 50; Spencer an George Spencer, 09. Juni 1864, In: Spencer 1904b, Bd. 2, S. 99-100: „I arrived at a point of view from which Darwin's doctrine of ,Natural Selection“ is seen to be absorbed into the general theory of Evolution as I am interpreting it".

158 Spencer (1883a) The Principles of Biology. [Bd. 1: 1864, Bd. 2: 1867] New York: Appleton, Bd. 1, S. 409-410: „To say that functional adaptation to conditions, produces either evolution in general $[\ldots]$ is to raise further questions $[\ldots]$ The biological induction must itself be interpreted. Only when the process of evolution of organisms, is affiliated on the process of evolution in general, can it be truly said to be explained. The thing required is to show that its various results are corollaries from first principles".

159 Vgl. Spencer 1883a, Bd. 1, S. 405ff.

160 Vgl. Herbert Spencer an Charles Darwin (22. Februar 1860). In: CCD Bd. 8, S. 98-99: „You have wrought a considerable modificn in the views I held [...] But I \& every one overlooked the selection of ,sponta- 
inneren an die äußeren Strukturen schaffen. ${ }^{161}$ Dabei blieb aber Darwins These der spontanen Variation auf der Strecke, an deren Stelle Spencer die Annahme einer zweischrittigen Evolution setzte: Eine direkte Evolution würde nach herkömmlicher lamarckscher Art funktionaler Adaption an die Umweltbedingungen ablaufen, eine indirekte Evolution wäre dann die natürliche Auslese, bei Spencer das survival of the fittest, bevor dann wieder der lamarcksche Mechanismus der Vererbung einsetze. ${ }^{162}$ Vor allem betonte er neben der Wirkung äußerer Faktoren, die die organische Evolution bedingten, auch die Bedeutung eines inneren Faktors, der Tendenz zur Heterogenität. ${ }^{163}$ Evolution umfaßte für Spencer zwei wesentliche Prozesse: Wachstum und Entwicklung. Während er unter Wachstum lediglich eine Zunahme an Masse oder Umfang verstand, sei Entwicklung eine Zunahme an Struktur. ${ }^{164}$ Wachstum und Entwicklung hingen aber eng miteinander zusammen, da Wachstum ohne Differenzierung der Struktur nur in begrenztem Maße möglich sei. ${ }^{165}$ Darwin selbst, das bezeugen seine Korrespondenzen etwa mit Joseph Dalton Hooker, war von Spencers Methode nicht überzeugt, doch führte dies zu keiner öffentlichen Kritik und zu keinem internen Disput mit den Darwinianern des X-Clubs. ${ }^{166}$

Spencers Evolutionstheorie trägt deutliche Merkmale seiner frühen Annahmen über soziale Entwicklung, die er in den naturwissenschaftlichen Kontext übertrug. Die teleologische Fortschrittsvermutung findet sich in der aller Entwicklung übergeordneten Tendenz zum Gleichgewicht wieder, der Individualismus in der Annahme, Individuation sei ein Ausdruck evolutionärer Höherentwicklung. Doch Spencers Hinwendung zu den Naturwissenschaften erschöpfte sich nicht in der Wahl einer neuen Semantik. Er entwickelte die Systematik seiner Evolutionstheorie

neous " variation without which I think you have clearly shown that many of the phenomena are insoluble”; Valerie A. Haines (1997) ,Spencer and His Critics". In Charles Camic (Hrsg.): Reclaiming the Sociological Classics: The State of Scholarship. New York: Blackwell, S. 81-111, S. 96; Harris 1969, S. 178.

161 Vgl. Spencer 1883a, Bd. 1, S. 446: ,that natural selection is capable of producing fitness between organisms and their circumstances".

162 Vgl. Spencer 1883a, Bd. 1, S. 450ff; Robert J. Richards (1987) Darwin and the Emergence of Evolutionary Theories of Mind and Behavior. Chicago: University of Chicago Press, S. 291f; Jones 1980, S. 78f; John W. Burrow (1970) Evolution and Society. A Study in Victorian Social Theory. Cambridge: Cambridge University Press, S. 202.

163 Vgl. Spencer 1883a, Bd. 1, S. 423ff.

164 Vgl. Spencer 1883a, Bd. 1, S. 133: ,increase of structure“.

165 Vgl. Spencer 1883a, Bd. 1, S. 110ff.

166 Vgl. Charles Darwin an Joseph Dalton Hooker, 23. Juni 1863. In: CCD Bd. 11, S. 504. 
unter Heranziehung naturwissenschaftlicher Theorien. Die Embryologie von Baers lieferte ihm ein Modell der Entwicklungsrichtung, Lamarck den Mechanismus für diese Entwicklung. ${ }^{167}$ Aus diesen Elementen fügte Spencer eine Theorie organischer Evolution zusammen, die deshalb kein simples Ableitungsprodukt seiner politischen Überzeugung war, sondern einer naturwissenschaftlichen Rationalität folgte. So war Spencer, abgesehen von dem Umstand, daß er der erste moderne Evolutionstheoretiker war, an jenen naturwissenschaftlichen Evolutionsdiskurs anschlußfähig, der im Umkreis Darwins vor allem von Huxley und Hooker produziert wurde.

\subsection{Archetypen und Transmutation. Huxleys Rezeption der Evolutionstheorie}

Huxley orientierte sich in den fünfziger Jahren des neunzehnten Jahrhunderts noch stark an der von Cuvier und von Baer formulierten Kritik am Linnéschen Modell einer kontinuierlichen Ordnung des Lebens. ${ }^{168}$ Er zeigte sich gegenüber transmutativen und progressivistischen Modellen ähnlich skeptisch wie Owen, der aus seiner Kritik das Konzept der Archetypen entwickelt hatte. ${ }^{169}$ Huxley war zunächst von diesem Modell überzeugt und hielt die Unterschiede zwischen den Archetypen für so deutlich, daß keine Übergänge zwischen ihnen möglich seien. ${ }^{170}$

Von Baers Konzept der Haupttypen, Gruppen von Arten, die auf einem jeweils gemeinsamen Grundplan fußten, Cuviers Ablehnung der Lamarckschen Evolutionsvorstellung und Owens Vorstellung von Archetypen waren die Quellen, aus denen sich Huxleys Konzept der persistenten Typen speiste. Dieses entwickelte er in Auseinandersetzung mit den meist progressivistisch entworfenen Transmutationstheorien und stellte so in Abrede, daß sich die „Fortschrittstheorie“ paläontologisch belegen ließe, denn die archäologischen Funde zeigten, daß die Arten

167 Vgl. Haines 1988, S. 1205.

168 Vgl. Lyons 1999, S. 59, S. 65.

169 Vgl. Desmond 1989, S. 335-372; Nicolaas A. Rupke (1993) „Richard Owen's Archetype“. In: Isis 84, S. 231-251.

170 Vgl. Huxley (1853) „On the Morphology of the Cephalous Mollusca as Illustrated by the Anatomy of Certain Heteropoda and Pteropoda Collected During the Voyage of H.M.S. ,Rattlesnake“ in 1846-50“. In: [Philosophical Transactions of the Royal Society 1, 1853, S. 29-66] The Scientific Memoirs of Thomas Henry Huxley, Bd. 1, S. 52-93, S. 77: „the differences between the three archetypes are so sharp and marked as to allow no real transition between them". 
sich nicht wesentlich verändert hätten. ${ }^{171}$ Als persistente Typen bezeichnete Huxley jene „Pflanzen- oder Tierarten, die durch lange Epochen hindurch existierten, manchmal über die gesamte Spanne der dokumentierten Zeit mit nur wenig Änderungen“. ${ }^{172}$

Als die ersten Entrüstungsstürme wegen Origin of Species losbrachen, verpflichtete sich Huxley, für bevorstehende Auseinandersetzungen seine „Klauen zu wetzen“. ${ }^{173}$ Er schrieb an Darwin:

„Seit ich von Bärs Essays vor neun Jahren gelesen habe, hat kein Buch der Naturgeschichtlichen Wissenschaft einen derart großen Eindruck auf mich gemacht $[\ldots]$. In Bezug auf die ersten vier Kapitel stimme ich voll und ganz den darin vorgestellten Prinzipien zu. Ich denke, Sie haben eine wahre Ursache für die Entstehung der Arten aufgezeigt [...]. Die einzigen Einwände, die sich in mir regten, sind -1 . Daß Sie sich mit einer unnötigen Schwierigkeit beladen haben, Natura non facit saltum so uneingeschränkt zu akzeptieren; und 2. Es ist mir nicht klar, warum es überhaupt zur Variation kommen soll, wenn kontinuierliche physische Bedingungen von so geringer Bedeutung sind, wie Sie vorschlagen“. ${ }^{174}$

171 Vgl. Huxley (1854) „Vestiges of the Natural History of Creation“. In: [The British and Foreign Medico-Chirurgical Review 13, 1854, S. 425439] The Scientific Memoirs of Thomas Henry Huxley Bd. 5, S. 1-19, S. 7: „But has the progression theory any real foundation in the facts of palaeontology? We believe it has none“. Vestiges of the Natural History of Creation wurde 1844 anonym von dem schottischen Verleger Robert Chambers verfaßt. Es war ein publizistischer Erfolg und löste sowohl heftigen kirchlichen Widerstand als auch vernichtende Kritik von wissenschaftlicher Seite aus. Dennoch lobte Darwin an Vestiges, daß Chambers damit wichtige Hindernisse für die kommenden wissenschaftlichen Umwälzungen beseitigt hätte.

172 Huxley (1859a) „Time and Life: Mr. Darwin's ,Origin of Species““. In: Macmillan's Magazine 1, S. 142-148, S. 144-145: ,particular kinds of animals and plants which have existed throughout vast epochs, sometimes through the whole range of recorded time, with very little change. By reason of this persistency, the typical form of such a kind might be called a ,persistent type, ' in contradiction to those which have appeared for but a short time in the course of the world's history".

173 Vgl. Huxley an Charles Darwin, 18. November 1859. In: LLTHH, Bd. 1, S. 176: „I am sharpening up my claws and beak in readiness”.

174 Huxley an Darwin, 18. November 1859. In: LLTHH, Bd. 1, S. 175-176: „Since I read Von Bär's essay, nine years ago, no work on Natural History Science I have met with has made so great an impression upon me [...]. As to the first four chapters, I agree thoroughly and fully with all the principles laid down in them. I think you have demonstrated a true cause for the production of species [...]. The only objections that have occurred to me are -1 st, That you have loaded yourself with an unnecessary difficulty in adopting Natura non facit saltum so unreser- 
Huxleys Vorbehalte rührten am Wesentlichen des Origin, denn er bezweifelte dessen Annahme transmutativer Übergänge und spontaner Variationen. Offensichtlich nahm er für eine Variation auch immer einen Impuls aus den Umweltbedingungen an, da er nicht von einem dem Organismus inneren Perfektibilitätspotential ausging. Diese Kritik hielt ihn nicht davon ab, mit großer Wirkung zugunsten Darwins in die öffentliche Diskussion einzugreifen. Ende 1859 und Anfang 1860 veröffentlichte er insgesamt drei Rezensionen des Origin of Species und hielt an der Royal Institution die erste öffentliche Vorlesung über das Buch. ${ }^{175}$

Ungeachtet seiner Zweifel erkannte Huxley im Origin of Species offenbar einen wissenschaftspolitischen Nutzen. Gefürchtet von ,älteren Damen beiderlei Geschlechts“, erweise sich das Buch als „ein wahres Sturmgeschütz in der Waffenkammer des Liberalismus“. ${ }^{176}$ Es einzusetzen war offenbar nicht von einer bedingungslosen Zustimmung abhängig. Huxley war folglich nicht nur am theoretischen, sondern auch vielleicht sogar vor allem - am politischen Nutzen des Origin of Species interessiert. ${ }^{177}$ Seiner fulminanten politischen Lobpreisung folgte eine eher nüchterne wissenschaftliche Bestandsaufnahme. Huxley differenzierte zwischen Arten in morphologischer und in physiologischer Hinsicht, führte Beispiele der zufälligen Variation an und stellte die Notwendigkeit der Isolation heraus, damit sich Variationen verstetigen könnten. Zwar beschrieb er die Modifikation innerhalb einer Art und den daraus gegebenenfalls resultierenden adaptiven Vorteil, doch auf Darwins bereits im Titel des Buches angekündigtes Kernthema, durch die Mechanismen der zufälligen Mutation und der natürlichen Auslese die Entstehung neuer Arten zu erklären, ging Huxley nicht ein. Zuletzt bekräftigte er erneut seine Einschätzung, daß Origin of Species zwar eine überzeugende Hypothese darstelle, die sich aber die Weihen einer Theorie erst durch einen noch zu erbringenden empirischen Beleg ver-

vedly; and 2nd, It is not clear to me why, if continual physical conditions are of so little moment as you suppose, variation should occur at all".

175 Vgl. Huxley 1859a; Huxley 1860a; Huxley (1859b) „The Darwinian Hypothesis“. In: [The Times, 26. Dezember] Collected Essays, Bd. 2, S. 1-21; Huxley (1860b) „On Species and Races, and Their Origin” [Proceedings of the Royal Institution 3, 1858-1862, S. 195-200 und Annual Magazine of Natural History 5, S. 344-346] The Scientific Memoirs of Thomas Henry Huxley, Bd. 2, S. 388-394. Zur Vorlesung an der Royal Institution vgl. Desmond 1998, S. 267-269.

176 Huxley: (1860a) „The Origin of Species“. In: [Westminster Review 17 (n.s.), S. 541-570] Collected Essays, Bd. 2, S. 22-79, S. 22-23: „old ladies of both sexes consider it a decidedly dangerous book [...] while every philosophical thinker hails it as a veritable Whitworth gun in the armoury of liberalism".

177 Vgl. Lyons 1999, S. 82-83. 
dienen müsse, denn es sei nicht bewiesen, „daß eine Gruppe von Tieren, die alle Charakteristika einer Art in der Natur haben, jemals durch Auslese, künstliche oder natürliche, geschaffen wurde“. ${ }^{178}$

Zwei Annahmen Darwins teilte Huxley hingegen vorbehaltlos, den struggle for existence genannten malthusianischen Ansatz des Ressourcenmangels und den Mechanismus der Anpassung an die Umwelt. Den Vorgang der natürlichen Auslese erklärte Huxley wie Darwin mit der Analogie des Züchters, natürliche Auslese wirke allein auf zufällige $\mathrm{Mu}$ tationen und bevorzuge dabei jene Organismen, deren Eigenheit eine bessere Anpassung darstelle. ${ }^{179}$

Den Widerspruch zwischen seinen Archetypen und Darwins gradueller Modifikation versuchte Huxley dadurch abzufedern, daß er auf die Verstetigung vorzeitlicher Modifikationen auswich, ${ }^{180}$ ohne hingegen die Bedingungen einer derart einsetzenden Persistenz zu klären:

„Wenn es wahr ist, daß alle lebenden Arten das Ergebnis der Modifikation anderer und einfacherer Formen sind, muß die Existenz dieser wenig veränderten persistenten Typen [...] anzeigen, daß sie nur die endgültigen Zustände einer enormen Folge von Modifikationen sind, die während der großen Zeitspanne der vorgeologischen Zeit geschahen“. ${ }^{181}$

178 Huxley 1860a, S. 74: ,it is not absolutely proven that a group of animals, having all the characters exhibited by species in Nature, has ever been originated by selection, whether artificial or natural".

179 Vgl. Huxley 1859b, S. 18-19: „Suppose that in the midst of this incessant competition some individuals of a species (A) present accidental variations which happen to fit them a little better than their fellows [...], then the chances are in favour, not only of these individuals being better nourished than the others, but of their predomination over their fellows in other ways, and of having a better chance of leaving offspring [...]. $[\mathrm{T}]$ he weaker variety will eventually be destroyed $[\ldots]$ and the stronger will take its place".

180 Sherrie Lynne Lyons sieht seine Bemühungen, Darwins Konzept der Modifikation mit seiner Vorstellung von persistenten Typen zu vereinbaren, weniger als einen Kompromiß denn als einen Versuch, Darwin von progressivistischen und teleologischen Interpretationen abzugrenzen, da Huxley gerade hier die größte theoretische Verunreinigung befürchtete (Vgl. Lyons 1999, S. 142, S. 161); Vgl. Erling Eng (1978) „Thomas Henry Huxley's Understanding of ,Evolution““. In: History of Science 16, S. 291-303, S. 295.

181 Huxley 1859a, S. 146: ,if it be true that all living species are the result of the modification of other and simpler forms, the existence of these little altered persistent types [...] must indicate that they are but the final terms of an enormous series of modifications, which had their being in the great lapse of pre-geologic time“. 
Hier verband Huxley das transmutative Element Darwins mit seiner Annahme persistenter Typen, indem er behauptete, transmutativ entstandene Arten seien irgendwann zu persistenten Typen geworden. Er beschränkte damit den Wirkungszeitraum der darwinschen Theorie auf die vorgeologische Zeit. Dabei hob er vor allem zwei Feststellungen hervor. Erstens, daß persistente Typen neben den Variationen, wie sie Darwin beschrieb, existierten, und zweitens, daß die Modifikationen keinen progressivistischen Charakter hatten, also nicht an sich zu höherer Perfektion drängten. ${ }^{182}$ Und eben diesen Punkt betonte Huxley auch bei Darwins Theorie. Sie schlösse „,keine notwendige Progression oder ständige Modifikation“ ein und stimme „mit der Persistenz eines gegebenen Grundstocks über einen Zeitraum hinweg“ überein. ${ }^{183}$

Erst später, in den siebziger Jahren schwenkte Huxley auf eine Argumentation gradueller Mutation ein. In diesem Zusammenhang verwendete er auch den Begriff ,Evolution` zum ersten Mal systematisch:

„Jene, die es mit der Doktrin der Evolution halten (und ich bin einer von ihnen) verstehen, daß es Grund für die Vermutung gibt, daß die Welt, mit allem was in ihr und auf ihr ist, nicht in dem Zustand zu existieren begann, in dem wir sie jetzt sehen [...]. Jemand, der die Nebel-Hypothese in der Astronomie anwendet, oder der ein Uniformitarier in der Geologie ist, oder ein Darwinianer in der Biologie, ist [...] ein Anhänger der Doktrin der Evolution“. ${ }^{184}$

182 Vgl. Huxley (1862a) „Geological Contemporaneity“. In: [Quarterly Journal of the Geological Society 18, S. 40-54] Collected Essays, Bd. 8, S. 272-304, S. 298.

183 Huxley (1863a) „On Our Knowledge of the Causes of the Phenomena of Organic Nature (Six Lectures to Working Men)“. In: Collected Essays, Bd. 2, S. 307-475, S. 461: „It is one remarkable peculiarity of Mr. Darwin's hypothesis that it involves no necessary progression or incessant modification, and that it is perfectly consistent with the persistence for any length of time of a given primitive stock, contemporaneously with its modifications".

184 Huxley (1868) „On the Animals Which Are Most Nearly Intermediate between Birds and Reptiles“. In: [Geological Magazine 5, S. 357-363] The Scientific Memoirs of Thomas Henry Huxley, Bd. 3, S. 303-313, S. 303: ,Those who hold the doctrine of Evolution (and I am one of them) conceive that there are grounds for believing that the world, with all that is in it and on it, did not come into existence in the condition which we now see it $[\ldots]$ one who adopts the nebular hypothesis in Astronomy, or is a Uniformitarian in Geology, or a Darwinian in Biology, is [...] an adherent of the doctrine of Evolution“. Zur sogenannten Nebel-Hypothese vgl. Simon Schaffer (1989) „The nebular hypothesis and the science of progress“. In: James R. Moore (Hrsg.): History, humanity, and evolution. Essays for John C. Greene. Cambridge: Cambridge University Press, S. 131-164. 
Auch wenn dies eine weit gefaßte Definition der Evolution war, verband Huxley sie jetzt mit graduellen Mutationen. Dieser Wandel vollzog sich über seine Studien der bei Solnhofen Mitte des neunzehnten Jahrhunderts gefundenen Flugsaurier Archaeopteryx und Compsognathus, die sowohl Eigenschaften von Reptilien als auch von Vögeln aufwiesen. ${ }^{185}$ Huxley nahm eine genealogische Verbindung der Dinosaurier sowohl zu den Vögeln als auch zu den Reptilien an. ${ }^{186}$ So tastete er sich zögerlich an die für Darwins Theorie so wichtige Annahme gradueller Modifikation heran und gab seine Vorstellung von den sprunghaften Entwicklungen in der Natur letztlich auf. Der Schluß jedoch, den Mario Di Gregorio zieht, Huxley habe erst ab 1868 mit der Evolutionstheorie zu arbeiten begonnen, beruht auf einer Identifikation der Evolutionslehre mit der Theorie Darwins, die die diskursive Entstehung der Evolutionstheorien ausblendet. ${ }^{187}$ Dieses diskursiven Settings der Evolutionstheorien wegen hat auch Sherrie Lyons betont, daß Peter Bowlers Einschätzung, Huxley sei zwar ein Entwicklungstheoretiker, aber kein Evolutionist gewesen, auf einer zu trennscharfen Definition von Evolution und Entwicklung basiere, die der historischen Genese der Bergriffe nicht gerecht werde. ${ }^{188}$ Selbst Darwin habe für seine Theorie auf von Baers embryologische Entwicklungstheorie zurückgegriffen.

In Huxleys Verhältnis zu Evolutionslehre und Darwinscher Theorie zeigt sich deutlich die kulturelle Dimension des Evolutionsdiskurses

185 Vgl. Huxley 1868, S. 306: „the total amount of approximation to the reptilian type is but small, and the gap between reptiles and birds is but very slightly narrowed by their existence“. Desmond (1998, S. 128) und Lyons (1999, S. 167) weisen darauf hin, daß Huxley Archaeopteryx den Status eines eingeschobenen Typs (,intercalary type“) zugewiesen hat.

186 Vgl. Huxley 1868, S. 312: ,it can hardly be doubted that a lithographic slate of Triassic age would yield birds so much more reptilian than Archaeopteryx, and reptiles so much more ornithic than Compsognathus, as to obliterate completely the gap which they still leave between reptiles and birds“. Die jüngere Forschung zur Geschichte der Naturwissenschaften hat mit dem hartnäckigen Mythos aufgeräumt, der seit Ende des neunzehnten Jahrhunderts bestand und besagte, daß Huxley mittels der archäologischen Funde Richard Owen argumentativ ausgestochen habe. Diese Darstellung ist jedoch eine grobe Vereinfachung der Auseinandersetzung zwischen Owen und Huxley, auf die hier nur unzureichend eingegangen werden kann (vgl. Peter J. Bowler (1997) „Thomas Henry Huxley and the Reconstruction of Life's Ancestry“. In: Alan P. Barr (Hrsg.): Thomas Henry Huxley's Place in Science and Letters: Centenary Essays. Athens, Georgia: University of Georgia Press, S. 119-139, S. 128; Desmond 1982, S. 124-146).

187 Vgl. Mario A. Di Gregorio (1982) „The Dinosaur Connection: A Reinterpretation of T.H. Huxley's Evolutionary View“. In: Journal of the History of Biology 15, S. 397-418, S. 406. Vgl. Lyons 1999, S. 79-80. 
jener Jahre, die John C. Greene mit dem Begriff des Weltbilds treffend bezeichnet hat. ${ }^{189}$ Wird der Evolutionsdiskurs als Weltbild und nicht als ein enges, mit Darwins Theorie identifiziertes, theoretisches Bekenntnis gefaßt und wird sein Facettenreichtum auch auf der sozialen und der politischen Ebene berücksichtigt, dann entsteht nicht nur eine Grundlage, auf der Huxleys Kampagnen und sein Einsatz für die Evolutionslehre verstanden werden können. Durch ein solches Verständnis des Evolutionsdiskurses wird auch erklärlich, warum für einen bestimmten Zeitraum die theoretisch so anders gelagerten Orientierungen Lubbocks und Spencers kompatibel mit Huxleys eigentlich ja professionalistisch und anti-progressivistisch ausgerichteter Programmatik waren.

\subsection{Metamorphosen, Essays and Reviews. Lubbocks Rezeption der Evolutionstheorie}

Im Vorfeld der Veröffentlichung des Origin of Species war Darwin besorgt darüber, wie Huxley sich positionieren würde, Lubbock galt dagegen als ein „enthusiastischer Konvertit“. ${ }^{190}$ Auch Lubbock griff in die Kontroversen um Darwins Buch ein und verteidigte es bei der legendären Tagung der British Association in Oxford: „Ich stand an Huxleys Seite und ergriff das Wort für die natürliche Auslese“, erinnerte er sich in einem Nachruf auf seinen Mitstreiter. ${ }^{191}$ Dieser frühen Verpflichtung folgte allerdings keine eigene theoretische Darlegung oder Auseinandersetzung mit der Evolutionstheorie. Statt dessen produzierte er am Mikroskop minutiöse anatomische Studien von Insekten, in denen er nur sporadisch auf die Evolutionslehre oder Darwins Theorie verwies. ${ }^{192}$ Tat-

189 Vgl. Greene (1981c) „Darwinism as a World View“. In: Ders. (Hrsg.): Science, Ideology, and World View. Essays in the History of Evolutionary Ideas. S. 128-157; Michael Ruse (1997) „Thomas Henry Huxley and the Status of Evolution as Science“. In: Alan P. Barr (Hrsg.): Thomas Henry Huxley's Place in Science and Letters. Athens, Georgia: University of Georgia Press, S. 140-158, S. 149.

190 Darwin an Wallace, 06. April 1859. In: CCD, Bd. 7, S. 279: „enthusiastic convert".

191 Lubbock (1966) Essays \& Addresses. 1900-1903. [1903] Freeport NY: Books for Libraries, S. 2: „I stood by Huxley's side and spoke up for Natural Selection“; vgl. Darwin an Lyell, 05. Juli 1860. In: CCD, Bd. 8, S. 281.

192 So erklärt er, daß Insekten in früheren Metamorphose-Stadien den Umweltbedingungen ausgesetzt seien und deshalb sehr unterschiedliche Formen annehmen würden (Lubbock (1866) „On the Development of Chloëon (Ephemera) dimidiatum. Part II“. In: Transactions of the Linnean Society 25, S. 477-491, S. 485: „Those who believe that animals 
sächlich habe sie sich die Darwinsche Theorie, so Lubbock, bei der Erklärung der anatomischen Unterschiede zwischen den Stadien der Metamorphose als problematisch erwiesen:

„Ich denke, daß ein Schlüssel zu der Schwierigkeit in der Unterscheidung zwischen Entwicklung und adaptivem Wandel gefunden werden kann. [...] Es ist unstrittig [...] daß, während die embryonale Entwicklung eines Tieres im Ei ein Abriß seiner spezifischer Geschichte sein mag, dies keinesfalls der Fall bei Arten ist, in denen die unfertigen Formen separat und unabhängig existieren". ${ }^{193}$

Lubbock stellte die Gültigkeit der Theorie, daß die Phylogenese eines Organismus seine Ontogenese wiederspiegele, bei den Insekten in Frage und meinte, daß bei ihnen dem alternierenden Generationenwechsel ein größeres Erklärungspotential zugeschrieben werden müsse. ${ }^{194}$ Er hatte seine anatomische Forschung nicht explizit darauf ausgerichtet, die noch umkämpfte Evolutionstheorie aufzumunitionieren oder ihr speziell in seinem Wissenschaftsfeld, der Entomologie, zum Durchbruch zu verhelfen. Der Referenzrahmen seiner Studien blieb strikt auf die Disziplin selbst beschränkt. Bei der Diskussion der Metamorphosestadien von Insekten verwendete er den Begriff „originelle Typen“, und rief damit eine archetyp-ähnliche Interpretation der Insektenlarven auf. ${ }^{195} \mathrm{Da}$ er dennoch als Darwinianer galt, lag also mehr an seiner sozialen Einbettung in das Umfeld Darwins und an seiner Teilhabe am X-Club Netzwerk, als an einer theoretischen Übereinstimmung.

are susceptible of great, though gradual, change through the influence of external conditions, whether acting, as Mr. Darwin has suggested, through natural selection, or in any other manner, will see no reason why these changes should be confirmed to the mature animal").

193 Lubbock (1874) On the Origin and Metamorphoses of Insects. London: Macmillan, S. 70-71: „A clue to the difficulty may, I think, be found in the distinction between development and adaptive changes. [...] It is evident $[. .$.$] that while the embryonic development of an animal in the$ egg may be an epitome of its specific history, this is by no means the case with species in which the immature forms have a separate and independent existence".

194 Vgl. Lubbock 1874, S. 64, S. 75-78; vgl. allgemein Stephen J. Gould (1977) Phylogeny and Ontogeny. Cambridge, Mass.: Harvard University Press.

195 Lubbock (1860) „On the Distribution of the Tracheæ in Insects“. In: Transactions of the Linnean Society 23, S. 23-50, S. 49: ,in some cases the tracheæ of the larvæ seem to agree in species where those of the perfect insect are different; so that [...] it would seem that the larval tracheæ are in both respects less differentiated, and more in accordance with the original type than those of perfect insects“. 
Ein Jahr nach der Veröffentlichung von Origin of Species wurde eine zweite, damals kaum minder provokante Schrift veröffentlicht, Essays and Reviews. Sie umfaßte sieben Aufsätze zu Fragen der religiösen Erziehung, die Mehrzahl ihrer Autoren waren an Oxforder Colleges tätig und gruppierte sich um den Oxford Professor Benjamin Jowett und den Rugby-Direktor Frederick Temple. Der Umgang mit der Bibel in Essays and Reviews wurde von etlichen Klerikalen als Profanisierung verstanden und die Angriffe gegen die Autoren gipfelten in Exkommunizierungsverfahren. ${ }^{196}$ Lubbock initiierte nun maßgeblich eine Kampagne zur Verteidigung der von der anglikanischen Kirche bedrängten Autoren. ${ }^{197}$ Seine Lesart der Veränderungen im wissenschaftlichen Denken, für die Darwins Origin nur der jüngste und wirkungsvollste Beitrag gewesen sei, offenbart sich im Text eines von ihm verfaßten Memorandums:

„Da wir denken, daß die Entdeckungen der Wissenschaft und der allgemeine Fortschritt des Denkens einige Modifikationen der Ansichten theologische Angelegenheiten betreffend notwendig machen, begrüßen wir diesen Ansatz, die religiöse Lehre auf eine festere und breitere Basis zu stellen“. ${ }^{198}$

Lubbock konnte viele prominenten Zeitgenossen, wie Darwin oder Lyell, zur Unterzeichnung bewegen, doch Huxley und Hooker verweigerten die Unterstützung. ${ }^{199}$ Er ergriff die Initiative für die Autoren von Essays and Reviews, da er in ihnen kircheninterne Reformatoren sah, die sich bemühten, den christlichen Glauben mit den Entwicklungen in der Wissenschaft in Einklang zu bringen. Hier liegt ein wesentlicher Unterschied zu Huxley, der sich nicht in die Debatte um Essays and Reviews einschaltete, weil er davon überzeugt war, daß Wissenschaft und Religion nicht in einem Konflikt stünden, sondern Fragen in verschiedenen

196 Vgl. allgemein Victor Shea, William Whitla (Hrsg.) (2000) Essays and Reviews: The 1860 Text and its Reading. Charlottesville: University of Virginia Press; Whitla 2000; W. H.Brock, R. M. MacLeod (1979) „The Scientists ' Declaration: Reflexions on Science and Belief in the Wake of Essays and Reviews, 1864-5“. In: British Journal for the History of Science 9, S. 39-66, S. 45; Joseph L. Altholz (1994) Anatomy of a Controversy: The Debate over „Essays and Reviews“ 1860-1864. Aldershot: Scholar Press.

197 Vgl. Patton (im Erscheinen) Kapitel 3.

198 John Lubbock, zitiert in: Hutchinson 1914, Bd. 1, S. 58: „Feeling as we do that the discoveries in science, and the general progress of thought, have necessitated some modification of the views generally held on theological matters, we welcome these attempts to establish religious teaching on a firmer and broader foundation".

199 Vgl. Lubbock an Huxley, 28. Februar 1861. In: HP 22, f. 61-2. 
Sphären behandelten. Lubbock glaubte hingegen, daß aus den Erkenntnissen der Wissenschaften für die Religion ein neues Fundament entstehen müßte.

Dieser Unterschied zwischen Huxley und Lubbock verdankte sich der äußerst unterschiedlichen sozialen Herkunft der beiden. Sie spielte bei der Orientierung in diesem Konflikt eine wesentliche Rolle. Lubbock war hier weniger ein Vertreter des ,scientific young England', sondern vielmehr, wie William Spottiswoode, der mit ihm gemeinsam die Kampagne führte, ein Vertreter des alten Establishments. Seine Reputation in diesen Kreisen hing ganz wesentlich von einer diskurskompatiblen Haltung in dieser Frage der Vereinbarkeit von Religion und neuer Wissenschaft ab. In diesem Rollenkonflikt liegt auch die Ursache, warum Lubbock sich wissenschaftspolitisch vor allem um einen Interessenausgleich zwischen Wissenschaft und Klerus sorgte.

\subsection{Zusammenfassung}

Obwohl Huxley und Lubbock gleichermaßen zu jenem kleinen Kreis von Darwinianern zählten, der ab 1859 in der scientific community und in der Öffentlichkeit die Durchsetzung der Darwinschen Lehre stritt, werden erhebliche inhaltliche Unterschiede zwischen ihrem und Darwins Verständnis der Artenentwicklung deutlich. Wie Peter Bowler richtig schreibt, verfolgte der X-Club eher eine undarwinianische Revolution. Darwin steuerte zu ihren Vorstellungen zwar maßgebliche Elemente bei, war jedoch nicht ihre einzige Quelle. Sowohl Huxley als auch Lubbock betonten die Beständigkeit der Typen und bekannten sich erst spät beziehungsweise nur bedingt zu Darwins Theorie. Sie repräsentierten damit ein Evolutionsverständnis, das sich durch eine breite Kompatibilität auszeichnete und das auch vorevolutionäre Elemente wie Malthus' Ressourcenmangel, Owens Archetypen, Entwicklungsmodelle der Embryologie und Metamorphosetheorien integrierte.

In Huxleys und Lubbocks eher distanzierter Darwinrezeption zeichnet sich die kulturelle Dimension der Evolution als Weltbild ab. Dieses Weltbild fungierte als eine Klammer um sehr verschiedene Evolutionstheorien und verband eine theoretische mit einer sozialen Dimension. Dabei spielte das Selbstbild des X-Clubs als Schaltzentrale einer jungen Garde professioneller Wissenschaftler, die sich gegen das Establishment durchsetzen mußten, eine zentrale Rolle. Ihr Evolutionsverständnis definierte sich in Abgrenzung zur tradierten teleologischen oder christlichen Interpretationen der Natur. Die Bedeutung des Origin of Species war deshalb zunächst die eines effektiven Sturmgeschützes, mittels dessen 
die Bastionen des orthodoxen Wissenschafts-Establishments perforiert werden sollten. Im Kontext einer breiter angelegten Säkularisierungskampagne wurde dabei auch immer wieder die religiöse Dominanz in den Wissenschaften anvisiert. ${ }^{200}$

So wird deutlich, warum Spencer, der heute als Wiedergänger Lamarcks in der Evolutionsgeschichte nur noch ein Randdasein fristet, von den Kanonieren am Sturmgeschütz nicht ebenfalls ins Visier genommen wurde. In wesentlichen Punkten war seine Evolutionstheorie anschlußfähig an die Kampagnen des X-Clubs. Greene sieht den Kern des theoretischen Wandels und den gemeinsamen Nenner, auf den sich Spencer wie auch Darwin, Huxley und Lubbock verständigen konnten, im wesentlichen darin, daß es sich um die Transformation einer statischen, taxonomisch orientierten Naturgeschichte zu einer dynamischen und Kausalitäten betonenden, evolutionären Biologie gehandelt habe. ${ }^{201}$

Der X-Club, wie auch das Netzwerk vor seiner Gründung, erfüllte für ungefähr fünfzehn Jahre die Funktion eines Koordinierungsinstruments, das seinen Mitgliedern nicht nur gesellige Momente verschaffte, sondern ihnen in erster Linie gestattete, Kräfte für ihre wissenschaftspolitische Kampagnen zu bündeln. Die Evolutionstheoretiker des X-Clubs waren die Protagonisten nicht einer darwinianischen, sondern einer evolutionstheoretischen Revolution im erweiterten Sinne. Mit beachtlichem Engagement intervenierten sie in Debatten um naturwissenschaftliche Fragen, die vor allem durch Darwins Origin of Species aktuell geworden waren.

Neben der Royal Society, der Royal Institution oder der British Association gab es aber noch ein weiteres Interventionsfeld, das von der XClub-Forschung bislang vernachlässigt wurde, obwohl ein Drittel seiner Mitglieder aktiv dort in Erscheinung trat und mit Spencer ein Vierter thematisch Flankenschutz bot: die Anthropologie und die Rassentheorien. Darwin hatte im Vorwege seines Origins über die Verbindung seiner Theorie zur Entwicklung der Menschheit spekuliert, Spencer hatte den Zusammenhang zwischen organischer und sozialer Evolution explizit gemacht. Entsprechend entwickelten Lubbock, Huxley und Busk in den Kontroversen um Darwin nicht nur ihre eigene Interpretation der Evolutionstheorie, sondern auch eine evolutionäre Perspektive auf Anthropologie, soziale Evolution und Rassentheorien. Der folgende Abschnitt untersucht ihre Initiativen im Feld der Anthropologie.

200 Vgl. Ruth Barton (1983) „Evolution: The Whitworth Gun in Huxley's War for the Liberation of Science from Theology“. In: David Roger Oldroyd, Ian Langham: The Wider Domain of Evolutionary Thought. Dordrecht u.a.: Reidel, S. 261-286, S. 262. 


\section{X-Club und Anthropologie}

„Die große Epoche der Wissenschaft des Menschen in der Moderne spannte sich ungefähr über die dreißig Jahre von 1840 bis 1870 . Man könnte es fast einen dreißigjährigen Krieg nennen - einen Krieg zwischen zwei Worten, Ethnologie und Anthropologie, einen Krieg zwischen Historikern und Philosophen auf der einen Seite und jenen, die für die Wissenschaften standen, insbesondere für die Biologie [...], auf der anderen, einen Krieg zwischen Humanisten, deren Wissenschaft in Beziehung zu ihrer Verteidigung einer Sache stand einerseits und reinen Wissenschaftlern, die wissenschaftliche Wahrheit von allen anderen menschlichen Belangen trennten, anderseits" (Sol Tax, 1964). ${ }^{1}$

Die wissenschaftspolitischen Interventionen des X-Clubs beschränkten sich nicht auf das Feld der Naturwissenschaften. Er griff ebenfalls in die in der Anthropologie schwelende Kontroverse um klassifikatorische Systeme der Menschen, in die Auseinandersetzungen um Fragen der sozialen Evolution und in institutionalisierte Konflikte zwischen konkurrierenden wissenschaftlichen Gesellschaften ein. Wenn überhaupt, werden die Eingriffe der Evolutionstheoretiker der ersten Stunde von der Anthropologiegeschichte nicht zusammenhängend, sondern als individuelle Beteiligungen betrachtet. Das Verhältnis von Anthropologie und Evolu-

1 Sol Tax (1964) „The Setting of the Science of Man“. In: Ders. (Hrsg.): Horizons of Anthropology. London: Allen and Unwin, S. 15-24, S. 15: „For the study of man, the great period in modern times extended over the thirty years from about 1840 to 1870 . One might almost call it a ,thirty years' war' - a war between two words, Ethnology and Anthropology, a war between those who were historians and philosophers on the one side, and those who were for science, particularly biology [...] on the other; a war between humanitarians whose science was related to their advocacy of a cause on one side and, on the other, pure scientists who would separate scientific truth from all other human concerns". 
tionstheorie ist deshalb in seiner frühen historischen Entwicklung nur ungenau erfaßt. ${ }^{2}$

Die Verwissenschaftlichung der Weltsicht erfaßte auch die Lehre vom Menschen in ihrer ganzen Bandbreite. Sol Tax' Einschätzung der Bedeutung der Entwicklungen Mitte des neunzehnten Jahrhunderts für das wissenschaftliche Menschenbild hebt das Element in Konflikt geratener Ansichten und Wertorientierungen in dieser Phase hervor. Auch in der Anthropologie waren unter dem Einfluß der Turbulenzen in den Naturwissenschaften Kontroversen und heftige Auseinandersetzungen ausgebrochen. Doch wie zu sehen sein wird, reichten die theoretischen Erschütterungen der Anthropologie und der Rassentheorien durch die wissenschaftliche Revolution in den Naturwissenschaften nicht aus, um ihre theoretische Anpassung an die veränderten Koordinaten in den $\mathrm{Na}$ turwissenschaften zu induzieren. Die inhaltliche Modernisierung der rassentheoretischen Wissensbestände erforderte eine Modernisierung der sozialen Strukturen, in denen dieses Wissen generiert und bewahrt wurde.

In den Kapiteln dieses Abschnittes werden die Kampagnen des XClubs zur Etablierung einer evolutionstheoretischen Auffassung des Menschen und seiner Geschichte diskutiert und die institutionelle Seite des evolutionstheoretischen Paradigmawechsels in der Anthropologie behandelt. Dabei werden verschiedene Aspekte dieses Paradigmawechsels an unterschiedlichen Kontroversen exemplifiziert. Die Abfolge von Kontroversen, an denen sich der X-Club in den sechziger Jahren beteiligte, wurde von einer Auseinandersetzung über die Naturalisierung des Menschen angeführt, die Huxley mit einem Vertreter des Klerus, Bischoff Wilberforce und mit seinem Rivalen Richard Owen austrug. Auf dem hierin geschaffenen Fundament der evolutionären Anthropologie bauten weitere Diskussionen über strittige anthropologische Fragen auf. Auf physisch-anthropologischer Ebene debattierte Huxley über den Neandertaler und die Entwicklung des Menschen, auf kultur-anthropologischer Ebene setzte sich Lubbock mit der Frage nach einer degenerativen oder einer progressiven Entwicklung von Gesellschaften auseinander. In diesen Debatten setzten die Akteure des X-Clubs eine evolutionäre Rassentheorie gegen antinaturalistische und gegen monogenistische

2 Zwar wird allgemein von einem bedeutenden Impuls durch Darwins Origin of Species für die Anthropologie ausgegangen. Doch wird dieser Impuls in der Regel als diskursiv vermittelt und über die allgemeine Verbreitung des Werks erklärt (vgl. z.B. Shapiro 1959, S. 374; Adam Kuper (1997) „On Human Nature: Darwin and the Anthropologists“. In: Mikuláš Teich, Roy Porter, Bo Gustavson (Hrsg.): Nature and Society in Historical Context. Cambridge: Cambridge University Press, S. 274-290). 
wie polygenistische Ansätze durch. Die verschiedenen theoretischen Dimensionen fielen in einer letzten Kontroverse zusammen, die der XClub mit den Polygenisten der Anthropological Society führte.

\subsection{Skandalisierung. Evolution und die Stellung des Menschen in der Natur}

Die Interpretation der Stellung des Menschen in der Natur war der Prüfstein für jede grundlegende Theorie über die Entstehung der Arten. Darwin wußte um die Implikationen seiner Theorie hinsichtlich dieser brisanten Frage. Obgleich er selbst an der Sonderstellung des Menschen zweifelte, wich er dieser Debatte aus. Vergebens, denn Kritiker wie Verteidiger, vor allem Huxley, versuchten sofort, die Haltbarkeit der Darwinschen Theorie, wie sie sie verstanden, auf gerade diesem Feld zu erproben. Wie Rassentheorien mit dieser Debatte verknüpft und auf welche Weise sie dort mit einer entwicklungstheoretischen Prägung versehen wurden, wird in der folgenden Analyse der Auseinandersetzungen Huxleys mit Wilberforce über die Abstammung des Menschen vom Affen und mit Owen über die menschliche Gehirnstruktur untersucht.

\subsection{1 "Ape-Theory". Huxley contra Wilberforce}

Im Sommer 1860 kam es bei der Jahrestagung der British Association in Oxford zwischen Huxley und einem Vizepräsidenten dieser Gesellschaft, dem Oxforder Bischof Samuel Wilberforce, zu einem legendären Wortgefecht, das oft zum Sinnbild für den Zusammenstoß von christlicher und wissenschaftlicher Weltanschauung stilisiert wurde. ${ }^{3}$ In dieser Auseinandersetzung keimte jedoch nicht nur Huxleys Agnostizismus, sondern auch sein Interesse, die Stellung des Menschen in der Natur zu klären; ein Interesse, das den Kern einer umfangreichen anthropologischen Forschung bilden sollte. ${ }^{4}$

3 Es wurde als Radiohörspiel der BBC inszeniert, das nach seiner Ausstrahlung als Klanginstallation der Darwin-Ausstellung in Downe House aufgenommen wurde (vgl. J. R. Lucas (1979) „Wilberforce and Huxley: A Legendary Encounter“. In: The Historical Journal 22, S. 313-330, S. 313).

4 Vgl. allgemein D. W. Dockrill (1971) "T. H. Huxley and the Meaning of ,Agnosticism““. In: Theology 74, S. 461-477; Lightman 1987. 
Samuel Wilberforce hatte sich bereits einen Namen als konservativer Kritiker liberaler Kirchenmänner gemacht. ${ }^{5}$ So gehörte er zu den Protagonisten der klerikalen Kampagne gegen die Verfasser von Essays and Reviews. Als ein an den Wissenschaften, insbesondere der Mathematik und der Ornithologie interessierter Laie, als Mitglied der Geological Society und als Würdenträger der gastgebenden Stadt saß er der British Association als Vizepräsident in Oxford vor. Zum Zeitpunkt der Tagung hatte er dem Quarterly Review bereits eine Rezension von Darwins Origin of Species zugesandt, die im darauffolgenden Monat erscheinen würde. ${ }^{6}$ Darin nahm er eine wissenschaftliche Perspektive ein, die Darwin das Zugeständnis abnötigte, Wilberforce hätte ungewöhnlich clever argumentiert und den Finger auf einige Schwachstellen gelegt. ${ }^{7}$ Um dem Bischof nicht mehr Anerkennung als unbedingt nötig zubilligen zu müssen, versicherten sich Darwin und Hooker, daß hinter Wilberforce' Argumentation letztlich Richard Owen stecken müsse. ${ }^{8}$

Die Szenerie, vor der es in Oxford zum Wortgefecht zwischen Wilberforce und Huxley kam, ist oft beschrieben worden. Es existieren eine Reihe von Augenzeugenberichten, doch in Anbetracht ihrer Widersprüchlichkeiten ist die Rekonstruktion des Ereignisses nicht mit letzter Sicherheit möglich. ${ }^{9}$ Huxley und Hooker fanden sich auf dem Podium einer gut besuchten Sitzung ein, die Zahlen schwanken zwischen vierhundert und tausend Anwesenden. ${ }^{10}$ Sie alle waren mit der Erwartung gekommen, einer Diskussion über die Lehre Darwins beizuwohnen, die Wissenschaft und Öffentlichkeit gleichermaßen beschäftigte.

5 Vgl. allgemein Standish Meacham (1970) Lord Bishop. The Life of Samuel Wilberforce, 1805-1873. Cambridge, Mass.: Harvard University Press.

6 Vgl. Samuel Wilberforce (1860) „On the Origin of Species, by means of Natural Selection; or the Preservation of Favoured Races in the Struggle for Life. By Charles Darwin, M.A., F.R.S. London 1860“. In: Quarterly Review 102, S. 225-264; Reginald G. Wilberforce (1881) Life of Samuel Wilberforce. Bishop of Oxford and Winchester. London: Murray, Bd. 2, S. 450.

7 Vgl. Darwin an Huxley, 20. Juli 1860. In: CCD Bd 8, S. 294-295; Di Gregorio 1984, S. xx.

8 Vgl. Hooker an Darwin, 2. Juli 1860. In: CCD Bd. 8, S. 270; Darwin an Huxley, 20. Juni 1860. In: CCD Bd. 8, S. 294. Das Bild eines von Owen aufmunitionierten Wilberforce wird von Wissenschaftshistorikern wie William Irvine, Michael Ruse und anderen fortgeschrieben (vgl. Ruse 1979, S. 242; Irvine 1963, S. 5).

9 Vgl. Meacham 1970, S. 215-216; Irvine 1963, S. 1-8; Desmond, Moore 1994, S. 557-563; Desmond 1998, S. 275-278; Leonard Huxley 1900, Bd. 2, S. 179-189; Lucas 1979; Jensen 1988; Jensen 1991, S. 68-86.

10 Vgl. The Evening Star, 2. Juli 1860, S. 3, zit. nach Jensen 1988, S. 165; Hooker an Darwin, 2. Juli 1860. In: CCD Bd. 8, S. 270. 
Nach einer angeregten Debatte, in der Huxley es zweimal ablehnte, auf aus dem Publikum vorgebrachte Kritik an Darwins Theorie einzugehen, erhielt Wilberforce das Wort. Der Legende nach gipfelte sein Beitrag in der an Huxley gerichteten Frage, ob er nun großväterlicherseits oder großmütterlicherseits vom Affen abstamme. ${ }^{11}$ Doch diese Frage, die damals als skandalös empfunden worden sein muß, überschattet den Umstand, daß Wilberforce sich ausführlich inhaltlich mit Darwins Buch auseinandergesetzt hatte, letztlich wird er eine kurze Version seiner Rezension vorgetragen haben. ${ }^{12}$ Huxley schilderte zwei Monate nach dem Ereignis, wie er Wilberforce entgegengetreten sei:

„Wenn mir denn schon die Frage gestellt wird, sagte ich, ob ich lieber einen erbärmlichen Affen oder einen Mann zum Großvater hätte, der von der Natur reich beschenkt wurde, über große Mittel und Einfluß verfügt und dennoch diese Möglichkeiten bloß nutzt, um eine ernste wissenschaftliche Diskussion lächerlich zu machen - würde ich ohne zu zögern den Affen vorziehen. Woraufhin unter den Leuten nicht enden wollendes Gelächter einsetzte - und sie folgten dem Rest meiner Argumentation mit größter Aufmerksamkeit. Lubbock und Hooker sprachen nach mir mit großer Überzeugungskraft, und so gelang es uns, dem Bischof und seinen Anhängern endgültig den Mund zu stopfen. [...] Ich teile Ihnen dies mit, weil alle möglichen Berichte kursieren, zum Beispiel daß ich gesagt hätte, ich wäre lieber ein Affe als ein Bischof, usw. [...] Ich glaube ich war ganze vierundzwanzig Stunden lang der populärste Mann in Oxford“. ${ }^{13}$

11 Die einzige zeitgenössische Quelle, die diese Frage wiedergab, war die Londoner Zeitung The Press, die einen Korrespondenten vor Ort hatte: „The Bishop of Oxford [...] asked the Professor whether he would prefer a monkey for his grandfather or his grandmother" (The Press, 7. Juli 1860, S. 656, zitiert nach Jensen 1988, S. 166).

12 Vgl. The Athenaeum, 7. Juli 1860, S. 19 und 14. Juli 1860, S. 64-65; Lucas 1979 , S. 316-321.

13 Huxley an Dyster, 9. September 1860, HP 15, f. 117-118: „If then, I said, the question is put to me would I rather have a miserable ape for a grandfather or a man highly endowed by nature and possessed of great means and influence and yet who employs those faculties for the mere purpose of introducing ridicule into a grave scientific discussion - I unhesitatingly affirm my preference for the ape. Whereupon there was inextinguishable laughter among the people - and they listened to the rest of my argument with the greatest attention. Lubbock \& Hooker spoke after me with great force $\&$ among us we shut up the bishop \& his laity. [...] I assure of this because all sorts of reports were spread about, e.g., that I had said I would rather be an ape than a bishop, etc. [...] I believe I was the most popular man in Oxford for full four and twenty hours afterwards". 
In Huxleys Wahrnehmung hatte Wilberforce einen unwissenschaftlichen Beitrag geleistet. Hooker jedoch schilderte gegenüber Darwin, daß er Wilberforce' Kritik am Origin of Species widerlegt habe und räumte Huxley nur eine Nebenrolle ein. ${ }^{14}$ Einen verbalen Ausfall Wilberforce' gegenüber Huxley erwähnte er nicht. In seiner Schilderung des Verlaufs und Ausgangs dieser Sitzung hatte er selbst den Sieg davongetragen und sich Anerkennung aus beiden Lagern verdient. Eine Sichtweise, die bei aller Schärfe dennoch die Dimension des wissenschaftlichen Disputs zum Kern der Argumentation erhob, gab auch der Bericht in The Athenaeum einige Tage später wieder. Der Reporter des Athenaeum schrieb, daß Huxley Darwins Theorie verteidigt und deren Behandlung als bloße Hypothese verworfen habe. ${ }^{15}$

Die Diskrepanz zwischen Hookers und Huxleys Einschätzungen der Rollen an diesem Vormittag in Oxford zeigt zwar, daß zeitnah keine Klarheit über die Bedeutung des Vorgangs bestand. Doch Hookers Akzentuierung der wissenschaftlichen Kontroverse wurde kaum geteilt. Vielmehr teilen die meisten Huxleys Einschätzung, da sich das öffentliche Interesse an dieser Auseinandersetzung auf den Aspekt eines möglichen Skandals fokussierte. Diese Gewichtung kam Huxley ganz recht, denn er sprach nicht nur dem Bischof, sondern überhaupt einem Großteil der Anwesenden den Anspruch der Wissenschaftlichkeit ab.

John Lucas hat auf minutiöse Weise versucht, die Kontroverse zu rekonstruieren. Er geht dabei davon aus, der kolportierte Wortlaut gebe nicht den wirklichen Verlauf der Diskussion wieder und hält es für unwahrscheinlich, daß Wilberforce sich in der später skandalisierten Weise über Huxleys Großmutter geäußert habe. Lucas analysiert eine Bedeutungsverschiebung in der Folge dieses an sich harmlosen Ereignisses und hält sie für das Resultat einer Selbststilisierung der Darwinianer, die sich in einer unterdrückten Minderheitenrolle wähnten. ${ }^{16}$ Insofern hatte Huxley hier den Grundstein für den, wie John Brooke es formuliert, „Gründungsmythos“ der Evolutionisten gelegt, der die Ebenen der theo-

14 Vgl. Hooker an Darwin, 2. Juli 1860. In: CCD Bd. 8, S. 270-271: „\& then I proceeded to demonstrate [...] 1 that he [Wilberforce, T.G.] could never have read your book $\& 2$ that he was absolutely ignorant of the rudiments of Bot. Science - I said a few more on the subjec of my own experience, $\&$ conversion $\&$ wound up with a few observations on the relative position of the old \& new hypotheses".

15 Vgl. The Athenaeum, 7. Juli 1860, S. 64-65.

16 Vgl. Lucas 1979, S. 327. Jensen hält Lucas' Kernannahme, daß der Wortlaut der Debatte verzerrt kolportiert worden sei, der mehrdeutigen Quellenlage wegen für kaum belegbar (vgl. Jensen 1988, S. 167, FN 53). 
retischen Auseinandersetzung mit der der Professionalisierung der Wissenschaften verschweißte. $^{17}$

Die Signifikanz dieser Auseinandersetzung liegt nicht in der, wie Jensen argumentiert, fälschlichen Annahme begründet, hier sei ein eindeutiger Sieg für die Sache der Evolutionstheorie errungen worden, Publikum und Kontrahenten hatten durchaus verschiedene Ansichten über den Ausgang dieses Kräftemessens. ${ }^{18}$ Dies läßt sich sehr wohl im Kontext der sich von klerikaler Dominanz emanzipierenden Wissenschaften lesen: „Huxleys Truppen trieben den Keil zwischen Wissenschaft und Theologie tiefer", schreibt Desmond. ${ }^{19}$ Die Bedeutung dieser Auseinandersetzung liegt darin, daß sie Huxleys Ruf als Verfechter der umstrittenen ,Affen-Theorie" nicht nur in der Wissenschaft, sondern auch in der Öffentlichkeit zementierte. Die von Lucas herausgearbeitete Sinnverschiebung im Rahmen der Legendenbildung vom Wortgefecht zwischen Wilberforce und Huxley zeigt, daß die Vermutung einer Abstammung des Menschen vom Affen von so zentraler Bedeutung war, daß sie die Wahrnehmung eines letztlich banalen verbalen Schlagabtauschs maßgeblich beeinflußte. Deshalb trifft Joseph Altholz' Einschätzung zu, daß weniger die Sprecher als das Publikum dieses historische Ereignis geschaffen hätten. ${ }^{20}$

Darwins Ansinnen, Implikationen für die Interpretation des Menschen aus der Diskussion seines Buches heraushalten zu können, erweist sich im Licht dieses Ereignisses als naiv, vor allem, da bereits seit 1857 eine Auseinandersetzung zwischen Owen und Huxley schwelte und in Vorlesungen wie an der Royal Institution ausgetragen wurde, die sich mit der anatomischen Sonderstellung des Menschen befaßten. Sie wurde durch die Skandalisierung des Schlagabtausches zwischen Huxley und Wilberforce ins Rampenlicht des öffentlichen Interesses geschoben.

17 John Brooke (Internetquelle) „Lecture at Queen's Lecture Theatre, Emmanuel College, Cambridge, 26. 02. 2001“. In: www.st-edmunds.cam.ac.uk/ cis/brooke /lecture1.html: „foundation myth“.

18 Vgl. Jensen 1988, S. 177-178.

19 Desmond 1998, S. 279: „Huxley's troops were hammering the wedge deeper between science and theology".

20 Vgl. Joseph L. Altholz (1980) „The Huxley-Wilberforce Debate revisited". In: Journal of the History of Medicine and Allied Sciences 35, S. 313-316, S. 316. 


\subsection{2 „Hippocampus minor“. Huxley contra Owen}

Ebenfalls bei der British Association in Oxford, historisch allerdings im Schatten des Wortgefechtes zwischen Huxley und Wilberforce, kam es zu einer weiteren bedeutenden Konfrontation. Zwei Tage zuvor war Huxley mit Richard Owen aneinander geraten. In einer Sitzung, die durch einen Beitrag über Darwins Origin of Species eingeleitet wurde, drehte sich ihr Disput um die physiologischen Unterschiede zwischen den Gehirnen von Gorilla und Mensch. ${ }^{21}$ Jedoch entstand in dieser Debatte kein einheitliches, sondern ein rassen-differenzierendes, hirnanatomisches Bild des Menschen. Diese Debatte war prägend für den anthropologischen Diskurs, weil mit ihr sowohl die evolutionäre Anthropologie begann als auch das anthropologische Interesse Huxleys. Diese kurze Begegnung hatte eine längere Vorgeschichte.

\section{Affe-Mensch-Beziehung}

Bereits 1699 hatte der englische Naturalist Edward Tyson in einer anatomischen Studie über Menschenaffen Schimpansen als Pygmäen bezeichnet und damit zum einen die Unsicherheit über die noch kaum bekannten Menschenaffen bezeugt, zum anderen aber auch verdeutlicht, daß Übergangsformen zwischen Menschen und Affen durchaus in das durch Linné geprägte Denken der Naturalisten paßte. ${ }^{22}$ Auch Pieter Campers anthropomorphe Darstellungen des Orang-Utans aus dem ausgehenden achtzehnten Jahrhundert, in denen Menschenaffen beispielsweise in Hosen abgebildet wurden, trugen zur Verbreitung dieser Vermutung von graduellen Übergängen zwischen Menschen und Affen bei, die immer auch eine Komponente der enthumanisierenden Darstellung der Afrikaner beinhaltete. ${ }^{23}$

21 Vgl. LLTHH, Bd. 1, S. 180. Der Titel des Beitrags von Charles Daubeny lautete: „On the final causes of the sexuality of plants, with particular reference to Mr. Darwin's work on the Origin of Species“; Vgl. „Report of the British Association meeting in Oxford, 26 June - 3 July 1860. Thursday session of Section D. - Zoology and botany, including physiology. President: John Stevens Henslow“. In: The Athenæeum, 07. Juli 1860, S. 25-26 (Zitiert nach: CCD Bd. 8, S. 591-593).

22 Vgl. Edward Tyson (1699) Orang-Outang: Or the Anatomy of a Pygmie Compared with That of a Monkey, an Ape, and a Man. London: Bennet, Brown.

23 Vgl. Petrus Camper (1782) Natuurkundige Verhandelingen over den $O$ rang Outang; en eenige andere Aap-soorten. Over den Rhinoceros met den Dubbelen Horen; en over het Rendier. Amsterdam: Meijer en Warnars., Tafel 4, Fig. 1. 
$\mathrm{Zu}$ dieser Zeit ging in Deutschland der Anatom Soemmering der Frage nach, ob der Europäer oder der Neger dem Affen ähnlicher wäre, und 1827 hatte der französische Naturalist und Lamarck-Anhänger Jean Baptiste Bory de Saint Vincent den Menschen in das Schema transmutativer Entstehungen eingegliedert und seine Abstammung vom Affen erklärt. ${ }^{24}$ Damit hatte sich Bory weiter vorgewagt, als die Wissenschaft $\mathrm{zu}$ akzeptieren bereit war. Allerdings war eine wissenschaftliche Beweisführung aufgrund der nur schwer zu erhaltenen Primatenkadaver lange Zeit kaum möglich. Lamarck hatte seinerseits vermutet, daß ein Schimpanse, der dazu gezwungen würde, sich auf dem Boden fortzubewegen, seinen greifenden großen Zeh verlieren, sukzessive den aufrechten Gang annehmen und zuletzt aufgrund veränderter sozialer Beziehungen im Gesichtswinkel mutieren würde. ${ }^{25}$ Bory nahm im Unterschied zu Lamarck an, daß auch die Intelligenz der Primaten der des Menschen ähnelte. ${ }^{26}$

Als Huxley und Owen aufeinandertrafen, waren also die anatomische Beschaffenheit des Gehirns und des Fußes bereits als Anhaltspunkte der Differenz zwischen dem Menschen und jenen Tieren, bei denen die größte verwandtschaftliche Nähe vermutet wurde, verwendet worden. Alle diese Ansätze beruhten auf einem weder wissenschaftlich operationalisierten noch irgendwie quantifizierten Verfahren des anatomischen Vergleichs zwischen Menschen und Affen. In dieser Tradition bewegte sich auch die von Huxley und Owen über einen längeren Zeitraum geführte Debatte um die anatomische Beweisführung des Verwandtschaftsverhältnisses der Primaten.

Richard Owen begann ab 1830 anatomische Studien an Primaten vorzunehmen. ${ }^{27} \mathrm{Zu}$ dieser Zeit lebten in Europa nur jugendliche Schimpansen, die in Gefangenschaft starben, bevor sie ausgewachsen waren. Durch Zufall entdeckte Owen in einer Sammlung das vollständige Skelett eines ausgewachsenen Tieres und konnte dadurch auf die signifikanten Unterschiede zwischen den Schädeln eines jugendlichen und eines erwachsenen Schimpansen aufmerksam machen. ${ }^{28}$ Bis dahin hatte

24 Vgl. Soemmering 1785, S. XIV; Jean Baptiste Bory de Saint Vincent (1827) „Orang“. In: Dictionnaire classique de l'histoire naturelle, Paris, Bd. 12, S. 261-285.

25 Vgl. Desmond 1989, S. 289.

26 Vgl. Desmond 1989, S. 289.

27 Vgl. Richard Owen (1830) „On the Anatomy of the Orang Outang (Simia satyrus, L.)“. In: Proceedings of the Committee of Science and Correspondence of the Zoological Society 1, S. 4-5, S. 9-10, S. 28-29, S. 6772.

28 Vgl. Richard Owen (1835) „On the Osteology of the Chimpanzee and Orang Utan“. In: Transactions of the Zoological Society 1, S. 343-379. 
man nur die Schädel von jugendlichen Schimpansen mit dem des Menschen verglichen. Verfechter der Transmutationsthese - wie Lamarck oder Bory - betrachteten die hierbei festgestellte relative Ähnlichkeit als Beweis für die Verwandtschaft von Mensch und Affe. ${ }^{29}$ Owen führte nun aus, daß der Schädel des ausgewachsenen Schimpansen deutlich andere Proportionen als der des jugendlichen aufweise. Besonders die Proportion von Schädel und Gesichtspartie einschließlich der Kieferknochen hätte sich stark verändert. Beim ausgewachsenen Schimpansen falle die Schnauze deutlich größer aus, hingegen deute die vergleichsweise klein gebliebene Kranialkammer auf ein frühzeitiges Ende des Wachstumsprozesses. Er hatte damit einen Trumpf in der Hand, mit dem er der auf anatomischer Vergleichbarkeit beruhenden Vermutung einer genealogischen Verbindung zwischen Mensch und Primaten die Grundlage entziehen konnte.

Owen bediente sich des zu seiner Zeit bereits traditionsreichen Verfahrens, Afrikanern eine affenartige Physiognomie anzudichten, wehrte sich aber gegen die Schlußfolgerung, in manchen der als primitiv Attributierten ließe sich eine Übergangsform vom Primaten zum Menschen finden:

„Es trifft zu, daß beim Menschen das Kranium in seinen relativen Proportionen zum Gesicht zwischen den unterschiedlichen Stämmen, je nach dem Grad der Zivilisation und der Zerebral-Entwicklung, die sie erreicht haben, variiert; und daß sich bei den niedrigeren äthiopischen Arten und Papuans der Schädel den Proportionen der Quadrumanen annähert: Aber in diesen Fällen [...] finden sich immer eine Kieferform und Proportionen der Zähne, die unfehlbare und unüberwindbare generische Unterschiede zwischen Mensch und Affe darstellen“. ${ }^{30}$

Owen unterstellte hier eine kausale Verbindung zwischen kulturellen Errungenschaften und körperlichen Eigenschaften, doch systematisierte

29 Vgl. Charles G. Gross (1999) „The Hippocampus Minor and Man's Place in Nature: A Case Study in the Social Construction of Neuroanatomy“. In: Ders.: Brain, Vision, Memory. Tales in the History of Neuroscience. Cambridge, Mass.: Harvard University Press, S. 137-178, S. 141.

30 Owen 1835, S. 371: „It is true that in the human subject the cranium varies in its relative proportions to the face in different tribes, according to the degree of civilization and cerebral development which they attain; and that in the more debased Æthiopian varieties and Papuans, the skull makes some approximation to the Quadrumanous proportions: but in these cases [...] it is always accompanied by a form of the jaws, and by a disposition and proportions of the teeth, which afford unfailing and impassable generic distinctions between Man and the Ape“. Quadrumana (Vierhändige) war eine Bezeichnung für Menschenaffen. 
er diese Annahme nicht weiter. Sein anthropologisches Interesse reichte nicht über ein gängiges Vorurteil hinaus. Allerdings war er an einer taxonomischen Isolation des Menschen interessiert, die einerseits Übergänge zu den Affen ausschließen und andererseits die Einheit der Spezies Mensch betonen sollte. ${ }^{31}$ Die vergleichenden anatomischen Studien an Skelettaufbau und Schädelform von Mensch und Primaten ergänzte Owen später um anatomische Vergleiche der Gehirne selbst. Er vermutete kleinere Gehirnen bei den ,Papuans', zu denen er auch Australier und Tasmanier rechnete, und ging von einer Korrelation mit unterstellten kulturellen Eigenschaften aus: „Bei den unteren, ungebildeten, unzivilisierten Rassen ist das Gehirn kleiner als bei den höheren, zivilisierteren und gebildeteren Rassen“. ${ }^{32}$

1858 veröffentlichte Owen, der auch der ,britische Cuvier' genannt wurde, ein Klassifikationsschema der Säugetiere, in dem er die Klassifikation des großen französischen Naturalisten durch ein Schema ersetzte, das auf der Struktur des Gehirns beruhte. ${ }^{33}$ Er führte einige anatomische Kriterien an, die das Menschengehirn taxonomisch von dem der Primaten unterschieden und zugleich die Primaten den Affen anatomisch annäherten. Allein das Gehirn des Menschen weise im hinteren Bereich einen dritten Hirnlappen, ein hinteres Horn an der Nebenkammer und eine hippocampus minor genannte Hirnregion auf. Für den Menschen

31 Seine Behauptung, daß der Mensch eine eigene Gattung darstelle, war deshalb eine explizite Absage an zeitgenössische Theorien der Polygenisten: „The unity of the human species I regard as demonstrated by the constancy of those osteological and dental characters [...]. Man is the sole species of his Genus, the sole representative of his Order; he has no nearer physical relations with the brute-kind than those which mark the primary (unguiculate) division of the placental subclass of Mammalia" (vgl. Richard Owen (1849) „Osteological Contributions to the Natural History of the Chimpanzees (Troglodytes, Geoffroy), including the description of the Skull of a large species (Troglodytes Gorilla, Savage) discovered by Thomas S. Savage, M.D., in the Gaboon country, West Africa“. In: Transactions of the Zoological Society of London 3, S. 381-422, S. 417).

32 Richard Owen (1855) „On the Anthropoid Apes, and their relations to Man“. In: Proceedings of the Royal Institution 2, S. 26-41, S. 36: „In the low, uneducated, uncivilized races, the brain is smaller than in the higher, more civilized, and more educated races“.

33 Vgl. Richard Owen (1858) „On the Characters, Principles of Division, and Primary Groups of the Class Mammalia". In: Journal of the Proceedings of the Linnean Society of London 2, S. 1-37; Richard Owen (1860a) „On the Cerebral System of Classification of the Mammalia“. In: Proceedings of the Royal Institution 3, S. 174-189. Owen unterteilte die Klasse der Säugetiere in vier Unterklassen, nach Beschaffenheit des Hirns: Lyencephala (lose zusammenhängende Hirnpartien), Lissencephala (glatte Gehirne), Gyrencephala (gewundene Hirne) und Archencyphala (herrschende Hirne). 
richtete er eine eigene Ordnung ein, die er „Archencephala“ zu nennen vorschlug, die ,Hirn-regierten “ ${ }^{34}$ Aufgrund des besonderen Aufbaus des menschlichen Fußes bezeichnete er die Menschen zudem als Ordnung der Bimana, der Zweihändigen, während die Primaten als Quadrumana (Vierhändige) eine eigene Ordnung in einer anderen Klasse der Säugetiere bildeten.

Besonders auf den hippocampus minor konzentrierten sich die Kontroversen über Owens Ansatz. ${ }^{35}$ Huxley hatte eine erste Kritik an seinem Klassifikationsansatz bereits 1858 in einer Vorlesung an der Royal Institution geübt, in der er erklärte, die anatomischen Unterschiede zwischen Gorilla und Mensch seien kaum größer als die zwischen Gorilla und Pavian. ${ }^{36}$ Bei all diesen, den taxonomischen Überlegungen zugrundeliegenden, vergleichenden anatomischen Studien ging es im Kern um die Frage, mit welcher Gewichtung Verschiedenheit und Ähnlichkeit zu interpretieren wären.

Doch abgesehen von dieser Vorlesung und einigen bissigen Briefen beschäftigten sich Huxley und seine Mitstreiter zu diesem Zeitpunkt nicht weiter mit Owens Konstruktion einer Sonderstellung des Menschen in der Natur. Erst dessen Kritik am Origin of Species und das unter großer öffentlicher Anteilnahme skandalisierte Wortgefecht mit Wilberforce machten Huxley auf die Problematik der Position Owens aufmerksam. Diese Ereignisse verdeutlichten, daß die von Owen in Abrede gestellte Entwicklungsbeziehung zwischen Menschen und Primaten zum zentralen Feld der Debatte um Darwins Buch geworden war.

Darwin erwartete eine heftige Reaktion Owens auf Origin of Species: ,ich vermute stark, daß Anerkennung, die irgendeinem anderen zuteil wird, in seinen Augen eine ihm vorenthaltene Anerkennung ist. Die Wissenschaft ist ein so schmales Feld, daß auf dem Hof nur Platz für einen Hahn sein sollte“. ${ }^{37}$ Er ging also davon aus, daß sein Buch nicht nur Owens Theorie, sondern auch dessen Stellung in der scientific community direkt in Frage stellen würde. Owens Kritik erfüllte Darwins

34 Vgl. Owen 1858, S. 20.

35 Owen 1858, S. 19-20: „Their posterior development is so marked, that anatomists have assigned to that part the character of a third lobe; it is peculiar to the genus Homo, and equally peculiar is the ,posterior horn of the lateral ventricle,' and the ,hippocampus minor,' which characterize the hind lobe of each hemisphere".

36 Vgl. Huxley: „The Principles of Biology. Lecture 10: The Distinctive Characters of Man“. 16. März 1858, Royal Institution. In: HP 36.97-100.

37 Darwin an Huxley, 28. Dezember 1859. In: CCD Bd. 7, S. 459: ,for credit given to any other man, I strongly suspect is in his eyes so much credit robbed from him. Science is so narrow a field, it is clear there ought to be only one cock of the walk“". 
schlimmste Erwartungen. ${ }^{38}$ In einer nur halbherzig anonymisierten Rezension warf Owen ihm eine mangelhafte Beweisführung vor und erklärte, es handele sich deshalb nur um eine Hypothese, die noch einer Überprüfung ihrer Erklärungskraft unterzogen werden müsse. ${ }^{39}$ In dieser Hinsicht wich seine Einschätzung kaum von der Huxleys ab. Doch die inhaltliche Kritik war elementar, denn er lehnte Darwins Mechanismus der natürlichen Auslese rundweg ab. Owen war in seiner Rezension noch nicht auf mögliche Implikationen der Darwinschen Theorie für die naturwissenschaftliche Einordnung des Menschen eingegangen. In Oxford hingegen, zwei Monate nach seinem Artikel im Edinburgh Review, berief er sich in einer Diskussion über die Bedeutung des Origin of Species für die Stellung des Menschen in der Natur auf seine komparativen anatomischen Hirnstudien und stellte die transmutative Annahme des Origin of Species in Frage. ${ }^{40}$

Huxley erwiderte, daß anatomische Unterschiede zu vernachlässigen seien, weil einzig die Sprachbegabung den Unterschied zwischen Primat und Mensch ausmache. ${ }^{41} \mathrm{Er}$ mag bereits hier geahnt haben, daß die Argumentation Owens nur über die Frage der Stellung des Menschen in der Natur auszuhebeln sein würde; die skandalumwitterte Sitzung mit Wilberforce überzeugte ihn endgültig von der Bedeutung und Tragfähigkeit dieser Diskursebene für die von ihm verfolgte Etablierung der Evolutionslehre.

Huxley startete in der Folge der Jahrestagung der British Association eine breit angelegte Kampagne gegen Owen, in die er andere Wissenschaftler einbezog. Sie war zugleich auch sein Einstieg in die physische Anthropologie und seine Aufsatzsammlung Man's Place in Nature (1863) wurde des öfteren als die erste konsequente Anwendung der Darwinschen Lehre auf den Menschen bezeichnet. ${ }^{42}$ Huxley ging es darum, den Menschen als Spezies der Gruppe der Primaten zu etablieren. Anhand vergleichender anatomischer Studien legte er strukturelle Ähnlichkeiten zwischen Mensch und Menschenaffen dar. Seine Argumentation beschränkte sich nicht auf die Ebene theoretischer Erörterun-

38 Vgl. Darwin an Lyell, 03. Dezember 1859. In: CCD Bd. S. 413; Desmond, Moore 1994, S. 554; Desmond 1998, S. 263.

39 Vgl. Richard Owen (1860b) „Darwin on the Origin of Species“. In: Edinburgh Review, April, S. 487-532. Darwin teilte Lyell seine Vermutung über Owens Urheberschaft des Edinburgh Review-Artikels mit (Darwin an Lyell, 10. April 1860. In: CCD Bd. 8, S. 154).

40 Vgl. Richard Owen (1861a) „Origin of Species“. In: Natural History Zoology. The Year Book of Facts, S. 203.

41 Vgl. Owen 1861a, S. 204.

42 Vgl. Lyons 1999, S. 189; Gross 1999. 
gen, sie wies auch eine Dimension der fortschreitenden Professionalisierung der Wissenschaften auf.

Huxley mobilisierte eine Reihe von Experten, die seinen Befund stützten, und setzte - stärker als Owen - Meßverfahren ein, die den gesteigerten Wissenschaftlichkeitsansprüchen der Zeit genügen sollten. Er nahm zunächst anatomische Messungen vor, mittels derer er Homologien zwischen dem Fuß des Menschen und des Gorillas identifizierte. Hatte Owen noch die Zuordnung der Primaten und somit des Gorillas zur Klasse der Quadrumana nach Cuvier aufrechterhalten, so betonte Huxley, daß der Gorilla wie der Mensch zweihändig sei und über einen vollwertigen Fuß verfüge. ${ }^{43}$ Doch seine Schlußfolgerung, daß der Fuß des Gorillas strukturell dem des Menschen eher ähnele als dem anderer Primaten und erst recht dem anderer Affen, erfolgte mit dem Hinweis, daß anatomische Unterschiede des Fußes auch beim Menschen ausgemacht werden könnten:

,[E]s darf nicht außer Acht gelassen werden, daß der große Zeh der Zivilisierten, von Kindheit an beschränkt und eingezwängt, stark benachteiligt ist und daß er sich bei unzivilisierten und barfüßigen Völkern eine große Mobilität und sogar eine Art von Oppositions-Befähigung erhalten hat““ ${ }^{4}$

Huxleys Kritik an Owens klassifikatorischer Trennung von Menschen und Primaten beruhte nicht allein auf einem anatomischen Beweis der strukturellen Vergleichbarkeit des Fußes von Mensch und Gorilla. Vielmehr stützte er seine Argumentation auch auf eine nach dem Zivilisationsgrad differenzierte Betrachtung der Anatomie des menschlichen Fußes. Es gäbe nur derart geringe anatomische Unterschiede zwischen dem Fuß des Menschen und dem des Gorillas, daß sie als das Resultat eines bestimmten wiederholten Gebrauchs, einer ,physiologischen $\mathrm{Ar}$ beitsteilung“, wie Huxley schrieb, zu gelten hätten. ${ }^{45}$

Größere Bedeutung maß er der von Owen aufgestellten Behauptung bei, das menschliche Hirn zeichne sich durch die strukturelle Besonder-

43 Vgl. Huxley (1861b) „On the Relation of Man to the Lower Animals“. In: [Ursprünglich: „On the Zoological Relations of Man with the Lower Animals“. In: Natural History Review (n.s.) 1, S. 67-84] Collected Essays, Bd. 7, S. 77-156, S. 126.

44 Huxley 1861b, S. 119: ,it must not be forgotten that the civilized great toe, confined and cramped from childhood upwards, is seen to a great disadvantage, and that in uncivilized and barefooted people it retained a great amount of mobility, and even some sort of opposability“.

45 Huxley 1861b, S. 126: „Nor can it be doubted that the greater division of physiological labour in Man, so that the function of support is thrown wholly on the leg and foot, is an advance in organization of very great moment to him“. 
heit des hippocampus minor aus. Zur Untermauerung seiner Kritik an dieser Behauptung bewegte Huxley befreundete Anatomen wie George Rolleston oder William Flower, die er zu seinem ,scientific young England" rechnete, ebenfalls Studien an den Hirnen von Affen, Primaten und Menschen vorzunehmen, und stellte ihnen den Natural History Review als Veröffentlichungsplattform zur Verfügung. Neben diesen Experten, die seine Position rundweg unterstützten, konnte Huxley auch eine Stellungnahme von holländischen Koryphäen der Hirnanatomie gewinnen, die ebenfalls im Natural History Review erschien. ${ }^{46}$

Auch wenn dieses Magazin im Vergleich zu den großen Journalen nur eine verhältnismäßig geringe Auflage hatte, nahm es dennoch in den Jahren seines Erscheinens eine zentrale Rolle in der scientific community ein, denn der Natural History Review konnte einerseits auf ebenso renommierte wie professionelle Autoren verweisen und war andererseits das einzige Magazin, das sich allein der neuen Wissenschaftlichkeit verpflichtet hatte. Nicht nur überstieg die Anzahl der veröffentlichten Beiträge zu wissenschaftlichen Fragen die Gesamtzahl der wissenschaftlichen Beiträge, die im gleichen Zeitraum in den am weitesten verbreiteten und anerkanntesten Journalen Englands erschienen. Der Natural History Review wies auch den höchsten Anteil an anthropologischen Themen auf. ${ }^{47}$ In der Auseinandersetzung um den Platz des Menschen in der Natur zahlte sich die Arbeit, die Huxley und die anderen X-Club Mitglieder hierin investiert hatten, aus. Die Kampagne gegen Owen konnte durch die Kontrolle dieses Organ wesentlich gestützt werden, denn die Beiträge namhafter Anatomen verkündeten unisono das Vorhandensein eines hippocampus minor auch in den Gehirnen der untersuchten Affen und Primaten.

Ging es in inhaltlicher Hinsicht in dieser Kontroverse um die Untermauerung der Evolutionstheorie und der transmutativen Entstehung der Arten, so ging es in methodischer Hinsicht um Fragen der Beobachtungsweisen, Sektionstechniken und Präparationsverfahren. Dabei steigerte Huxley die Dramatik der Diskussion, indem er gegen Owen den schweren Vorwurf der wissenschaftlichen Täuschung erhob. Er warf

46 George Rolleston (1861) „On the Affinities of the Brain of the Orang Utang“. In: Natural History Review 1, S. 210-217; John Marshall (1861) „On the Brain of a Young Chimpanzee“. In: Natural History Review 1, S. 296-315; Schroder van den Kolk, Willem Vrolik (1862) „Note sur l'encéphale de l'orang utang“". In: Natural History Review 2, S. 111-117; William Henry Flower (1862) „On the Posterior Lobes of the Cerebrum of the Quadrumana“. In: Philosophical Transactions of the Royal Society of London, Biology 152, S. 185-201; William Henry Flower (1863) „On the Brain of the Siamang“. In: Natural History Review 3, S. 279-287.

47 Vgl. Anhang: Tabelle 1. 
ihm nicht bloß einen Irrtum, sondern die bewußt manipulative Verwendung von Abbildungen und Aussagen anderer Hirnanatomen vor. ${ }^{48}$ Huxley ging es, wie er in einem Brief durchscheinen ließ, um die Zerstörung der Reputation Owens. ${ }^{49}$ Doch abseits der Polemiken Huxleys wurden auch mögliche Fehler diskutiert, die Owen unterlaufen sein könnten. ${ }^{50}$ Auf diese Weise verbanden sich die Diskussionsebenen der taxonomischen Aussagen und der anatomischen Methodik. Durch den Aspekt der Wissenschaftlichkeit und der methodischen Aktualität gewann die zu diesem Zeitpunkt noch umstrittene evolutionäre Interpretation zusätzliche Legitimation.

Die Auseinandersetzung um die Existenz des hippocampus minor erregte in der damaligen Öffentlichkeit enormes Interesse, sie beschädigte Owens Ansehen erheblich und wird von der Wissenschaftsgeschichte regelmäßig als ein Sieg Huxleys und der Evolutionisten dargestellt. ${ }^{51}$ Wie der Owen-Biograph Nicolaas Rupke betont, hatte Owen seine zunächst absolute Aussage über die Besonderheit des hippocampus minor und der anderen Charakteristika des menschlichen Hirns in späteren Stellungnahmen relativiert und zugestanden, daß es sich eher um graduelle Unterschiede der Ausprägung der fraglichen Hirnpartien handele.$^{52}$ Huxley

48 Vgl. Huxley (1861a) „Man and the Apes“. In: The Athenaeum, 27. März und 21. Sept., S. 433, S. 498, S. 433; Huxley (1862c) „The Brain of Man and Apes“. In: Medical Times and Gazette, 25. Oktober, S. 449.

49 Vgl. Huxley an Frederick Dyster (11. Oktober 1862). In: HP 15.123: „I will nail him out like the kite to the barn door as an example to all evil doers".

$50 \mathrm{Vgl}$. Charles Lyell (1914) On the Geological Evidence of the Antiquity of Man. [1863] London: Dent, S. 373-384.

51 Vgl. Desmond 1998, S. 292-298; Gross 1999, S. 141; Nicolaas A. Rupke (1994) Richard Owen. Victorian Naturalist. New Haven, London: Yale University Press, S. 287. Diese Auseinandersetzung fand ihren Schlußpunkt 1862 bei der Jahrestagung der BAAS in Cambridge. Huxley saß der Themensektion zu Zoologie, Botanik und Physiologie (Sektion D) vor, in der Owen erneut versuchte, seine Position darzulegen. Huxley, Rolleston und Flower fanden mit ihren Darstellungen allerdings deutlich mehr Zuspruch. Huxley schreibt im Bewußtsein des Triumphes an Darwin: „All the people present who could judge saw that Owen was lying \& shuffling - the other half saw he was getting the worst of it but regarded him I think, rather as an innocent old sheep, being worried by three particularly active young wolves“ (Huxley an Darwin, 09. Oktober 1862. In: CCD 10, S. 450).

52 Vgl. Rupke 1994, S. 291-292. Allerdings hat Owen noch 1866 das ,Hippocampus minor' und ,Horn der hinteren Kammer' als besondere und unterscheidende Merkmale (peculiar and distinctive characters") des menschlichen Hirns bezeichnet und ihnen damit einen anderen Stellenwert als den von ihm identifizierten graduellen Unterschieden zwischen Menschenund Affenhirn eingeräumt (Vgl. Richard Owen (1866) „Contribution to 
überging diese Korrekturen, die Owen in seiner Argumentation vornahm. ${ }^{53}$ Er fixierte Owen gewissermaßen auf seiner Ursprungsposition, um an ihm seine eigene Argumentation entwickeln zu können.

Die Debatte zwischen Huxley und Owen war nicht nur für die Durchsetzung der Evolutionstheorie, sondern auch für den anthropologischen Diskurs bedeutend. Die Etablierung eines evolutionären Verständnisses der Beziehung zwischen Mensch und Primaten verband sich mit der traditionellen Rassendifferenzierung der Anthropologie. Huxley hatte - wie Owen - die Gehirnvolumina einiger Menschenaffen nicht einfach mit dem eines beliebigen Menschen, sondern mit dem eines sogenannten Buschmanns verglichen und dabei festgestellt:

„Es gibt einen auffälligen Unterschied in absoluter Masse und Gewicht zwischen dem niedrigsten menschlichen Gehirn und dem des höchsten Affen - ein Unterschied, der um so bemerkenswerter ist, wenn wir uns daran erinnern, daß ein voll ausgewachsener Gorilla wahrscheinlich annähernd doppelt so schwer ist wie ein Bosjemann“. ${ }^{54}$

Da der Versuch, körperliche Merkmale zu identifizieren, die eine Unterscheidung und Bestimmung von Menschenrassen ermöglichen sollten, ein zentrales Element der anthropologischen Agenda war, und weil Owen zuvor selbst auf den ,Boschiman' zurückgegriffen hatte, ${ }^{55}$ ist

the Natural History of the Anthropoid Apes. No. VIII. On the External Characters of the Gorilla (Troglodytes Gorilla)“. In: Transactions of the Zoological Society of London 5, S. 243-283, S. 267). Rupke interpretiert Owens Rückzug großzügiger als es dessen Beharren eigentlich zuläßt.

53 Owen: „The Gorilla and the Negro“. In: The Athenaeum, 23. März 1861, S. 395-396: ,the hippocampus minor, which as developed and extended in the human brain, and as defined in human anatomy, is peculiar to man“. Hier geht Owen offensichtlich von einem signifikanten Unterschied der Ausbildung aus, nicht aber davon, daß das Hippocampus minor bei den Primaten nicht existiere. Huxley aber unterstellt in einer Gegendarstellung, daß Owen beständig seine alte Annahme wiederhole, vgl. Huxley 1861a, S. 433: „Professor Owen [...] pointing out, afterwards, how they [Tiedemann, Cuvier, Gratiolet und andere, T.G.] had been so misled as not only to describe, but to figure, structures which have no existence".

54 Huxley 1861b, S. 140: ,there is a very striking difference between the lowest human brain and that of the highest ape - a difference which is all the more remarkable when we recollect that a fullgrown Gorilla is probably pretty nearly twice as heavy as a Bosjeman“.

55 Owen 1858, S. 20: „Not being able to appreciate, or conceive of the distinction between the physical phænomena of a Chimpanzee and of a Boschiman, or of an Aztek with arrested brain-growth [...] I cannot shut my eyes to the significance of that all-pervading similitude of structure [...] which makes the determination of the difference between Homo and Pithecus the anatomist's difficulty“. 
Huxleys beiläufiger Behauptung, er habe den „Bosjemann“ als Vergleich herangezogen, weil dieser sich gerade in der gleichen Sammlung befand, mit Skepsis zu begegnen. ${ }^{56}$ Er hatte sich für diesen Vergleich entschieden, weil er dem ,Bosjemann“ ein ,niedriges Gehirn` unterstellte: ${ }^{57}$

„Der Unterschied des Gehirngewichts zwischen den höchsten und den niedrigsten Menschen ist bei weitem größer, relativ [zum Körpergewicht, T.G.] wie absolut, als jener zwischen dem niedrigsten Menschen und dem höchsten Menschenaffen“. 58

Daß er nicht von den kleinsten, sondern von den niedrigsten Gehirnen, beziehungsweise von den Gehirnen der niedrigsten Menschen schrieb, offenbart die wertende Verbindung von Masse und Güte. Die Evolutionstheorien hatten zwar teleologische Konzeptionen der alten Entwicklungstheorien weitgehend, wenn auch nicht rückstandlos, ausgesteuert, doch ein Wertigkeitsverständnis der Entwicklung, war in ihnen jedoch erhalten geblieben und drückte sich in der Unterscheidung von niedrigen und höheren Organismen aus. Dies wird besonders in dem von Spencer systematisierten Zusammenhang von Wachstum und Komplexitätszunahme in Laufe der Evolution deutlich. Diese evolutionäre Logik erlaubte, das stereotype Bild des Buschmanns aufzugreifen, über dessen

56 Vgl. Huxley 1861b, S. 98.

57 Lyons (1999, S. 205) schreibt über Huxleys „strategy for convincing people that humans were no exception to Darwin's theory. $[\ldots][\mathrm{H}] \mathrm{e}$ asked how closely related apes and humans were, approaching the question just as a taxonomist would investigate how closely related were the cat and the dog“. Sie nimmt von dem Umstand, daß Huxley sich des ,Bosjemann“ für seinen Vergleich bedient, keine Kenntnis, der für eine Bewertung der Huxleyschen Argumentation aber insofern wichtig ist, als daß er die rassistische Differenzierung zwischen höheren und niederen Menschen über mutmaßlich unterschiedliche Gehirnvolumina konstruiert. Dies ist ein für die Huxley-Forschung repräsentativer Umgang (bspw. William Irvine (1960) Thomas Henry Huxley. London: Longmans, Green, S. 11; Ashforth 1969, S. 39-42). Den Vorwurf des Rassismus erhebt Lyons dann auf der folgenden Seite gegenüber Owen, „one of his more racist statements“ (S. 206) heißt es über eine Textstelle, die Huxley selbst zitiert und in der es heißt: „Not being able to appreciate or conceive of the distinction between the physical phenomena of a chimpanzee and a Boschiman or of an Aztec, with arrested brain growth, [...] I cannot shut my eyes to the significance of that all-pervading similitude of structure" (ibid.). Wenn Owens Versuch, den ,Boschiman“ in die Nähe der Affen zu rücken als rassistisch erkannt wird, warum dann nicht auch Huxleys Umgang mit dem ,Bosjeman'?

58 Huxley 1861b, S. 142-143: „the difference in weight of brain between the highest and the lowest men is far greater, both relatively and absolutely, than that between the lowest man and the highest ape“. 
angebliche Primitivität und vermeintlich kleines Hirn bereits im Diskurs über die sogenannten Wilden Gewißheit geschaffen worden war.

Huxleys wesentliches Unterscheidungsmerkmal zwischen den Hirnen von Mensch und Primaten bestand in deren Größe. Die Entwicklung zwischen dem Gorilla und dem Menschen müsse aufgrund des signifikanten Größenunterschieds einen Sprung vollzogen haben. An dieser Stelle scheint der zeitgleiche Disput zwischen Darwin und Huxley über die Frage wieder auf, ob in der Natur sprunghafte Veränderungen überhaupt möglich seien. Während Huxley einen quantitativen Sprung zwischen Mensch und Primaten etablierte, führte er anhand des gleichen Unterscheidungskriteriums auch eine Rassendifferenz ein, die zugleich mit einer zivilisatorischen Differenz verknüpft wurde. Diese Rassendifferenz wurde von Huxley im entwicklungsgeschichtlichen Kontext interpretiert. Huxley habe versucht, so Stephen J. Gould, die in seinen Augen unerhört große Lücke zwischen den Primaten und den Menschen zu schließen. Es sei ihm nicht darum gegangen, ,ganze Menschen-Gruppen anzugreifen“. ${ }^{59}$ Doch das für Huxley einzig klassifikatorisch relevante Merkmal der Gehirngröße schuf ein eindimensionales Entwicklungsgefälle, das nicht nur einen sprunghaften Abstand zwischen dem Gorilla und dem ,Bosjeman“, sondern auch einen enormen Entwicklungsabstand zwischen dem ,Bosjeman“ und dem zivilisierten Europäer registrierte.

Der Zeitpunkt, an dem Huxley die physische Anthropologie zu einem Arbeitsschwerpunkt machte, verdeutlicht, daß die Kampagne gegen Owen aus dem Kontext der Debatten um Darwins Origin of Species heraus entwickelt wurde. ${ }^{60}$ Dies macht Huxley zum ersten - in der öffentlichen Wahrnehmung - darwinianischen Anthropologen. Hieraus ergibt sich eine unmittelbare Verbindung zwischen der Transformation der Naturwissenschaften auf der einen und der Entstehung der modernen Anthropologie auf der anderen Seite.

Huxley widerlegte Owen mit genau jenen Methoden, die der selbst angewandt hatte: Beobachten und Messen. Seine Kampagne gegen Owen beruhte bis 1862 auf der Feststellung, daß ein Hippocampus minor nicht allein im menschlichen Gehirn zu finden sei. Doch in Man's Place in Nature ging er im Jahr darauf einen Schritt weiter und über den bloßen Nachweis von Homologien zwischen dem menschlichen Gehirn

59 Gould 1998, S. 135: „I do not think that Huxley, a racial liberal by the standards of his time, advanced this argument with intent to impugn entire groups of human beings. Rather, he was trying to plug a hole in his central argument for evolutionary continuity by finding some way to fill the embarrasingly large space in cranial capacity between gorilla and average human“.

60 Vgl. Huxley 1861b, S. 147. 
dem der Primaten hinaus. Er komplettierte seine Beweisführung, daß der Mensch als Resultat gradueller Mutationen Teil der Natur und nächster Verwandter der Primaten sei, anhand rassendifferentieller, kraniometrischer und anthropometrischer Messungen.

Der evolutionstheoretische Paradigmawechsel in den Wissenschaften, zu dem die Emanzipation von der klerikalen Interpretationshoheit ebenso zählte wie die Etablierung neuer Standards der Wissenschaftlichkeit und die wachsende Autonomie der Disziplinen, ging an dieser Stelle also mit der wissenschaftlichen Begründung einer rassischen Differenz einher. Die war nicht nur deswegen modern, weil sie eine Reihe von wissenschaftlichen Verfahren des Messens und Beobachtens mobilisierte und so den wissenschaftlichen Standards der Zeit genügte. Sie war es auch insofern, als sie im Kontext der Evolutionstheorien entwickelt wurde. Auf diese Weise wurde in die an sich statische Rassentaxonomie das dynamische Moment der Entwicklung eingeführt, das in anderen Segmenten des naturwissenschaftlichen Diskurses zwar nicht unumstritten war, aber bereits spürbar die Diskussion prägte.

Huxley legte in seiner Auseinandersetzung mit Owen den Grundstein für eine Rassentheorie, deren evolutionärer Zuschnitt die Anschlußfähigkeit an die Entwicklung der Naturwissenschaften sicherstellte. Diese Anschlußfähigkeit war in zweifacher Hinsicht bedeutend. Zum einen war sie notwendig, da sich Rassentheorien auf naturwissenschaftliches Wissen beriefen. Eine epistemische Kompatibilität war von daher ein Grunderfordernis dieser theoretischen Anlehnung, die eben nicht aus einer bloß legitimatorischen Zweckmäßigkeit entsprang. Zum anderen zeigte die Entwicklung der Debatte zwischen den Evolutionisten und ihren Gegenspielern der ersten Stunde, Wilberforce und Owen, daß gerade die Frage der Stellung des Menschen für naturwissenschaftliche Konzepte der Prüfstein war, an dem ihre Plausibilität gemessen wurde. Insofern war sowohl Huxleys Kampagne gegen Owen als auch seine Auseinandersetzung mit Wilberforce wichtige Etappen bei der Durchsetzung der Evolutionstheorie überhaupt.

\subsection{Rationalisierung. Evolution und Monogenismus}

Auch wenn Monogenismus und Evolutionstheorien die Annahme einer Entwicklung, im Unterschied zum statischen Modell des Polygenismus, teilten, bedeutet dies nicht, daß ihre Positionen deckungsgleich gewesen wären. Vielmehr waren etliche Kernannahmen des traditionellen Monogenismus mit der evolutionären Interpretation der Rassen ebenso unver- 
einbar wie die der Polygenisten. Weder die Annahme der Akklimatisierung, noch die Vermutung, der Ursprungsort der Menschheit wäre in einer Hochlandregion Asiens zu finden, noch die damit oft verbundene Vorstellung einer Degeneration jener Rassen, die die außereuropäischen Erdteile besiedelten, waren mit der Evolutionstheorie vereinbar. Zwar war die Akklimatisierungstheorie bereits in der ersten Hälfte des neunzehnten Jahrhunderts in Mißkredit geraten und verworfen worden, andere Hypothesen des Monogenismus waren dadurch aber nicht nachhaltig beeinträchtigt worden. Einige der Kampagnen des X-Clubs setzten sich deshalb intensiv mit dem Monogenismus auseinander.

Zwar verstummte auch der Monogenismus vor der massiven Säkularisierungskampagne der Evolutionisten in den frühen sechziger Jahren fast vollständig und zog sich auf linguistisches Terrain zurück. Es gab jedoch in Diskussionen über anthropologische Teilfragen Versuche, einer monogenistischen Lesart erneut Gehör zu verschaffen. Zum einen vertraten manche Monogenisten die Ansicht, der Neandertaler repräsentiere ein Zwischenglied zwischen den Menschen und den Primaten. Zum anderen formulierten Monogenisten Zweifel an der Entwicklungsrichtung der sozialen Evolution und brachten erneut die Behauptung des Monogenismus in Stellung, die Existenz von Gesellschaften auf verschiedenen zivilisatorischen Niveaus sei auf einen degenerativen Prozeß zurückzuführen.

\subsection{1 "Missing Links“. Die Neandertaler-Debatte}

Eine anthropologische Kontroverse, in der die Evolutionisten die Interpretationen von Seiten der Polygenisten und der Monogenisten gleichermaßen ablehnten, war die Frage nach Bedeutung und Einordnung der fossilen Knochen aus dem Neandertal bei Düsseldorf, die bereits im Sommer 1856 geborgen worden waren. Dieser und ähnliche Funde nahe dem belgischen Engis wurde bereits 1832 ein fossiler Menschenschädel entdeckt - stellten die damalige Wissenschaft nicht nur vor die Aufgabe einer Altersbestimmung. Sie warfen auch die Frage auf, ob es sich hierbei um Vorfahren des modernen Menschen handelte oder um eine Art, die keine genealogische Verbindung $\mathrm{zu}$ ihm hatte. ${ }^{61}$ Besonders nachdem die Dimensionen der Vorgeschichte der Menschheit erkannt und mehrheitlich akzeptiert waren, veränderte sich die Bewertung der

61 Vgl. Bernard Campbell (1956) „The Centenary of Neanderthal Man“. In: Man 56, S. 156-158, S. 157. 
Funde aus Engis und dem Neandertal. Ihr nun anzunehmendes enormes Alter öffnete neue Dimensionen der Menschheitsgeschichte. Besonders die stark ausgeprägte Augenbrauenwulst regte zu Vergleichen mit Primaten an und ließ die Spekulationen ins Kraut schießen. ${ }^{62}$

Die ersten Deutungen des Neandertalfundes wurden in Deutschland vorgelegt. Nachdem der Amateurgelehrte Karl Fuhlrott den Fund von Steinbruch-Arbeitern übernommen hatte, war es der Bonner Biologe Hermann Schaaffhausen, der 1858 die erste wissenschaftliche Beschreibung der Knochen veröffentlichte. ${ }^{63}$ Eine stratigraphische Bestimmung des Alters war aufgrund der Umstände des Fundes nicht mehr möglich, und so konzentrierte sich die Diskussion auf die Deutung der anatomischen Details. Besonders hob Schaaffhausen die ausgeprägten Augenbrauenwülste hervor. Angesichts seiner animalischen Erscheinungsform sei an dem Schädel das relativ große Gehirnvolumen bemerkenswert. Zusammengenommen betrachtete er die physiognomischen Besonderheiten des Schädels als „Rassemerkmale““. ${ }^{64}$

Schaffhausen war davon überzeugt, daß die besondere Form des $\mathrm{Ne}$ andertalerschädels auf eine besonders frühe Art des Menschen, vielleicht sogar auf eine Übergangsform zwischen Mensch und Primaten hinweise und daß es sich um ein Exemplar jener ,wilden Rassen Nord-Westeuropas“ handele, die bereits in vorgeschichtlichen Zeiten gelebt hätten. ${ }^{65}$ Seine Neandertalertheorie verband sich mit einer monogenistischen Perspektive auf die Entwicklung der Menschheit, die deren Ursprung in Europa vermutete. Die monogenistische Interpretation des Neandertalers war von der Suche nach einem Bindeglied bestimmt, das gewissermaßen die von Owen geschaffene anatomische Distanz zwischen den Primaten und dem Menschen überbrücken sollte.

Wie Schaaffhausen sprachen sich auch andere Monogenisten für eine mögliche genealogische Verbindung zwischen Neandertaler und modernem Menschen aus. Sie vermuteten im Neandertaler das missing link

62 Vgl. John Reader (1981) Missing Links. The hunt for earliest man. Boston, Toronto: Little, Brown, S. 20-36.

63 Vgl. Willy Bürger (1956) Johann Carl Fuhlrott. Der Entdecker des Neandertalmenschen. Wuppertal: Abendland Verlag.

64 Vgl. Hermann Schaaffhausen (1861) „On the Crania of the Most Ancient Races of Man“. In: Natural History Review 1, S. 155-172, S. 162: „racecharacter". Übersetzung von George Busk, Originaltitel: Hermann Schaaffhausen (1858) „Zur Kenntnis des ältesten Rassenschädel“. In: Archiv Verbindung mehrerer Gelehrten, S. 453-488.

65 Vgl. Hermann Schaaffhausen (1856) „Über Beständigkeit und Umwandlung der Arten“. In: Verhandlungen des Naturhistorischen Vereins der Preußischen Rheinlande und Westphalens 10, S. 420-451. 
zwischen Menschen und Primaten. ${ }^{66}$ Die charakteristische Physiognomie deuteten sie deshalb als ein sogenanntes Rassenmerkmal und betonten das hohe Alter des Fundes, das sie aus seinen physiognomischen Besonderheiten ableiteten. In eine zunächst ähnliche Richtung argumentierte in Großbritannien William King. Wegen der vorzeitlichen Datierung des Neandertalers ging King aber nicht nur davon aus, daß er ein Zwischenglied zwischen Mensch und Primaten darstelle. Bereits im Gravitationsfeld des Affen-Theorie behauptete er, daß der Neandertaler anatomisch besonders den Primaten ähnele, und ,ziemlich eng mit dem Schädel des Schimpansen“ übereinstimme. ${ }^{67}$

Die Monogenisten suchten im Neandertaler vor allem einen - neuen - Beweis des gemeinsamen Ursprungs aller Menschen, nachdem durch den Glaubwürdigkeitsverlust der Akklimatisierungsthese das tragende Argument ihrer säkularisierten Dezendenztheorien weggebrochen war. In Diskussionen wie der über den Neandertaler entstanden auch monogenistische Theorien, die progressivistisch und nicht mehr rein degenerationistisch argumentierten. Doch diese monogenistischen Ansätze extrapolierten die von ihnen angenommene, progressive Entwicklung von den Primaten über den Neandertaler zum modernen Menschen nicht in die von ihnen weiterhin diffus degenerationistisch konstruierte Rassenhierarchie. Welche Stellung der Neandertaler in diesem Modell letztlich einnahm, war der Willkür der Interpretationen überlassen. King ging dabei am weitesten und näherte ihn stärker den Primaten, andere gingen hingegen von einer frühen Menschenform im Übergangsfeld von Primaten und Menschen aus.

Es war der polygenistisch argumentierende Rudolf Virchow, der Schaaffhausens Deutungen als erster und am vehementesten entgegentrat und den Neandertaler für einen pathologisch Mißgebildeten hielt. ${ }^{68}$ Die Kontroverse zwischen den Monogenisten und den Polygenisten war der Hintergrund für die einander widersprechenden Ansichten über den Neandertalerschädel. Die Polygenisten traten der monogenistischen missing-link-Hypothese mit der vehementen Ablehnung der vorzeitlichen Datierung des Neandertalers entgegen und konstruierten gezwungenermaßen pathologische Erklärungen für dessen charakteristische Physiognomie.

66 Vgl. Jacob W. Gruber (1948) „The Neanderthal Controversy: NineteenthCentury Version“. In: The Scientific Monthly 67, S. 436-439, S. 438.

67 Vgl. William King (1864) „The Reputed Fossil Man of the Neanderthal“. In: Quarterly Journal of Science 1, S. 88-97, S. 96.

68 Vgl. Eric Trinkaus; Pat Shipman (1994) The Neanderthals: Changing the Image of Mankind. London: Pimlico, S. 57-58. 
Die Kritiker an Schaaffhausens Interpretation wurden von Johann Friedrich Carl Mayer angeführt, der im Sinne Virchows von einer pathologischen Verformung des Schädels schrieb. Mayer bezweifelte ein hohes Alter der Knochen und spekulierte, der Neandertaler sei eher ein mongolischer Kosak gewesen, der mit einem russischen Reiterheer 1814 gegen Frankreich gezogen wäre. ${ }^{69}$ Einige Jahre später erklärte Virchow, daß der Neandertaler rachitisch gewesen sein mußte. Er könne deshalb nur jüngeren Datums sein, da sein Überleben von entwickelten Sozialstrukturen abgehangen habe, die bei vorgeschichtlichen wie primitiven Gesellschaften nicht gegeben gewesen seien. ${ }^{70}$ Auch andere Polygenisten stellten bei der Neandertalerdiskussion auf eine abnorme Deformation des Kraniums und der Augenbrauenpartie ab. ${ }^{71}$

Der britische Polygenist Charles Carter Blake reagierte 1861 auf die Übersetzung von Schaaffhausens Bericht über den Neandertaler im $\mathrm{Na}$ tural History Review und wies dessen Altersbestimmung zurück. Er berief sich auf eine anatomische Ähnlichkeit mit Schädeln zeitgenössischer Wilder. ${ }^{72}$ Über die anatomischen Merkmale des Schädels schrieb er weiter:

„Alle diese Eigenschaften stehen im Einklang mit der Annahme, daß das Neandertaler Skelett zu irgendeinem armen Idioten oder Einsiedler gehörte, der in der Höhle starb, in der seine Überreste gefunden wurden“" ${ }^{73}$

Der britische Mediziner und Anthropologe Joseph Barnard Davis führte die besondere Erscheinung des Schädels auf einen pathologisch verfrühten Verschluß der Schädelnähte zurück. ${ }^{74}$ Das weitere Wachstum

69 Vgl. Johann Friedrich Carl Mayer (1864) „Ueber die fossilen Ueberreste eines menschlichen Schädels und Skelettes in einer Felsenhöhle des Düssel- oder Neander-Thales“. In: Archiv für Anatomie, Physiologie und wiss. Medicin 1, S. 1-26, S. 20.

70 Vgl. Ursula Zängl-Kumpf (1990) Hermann Schaaffhausen (1816-1893). Die Entwicklung einer neuen physischen Anthropologie im 19. Jahrhundert. Frankfurt: R. G. Fischer, S. 193.

71 Während sich die deutschen und die britischen Polygenisten hierin einig waren, stellte Paul Broca in Frankreich eine Ausnahme dar, er hielt die Form des Neandertalerschädels nicht für ein Indiz von Idiotie (vgl. Trinkaus, Shipman 1994, S. 83).

72 Vgl. Charles Carter Blake (1861) „On the Occurrence of Human Remains Contemporaneous with those of Extinct Animals“. In: The Geologist 4, S. 365; vgl. Ronald Millar (1974) The Piltdown Man. A Case of Archaeological Fraud. St Albans: Paladin, S. 62.

73 Charles Carter Blake (1862) „On the Cranium of the Most Ancient Races of Man“. In: The Geologist 5, S. 206.

74 Vgl. Joseph Barnard Davis (1864) The Neanderthal Skull: Its Peculiar Conformation explained Anatomically. London, S. 7. 
des Schädels und des Gehirns hätten seine besonders längliche Form bedingt. Da Davis davon ausging, daß die besondere Form des Neandertalerschädels eine individuelle Deformation darstellt, nahm er an, daß die frühen Bewohner Europas anatomisch den gegenwärtigen geglichen hätten. Er schrieb:

„Es gibt keinen hinlänglichen Grund, ihm die volle Verstandeskraft seiner Rasse abzusprechen, zumindest was die Größe des Gehirns betrifft. [...] Für den Schluß, daß er zu einer äußerst minderwertigen Rasse gehörte, wie die Australier, sehe ich keinen Beleg. [...] Daß die besonders frühen Bewohner Europas, die normale Schädel hatten, in ihrer Hirnmasse unterlegen waren, [...], bezweifele ich. [...] [E]s gibt keinen Grund, sie [...] im Vergleich zu vielen modernen Europäern für minderwertig zu halten“ “ ${ }^{75}$

Die polygenistischen Interpretationen des Neandertalers waren sich weitgehend darin einig, daß es sich nicht um einen vorgeschichtlichen, sondern um einen eher rezenten wenngleich pathologischen Menschen handelte. Die einhellige Ablehnung der prähistorischen Datierung des Neandertalers durch die Polygenisten rührte daher, daß ihre Rassentheorie auf die Unveränderbarkeit rassischer Eigenschaften pochte und deshalb unvereinbar mit jedweder Konzeption einer transmutativen oder evolutionären Verbindung zwischen Neandertaler und Europäer war.

Für die Evolutionstheoretiker waren beide Positionen untragbar. Busk hatte 1861 Schaaffhausens Aufsatz über den Neandertaler im $\mathrm{Na}$ tural History Review übersetzt und kommentiert. Er ging in seinem Kommentar nicht auf Schaaffhausens Versuch ein, den Schädel über den Vergleich mit anderen Fossilien einer vor-römischen oder keltischen Epoche zuzuordnen. Statt dessen nahm er den Neandertaler Schädel sogleich in die durch die Entwicklungen nach 1859 revolutionierte Debatte über den prähistorischen Menschen auf:

„Es ist zu einem Gegenstand [...] von besonderem Interesse geworden, zu bestimmen, wie weit es möglich ist, sich anhand der wenigen Überreste seiner Knochen, die bislang gefunden wurden, zu vergewissern, ob und in welcher

75 Joseph Barnard Davis (1863) „The Neanderthal Skull: Its Peculiar Conformation explained Anatomically“. In: Memoirs of the Anthropological Society 1, S. 281-295, S. 293-294: „There is no adequate reason for denying the full powers of mind belonging to his race, to the Neanderthal man - at least as far as the size of his brain is concerned; [...]. In favour of the conclusion that he belonged to a very inferior race, such as the Australians, I do not see any evidence. [...] That the very ancient inhabitants of Europe, who had normal skulls, were much inferior in mass of brain [...], I am led to doubt. $[\ldots][\mathrm{T}]$ here is no ground for regarding them $[\ldots]$ as inferior to many modern Europeans". 
Hinsicht die Ur-Rasse oder Rassen sich von jenen unterschieden, die die Welt gegenwärtig bewohnen“" ${ }^{76}$

Dabei betonte er, daß die physiognomisch charakteristischen Merkmale des Neandertalers eine signifikante Ähnlichkeit mit den Primaten aufwiesen und es sich deshalb beim Neandertaler um „einen sehr wilden Typus“" handele. ${ }^{77}$ Busk verwendete den Begriff des Wilden im Kontext des Vergleiches verschiedener physiognomischer Merkmale. Er verschmolz den diskursiv gesetzten Gehalt des Begriffs der kulturellen Primitivität mit körperlichen Eigenschaften, die er gleichermaßen zur Bestimmung von „Menschenrassen“ (,Races of Man“) heranzog.

Wenn er zudem Ähnlichkeiten bestimmter kranialer Eigenschaften von „wilden und barbarischen Rassen“ und dem Neandertalerschädel annahm, die sie gegenüber dem europäischen Schädel auszeichneten, verdeutlicht sich, daß Busk mit dem Rassenbegriff sowohl prähistorische als auch gegenwärtige Gesellschaften beschrieb. ${ }^{78}$ Mit der Gewißheit einer entwicklungsgeschichtlichen Verbindung zwischen dem $\mathrm{Ne}$ andertaler, den Primaten und den gegenwärtigen Menschen diskutierte er Schaaffhausens Theorie als eine wertvolle Quelle für die Untermauerung der noch schwer umkämpften Frage nach dem Alter und der naturgeschichtlichen Einordnung des Menschen. Er teilte deshalb dessen Einschätzung, daß der Neandertaler der älteste fossile Fund in Europa und noch älter als der Fund bei Engis sein müsse.

Die Neandertaler-Debatte wirkte sich unmittelbar auf die Interpretation anderer fossiler Funde aus. Bereits 1848 wurde in der GenistaHöhle auf Gibraltar ein gut erhaltener Schädel gefunden. Doch erst 1862 gelangte der Fund nach England und platzte dort mitten in eine heftige Debatte um die Zeit und die Umstände, unter denen prähistorische Menschen gelebt haben könnten. Busk reiste gemeinsam mit Hugh Falconer nach Gibraltar und nahm die Höhle in Augenschein. Ihren Bericht, der sich sowohl auf die Fundstelle selbst, als auch auf den Schädel bezog, hier ergänzten sich die Kompetenzbereiche des eher archäologisch arbeitenden Paläontologen Falconer und des anthropometrisch arbeitenden

76 George Busk (1861a) „On the Crania of the Most Ancient Races of Man. By Professor D. Schaaffhausen, of Bonn. (From Müller's Archiv, 1858, pp. 453). With Remarks, and original Figures, taken from a Cast of the Neanderthal Cranium“. In: Natural History Review 1, S. 172-176, S. 172: „It has become a matter [...] of extreme interest to determine how far it may be possible, from the scanty remains of his bones as yet discovered, to ascertain whether, and in what respects, the priscan race or races may have differed from those which at present inhabit the earth".

77 Busk 1861a, S. 173: ,a very savage type“.

78 Busk 1861a, S. 174: „,savage and barbarous races“. 
Busk - trugen sie 1864 der British Association vor. ${ }^{79}$ Sie erklären, daß der Gibraltarschädel dem Neandertalerschädel sehr ähnlich sei und zu menschlich, um eine Bindeglied zwischen den Primaten und dem Menschen darzustellen. ${ }^{80}$ Damit legten sie den Grundstein für die Annahme, daß der Neandertaler einst weite Teile Europas besiedelt haben müsse. ${ }^{81}$ Busk und Falconer waren davon überzeugt, mit diesem Schädel sei ein weiterer Mosaikstein gefunden worden, der in das Bild des prähistorischen Menschen eingefügt werden könne, und sie verwendeten ihn als weiteres Indiz gegen die Hypothese, die Besonderheit des Neandertalerschädels könnte pathologische Ursachen haben. ${ }^{82}$

Huxley griff 1862 in die Debatte um den Neandertaler ein. Wie vor ihm Busk war auch er der Ansicht, daß der Neandertaler kein Bindeglied zwischen dem Menschen und den Primaten darstellt. Er hielt ihn schlicht für eine frühe Form des Menschen. Zur Unterfütterung seiner Annahme nahm er vor allem eine Vermessung des Schädelinnenraumes des Neandertalers vor. Beim Neandertalschädel diagnostizierte Huxley deshalb nicht, wie Fuhlrott und andere, bloß eine stark ausgebildete Augenwulst, sondern vor allem, daß der ,,vordere Hirnlappen“ stark ,,abgeflacht“ gewesen sein müsse. ${ }^{83}$ Dieser und einiger anderer Charakteristika wegen war er überzeugt, daß in einigen Punkten eine „Ähnlichkeit zwischen dem Neandertal-Kranium und bestimmten australischen Schädeln“ bestünde, die er zur Verdeutlichung übereinanderprojizierte (vgl. Abb. $1) .^{84}$

79 Vgl. George Busk; Hugh Falconer (1865) „On the Fossil Contents of the Genista Cave, Gibraltar“. In: Quarterly Journal Geological Society 21, 364-370

80 Vgl. Gruber 1948, S. 439.

81 Vgl. George Busk; Hugh Falconer (1863) „An account of the proceedings of the late conference held in France to enquire into the circumstances attending the reported discovery of a Human Jaw in the gravel at MoulinQuignon, near Abbeville ...". In: Natural History Review 3, S. 423-462. Diese Einordnung des Gibraltarfundes wird heute als Irrtum betrachtet (vgl. B. A. Wood (1979) „The ,Neanderthals" of the College of Surgeons“. In: Annals of the Royal College of Surgeons 61, S. 385-389).

82 Vgl. Arthur Keith (1911) „The Early History of the Gibraltar Cranium“. In: Nature 87, S. 313-314.

83 Huxley (1862d) „On Some Fossil Remains of Man“. In: [Proceedings of the Royal Institution of Great Britain 3, 1858-62, S. 420-422] Collected Essays, Bd. 7, S. 157-208, S. 182: ,that the posterior lobe of the brain of the Neanderthal man must have been as much flattened as I suspected it to be".

84 Huxley 1862d, S. 185: „one among several points of similarity between the Neanderthal cranium and certain Australian skulls"; vgl. Desmond: 1998, S. 301. 
Abb. 1. Huxley: Neandertaler und Australier. ${ }^{85}$

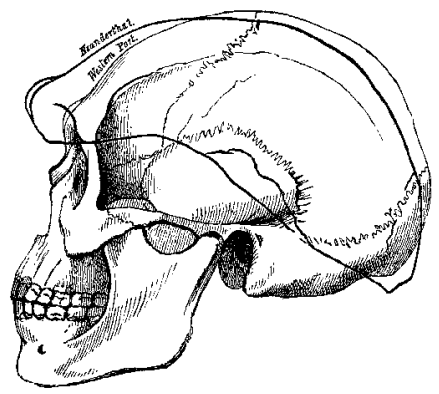

Dabei kam er zu dem Ergebnis:

„Das Neandertal-Kranium ist keinesfalls so einzig, wie es zunächst scheint. Es stellt vielmehr den extremen Eckpunkt einer Serie dar, die graduell zu den höchsten und am besten entwickelten Krania führt. Einerseits stehen ihm die abgeflachten australischen Schädel nahe [...] von denen aus uns andere australische Schädel graduell zu Schädeln führen, die ziemlich dem Typ des Engis Kraniums entsprechen. Und andererseits ist es sogar den Schädeln jener vorzeitlichen Menschen viel ähnlicher, die Dänemark in der Steinzeit bevölkerten". 86

Huxley befand, daß die fossilen Funde aus Engis und dem Neandertal nicht, wie von vielen Monogenetikern behauptet, die Lücke zwischen Affe und Mensch schlössen. ${ }^{87}$ Er hatte in seiner Diskussion den Nean-

85 Huxley 1862d, S. 202: Fig. 31 „An Australian skull form Western Port [...] with the contour of the Neanderthal skull“".

86 Huxley 1862d, S. 205-207: „The Neanderthal cranium is by no means so isolated as it appears to be at first, but forms, in reality, the extreme term of a series leading gradually from it to the highest and best developed of human crania. On the one hand, it is closely approached by the flattened Australian skulls [...] from which other Australian forms lead us gradually up to skulls having very much the type of the Engis cranium. And, on the other hand, it is even more closely affined to the skulls of certain ancient people who inhabited Denmark during the stone period"“.

87 In einer sich an die Veröffentlichung von Man's Place in Nature anschlieBenden internationalen Kontroverse wird Huxley in einer Erwiderung an den deutschen Anatomen Mayer noch deutlicher: „If the dissector of Jeremy Bentham had found a levator claviculae, or a couple of bellies of the flexor brevis digitorum arising from the tendons of the deep flexor of the foot, as is sometimes the case in man, he would have had a perfect right to say that these were pithecoid characters; but it by no means follows that he should have supposed the philosopher to be the ,missing link', or a homo 
dertaler näher an den modernen Menschen herangerückt, als es die monogenistische Hypothese eines Bindegliedes vorsah. Damit hatte er zugleich auch Spekulationen verworfen, die eine solche Zwischenstufe etwa bei den Australiern oder Buschmännern vermuteten. Doch zugleich rückte er die Australier in die Nähe der Neandertaler und suggerierte so, bei ihnen handele es sich um eine prähistorische Form, die sich kaum entwickelt habe. ${ }^{88}$ Dennoch wies er die für ihn naheliegende, aber unbelegbare Annahme zurück, die Gehirne der „niederen Rassen“ stünden auf einer wie auch immer definierten Zwischenstufe zwischen Menschenaffen und Europäern. ${ }^{89}$

Wie schon bei der Diskussion um das Verhältnis von Gorilla und Mensch baute Huxley auch bei der Erörterung des Verhältnisses des Neandertalers zum Menschen eine rassendifferenzierte Argumentation auf. Die Darstellung einer anatomischen Vergleichbarkeit und entwicklungsgeschichtlichen Nähe von Gorilla und Mensch hatte er durch eine Unterscheidung zwischen ,höheren“ und ,niedrigeren“ Menschen und durch die Annäherung des sogenannten Buschmanns an die Primaten unterstützt. Analog sicherte er nun seine Annahme, der Neandertaler sei ein früher Mensch und keine Übergangsform zwischen den Primaten und dem Menschen, durch die Annäherung des Schädelprofils des Neandertalers an das eines Australiers ab. Im gleichen Maße, wie Huxley den Neandertaler in die Spezies Mensch eingemeindete und ihn ebensoweit

pithecoides (Mayer)“ (Huxley (1864b) „Further Remarks Upon the Human Remains from the Neanderthal". In: [Natural History Review n.s. 4, S. 429-446] The Scientific Memoirs of Thomas Henry Huxley, Bd. 2, S. 573-590, S. 587).

88 Die anatomische Ähnlichkeit von Neandertaler und Australier, die Huxley hier konstruierte, wurde zwar Anfang des zwanzigsten Jahrhunderts zurückgewiesen. Doch um die Berechtigung zu unterstreichen, Homo neanderthaliensis als eigene Gattung betrachten zu können, hatte der französische Anthropologe Marcellin Boule (1861-1942) noch 1908 die Australier als vermeintlich primitivste Menschenrasse zum Vergleich mit dem Neandertaler herangezogen (vgl. Christopher Stringer, Clive Gamble (1993) In Search of the Neanderthals. Solving the Puzzle of Human Origins. New York, Thames and Hudson, S. 16, S. 25). Die Konstruktion einer Verbindung zwischen Australiern und Primaten erweist sich so als ein hartnäckiger Topos im anthropologischen Diskurs.

89 Vgl. Huxley 1862d, S. 186-188: „The ape-like arrangement of certain muscles which is occasionally met with in the white races of mankind, is not known to be more common among the Negroes or Australians: nor because the brain of the Hottentot Venus was found to be smoother, to have its convolutions more symmetrically disposed, and to be, so far, more apelike than that of ordinary Europeans, are we justified in concluding a like condition of the brain to prevail universally among the lower races of mankind, however probable that conclusion may be". 
vom Affen trennte wie den Menschen selbst, degradierte er die Australier zu zeitgenössischen Pendants der ersten Menschen.

Huxley, ebenso wie Busk, arbeitete auf Grundlage der Überzeugung, daß alle Rassen einen gemeinsamen Ursprung gehabt hätten. Doch wie seine Diskussion des Verhältnisses von modernem Menschen zum Neandertaler und zum Primaten zeigt, führte die evolutionäre Erklärung einer gemeinsamen Abkunft des Menschen keineswegs zu einem Gleichheitspostulat. Vielmehr schuf Huxley ein Modell, in dem die soziale Distanz zwischen den von ihm angenommenen Menschenrassen über die Konstruktion eines Entwicklungsabstandes erklärt und festgeschrieben wurde. Die evolutionäre Entwicklung des Menschen habe jene anatomischen Unterschiede hervorgebracht, die die rassentaxonomische Diskussion beherrscht hatten.

Dabei beschränkte er sich nicht auf phänotypische Qualitäten. Da er das gleiche Maß an Intelligenz bei prähistorischen Europäern wie dem Neandertaler und Australier unterstellte, stellte er eine Korrelation zwischen kultureller und anatomischer Entwicklung her. ${ }^{90}$ Durch den Vergleich der Kulturtechniken vorgeschichtlicher Menschen mit denen der zeitgenössischen Wilden kam er zu dem Ergebnis, daß „die Bräuche und Lebensweisen jener Menschen [der sog. Primitiven, T.G.] seit der Zeit des Mammuts [...] unverändert blieben““.91 Huxleys Modell der Evolution des Menschen war deshalb in Wirklichkeit ein Modell sozialer Evolution, bei dem beide Dimensionen, kulturelle wie anatomische Entwicklung, als miteinander verbunden auftraten.

In dieser Debatte über den Neandertaler spielte die zuvor noch so bedeutende soziale und politische Dimension der Etablierung des Evolutionsparadigmas keine Rolle. In ihr ging es nicht um die Professionalisierung der Anthropologie, ihren Methodenhaushalt oder die Berechtigung, am anthropologischen Diskurs teilzuhaben. Dies lag zum einen daran, daß die Kontrahenten der Evolutionstheoretiker, Monogenisten wie Polygenisten, von Busk und Huxley als ernstzunehmende Wissenschaftler betrachtet wurden. Zum anderen resultierte diese Form der Konfliktführung aus dem Umstand, daß die beteiligten Monogenisten und Polygenisten nur eine wissenschaftliche Gegenposition aber keine Gefahr für die berufliche Entwicklung der Evolutionisten darstellten. Es mußten folglich nicht alle Ebenen, auf denen die Auseinandersetzung von den

90 Huxley 1864b, S. 589: „Thus the difference of the races is already manifest in the highest antiquity, when our country was inhabited by men who, in intelligence, were on a level with the Australian savages of the present day".

91 Huxley 1862d, S. 208: ,the habits and modes of living of such people [...] have remained the same from the time of the Mammoth [...] till now". 
Akteuren des X-Clubs geführt wurde, bedient werden. Dennoch hatten Huxley und Busk an dieser Stelle die evolutionäre Interpretation prominent in die Debatte über den Neandertaler eingeführt und in ihr verankert. Ein vollständiger Paradigmawechsel, bei dem der evolutionstheoretische Orientierungskomplex seine Vorläufer effektiv aus dem Diskurs verdrängte, dürfte ihnen hier aber noch nicht gelungen sein, denn, wie bei der Analyse der Kontroverse zwischen Anthropological Society und Ethnological Society noch zu sehen sein wird, die polygenistischen Interpreten des Neandertalers waren auch noch nach der hier skizzierten Debatte aktiv.

\subsection{2 "True Savages“. Kontroversen über Degenerationstheorien}

Neben den monogenistischen Deutungen des Neandertalers drückte sich der Vorbehalt gegen die Evolutionstheorien in der Wiederkehr einer klassischen Position des Monogenismus aus, der Behauptung, die nichtweißen und vermeintlich primitiven Rassen resultierten aus einer Degeneration ursprünglich höher zivilisierter Rassen. Auf die Frage nach der Richtung der sozialen Entwicklung und ihrer etwaigen Auswirkung auf die Differenzierung der Menschenrassen gab es seit der Aufklärung zwei konträre Antworten, eine progressivistische und eine degenerationistische. Um eben diese Frage nach der Richtung und der Mechanik sozialer Entwicklung ging es in einer Auseinandersetzung zwischen John Lubbock und George Douglas Campbell, dem Duke of Argyll, die sich 1867 im Anschluß an die Jahresversammlung der British Association in Dundee entspann.

Das öffentliche Interesse an dieser Auseinandersetzung wurde durch das Renommee der Kontrahenten verstärkt. Lubbock hatte sich zu diesem Zeitpunkt bereits als Darwinianer und Wissenschaftspolitiker etabliert, der Duke of Argyll war ein profilierter Oberhausabgeordneter und politischer Essayist. ${ }^{92}$ Außerdem hatte er sich als erklärter Gegner der Evolutionstheorie hervorgetan und gehörte zu jenen Kreisen des Establishments, in denen Richard Owen verkehrte und die ihn zu seiner Kritik an Darwin ermuntert hatten. ${ }^{93}$ Auslöser für die Kontroverse mit Lubbock war dessen Kritik am Dubliner Erzbischof Richard Whately, der Jahre

92 Vgl. Bowler 1989, S. 81-82.

93 Vgl. George Campbell, Duke of Argyll (1867) The Reign of Law. London: Strahan; Rev. Richard Owen (1894) The Life of Richard Owen. London: John Murray. 1894, Bd. 2, S. 59. 
zuvor behauptet hatte, unterschiedliche zivilisatorische Zustände wären die Produkte degenerativer Prozesse.

Whately, dessen damaliger Ruf auch außerhalb der Kirche auf seinen Schriften zur Logik und zur Sozialpolitik beruhte, ${ }^{94}$ hatte zuletzt 1854 einen Aufsatz verfaßt, in dem er seine Version der Degenerationstheorie darlegte, dabei aber nur die wesentlichen Punkte seiner Lectures on Political Economy von 1832 wiederholte. ${ }^{95}$ Seine Position selbst war also alt und in keiner Weise von den wissenschaftlichen Turbulenzen der sechziger Jahre des neunzehnten Jahrhunderts geprägt. Für konservative Gegner der Evolutionstheorie galt sein antiprogressivistischer Ansatz aber immer noch als ein brauchbarer Referenzpunkt.

Whately war davon ausgegangen, daß menschliche Gesellschaften auf einer bestimmten zivilisatorischen Stufe begonnen haben müssen, die durch eine göttliche Instruktion geschaffen worden sei. Er richtete sich explizit gegen jene Fortschrittsdenker und politischen Ökonomen, die den Ausgangspunkt des zivilisatorischen Prozesses in einem wilden Zustand vermutet hatten: ${ }^{96}$

„Wir haben keinen Grund anzunehmen, daß sich irgendeine Gemeinschaft ohne äußere Hilfe von einem Zustand ausgesprochener Barbarei in irgend etwas, das Zivilisation genannt werden kann, jemals verwandelt habe oder jemals verwandeln kann. [...] Der Fortschritt durch eigene, interne Mittel jedweder zivilisierten Gesellschaft muß immer von einem Zustand jenseits vollständiger Barbarei begonnen haben“. ${ }^{97}$

Er war davon überzeugt, daß diese erste externe Hilfe, die dem Menschen aus absoluter Barbarei geholfen habe, die Gottesgabe des Verstandes gewesen sei. Erst von dieser zivilisatorischen Stufe ausgehend habe eine soziale Entwicklung beginnen können, aus der zuletzt die europäischen Industrienationen hervorgegangen seien. Doch, und dies ist neben der kreationistischen Grundannahme Whatelys der zweite Punkt, an dem ihm die evolutionäre Sicht auf den Ursprung des Menschen und

94 Richard Whately (1787-1863) wurde 1831 zum Erzbischof Dublins bestellt. In den 1830er Jahren war er Royal Commissioner zur Frage der Armut in Irland.

95 Vgl. Richard Whately (1832) Introductory Lectures on Political Economy. London: Parker.

96 Vgl. Whately 1832, S. 106.

97 Whately 1832, S. 108: ,[W]e have no reason to believe that any community ever did, or ever can, emerge, unassisted by external helps, from a state of utter barbarism, into any thing that can be called civilization. [...] $[\mathrm{T}]$ he progress of any community in civilization, by its own internal means, must always have begun from a condition removed from that of complete barbarism". 
die evolutionäre Rassentheorien widersprachen, sein Verständnis von zivilisatorischer Entwicklung war weder identisch mit dem der Evolutionstheoretiker noch mit dem der Philosophen der Aufklärung. Denn das menschliche Sein begann für ihn auf zivilisierter Stufe, die Menschheit habe sich nicht selbst zivilisieren können, es habe folglich auch keinen Naturzustand des Menschen gegeben. ${ }^{98}$ Der Fortschritt, den er von diesem gottgegebenen zivilisatorischen Fundament ausgehend konstatierte, fiel deshalb vergleichsweise unspektakulär aus. Die Primitivität der vermeintlich Wilden stellte für Whately nicht einen sozialen Urzustand, sondern einen Zustand der Degeneration aus einem vormals zivilisierteren Zustand dar, ,alle Wilden müssen ursprünglich von einem zivilisierteren Zustand degeneriert sein".99 Ihr Zustand sei durch Vertreibung und Krieg geschaffen worden:

„Sie müssen inmitten schmerzlicher Kämpfe für das bloße Überleben ihre Aufmerksamkeit von allen anderen Dingen abgewandt haben. Sie müssen so lange der Materialien und Möglichkeiten beraubt worden sein, um viele ihrer Fertigkeiten auszuüben, bis das Wissen darüber verloren war“. ${ }^{100}$

Whately nahm zwar zwei Entwicklungsrichtungen an. Doch er gewichtete ihre Effekte unterschiedlich. Die Degeneration versetzte manche Gesellschaften in den Zustand der Primitivität, während die progressive Entwicklung auf der anderen Seite zwar einen Fortschritt, aber keine substantielle Veränderung bewirkt habe, sondern allerhöchstens eine Sublimierung der Zivilisation. Whatelys Programm versuchte, das christliche Dogma gegen die Entwicklungsmodelle der Aufklärungsphilosophie zu verteidigen. Ihm ging es vor allem um eine Zurückweisung der Annahme des Naturzustands.

Lubbock verwendete Whately, um den christlichen Diskurs zusammen mit der monogenistischen Degenerationshypothese zu demontieren. Er erklärte, daß es „Anzeichen von Fortschritt auch unter Wilden“ gäbe und daß die zivilisierten Gesellschaften Spuren ursprünglicher Barbarei aufwiesen. ${ }^{101}$ Seiner Ansicht nach könnten bestimmte kulturelle Errun-

98 Vgl. Whately 1832, S. 122-123.

99 Whately 1832, S. 111: ,all savages must originally have degenerated from a more civilized state of existence".

100 Whately 1832, S. 119: „They must, amidst a series of painful struggles for mere existence, have their attention drawn off from all other subjects; they must be deprived of the materials and the opportunities for practising many of the arts, till the knowledge of them is lost".

101 Lubbock (1868a) „The Early Condition of Man”. In: Anthropological Review 6, S. 1-21, S. 5: ,there are indications of progress even among savages“. 
genschaften nicht verloren gehen, beispielsweise die Religion. Er verwies auf die zahllosen Berichte von Reisenden über den vermeintlich amoralischen und religionslosen Zustand der meisten Wilden und sah darin der Vermutung einer Degeneration der Wilden von einer höheren Zivilisationsstufe widerlegt. ${ }^{102}$ Bei den zeitgenössischen Wilden aus Übersee habe Whately sein Argument dadurch abzusichern versucht, daß er auf Berichte verwiese, die Beleg für den angeblichen Stillstand ihrer sozialen Entwicklung seien. Lubbock nahm hingegen ein langsames Fortschreiten sozialer Entwicklungen bei den sogenannten Wilden an. Daß dieser Prozeß oftmals verkannt wurde, sei einer ethnologischen Beobachtungsunschärfe geschuldet, die Lubbock auf mangelnde Selbstreflexion der Beobachter zurückführte:

„Wir sind daran gewöhnt, um uns herum so rapide Verbesserungen zu sehen, daß wir vergessen, wie kurz ein Jahrhundert in der Geschichte der menschlichen Rasse ist. Selbst wenn man die herkömmliche Zeitrechnung nimmt, ist es deutlich, daß, wenn irgendeine Rasse in sechstausend Jahren nur vom Zustand äußerster Barbarei zum Zustand der Australier fortschreiten konnte, wir nicht allzu große Veränderungen in einem Jahrhundert erwarten sollten“. ${ }^{103}$

Whatelys Unterstellung, viele wilde Gesellschaften entwickelten sich erst gar nicht, versuchte Lubbock also dadurch zu entkräften, daß er auf die in seinen Augen nur ärmliche soziale Entwicklung der Australier verwies. Dieser Zurückweisung einer negativen Beweisführung, die aufgrund des nicht beobachteten Fortschritts auf Rückschritt schloß, schob Lubbock einen positiven Beweis für den zivilisatorischen Fortschritt auch sogenannter primitiver Gesellschaften nach. Er hielt den australischen Bumerang für den schlußendlichen Beweis der Unmöglichkeit sozialer Degeneration:

„Diese Waffe ist keiner anderen Rasse von Menschen bekannt [...]. Wir können es nicht als das Relikt der ersten Zivilisation betrachten, sonst wäre es jetzt nicht auf nur eine Rasse beschränkt. Die Australier können es aus dem gleichen Grund auch nicht von einem zivilisierten Besucher erlernt haben. Es ist deshalb $[\ldots]$ der klare Beweis eines Schritts nach vorn $[\ldots]$, der von einem

102 Vgl. Lubbock 1868a, S. 6.

103 Lubbock 1868a, S. 3: „We have been accustomed to see around us an improvement so rapid that we forget how short a period a century is in the history of the human race. Even taking the ordinary chronology, it is evident that if in six thousand years a given race has only progressed from a state of utter savagery to the condition of the Australian, we could not expect to find much change in one more century“. 
Volk vollzogen wurde, von dem Erzbischof Whately sicherlich zugeben würden, daß sie wirklich Wilde sind“. ${ }^{104}$

Bei der Diskussion der australischen Kultur verfuhr Lubbock auf der Ebene der sozialen Evolution analog zu Huxleys Einordnung des Australierschädels in ein organisches Evolutionsschema. Die Australier galten beiden als Beispiele der ersten Menschen. War es für Huxley vor allem wichtig, sie über anatomische Vergleiche in die Nähe des Neandertalers zu rücken, so unterstellte Lubbock ihnen eine nur rudimentäre kulturelle Entwicklung.

In Dundee hatte Lubbock ein begeistertes Publikum vorgefunden, das seine Kritik an Whatleys Degenerationsthese mit großem Applaus bedachte. ${ }^{105}$ Innerhalb der scientific community war zu diesem Zeitpunkt also eine evolutionäre Interpretation der Geschichte der Menschheit keineswegs mehr marginal. Doch der Monogenismus war durch die Kritik Lubbocks noch nicht endgültig diskreditiert. Der Duke of Argyll löste nur wenige Monate später eine zweite Kontroverse über die Degenerationshypothese aus. Ihm ging es in erster Linie nicht um eine Verteidigung Whatelys, sondern um die Widerlegung der Evolutionslehre, insbesondere in ihrer Anwendung auf die Menschheitsgeschichte. Dabei war der Duke of Argyll zu diesem Zeitpunkt alles andere als ein isolierter Vertreter einer bereits durch die naturwissenschaftliche Entwicklung marginalisierten Position. Wie bei Whately verknüpfte sich in seiner Argumentation die Degenerationshypothese mit einer biblischen Interpretation des Menschen.

Die grundsätzliche Befähigung zur Zivilisation hielt Argyll für ein Merkmal, das auch den ersten Menschen ausgezeichnet habe, und das den wesentlichen Unterschied zwischen Mensch und Tier ausmache. Anders als Whately ging er nicht von einer göttlichen Instruktion, sondern von einer instinktiven Anlage aus, die diese Befähigung geschaffen habe. ${ }^{106}$ Diese Konzession zeigt bereits deutlich die Diskursverschiebung im religiös orientierten Segment der wissenschaftlichen Debatten, die Anfang der sechziger Jahre des neunzehnten Jahrhunderts bereits in

104 Lubbock 1868a, S. 7: „This weapon is known to no other race of men [...]. We cannot look on it as a relic of primeval civilization, or it would not now be confined to one race only. The Australian cannot have learned it from any civilized visitor for the same reason. It is, therefore [...] a clear proof of a step in advance [...] made by a people whom Archbishop Whately would certainly admit to be true savages“.

105 Vgl. The Times, 11. September 1867, S. 10.

106 Vgl. George Campbell, Duke of Argyll (1869) Primeval Man. An Examination of Some Recent Speculations. New York: George Routledge, S. 142-143. 
der Kontroverse um den Sammelband Essays and Reviews zu Tage getreten war. Argyll nahm an, daß die instinktiven Anlagen des Menschen qualitativ anders als die der Tiere seien. Deshalb könne sich der Mensch auch nicht aus einem Naturzustand heraus entwickelt haben, er ,war immer Mensch und nichts geringeres““. 107

Argyll hielt es deshalb für unlauter, den ersten Menschen einen $\mathrm{Zu}$ stand schierer Barbarei zuzuschreiben und diese Annahme darüber abzusichern, daß ihr Ebenbild in den gegenwärtigen Wilden zu finden sei. Er verwarf also zwei Grundsätze der Evolutionstheorien gleichermaßen. Zum einen lehnte er die Naturalisierung des Menschen durch die Evolutionslehre ab. Zum anderen wies er die Annahme der Entwicklung des Menschen aus einem barbarischen Urzustand zurück. Darin drückte sich derselbe Dünkel wie bei Whately aus. Der als unzivilisiert und vor allem als religionslos beschriebene, im Naturzustand vermutete Wilde konnte unmöglich der Ausgangspunkt einer sozialen Entwicklung sein. Argyll stieß sich insbesondere an Lubbocks Beschreibung der sozialen Strukturen am Nullpunkt der sozialen Evolution. Religionslosigkeit, Frauenraub oder Kannibalismus seien Ausdruck eines moralischen Niedergangs, durch den „die grausamsten Bräuche eingeführt“ worden seien, die „,schlimmsten Seiten der [menschlichen] Natur“ hätten „die besten überwältigt"“. ${ }^{108}$

Argyll und Whately sahen sich und den kreationistischen Diskurs der gleichen Problematik gegenüber. Durch die wachsende Zahl von ethnographischen Reiseberichten hatte sich das Bild des edlen Wilden mit dem empirischen Wilden verbunden. Zur Abwehr der Profanisierung des Menschen und seines Ursprungs konstruierten sie eine degenerationistische Erklärung des Zustands der vermeintlich Wilden. Diese Prämisse wird allein dadurch deutlich, daß Argyll sich kaum um eine Darstellung des gesellschaftlichen Fortschritts bemühte, sondern in erster Linie an einer Begründung der primitiven Lebensweise interessiert war. Dabei stütze er sich wie Whately auf die Auswirkungen von Krieg und Vertreibung, um die überlieferten miserablen Lebensbedingungen der Wilden zu erklären: „Die Rassen, die am weitesten vertrieben wurden, dürften die primitivsten gewesen sein“ ${ }^{109}$

Die Antwort Lubbocks folgte 1869 in Exeter, erneut bei einem Jahrestreffen der British Association. Er nutzte dieses dezidiert wissen-

107 Campbell 1869, S. 150: „Man has always been Man, and nothing less“.

108 Campbell 1869, S. 135: „customs the most cruel and depraved become established"; ,,we come upon the fact [...] of the worst parts of his nature to overcome the best".

109 Campbell 1869, S. 162: ,the races which were driven farthest would be the rudest"; vgl. S. 167-170. 
schaftliche Forum, um diese letzten Vorbehalte des traditionellen Monogenismus zu demontieren. Lubbock wies vor allem Argylls Kritik an der Naturalisierung des Menschen zurück und verband diesen Punkt mit der Frage nach dem Zusammenhang von Intellekt und Zivilisation. Er meinte dabei, der Intellekt des Menschen sei kein Alleinstellungsmerkmal, da dieser auch die sozialen Insekten auszeichne, und behauptete, daß Argylls Argumentation unbeabsichtigt die Einheit der Menschheit in Frage stelle:

„Es scheint mir unlogisch, den Menschen aufgrund seiner mentalen Überlegenheit zoologisch von den anderen Primaten zu trennen, und dennoch die Einheit der Menschheit zu betonen, ungeachtet der mentalen Unterschiede zwischen den verschiedenen Rassen der Menschen“. ${ }^{110}$

Lubbock nahm folglich an, daß eine psychische Eigenschaft, die ein Lebewesen $\mathrm{zu}$ intelligentem und sozialem Handeln befähige, allen Menschen, aber auch etlichen Tieren eigen wäre. Die Verteilung variiere derart, daß die Unterteilung mit der gleichen Berechtigung zwischen Ameisen und Menschen, wie auch zwischen verschiedenen Rassen gezogen werden könne. ${ }^{111}$ Zieht man von dieser Argumentation eine gehö-

110 Lubbock (1870b) „On the Primitive Condition of Man - Part 2“. In: The Origin of Civilisation and the Primitive Condition of Man, Mental and Social Condition of Savages. New York: Appleton, S. 325-362, S. 338: „It seems to me [...] illogical to separate man zoologically from the other primates on the ground of his mental superiority, and yet to maintain the specific unity of the human race, notwithstanding the mental differences between different races of men". Dieser Aufsatz Lubbocks basierte auf einem Manuskript, das er 1869 bei der British Association in Exeter vorgetragen hatte.

111 Lubbock hatte in jenen Jahren begonnen, seine entomologischen Studien auf das Studium des sozialen Verhaltens staatenbildender Insekten zu verlagern. 1866 führte er aus: „Look, then, at the ants; they build houses, they keep domestic animals [aphids], and they make slaves; if we deny to them the possession of reason we might almost as well question it in the lower races of Man: insects cannot speak, indeed, but they evidently communicate by means of their antennae, just like certain North American Indians, who cannot understand one another's language, but who can yet converse together with ease and fluency by a code of signs" (zitiert nach Clark 1997, S. 160). Lubbock hatte dabei, wie John Clark schreibt, die verbreitete Ansicht von einer ,psychischen Einheit“ von Insekten und Menschen geteilt und weiter entwickelt: „Most commonly, mental evolution was constructed as progressive developmentalism, which culminated in educated European man. Under this construct, the savage and the animal could be ,tamed', ,domesticated' or ,civilized' by European man because they all shared the same basic mental components, but at different developmental stages on the evolutionary ladder" (Clark 1998, 
rige Portion Polemik ab, so bleibt doch die Überzeugung, daß sich die Rassen in gravierendem Umfang intellektuell unterschieden. Dies war eine Behauptung, die Lubbock bis dahin noch nicht aufgestellt und die er deshalb wohl erst bei seiner Erwiderung Argylls entwickelt hatte. Zudem räumte er einer Rassenkonzeption, in der Rassen als regionale Anpassungsergebnisse betrachtet wurden, eine bedeutende Rolle bei seiner Erklärung sozialer Unterschiede ein:

„Es ist meine Überzeugung, daß die großen Kontinente bereits von einer verbreiteten, wenn auch spärlichen Bevölkerung besiedelt gewesen waren, als der Mensch noch nicht weiter fortgeschritten war als der niedrigste Wilde heutzutage. Und auch wenn ich weit davon entfernt bin, zu glauben, daß die verschiedenen Grade der Zivilisation, die heute auftreten, restlos durch die Umstände erklärt werden, die gegenwärtig bestehen, scheinen mir die Umstände doch viel Licht auf die sehr unterschiedlichen Maße an Fortschritt zu werfen, die von verschiedenen Rassen erreicht werden". ${ }^{112}$

Aus der Zurückweisung der Annahme Argylls, die gegenwärtigen Wilden seien durch Vertreibung in unwirtliche Regionen degeneriert, entstand bei Lubbock, der den möglichen Einfluß der Umweltbedingungen nun stärker berücksichtigte als noch bei seinen Darstellungen des kulturellen Lebens im bronze- und steinzeitlichen Nordeuropa, eine evolutionäre Rassentheorie, bei der kulturelle und intellektuelle Adaption an die Umwelt über das Maß des sozialen Fortschritts bestimmten.

S. 44). Nun behauptete Lubbock allerdings nicht, daß eine evolutionäre Entwicklung von den Ameisen zum Menschen geführt habe, schließlich wies er gleich auf der ersten Seite seines Buches Ants, Bees, and Wasps darauf hin, daß die Menschenaffen dem Menschen in anatomischer Hinsicht am nächsten stünden, allerdings nähmen, was die Intelligenz beträfe, diesen Rang die Ameisen ein (vgl. Lubbock (1882) Ants, Bees, and Wasps. London: Kegan Paul, S. 1, vgl. auch J. Arthur Thomson (1924) „Zoology (Animal Behaviour)“. In: Grant Duff 1924, S. 115-156; George J. Romanes (1882) „Ants, Bees, and Wasps“. In: Nature 26, S. 121-123). Lubbock griff auf Beispiele vermeintlich primitiver Kulturen zurück, um Ähnlichkeiten und Parallelen zwischen der sozialen Organisation der Ameisen und der Menschen herauszustellen.

112 Lubbock 1870b, S. 345: „It is my belief that the great continents were already occupied by a widespread, though sparse population, when man was no more advanced than the lowest savages of to-day; and although I am far from believing that the various degrees of civilization which now occur can be altogether accounted for by the external circumstances as they at present exist, still these circumstances seem to me to throw much light on the very different amount of progress which has been attained by different races". 
Argyll hatte von einer bereits marginalisierten Position aus in den wissenschaftlichen Diskurs eingegriffen. Dies lag allerdings nicht allein an seinem Monogenismus. Wie im vorigen Kapitel der betont wissenschaftliche Charakter der Auseinandersetzung der Evolutionisten mit den polygenistischen Anthropologen über die Neandertaler-Frage gezeigt hat, war der theoretische Standpunkt allein noch kein hinlänglicher Grund, die Wissenschaftlichkeit eines Arguments in Frage zu stellen. Doch im Zuge der Professionalisierung der Wissenschaften war das modernisierende Element der Evolutionstheorien mitentscheidend für die Rezeption durch die scientific community geworden. Die Anerkennung, die Lubbock als etabliertem Wissenschaftler, nicht nur in Dundee und in Exeter, gezollt wurde, blieb Argyll deshalb versagt.

Dieser Umstand verdeutlicht, daß, auch wenn die vom X-Club forcierte Professionalisierung der viktorianischen Wissenschaften Ende der sechziger Jahre des neunzehnten Jahrhunderts in institutioneller Hinsicht erst langsam Wirkung zeigte, der Duktus der wissenschaftlichen Debatten bereits von der Ausgrenzung der Amateurwissenschaftler bestimmt war. Die Modernisierung der Rassentheorie verband sich deshalb an dieser Stelle mit der Modernisierung der Wissenschaften.

Lubbock vertraute dazu auf seine Reputation als erfahrener Archäologie und Prähistoriker. Mit dem Gewicht einer wissenschaftlichen Autorität griff er die Degenerationstheorie an und entzog so dem Monogenismus eine wichtige theoretische Stütze. Lubbock setzte der Degenerationshypothese eine strikt progressivistische Lesart der sozialen Entwicklung entgegen. Für die Durchsetzung einer evolutionären Anthropologie war die dabei eingeleitete Eliminierung der Degenerationstheorie von zentraler Bedeutung, vergleichbar der des Polygenismus. Mit dem führte der X-Club in den sechziger Jahren eine zähe Auseinandersetzung, die verschiedene Problemfelder der Anthropologie berührte und in der der evolutionstheoretische Orientierungskomplex auf theoretischer, wissenschaftspolitischer wie politischer Ebene durchgesetzt wurde.

\subsection{Institutionalisierung. Evolutionstheorie und Polygenismus}

In den sechziger Jahren des neunzehnten Jahrhunderts waren Anthropologie und Ethnologie noch nicht als Forschungsfelder an den Universitäten etabliert. Der institutionelle Rahmen, in dem diese Wissenschaften sich organisierten, war auf Gelehrtengesellschaften und die von ihnen herausgegebenen Journale begrenzt. 
Als im Januar 1863 die Anthropological Society of London gegründet wurde, war dies deshalb ein einschneidender Vorgang. Zumal sich unter der Federführung des Mediziners James Hunt ihre elf Gründungsmitglieder von der Ethnological Society abgespalten hatten. 1865 gaben sie rückblickend drei Gründe für diesen Schritt an - einen organisatorischen, einen wissenschaftlichen und einen politischen: Es habe der Bedarf nach einem neuen Publikationsorgan bestanden, der physisch-anthropologische Aspekt sei in der Ethnological Society unterrepräsentiert gewesen und man habe ,verschiedene aufregende Fragen, die gegenwärtige Ereignisse auf die Tagesordnung gesetzt haben“, diskutieren wollen. Letzteres war zweifellos eine Anspielung auf die Frage der Sklaverei, die 1861 mit dem amerikanischen Sezessionskrieg wieder auf die ,Tagesordnung ' geschrieben worden war. ${ }^{113}$

Zwar hat sich die Anthropologiegeschichte ausführlich mit der Gründung und der Geschichte der Anthropological Society befaßt und dabei einhellig festgestellt, daß sich die profiliertesten Vertreter der Evolutionstheorie, also die Prominenz aus dem X-Club, in der alten Ethnological Society organisierten. Doch ihre Beweggründe, sich überhaupt in diesem Konflikt zu positionieren, bleiben, im Unterschied zu denen der Gründer der Anthropological Society, unklar. ${ }^{114}$ Unklar ist weiterhin, warum und wie für die aktiven Wissenschaftler des X-Club-Netzwerkes die Einflußnahme auf die Organisationen des Themenkreises Anthropologie wichtig wurde und warum sie sich dann der Ethnological Society anschlossen, oder, wie Arthur Keith es formuliert, sie der Anthropologie als solcher ,zur Hilfe eilten“. ${ }^{115}$ Diese Hilfestellung führte 1871 zur Vereinigung von Anthropological und Ethnological Society und zur Gründung des noch heute aktiven Anthropological Institute.

113 Luke Burke (1865) In: Ethnological Journal, S. 4-5: „,various exciting questions which current events were bringing into prominence"; vgl. Stocking 1971, S. 376.

114 Manch ein Historiker hat gar mit Überraschung registriert, daß kaum ein namhafter Vertreter der Evolutionstheorie Mitglied der Anthropological Society war, da deren erklärte Forschungsagenda mit ihren Ansätzen kompatibler gewesen sei, als die der alten Ethnological Society, etwa Burrow 1963, S. 153; vgl. Ronald Rainger (1978) „Race, Politics, and Science: The Anthropological Society of London in the 1860s“. In: Victorian Studies 22, S. 51-70, S. 65.

115 Arthur Keith (1934) „,65. Centenary of the Birth of Lord Avebury“. In: Man 34, S. 49-51, S. 50: „Lord Avebury came to rescue of anthropology in England“. 


\subsection{1 "Nest of Impostors". Die Anthropological Society}

Bereits der Vorläufer der Anthropological Society, die Ethnological Society wurde Ende 1843 als eine Abspaltung ins Leben gerufen. Sie trat gewissermaßen als wissenschaftlicher Flügel aus der Aboriginal Protection Society hervor, die 1837 aus den erfolgreichen Kampagnen zur Abschaffung der Sklaverei in den Kronkolonien heraus gegründet worden war. ${ }^{116}$ Obwohl die Agenda der Aboriginal Protection Society auch ein wissenschaftliches Interesse an den sogenannten Eingeborenen einschloß, gab ihre generell philanthropische Ausrichtung Anlaß zu Friktionen. Die Grundsatzerklärung der Ethnological Society betonte deshalb ihre wissenschaftliche Ausrichtung, ihr ,einziges Ziel sollte die Beförderung und Verbreitung des wichtigsten und interessantesten Zweiges des Wissens sein, das des Menschen, - Ethnologie“. ${ }^{117}$ Die Verlagerung des Schwerpunktes auf eine wissenschaftliche Orientierung bedeutete allerdings nicht, daß die philosophisch-anthropologische Grundlage aufgegeben wurde, auf der Abolitionismus und Philanthropismus der Aboriginal Protection Society fußten. Im Gegenteil war das alte Motto der Emanzipationsbewegung, ab uno sanguine, von einem Blut, auch das ethische Fundament der Ethnological Society. Damit hatte sich diese Neugründung zugleich einer monogenistischen Perspektive verpflichtet. Ihr erklärtes Ziel war die Identifizierung der Ursachen, die zu den ,unterschiedlichen physischen wie moralischen Charakteristiken der Varietäten der Menschheit" geführt hätten. ${ }^{118}$

Ihre wissenschaftliche Prägung erhielt die Ethnological Society in erster Linie durch eines ihrer berühmtesten Mitglieder, ihren langjährigen Präsidenten, James Cowles Prichard. ${ }^{119}$ Prichard verfolgte einen

116 Vgl. Stocking 1971, S. 371.

117 Richard King (1844) „Address to the Ethnological Society of London“. In: Journal of the Ethnological Society 2, S. 9-40, S. 15-16: „whose sole object should be the promotion and diffusion of the most important and interesting branch of knowledge, that of man, - Ethnology".

118 Ethnological Society of London (1850) Regulations. London: Ethnological Society, S. 5 (zitiert nach Stocking 1971, S. 372): ,the distinguished characteristics, physical and moral, of the varieties of Mankind“.

119 James Cowles Prichard (1786-1848) studierte in London und Edinburgh Medizin und praktizierte in Bristol. Vgl. Hannah Franziska Augstein (1999) James Cowles Prichard's Anthropology: Remaking the Science of Man in Early Nineteenth-Century Britain. Amsterdam etc.: Rodopi; Stocking (1973) „From Chronology to Ethnology. James Cowles Prichard and British Anthropology 1800-1850“. In: James Cowles Prichard: Researches into the Physical History of Man. Chicago: University of Chicago Press, S. ix-cx, S. xlviii. 
christlichen Monogenismus und ging davon aus, daß die Menschheit entsprechend der biblischen Erzählung einen gemeinen Ursprung habe. ${ }^{120}$ Trotzdem lehnte er die althergebrachte Akklimatisierungsthese ab. Für ihn waren Unterschiede der Hautfarbe nicht dem Einfluß der Umwelt, sondern dem Grad der Zivilisation geschuldet. Mit zunehmender Zivilisation würde die Hauttönung heller. Deshalb behauptete er, daß „der ursprüngliche Stamm von Menschen [...] Neger“ gewesen wären. ${ }^{121}$

Im Unterschied zu anderen christlich-traditionellen Monogenisten berief sich Prichard aber nicht allein auf die religiöse Überlieferung. Er war wegen des wachsenden Legitimationsdrucks, dem sich die monogenistischen Ansätze ausgesetzt sahen, besonders an einer wissenschaftlich abgesicherten Beweisführung interessiert. Seine Theorie umfaßte deshalb sowohl eine physische Rassenkunde als auch kulturelle, vor allem linguistische Studien.

Aus der strukturellen Verwandtschaft jener Sprachen, die von Schlegel und anderen Linguisten als indo-europäische Sprachen zusammengefaßt wurden, schloß Prichard, „daß die Nationen selbst von einem ursprünglichen Volk abstammten, und folglich, daß die Unterschiedlichkeit der Hautfarbe und anderer physischer Eigenschaften [...] die Effekte der Variation eines ursprünglich gemeinsamen Typs sind“. ${ }^{122}$ Prichard hatte anfangs eine physische Anthropologie entworfen, die drei Schädelformen identifizierte, prognathische, pyramidische und ovale Schädel. Die Schädelformen ordnete er allerdings keinen Rassen zu, sondern betrachtete sie als Anzeichen unterschiedlicher Zivilisationsgrade. ${ }^{123}$ Er sah sich jedoch in den verschiedenen Auflagen seines Hauptwerkes Researches into the Physical History of Mankind zwischen 1808 und 1847 immer wieder veranlaßt, das taxonomisch relevante Hauptkriterium zur Unterscheidung der Rassen zu wechseln, von der Hautfarbe über Körperproportionen oder Krankheitsmuster bis hin zur Psychologie. ${ }^{124}$

120 Vgl. Stocking 1987, S. 49.

121 James Cowles Prichard (1813) Researches into the Physical History of Man. London: Arch, S. 233: ,the primitive stock of men were Negroes“.

122 James Cowles Prichard (1848) „On the Relations of Ethnology to Other Branches of Knowledge“. In: Journal of the Ethnological Society of London 1, S. 301-329, S. 321: ,that the nations themselves descended from one original people, and, consequently, that the varieties of complexion, and other physical characters [...] are the effects of variation from an originally common type".

123 Vgl. Banton 1998, S. 40.

124 Vgl. Augstein 1999, S. 71-73. 
Vor diesem Hintergrund ist sein Interesse an einem sprachwissenschaftlichen Fundament für seine Rassentheorie als Reaktion auf die Defizite der anatomischen Beweisführungen zu verstehen. Hier wird die Krisenhaftigkeit der Anthropologie deutlich. Prichard vollzog jene Suchbewegungen, die bereits die Rassentheoretiker des frühen neunzehnten Jahrhunderts zu einer Vielzahl von sich teilweise widersprechenden Methoden geführt hatten. Dadurch war eine epistemisch unklare Situation entstanden, in der sich die physischen Anthropologen von ihrem Ziel, eine vereinheitlichte Rassentheorie zu errichten, immer weiter entfernten.

Die linguistische Tradition war aufgrund des Einflusses Prichards zwar von großem Gewicht für die Ethnological Society, doch in ihr existierten auch gegenläufige Strömungen. Am prominentesten vertrat ein weiterer langjähriger Vorsitzender, John Crawfurd, einen explizit antilinguistischen und polygenistischen Ansatz. ${ }^{125}$ Seine Ablehnung der monogenistischen These der Einheit der Menschheit veranlaßte ihn jedoch nicht, zugleich die mit den Polygenismus oft korrelierende politische Perspektive einzunehmen. Er blieb dem philanthropischen Erbe der Gesellschaft treu und lehnte die Sklaverei der Südstaaten ab. Insbesondere verwarf er die Vorstellung, Rassen könnten nur in den ihnen angestammten Umweltbedingungen leben. ${ }^{126}$ In der Ethnological Society konnten folglich verschiedene, äußerst konträre theoretische Orientierungen nebeneinander bestehen. Hingegen einte ihre Mitglieder lagen Zeit der Philanthropismus, der das wesentliche Element des Selbstverständnisses der Ethnological Society war.

Die Ethnological Society gab zwischen 1843 und 1871 das Journal of the Ethnological Society und die Transactions of the Ethnological Society heraus. Vorrübergehend gelang es ihr, bei den Jahreskonferenzen der British Association ab 1846 eine eigene ethnologische Subsektion innerhalb der Sektion D für Zoologie und Botanik einzurichten. ${ }^{127}$ Eine solche Themensektion einrichten zu können, bedeutete für eine wissenschaftliche Disziplin den Ritterschlag durch die scientific com-

125 John Crawfurd (1783-1868) war Arzt und Diplomat und arbeitete zwischen 1803 und 1830 in Indien. Nach seiner Rückkehr nach England profilierte er sich als Orientalist und Linguist. Vgl. John Crawfurd (1861a) „On the Aryan or Indo-Germanic Theory“. In: Transactions of the Ethnological Society of London 1, S. 268-286; John Crawfurd (1865) „On Language as a Test of the Races of Man“. In: Transactions of the Ethnological Society of London 3, S. 1-9.

126 Vgl. John Crawfurd (1861b) „On the Classification of the Races of Man“. In: Transactions of the Ethnological Society of London 1, S. 354378, S. 360.

127 Vgl. Stocking 1987, S. 245. 
munity. Doch diese Ehrung war nicht von Dauer. Ab 1850 wurde die Sektion E für einige Jahre unter dem Titel „Geographie und Ethnologie“ geführt. Der Umstand, daß sie ab Mitte der fünfziger Jahre wieder allein den Geographen zugedacht wurde, macht nicht nur deutlich, daß die Ethnological Society in diesen Jahren mitgliederschwach und arm an Einfluß war. Er zeigt auch, daß Ethnologie noch nicht allgemein als Wissenschaft anerkannt wurde.

Dies lag auch am politischen Charakter der Ethnological Society. Ihr politisches Bekenntnis wog stärker als die von ihren Mitgliedern verfolgten unterschiedlichen Theorietraditionen. Dadurch wurde auch die Ethnologie als solche in ihrer Anerkennung als Wissenschaft beeinträchtigt. Die Verbindung ethnologischer Forschung mit philanthropischer Politik unterminierte aber nicht nur die Anerkennung der Ethnologie innerhalb der scientific community. An ihr entzündeten sich interne Konflikte, denn sie wurde von Kritikern für den enormen Mitgliederschwund verantwortlich gemacht, den die Gesellschaft in den fünfziger Jahren hinnehmen mußte. ${ }^{128}$

\section{Die Gründung der Anthropological Society}

Mit schwindenden Mitgliederzahlen der Ethnological Society wurde der Einfluß einer Fraktion immer spürbarer, die durch einige in der Mitte der fünfziger Jahre beigetretene Mitglieder gebildet wurde, und die sich durch eine eher physisch-anthropologische Orientierung auszeichnete. $\mathrm{Zu}$ dieser Gruppierung zählten Joseph Barnard Davis, Joseph Thurnam und John Beddoe. Der agilste Vertreter dieser Richtung war aber James Hunt, der 1856 zum Sekretär der Gesellschaft ernannt wurde. ${ }^{129}$ Auf der einen Seite war dieser Kreis für die Wiederbelebung der Ethnological Society gegen Ende der fünfziger Jahre maßgeblich. Er führte neue wissenschaftliche Ansätze ein, wie beispielsweise die Kraniometrie Thurnams, die archäologischen Studien Davis oder die Rassenlehre des schottischen Chirurgen Robert Knox, der vor allem James Hunt anhing. Knox, der wegen eines Skandals um Leichen, die er für seine anatomischen Studien beschaffen ließ, seine Heimat Edinburgh in jungen Jahren hatte verlassen müssen und später als Arzt in London lebte, war vielleicht auch wegen des Bannstrahls des Establishments für die polygenistischen Abweichler innerhalb der Ethnological Society attraktiv. ${ }^{130}$

128 Vgl. Stocking 1971, S. 373-374.

129 Vgl. Stocking 1987, S. 246-247.

130 Vgl. Isobel Rae (1964) Knox: The Anatomist. Edinburgh, London: Oliver and Boyd; Michael D. Biddiss (1976) „The Politics of Anatomy: Dr. Robert Knox and Victorian Racism“. In: Proceedings of the Royal So- 
Aus diesem Kreis wurde die Kritik an der philanthropischen und linguistischen Tradition der Ethnological Society immer lauter. Zudem lehnten die Dissidenten um den rührigen James Hunt den bei der Ethnological Society gepflegten Duktus der Philanthropie ab. Als es 1863 zur Spaltung der Gesellschaft und zur Gründung der Anthropological Society kam, war diese Abspaltung auch Ausdruck einer Eskalation ihrer Krisenhaftigkeit, weil durch die Evolutionstheorie jenes naturwissenschaftliche Referenzsystem ins Schwanken geraten war, auf das sich Monogenisten wie Polygenisten beriefen. Durch die sich ab 1860 abzeichnende, evolutionstheoretische Revolution in den Naturwissenschaften wurden die Zentrifugalkräfte, die letztlich zur Spaltung in Ethnological Society und Anthropological Society führten, noch verstärkt.

Der krisenhafte Verlust der Grundlagen etablierter Denkmuster wurde durch die Akzentuierung theoretischer Unabhängigkeit kompensiert, die sich in der Aufspaltung in zwei Gesellschaften ausdrückte. Diese war für die Ethnological Society durchaus existenzbedrohend. Die Anthropological Society war für viele auch deshalb die attraktivere Gesellschaft, weil sie es verstand, der gutmütigen, wenn auch nicht minder chauvinistischen Agenda der Ethnological Society ein anti-philanthropisches und mit den Jahren auch immer verruchteres Programm entgegenzusetzen. Stocking beschreibt, daß die Anthropological Society sich mit einer Aura des Skandals umgab, indem etwa der Vorsitz ihres Cannibal Club mit einem Hammer in Form eines vermeintlichen Negerschädels zur Ruhe rief oder das Skelett eines angeblichen Wilden ins Fenster seiner Räume gehängt wurde. ${ }^{131}$

Die Orientierung Hunts an Robert Knox ist der deutlichste Ausdruck des theoretischen Bruchs mit der monogenistischen Tradition der Ethnological Society, denn Knox war zu jener Zeit der führende Theoretiker des Polygenismus in England. Er hatte 1850 The Races of Man veröffentlicht, und darin vor allem Prichards linguistischen Ansatz kritisiert. ${ }^{132}$ Menschenrassen stellten für Knox stabile Einheiten dar, die sich in körperlicher wie in psychischer Hinsicht deutlich voneinander unterschieden. Die unveränderbaren Rasseneigenschaften waren dabei bestimmend, wie er schrieb: „Rasse ist alles: Literatur, Wissenschaft, Kunst - mit einem Wort, die Zivilisation hängt von ihr ab“. ${ }^{133}$ Die sozia-

ciety, Medicine 69, S. 245-250; Philip F. Rehbock (1983) The Philosophical Naturalists. Themes in Early Nineteenth-Century British Biology. London: University of Wisconsin Press, S. 31-55.

131 Vgl. Stocking 1971, S. 380.

132 Knox 1850, S. 9: „,his Zoological history“.

133 Knox 1850, S. 7: „Race is everything: literature, science art - in a word, civilization depends on it“". 
len Unterschiede zwischen verschiedenen Gesellschaften wären deshalb durch die jeweiligen Rasseneigenschaften bedingt. Rassen basierten auf Reinheit und Trennung, Rassenmischungen wären immer pathologisch, weshalb Knox im Sinne der etablierten Unterscheidung von Rasse und Art erklärte, daß die Rassen der Menschen letztlich verschiedene Arten des Menschen darstellten. ${ }^{134}$

Konkreter Anlaß des Bruchs zwischen der Gruppe um Hunt und der Mehrheit der Ethnological Society war eine Meinungsverschiedenheit über Illustrationen eines Artikels für das Journal der Ethnological Society, die auf die unterschiedlichen Positionen in der Rassentheorie zurückzuführen ist. Es handelte sich um Darstellungen der Bewohner Sierra Leones, ehemaliger Sklaven, die deshalb von besonderem Interesse für den britischen Philanthropismus waren. Hunt legte sein Amt als Sekretär der Ethnological Society nieder, weil die von ihm favorisierten Abbildungen nicht mit dem wohlwollenden Blick der Philanthropen vereinbar waren. Die letztlich veröffentlichten Illustrationen seien im Vergleich zu jenen in den Schriften der Polygenisten verhältnismäßig romantisierend ausgefallen, so Stocking. ${ }^{135}$

Die eingangs angeführte Begründung der Anthropologen, ein Forum für die Diskussion tagesaktueller Fragen schaffen zu wollen, weist auf Motive hin, die außerhalb der wissenschaftspolitischen Dynamik der Ethnological Society zu suchen sind. Offenbar waren politische Beweggründe mit ausschlaggebend für die Gründung dieser wissenschaftlichen Gesellschaft. In erster Linie handelte es sich um die Frage der Sklaverei. Die Sklaverei war zwar in den Kronkolonien schon 1834 beendet worden, ${ }^{136}$ doch mit dem Ausbruch des Sezessionskrieges 1861 in Nordamerika wurde die Problematik der Sklaverei und der Emanzipation der ehemaligen Sklaven in Amerika auch in Großbritannien wieder aktuell. ${ }^{137}$ Während die Ethnological Society traditionsbedingt für das Ende der Sklaverei in den Südstaaten eintrat, bezog die Anthropological Society nach ihrer Gründung einen die Sklaverei befürwortenden Standpunkt.

Auf deren Rechtfertigung lief auch Hunts Aufsatz „On the Negro's Place in Nature" hinaus, der 1863 in der ersten Ausgabe der von der Anthropological Society herausgegebenen Memoirs erschien. Zwar distanzierte er sich darin von Grausamkeiten und überseeischem Sklaven-

134 Vgl. Biddiss 1976, S. 248.

135 Vgl. Stocking 1971, S. 376

136 Vgl. Robin Blackburn (2000) The Overthrow of Colonial Slavery, 17761848. London, New York: Verso, S. 419-497.

137 Vgl. Llewellyn Woodward (1962) The Age of Reform, 1815-1870. Oxford: Clarendon Press, S. 307-310. 
handel, erklärte aber, daß allein durch ihre Versklavung die ,Neger` zivilisiert werden könnten, ein Effekt, der in Nordamerika bereits deutlich zutage getreten sei, da die Sklaven dort zivilisierter als die freien Afrikaner seien: ${ }^{138}$ „Nirgends scheint der Neger-Charakter so hell wie in seiner kindlichen und liebevollen Anhänglichkeit an seinen Herrn und dessen Familie“. 139

Damit stellte Hunt eine Behauptung auf, die er präzise gegen eines der Hauptargumente des abolitionistischen Diskurses innerhalb der Ethnological Society konstruierte und das am Kern des Disputs über die Darstellungen der Bewohner Sierra Leones ansetzte. Während die Philanthropen ihr Verbesserungsprogramm nur unter Bedingungen individueller Freiheit für realisierbar hielten, behaupteten Hunt und andere Befürworter der Sklaverei, daß die ,Neger" nicht durch Bildung, sondern nur durch Anleitung und Disziplin zivilisiert werden könnten. ${ }^{140}$

Hunt entwickelte seine polygenistische Kritik an der Annahme eines gemeinsamen Ursprungs aller Menschen deutlich bevor sich die Anthropological Society von der Ethnological Society abspaltete. Sein Entwurf einer „Ethno-Klimatologie“ von 1862 basierte auf der - gegen die Akklimatisierungsthese gerichteten - Überzeugung, daß Menschenrassen in spezifischen Klimata entstanden seien und unter anderen klimatischen Umständen nicht leben könnten:

„In jedem Klima finden wir den Menschen in Harmonie mit dem Klima an, und wenn er nicht in Harmonie lebt, wird er aufhören zu existieren. [...] Jede Menschenrasse [...] hat bestimmte vorgeschriebene, heilsame Grenzen, aus denen sie nicht straflos entfernt werden kann“. ${ }^{141}$

Hunt führte weiter aus, daß, auch wenn zivilisatorische Errungenschaften es den Europäern ermöglichten, extreme Klimabedingungen zu ertragen, damit noch keine dauerhafte Anpassung erreicht wäre. Europäer in den Kolonien würden krank, unfruchtbar und degenerierten nach we-

138 Vgl. James Hunt (1863) „On the Negro's Place in Nature“. In: Memoirs Read Before the Anthropological Society of London 1, S. 1-60, S. 54-55.

139 Hunt 1863, S. 55: „Nowhere does the Negro character shine so brightly as it does in his childish and fond attachment for his master and his family“.

140 Vgl. Rainger 1978, S. 54-55.

141 James Hunt (1862) „On Ethno-Climatology; or, the Acclimatization of Man”. In: Report of the 31st Meeting of the BAAS, Manchester 1861. London, S. 129-150, S. 131: ,In every climate we find man organized in harmony with the climate; and if he is not in harmony, he will cease to exist [...] Every race of man [...] has certain prescribed geographical salubrious limits from which it cannot with impunity be displaced". 
nigen Generationen. ${ }^{142}$ Nur durch Rassenmischungen könnten sie unter solchen Bedingungen überleben, doch die hätte ihrerseits unausweichlich eine mischungsbedingte Degeneration zur Folge. ${ }^{143}$

Seine Annahme, die Menschen seien auf ihre angestammten Umweltbedingungen fixiert, ließ Hunt jene Ansätze verwerfen, die einen gemeinsamen Ursprung der Menschheit annahmen. Im Gegensatz zu den monogenistischen und linguistischen Vermutungen über die Verbreitung des Menschen durch Wanderungsbewegungen und Akklimatisierungen behauptete er, daß die „Negerrasse ohne Fortschrittsgeschichte und die Neger seit Tausenden von Jahren jene unzivilisierte Rasse waren, die sie gegenwärtig sind“ “. ${ }^{144}$ Rassen waren für Hunt stabile und unveränderbare Resultate der Entstehung in einer bestimmten Umwelt.

Die Anthropological Society entwickelte ihre polygenistische Agenda auf mehrfache Weise. Zum einen durch die Rezeption polygenistischer Klassiker in ihren Journalen. Bereits in der ersten Ausgabe ihres Anthropological Reviews druckte sie mehrere Aufsätze von Robert Knox ab. Knox, der 1862 gestorben war, hatte den Polygenismus schnörkellos auf den Punkt gebracht:

„Weder Klima noch Politik noch externe Umstände verändern jemals eine Rasse. Sie können und werden sie zwar beeinträchtigen und mit der Zeit vernichten, aber sie schaffen niemals eine neue Rasse“. ${ }^{145}$

Darüber hinaus versuchte die Anthropological Society, eine polygenistische Interpretation in bestimmten Fachdiskursen wie dem über die Deutung fossiler Menschenknochen zu verankern. So organisierte sie 1864 eine Tagung zur Neandertaler-Debatte, in der vor allem Joseph Barnard Davis und Charles Carter Blake ihre bereits in den Jahren zuvor entwickelten Theorien über den Neandertaler vortrugen. ${ }^{146}$ Außerdem vertra-

142 Vgl. Hunt 1862, S. 136-147.

143 Vgl. Hunt 1862, S. 144-145.

144 Hunt 1863, S. 30: ,that the Negro race has been without a progressive history; and that Negroes have been for thousands of years the uncivilized race they are at this moment".

145 Robert Knox (1863) „Ethnological Inquiries and Observations“. In: Anthropological Review 1, S. 246-270, S. 253: „Nor climate, nor government, nor external circumstances, ever alter race. They may, and they do affect them, and in time destroy them; but they never give rise to a new race".

146 Vgl. Charles Carter Blake (1864a) „On the alleged Peculiar Characters, and Assumed Antiquity of the Human Cranium from the Neanderthal". In: Journal of the Anthropological Society 2, S. cxxxix-clvii; Millar 1974, S. 65. 
ten Mitglieder der Anthropological Society einen dezidiert polygenistischen Standpunkt in der Kontroverse über die genealogische Verbindung des Menschen zu den Primaten.

Neben kritischen Rezensionen von Huxleys Man's Place in Nature war es vor allem Charles Carter Blake, der für Owen Partei ergriff, gleichwohl der ein erklärter Gegner des Polygenismus war. ${ }^{147}$ Blake war ein Schüler Owens und trat, wie Rupke schreibt, jene wissenschaftliche Verteidigung der Thesen Owens an, die der selbst weitgehend schuldig geblieben wäre. ${ }^{148}$ Neben anatomischen Unterschieden der Gehirne berief sich Blake auf Unterschiede des Aufbaus von Muskulatur und Sehnen im Fuß des Menschen und des Gorillas und versuchte zu zeigen, daß der Fuß des Gorillas im Unterschied zum menschlichen Fuß die Fähigkeit zu greifen besäße. ${ }^{149}$ Zugleich wies er die Annahme Huxleys zurück, daß der menschliche Fuß, besonders bei den vermeintlich unzivilisierten Menschen, eine rudimentäre Greifapparatur darstelle. ${ }^{150} \mathrm{Im}$ Bestreben, mögliche Anhaltspunkte der Evolutionstheoretiker zu unterminieren, gab Blake einen Klassiker des rassistischen Diskurses auf, der bis ins neunzehnte Jahrhundert zur physischen Differenzmarkierung zwischen Weißen und Schwarzen konstruiert wurde, denn eine Greifbefähigung des Fußes wurde lange Zeit exklusiv den Schwarzen zugeschrieben.

\section{Die Intervention des X-Clubs}

Die Abspaltung der Anthropological Society bewog die Mitglieder des späteren X-Clubs nicht umgehend zu einer Reaktion. Huxley und Dar-

147 Vgl. Anon. (1863) „On the Relation of Man to the Lower Animals“. In: Anthropological Review 1, S. 107-117; [alias Anthropos] (1863b) „Man and Beast". In: Anthropological Review 1, S. 153-162 Charles Carter Blake (1863b) [alias Anthropos, vgl. Bloxam 1893, S. 37] „Man and Beast“. In: Anthropological Review 1, S. 153-162. Owen beteiligte sich nur am Rande am anthropologischen Diskurs, dabei machte er unzweifelhaft deutlich, daß er verschiedenen Annahmen des Rassendiskurses gegenüber skeptisch war. So schrieb er einerseits, daß er sich mit wachsenden Schwierigkeiten konfrontiert sah, wollte er, ausgehend vom Schädel, eine Bestimmung der Rasse versuchen (vgl. Richard Owen (1860c) „Report on a Series of Skulls of various Tribes of Mankind inhabiting Nepal, collected, and presented to the British Museum, by Bryan H. Hodgson, esq., late resident in Nepal, \&c. \&c.“. In: Report of the 29th Meeting of the British Association for the Advancement of Science, S. 95-103, S. $102)$.

148 Vgl. Rupke 1994, S. 289-290.

149 Vgl. Charles Carter Blake (1863a) „Professor Huxley on Man's Place in Nature“. In: Edinburgh Review 117, S. 541-569.

150 Vgl. Kap. 3.1.2. 
win nahmen noch im Februar 1863 dankbar die Ehrenmitgliedschaft der frisch gegründeten Anthropological Society entgegen, die bestrebt war, einflußreiche Naturwissenschaftler für sich zu gewinnen. ${ }^{151}$ Erst durch Lubbocks Beitritt zur Ethnological Society begann der X-Club, institutionell in die Anthropologie involviert zu werden. Lubbock hatte persönliche Beziehungen zu Mitgliedern der Ethnological Society, zu den Archäologen Pitt Rivers und John Evans und zum X-Club-Mitglied William Spottiswoode, der schon vor dem Schisma der Ethnological Society angehört hatte und seit Juni 1862 in ihrem Leitungsgremium saß. Lubbock trat ihr im Januar 1863 bei, also zeitgleich mit der Gründung der Anthropological Society. ${ }^{152}$

Er stand als umtriebiger Archäologe und profilierter Evolutionist für den wissenschaftlichen und wissenschaftspolitischen Aufbruch, den die profillose und durch den Austritt der ehemaligen Mitglieder um Hunt geschwächte Ethnological Society nötig hatte. Ihm wurde deshalb bereits wenige Monate später die Präsidentschaft angetragen, obwohl er viel Zeit bei Ausgrabungen in Frankreich verbrachte und wenig Anwesenheit garantieren konnte. ${ }^{153}$ Nun kündigte auch Huxley seine Bereitschaft an, in der Gesellschaft mitzuwirken:

„Mein lieber Lubbock, ich bin hoch erfreut, von Busk zu erfahren, daß Sie der neue Präsident der Ethnological Society werden. Unter diesen Umstände werde ich natürlich Mitglied und mein Bestes tun, um Sie zu unterstützen [...]. Lassen Sie Rolleston und [...] alle guten Männer von Ihrem Vorhaben wissen. Busks Hinweis kam gerade zur rechten Zeit, denn eine halbe Stunde zuvor hatte ich mein Ehrendiplom an dieses Nest von Hochstaplern, die Anthropological Society, zurückgesandt, mit einer kleinen Erklärung, daß ich nichts mit ihnen zu tun haben möchte. Die gerade veröffentliche Ausgabe ihres Journals enthält einen Artikel über ,Man and Beast' mit einem ehrrührigen Angriff auf Rolleston (nicht zu erwähnen ein Haufen Lügen über mich, was ich gewohnt bin), und ich ergriff glücklich die Gelegenheit, die Verbindung, die sie mir aufnötigten, zu kappen“. ${ }^{154}$

151 Vgl. RAI, A 3:1 - Anthropological Society of London, Council Minutes, f. 6 und 8-9, Council Meetings vom 18. und 24. Februar 1863.

152 Vgl. RAI. A1: Council Minutes Book, Ethnological Society of London, f. 290 (Spottiswoode); f. 295 (Lubbock).

153 Vgl. Hutchinson 1914, Bd. 1. S. 56.

154 Huxley an Lubbock, 2. Mai 1863. In: AP, ADD 49640, f. 53-54: „My dear Lubbock. I am very pleased to hear from Busk that you are to be the new President of the Ethnological Society. Of course, under that circumstance, I shall become a member and do my best to help you through [...]. Let Rolleston and [...] all the good men true know of your intention. Busk's information came in the nick of time, as half an hour before, I had sent back my Honorary Diploma to that nest of impostors the 
Aus diesem Vorgang wird zweierlei ersichtlich. Zum einen, daß die Vorbehalte Huxleys gegenüber der Anthropological Society ihn nicht davon abgehalten hatten, ihre Ehrung anzunehmen, obwohl er bereits Konflikte mit ihren Hauptakteuren ausgetragen hatte. Zum anderen, daß die Anthropological Society keineswegs von Beginn an anti-darwinianisch agierte, sondern vielmehr versuchte, über die Mitgliedschaft Darwins und Huxleys das von ihnen verkörperte wissenschaftlich-dynamische Element zu integrieren. Der Artikel, in dem Huxley und Rolleston angegriffen wurden, war zwar für Huxley Anlaß zum Bruch mit der Anthropological Society, doch eine Perspektive, ihr effektiv entgegentreten zu können, ergab sich erst durch Lubbocks Präsidentschaft bei der Ethnological Society. Ganz offensichtlich hatte Huxley bis zu diesem Zeitpunkt ein Engagement dort nicht erwogen.

Als im Mai dann er und Busk der Ethnological Society beitraten, wurden sie unmittelbar in den Vorstand berufen - auf der gleichen Sitzung übrigens, auf der Lubbock offiziell zum Präsidenten ernannt, der bisherige Amtsinhaber Crawfurd Vizepräsident und Hunts Austritt aus der Gesellschaft bekanntgegeben wurde. ${ }^{155}$ Spottiswoode saß weiterhin mit ihnen im Vorstand und Francis Galton, der damals noch wenig bekannte Cousin Darwins, hatte das Amt des Sekretärs von Hunt übernommen. ${ }^{156}$ Ein halbes Jahr später löste Busk Crawfurd als Vizepräsidenten ab. ${ }^{157}$ Dies war nun wahrlich eine Palastrevolte. In nur wenigen Monaten hatten die Evolutionstheoretiker die wissenschaftspolitische Führung der durch den Austritt der Fraktion um Hunt destabilisierten Ethnological Society übernommen.

Huxleys ursprüngliches Zögern zeigt, daß die „Kompatibilität der alten Ethnological Society und des neuen Evolutionismus“, mit der Stocking den Beitritt der Evolutionisten zur Ethnological Society erklärt, sich ihnen selbst nicht aufdrängte. ${ }^{158}$ Diese Kompatibilität beschränkte

Anthropological with a petite note declining to have anything to do with them. The number of their Journal just published contains an article on „Man and Beast” with a discreditable attack on Rolleston (to say nothing of a mass of lies about myself which I am used to) and I gladly seized the opportunity of cutting the connection they had forced upon me"; vgl. Huxley an Charles Carter Blake, 02. Mai 1863. In: HP 11, f. 17.

155 Vgl. RAI. A1, f. 298-299.

156 Mit Francis Galton arbeitete das X-Club Netzwerk wenig später in der Redaktion des Readers zusammen, ein wichtiger Hinweis auf die Kompatibilität ihrer Ansätze innerhalb der Ethnological Society (vgl. Spencer an Lubbock, 12. November 1864. In: AP, ADD 49640, f. 174-175).

157 Vgl. RAI, A1, f. 301.

158 Stocking 1971, S. 379: „The underlying compatibility of the old ethnology and the new evolutionism is illuminated in an interesting way by a remark which Richard Cull had made in 1851. Discussing the relations 
sich auf die geteilte Annahme eines gemeinsamen Ursprungs der Menschheit. ${ }^{159}$ Doch die Ethnological Society stand nicht vollständig in der Tradition des Prichardschen Monogenismus, denn ihr damaliger Präsident John Crawfurd war ein erklärter Polygenist. Crawfurds Position war den Evolutionisten ein beständiger Dorn im Auge, doch er war so einflußreich, daß sie sich mit ihm arrangieren mußten. ${ }^{160}$ So scheint letztlich die Gelegenheit, eine für die Auseinandersetzung mit dem Polygenismus strategisch günstige Körperschaft übernehmen zu können, den Ausschlag für die Intervention des X-Clubs auf Seiten der Ethnological Society gegeben zu haben.

Die Ethnological Society wurde vom X-Club als eine Plattform verwendet, gerade so wie zuvor der Natural History Review und wenig später der Reader. Der Übernahme der Ethnological Society folgte ihre Wiederbelebung. Auch das eigene Publikationsorgan, die Transactions of the Ethnological Society, erschien jetzt wieder regelmäßig. ${ }^{161}$ Zwar blieben die Mitgliederzahlen weit hinter denen der rivalisierenden Anthropological Society zurück, dennoch war ein signifikanter Zuwachs zu verzeichnen. Die Anthropological Society behauptete von sich, zeitweise bis zu achthundert Mitglieder zu haben, doch waren diese Zahlen geschönt, die Mitgliederstärke der Ethnological Society schwankte zwischen zwei- und dreihundert. ${ }^{162}$

between the ,ethnologist ' and the ,naturalist ', Cull suggested that the former studied ,past history in order to trace descent and origin'. He then went on to ask: ,But who ever heard of a Naturalist studying fossils to trace descent and origin?"“. Stocking stützt sich auf einen 1864 bereits dreizehn Jahre alten Aufsatz des Ethnologen Richard Cull im Journal of the Ethnological Society (Richard Cull (1851) „Remarks on the nature, objects, and evidences of ethnological science". In: Journal of the Ethnological Society 3, S. 102-111). Doch zum einen diskutierte Cull bloß einen methodischen Unterschied zwischen Ethnologie und Naturwissxenschaften. Zum anderen spielte Cull innerhalb der Ethnological Society eine unbedeutende Rolle und weder Huxley, noch Lubbock, noch Busk bezogen sich auf ihn. Stockings Ansatz, die Kompatibilität zwischen den monogenistischen Ethnologen und den Evolutionstheoretikern aus dieser isolierten Methodenüberlegung abzuleiten, ist deshalb wenig überzeugend.

159 Vgl. auch Michael Banton (1967) Race Relations. London: Tavistock, S. 36.

160 Vgl. Huxley an Lubbock 18. Oktober 1867. In: AP ADD 49642, f. 6365, f. 63.

161 Vgl. George W. Bloxam (1893) Index to the Publications of the Anthropological Institute of Great Britain and Northern Ireland [1843-1891]. London: The Anthropological Institute, S. vi.

162 Vgl. Huxley an Lubbock, 24. Januar 1868. In: HP 2.140; Desmond 1998, S. 343. 


\subsection{2 "Our prognathous relative“. Anthropologische Kontroversen}

Die Zweckorientierung der Gründung der Anthropological Society schlug sich nur langsam in der theoretischen Gewichtung ihrer Agenda nieder, verglichen mit der der Ethnological Society. In der ersten Ausgabe des Anthropological Reviews basierte noch die Hälfte der Artikel auf einer ethnologischen Methodologie, der physisch-anthropologische Akzent kristallisierte sich erst in den folgenden Nummern und Jahrgängen immer deutlicher heraus. Trotzdem finden sich durchgängig ethnologische Beschreibungen in den Periodika der Anthropological Society und umgekehrt physisch-anthropologische Studien in denen der Ethnological Society. ${ }^{163}$ Die Konturen der beiden Gesellschaften waren also nicht von einem methodischen Dualismus geprägt.

Die Evolutionstheoretiker des X-Clubs hatten überraschend wenig Anteil an den Veröffentlichungen der Ethnological Society. Busk schien sich zunächst thematisch zu orientieren und veröffentlichte seine prähistorischen Anatomiestudien im physisch-anthropologisch ausgerichteten Journal der Anthropological Society. Erst ab Ende der sechziger Jahre berücksichtigte er die politischen Koordinaten des Konflikts und schrieb in den Journalen der Ethnological Society. ${ }^{164}$ Lubbock publizierte die Mehrzahl seiner ethnologisch relevanten Artikel im eigenen Natural History Review, ebenso Huxley, der zudem im Reader oder im Fortnightly Review veröffentlichte. Beide mieden in der Hochphase der wissenschaftspolitischen Auseinandersetzung mit der Anthropological Society bemerkenswerter Weise die Organe der Ethnological Society, auch in jenen Jahren, in denen sie hier leitende Positionen innehatten. ${ }^{165}$

163 Vgl. Bloxam 1893.

164 Fünf der sechs Beiträge erschienen 1869 und 1870, einer bereits 1866.

165 Dieser Umstand ist nicht damit zu erklären, daß Huxley seine eher politische Beiträge zur Debatte um die Emanzipation vom wissenschaftlichen Diskurs der Ethnological Society getrennt halten wollte, denn auch seinen Aufsatz „On the Methods and Results of Ethnology“ erschien 1865 in der ersten Ausgabe des Fortnightly Review. Erst 1869 und 1870 veröffentlichte Huxley einige Skizzen zu den Grundsätzen der Ethnologie im Journal of the Ethnological Society: Huxley (1869a) „On the Ethnology and Archæology of India“. In: [The Journal of the Ethnological Society of London, n.s. 1, S. 89-93] The Scientific Memoirs of Thomas Henry Huxley, Bd. 3, S. 427-431, Huxley (1869b) „On the Ethnology and Archæology of North America“. In: [The Journal of the Ethnological Society of London, n.s. 1, S. 218-221] The Scientific Memoirs of Thomas Henry Huxley, Bd. 3, S. 432-435; Huxley (1870b) „On the Ethnology of Britain“. In: [Journal of the Ethnological Society of London, n.s. 2, S. 382-384] The Scientific Memoirs of Thomas Henry Hux- 
Zwar erreichte der Reader eine breitere Öffentlichkeit als etwa die Transactions der Ethnological Society. Doch Huxley scheint es darum gegangen zu sein, seiner Position eine Rezeption unabhängig von den einengenden Bedingungen der Auseinandersetzung zwischen den beiden Gesellschaften zu ermöglichen. Offenbar waren Huxley und Lubbock besorgt, ihre wissenschaftliche Position könnte durch die politischen Querelen, in die sie involviert waren, Schaden nehmen. Dies wird auch daran deutlich, daß Huxley seine Position zur Emanzipationsfrage nicht in einem wissenschaftlichen, sondern in einem politischen Journal darlegte.

Die sich langsam herausbildende, thematische Differenzierung zwischen der Anthropological Society und der Ethnological Society vollzog sich parallel zur Herausbildung prononcierter Unterschiede in der Interpretation sozialer und anthropologischer Tatbestände, die sich immer im Koordinatenfeld der Kontroverse zwischen Monogenismus und Polygenismus ausrichteten. Die Intensität der offenen Auseinandersetzung erreichte erstmals 1866 einen Höhepunkt, in der Konvergenz dreier Diskurse. Es handelte sich um die Frage der Emanzipation der Schwarzen, der Ethnologie der Bewohner der britischen Inseln und der Anwendung der Evolutionstheorie auf den Menschen. In diesen Debatten schärften sich die wissenschaftlichen wie die politischen Konturen der evolutionären Rassentheorien.

\section{Emanzipationsdiskurs}

1865, nach dem Ende des amerikanischen Sezessionskrieges, diskutierte die Anthropological Society in ihren Sitzungen eine Reihe von Aufsätzen, die die Missionarsarbeit in Afrika und in der Karibik in Frage stellten. Gastredner, die selbst Veteranen der Missionierung gewesen waren, mußten sich der Behauptung erwehren, die hinter dieser Arbeit stehende Hoffnung sei abwegig, die Missionierten auf diese Weise zivilisieren zu können. ${ }^{166}$

ley, Bd. 3, S. 551-553; Huxley (1870c) „On the Geographical Distribution of the Chief Modifications of Mankind“. In: [Journal of the Ethnological Society of London n.s. 2, S. 404-412] The Scientific Memoirs of Thomas Henry Huxley, Bd. 3, S. 564-571.

166 Vgl. Burnard H. Owen (1865) „Missionary Successes and Negro Converts“. In: Anthropological Review 3, S. clxxxiv-ccxlvi; W. Winwood Reade (1865) „Efforts of Missionaries among Savages“. In: Anthropological Review 3, S. clxiii-clxxxiii. Während Reade für die polygenistische Kritik am Missionswerk stand, versuchten Owen und John William Colenso, es zu verteidigen. 
Hintergrund dieser Auseinandersetzung mit der Missionarstätigkeit war der Skandal um den Bischof von Natal, John William Colenso. Colenso hatte, er behauptete aufgrund der skeptischen Fragen von Konvertierten, die biblische Narration in Details für unglaubwürdig erklärt. Sein Buch, Pentateuch and the Book of Joshua Critically Examined, erschien 1862, im darauffolgenden Jahr wurde er der Ketzerei für schuldig befunden und seines Amtes enthoben. ${ }^{167}$ Dieser kirchenpolitische Vorgang wurde von Gegnern und Unterstützern Colensos gleichermaßen skandalisiert. Dabei zeigt das Ausmaß der öffentlichen Kontroverse ebenso wie die große Nachfrage nach Colensos Schrift, daß die Kirche ihre uneingeschränkte Diskurshoheit bereits verloren hatte.

$\mathrm{Zu}$ den prominentesten Unterstützern Colensos zählte der X-Club. Colenso war im Juni 1865 Gast bei einem Dinner des Clubs, der für seine Rehabilitierung eintrat. ${ }^{168}$ Ein Unterstützungsfond für ihn wurde im Reader beworben. ${ }^{169}$ Colenso fügte sich in die Kampagne des X-Clubs zur Beschränkung des Erklärungsanspruches der Kirche ein, denn er hatte gerade die Reichweite des biblischen Erklärungsanspruches auf den Prüfstand gehoben. Auf der anderen Seite bot die Anthropological Society eine Plattform für wüste Angriffe auf Colenso, der als „Niggerlover" verunglimpft wurde und an dessen Missionarsarbeit die Unzivilisierbarkeit der Schwarzen demonstriert werden sollte, von denen behauptet wurde, sie könnten den wahren Glauben gar nicht annehmen. ${ }^{170}$

Im Unterschied zur Anthropological Society, die diese Frage auf ihre Tagesordnung setzte, hielt Huxley die politische Positionierung des XClubs sorgsam fern von der Ethnological Society. Diese Strategie wird an einer anderen kontrovers diskutierten Frage des Emanzipationsdiskurses deutlich. Obwohl die Ethnological Society sich nicht von ihrer philanthropischen Tradition gelöst hatte, veröffentlichte Huxley seine philanthropismuskompatiblen Beiträge zum Sezessionskrieg, zu Sklaverei und Emanzipation der Schwarzen im Mai 1865 im Reader und nicht im Journal der Ethnological Society. Auf diese Weise versuchte er, das offenbar noch fragile wissenschaftliche Image der Ethnological Society nicht durch politische Statements zu gefährden.

Huxley argumentierte vorbehaltlos für das Ende der Sklaverei. Die Emanzipation der Schwarzen sei auf der Grundlage der moralischen

167 Vgl. Jan Morris (1998) Heaven's Command: An Imperial Progress. London: Faber and Faber 1998, S. 323-328; Ronald L. Numbers: „,The Most Important Biblical Discovery of Our Time‘: William Henry Green and the Demise of Ussher's Chronology“. In: Church History 69, 2000: www.wls.wels.net/conted/Science/ussher.pdf (Internetquelle).

168 Vgl. JTAH, Bd. 4, S. 213, 12. April 1865; Spencer 1904b, Bd. 2, S. 114.

169 Vgl. The Reader 6, 24. Juni 1865, S. 70.

170 Vgl. Desmond 1998, S. 315. 
Verpflichtung erforderlich, da alle Menschen die gleichen Rechte genießen müßten. ${ }^{171}$ Doch er hob als Vorzug der Emanzipation der Schwarzen insbesondere die moralische Erleichterung für die Weißen hervor. Es handele sich um ,eine doppelte Emanzipation, und der Master wird von der Freiheit mehr profitieren als der Befreite“. ${ }^{172}$ Als Beruhigung derjenigen Weißen, die von der Sklaverei mittelbar sozial profitierten, schob er eine mit rassentheoretischen Elementen versehene Erklärung nach, warum die soziale Ordnung durch die Befreiung der Sklaven nicht in Frage gestellt würde: ${ }^{173}$

„Es mag ganz richtig sein, daß einige Neger besser sind als einige Weiße, aber kein rational denkender Mensch, der die Fakten kennt, glaubt, daß der durchschnittliche Neger dem durchschnittlichen weißen Mann ebenbürtig oder gar überlegen ist. Und wenn das stimmt, ist es einfach unvorstellbar, daß, wenn alle seine Behinderungen beseitigt sind und unser prognathischer Verwandter frei agieren kann, keinen Unterstützer und keinen Unterdrücker hat, er in der Lage sein wird, erfolgreich mit seinen Rivalen mit dem größeren Gehirn und dem kleineren Kiefer zu konkurrieren, in einem Wettbewerb, der durch Ideen und nicht durch Beißen ausgetragen wird. Die höchsten Plätze in der Hierarchie der Zivilisation werden ganz sicher nicht in Reichweite unserer dunklen Cousins liegen, deshalb ist es nicht nötig, sie auf die untersten zu beschränken“. ${ }^{174}$

171 Vgl. Huxley (1865b) „Emancipation - Black and White“. In: [The Reader 5, 1865, S. 561-562)] Collected Essays, Bd. 3, S. 60-75, S. 67. Die ,weiße Emanzipation“ im Titel des Aufsatzes bezieht sich auf die Frage des Frauenwahlrechts.

172 Huxley 1865b, S. 68: ,a double emancipation, and the master will benefit by freedom more than the freed man".

173 Brantlinger schreibt, daß Huxley die Sklaverei nicht deswegen abgeschafft wissen wollte, weil Afrikaner den Europäern gleichstünden, sondern weil die Sklaverei die natürliche Auslese einschränke (vgl. Brantlinger 1997, S. 269). Allerdings betonte Huxley den Aspekt der natürlichen Auslese, die im anschließenden Zitat allerhöchstens in der Form ökonomischer Selektion auftritt, kaum. Seine Ablehnung der Sklaverei scheint vielmehr ethischer Natur gewesen zu sein und sich mit der politischen wie wissenschaftspolitischen Kontroverse zwischen Polygenismus, Monogenismus und evolutionären Rassenansätzen verbunden zu haben.

174 Huxley 1865b, S. 66-67: „It may be quite true that some negroes are better than some white men; but no rational man, cognisant of the facts, believes that the average negro is the equal, still less the superior, of the average white man. And, if this be true, it is simply incredible that, when all his disabilities are removed and our prognathous relative has a fair field and no favour, as well as no oppressor, he will be able to compete successfully with his bigger-brained and smaller-jawed rival, in a context which is to be carried out by thoughts and not by bites. The highest places in the hierarchy of civilization will assuredly not be within reach 
Huxley griff hier den rassistischen Topos auf, Schwarze wären aufgrund ihrer ,prognathischen“ Physiognomie eher für primitive Formen der Auseinandersetzung prädestiniert, hätten aufgrund der Schädelform ein kleineres Gehirn und wären deshalb weniger intelligent. ${ }^{175}$ In der Tat ging er bei seinen kraniometrischen Studien bedächtiger vor, aber er war hier nicht an der Generierung wissenschaftlicher Aussagen interessiert. Die Hinweise auf Kiefer und Gehirn mögen saloppe Bemerkungen gewesen sein, doch sie bezogen sich auf die für ihn sichtbaren Indikatoren einer biologischen Differenz, die in seinen Augen soziale Unterschiede bedingten. ${ }^{176}$

Huxleys Antwort auf die rhetorische Frage des Philanthropismus, „Bin ich nicht ein Mensch und ein Bruder?“, fiel also ambivalent aus. ${ }^{177}$ Zum einen wandte er sich explizit gegen die Unterdrückung durch die Sklaverei und damit gegen deren Befürworter in England, zuvorderst die Anthropological Society. Zum anderen aber betonte er die soziale Differenz zwischen Schwarzen und Weißen und behauptete, daß sie evolutionsbiologisch begründbar wäre.

Die wissenschaftspolitische Einigkeit zwischen den Mitgliedern des $\mathrm{X}$-Clubs, die sie in ihren Kampagnen für die Etablierung der Evolutionslehre demonstrierten, konnte allerdings die Unterschiede in Fragen der grundsätzlichen politischen Orientierungen nicht kaschieren. Diese traten im Kontext einer politischen Debatte zu Tage, die Mitte der sechziger Jahre unter großer öffentlicher Beteiligung geführt wurde: Der Kontroverse um den jamaikanischen Gouverneur Edward John Eyre und die von ihm veranlaßte blutige Niederschlagung eines Aufstandes unter den Schwarzen der Insel. Die Nachrichten aus Jamaika, die England im Herbst 1865 erreichten, lösten eine mehrere Jahre andauernde Debatte

of our dusky cousins, though it is by no means necessary that they should be restricted to the lowest".

175 Vgl. Di Gregorio 1984, S. 173.

176 Evelleen Richards hat auf die Fadenscheinigkeit der liberalen Emanzipationsrhetorik Huxleys hingewiesen, aber wenn sie schreibt, Hunt sei im Gegensatz zu Huxley derjenige gewesen, der ,,a range of reactionary political and social positions on the interrelated Negro and woman questions" biologisiert habe, übersieht sie Huxleys eigenen biologisierenden Ansatz (vgl. Evelleen Richards (1989) „Huxley and woman's place in science: The ,woman question" and the control of Victorian anthropology“. In: James R. Moore (Hrsg.): History, Humanity, and Evolution: Essays for John C. Greene. Cambridge: Cambridge University Press, 1989, S. 253-284, S. 277).

177 Huxley 1865b, S. 66: „Quashie's plaintive inquiry, ,Am I not a man and a brother?““. 
darüber aus, ob Eyre als Held behandelt werden solle oder ob er sich für sein Vorgehen vor Gericht verantworten müsse. ${ }^{178}$

Zwischen 1833 und 1838 war die Sklaverei in den britischen Kolonien offiziell abgeschafft worden. ${ }^{179}$ Dennoch waren in Jamaika wie in anderen Kolonien die Lebensbedingungen der ehemaligen Sklaven mehrheitlich ärmlich, nur wenige hatten es zu einer bürgerlichen Existenz, zu politischen Ämtern oder gar zu Grundbesitz gebracht. Zu diesen wenigen zählte George William Gordon, der sich als politischer Gegner des jamaikanischen Establishments, dem in erster Linie die dortigen $\mathrm{Zu}$ ckerfarmer angehörten, profiliert hatte. ${ }^{180}$

Soziale Spannungen zwischen den überwiegend weißen Farmern und den schwarzen Landarbeitern hatten zu einem Aufstand geführt, der blutig niedergeschlagen wurde. Eyre hatte Gordon für einen Aufrührer gehalten, ihn in das Aufstandsgebiet verschleppt und dort unter Kriegsrecht hinrichten lassen. ${ }^{181}$ Diese Hinrichtung und das brutale Vorgehen der Truppen gegen Aufständische und Unbeteiligte hatten in England heftige Kritik ausgelöst. Sie wurde vor allem vom Mittelkasse-Milieu des Nonkonformismus sowie von Baptisten getragen, die bereits die Missionierung der Sklaven als ihre Aufgabe betrachtet, maßgeblich an der Gründung der Bewegung gegen die Sklaverei Ende des achtzehnten Jahrhunderts mitgewirkt hatten und weiterhin für die Emanzipation der ehemaligen Sklaven eintraten. ${ }^{182}$

Unmittelbar nach Bekanntwerden der Ereignisse auf Jamaika vereinigten sich diese Kreise mit liberalen Aktivisten im Jamaica Committee. Durch dessen Kopf John Stuart Mill wurden Spencer und - als weitere bedeutende Vertreter der Evolutionslehre - Darwin, Lyell, Wallace und Huxley gewonnen, Spencer und Huxley nahmen Funktionen in seinem Exekutivrat war. ${ }^{183}$ Spencer betonte in seiner Autobiographie den be-

178 Vgl. Bernard Semmel (1962) The Governor Eyre Controversy. London: Macgibbon, Kee, S. 13-14; Bolt 1971, S. 75-108.

179 Vgl. Woodward 1962, S. 372-374; Blackburn 2000, S. 293-329.

180 Vgl. Semmel 1962, S. 38-41.

181 Vgl. Semmel 1962, S. 38-55.

182 Vgl. Roger Anstey (1980) „The pattern of British abolitionism in the eighteenth and nineteenth centuries“. In: Roger Anstey, Christine Bolt, Symour Drescher (Hrsg.): Anti-slavery, religion and reform. Folkstone: Dawson, S. 19-42, S. 19-42; Semmel 1962, S. 18-25.

183 Vgl. John Stuart Mill an Spencer, 15. August 1866. In: Francis E. Mineka, Dwight N. Lindley (Hrsg.) (1972) The Later Letters of John Stuart Mill, 1849-1873. Toronto, London: University of Toronto Press, S. 1191-1192; Frederick William Chesson (Sekretär des Jamaica Committees) an Huxley, 20. Oktober 1866. In: HP 11, f. 184-187; Spencer an Darwin, 2. November 1866. In: CCD, Bd. 14, S. 372; Wiltshire 1978, S. 83. 
sonderen Einfluß der Evolutionisten auf die Politik des Jamaica Committees, was zumindest für die Phase ab 1866 zutrifft, als Mill dessen Vorsitz übernommen hatte. ${ }^{184}$ Dabei schien diese Positionierung alles andere als selbstverständlich. So schrieb Huxley an Darwin:

„Ich bin froh, von Spencer zu hören, daß Sie auf der richtigen (daß heißt, meiner) Seite in der Jamaika-Sache stehen. Aber es ist überraschend, daß Menschen, die normalerweise gemeinsam handeln, sich darüber entzweien“. ${ }^{185}$

Auch innerhalb des X-Clubs waren die Meinungen geteilt. Lubbock positionierte sich in der Frage nicht öffentlich, im Privaten muß er sich aber gegen Eyre gestellt haben, wie sein Biograph Mark Patton rekonstruiert. ${ }^{186}$ Tyndall hingegen trat dem Komitee zur Unterstützung Eyres bei und übernahm dort später sogar den Vorsitz. ${ }^{187}$ Er berief sich in dieser Position auch auf Hooker, der ihm geschrieben hatte: „Der Neger auf Jamaika [...] ist verderblich, [...] er ist bestenfalls ein gefährlicher Wilder"; Tyndall erklärte weiter, daß er es ablehne, die Schwarzen als den Engländern gleichwertig anzuerkennen. ${ }^{188}$

Es gelang den Mitgliedern des X-Clubs jedoch problemlos, die Meinungsverschiedenheiten, die in diesen konträren Positionierungen $\mathrm{zu}$ Tage traten, durch gegenseitige Freundschaftserklärungen zu entschärfen. ${ }^{189}$ Diese Beteuerungen zeigen, daß den Beteiligten die Sprengkraft dieser Kontroverse für ihren Club durchaus bewußt war. Sie konnten sie dadurch bändigen, daß die Frage ausschließlich politisch behandelt wurde. Daran wird deutlich, daß zu diesem Zeitpunkt die Kohäsion des XClubs auf der persönlichen Freundschaft wie auf geteilten beruflichen

184 Vgl. Spencer 1904b, Bd. 2, S. 143.

185 Huxley an Darwin, 11. November 1886. In: CCD, Bd. 14, S. 385: „I am glad to hear from Spencer that you are on the right (that is my) side in the Jamaica business. But it is wonderful how people who commonly act together are divided about it".

186 Vgl. Patton (im Erscheinen), Kap. 6.

187 Thomas Carlyle (1795-1881) war Historiker und Essayist und hatte sich mit seinem „Occasional Discourse on the Nigger Question“ in Frazer's Magazine 1849 einen Ruf als vehementer Gegner der Emanzipation und der philanthropischen Bewegung gemacht.

188 Hooker an Tyndall, 03. Mai 1866. In: Royal Institution: Tyndall Papers/1/H/498 (Ident. Tyndall Papers/1/Typ/8/Seite 2571); Vgl. Semmel 1962, S. 125.

189 Huxley und jene Freunde, die Eyre unterstützten, versicherten sich gegenseitig in Briefwechseln den Fortbestand ihrer Freundschaft, vg. Kingsley an Huxley, 6. November 1866. In: HP 19, f. 241-242; Huxley an Kingsley, 8. November 1866. In: HP 19, f. 243-246; Tyndall an Huxley, November 1866. In: HP 8, f. 49 (ident. mit HP 1, f. 40); Huxley an Tyndall, 9. November 1866. In: HP 8, f. 52 (ident. mit HP 9, f. 28-29). 
Interessen beruhte, die mehr Gewicht hatten als politische Differenzen. Inmitten der wissenschaftlichen Kontroversen, die der X-Club führte, durfte die Effektivität ihrer gebündelten Schlagkraft nicht aufs Spiel gesetzt werden. Gerade vor dem Hintergrund dieses eleganten Krisenmanagements drückt die später sogar öffentlich ausgetragene Streiterei zwischen Huxley und Spencer den Niedergang des X-Clubs aus.

Bei der Eyre-Kontroverse ging es nicht allein um die moralische Beurteilung der Vorkommnisse auf Jamaika, denn sie hatte sich mit der sozialpolitischen Problematik Englands jener Zeit verbunden. Politisch Radikale hatten wiederholt zu Massendemonstrationen für das allgemeine Wahlrecht in London aufgerufen, und auf die irische Unabhängigkeitsbewegung der Fenier gingen mehrfach terroristische Anschläge oder kleine Insurrektionen in Irland und England zurück. ${ }^{190}$ Die Frage stand im Raum, ob das Standrecht, das Eyre in Jamaika praktiziert hatte, auch in England eingeführt werden würde. Ultrarechte Konservative und Gegner der Emanzipation von Unterschichten und nationalen Minderheiten befürworteten dies. Tyndall zog deshalb gerade hier eine Trennungslinie. Er argumentierte mit einer unterschiedlichen Wertigkeit der Rassen. Die rechtfertigte es, in den Kolonien freie Bewohner des Commonwealth', aber eben Schwarze, mit härtesten Mitteln niederzuwerfen, nicht aber seine irischen Landsleute.

Auf der anderen Seite, im Lager des Jamaica Committees, gab es ebenfalls unterschiedliche Argumentationen. Während traditionelle Abolitionisten, religiöse Philanthropen und radikale Liberale wie Mill ihre Forderung, Eyre müsse sich vor Gericht für sein Vorgehen verantworten, mit einer nicht selten patronisierenden Anwaltschaft der Opfer und ihrer politischen Forderungen verbanden, ${ }^{191}$ nahmen Vertreter des Lagers der Evolutionstheoretiker eine andere Perspektive ein. Als die Pall Mall Gazette, die eher zur Pro-Eyre-Fraktion neigte, sich spitzzüngig erkundigte,

„,in wie weit Sir Charles Lyells und Mr. Huxleys besondere Ansichten der Entwicklung der Arten sie beeinflußte, auch dem Neger jene mitleidige Anerkennung zu gewähren, die sie sogar bis zum Affen als ,einem Mann und einem Bruder" auszuweiten bereit sind", ${ }^{192}$

190 Vgl. Catherine Hall (2000) „The nation within and without“. In: Catherine Hall, Keith McClelland, Jane Rendall: Defining the Victorian $\mathrm{Na}$ tion. Class, Race, Gender and the Reform Act of 1867. Cambridge u.a.: Cambridge University Press, S. 179-233, S. 179-233.

191 Vgl. Hall 2000, S. 201.

192 Huxley (1866b) „Letter on Jamaica Committee“. In: Pall Mall Gazette 4, 31. Oktober, S. 3, S. 3: „It would be curious also to know how far Sir Charles Lyell's and Mr. Huxley's peculiar views on the development of 
erklärte Huxley in der nächsten Ausgabe: „Ich bin weder durch ,meine besondere Ansicht der Entwicklung der Arten' noch durch irgendeine besondere Vorliebe oder Bewunderung für den Neger dazu bewegt worden, diesem Komitee beizutreten“, der Grund sei vielmehr die Klärung der Frage, ob die Hinrichtung Gordons einen Mord darstelle. ${ }^{193}$ Er betonte die Unabhängigkeit seiner politischen Position von seiner evolutionären Anthropologie. Zum anderen engte er seine Sicht auf eine juristische Frage ein und blendete so den Kontext des Emanzipationsdiskurses aus, in den seine philanthropischen Mitstreiter ihre Kampagne stellten. Huxley nahm diese Trennung vor, da er annahm, daß die unterschiedlichen Positionen, die in der Kontroverse bezogen wurden, auf grundsätzliche politische Überzeugungen zurückzuführen seien - sein wissenschaftliches Wissen hingegen behandelte er als faktisch und als werturteilsfrei. $^{194}$

Bernard Semmel notiert in seiner detaillierten Studie der Eyre-Kontroverse eine bemerkenswerte Verteilung der viktorianischen Prominenz auf die beiden rivalisierenden Komitees. Während sich für Eyre die herausragendsten Literaten engagierten, neben Thomas Carlyle vor allem John Ruskin, Alfred Tennyson, Charles Kingsley und Charles Dickens, versammelte sich im Jamaica Committee eher die Wissenschaftler. Semmel führt diesen Umstand auf den bürgerlichen Hintergrund von Wissenschaftlern wie Huxley, Darwin oder Spencer zurück, den sie mit den Nonkonformisten teilten. Doch die soziale Lage allein kann keine hinlängliche Determinante der Haltung in der Eyre-Frage gewesen sein, was schon an Hooker und Tyndall deutlich wird, die aus ähnlichen sozialen Verhältnissen stammten wie Huxley oder Spencer.

Die Frage, warum sich Huxley und Spencer als Kritiker Eyres positionierten, wird allerdings beantwortet, wenn der Konflikt um die Ja-

species have influenced them in bestowing on the Negro that sympathetic recognition which they are willing to extend even to the ape as , a man and a brother"“.

193 Huxley zitiert nach LLTHH, Bd. 1, S. 279-280: „I have been induced to join that committee neither by my,peculiar view on the development of species, ' nor by any peculiar love for, or admiration of the Negro [...]; but because the course which the committee proposes to take appears to me to be the only one by which a question of the profoundest practical importance can be answered. That question is, Does the killing a man in the way Mr. Gordon was killed constitute murder in the eyes of the law, or does it not?".

194 Vgl. Huxley an Kingsley, 8. November 1866. In: LLTHH Bd. 1, S. 281282: „Don't suppose that I have any particular admiration for Gordon. [...] In point of fact, men take sides on this question, not so much by looking at the mere facts of the case, but rather as their deepest political convictions lead them". 
maika-Affäre in den Kontext der wissenschaftspolitischen Auseinandersetzungen zwischen den Evolutionstheoretikern und den Polygenisten gerückt wird, denn Huxley und Spencer engagierten sich nicht allein wegen ihrer politischen Haltung oder einer moralischen Empörung im Jamaica Committee. Für sie handelte es sich um eine Kontroverse, die den Kern ihres Verständnisses von sozialer Evolution berührte. Sie waren davon überzeugt, daß die Sklaverei ein Hindernis der sozialen Evolution darstellte - ein Zwangsverhältnis für die Sklaven, ebenso wie für die Sklavenhalter.

Darüber hinaus war insbesondere für Huxley die Eyre-Kontroverse ein Gelegenheit, in der Auseinandersetzung mit der Anthropological Society vor der interessierten Öffentlichkeit einen politischen Mißbrauch der Wissenschaften durch die polygenistischen Gegner der Emanzipation anzuprangern. Während die Anthropological Society öffentliche Versammlungen zur Unterstützung Eyres abhielt und Hunt dessen Vorgehen lobte, war Huxley bemüht, seinen pro-emanzipatorischen Standpunkt außerhalb der wissenschaftlichen Sphäre zu entwickeln. ${ }^{195}$ So stellte die Kontroverse um den Gouverneur Eyre eine Verlängerung der wissenschaftspolitischen Fronten in eine Debatte hinein dar, die durch die Klassenfrage in England und den Emanzipationsdiskurs der Zeit politisch hoch aufgeladen war.

195 Vgl. Stocking 1971, S. 379; Jmes Hunt (1866c) „Address delivered at the third anniversary meeting of the Anthropological Society of London“. In: Journal of the Anthropological Society 4, S. lix-lxxxi, S. Ixxviii. Semmel zeigt sich überrascht, daß zwar Evolutionstheoretiker wie Darwin und Spencer für die Doktrin des Überleben des Stärksten standen, es aber die Literaten und Gegner der Evolutionslehre waren, die diese Doktrin in ihre Argumentation zur Jamaikafrage einfließen ließen. Er erklärt dieses vermeintliche Paradox mit einer Differenzierung von innerem (,,internal“, für den Spencer stünde) und äußerem (,external“, für den später Benjamin Kidd stünde) Sozialdarwinismus, also auf die Klassenfrage oder auf Krieg oder ,Rassenkampf ' angewandten Sozialdarwinismus (vgl. Semmel 1962, S. 120). Doch einerseits übersieht dies, daß Spencer selbst in seine Theorie sozialer Evolution dem Krieg und dem vermeintlichen Aussterben angeblich schwächerer Rassen große Bedeutung beimaß (vgl. Kapitel 4.4). Zum anderen impliziert Semmel damit, daß Carlyle ein Sozialdarwinist Kiddschen Zuschnitts gewesen sei. Doch dessen Befürwortung der Sklaverei basierte nicht auf einer sozialdarwinistischen Diagnose, sondern auf einer polygenistischen und rassistischen Argumentation, die die Sklaverei zu legitimieren versuchte, indem sie die Sklaven zu einer minderwertigen Art Mensch erklärte. 


\section{Die Anthropologie der britischen Inseln}

In der ersten Hälfte des neunzehnten Jahrhunderts entwickelte sich ein besonderes Interesse an der Frage der ethnischen Zusammensetzung der Bevölkerung der britischen Inseln. Im romantisierenden Diskurs über die frühe Geschichte Englands wurde die Vorstellung geprägt, daß sich die britische Gesellschaft aus Kelten, Angeln, Sachsen, Normannen und Skandinaviern zusammensetze, die in verschiedenen Epochen die Inseln besiedelt hatten. Einer der ersten großangelegten Versuche, diese Frage unter rassentheoretischen Gesichtspunkten zu beantworten, war Thurnam und Davis Crania Britannia, das ab 1856 in mehreren Auflagen erschienen war. ${ }^{196}$ Sie gingen davon aus, daß die Schädelform ein stabiles Rassenmerkmal und somit einen sicheren Indikator für die jeweilige ,rassische Komposition“ der Bevölkerung auf den britischen Inseln sei. ${ }^{197}$ Mit der Expansion der Archäologie und der Weiterentwicklung kraniometrischer Verfahren hatte der Diskurs über die Rassen, aus denen sich möglicherweise die britische Bevölkerung zusammensetzte, Mitte des neunzehnten Jahrhunderts eine neue Dynamik erhalten.

Weil die Polygenisten von der Konstanz bestimmter Rassenmerkmale ausgingen und weil die Bevölkerung der britischen Inseln, insbesondere die Iren, Gegenstand eines stark ethnisierenden Identitätsdiskurses geworden waren, verband sich diese früh- und vorgeschichtliche Frage unmittelbar mit der zeitgenössischen Politik. Das Interesse an einer Anthropologie der britischen Inseln speiste sich aus der tagespolitischen Brisanz, der in Irland ab 1865 populär gewordenen Fenier und der sozialen Frage, bei der ebenfalls die seit geraumer Zeit in England lebenden irischen Arbeitsmigranten eine wichtige Rolle spielten. ${ }^{198}$

Diese politischen Diskurse dürften die Herausgeber des Anthropological Review bewogen haben, ab 1866 ein Forum für Studien der vergleichenden Anthropologie der britischen Inseln anzubieten. ${ }^{199}$ Etliche Aufsätze in den Journalen der Anthropological Society verfolgten dabei die Absicht, eine spezifisch irische oder keltische Physiognomie zu beschreiben. So entdeckte beispielsweise Charles Carter Blake an einem Schädel aus Irland affenartige Züge, und John Beddoe kam zu dem Schluß, daß der irische Schädel generell prognathisch und länglich sei -

196 Vgl. Joseph Thurnam, John Barnard Davis (1856) Crania Britannica. Delineations and Descriptions of the Skulls of the Aboriginal and Early Inhabitants of the British Islands. London: Selbstverlag.

197 Vgl. Stocking 1987, S. 66.

198 Vgl. Woodward 1962, S. 359-360; James Camlin Beckett (1982) Geschichte Irlands. Stuttgart: Kröner, S. 202-204.

199 Vgl. Anthropological Review 4, 1866, S. 1. 
Vermutungen über die „Existenz einer Rasse kugelköpfiger Iren“ hielt er für abwegig. ${ }^{200}$ John Barnard Davis verließ sich nicht allein auf eine Beschreibung des Schädels und glaubte im „keltischen Auge“, einer bestimmten Farbgebung der Iris, einen zuverlässigen Indikator keltischen Bluts entdeckt zu haben. ${ }^{201}$

Es ging nun nicht mehr bloß um eine Frage der Genealogie, sondern um die Errichtung einer Typologie der Gesellschaft, die unmittelbar an die politische und die sozialpolitische Diskussion im viktorianischen Britannien anknüpfte. Dies wird insbesondere deutlich, wenn die physiognomische Identität der Kelten oder Iren mit einer Charakterisierung der ,gälischen Mentalität“ verbunden wurde.

Im Anthropological Review wurde ihnen nach ausführlichen physiognomischen Beschreibungen ,eine schnelle Auffassungsgabe, aber mangelnde Tiefe des Denkvermögens“ zugeschrieben, sie seien „halsstarrig und erregbar“, neigten zu „Widerspenstigkeit“, hätten einen „Hang zur Zusammenrottung“, wären für „,monotone und rein mechanische Arbeiten“ prädestiniert und ließen es an „Vernunft und Voraussicht" mangeln. ${ }^{202}$ Dies stelle eine beachtliche Sammlung von damals verbreiteten Stereotypen über die Iren dar, die selbst noch die Arbeitsverhältnisse unterprivilegierter und pauperisierter Arbeiter als Ausdruck ihrer inneren Veranlagung deutete. Aus diesen Elementen setzte sich der Diskurs der Anthropological Society über die Iren zusammen; auch die rein historisch und prähistorisch operierende Forschung zu den Kelten oder den Rassen der britischen Inseln wurde in diesem Kontext rezipiert.

Eine Debatte zwischen der Anthropological Society und den Evolutionisten der Ethnological Society entzündete sich an einem Bericht über prähistorische Gräber, die nahe des Schlosses Keiss in der schottischen Hochlandregion Caithness gefunden wurden. Huxley und Busk hatten

200 Vgl. Charles Carter Blake (1866) „On Certain „Simious“ Skulls with Especial Reference to a Skull from Louth in Ireland". In: Memoirs of the Anthropological Society 2, S. 74-81; John Beddoe (1866) „On the HeadForms of the West of England“. In: Memoirs of the Anthropological Society 2, S. 348-357, S. 355: „existence of any race of globular-headed Irish".

201 Zitiert in Beddoe 1866, S. 352: „Keltic eye“.

202 D. Mackintosh (1866) „Comparative Anthropology of England and Wales“. In: Anthropological Review 4, S. 1-21, S. 16: „Gaelic Mental Characteristics. - Quick in perception, but deficient in depth of reasoning power; headstrong and excitable; tendency to oppose; strong in love and hate; at one time lively, soon after sad; vivid in imagination; extremely social, with a tendency for crowding together; forward and selfconfident; deficient in application to deep study, but possessed of great concentration in monotonous or purely mechanical occupations, such as hop-picking, reaping, weaving, etc.; want of prudence and foresight". 
die menschlichen Überreste untersucht und befunden, daß die dort versammelten Skelette prähistorischen Ursprungs wären und daß ihre signifikanten anatomischen Unterschiede auf verschiedene Herkunftsregionen in Europa schließen ließen. ${ }^{203}$ Huxley verglich einzelne Knochenpartien mit entsprechenden Knochen moderner Menschen und erklärte, daß die Funde bei Keiss von Menschen stammten, die anatomisch zwischen Europäern und Wilden stünden. ${ }^{204}$ Für die zeitgenössischen Briten und Iren befand er:

„Unsere Bevölkerung enthält drei verschiedene ethnologische Elemente: I. Brachykephale Xanthochroi [breitschädelige Blonde, T.G.]; II. Dolichokephale Xanthochroi [langschädelige Blonde, T.G.]; und III. Melanochroi [Dunkelhaarige, T.G.]. Zu Caesars Zeiten und für eine unbestimmbar lange Zeitspanne zuvor enthielt Gallien das erste und das dritte dieser Elemente, und an den Küsten der Ostsee lebte das zweite. In anderen Worten, die ethnologischen Elemente der Irisch-Britischen Inseln sind identisch mit denen der nächstgelegenen Teile des Europäischen Kontinents“ “205

Diese Ausdeutung harmonierte mit der Entwicklungshypothese und der Annahme von Migrationsbewegungen der Evolutionstheorien. Die Anthropological Society veröffentlichte deshalb als Erwiderung eine Reihe von Artikeln, in denen zum einen das Alter der Funde in Frage gestellt wurde und zum anderen die Besonderheiten mancher der von Huxley untersuchten Knochen auf individuelle, krankhafte Deformationen zurückgeführt wurden. ${ }^{206}$

Die Diskussion um die ethnische Zusammensetzung der Briten und Iren erhielt 1869 durch die Gesetzesvorlagen zur sogenannten Home-

203 Vgl. Huxley (1866a) „Notes upon the Human Remains from Keiss“. In: Samuel Laing: Pre-Historic Remains of Caithness. London, Williams and Norgate, S. 83-160, S. 146.

204 Vgl. Huxley 1866a, S. 146.

205 Huxley 1866a, S. 133-134: „Our population contains three distinct ethnological elements: I. Xanthochroi brachycephali; II. Xanthochroi dolichocephali; and III: Melanochroi. In Caesar's time, and for an indefinitely long preceeding period, Gaul contained the first and third of these elements, and the shores of the Baltic presented the second. In other words, the ethnological elements of the Hiberno-British Islands are identical with those of the nearest adjacent parts of the continent of Europe".

206 Vgl. Joseph Anderson (1866) „On Human Remains at Keiss“. In: Journal of the Anthropological Society 4, S. clii-clvi; George Petrie (1866) „Letter on Human Remains from Keiss“. In: Journal of the Anthropological Society 4, S. cl-clii; Robert L. Shearer (1866) „On the Human Remains at Keiss“. In: Journal of the Anthropological Society 4, S. clviiclxiii; James Hunt (1866b) „On the Keiss Graves“. In: Journal of the Anthropological Society 4, S. clxiii-clxx. 
Rule, die die liberale Regierung William Gladstones vorlegte, erneut politische Aktualität. Der Versuch, den Iren eine politische Teilautonomie zuzugestehen, scheiterte jedoch mehrmals am Widerstand von Konservativen und irischen Unionisten. Befürworter dieser Maßnahme hatten behauptet, die Iren hätten das Recht auf eine zumindest innenpolisch souveräne Führung, da sie eine andere Rasse als die Briten darstellten. ${ }^{207}$ Huxley fuhr gegen diese Behauptung wissenschaftliche Beweise auf. Dabei wich seine Begründung, daß die Iren keine andere Rasse als die Engländer seien, von seiner zuvor im Kontext der Keiss-Debatte entwickelten Theorie der Abstammung der Bevölkerung auf den britischen Inseln von drei europäischen persistenten Modifikationen wieder ab:

„Zwei verschiedene ethnologische Elemente koexistierten wahrscheinlich auf diesen Inseln als das Land von den Römern entdeckt wurde, und spätere Invasionen [...] haben keinen neuen Urstamm eingeführt, sondern sie haben bloß das eine oder andere der bestehenden Elemente beeinflußt“ ${ }^{208}$

Diese beiden äußerst unterschiedlichen Typen würden „durch kleinste Unterschiede der Gradierung ineinander übergehen" und in allen Teilen der britischen Inseln anzufinden sein. ${ }^{209}$ Es gäbe allerhöchstens signifikante Häufungen der Hellhaarigen im Westen und eine größere Häufigkeit von Dunkelhaarigen im Osten Englands. ${ }^{210}$ Huxleys evolutionäre Anthropologie ging im Unterschied zur polygenistischen Anthropologie also auch bei der Erörterung der damals virulenten Frage nach der ethnologischen Komposition der Bevölkerung der britischen Inseln von unendlich vielen Übergangsformen aus, die er allerdings nicht als Ergebnisse eines Anpassungsprozesses, sondern als Resultate einer Mischung von ursprünglich zwei, oder auch drei, Urstämmen verstand. Doch offenkundig kam es Huxley hierbei weniger auf eine konsistente

207 Vgl. Steve Garner (2004) Racism in the Irish Experience. London: Pluto Press, S. 114-139.

208 Huxley (1870a) „The Forefathers of the English People“. In: Nature 1, S. 514-515, S. 551-552: „two distinct ethnological elements probably coexisted in these islands when the country was discovered by the Romans; and the subsequent invasions $[\ldots]$ have not introduced any new stock, but have merely affected one or other of the preexisting elements“. ,Stock“ einfach mit dem Begriff des Stamms zu übersetzen, hätte die Gefahr einer Verwechslung mit dem verbreiteten und ethnologische aufgeladenen Begriff des Stamms bedeutet. Mit der hier gewählten Formulierung ,Urstamm“ soll einer möglichen Verwechslung vorgebeugt werden.

209 Huxley 1870a, S. 514: „they pass into one another by every shade of gradation".

210 Vgl. Huxley 1870a, S. 514. 
Bestimmung einer Zahl der Urstämme an, als auf die Zurückweisung der Behauptung distinkter, unvermischter Rassen.

\section{Anthropological Society und Evolutionstheorie}

Daß die Anthropological Society kurz nach ihrer Gründung noch versucht hatte, Evolutionstheoretiker wie Huxley und Darwin für sich zu gewinnen, mag eher Ausdruck taktischen Kalküls als inhaltlicher Affinität gewesen sein, denn zur gleichen Zeit geißelte Hunt in seinem Aufsatz „Man's Place in Nature“ Huxleys These der evolutionären Verbindung zwischen Primaten und Menschen. ${ }^{211}$ Ähnlich skeptisch verhielt sie sich 1864 gegenüber einem minder prominenter Vertreter der Evolutionstheorie, Alfred Russel Wallace.

Wallace hatte vor der Anthropological Society versucht, den Ursprung der Rassen aus der Theorie der natürlichen Auslese abzuleiten. Seine Ausgangsfrage war der Gegensatz von Polygenismus und Monogenismus. $^{212}$ Er glaubte, mit Darwins Theorie der natürlichen Auslese diesen Widerspruch und das Problem des Monogenismus überwinden zu können, die Persistenz der Rassenmerkmale nicht erklären zu können. ${ }^{213}$ Allerdings basierte seine Überlegung auf der Annahme, die Entwicklung des Menschen reiche nicht nur Millionen Jahre zurück, sondern vor allem hätten sich die Rassen bereits in der frühesten Phase des Menschen durch die Wirkung der natürlichen Auslese herausgebildet. Erst danach habe der Mensch jene Fähigkeiten entwickelt, die sein heutiges Menschsein ausmachten, Sprache, Intelligenz und Empathie. Seine Intelligenz habe den Menschen in die Lage versetzt, Veränderungen der Umweltbedingungen mit einer Anpassung der Kulturtechniken zu begegnen, deshalb habe die natürliche Auslese keine Auswirkung auf die einmal herausgebildeten, vermeintlich rassischen Merkmale. ${ }^{214}$

Doch die Anthropological Society war von seinen Erläuterungen nicht überzeugt. Moniert wurden Wallace' Trennung von somatischer und sozialer Entwicklung, seine Behauptung, der Mensch könne sich an alle klimatischen Verhältnisse anpassen und seine Annahme, das Gehirn des Menschen würde sich im Lauf der sozialen Evolution verändern.

211 Vgl. Hunt 1863, S. 51.

212 Vgl. Alfred Russel Wallace (1864) „The Origin of Human Races and the Antiquity of Man deduced from the theory of ,Natural Selection“". In: Anthropological Review 2, S. clviii-clxxxvii, S. clviii: ,is man of one or many species?".

213 Vgl. Wallace 1864, S. clix, S. clxvi.

214 Vgl. Wallace 1864, S. clxv: ,in proportion as man's social, moral and intellectual faculties became developed, his physical structure would cease to be affected by the operation of ,natural selection "“. 
Hunt und andere Polygenisten nahmen Wallace' Angebot der Ausweitung des zeitlichen Horizonts auf etliche Millionen Jahre nicht an. Sie betonten statt dessen die Unveränderbarkeit von Rassen, die allein unter bestimmten Umweltbedingungen leben könnten und sicherten diese Annahme durch das Argument der Unvermischbarkeit der Rassen ab. Die hier erteilte Abfuhr wiederholte Hunt zwei Jahre später in einer Diskussion der Ansätze von Huxley und Wallace.

Huxley hatte 1865 ,elf jederzeit unterscheidbare Urstämme oder persistente Modifikationen der Menschheit" identifiziert, zwischen denen kaum Mischformen existierten und die ihre Charakteristik als distinkte Typen nicht verlören. ${ }^{215}$ Er konstruierte also eine Entstehungsgeschichte der Rassen, die vor allem die Unterschiede zwischen den Rassen über die Mechanismen der Anpassung, der Isolation und des Überlebenskampfes zu erklären versuchte. Darüber hinaus bekräftigte er seine Annahme eines gemeinsamen Ursprungs der Menschheit. ${ }^{216}$ Seine Begriffswahl führte er explizit in Abgrenzung zu den bestehenden Begriffen von ,Rasse“ oder ,Art' ein:

„Ich spreche von ,persistenten Modifikationen“ oder ,Urstämmen“ anstatt von ,Variation“ oder ,Rasse' oder ,Art', weil jeder dieser letzteren, wohlbekannten Begriffe [...] eine vorgefertigte Meinung impliziert, die jene Probleme betrifft, deren Lösung letztlich das Ziel der Wissenschaft ist, und Ethnologen sind deshalb besonders gezwungen, [...] ihre Urteile unvoreingenommen zu treffen". 217

Die Polygenisten der Anthropological Society konnten aufgrund dieser Voraussetzungen Wallace' und Huxleys Ansätze einer evolutionäre Anthropologie und ihr Versprechen, ,alles Gute der monogenistischen und der polygenistischen Schulen zu versöhnen und zu kombinieren“, nicht akzeptieren. ${ }^{218}$ Hunt berief sich in seiner Erwiderung auf Aussagen

215 Huxley (1865a) „On the Methods and Results of Ethnology”. In: [Fortnightly Review 1, S. 257-277] Collected Essays, Bd. 7, S. 209-252, S. 234: ,eleven readily distinguishable stocks, or persistent modifications of mankind". Zur ihrer vermeintlichen Vermischung vgl. ebd. S. 234, S. 238.

216 Huxley 1865a, S. 249.

217 Huxley 1865a, S. 209-210: „I speak of ,persistent modifications“ or ,stocks' rather than of ,varieties, ' or ,races, ' or ,species, ' because each of these last well-known terms implies [...] a preconceived opinion touching one of those problems, the solution of which is the ultimate object of the science; and in regard to which, therefore, ethnologists are especially bound to keep [...] their judgements freely balanced".

218 Huxley 1865a, S. 248: ,reconciling and combining all that is good in the Monogenistic and Polygenistic schools“. 
prominenter Anthropologen, die allesamt den polygenen Ursprung der Menschen, die Unmöglichkeit längerfristig stabiler Rassenmischungen und das Unvermögen des Menschen, sich an beliebige Klimata anzupassen, bekräftigten. ${ }^{219}$ Den Darwinschen Ansatz in der Anthropologie und seine Annahme eines gemeinsamen Ursprungs der Menschheit lehnte neben anderen nun auch Hermann Schaaffhausen ab. ${ }^{220}$

Die zunehmenden Angriffe der Anthropological Society auf die Theoretiker der sozialen Evolution markierten eine Verschärfung der Kontroverse, die sich bereits in der Emanzipationsdebatte angedeutet hatte. Für Hunt war bei Monogenisten und Evolutionisten in dieser Zeit neben den „religiösen Wahn“ der „Menschenrechte-Wahn“ getreten, der auf der ,gigantischen Annahme absoluter menschlicher Gleichheit" fuBe. ${ }^{221}$ War die Anthropological Society unter dem Eindruck gegründet worden, daß der Ethnological Society - aufgrund der Weiterentwicklung in den geologischen, archäologischen und entwicklungsbiologischen Wissensbeständen - der Boden ihrer christlichen Weltanschauung weggebrochen sei, so sah sie sich nur wenige Jahre später einer Ethnological Society gegenüber, die durch die Intervention des X-Clubs zumindest in ihrer Außendarstellung auf ein solides und modernisiertes wissenschaftliches Fundament gestellt worden war. Hierdurch verlor die ursprüngliche Begründung für die Gründung der Anthropological Society, an Gewicht, hatte sie sich doch als eine wissenschaftliche Abspaltung von der philanthropischen und als unwissenschaftlich dargestellten Ethnological Society empfunden.

In der Folge war die Anthropological Society deshalb gezwungen, ihre Abgrenzung von der Position der Evolutionisten stärker zu akzentuieren. Dabei versuchte sie, die ,große Frage der ,Rasse““ zu ihrem Alleinstellungsmerkmal zu entwickeln. ${ }^{222}$ Etliche Rassismushistoriker haben diesen exklusive Anspruch unhinterfragt akzeptiert und stellten die Anthropological Society als die rassistischere Gesellschaft dar. ${ }^{223}$

219 Vgl. James Hunt (1866a) „On the Application of the Principle of Natural Selection to Anthropology“. In: Anthropological Review 4, S. 320-340.

220 Vgl. Hermann Schaaffhausen (1868) „Darwinism and Anthropology“. In: Journal of the Anthropological Society 6, S. cviii-cxvii.

221 James Hunt (1867) „Address to the Anthropological Society“. In: Journal of the Anthropological Society 5, S. xlvi-lxx, S. lix: ,religious mania“, ,rights-of-man mania“, „gigantic assumption of absolute human equality“.

222 James Hunt (1866d) „On the Application of the Principle of Natural Selection to Anthropology“. In: Anthropological Review 4, S. 320-340, S. lxxviii: ,great question of ,race““.

223 Bspw. John W. Burrow (1963) „Evolution and Anthropology in the 1860's: The Anthropological Society of London, 1863-71“. In: Victorian Studies 7, S. 137-154; Stepan 1982; Stocking 1987. 
Doch dabei wird übersehen, daß der evolutionäre Ansatz Huxleys und der anderen Evolutionisten nicht weniger von verschiedenwertigen menschlichen Rassen ausging und keineswegs einem universellen Gleichheitsgrundsatz verpflichtet war, wie Hunt polemisierte.

Durch den Eintritt der Evolutionisten in den Konflikt zwischen der Ethnological Society und der Anthropological Society verlor die Anthropological Society sukzessive den Nimbus wissenschaftlicher Solidität. Ihr für viele Zeitgenossen anrüchiges Gebaren, vor allem das ihrer Abendgesellschaft, dem Cannibal Club, nahm hingegen immer mehr Raum in der öffentlichen Wahrnehmung ein. Die Evolutionisten des XClubs arbeiteten mit Erfolg auf mehreren Ebenen der Auseinandersetzung an der Marginalisierung der Anthropological Society, ohne jedoch das Ziel einer Vereinigung der beiden Gesellschaften aus den Augen zu verlieren.

\section{Vereinigung: Das Anthropological Institute}

Die Abspaltung der Anthropological Society von der Ethnological Society wurde als Schisma empfunden und als ein Hindernis für die Anerkennung der von ihnen repräsentierten Disziplinen durch die scientific community betrachtet. Zuverlässigster Indikator dieser Anerkennung war in den viktorianischen Wissenschaften die Präsenz bei der British Association. Die Etablierung einer eigenen Sektion bei den Zusammenkünften der British Association war schon für die Ethnological Society mit Schwierigkeiten verbunden und von Rückschlägen gekennzeichnet gewesen. Bereits vom Herbst 1863 an versuchte die Anthropological Society erfolglos, die Einrichtung einer anthropologischen Sektion oder die Aufnahme des Begriffs Anthropologie in den Titel einer ihrer Sektionen zu bewirken. ${ }^{224}$ Eine eigenständige anthropologische Sektion wurde erst 1884 zugelassen. ${ }^{225}$

Hunt erklärte, daß die Unterordnung der Anthropologie unter Geographie und Ethnologie der wissenschaftlichen Eigenständigkeit der

224 Vgl. Charles Carter Blake 1864b) „Report on the Anthropological Papers read at the Newcastle Meeting of the British Association for the Advancement of Science, in August and September, 1863“. In: Journal of the Anthropological Society 2, S. i-vi; Charles Carter Blake (1865) „Report on the Anthropological Papers read at the Bath Meeting of the British Association for the Advancement of Science, September 1864". In: Journal of the Anthropological Society 3, S. ii-vi; Hunt: „To the members of the British Association for the Advancement of Science“. In. RAI, A8, Suppl. 2/1.

225 Vgl. Stocking 1987, S. 254; MacLeod, Collins 1981, S. 90-95. 
Anthropologie nicht gerecht würde. ${ }^{226}$ Er berief sich dabei auch auf Huxleys Erklärung, die Ethnologie sei eine Abteilung der Anthropologie. Dennoch nutzten Lubbock und Huxley 1866 erfolgreich ihren Einfluß, um das Ansinnen der Anthropological Society, eine anthropologische Sektion zu installieren, zu verhindern. ${ }^{227}$ So wurde, auf Vorschlag Huxleys, nur eine anthropologische Subsektion innerhalb der Biologie-Sektion eingerichtet. ${ }^{228}$ Hierbei wurde nun besonders auf eine paritätische Besetzung der Gremien geachtet. Alfred Russel Wallace übernahm auf Huxleys Vorschlag hin den Vorsitz, im Vorstand wurden die Sitze zwischen den beiden Gesellschaften gleichmäßig verteilt.

Auch wenn bei der British Association dieses Schema im darauffolgenden Jahr wieder aufgegeben wurde, spornte es beide Seiten zu Anstrengungen für eine Vereinigung von Anthropological Society und Ethnological Society an. ${ }^{229}$ Man ging offenkundig davon aus, daß zum einen die nachhaltige Etablierung einer Wissenschaft des Menschen eine Vereinigung der beiden rivalisierenden Gesellschaften voraussetzte und daß zum anderen die anvisierte Vereinigung im eigenen Sinne geprägt werden könne. An diesen Ansprüchen, an wechselseitigen Vorbehalten gegenüber den Namensvorschlägen für die zukünftige Gesellschaft sowie an dem Verdacht, die Anthropological Society würde ihren finanziellen Status schönen, scheiterte dieses Anliegen zunächst.

Dabei scheint neben den vorgebrachten sachlichen Gründen der größte Widerstand gegen eine Vereinigung von den jeweiligen Einflußnahmen Hunts und Crawfurds ausgegangen zu sein. Erst nachdem Crawfurd im Mai 1868 und Hunt im Sommer des darauffolgenden Jahres gestorben waren, wurden die Verhandlungen erneut aufgenommen - und diesmal erfolgreich zu Ende gebracht. Großen Anteil daran hatte Hux-

226 Hunt: Anniversary Address delivered before the Anthropological Society of London, January 3rd, 1865. London 1865. In: RAI A8, Suppl. $2 / 2$.

227 Vgl. Stocking 1987, S. 254.

228 Vgl. Charles Carter Blake (1867) „Report on the Anthropological Papers read at the Nottingham Meeting of the British Association for the Advancement of Science, 1866". In: Journal of the Anthropological Society 5, S. iv-viii.

229 Vgl. Lubbock an Huxley, 16. September 1866. In: HP 22, f. 67; James Hunt an Huxley, 06. Oktober 1866. In: HP 18, f. 334-338, James Hunt an Huxley, 12. Oktober 1866. In: HP 18, f. 339-342; Huxley an James Hunt, 16. Oktober 1866. In: HP 343; James Hunt an Huxley, 28. Mai 1869. In: HP 33, f. 3-4; Huxley an James Hunt, 29. Mai 1869. In: HP 33, f. 5; James Hunt an Huxley, 30. Mai 1869. In: HP 33, f. 6-9; John Frederick Colingwood an Huxley, 18. Januar 1871. In: HP 12, f. 278-279; Huxley an Colingwood, 19. Januar 1871. In: HP 33, f. 280; Colingwood and Huxley, 23. Januar 1871. In: HP 33, f. 281-282. 
ley, der Crawfurds Amt des Präsidenten der Ethnological Society übernommen hatte. ${ }^{230}$ Er leitete umgehend Vorbereitungen für die Vereinigung der beiden Gesellschaften ein. ${ }^{231}$

Im Januar 1871 nahm das Anthropological Institute of Great Britain and Ireland seine Tätigkeit auf. Auch wenn sein Vorstand paritätisch besetzt wurde, hielten dennoch die Evolutionisten von Beginn an die Schlüsselpositionen des Sekretärs und des Präsidenten besetzt. Auf Lubbock als ersten Präsidenten konnten sich auch die Mitglieder der Anthropological Society verständigen, die Huxley in diesem Amt noch abgelehnt hatten. ${ }^{232}$ In den beiden darauffolgenden Amtsperioden bekleidete Busk diese Position. Ihm folgten profilierte Anthropologen, die bereits unter dem Evolutionsparadigma arbeiteten. Busk und Huxley waren in den ersten beiden Jahren Vizepräsidenten. Das Anthropological Institute stand so nahezu unangefochten im Zeichen einer evolutionären Anthropologie. Ein einziger - allerdings erfolgloser - Versuch war zu verzeichnen, polygenistische Akzente durchzusetzen. Die ohnehin wenig einflußreichen Dissidenten gründeten noch in der Niederlage eine eigene London Anthropological Society. Doch nach weniger als zwei Jahren wurden sie wieder in die Reihen der Mitglieder des Anthropological Institutes aufgenommen. $^{233}$

Mitte der siebziger Jahre des neunzehnten Jahrhunderts war das Anthropological Institute eine gefestigte Organisation und die Mitglieder des X-Clubs zogen sich aus den leitenden Ämtern zurück. Ihre Intervention kann nach knapp zehnjähriger Auseinandersetzung als die mit dem größten und eindeutigsten Erfolg gekrönte wissenschaftspolitische Kampagne des X-Clubs betrachtet werden. Die Überwindung des Schismas in der Anthropologie, die nur über die Etablierung der Evolutionstheorie als einen die Beschränkungen der alten Ansätze überwindenden epistemischen Rahmens bewerkstelligt werden konnte, löste zugleich auch die Reputationskrise der Anthropologie und ebnete ihr den Weg, den Status einer anerkannten Wissenschaft zu erlangen.

Zwar diskutiert George Stocking einen Fortbestand des Polygenismus in der postdarwinianischen Anthropologie, doch seine Beispiele stammen aus Kontinentaleuropa und den Vereinigten Staaten. ${ }^{234}$ Wäh-

230 Vgl. RAI, A1, f. 346, f. 347.

231 Vgl. RAI, A1, f. 347, f. 348.

232 Vgl. Huxley an Lubbock, 22. Januar 1871. In: AP ADD 49643, f. 141142; Lubbock an Huxley, 26. Januar 1871. In: AP ADD 49643, f. 148.

233 Vgl. Stocking 1971, S. 384.

234 Vgl. Stocking, George W. (1968a) „French Anthropology in 1800”. In: Ders. (Hrsg.): Race, Culture and Evolution. Essays in the History of Anthropology. New York: Free Press, S. 13-41; Stocking (1968b) „The 
rend in der französischen Anthropologie noch lange nach 1860 polygenistische Ansätze institutionell verankert waren, ${ }^{235}$ zeigte sich der deutsche anthropologische Diskurs, in dem wie in Frankreich ab 1863 Darwins Theorie intensiv rezipiert wurde, stärker von der vordarwinschen, philosophischen Anthropologie geprägt, was insbesondere die Schriften Matthias Jacob Schleidens oder Ernst von Baers kennzeichnet. ${ }^{236}$ Die britische Anthropologie stand zudem, anders als etwa die deutsche, deutlicher im Zeichen der Debatte um Emanzipation und Sklaverei, weshalb die Institutionalisierung der evolutionären Anthropologie mit der Grenzziehung zwischen wissenschaftlicher Systemrationalität und politischen, außerwissenschaftlichen Diskursen einherging.

\section{Resümee}

Die Evolutionisten führten ihre wissenschaftliche Rationalität derart massiv in die Agenda der Ethnological Society ein, daß die Glaubensgrundsätze und politischen Überzeugungen, gegen die sich die Anthropological Society anfangs als rein wissenschaftliche Unternehmung abzugrenzen versuchte, deutlich an Gewicht verloren.

Das Engagement der Evolutionisten bei der Ethnological Society stellte für manchen Historiker ein Paradoxon dar, da es ja die Anthropological Society war, die sich anfangs als die wissenschaftlichere Organisation präsentierte. Doch dieser Umstand erklärt sich durch persönliche Beziehungen wie Lubbocks Verbindungen zu führenden Köpfen der Ethnological Society und dadurch, daß Huxley bereits Konflikte mit führenden Vertretern der Anthropological Society ausgefochten hatte.

George Stocking und mit ihm weitere Anthropologie-Historiker führten zusätzlich und zum Teil mit viel Gewicht andere Ursachen an, etwa Hunts erklärte Ablehnung der Theorie Darwins oder die Frage des wissenschaftlichen Stils. ${ }^{237}$ Doch die von vielen Zeitgenossen als skandalös empfundene Selbstinszenierung der Anthropological Society ent-

Persistence of Polygenist Thought in Post-Darwinian Anthopology“. In: Ders. (Hrsg.): Race, Culture and Evolution. S. 42-68.

235 Vgl. auch Elizabeth A.Williams (1985) „Anthropological Institutions in Nineteenth-Century France“. Isis 76, S. 331-348; George W. Stocking (2001) Delimiting Anthropology: Occasional Essays and Reflections. Madison, Wisc.: University of Wisconsin Press, S. 207-217.

236 Vgl. Breidbach u.a. 2004; Hoßfeld 2005, S. 78-106.

237 Vgl. Stocking 1987, S. 249; Conrad C. Reining (1962) „A Lost Period of Applied Anthropology“. In: American Anthropologist 64, S. 593-600; Rainger 1978, S. 59. Auf Stockings Überlegung beziehen sich auch andere Autoren, die den Antagonismus zwischen Anthropological und Ethnological Society behandeln (vgl. Desmond 1998, S. 343; Rainger 1978, S. 65). 
wickelte sich erst im Laufe der Jahre, und Hunt äußerte sich erst ab Mitte der sechziger Jahre explizit gegen Darwin und dessen Theorie der natürlichen Auslese. Zu diesem Zeitpunkt aber waren Huxley, Lubbock und Busk bereits mehrere Jahre aktive Mitglieder in leitenden Positionen der Ethnological Society. ${ }^{238}$

Der Graben mag sich durch derartige Ereignisse und Erklärungen vertieft haben, sie boten hingegen kein Motiv für die Evolutionisten, sich gegen die Anthropological Society zu engagieren. Das Argument, der Stil der Anthropological Society hätte die Evolutionisten gegen sie eingenommen, wird außerdem durch das von Huxley während seiner Präsidentschaft der Ethnological Society wieder eingeführte Verbot der Teilnahme von Frauen an deren Sitzungen unterlaufen, denn dabei orientierte man sich, wie Evelleen Richards darlegt, explizit am Verfahren der Anthropological Society. ${ }^{239}$

Die Klärung der Frage, warum sich die Evolutionisten der Ethnological Society und nicht der Anthropological Society anschlossen, läßt aber die bedeutendere Frage unbeantwortet, warum sie überhaupt in diese Auseinandersetzung eingriffen. Die Notwendigkeit dieser arbeitsintensiven Maßnahme läßt sich nur im Kontext der anderen Interventionsfelder des X-Clubs erklären. Wie Huxley erklärte, war die Anwendung der Evolutionstheorie auf die Anthropologie der Prüfstein ihrer grundsätzlichen Stichhaltigkeit. ${ }^{240}$ Zur Durchsetzung der Evolutionstheorie im anthropologischen Diskurs war aber mehr als in der Öffentlichkeit prominent plazierte Kontroversen erforderlich, wie etwa mit Owen oder Argyll. Sie setzte die Kontrolle der institutionalisierten Anthropologie voraus. Auf diese Notwendigkeit wurden die Evolutionstheoretiker des X-Clubs spätestens durch die Abspaltung der Anthropological Society von der Ethnological Society aufmerksam gemacht.

In institutioneller Hinsicht erfolgte ihre Intervention in die anthropologische Debatte deshalb unter der Maßgabe der Vereinigung der beiden Gesellschaften, um Einheitlichkeit der Anthropologie im Zeichen des Evolutionsparadigmas herzustellen. In theoretischer Hinsicht zielten die Auseinandersetzungen und Kampagnen auf eine Überwindung der beiden durch diese Gesellschaften repräsentierten Ansätze der Anthropologie, auf die Überwindung von Monogenismus und Polygenismus.

238 Stocking und Rainger zitieren selbst aus Texten Hunts die aus dem Jahr 1866 (Hunt 1866a, bei Rainger 1978, S. 55-56) und dem Jahr 1868 stammen (James Hunt (1868) „Presidential Address“. In: Anthropological Review 6, S. 72-79, bei Stocking 1971, S.378).

239 Vgl. Evelleen Richards 1989, S. 275.

240 Vgl. Huxley 1865a, S. 252. 


\subsection{Zusammenfassung}

In den in diesem Abschnitt behandelten wissenschaftspolitischen Kontroversen ging es um die Einführung des Evolutionsparadigmas in die Rassentheorien und um die soziale wie institutionelle Seite dieser wissenschaftlichen Revolution. Sie war ersichtlich nicht das Ergebnis einer bloß diskursiven Verkopplung, sondern das Resultat konkreter Interventionen der prominentesten Evolutionstheoretiker. Das Eingreifen des XClubs, vor allem Huxleys, in die Debatten um die Mensch-Primaten-Beziehung und um den Neandertaler stellte den Ausgangspunkt der evolutionären Anthropologie dar. Die Evolutionstheoretiker hatten erkannt, $\mathrm{da} ß$ die universelle Etablierung der Evolutionstheorie ihre erfolgreiche Applikation in der Theoriebildung über den Ursprung des Menschen, über seine Beziehung zur Natur und über die Ursachen der körperlichen wie der sozialen Unterschiede zwischen den Menschen voraussetzte. In diesen Debatten wurde die evolutionstheoretische Integration des Menschen in die Natur demonstriert und damit einer evolutionären Anthropologie der Boden bereitet.

Da aufgrund der Kontroverse über die Evolutionstheorie dem ohnehin schon krisenhaften anthropologischen Diskurs der traditionelle Bezugsrahmen weggebrochen war, entstand eine Situation methodischer wie theoretischer Orientierungslosigkeit, die sich in der Teilung von Anthropological Society und Ethnological Society entlud.

Die Konfliktführung des X-Clubs zeichnete sich durch eine bemerkenswerte Variabilität aus. Die Auseinandersetzungen mit Wilberforce und Owen verlagerte Huxley öffentlichkeitswirksam auf die Ebene von Wissenschaftlichkeit und Professionalität, die Debatte über den Neandertaler wurde hingegen strikt auf die Ebene eines wissenschaftlichen Theoriekonfliktes begrenzt. In der Kontroverse über Gouverneur Eyre konnten Tyndall und Huxley ihre Meinungsverschiedenheit als rein politische Frage isolieren, von den gemeinsamen Projekten des X-Clubs trennen und ihre Eskalation vermeiden. Anders, als Jahre später bei Huxleys Streit mit Spencer, der in der Öffentlichkeit geführt wurde.

Eine Eskalation, wie noch gegen Owen und Wilberforce, war gegen die polygenistischen Anthropologen in der frühen Neandertalerdebatte nicht nötig, da sie zu diesem Zeitpunkt noch kein institutionelles Hindernis für die wissenschaftspolitischen Ziele des X-Club darstellten. Diesen Zielen ordneten die X-Club-Mitglieder in den sechziger Jahren auch ihre politischen Differenzen unter. Selbst wenn ein Konflikt eine offen politische Dimension aufwies, wurde diese nach Möglichkeit betont von seiner theoriebildenden Dimension getrennt. Grundsätzlich nahmen sie einen Gestus der Entpolitisierung der Anthropologie an, mit- 
tels dessen sie die Autonomie der Systemrationalität der Wissenschaft festigen wollten. Für die Anerkennung der Anthropologie als Wissenschaft durch die scientific community war diese Betonung einer rein wissenschaftlich und nicht politisch motivierten Anthropologie elementar.

In den sowohl theoriebildenden als auch wissenschaftspolitischen Interventionen des X-Clubs entwickelten seine Mitglieder die verschiedenen Elemente einer evolutionären Anthropologie. Der Begriff der Rasse wurde in der hippocampus-minor-Debatte vergleichend-anatomisch zum Begriff der Art ins Verhältnis gesetzt. Er wurde in der Neandertaler-Diskussion mit einem Verständnis progressiver physischer Evolution versehen. Rassen wurden, vor allem von Lubbock in seiner Auseinandersetzung mit Argyll, als Kulturträger und deren Evolution als in der Regel progressiv definiert. Und Rassen wurden im Kontext der Auseinandersetzungen mit dem Polygenismus der Anthropological Society als Differenzierungs- und Mischprodukte der einen Spezies Mensch definiert.

Die evolutionären Anthropologen des X-Clubs führten die sozialen Unterschiede zwischen vermeintlichen Rassen auf Entwicklungen zurück, deren physische und kulturelle Komponenten sie zu einer Theorie sozialer Evolution verschmolzen. Die Hervorhebung entwicklungsbedingter Unterschiede stellte dabei die Unterschiede selbst aber keinesfalls in Frage. Ungeachtet ihrer Betonung eines gemeinsamen Ursprungs der Menschheit waren die evolutionären Rassentheorien also keineswegs egalitaristischer als ihre traditionellen Vorläufer. Zwar verhielten sie sich zu Emanzipationsforderungen kompatibler als etwa der Polygenismus, doch Huxleys Erklärung, daß aufgrund der geringeren Intelligenz der Schwarzen die soziale Ungleichheit erhalten werde, zeigt, daß die Annahme einer Ungleichwertigkeit der Rassen elementar für den Ideenhaushalt der evolutionären Rassentheorien war.

Die effektive Implementierung einer evolutionären Interpretation der Rassenthematik wird vielleicht durch Darwins Descent of Man am deutlichsten. Darwin hatte davon Abstand genommen, im Origin of Species die Frage der Bedeutung seiner Theorie für den Menschen zu erörtern. Diese Diskussion holte er zwölf Jahre später in Descent of Man nach. Dieses Buch sollte aber nicht als eine logische Folge aus Darwins Origin of Species verstanden werden. ${ }^{241}$ Es war, darauf haben Bowler und andere hingewiesen, von vielfachen Rückgriffen auf den anthropologischen und ethnologischen Diskurs der Jahre zuvor gekennzeichnet. ${ }^{242}$

241 Vgl. bspw. H. James Birx (1998) „Introduction“. In: Charles Darwin: The Descent of Man and Selection in Relation to Sex. [1874²] New York: Prometheus Books, S. ix-xxviii, S. ix-x.

242 Vgl. Bowler 1989, S. 94-96. 
Darwin berief sich explizit auf die Ergebnisse der Forschung Huxleys und Lubbocks. ${ }^{243}$ Grundsätzlich hielt er den Polygenismus wie den Monogenismus für überwunden und er erklärte unmißverständlich: ,,alle Rassen des Menschen sind Nachkommen von einem einzigen, ursprünglichen Urstamm“. ${ }^{244}$ Descent of Man markierte eine Diskursverschiebung in den Rassentheorien, die es ihm erst ermöglichte, jene Leerstelle zu schließen, die er 1859 noch bewußt in Kauf genommen hatte. Diese Diskursverschiebung ging im wesentlichen auf die Interventionen des X-Clubs zurück.

Der X-Club focht seine Kampagne zur Etablierung des Evolutionsparadigmas in den Rassentheorien in der gesamten Bandbreite des damaligen anthropologischen Diskurses aus. Es wurden einerseits die sozialen und institutionellen Strukturen modifiziert, in denen die Produktion, Entwicklung und Fortschreibung des anthropologischen Wissens verankert war. Andererseits wurden im sozialen Feld der Wissenschaften vorevolutionstheoretische und antievolutionstheoretische Sichtweisen samt ihrer Befürworter marginalisiert.

Diese Aktivitäten waren die Rahmenbedingungen für eine theoretische Modernisierung der Rassentheorien. In den wissenschaftlichen Kontroversen und wissenschaftspolitischen Auseinandersetzungen entwickelten die Evolutionstheoretiker des X-Clubs umfangreiche Werke, in denen sie ihre evolutionstheoretische Neujustierung des Rassenbegriffs fortsetzten. Diese Textproduktion abseits wissenschaftspolitischer Turbulenzen wird im folgenden Abschnitt auf die Konstruktion eines evolutionären Rassenbegriffes hin untersucht.

243 Vgl. Darwin 1998b, S. 6 und S. 132.

244 Darwin 1998b, S. 183: ,all the races of man are descended from a single primitive stock". 


\section{Evolution und Rassentheorien}

Nachdem im zweiten Abschnitt der evolutionstheoretische Paradigmawechsel in den Naturwissenschaften ins Verhältnis zum X-Club gesetzt wurde und im dritten Abschnitt die wissenschaftspolitische Intervention des X-Clubs für den evolutionstheoretischen Paradigmawechsel in der Anthropologie sowie die Bedingungen ihrer institutionellen Modernisierung diskutiert wurden, soll in den Kapiteln dieses Abschnitts die theoretische Seite der Transformation der Rassentheorien untersucht werden.

Die evolutionären Rassentheorien der Akteure des X-Clubs werden in Hinblick auf ihre Prägung und Verwendung des Begriffs Rasse, auf die Logik ihrer Erklärungen sozialer Unterschiede durch biologische Ursachen und auf Wesen und Reichweite ihres spezifisch evolutionstheoretischen Zuschnitts untersucht. Darüber hinaus wird in diesem Abschnitt herausgearbeitet, inwieweit die evolutionären Rassentheorien eine der institutionellen Modernisierung der Anthropologie entsprechende theoretische Modernisierung darstellten und auf welcher Ebene diese Modernisierung vor allem vollzogen wurde. Hierfür wird insbesondere die Fortschreibung vorevolutionärer rassentheoretischer Versatzstücke und tradierter Stereotype untersucht und analysiert, welche Bedeutung diese Altbestände für die evolutionären Rassentheorien hatten.

Die Untersuchung beschränkt sich grob auf jenes Vierteljahrhundert, das zwischen Spencers erstem Buch von 1851 und der Mitte der siebziger Jahre des neunzehnten Jahrhunderts liegt. ${ }^{1}$ In diesem Zeitraum voll-

1 Spencer hat zwar wesentliche und gesellschaftstheoretisch relevante Teile seiner Synthetic Philosophy noch in den Jahren danach veröffentlicht, doch finden sich in den späteren Bänden der Principles of Sociology oder den Principles of Ethics keine substantiellen Veränderungen seiner Rassenkonzeption. Darum werden seine Schriften des späten neunzehnten Jahrhunderts nur an wenigen Punkten aufgegriffen. 
zog sich im wesentlichen die Durchsetzung der Evolutionstheorie. Ihre erfolgreiche Implementierung markiert zugleich das Ende der Intervention des X-Clubs in die Anthropologie und seinen einsetzenden Bedeutungsverlust als Mittel zur Orchestrierung wissenschaftspolitischer Kampagnen. Spencer war in den Kampagnen seiner X-Club-Gefährten kaum in Erscheinung getreten. Dennoch war er für die Etablierung der Evolutionslehre in den Wissenschaften und vor allem für ihre Verankerung im öffentlichen Diskurs von zentraler Bedeutung. Dies gilt in noch größerem Maße für die sich zu jener Zeit ausdifferenzierenden und institutionalisierenden Human- und Sozialwissenschaften. Hier muß seine Soziologie nicht nur als ein die Disziplin erheblich prägendes Werk, sondern auch als der vollständigste Entwurf einer Theorie der sozialen Evolution gelten.

Spencer Rassentheorie war sicherlich aufgrund seiner Popularität unter seinen Zeitgenossen nicht minder einflußreich als die Huxleys. Aber gerade ihrer Unabhängigkeit vom Wissenschaftlichkeitsdiskurs in der Anthropologie wegen kann sie auch als Indikator für die Reichweite der Modernisierungsbestrebungen Huxleys, Lubbocks und Busks herangezogen werden.

\section{1 „Widely Contrasted Forms of the Human Cranium". Der Rassenbegriff in der Anthropologie Thomas Henry Huxleys}

Auslöser für Huxleys anthropologische Forschung war die Kontroverse um die Evolutionstheorie Anfang der sechziger Jahre des neunzehnten Jahrhunderts. Zwar hatte er bereits Ende der vierziger Jahre in seinen Aufzeichnungen an Bord der Rattlesnake etliche Begegnungen mit Australiern und Papua-Insulanern festgehalten. Aus diesen Notizen entwickelte sich jedoch kein ethnologisches Interesse, und zurück in London arbeitete Huxley an anatomischen Studien von wirbellosen Tieren und trieb seine naturwissenschaftliche Karriere voran. Das wissenschaftliche Interesse am Menschen wurde also nicht durch die Begegnung mit vermeintlich primitiven Einwohnern Australiens, sondern durch einen Theoriekonflikt ausgelöst. $^{2}$

2 Julian Huxley irrt deshalb, wenn er erklärt, daß diese Begegnungen ein Forschungsinteresse bei seinem Großvater initiiert hätten (vgl. Julian Huxley 1936, S. 125). 


\section{Anthropometrie}

In den Debatten um das Verhältnis des Menschen zum Neandertaler und zu den Menschenaffen hatte Huxley bereits implizit eine vergleichendanatomische Rassentheorie entworfen. Diesen Kern baute er in den Folgejahren zu einer komplexen anthropometrischen Methodologie aus. Nun ging es nicht mehr um die Bestimmung des Platzes des Menschen in der Natur, sondern um die Entwicklung einer meßtechnisch fundierten Taxonomie der Menschenrassen und um die Generierung von Aussagen über mögliche Entwicklungsbeziehungen zwischen den Rassen. Huxley entwickelte dieses Programm vor dem Hintergrund einer in die Krise geratenen Anthropologie, in der verschiedene, zum Teil gegenläufige anthropometrische Verfahren nebeneinander existierten und eine methodische Orientierungslosigkeit ausdrückten.

Angesichts einer geschwächten anthropologischen Methodologie versuchte Huxley, drei anthropometrische Maße für seine physische Anthropologie kombiniert einzusetzen: den Gesichtswinkel, das Kranialvolumen und den Kranialindex. ${ }^{3}$ Dafür schlug er vor, den Gesichtswinkel Campers zu modifizieren. Der beruhe auf allzu variabel konstruierten Achsen, ihm fehle eine feste Bezugsgröße, eine stabile Basiskranialachse. ${ }^{4}$ Mit ihr meinte er, eine solidere Basis für die Identifikation der als „orthognathisch“ und „prognathisch“ charakterisierten Gegensätze gefunden zu haben. ${ }^{5}$ Auch Retzius' Kranialindex nahm Huxley in modifizierter Form in seine Methodologie auf. Außerdem bezog er sich auf Thurnams Differenzierung der ursprünglichen Grobeinteilung von brachykephalisch und dolichokephalischen Schädeln und

3 Vgl. Huxley (1862b) „A Lecture on the Fossil Remains of Man, delivered at the Royal Institution, Feb. 7th 1862“. In: The Lancet, 15. Februar, S. 166-167; Di Gregorio 1984, S. 148.

4 Vgl. Huxley 1862d, S. 192: „,no comparison of crania is worth very much that is not founded upon the establishment of a relatively fixed base line, to which the measurements, in all cases, must be referred“. Huxley verweist darauf, daß diese Basislinie mit aufsteigender Ordnung immer kürzer werde, auch im Verhältnis zum darüber sich aufwölbenden Schädelinnenraum. 1867 veröffentlichte Huxley einen Bericht, in dem über fünfzig Einzelmessungen und -Werte aufgelistet sind, die er zu seiner Bestimmung des Charakters der Schädel durchführte (vgl. Huxley (1867) „On Two Widely Contrasted Forms of the Human Cranium“. In: [Journal of Anatomy and Physiology 1, S. 66-70] The Scientific Memoirs of Thomas Henry Huxley, Bd. 3, S. 214-230, S. 221-223). Am entscheidensten ist für ihn aber dennoch der kephalische Index, das simple Verhältnis von Breite und Länge des Schädels, mittels dessen er die beiden Schädel mit anderen vergleicht (S. 224-225); vgl. Di Gregorio 1984, S. 151.

5 Vgl. Huxley 1862d, S. 189-191. 
führte nun neben runden und langen Schädeln, ovale (,orthocephalic“) und überlange (,,mecistocephalic“") Schädel ein. ${ }^{6}$ Die Kernfrage, deretwegen Huxley all diese Überlegungen überhaupt lohnenswert erschienen, lautete:

„können wir zwischen den niedrigsten und den höchsten Formen des menschlichen Kraniums irgendein Äquivalent entdecken [...] zur Revolution der Seiten- und Deckenknochen des Schädels auf der Basiskranialachse, die wir bei der Abfolge der Säugetiere so deutlich erkennen können? Zahllose Beobachtungen lassen mich glauben, daß wir diese Frage bejahen müssen“" ${ }^{7}$

Huxley illustrierte seine Hypothese durch Schädelvergleiche zwischen Biber und Pavian einerseits und Menschenschädeln andererseits (vgl. Abb. 2 und Abb. 3).

Abb. 2. Huxley: Evolution der Schädelproportionen bei Säugetieren.... ${ }^{8}$

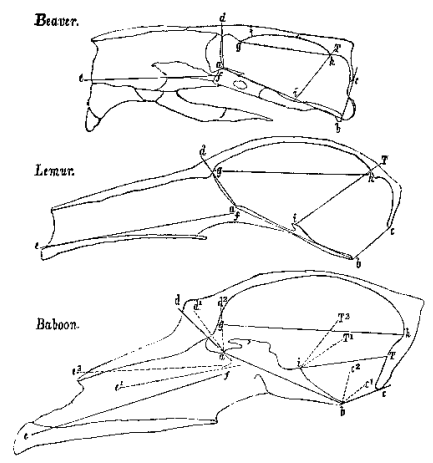

Abb. 3. ... und beim Menschen

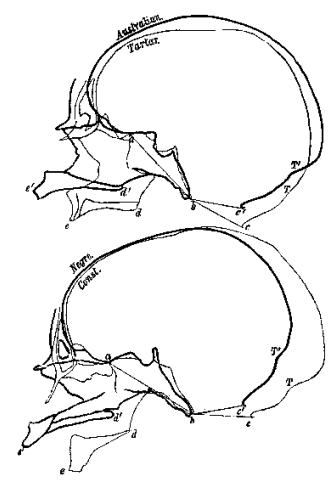

6 Vgl. Huxley 1866a, S. 83-85.

7 Huxley 1862d, S. 195-197: „Now comes the important question, can we discern, between the lowest and the highest forms of the human cranium anything answering [...] to this revolution of the side and roof bones of the skull upon the basicranial axis observed upon so great a scale in the mammalian series? Numerous observations lead me to believe that we must answer this question to the affirmative".

8 Abb. 2: Fig. 29. In: Huxley 1862d, S. 193: „Longitudinal and vertical sections of the skulls of a Beaver [...], a Lemur [...], and a Baboon“; Abb. 3: Fig. 30. In: Huxley 1862d, S. 196: „Sections of orthognathous (light contour) and prognathous (dark contour) skulls“. 
Eine evolutionäre Aufwärtsentwicklung der Säugetierschädel voraussetzend, verglich er Querschnitte von Menschenschädeln, um eine entsprechende Entwicklung der Schädelproportionen aufzuzeigen. Zum einen legte er das Profil eines Australiers mit dem eines Tartaren übereinander, zum anderen das eines „Negers“ mit dem Schädelprofil einer „unklaren Rasse“ aus Konstantinopel. ${ }^{9}$ Aus dieser Gegenüberstellung, so Huxley, würde ersichtlich, daß die prognathischen Schädel, als die er den australischen und den Schädel des ,Negers ' betrachtete, sich von den orthognathischen auf die gleiche Weise unterschieden, wenn auch geringfügiger, wie die Schädel der niederen Säugetiere von den menschlichen Schädeln. ${ }^{10}$

Indem Huxley explizit einen Vergleich von niederen Säugetierschädeln mit Menschenschädel anstrengte, verband er die in den Graphiken noch separat behandelten Entwicklungsreihen. Zum einen konstruierte er so ein evolutionäres Entwicklungsmuster von durch signifikante Schädelprofile gekennzeichneten Rassen. Zum anderen implizierte dieses Modell die Vorstellung einer progressiven Entwicklung, da es die normative Dimension der Begriffe ,niedrig ' und ,höher' integrierte, mit denen Huxley die Schädel der Säugetiere charakterisiert hatte.

Die überwiegende Zahl der anthropologischen Theorien zielte nicht nur auf eine Bestimmung des Verhältnisses von Mensch und Natur und auf eine Erklärung der physischen Unterschiede der Menschen ab, sondern versuchte zugleich, diese Unterschiede in ihrer räumlichen Verteilung zu erfassen und zu erklären. Auch Huxley beschäftigte sich mit dieser Kernfrage des anthropologischen Diskurses. Obwohl eine hinreichende Datenbasis noch fehlen würde, meinte er, eine geographische Verteilung physischer Charakteristika der Rassen skizzieren zu können: ${ }^{11}$

„Zeichne eine Linie, von der Goldküste Westafrikas zu den tartarischen Steppen auf einen Globus. Am südlichen und westlichen Ende leben die am meisten dolichokephalischen, prognathischen, kraushaarigen, dunkelhäutigen Menschen - die wirklichen Neger. Am nördlichen und östlichen Ende dieser Linie leben die am meisten brachykephalischen, orthognathischen, glatthaarigen,

9 Vgl. Huxley 1862d, S. 197 („Negro“, „uncertain race“).

10 Vgl. Huxley 1862d, S. 197-198: „It appears, at once [...] that the prognathous skulls $[\ldots]$ do really differ from the orthognathous in much the same way as though to a far less degree than, the skulls of the lower mammals differ from those of Man“.

11 Huxley 1862d, S. 199: „I do not think we shall have any very safe basis for the ethnological craniology which aspires to give the anatomical characters of the crania of the different Races of Mankind“. 
gelbhäutigen Menschen - die Tartaren und Kalmücken. Die beiden Enden dieser imaginären Linie sind in der Tat ethnologische Antipoden“. ${ }^{12}$

Huxley erklärte, daß die Habitate dieser ,gegensätzlichen Rassen“ selbst starke Kontraste zueinander darstellten. ${ }^{13}$ Zwar führte er diesen Zusammenhang von Klima und Schädelform nicht weiter aus, doch seine Betonung dieser parallelen Gegensätze knüpfte an die seit der Akklimatisierungsthese im Rassendiskurs verbreiteten Assoziationen der Klimate mit Zivilisationsleistung und Charakter an. ${ }^{14}$ In der Mitte der von Huxley gedachten Linie fänden sich Rassen, in denen diese Eigenschaften in unterschiedlichsten Zusammensetzungen aufträten. ${ }^{15}$ Von Zentralasien in Richtung Australien würden dann sukzessive jene physiognomischen Merkmale deutlicher hervortreten, die den „Negrito“-Typ charakterisierten: vorstehender Kiefer, dunkle Haut, glattes Haar. ${ }^{16}$ Huxleys Modell der geographischen Verteilung körperlicher Merkmale basierte auf der Annahme eines Spektrums von Rasseneigenschaften, das zwischen den Extremen eine unendliche Anzahl von Übergangsformen aufwies.

Angekommen beim Australier, griff Huxley einen anderen Aspekt seiner anthropologischen Studien auf, die Frage des Verhältnisses von Mensch und Neandertaler. Obwohl er zunächst erklärte, daß viele aust-

12 Huxley 1862d, S. 199: „Draw a line on a globe, from the Gold Coast in Western Africa to the steppes of Tartary. At the southern and western end of that line there live the most dolichocephalic, prognathous, curly-haired, darkskinned of men - the true Negroes. At the northern and eastern end of the same line there live the most brachycephalic, orthognathus, straighthaired, yellow-skinned of men - the Tartars and Calmucks. The two ends of this imaginary line are indeed, so to speak, ethnological antipodes".

13 Vgl. Huxley 1862d, S. 200: „damp, hot, steaming“, „bitterly cold in winter".

14 Cyril Bibby (1972, S. 142) hält diese gedachte Landkarte für einen „,very modern view of human variation, so unlike the racialist theorising of many scientists during succeeding decades“. Bibby schreibt in den frühen Siebzigern und orientiert sich an der damals gängigen Rassismus-Definition, nach der Rassismus die Ableitung sozialer Ungleichheit aus dem Tatbestand der nun mal bestehenden Rassen darstellt. Nur wurde seine Einschätzung von nachfolgenden Huxley-Forschern bisher nicht korrigiert.

15 Vgl. Huxley 1862d, S. 199: „A line drawn at right angles, or near so, to this polar line through Europe and Southern Asia to Hindostan, would give us a sort of equator, around which round-headed, oval-headed, and oblong-headed, prognathous and orthognathous, fair and dark races - but non possessing the excessively marked characters of Calmuck or Negro group themselves".

16 Vgl. Huxley 1862d, S. 200: ,the projecting jaws, and the dark skin reappear; with so much departure, in other respects, from the Negro type, that ethnologists assign to these people the special title of ,Negritoes ““. 
ralische Schädel in ihrer Form dem „Durchschnitt jeder anderen Rasse“ glichen, ${ }^{17}$ entdeckte er noch einen anderen Schädeltyp, anhand dessen er die evolutionäre Verbindung zum Neandertaler zu rekonstruieren versuchte. Doch die Ähnlichkeit war nicht ohne zusätzliche Vorkehrungen zu erkennen, und deshalb erklärte er, daß beide Schädel sich nur gleichen würden, zöge man den australischen ein wenig in die Länge, flache ihn etwas ab, und vergrößere entsprechend die Augenbrauenwulst. ${ }^{18}$

Huxley griff hier zu einer kühnen Konstruktion. Hätte er die anatomische Differenz zu quantifizieren versucht, wäre deutlich geworden, daß jeder beliebige Schädel durch mehr oder weniger geringfügige Modellierung in Gedanken dem Neandertalerschädel hätte angeglichen werden können. Zwar findet sich in allen anthropometrischen Maßen ein konstruktives Moment, durch das der Zusammenhang von sozialen Eigenschaften und körperlichen Merkmalen hergestellt wird. Dies wird allein schon an der Willkürlichkeit deutlich, mit der die Schädel zur Exemplifizierung der nachzuweisenden Entwicklung ausgewählt werden.

Standards der Wissenschaftlichkeit, um deren Etablierung Huxley sich sowohl in den Naturwissenschaften als auch in der Anthropologie engagiert bemühte, waren zur Plausibilisierung derart angestrebter Befunde, insbesondere vor dem Hintergrund der Krisenhaftigkeit der Anthropologie, notwendig. Um die Annahme einer evolutionären Entwicklung des Menschen zu untermauern, wofür die Behauptung einer neandertalerähnlichen Physiognomie der Australier diente, hatte Huxley aber die wissenschaftlichen Standards aufgegeben, deren Bedeutung er zuvor, wie bei der Argumentation für die Basiskranialachse, noch betont hatte. Er hatte eine evolutionäre Entwicklung zwischen Australier und Europäer schon bei der Übereinanderprojizierung der Schädelprofile konstruiert. Hier nun ging es ihm aber um den Nachweise einer engen Homologie, für den seine Meßmethoden nicht hinreichten. Anstatt diese Unzulänglichkeit zum Anlaß kritischer Methodenreflektion zu nehmen, spornte sie ihn an, das knöcherne Kranium gedanklich in den Zustand erhöhter Plastizität zu versetzen, um seine Primitivitätsvermutung untermauern zu können. Damit bewies er aber vor allem die Formbarkeit seiner Wissenschaftsstandards, die sich dem Erkenntnisinteresse, aus dem heraus sie entstanden waren, unterordneten.

17 Vgl. Huxley 1862d, S. 201.

18 Vgl. Huxley 1862d, S. 202: „A small additional amount of flattening and lengthening, with a corresponding increase of the supraciliary ridge, would convert the Australian brain case into a form identical with that of the aberrant fossil“". 


\section{Öffentliche Vorlesungen}

Huxley begann ab 1864, ethnologische Vorlesungen öffentlich und am Working Men's College speziell für ein Arbeiterpublikum zu halten. ${ }^{19}$ Aber auch die renommierte Fullerian Lecture an der Royal Institution widmete er mehrmals der Ethnologie. ${ }^{20}$ Durch diese Vorlesungen hoffte er, die Öffentlichkeit für seine evolutionäre Anthropologie zu mobilisieren. Der Zeitpunkt, an dem er mit ethnologischen Vorlesungen begann, läßt vermuten, daß er hier einen evolutionstheoretischen Gegendiskurs nicht gegen die konservativen Gegner der Naturalisierung des Menschen wie Owen oder Wilberforce richtete, sondern gegen die populäre Anthropological Society, mit der sich der X-Club 1864 auseinanderzusetzen begann.

In diesen Vorlesungen definierte er den Begriff ,ethnologisch` als Beschreibung und Interpretation des sozialen und kulturellen Seins und verband diese sozialen Kategorien mit anatomischen Charakterisierungen zu einer Typologie der „Rassen der Menschheit“, wie der Titel seiner ersten Vorlesungsreihe lautete. ${ }^{21}$ Die Vorlesungen befaßten sich mit „Australiern und Negritos“, „Negern“, „Malayen und Polynesiern“, „Amerikanern“ und mit „Zentralasiaten, Ariern und Syro-Arabern“. ${ }^{22}$ Huxley stützte sich für die Beschreibungen der Rassen, ihrer Verteilung und genealogischen Beziehungen sowohl auf anthropometrische Studien, als auch auf Berichte über soziale und kulturelle Strukturen der jeweiligen Gesellschaften. Er machte einerseits Angaben über Haare und Hautfarbe, den Knochenbau und das Gehirn, andererseits aber auch Wohnform, Kleidung, Agrartechniken, familiäre Beziehungen, Religion und Sprache zum Gegenstand seiner Vorlesungen. ${ }^{23}$

Er konstruierte hierbei eine Korrelation zwischen kulturellen und physischen Komponenten, die verdeutlicht, daß seine anthropometrische Identifizierung von Rassenmerkmalen nicht von der kulturellen Inter-

19 Vgl. Ed Block (1986) „T. H. Huxley's Rhetoric and the Popularization of Victorian Scientific Ideas: 1854-1874“. In: Victorian Studies 30, S. 363386, S. 371.

20 Vgl. HP XVI.142, Ankündigung einer Vorlesungsreihe am Londoner Mechanics' Institute im Januar und Februar 1867 und HP 102.14, Ankündigung der zwölf Lesungen an der Royal Institution 1868, und HP 33.72, Ankündigung für weitere 12 Vorlesungen im Mai 1867.

21 Die Vorlesungen, wurden unter dem Titel „The Races of Mankind. Their Distribution and Relations. By Thomas H. Huxley, F.R.S.“ im November und Dezember 1864 im Museum of Practical Geology gehalten (HP 102.1); vgl. auch LLTHH, Bd. 1, S. 249.

22 Vgl. HP 102.1.

23 Vgl. HP 102.3. 
pretation der Zivilisationsleistung zu trennen ist. Im Kontext des viktorianischen Diskurses über die Wilden bestand kein Zweifel an ihrer kulturellen Primitivität. Huxleys Messungen und Rassifizierungen waren nicht einfach eine Extrapolation des Systems naturwissenschaftlicher Taxonomien in die Anthropologie hinein. Sie waren von Beginn an mit Wissen um die soziale Differenz konstruiert worden und zielten auf ihre naturalisierte Erklärung.

Bemerkenswerterweise nahm Huxley seine kraniometrischen Überlegungen nicht in sein Lehrbuch für die Studierenden der komparativen Anatomie auf. ${ }^{24}$ Er behandelte in seinen anatomischen Vorlesungen, auf denen sein Lehrbuch basierte, die Elemente, aus denen sich der menschliche Schädel zusammenfügt, und konstruierte über den Vergleich mit Schädeln anderer Wirbeltiere eine Entwicklungsgeschichte verschiedener Knochengruppen. Dabei ging er allerdings nicht auf Affen oder Primaten ein. Ebensowenig griff er auf Vergleichsstudien von Schädeln verschiedener Rassen zurück.

Huxley engagierte sich für die Etablierung einer professionellen naturwissenschaftlichen und medizinischen Hochschulausbildung. Seine Bemühungen spiegelten sich auch in der thematischen Bandbreite seines Anatomie-Lehrbuches wider, das, wie viele Lehrbücher seiner Zeit, im Zeichen der Akademisierung und Professionalisierung der medizinischen Ausbildung stand. An dem Umstand, daß es das methodische Gerüst seiner Anthropologie kraniometrischer und anthropometrischer Verfahren umging und die Erkenntnisse der Anthropologie nicht in den Kanon der Humanwissenschaften aufzunehmen bereit war, zeigt sich, daß er offenbar versuchte, die als politisch belastet empfundene Anthropologie von einem engeren akademischen Diskurs und wissenschaftlich seriösen Wissensbeständen zu separieren. Dies unterstreicht die Ambivalenz in Huxleys Kampagnen zur Verwissenschaftlichung der Anthropologie. Er hielt sie 1864, zu Beginn der Intervention des X-Clubs, offensichtlich noch für stark politisch determiniert.

\section{Methoden der Ethnologie}

1865, in „Methods and Results of Ethnology“, erklärte Huxley, die rivalisierenden Positionen des Monogenismus und des Polygenismus mit der Lehre Darwins überwunden zu haben. Zwar hieß es beschwichtigend, Darwins Theorie erlaube, ,,alles Gute der monogenistischen und der po-

24 Vgl. Huxley (1864a) Lectures on the Elements of Comparative Anatomy. London: Churchill and Sons, S. 113-161, S. 278-303. 
lygenistischen Schule zu versöhnen und zu kombinieren“. ${ }^{25}$ Doch er schonte in seiner Kritik keine der beiden Positionen. Die monogenistischen Ansätze, von denen er ohnehin nur die wissenschaftlich und nichtchristlich argumentierenden wie die Blumenbachs oder Prichards berücksichtigte, lehnte er wegen des „Hokuspokus“ ihres kaukasischen Ursprungsmythos ab, die Polygenisten auf der anderen Seite hätten keinerlei Beweis für ihre Annahme verschiedener Ursprünge der Menschenrassen erbracht. ${ }^{26}$

Für Huxley stand fest, daß zwar die Menschen einen gemeinsamen Ursprung hätten. Dessen Lokalisierung sei allerdings zweitrangig und er führte aus, daß die physischen Unterschiede der Menschenrassen Ergebnisse eines differenzierten Anpassungsprozesses und geographisch bedingter Isolationen darstellten. ${ }^{27}$ Vor diesem Hintergrund definierte er das Verhältnis von Ethnologie und Anthropologie folgendermaßen:

„Ethnologie ist die Wissenschaft, die die besonderen Charakteristika der persistenten Modifikationen bestimmt, die Verbreitung dieser Modifikationen in Gegenwart und Vergangenheit feststellt und versucht, die Ursachen oder Existenzbedingungen der Modifikationen und ihrer Verbreitung zu entdecken. [...] So definiert, ist Ethnologie ein Zweig der Anthropologie, jener großen Wissenschaft, die die Komplexität der menschlichen Struktur entwirrt“ ${ }^{28}$

Ginge es um die damalige Kernfrage der Anthropologie nach der Beziehung der Rassen zueinander, dann lieferte allein ein physisch-anthropologischer Ansatz zuverlässige Aussagen, denn weder sprachliche Ähnlichkeiten noch vergleichbare Kulturtechniken belegten seiner Ansicht nach eine genealogische Beziehung. Auch die Geschichtsschreibung sei für eine solche Bestimmung nur von eingeschränktem Nutzen, denn Huxley hielt einen Großteil der Menschheit für geschichtslos. Australier und andere Bevölkerungen wären schon ,am Anfang der Geschichte substantiell das [gewesen], was sie jetzt sind" und hätten also keinerlei

25 Huxley 1865a, S. 248: ,reconciling and combining all that is good in the Monogenistic and Polygenistic schools".

26 Huxley 1865a, S. 246: „hocus-pocus“, vgl. S. 244-247.

27 Vgl. Huxley 1865a, S. 249-251.

28 Huxley 1865a, S. 209-210: „Ethnology is the science which determines the distinctive characters of the persistent modifications of mankind; which ascertains the distribution of those modifications in present and past times, and seeks to discover the causes or conditions of existence, both of the modifications and of their distribution. [...] Ethnology, as thus defined is a branch of Anthropology, the great science which unravels the complexities of human structure“. 
Entwicklung vollzogen. ${ }^{29}$ Die durch seine Messungen konstruierte Primitivität bestimmter Rassen kombinierte er hier mit der Unterstellung einer kulturellen Primitivität.

Huxley berief sich bei der Vorstellung seiner ,rein zoologischen Methode" auf Carl von Linnés Systema Naturae. Linné habe seine Unterteilung der Menschen (Americanus, Europaeus, Asiaticus, Afer, Monstrous) nicht durch ,irgendeine Täuschung über sprachliche Besonderheiten" verunreinigt, meinte Huxley und behauptete weiter, daß die Gründer der Ethnologie, für ihn Buffon und Blumenbach, strikt im Linnéschen Sinne gearbeitet hätten. ${ }^{30}$ James Cowles Prichard hingegen tat er - ungeachtet dessen physisch-anthropologischen Ansatzes - als einen Linguisten ab, der keine belegbaren Ergebnisse hervorgebracht habe. ${ }^{31}$ Gleichwohl Huxley seine Anthropologie auf einer anthropometrischen Methodologie aufbaute, und den Erkenntnisgewinn der kulturell orientierten Ethnologie bei der Lösung der Frage nach der Beziehung der Rassen zueinander für gering hielt, griff er bereitwillig auf soziale Tatbestände zurück, vor allem dann, wenn er sie als zusätzlichen Beweis einer isolierten Existenz nutzbar machen konnten. ${ }^{32}$

Daß Huxley physischen Merkmalen eine robustere Validität zusprach als kulturellen Merkmalen, macht auch das Beispiel der sogenannten Negritos deutlich. Zu diesen rechnete er die Tasmanier, die seinerzeit als besonders primitiv galten, da man davon ausging, daß sie nach dem Kontakt mit Europäern ausgestorben seien. ${ }^{33}$ Andere ,Negrito'-Populationen, so Huxley, würden zwar auf höherem kulturellen Niveau leben, doch er hielt ihre Entwicklungsfähigkeit für rassisch begrenzt. In Fällen, in denen sich bei ,Negritos“ Artefakte gefunden hätten, die auf eine unerwartet höhere Kulturtätigkeit hinwiesen, unterstellte er einen Kulturimport und schloß ihre unabhängige Entwicklungen aus:

„Pfeil und Bogen, Pfahlhäuser, Auslegerkanus, die Bräuche des Betelkauens und des Kawa-Trinkens [...] sind höchstwahrscheinlich nicht als Produkte einer indigenen Bevölkerung zu betrachten, sondern eher als Indikatoren für den Umfang, in dem fremde Einflüsse das ursprüngliche soziale Sein dieser Menschen verändert haben“. ${ }^{34}$

29 Huxley 1865a, S. 212: „were, at the dawn of history, substantially what they are now".

30 Vgl. Huxley 1865a, S. 220-221.

31 Vgl. ebd.; Augstein 1999.

32 Vgl. Huxley 1865a, S. 223-224.

33 Vgl. Huxley 1865a, S. 224; vgl. Brantlinger 2003, S. 124-130.

34 Huxley 1865a, S. 225: ,the bows and arrows, the perched houses, the outrigger canoes, the habits of betel-chewing and of kawa-drinking [...] are probably to be regarded not as products of an indigenous population, 
Huxley begründete diese Vermutung nicht weiter, er schien ihre Plausibilität dem Einverständnis anzuvertrauen, daß die ,Negritos‘ grundsätzlich nicht im Stande wären, diese Kulturgüter oder Kulturpraktiken selbst erfunden und entwickelt zu haben. Er berief sich an dieser Stelle auf eine diffusionistische Theorie über Kultur- und Technologietransfer, die ansonsten bei seinen Ausführungen über die zivilisatorische Distanz zwischen Europa und den vermeintlich Primitiven keine Rolle spielte. Grundsätzlich beschrieb er als Evolutionist die soziale Entwicklung als Funktion einer langsamen anatomischen Wandlung, die vor allem an der Veränderung des Kraniums abgelesen wurde. Seine diffusionstheoretische Annahme konstituierte deshalb eine methodische Ausnahme, um den ,Negritos‘ eine entsprechende Entwicklungsfähigkeit rundweg absprechen zu können.

Seine Anthropologie befaßte sich anfangs nur mit der Anatomie außereuropäischer beziehungsweise vorgeschichtlicher Menschen. Nur schrittweise nahm er in sie auch die Europäer auf. Jenen Typus, der vor allem in Nordeuropa beheimatet sei, sich aber auch bis nach Nordasien ausdehne, nannte er Xanthochroi, ein Begriff, mit dem helle Haarfarbe und ein heller Hautton bezeichnet wurden. ${ }^{35}$ Huxley vollzog die Konstruktion der Xanthochroi primär über Haar- und Hautfarbe, der Schädel rangierte nur als untergeordnetes anatomisches Kriterium, denn:

„Die kranialen Eigenschaften der Xanthochroi sind gegenwärtig nicht genau zu bestimmen. Die Skandinavier sind sicherlich langschädelig, aber viele Deutsche, [manche] Schweizer [...], die Slawen, die Finnen und die Türken sind kurzschädelig“. ${ }^{36}$

Während er die Nord- und Mitteleuropäer als Xanthochroi klassifizierte, konstruierte er für die Bewohner des Mittelmeerraumes den Typus des Melanochroi, die in der Mehrzahl langschädelig und von kleinerer Statur als die Xanthochroi wären. ${ }^{37}$ Ungeachtet ihrer derartig charakterisierten anatomischen Unterschiede rangierten Xanthochroi und Melanochroi bei Huxley auf gleicher zivilisatorischer Stufe:

but merely as indications of the extent to which foreign influences have modified the primitive social state of these people“.

35 Vgl. Huxley 1865a, S. 229-230: ,,yellow“ haired and ,pale“ in complexion".

36 Huxley 1865a, S. 231: „The cranial characters of the Xanthochroi are not, at present, strictly definable. The Scandinavians are certainly long-headed; but many Germans, the Swiss [...], the Slavonians, the Fins, and the Turks, are short-headed".

37 Vgl. Huxley 1865a, S. 232: „The majority of them are long-headed, and of smaller stature than the Xanthochroi“. 
„Von ihnen geht alles aus, was in Wissenschaft, Kunst, Justiz, Politik und Technik das Höchste ist. In ihren Händen befindet sich gegenwärtig die Ordnung der sozialen Welt und ihnen ist ihr Fortschritt zu verdanken“. ${ }^{38}$

Xanthochroi und Melanochroi sind zwei von insgesamt elf Typen des Menschen, die Huxley anatomisch identifizierte und in einer Tabelle arrangierte. Diese Tabelle ordnete sich nach dem Primärkriterium der Haarform. ${ }^{39}$ Sekundär unterschied sie anhand des Kranialindex' in Rund- oder Langschädel; zuletzt differenzierte sie nach Hautton (vgl. Abb. 4).

Abb. 4. Die persistenten Stämme der Menschheit nach Huxley. ${ }^{40}$

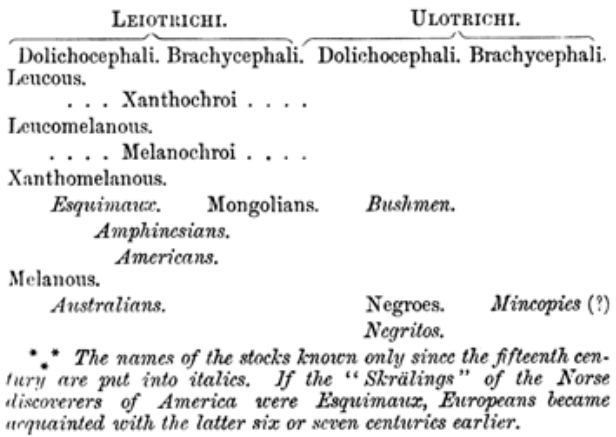

Die so definierten elf „Urstämme“ betrachtete er als ,persistente Modifikationen“ oder persistente Typen, ein Begriffsäquivalent für den durch die Anthropological Society in Mißkredit gebrachten Terminus ,Rasse ${ }^{41}$ Die persistenten Typen veränderten sich nicht, selbst wenn es

38 Huxley 1865a, S. 232: „It is needless to remark upon the civilization of these two great stocks. With them has originated everything that is highest in science, in art, in law, in politics, and in mechanical inventions. In their hands, at the present moment, lies the order of the social world, and to them its progress is committed".

39 Huxley hat in einem späteren Aufsatz Bory de St Vincent als Quelle für diese Differenzierung nach Haarform angegeben (vgl. Huxley 1866a, S. 132).

40 Abb. 4. In: Huxley 1865a, S. 235.

41 Huxley 1865a, S. 235: „eleven readibly distinguishable stocks, or persistent modifications, of mankind“. Patrick Brantlinger hat bemerkt, daß Huxley über diese elf Stämme behauptete, sieben von ihnen seien erst seit 400 oder weniger Jahren bekannt und unter diesen habe keiner eine schriftlich festgehaltene Geschichte; er hält dieses Element der Geschichtslosigkeit für Huxleys nicht-morphologisches Hauptunterscheidungskriterium (vgl. Brantlinger 1997, S. 267). 
seit Urzeiten zu Berührungen und territorialen Übergriffen zwischen ihnen gekommen sein müßte:

„Im Ganzen ist es wunderbar, daß so geringe Veränderungen durch diese wechselseitigen Invasionen und Vermischungen bedingt wurden. Wie gegenwärtig, so lebten die Melanochroi auch am Anfang der Geschichte an den Rändern des Atlantik und des Mittelmeeres, die Xanthochroi besiedelten den überwiegenden Teil Zentral- und Osteuropas und einen Großteil des westlichen und zentralen Asiens [...]. So weit die Geschichte uns lehrt, waren die Bevölkerungen Europas, Asiens und Afrikas in Bezug auf ihre allgemeinen Eigenschaften und Verbreitung vor zwanzig Jahrhunderten genau das, was sie jetzt sind“. ${ }^{42}$

Huxley führte dies vor allem aus einem Grund an. Ihm ging es um eine Widerlegung der polygenistischen Behauptung, daß einige der ,Urstämme' des Menschen sogar als eigene Arten verstanden werden müßten. Er hingegen erklärte, daß eine der hierfür regelmäßig angeführten Voraussetzungen, nämlich, daß zwischen diesen Arten nur eine geringere oder keine Fruchtbarkeit bestehen würde, jeglicher Grundlage entbehre. ${ }^{43}$ Gleichwohl war seine Konstruktion der ,Urstämme“ und ihre Betonung der Persistenz äußerst nah am polygenistischen Modell entwickelt. Dies drückte sich auch in der Begriffswahl aus, denn bereits die Polygenisten Josiah Nott und George Robins Gliddon hatten in ihrem Types of Mankind (1854) die Menschenrassen als ,permanente Typen“ bezeichnet. $^{44}$ Huxley teilte gewissermaßen deren Befund, ohne deren Erklärung zu akzeptieren.

Die von Huxley angenommene Dauerhaftigkeit der physischen Kriterien basierte aber nicht auf der polygenistischen Unfruchtbarkeitsvermutung, sondern auf der Annahme einer räumlichen Isolation. Deshalb unterschied sich sein Rassenverständnis vor allem in theoretischer Hinsicht von Vorläufern wie etwa Nott und Gliddon. Der Isolationseffekt war dabei das evolutionstheoretische, modernisierende Element in Huxleys Anthropologie.

42 Huxley 1865a, S. 238: „On the whole, however, it is wonderful how little change has been effected by these mutual invasions and intermixtures. As at the present time, so at the dawn of history, the Melanochroi fringed the Atlantic and the Mediterranean; the Xanthochroi occupied most of Central and eastern Europe, and much of Western and Central Asia; while Mongolians held the extreme east of the Old World. So far as history teaches us, the populations of Europe, Asia and Africa were, twenty centuries ago, just what they are now, in their broad features and general distribution".

43 Vgl. Huxley 1865a, S. 240-241.

44 Vgl. Banton 1998, S. 58. 
Seine Konstruktion persistenter Typen stellte allerdings nicht bloß eine evolutionstheoretisch modifizierte Variante des Polygenismus dar, vielmehr stand dieses Konzept in enger Verbindung zu seinem damaligen Evolutionsverständnis. Wie im zweiten Abschnitt dargelegt wurde, war er in den ersten Jahren nach der Veröffentlichung von Darwins Origin of Species alles andere als überzeugt von dessen Erklärung, die Artenvielfalt resultiere aus unendlich vielen, minimalen Mutationen. Sein Einwand, daß sich die Natur durchaus sprunghaft entwickele, korrespondierte daher mit seinem Modell persistenter Typen, zwischen denen er keine evolutionären Verbindungen herstellte.

Mario Di Gregorio diskutiert zwar Huxleys Klassifikationsschema der persistenten Typen, doch die hierin nicht zu leugnende rassistische Komponente führt er auf die Notwendigkeit zurück, den verbreiteten viktorianischen Rassenvorstellungen entsprechen zu müssen. ${ }^{45}$ Doch so harmlos, wie Di Gregorio es hier erscheinen lassen möchte, waren Huxleys Versuche nicht, eine Verwandtschaft zum Neandertaler über den Australier, oder eine Distanz zum Gorilla über den Buschmann zu konstruieren. Beide Überlegungen beruhten auf einer Darstellung von Australiern und Buschmännern als geschichtslose Primitive und zeichneten sich dadurch aus, daß sie diese tradierten Stereotype mit einer naturwissenschaftlich abgesicherten Erklärung versahen.

Ein Jahr nach seiner programmatischen Erklärung über die Methoden und Ergebnisse der Ethnologie schloß Huxley die anthropometrische Leerstelle, die die fehlende Forschung über die Europäer bei ihm bis dahin noch darstellte. Zumindest für die Nordeuropäer gab er nun eindeutige Verteilungen von Schädelformen an. Von den zeitgenössischen Schweizern und Südwestdeutschen bis hin zu den Skandinaviern weiche eine ausgeprägt runde einer ausgeprägt länglichen Schädelform. ${ }^{46}$ Bei den antiken Schädeln hingegen fänden sich umgekehrte Verhältnisse. ${ }^{47}$ Er führte diesen Umstand auf Ablösungsprozesse zurück, in denen eine

45 Vgl. Di Gregorio 1984, S. 166: „Of course, Huxley must pay lip service to the typical prejudice of Victorian anthropology“. Di Gregorio entschärft das Vorwurfspotential, indem er den polygenistischen Rassismus Hunts hervorhebt und daraus die Gegnerschaft mit Huxley ableitet (vgl. hierzu Kap. 3.3), und kommt zu dem Schluß, daß die Erklärung ,dimensionaler Unterschiede zwischen verschiedenen Rassen nicht notwendigerweise Rassismus" bedeute, sondern den Tatsachen entspräche (vgl. Di Gregorio 1984, S. 169: „To argue that there are dimensional differences among various races does not necessarily imply racism; it is simply a fact, implying no moral judgment").

46 Vgl. Huxley 1866a, S. 112.

47 Huxley 1866a, S. 134: ,in the prehistoric epoch, central Europe was peopled by short-headed Xanthochroi; northern (baltic) Europe by long-headed Xanthochroi; and Western Europe by dolichocephalic Melanochroi“. 
Rasse die andern verdrängt haben müsse und auf Migrationsprozesse, die sukzessive in Mitteleuropa und England zu moderateren Schädelformen, zu ausgeprägteren hingegen in geographischen Randlagen wie Skandinavien geführt hätten. ${ }^{48}$

Doch er mußte eingestehen, daß die Datenlage für weite Teile Europas unbefriedigend war. Hinter seiner Überlegung stand das Bedürfnis, zwei eigentlich widersprüchliche Eindrücke oder Aussagen miteinander zu harmonisieren. Zum einen konfrontierte ihn seine Alltagserfahrung mit der ganzen Bandbreite möglicher Schädelformen. Zum anderen vertraute er auf anthropometrisches Datenmaterial, das in der Regel anhand des einen oder des anderen Schädelmaßes ganze Rassen konstruierte.

Anstatt dieses Material im Lichte seiner Alltagsbeobachtungen in Frage zu stellen, versuchte er es mit eben dieser Erfahrung in Einklang zu bringen. Wie schon im vorigen Abschnitt diskutiert, ging Huxley davon aus, daß die Bevölkerung der britischen Inseln eine Mischung zwischen Xanthochroi und Melanochroi und somit eine Zusammensetzung aus verschiedenen europäischen Völkern mit jeweils eindeutigen Verteilungen der Schädelformen darstellte. Zudem nahm er an, daß die historischen Einwanderungen auf die britischen Inseln von Normannen wie von Skandinaviern bereits im gleichen Umfang in prähistorischer Zeit stattgefunden haben mußten. Huxley übertrug historisch dokumentierte Ereignisse in die Vorzeit und konnte damit seine Prämisse aufrecht halten, daß die Schädelform ein Rassemerkmal und als solches den Einflüssen der Rassenmischung ausgesetzt sei.

Die Auswirkungen von Vermischungen zwischen Rassen betonte Huxley exklusiv bei den Europäern. Die dieser Überlegung zugrundeliegende Annahme anatomischer Varianz mag vor allem dem reichlich verfügbaren Anschauungsmaterial geschuldet gewesen sein. Doch Huxley reagierte nicht mit einer Ausweitung seiner Stichproben an Schädeln von vermeintlich Primitiven. Da er von der Existenz und Identifizierbarkeit distinkter anatomischer Merkmale überzeugt war, erklärte er den Umstand, daß solche Merkmale in Europa nicht nachgewiesen werden konnten, durch einen Mechanismus, dem er ansonsten wenig Aufmerksamkeit widmete: Rassenmischung.

Huxleys Rückgriff auf das Konzept der Rassenmischung machte einerseits aus den vermeintlich Primitiven reine, unvermischte Rassen und andererseits die Rassenmischung zur Voraussetzung der zivilisatorischen Blüte, die er mit den Melanochroi und Xanthochroi verband. Allerdings grenzte Huxley die Wirkung solcher Mischungen zeitlich ein, denn er schloß sie für die einmal entstandenen persistenten Typen aus,

48 Vgl. Huxley 1866a, S. 111. 
deren Persistenz ja gerade auf der Stabilität ihrer signifikanten Rassenmerkmale beruhte. Das Modell der persistenten Typen ist deshalb mit Huxleys vormaliger Spekulation über ein Verlaufsspektrum phänotypischer Merkmale entlang verschiedener Achsen nicht mehr vereinbar. Hatte er zuvor noch auf die klimatischen Bedingungen verwiesen, die mit extremen physischen Eigenschaften korrespondierten, so betonte das Modell der persistenten Typen das statische Element der Merkmalskomposition.

\section{Darwinianische Anthropologie}

Darwins Theorie, so Huxley, enthalte den „Schlüssel zur Ethnologie““49 Die Vermutung, Anpassungsprozesse an verschiedene klimatische und geographische Besonderheiten hätten die körperliche Erscheinungsform des Menschen beeinflußt, war von zentraler Bedeutung für seine Theorie der Entstehung der Menschenrassen. Er stützte seine Begründung der unterschiedlichen Verbreitung physischer Merkmale der Menschen auf geographische Barrieren, die zu getrennten Entwicklungen verschiedener Rassen unter verschiedenen Umweltbedingungen geführt hätten. Dabei spekulierte er auch über versunkene Kontinente, durch die ehemals bestehende Verbindungen unterbrochen wurden. ${ }^{50}$ Dem Effekt solcher geographischer Barrieren auf die Entwicklung der Menschheit maß er deshalb besondere Bedeutung bei:

,[W]as für ein wundervoll effizientes ,Emigration Board“ muß überall auf der Welt am Werk gewesen sein, lange bevor Kanus oder gar Flöße erfunden wurden und lange bevor der Mensch [...] zum Wandern angetrieben wurde. Und wie diese wilden und primitiven Familien im Verlauf langer Folgen von Generationen von Land zu Land getrieben wurden, durch Beeinträchtigungen des Meeres oder der Sümpfe, oder durch schwere Sommerhitze oder Winterkälte dazu gezwungen, ihre Aufenthaltsorte zu ändern, welche Möglichkeiten müssen sich für das Spiel der natürlichen Auslese ergeben haben, eine FamilienVariation zu erhalten und eine andere zu vernichten!“泣

49 Huxley 1865a, S. 248: ,the key to ethnology“.

50 Huxley 1865a, S. 250: ,there must be half-a-dozen Atlantises beneath the waves of the various oceans of the world".

51 Huxley 1865a, S. 251: „,what a wonderful efficient ,Emigration Board“ must have been at work all over the world long before canoes, or even rafts, were invented; and before men were impelled to wander [...]. And as these rude and primitive families were thrust, in the course of long series of generations, from land to land, impelled by encroachments of sea or of marsh, or by severity of summer heat or winter cold, to change their positions, what opportunities must have been offered for the play of natural selection, in preserving one family variation and destroying another!“. 
Huxley setzte Wanderbewegungen voraus, die zur Besiedelung des Globus geführt hätten, und hob dabei auf geographische Isolationsmomente $\mathrm{ab}$, um die Herausbildung jener persistenten Typen zu erklären, die er zuvor taxonomisch beziehungsweise archetpyisch konstruiert hatte. Seine Argumentation spiegelte die im damaligen Evolutionsdiskurs diskutierte Frage nach der Bedeutung der Isolation für die Herausbildung der Spezifika einer Art wieder. Die versunkenen Kontinente erlaubten ihm dabei, Auffälligkeiten in seiner Klassifikation zu erklären, wie etwa die Verbreitung bestimmter Haarformen. Ungeachtet seiner Reserviertheit gegenüber Darwins Origin of Species in Hinblick auf dessen Erklärungspotential für die Entstehung der Arten war Huxley überzeugt, vom darwinschen Standpunkt aus die „Einheit des Ursprungs der Menschheit" beweisen zu können. ${ }^{52}$

Um 1870, als er mit großen Erfolgsaussichten die Annäherung zwischen der Ethnological Society und der Anthropological Society vorantrieb, modifizierte er sein Modell der persistenten Typen. Ging er zuvor noch von elf persistenten Typen aus, so reduzierte er deren Zahl nun auf neun. Deren Persistenz stellte er nunmehr als temporär begrenzt dar, denn sie stammten, so Huxley, ihrerseits von vier „Hauptmodifikationen der Menschheit“ ab. ${ }^{53}$ Durch die Einführung dieser Zeitdimension redynamisierte er sein Rassenmodell, das er bei der ersten Einführung der persistenten Typen noch mit einer dem Polygenismus vergleichbaren Statik versehen hatte.

Diese vier Haupttypen, ,australoider', ,negroider', ,xanthochroider und ,mongolischer' Typ, bevölkerten weitgehend von einander isolierte Regionen und Kontinente. ${ }^{54}$ Dies illustrierte eine Karte, die so ausgerichtet war, daß Australien und Ozeanien in der Bildmitte lagen (vgl. Abb. 5). Huxley wollte mit dieser Ausrichtung der Karte die möglichen Wege des Menschen bei der Besiedelung der Kontinente, aber auch die geographische Isolation betonen, die er als ursächlich für die phänotpyischen Unterschiede der Menschenrassen ansah. Eine derartige Lage diagnostizierte er auch für Australien und betonte, daß deretwegen die

52 Vgl. Huxley 1865a, S.252: ,unity of the origin of mankind“.

53 Huxley 1870c, S. 564: ,principal modifications of mankind“.

54 Bereits in „Methods and Results“ hatte Huxley vier der elf persistenten Modifikationen des Menschen hervorgehoben (,Negroes, Mongolians, Xanthochroi, and Melanochroi“", vgl. Huxley 1865a, S. 238), weil ihre Existenz, im Gegensatz zu der der restlichen sieben Typen, die über keine Geschichtsschreibung verfügten, schon vor 1450 schriftlich dokumentiert gewesen sei. Die Sonderstellung war also rein kulturell begründet. 
„eingeborene Bevölkerung Australiens eine der ausgeprägtesten aller Typen oder Grundformen des Menschen darstellt “. ${ }^{55}$

Abb. 5. Verteilung der persistenten Modifikationen der Menschheit nach Huxley. ${ }^{56}$

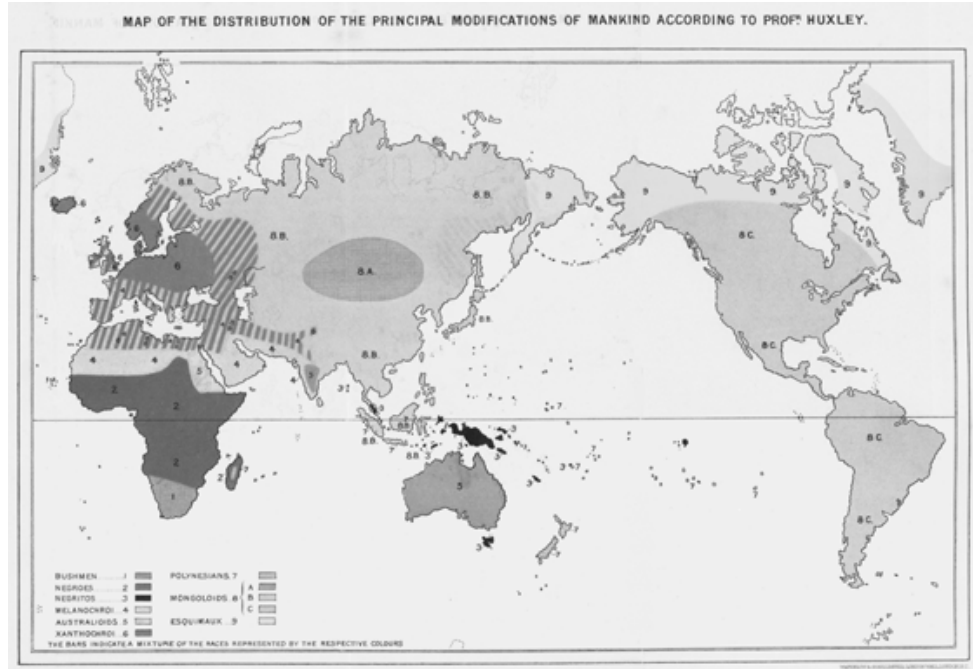

In Polynesien würden die vier Haupttypen zwar in einem ,relativ kleinen Areal zusammengedrängt“ leben, hätten sich aber nicht vermischt. ${ }^{57}$ Die einzige Mischform, die zwischen diesen Haupttypen entstanden sei, wären die südeuropäischen ,Melanochroi ', die er ,dunkle Weiße“ nannte, die aus einer „Mischung zwischen Xanthochroi und Australoiden“ resultierten und die mit „unzählbaren Gradierungen in den australischen Typ“ übergingen. ${ }^{58}$ Die vermutete Mischung zwischen zwei distinkten Typen war notwendig, weil die von Huxley herangezogenen physischen Merkmale nicht in der erforderlichen Reinheit auftraten.

Doch die Karte stellt noch weitere Mischungsvermutungen dar. Die schraffierten Flächen sollten Gebiete markieren, in denen Mischungen

55 Huxley 1870c, S. 564: „The indigenous population of Australia presents one of the best marked of all the types, or principal forms, of mankind".

56 Huxley, 1970c, S. 569. Legende zur Karte: 1. Bushmen; 2. Negroes; 3. Negritos; 4. Melanochroi; 5. Australoids; 6. Xanthochroi; 7. Polynesians; 8. (A, B, C) Mongoloids; 9. Esquimaux.

57 Huxley 1870c, S. 569: ,crowded into a relatively small area“.

58 Huxley 1870c, S. 569: ,, dark whites”, ,, an intermixture between the Xanthochroi and the Australoids”, „In Hindostan the Melanochroi pass by innumerable gradations into the Australoid type“. 
von Xanthochroi und Mongoloiden, zwischen Xanthochroi und Melanochroi, sowie zwischen Xanthochroi, Mongoloiden und Melanochroi vorkämen. In weiten Teilen Europas und Vorderasiens lebten deshalb nach Huxley Bevölkerungen, die in mehrfacher Weise aus Mischungen von persistenten Typen hervorgegangen sein mußten. Diese Darstellung einer ungleich höheren Vermischungsrate in Europa im Vergleich zu außereuropäischen Regionen auf dieser Karte zeigt, daß die Rassenlogik auch dort durchgehalten wurde, wo sich, wie in Europa, die Unterstellung räumlich isolierter, distinkter Urstämme oder Rassentypen für unhaltbar erwiesen haben mußte. Hieraus resultierte eine Inflation der $\mathrm{Zu}$ schreibung von Urstamm-Mischungen, da nur so die Schematik der distinkten Typen aufrecht erhalten werden konnte.

\section{Huxleys ethnologische Studien}

Inspiriert vom sich abzeichnenden Erfolg der wissenschaftspolitischen Kampagnen des X-Clubs in der Anthropologie, arbeitete Huxley eine evolutionäre Forschungsagenda aus. Dabei zog er ein Programm im imperialen Kontext auf. Zwei Ansätze verfolgte er besonders intensiv. Zum einen ging es um die photographische Dokumentation der Menschen, zum anderen um systematische Aufrisse der Ethnologien verschiedener geographischer Regionen. So beschloß die Ethnological Society 1869 unter seinem Vorsitz, die Ausdehnung des britischen Empires für sich nutzbar zu machen und

„die physischen Eigenschaften, die Sprachen, die Zivilisation, die Religion, kurz, die Ethnologie der verschiedenen Völker, über die Britannien herrscht, einer systematischen Untersuchung zu unterziehen“. 59

Grundlage für diese systematische Untersuchung sollte nach Huxleys Vorstellung eine Sammlung standardisierter Photographien sein, auf der Frauen wie Männer, idealerweise unbekleidet, neben einem Maßband posierten (vgl. Abb. 6).

59 Huxley 1869a, S. 427: ,subjecting the physical characters, the languages, the civilization, the religions, in short, the ethnology, of the various peoples over whom the rule of Britain extends, to systematic investigation“". 
Abb. 6. Aus Huxleys Sammlung ethnologischer Photographien, HP Box $H$.

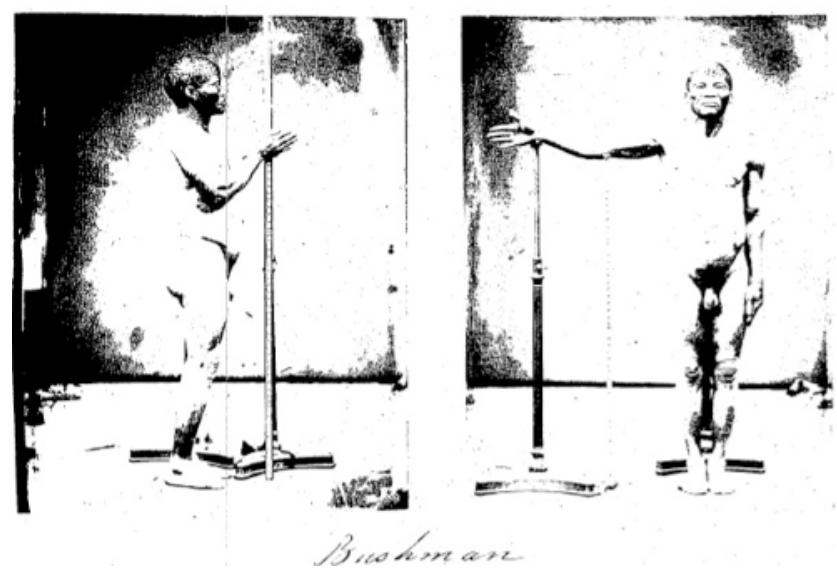

Diese ethnologischen Photographien sollten den Blick auf das Wesentliche freigeben. Die Frontal- und die Profilansicht sollten eine kraniometrische Auswertung zulassen, das Lineal, das sogenannte Anthropometer, anthropometrische Maße wie die Körperhöhe oder die Länge der Extremitäten abzulesen erlauben. ${ }^{60}$ Desmond hat in diesem Zusammenhang darauf hingewiesen, daß eine Voraussetzung für den Umgang mit solchen Bilddokumenten in der Ethnological Society der Ausschluß von Frauen von den Veranstaltungen war, den Huxley durchgesetzt hatte. ${ }^{61}$ Dies war zumindest seine offizielle Begründung für diesen Ausschluß. ${ }^{62}$

Um sein Vorhaben zu realisieren, erbat er bereits 1869 Unterstützung durch den Staatssekretär für die Kolonien (Secretary of State for the Colonies) und richtete seine Bitte um die Erstellung und Zusendung entsprechender Photographien an die Gouverneure der Kolonien. Doch obwohl Huxley in den nächsten Jahren etliche Photographien zugeleitet wurden, blieb seine Sammlung weit von einer vollständigen Erfassung der im Empire versammelten Bevölkerung entfernt. Zudem wurden seine methodischen Vorgaben oftmals ignoriert. Die ohnehin lückenhafte Sammlung enthält deshalb viele Bilder, die für Huxley bloß den Stellenwert von Schnappschüssen gehabt haben dürften. ${ }^{63}$ Etliche Schreiben

60 Vgl. Spencer 1992.

61 Vgl. Desmond 1998, S. 398.

62 Vgl. Kapitel 3.2.

63 Vgl. HP Box H und HP Box G. 
aus den Kolonien erzählten von der mangelnden Bereitschaft sich dem entwürdigenden Arrangement $\mathrm{zu}$ unterwerfen und photographieren $\mathrm{zu}$ lassen, andere wiederum berichteten von ethischen Bedenken der kolonialen Administration. ${ }^{64}$

Obwohl seine Bildersammlung deshalb höchst unvollständig blieb, war der Versuch nicht minder bemerkenswert. Die Photos wie Desmond bloß als eine visuelle Unterstützung für Huxleys Vorlesungen zu verstehen, sieht von den präzisen Instruktionen $a b$, nach denen sie erstellt werden sollten. Außerdem war Huxley auf kein Bildmaterial zur Illustration seiner Vorlesungen angewiesen, solches war zur Genüge vorhanden. ${ }^{65}$ Patrick Brantlinger sieht deshalb in ihnen zurecht den Versuch, eine anthropologische Materialbasis anzulegen:

„Huxleys ethnologisches Ziel war die kartographische und meßtechnische Erfassung aller Rassen der Welt. Nur eine solche vollständige Kartographie würde die Beweise bereitstellen, die nötig seien, die Rassen akkurat taxonomisch zu erfassen [...]. Die ethnologische Karte der menschlichen Rassen würde natürlich eine Hierarchie darstellen, sie würde beim großen Prozeß der Auslöschung der Primitivität, wenn nicht gar der der Primitiven selbst, helfen“ ${ }^{66}$

Er übersieht allerdings, daß Huxley keineswegs an einer vergleichbaren Datenerhebung im zeitgenössischen Europa gearbeitet oder auch nur Interesse an ihr gezeigt hatte. Di Gregorio hat erkannt, daß Huxley einen „ethnologischen Zensus [...] der britischen Besitzungen“ anstrebte. ${ }^{67}$ Doch beide nehmen nicht zur Kenntnis, daß Huxleys stillschweigende regionale Beschränkung der anthropologischen Erhebung eine Forschung impliziert, die aussagekräftige Daten nur von vermeintlich reinen

64 Vgl. bspw. Frederic Rogers an THH (26. Juli 1870) HP 40.112; Visc. Canterbury an Earl Granville (20.Mai 1870), HP 40.113-4; vgl. Desmond 1998, S. 397-398.

65 Adrian Desmond (1998, S. 398) schreibt: „these brooding images could be used to render Huxley's talks on the geography of mankind more graphic".

66 Brantlinger 1997, S. 273: „Huxley’s ethnological goal was the mapping and measurement of all the races of the world. Only such a total mapping would provide the evidence necessary to taxonomize the races accurately [...]. The ethnological map of human races would, of course, be also a hierarchy; it would help in the general process of eradicating savagery, if not the savages themselves"; vgl. Brantlinger 2003, S. 174.

67 Di Gregorio 1984, S. 175: ,ethnological census of the populations of the British possessions“. Diese Einschätzung des Materials trifft seine Problematik auch eher, als die Frank Spencers, der erklärte, daß Huxleys Versuch, physische Anthropologie auf solchen Bildern zu betreiben, aus technischen Gründen scheitern mußte (vgl. Spencer 1992, S. 100, S. 106). Allerdings diskutiert auch Di Gregorio nicht, warum Huxley auf eine Sammlung vergleichbaren Materials aus Europa keinen Wert legte. 
Rassen gewinnen wollte, und als solche galten ihm die Europäer eben nicht.

Dies wird auch an Huxleys anderem Projekt, seinen Entwürfen für die ethnologische Erfassung verschiedener Erdteile, deutlich. Einerseits verknüpfte er seine physische Anthropologie regelmäßig mit kulturellen Einschätzungen, etwa wenn er in seiner Vorlesungsreihe an der Ethnological Society einerseits die Bevölkerung Indiens wie Amerikas anatomisch und kraniometrisch definierte, dann aber die Frage nach den Bedingungen an hohe zivilisatorische Leistungen aufwarf und sie mit dem Hinweis auf geeignete klimatische Bedingungen $\mathrm{zu}$ beantworten versuchte. Nicht nur am Mittelmeer wären die ersten Hochkulturen entstanden, sondern auch am Golf von Mexiko. Und andererseits enthielt sich Huxley auffällig einer kraniometrischen oder anthropometrischen Bestimmung eben jener Bevölkerungen, die in seinen Augen solche Hochkulturen hervorgebracht hatten. Bei seiner Ethnologie Amerikas beispielsweise beschränkte er sich auf die Charakterisierung zweier phänotypischer Extreme:

„,[Z]wei äußerst verschiedene Formen unter den eingeboren Rassen Amerikas sind unterscheidbar, nämlich die Eskimo im extremen Norden und die Patagonier im Herzen Südamerikas. Die Eskimo sind von kurzer Statur and extrem dolichokephalisch, die Patagonier gehören im Gegensatz zu den am höchsten gewachsenen Menschen und sind äußerst brachykephalisch“. 68

Huxleys Schädellehre weist also immer dann Leerstellen auf, wenn in seinen Augen bedeutende Zivilisationen im Spiel sind, wie bereits bei seiner Diskussion der Xanthochroi zu sehen war. Seine physisch-anthropologischen Studien über die Europäer führte er allesamt an prähistorischen Schädeln durch. Das heißt, daß er sich vor allem für eine anatomische Definition der vermeintlich Primitiven interessierte, seine ethnologische Erfassung der Bevölkerung des Empires richtete sich vor allem auf die ,Anderen“. Die Differenz zwischen Zivilisation und Primitivität markierte Huxley über die Anatomisierbarkeit der Primitivität. Diese Einschätzung wird auch durch die Tatsache unterstrichen, daß Huxley in der gleichen Vorlesungsreihe eine Ethnologie für Großbritannien vor-

68 Huxley 1869b, S. 434: „two widely different forms are distinguishable among the native races of America, namely the Esquimaux, in the extreme north and the Patagonians in the heart of South America. The Esquimaux are short of stature and are extremely dolichocephalic; the Patagonians, on the contrary, are among the tallest of men, and are eminently brachycephalic". 
stellte, die ausschließlich historisch arbeitete und bei der Invasion der Normannen endete. ${ }^{69}$

Huxley betrieb Ethnologie als eine Untersuchung des Fremden und als eine Untersuchung des Vergangenen, und unterzog beide den gleichen Untersuchungsmethoden. Die zeitgenössischen vermeintlichen Wilden wurden so auf eine Stufe mit den vorzeitlichen Bewohnern Europas gestellt. Douglas Lorimer erklärt, Huxley habe seine Rassenkategorien weder nach Intelligenz gewertet noch versucht, eine soziale Evolution aus ihnen abzuleiten und allerhöchstens einige rassistische Stereotype kolportiert. Dabei übersieht er das rassenkonstituierende Element der Huxleyschen Kraniometrie ebenso wie das die Primitivität der außereuropäischen Rassen konstituierende Element einer ethnologischen, anthropologischen Forschung, die exklusiv die Fremden erfaßte und beschrieb. ${ }^{70}$ Diese Einengung auf die Frage, ob Huxley eine Hierarchie nach Intelligenz geschaffen habe, übersieht die kraniometrische Hierarchie ebenso wie die beständig von ihm eingeflochtene Verbindung von somatischer Entwicklung und kultureller Leistung. Huxley hatte die kulturelle Leistung direkt mit der kranialen und somatischen Evolution kurzgeschlossen und konnte dadurch die Frage der Intelligenz überbrücken.

\section{Fazit}

Huxleys Rassentheorie entstand im Zusammenhang der Verteidigung der Darwinschen Lehre. Aus den anthropologischen Argumenten seiner Interventionen in die Debatte um den Platz des Menschen in der Natur entwickelte er sukzessive eine umfangreiche Forschungsagenda der physischen Anthropologie mit einer entsprechenden Methodologie und steuerte $\mathrm{zu}$ diesem Wissenschaftsfeld vielfältige Untersuchungen bei. Bildete die Debatte um Darwins Origin of Species den Ausgangspunkt seiner Anthropologie, so stellte die erfolgreiche Fusion der Anthropological Society und der Ethnological Society zum Anthropological Institute ihren Höhepunkt und zugleich ihr Ende dar.

In dieser Dekade veränderte Huxley seine Rassentheorie mehrfach. Anknüpfend an die Neandertaler-Debatte, konstruierte er den evolutionären Entwicklungszusammenhang zwischen Australiern, ,Negern' und Europäern anhand kraniometrischer Studien, später schaltete er auf ein Modell statischer und distinkter Rasse-Typen um. Ein Modell, das er wiederum einige Jahre später durch die Konstruktion einer zeitlichen Abfolge von Haupttypen und Urstämmen dynamisierte. Die Wandlung

69 Vgl. Huxley 1870a; Huxley $1870 b$.

70 Vgl. Lorimer 1988, S. 412-413. 
seiner Vorstellungen stand im Zusammenhang mit dem Verlauf der Kontroversen in der Anthropologie und den Veränderungen seines naturwissenschaftlichen Evolutionsverständnisses. Zum Beispiel korrelierte sein Modell persistenter Typen auf der einen Seite mit jenem Naturverständnis, das er unmittelbar nach 1860 in den Auseinandersetzungen über Charles Darwins Origin of Species entwickelt hatte. Auf der anderen Seite wies es große Ähnlichkeiten zur polygenistischen Rassentheorie auf. Seine Dynamisierung gegen Ende der sechziger und Anfang der siebziger Jahre des neunzehnten Jahrhunderts hing mit Veränderungen in diesen Theoriedimensionen zusammen. Zum einen hatte Huxley über die Flugsaurier-Debatte Darwins Vorstellung gradueller modifikatorischer Übergänge letztlich akzeptiert und sich damit von seiner Archetypen-Konzeption getrennt. Dadurch verlor die Konzeption der persistenten Typen an Gewicht. Zum anderen konnte er sich von der Annahme persistenter Typen in seiner Rassentheorie lösen, weil gegen Ende der sechziger Jahre des neunzehnten Jahrhunderts der Polygenismus institutionell marginalisiert und im anthropologischen Diskurs die Definitionsmacht der Evolutionstheorien durchgesetzt worden war. Dies deutet die Einwirkung des Kontextes wissenschaftspolitischer Kampagnen und Kontroversen auf die Theoriebildung bei Huxley an. Wenn auch nicht völlig von den Bedingungen dieser Auseinandersetzungen geprägt, so hinterließen deren Verläufe doch ihre Spuren in der Dynamik seiner Begriffsbildung.

Huxley hatte zwar im Lauf der Jahre sein statisches Modell persistenter Typen durch die Erklärung eines prähistorischen Verlaufs dynamisiert, doch dies führte keineswegs zum Postulat fortlaufend progressiver Entwicklungen. Er führte die - physische - Genese von Rassen und persistenten Typen auf vorgeschichtliche Prozesse von Adaption, Selektion und Isolation zurück. Einen Fortbestand dieser evolutionären Entwicklungsmechanik bei den zeitgenössischen Rassen implizierte er allerdings bei seinen vergleichenden Diskussionen von Australier und Neandertaler und vom sogenannten Buschmann und Primaten. Die ihnen unterstellte Entwicklungslosigkeit deutet im Umkehrschluß eine Entwicklung bei den vermeintlich höheren Rassen an, vor allem, da er von einem gemeinsamen Ursprung aller Rassen und nicht ihrer separaten und dadurch kontingent asynchronen Entstehung ausging.

Darüber hinaus verband Huxley seine Rassenlogik mit der Vorstellung eines zivilisatorischen Prozesses, und schloß so die Evolution der Rassen mit der Evolution der Kultur kurz. Dies wird daran deutlich, daß er seine Einordnung der physischen Evolution immer wieder mit einer normativ entwickelten Einschätzung kultureller Leistungen in Verbindung brachte. In seiner physisch-anthropologischen Agenda war Kultur 
für ihn zwar nur ein Kriterium, das der Bestimmung der somatischen Evolution untergeordnet war. Dennoch hatte Huxley eine sehr genaue Vorstellung, welche Rasse oder welcher persistenter Typ zu welchen Kulturleistungen befähigt sein würde. Wurde die Erwartung übertroffen, erklärte er dies durch eine Hilfskonstruktion, indem er etwa einen Kulturimport annahm. Eine ähnliche Ausnahmesituation konstituierte sein Vorschlag, dem Beweis einer Homologie durch gedankliche Modellierung eines Schädels nachzuhelfen. Daß er in solchen Ausnahmefällen seine Wissenschaftlichkeitsstandards zu strapazieren bereit war, zeigt, wie sehr solche rassistisch strukturierten Wissensbestände am AgendaSetting seiner Anthropologie mitwirkten und ihr gewissermaßen vorgeschaltet waren.

Die Etablierung der Evolutionstheorie in der Anthropologie ging, wie im vorigen Abschnitt gezeigt wurde, mit der institutionellen Ausgrenzung vor- und anti-evolutionstheoretischer Positionen und ihrer Vertreter einher. Dies war die soziale Seite des evolutionstheoretischen Paradigmawechsels. $\mathrm{Zu}$ dessen theoriebildender Seite gehörte nicht nur die Installation eines neuen theoretischen Orientierungskomplexes, sie wies auch eine sich damit parallel vollziehende methodologische Modernisierung auf.

Das modernisierende Element der Methodologie Huxleys bestand in der Kombination zuvor gegeneinander entworfener kraniometrischer Maße, sowie seinem Versuch, anthropometrisches Material von allem Teilen der Erde zu erhalten. Seine Modernisierung führte aber keineswegs dazu, daß tradierte Stereotypisierungen der vermeintlich Wilden aufgegeben wurden. Vielmehr integrierte er sie in seine Rassentheorien und verhalf ihnen so zu einer robusteren Rationalität, insbesondere vor dem Hintergrund ihrer akuten Krisenhaftigkeit.

\section{2 "Anthropology, properly so termed". Rassendimensionen in der Anthropometrie George Busks}

George Busks anthropologisches Interesse wurde durch die Übersetzung von Schaaffhausens Beitrag zur Neandertalerdebatte geweckt. Seine anthropologischen Studien begann er in den frühen sechziger Jahren mit der Entwicklung von Meßverfahren, die in seinen Augen präzisere kraniometrische Messungen erlaubten. Dabei berief er sich an erster Stelle auf von Baers und Retzius' Meßmethoden und verstand sich in einer 
Forschungstradition, die auf Blumenbachs Arbeiten gründete. ${ }^{71}$ Mit Rückgriff auf von Baer ließ er klassifikatorische Zuordnungen auch auf anderen als den etablierten Maßen des Gesichtswinkels oder des kephalischen Index' beruhen. ${ }^{72}$ Busk versuchte, der Ethnologie durch die Überzeugungskraft der nackten Zahlen $\mathrm{zu}$ mehr wissenschaftlichem Gewicht zu verhelfen:

„So weit mir bekannt ist, gibt Professor Retzius nirgends Bedingungen oder Daten an, anhand derer die Proportionen, die einen dolichokephalischen oder brachykephalischen Schädel ausmachen, unterschieden werden können [...] Ein Ziel, das ich bei dem hier vorgeschlagenen Meßschema im Auge hatte, war, daß präzise numerische Werte an Stelle von Worten verwendet werden sollen, wenn von den Proportionen des Schädels berichtet wird“. ${ }^{73}$

Zur Eliminierung von Meßfehlern beim Auslitern der Gehirnvolumina entwickelt er einen Choremometer genannten Meßbecher, der das Hirngewicht genauer abzulesen erlaube. ${ }^{74}$ Wie bei der Altersbestimmung von Knochenfunden, die vor dem Hintergrund eines Fälschungsskandals in Frankreich 1863 besonders umstritten war, ${ }^{75}$ war Busk daran gelegen, dem Eindruck einer spekulativen Wissensproduktion vorzubeugen. ${ }^{76}$

71 George Busk (1861b) „Observations on a systematic Mode of Craniometry“. In: Transactions of the Ethnological Society 1, S. 341-348.

72 Zum einen berücksichtigte er die Öffnung der Zygomata und sprach dann von ,phenozygous“ Schädeln (Busk (1868) „Description of an Aino Skull“". In: Transactions of the Ethnological Society 6, S. 109-111), zum anderen bezeichnete er besonders niedrige brachykephalische Schädel als tapinokephalisch (vgl. Busk ((1874a) „Description of a Samoiede Skull in the Museum of the Royal College of Surgeons“. In: Journal of the Anthropological Institute 3, S. 494-497) „On the Discovery of Platycnemic Men in Denbingshire“. In: Journal of the Ethnological Society 2, S. 450468, und Busk 1874a). Keiner der beiden Faktoren wurde in den populären anthropometrischen Diskurs aufgenommen (wenngleich der Fachdiskurs auch heute noch damit operiert), auch Huxley zeigte kein Interesse und Busk selbst griff auch nur sporadisch auf sie zurück.

73 Busk 1861b, S. 343: „Professor Retzius nowhere, so far as I am aware, gives any terms or figures by which the proportions constituting a dolichocephalic or a brachycephalic cranium can be distinguished [...] One object I have had in view in the scheme of measurements now proposed, is that precise numerical values should be employed in place of words, in speaking of the proportions of the cranium".

74 Vgl. Busk (1874b) „Note on a Ready Method of Measuring the Cubic Capacity of Skulls“. In: Journal of the Anthropological Institute 3, S. 200204.

75 Vgl. Patrick J. Boylan (1979) „The controversy of the Moulin-Quignon jaw: the role of Hugh Falconer". In: Ludmilla J. Jordanova, Roy S. Porter: 
Seine methodologische Verpflichung, Zahlen sprechen zu lassen, löste Busk in einer Reihe von Beschreibungen prähistorischer, aber auch jüngerer Schädel ein, die sich zum Teil in privaten Sammlungen befanden, zum Teil im Museum des Royal College of Surgeons aufbewahrt oder dem Anthropological Institute gestiftet wurden. ${ }^{77}$ Zur Operatio-nalisierung der Vielzahl seiner anthropometrischen Daten verwendete er eine eigens entworfene tabellarische Darstellung (vgl. Abb. 7). ${ }^{78} \mathrm{Er}$ speiste durch diese Detailstudien dem anthropologischen Diskurs jenes Datenmaterial ein, auf dem aus seiner Sicht erst anthropologische Feststellungen gemacht werden können, denn „das Skelett vermittelt uns einen hervorragenden Eindruck, zu was für einer Art Mensch es gehörte". 79

Images of the Earth. Essays in the History of the Environmental Sciences. Chalfont St. Giles: British Society for the History of Science, S. 171-199.

76 Busk war die Problematik der Fälschungen präsent, denn er nahm in Abbeville an einer Fachtagung französischer und englischer Experten teil, die darüber entscheiden sollte, ob der dortige Fund eines menschlichen Unterkiefers authentisch sei (vgl. Busk; Falconer 1863). Busk und Falconer bezweifelten im Gegensatz zu ihren französischen Kollegen die Echtheit des Fundes und fürchteten um den Ruf der prähistorischen Archäologie und Anthropologie (vgl. Van Riper (1993), S. 134-139).

77 Im Archiv des Royal College of Surgeons sind von Busk an die zwanzig vorgedruckte Tabellen erhalten, „Table of Anatomical Measurements“ betitelt, in denen er kraniometrisch Rassen vermißt, Australier, Burmesen, Engländer, Grönländer, Negroes, etc. 25 Europäer hat er als durchweg dolichokephalisch identifiziert (vgl. Royal College of Surgeons, Busk Papers. 275 e 1(5)).

78 Bei Busk selbst findet sich kein Hinweis auf seine Urheberschaft für diese Tabellen. Doch 1866 bezeichnete Huxley sie beziehungsweise die Kombination der ihr zugrunde liegenden Maße als Busks Werk (Huxley 1866a, S. 161: „Table of Anatomical Measurements of the Crania from Keiss, taken according to Mr Busk's Method").

79 Busk (1866a), An Account of the Discovery of a Human Skeleton beneath a Bed of Peat on the Coast of Cheshire". In: Transactions of the Ethnological Society 4, S. 101-104, S. 103: „, [T] he skeleton [...] gives us an excellent idea of what manner of man it belongs to". 
Abb. 7. Busks „,Table of Anatomical Measurements “. 80

\begin{tabular}{|c|c|c|c|c|c|c|c|c|c|c|c|c|c|c|c|}
\hline & 1 & 2 & 3 & 4 & 5 & 6 & 7 & 8 & 9 & 10 & 11 & 12 & 13 & 14 & 15 \\
\hline & Length & Breadth & Height & \begin{tabular}{|c|}
$\begin{array}{c}\text { least } \\
\text { frontal } \\
\text { breadth }\end{array}$ \\
\end{tabular} & $\begin{array}{c}\text { greatest } \\
\text { frontal } \\
\text { breadth }\end{array}$ & $\begin{array}{l}\text { Parietal } \\
\text { breadth }\end{array}$ & $\begin{array}{c}\text { occipetal } \\
\text { breadth }\end{array}$ & $\begin{array}{c}\text { zygomatic } \\
\text { breadth }\end{array}$ & $\begin{array}{l}\text { frontal } \\
\text { radius }\end{array}$ & $\begin{array}{l}\text { vertical } \\
\text { radius }\end{array}$ & \begin{tabular}{|c|} 
perietal \\
radius
\end{tabular} & \begin{tabular}{|c}
$\begin{array}{c}\text { occipetal } \\
\text { radius }\end{array}$ \\
\end{tabular} & $\begin{array}{c}\text { maxillary } \\
\text { radius }\end{array}$ & nasal & $\begin{array}{c}\text { circumfe- } \\
\text { rence }\end{array}$ \\
\hline Hottentot mean & 7.06 & 5,26 & 5.53 & 3,77 & 4.45 & 5.08 & 4.25 & 4.91 & 4,52 & 4.55 & 4.67 & 4.16 & 3.99 & 3.6 & 19,7 \\
\hline Bushmen mean & 7,03 & 5,34 & 5,22 & 3,75 & 4,4 & 5,3 & 4,2 & 4,68 & 4,5 & 4,45 & 4,57 & 4 & 3,85 & 3,72 & 19,8 \\
\hline $\begin{array}{l}\text { modern Europ. } \\
\text { mean }\end{array}$ & 7,33 & 5,5 & 5,6 & 3,8 & 4,7 & 5,2 & 4,4 & & 4,6 & 4,7 & 4,8 & 4,2 & 3,9 & 3,7 & 20,1 \\
\hline & 16 & 17 & 18 & 19 & 20 & 21 & 22 & 23 & 24 & 25 & 26 & 27 & 28 & 29 & \\
\hline & $\begin{array}{l}\text { longi- } \\
\text { tudinal } \\
\text { arc }\end{array}$ & $\begin{array}{l}\text { longi- } \\
\text { tudinal } \\
\text { Frontal }\end{array}$ & $\begin{array}{c}\text { Iongi- } \\
\text { tudinal } \\
\text { Parietal }\end{array}$ & \begin{tabular}{|c|} 
longi- \\
tudinal \\
occi- \\
petal
\end{tabular} & $\begin{array}{c}\text { frontal } \\
\text { transverse } \\
\text { arc }\end{array}$ & \begin{tabular}{|c|} 
vertical \\
trans- \\
verse \\
arc
\end{tabular} & $\begin{array}{c}\text { parietal } \\
\text { transverse } \\
\text { arc }\end{array}$ & $\begin{array}{c}\text { occipetal } \\
\text { transverse } \\
\text { arc }\end{array}$ & $\left|\begin{array}{l}\text { propor- } \\
\text { tions of } \\
\text { breadth }\end{array}\right|$ & $\begin{array}{l}\text { propor- } \\
\text { tions of } \\
\text { heights }\end{array}$ & \begin{tabular}{|c|} 
propor- \\
tions of \\
occip. \\
radius
\end{tabular} & $\begin{array}{c}\text { propor- } \\
\text { tions of } \\
\text { maxillary } \\
\text { radius }\end{array}$ & $\begin{array}{c}\text { propor- } \\
\text { tions of } \\
\text { cranial axis }\end{array}$ & $\begin{array}{l}\text { facial } \\
\text { angle }\end{array}$ & \\
\hline Hottentot mean & 14,3 & 4,97 & 5,01 & 4,8 & 11,7 & 12,2 & 12,8 & 11,1 & 0,745 & 0,783 & & & & 0,41 & \\
\hline Bushmen mean & 14,47 & 5,04 & 4,79 & 4,6 & 11,5 & 12,06 & 12,9 & 11,3 & 0,759 & 0,742 & & & & 0,42 & \\
\hline $\begin{array}{l}\text { modern Europ. } \\
\text { mean }\end{array}$ & & 5,1 & 5,1 & 4,7 & 12 & 12,8 & 13,4 & 11,5 & 0,742 & 0,775 & & & & & \\
\hline
\end{tabular}

Busks Diskussion beschränkte sich oft auf die bloße Identifikation eines Schädels als dolichokephalisch oder brachykephalisch, orthognathisch oder prognathisch, ${ }^{81}$ mitunter stellte er aber auch Überlegungen an, in denen er zu Vergleichszwecken auf gröbere Referenzwerte zurückgriff, etwa auf „europäische Schädel“ oder ,,australische Formen des Schädels“ ${ }^{82}$ In solchen Fällen zielte er auf eine rassentaxonomische Bestimmung ab - etwa bei der Beschreibung zweier Schädel von den Andamanen. Die hatte er nach seiner kraniometrischen Tabelle mit Schädeln von indischen Hindus aus niedrigen Kasten und von Veddahs aus dem damaligen Ceylon verglichen:

„Jene beiden Klassen von Völkern wurden zum Teil wegen ihrer geographischen Beziehung zu den Andamanen ausgewählt und zum Teil, weil sie mit ihrem kleinen Schädel von allen Menschen den Andamanen am nächsten zu stehen scheinen“" ${ }^{83}$

Busk ging es also um die Frage, ob die meßbaren Charakteristika die Annahme einer Verwandtschaftsbeziehung zwischen Veddah, Hindus und Andamanen unterstützten oder nicht. Grundsätzlich nahm er für alle drei Gruppen aufgrund ihrer Schädelcharakteristika eine Abkunft aus Afrika an, gleichwohl er sie als ,Negritos ‘ bezeichnete, zu denen er auch

80 Busk: „Table of Anatomical Measurements“. In: Royal College of Surgeons of London, Busk Papers. 275 e 1(5).

81 Vgl. Busk 1866a, S. 101-104.

82 Vgl. Busk 1868, S. 11: „European skulls“; Busk (1866b) „Description of two Andamanese Skulls". In: Transactions of the Ethnological Society 4, S. 205-211, S. 209: „Australian forms of skull“.

83 Busk 1866b, S. 208: „Those two classes of people have been selected partly on account of their geographical relations to the Andamanese, and partly because, in the small size of the cranium, they appear to approach perhaps the nearest of all mankind to the Andamanese". 
Australier und Tasmanier rechnete. ${ }^{84}$ Er habe unter ihnen aber signifikante Unterschiede festgestellt, vor allem in Bezug auf die Verteilung des Volumens nach Schädelregionen:

„Verglichen mit den anderen Schädeln ist der Andamane vor allem in der vorderen Region defizitär, während er in der mittleren Region beträchtlich besser als die Veddah und in der hinteren annähernd ebenbürtig ausgestattet ist““ ${ }^{85}$

Busk strengte bei diesen Messungen keinerlei kulturelle oder soziale Interpretation an, doch könnte eine derartige Verteilungsanalyse als materielle Basis für eine phrenologische Deutung fungieren, die bestimmten Hirnregionen charakterliche Eigenschaften des Menschen zuweist. Andererseits lagen soziale oder kulturelle Interpretationsmuster seinen kraniometrischen Untersuchungen selbst zugrunde. So hatte er in obigem Beispiel explizit Schädel von Menschen niedriger Kasten gewählt, obwohl er den Vergleich allein über die räumliche Nähe rechtfertigte. Offenbar hielt er die Korrelation eines niedrigen sozialen Standes mit einem geringen Schädelvolumen für plausibel. Da er Schädelmaße für signifikante Indikatoren rassischer Merkmale hielt, zeigt sich, daß hier, wenn auch nicht auf die eigene Gesellschaft angewandt, ein rassifiziertes Bild sozialer Klassen zugrunde lag. Auf eine ähnliche Annahme stützte sich Busk bei einer Diskussion chinesischer Schädel. Einen statistischen Ausreißer bei einem Vergleich von (insgesamt nur zehn) Schädelindizes erklärte er ebenfalls über den sozialen Stand:

„die einzige Ausnahme ist ein chinesischer Pirat, dessen kephalischer Index .770 ist, und der wahrscheinlich von einer stärker gemischten Rasse als die Einwohner des Binnenlandes abstammt“" ${ }^{86}$

Er verband die angeblich besondere Schädelform nicht mit einer regionalen Abkunft, die er mit dem Verweis auf das Binnenland andeutete. In erster Linie ging er wie selbstverständlich von einer glaubwürdigen Verbindung zwischen der sozialen Randlage und einer Mischung von

84 Vgl. Busk 1866b, S. 209-210.

85 Busk 1866b, S. 209: ,[T] [he Andamanese, as compared with the other crania, is chiefly deficient in the frontal region, whilst he is considerably better furnished than the Veddah in the parietal, and very nearly his equal in the occipital, regions".

86 Busk (1870b) „Description of and Remarks upon an Ancient Calvaria from China, which has been supposed to be that of Confucius". In: Journal of the Ethnological Society 2, S. 73-81, S. 75: ,the only other exception being that of a Chinese pirate, whose cephalic index is .770, and who may not improbably have been of a more mixed race than the inhabitants of the interior". 
Rassen aus. Damit verfuhr er ähnlich wie Huxley, der ebenfalls auf die Annahme einer Rassenmischung auswich, wenn Meßverfahren keine eindeutigen Ergebnisse hervorbrachten. Den Überlegungen Busks liegt die Annahme zugrunde, Eigenschaften wie eine brachykephalische oder dolichokephalische Schädelform seien an sich hinlängliche Anhaltspunkte für die Bestimmung der Rasse:

„Es mag, denke ich, als Regel ausgegeben werden, daß bei allen brachykephalischen Schädeln die Breite die Höhe überschreitet, während das Gegenteil bei den dolichokephalischen der Fall ist. Individuelle Ausnahmen sind natürlich nicht selten, vor allem bei sehr gemischten Rassen, wie den modernen Engländern. Aber mir selbst sind nur zwei dolichokephalische Rassen bekannt, die auch wirklich so genannt werden können, bei denen diese Regel nicht gilt. Dies sind die Tasmanier (nicht die Australier) und die Buschmänner“ ${ }^{87}$

Wie Huxley betrachtete auch Busk die Engländer in dieser Argumentation als ein Rassengemisch. Beide demonstrierten in Überlegungen wie diesen eines jener neuen Merkmale des evolutionären Diskurses über Rasse, die Einschätzung, daß eine Mischung von Rassen nicht automatisch eine Verunreinigung, sondern, ganz im Einklang mit der Praxis der Züchter, von der sich Darwin sein Modell der natürlichen Auslese abgeschaut hatte, ein Veredelungspotential darstellte, das sich in bestimmten Konstellationen realisieren ließe.

Bei einer der wenigen Ausnahmen, die Busk von der Vermessung des Schädels wegführten, behandelte er eine besonders gestauchte, ,platycnemische“, Formung des Schienbeins, Tibia, bei einer Gruppe von prähistorischen Funden aus Denbighshire in Nordwales. Diese anatomische Besonderheit führte er auf einen Anpassungsprozeß zurück, den er durch Vergleiche mit Primatenknochen und Knochen lebender Menschen zu rekonstruieren versuchte:

„Wenn der Platycnemismus nicht als ein Rasse-Charakteristikum betrachtet werden kann, kann er noch weniger als ein Indikator für eine tendenzielle Affenähnlichkeit betrachtet werden, ein Begriff, den Monsieur Broca anscheinend zu bevorzugen geneigt ist. Es ist schon richtig, daß die Tibia von Gorilla

87 Busk 1870a, S. 467: „As a rule it may, I think, be stated that in all brachycepahlic skulls the breadth exceeds the height, whilst the reverse is the case in the dolichocephalic. Individual exceptions are of course not unfrequently met with, more especially among very mixed races, such as the modern English; but I am myself acquainted with only two dolichocephalic races, properly so termed, in which the rule does not hold good. These are the Tasmanian (not Australian) and the Bushman“. 
und Schimpanse in gewissem Maße platycnemisch sind, aber bei weitem nicht so sehr wie beim menschlichen platycnemischen Knochen. [...]

Aber dieser Vergleich mit den Menschenaffen mag vielleicht Grund für eine Annahme bieten, die eine mögliche Verbindung zwischen dieser besonderen Form der Tibia und dem Verhalten der Menschen, bei denen sie beobachtet wurde, betrifft. [...] Wäre es denn nicht zulässig zu fragen, inwieweit der Platycnemismus in einem Zusammenhang mit der größeren Bewegungsfreiheit und der generellen Verwendbarkeit der Zehen steht, die von jenen Völkern genossen wird, deren Füße nicht der Beengung durch Schuhwerk ausgesetzt sind“" 88

Busk diskutierte diese anatomische Eigenheit als Adaptionsresultat und Folge bestimmter Verhaltensweisen, die einen besonderen, affenartigen Einsatz des Fußes als Greifwerkzeug oder Kletterhilfe mit sich gebracht haben könnten. Er vermutete, ähnliche Ausprägungen bei zeitgenössischen schuhlosen Gesellschaften vorzufinden. Er argumentierte hierbei in Anlehnung an den stark rassistisch gefärbten Diskurs über den Greiffuß, denn durch die Unterstellung, Afrikaner hätten einen flexibleren großen Zeh, wurden sie im achtzehnten und neunzehnten Jahrhundert immer wieder mit den Primaten in Verbindung gebracht.

Anhand des kephalischen Index' diskutierte Busk zwei verschiedene Typen von Schädeln und ihre Verbreitung in Nord- und Südamerika. Durch anthropometrische Messungen und vor allem durch die Auswahl des samples konstruierte Extremformen veranlaßten manche physische

88 Busk 1870a, S. 459-460: „If, then, platycnemism cannot be regarded as of any value as a race-character, it can a fortiori be still less looked upon as indicative of simian tendencies, a notion that $\mathrm{M}$. Broca seems somewhat inclined to favour. It is quite true that the tibiæ of the gorilla and of the chimpanzee are, to a certain extent, platycnemic; but it is by no means so much as the human platycnemic bone. [...] But this comparison with the anthropoid apes may, perhaps, afford ground for a suggestion respecting some possible connexion between this peculiar form of the tibia and the habits of the people amongst whom it has been observed. [...] Would it not, then, be admissible to inquire how far [...] platycnemism may be connected with the greater freedom of motion and general adaptability of the toes enjoyed by those peoples whose feet have not been subjected to the confinement of shoes“. Einige Jahre später untersuchte Busk ein fossiles menschliches Wadenbein, das er vor der (wahrscheinlich letzten) Eiszeit datierte. Von diesem Wadenbein, meinte Busk, ließe sich nicht auf eine platycnemische Verformung des Schienbeins schließen. Auch hier schloß er, fast schon präventiv, die Interpretation des Platycnemismus als Indiz für eine entwicklungsgeschichtliche Verbindung aus (vgl. Busk (1874c) „Notice of a Human Fibula of Unusual Form, discovered in the Victoria Cave, near Settle, in Yorkshire“. In: Journal of the Anthropological Institute 3, S. 392-395; vgl. auch Busk (1873) „Man in the Settle Cave“. In: Nature 9, S. 70). 
Anthropologen, wie Morton in Crania Americana, sie auf eine künstliche Formung durch Bandagieren zurückzuführen. ${ }^{89}$

Busk jedoch meinte, daß nur bereits vorhandene Merkmale durch derartige Eingriffe verstärkt werden könnten. ${ }^{90}$ Deshalb nahm er an, daß es zwei ursprüngliche Schädelformen in Amerika gegeben haben müsse, rundliche und längliche. Durch bloßes Bandagieren vermöge der Mensch eben nicht jene Grundcharakteristika, die die Kraniometrie erkennbar gemacht habe, zu verändern. Nur ebenfalls vorgefundenen und als extrem länglich klassifizierten Schädeln schrieb Busk nun kulturellen Ursachen zu. Sie seien höchstwahrscheinlich aufgrund eines ästhetischen Verlangens modelliert worden. Die Grundcharakteristika, auf denen solche Bandagetechniken aufsetzten, wie eine dolichokephalische oder brachykephalische Schädelform, stünden außerhalb der Reichweite kultureller Einflüsse. Erst die wissenschaftlichen Untersuchungen der Kraniometrie gewährten deshalb in Busks Augen Einblick in die eigentliche Natur des Menschen.

Auch wenn er sich in seinen kraniometrischen Studien auf die anatomische Konstruktion von Rassemerkmalen konzentrierte, heißt dies nicht, daß er eine Korrelation mit signifikanten sozialen und kulturellen Unterschieden ausschloß oder nicht verfolgte. Denn in seinen Diskussionsbeiträgen bei der Ethnological Society und später beim Anthropological Institute oder bei der British Association betonte er die soziale Relevanz von bestimmten, unterstellten Rasseeigenschaften:

„Der Neger war eine derart unbewegliche Kreatur, daß er seit Anbeginn der Zeit kein Alphabet entwickelt, oder ein Schiff gebaut, oder ein einziges Tier domestiziert hatte, er war ein ebensolcher Wilder wie zu Anfang seines Landes". ${ }^{91}$

Busk griff hier den Topos der Geschichtslosigkeit der Wilden auf und betonte, daß bei ihnen kein Fortschritt und keine Entwicklung zu verzeichnen sei. In diesem Sinne ähnelte seine Argumentation Huxleys per-

89 Vgl. Busk (1874d) „Remarks on a Collection of 150 Ancient Peruvian Skulls, presented to the Anthropological Institute by T. J. Hutchinson, H. M. Consul at Callao". In: Journal of the Anthropological Institute 3, S. 8694, S. 93; Samuel George Morton (1839) Crania Americana, or, a comparative view of the skulls of various aboriginal nations of North and South America. Philadelphia: Pennington.

90 Vgl. Busk 1874d, S. 93-94.

91 Busk in einer Diskussion bei der BAAS, 1867, im Anschluß an einen Vortrag Lubbocks: „The Early Condition of Man“. S. 17: „The negro was so stationary a creature, that he had never from the beginning of time invented an alphabet, or built a ship, or domesticated a single animal: he was as great a savage as he had been in the early dawn of his country“. 
sistenten Typen. Beide waren an der Konstruktion einer Systematik der anatomischen Rassenunterschiede interessiert. Aus diesem auf Stetigkeit der Merkmale hin orientierten Ansatz entstand bei Busk ein Bild auch der sozialen Unveränderbarkeit bei nahezu allen außereuropäischen Gesellschaften. In diesem Zusammenhang könnte Busks Annahme, daß gerade die Europäer Produkte rassischer Mischung seien, Aufschluß über die von ihm vermutete Ursache für die Fortschrittsbefähigung geben, die allein die Europäer kennzeichne.

\section{Fazit}

Bei einer Ansprache als Präsident des Anthropological Institutes unterteilte Busk die Agenda des Instituts in drei Bereiche:

„I. Ethnographie, einschließlich der Sprachen, Sitten, Bräuche und physischer wie moralischer Charaktereigenschaften verschiedener Rassen oder Bevölkerungen.

II. Prähistorische oder Ur-Archäologie - die Materialien für das Studium der Beziehungen und Bedingungen der menschlichen Rasse im Verlauf der Zeit. III. Anthropologie, richtig verstanden, oder die Naturgeschichte des Menschen, betrachtet in zoologischem Sinne, einschließlich seiner psychischen Eigenschaften“. 92

Busk selbst hatte sich der reinen Anthropologie verschrieben. Sein Beitrag beschränkte sich auf anthropometrische Messungen. Er arbeitete ab den sechziger Jahren vor allem in seinem Labor am Royal College of Surgeons und verfertigte hier in großen Mengen Schädelmessungen und Vergleichsreihen, die er in seinen Tabellen dokumentierte. Mit seinen innovativen Neuerungen der Meßverfahren beteiligte er sich an der Modernisierung des damaligen anthropometrischen Diskurses.

Im Kontext der Etablierung evolutionärer Ansätze zur Rassentheorie griff er an der Seite Huxleys und Lubbocks in die Auseinandersetzungen zwischen der Ethnological Society und der Anthropological Society ein und arbeitete an der Widerlegung polygenistischer Positionen, wie bei der Diskussion um die Funde bei Keiss oder in der Frage der amerikanischen Kraniologie. Mit dem Nachweis einer evolutionären Entwicklung

92 Busk (1875) „,The President's Address“. In: Journal of the Anthropological Institute 4, S. 476-502, S. 476: „I. Ethnography, including the languages, manners, customs, and psychical and moral characteristics of different races or populations. II. Prehistoric or Priscan Archæology - the materials for studying the relations and conditions of the human race in Time. III. Anthropology, properly so termed, or the Natural History of man regarded in a zoological sense, including his psychical characteristics“. 
des Menschen befaßte sich Busk nicht, diese Dimension wurde nur in ihrer Negation aufgerufen, bei der Wiedergabe der stereotypen Behauptung, die sogenannten Wilden würden sich nicht entwickeln.

Doch neben diesen wissenschaftlichen und wissenschaftspolitischen Interventionen steuerte er dem anthropologischen Diskurs eher Detailergebnisse der Grundlagenbildung bei. Die methodologischen und theoretischen Grundlagen einer evolutionären Anthropologie, an denen Busk arbeitete, führten in seinem Fall nur zu einer bedingten Modernisierung ohne Aufgabe rassentheoretischer Altbestände. Busk war zwar in sozialer Hinsicht fester Bestandteil des Netzwerks der Evolutionstheoretiker, doch in seiner Anthropologie scheint eine evolutionäre Orientierung nur an einigen Punkten, dann vor allem in Form einer Anpassungslogik, durch.

\section{3 „Extremes of a series“. Rassenkonzepte in John Lubbocks Theorie sozialer Evolution}

Zeitgleich mit der Huxley-Owen-Kontroverse über die Mensch-Primaten-Beziehung hatte John Lubbock im frisch vom X-Club erworbenen Natural History Review eine Reihe von Artikeln plaziert, in denen er seine evolutionstheoretische Interpretation stein- und bronzezeitlicher Siedlungsreste in Nord- und Mitteleuropa entwickelte. Im Kontext dieser archäologischen Untersuchungen entwarf er eine ethnologische Forschungsagenda, bei der er sich nicht auf die bloße Altersbestimmung von Artefakten beschränkte, sondern vor allem an den Prozessen gesellschaftlicher Veränderungen seit der Vorzeit interessiert war. ${ }^{93}$

93 Lubbock hatte zwar schon 1855 ein Exzerptheft angelegt, in dem er unter anderem auch Robert Gordon Lathams Man and his Migrations (1851) ausführlich besprochen hatte (vgl. British Library. MS 62688, Notebooks of Sir John Lubbock, f. 26-27), doch die nächsten erhaltenen ethnologischen Exzerpte stammen dann schon aus den frühen sechziger Jahren (vgl. Royal Society: Lubbock Papers, MS 683 LUA 5). Ein ernsthaftes wissenschaftliches Interesse an der Ethnologie hatte Lubbock deshalb wohl in den fünfziger Jahren noch nicht. Ab 1863 begann er, eine umfangreiche Sammlung von prähistorischen Artefakten anzulegen, die er auch als Anschauungsobjekte in seine Vorlesungen mitnahm (Vgl. Janet Owen (1999) „The Collections Sir John Lubbock, The First Lord Avebury (1834-1913). ,An Open Book?““. In: Journal of Material Culture 4, S. 283-302; Hutchinson 1914, Bd. 1, S. 86). 


\section{Evolution und Diffusion}

In den Debatten der zeitgenössischen Archäologie über prähistorische Funde ging es neben ihrer Altersbestimmung auch um eine Zuordnung zu Epochen wie Stein- oder Bronzezeit. Da Fundorte von Siedlungen oftmals Spuren verschiedener Epochen aufwiesen, warfen sie regelmäBig die Frage nach den Ablösungsprozessen dieser Epochen auf. Ihr ging auch Lubbock nach, beispielsweise in seiner Diskussion der skandinavischen Kjökkenmöddinger - prähistorischer, überwiegend aus Muschelschalen gebildeter Abfallhaufen. Das Ende der Steinzeit, der diese Siedlungsreste zugerechnet wurden, führte er auf eine Völkerwanderung aus einem nicht näher bestimmten, zivilisierteren Osten zurück. Durch sie habe die Bronzezeit in Skandinavien Einzug erhalten, die durch zahllose Funde von bronzenen Artefakten und Waffen dokumentiert ist. Für die Annahme, der Epochenwechsel sei durch eine Völkerwanderung initiiert worden, berief sich Lubbock zunächst auf Gründe, die eine emergente Entwicklung der Bronzetechnik ausschließen sollten:

„Es ist unstrittig, daß die Menschheit ein Zeitalter des Kupfers durchlebt haben muß, bevor sie zum Wissen über Bronze gelangte. Das Fehlen jeden Hinweises auf eine solche Epoche in Nordeuropa [...] ist einer von mehreren Gründen, die Aneignung von Bronze nicht als eine Entdeckung der Steinzeitmenschen zu betrachten, sondern als einen Import nach Nordeuropa durch eine neue Rasse. [...] Es ist wahrscheinlich, daß die Menschen der Steinzeit von einer zivilisierteren Rasse, die aus dem Osten kam, unterworfen und teilweise ersetzt wurden“. .94

Zwei Aspekte seiner Argumentation sind bemerkenswert. Zum einen bezog Lubbock die äußeren, natürlichen Bedingungen in seine Überlegung über technische und soziale Entwicklung mit ein. Da er davon ausging, daß in Nordeuropa keine Bronze hergestellt werden konnte, weil die für diese Legierung notwendigen Metalle hier nicht vorkamen, nahm er einen Kulturimport an. Doch er argumentierte hierbei nicht im diffu-

94 John Lubbock (1861) „The Kjökkenmöddings: Recent GeologicoArchæological Researches in Denmark". In: Natural History Review 1, S. 489-504, S. 490: „Before arriving, however, at a knowledge of bronze, it is evident that mankind must have passed through an age of copper, and the absence in Northern Europe of any evidence of such a fact $[\ldots]$ is one among several reasons for regarding the acquisition of bronze, not as a discovery made by the men of the Stone period, but rather as an introduction into Northern Europe by a new race. [...] It is probable that the men of the Stone period were conquered and partly replaced, by a more civilized race coming from the East“". 
sionistischen Sinne eines Technologietransfers. Der Diffusionismus in der Ethnologie führt kulturelle Wandlungsprozesse auf eine migrationsoder handelsbedingte Verbreitung kultureller Errungenschaften mit jeweils regionalen Adaptionen zurück und wird als Gegenentwurf zum Evolutionismus begriffen. ${ }^{95}$ Lubbock hingegen stellte die Einführung der Bronze in Nordeuropa als Resultat eines Rassenkampfes dar, der auf der Logik des Überlebens des Stärkeren beruht haben sollte.

Anhaltspunkt für diese Vermutung war aber nicht allein das Fehlen von Kupfervorkommen in Nordeuropa, sondern auch die Beschaffenheit der Bronzewaffen. Lubbock nahm die kleineren Griffe der Gerätschaften der Bronzezeit zum Anlaß, auf kleinere Hände ihrer Besitzer zu schließen. Er hielt sie für einen Hinweis auf deren Abstammung aus Indien, und nahm offenkundig bei Indern und allgemein Asiaten eine kleinere Statur als bei den damaligen Europäern an. ${ }^{96}$ Auf die exakten Maße der Griffe der steinzeitlichen Werkzeuge hatte Lubbock aber keinen Zugriff gehabt, denn Holzgriffe waren nicht erhalten und einem Faustkeil konnte die Größe der ihn führenden Hand in den relevanten Dimensionen nicht abgeschaut werden. Lubbocks Vermutung, daß die Hände, die die steinzeitlichen Gerätschaften führten tatsächlich größer gewesen waren als jene der Menschen der Bronzezeit, deutet an, daß sich hier unbewußt eine mythische Vorstellung vom ,nordischen Typ“ eingeschlichen hatte. Lubbock stellte sich diese Waffen in den Händen hünenhafter Nordmänner vor - und schloß auf eine asiatische, kleinwüchsigen Rasse, die nur aufgrund ihrer technischen Überlegenheit die autochthonen Europäer unterwerfen konnte.

Lubbock ordnete die evolutionäre Logik an dieser Stelle einer Rassenlogik unter. Seine Annahme unterschiedlicher Körpergrößen von Asiaten und Europäern ließ ihn auf einen prähistorischen Rassenkampf schließen. Unstrittig ist, daß die Handgriffe der bronzenen Waffen für moderne Benutzer vergleichsweise klein ausfielen. Doch evolutionstheoretisch hätte er genausogut auf einen Wachstumsprozeß zwischen dem Bronzezeitmenschen und den zeitgenössischen Skandinaviern schließen können, doch das Rassenargument schien überzeugender gewesen zu sein. Einige Jahre später erklärte Lubbock in einer überarbeiteten Version dieser Erörterungen, daß es ausgedehnte Handelsnetze in der Bronzezeit gegeben haben müsse, da ansonsten die Herstellung dieser Legierung nicht möglich gewesen wäre:

95 Vgl. Freeland 1983, S. 189-199; Franz Boas (1982a) „Evolution or Diffusion?“. In: Ders.: Race, Language and Culture. [1940] Chicago: University of Chicago Press, S. 290-294; Franz Boas (1982c) „The Methods of Ethnology“. In: Ders.: Race, Language and Culture. S. 281-289.

96 Vgl. Lubbock 1861, S. 490-491. 
„Gerade die Existenz von Bronze ist Beweis für einen beachtlichen und ausgedehnten Handel, insofern wir nur zwei Länder kennen, nämlich Cornwall und die Insel Banca, von denen in größeren Mengen Zinn zu erhalten gewesen wäre. [...] Es ist berechtigt anzunehmen, daß die Kenntnis der Bronze nach Europa eingeführt und nicht dort selbst entdeckt wurde“. ${ }^{97}$

Allerdings hielt er an seiner Theorie der eingewanderten Rasse aus Asien fest, obwohl nicht nur die Rohmaterialien, sondern auch das Wissen um die Technik auf diesen Handelwegen hätten transportiert werden können. Der verbleibende Anhaltspunkt - die Griffgröße der bronzezeitlichen Schwerter - erlaubte es, auf rassische Unterschiede abzustellen, die für Lubbock am schwersten wogen.

Lubbock versuchte auch, seine Vermutung, daß die Einführung von Bronze in Nordeuropa auf die Einwanderung einer indischen Rasse zurückzuführen sei, mit einem Rekurs auf die anthropologische Schädellehre zu untermauern. Der britische Anthropologe David Thurnam hatte 1864 eine statistische Korrelation zwischen Schädelform und der Form der Begräbnisstätte entdeckt. ${ }^{98}$ Thurnam bediente sich des Schädelindex' von Retzius und stellte fest, daß in den länglichen Gräbern dolichokephalische, also längliche Schädel, und in den runden Gräbern brachykephalische, also runde Schädel gefunden wurden. ${ }^{99}$

„Ein derart beachtlicher Unterschied scheint gewiß auf einen Rassenunterschied hinauszulaufen, und Dr. Thurnam neigt dazu, die dolichokephalischen Menschen dem Neolithikum zuzuschreiben und die brachykephalischen der Bronzezeit. [...] Aber es muß bemerkt werden, daß, selbst wenn die Bronzezeit die Einwanderung einer neuen Rasse nach Europa markiert, diese sicherlich nicht die früheren Einwohner vernichtet, sondern zumindest die jungen

97 Lubbock (1867) „Address delivered to the Section of ,Primæval Antiquities" at the London Meeting of the Archaeological Institute, July 1866". In: Archaeological Journal of London 23, S. 190-211, S. 202: „The very existence of bronze proves that of a considerable and extensive commerce, inasmuch we only know two countries, namely Cornwall, and the Island of Banca, whence tin could have been obtained in large quantities. [...] [I]t is reasonable to conclude that the knowledge of bronze was introduced into, not discovered in, Europe".

98 Vgl. Joseph Thurnam (1864) „On the Two Principal Forms of Ancient British and Gaulish Skulls“. In: Memoirs of the Anthropological Society 1, S. 120-168.

99 Vgl. Lubbock (1872a) Pre-historic Times: As Illustrated by Ancient Remains, and the Manners and Customs of Modern Savages. [1865] London: Williams \& Norgate, S. 137. 
Frauen geschont haben dürften, so daß [...] es sehr unsicher ist, über den Charakter der Bevölkerung in der Bronzezeit zu spekulieren“. ${ }^{100}$

Interessant bei Lubbocks euphorischer Anerkennung dieser Korrelation als Beweis verschiedener Rassen ist der von ihm zwar zitierte, aber dann doch übergangene Mittelpart der tabellarischen Anordnung Thurnams. ${ }^{101}$ Zwischen den brachykephalischen und den dolichokephalischen Schädeln führte Thurnam eine nennenswerte Zahl sogenannter orthokephalischer Schädel an, die sich auf die länglichen wie die runden Gräber verteilten. Lubbock wollte aber die Vermutung untermauern, daß die Gräberformen verschiedene Epochen repräsentierten und die darin Bestatteten verschiedenen Rassen angehörten. Und so ging er auf diese nach dem kephalischen Index nicht als extrem eingestuften Schädel nicht weiter ein. Ihre Anwesenheit in beiden vermuteten Epochen hätte Lubbocks Zuordnung von Schädelform und Epoche durchaus in Frage stellen können.

Bei seiner Diskussion der archäologischen Funde aus der Schweiz ging Lubbock hingegen von einer unabhängigen, isolierten Entwicklung der Kulturtechniken aus, die durch die Artefakte dokumentiert würde. Aus stratigraphischer Lage und materieller Beschaffenheit sowie aus Funden von Tierüberresten leitete er $a b$, daß die Fundorte verschiedene Epochen der Stein-, Bronze- und Eisenzeit repräsentierten. Er schloß auf „,einen graduellen Fortschritt der Zivilisation und die Verbesserung der Künste, eine Zunahme der domestizierten Tiere und [...] die Existenz eines ausgeweiteten Handels“. ${ }^{102}$ Er argumentierte hier gänzlich entgegengesetzt der Vorstellung von jenem Rassenkampf, den er in Nordeu-

100 Lubbock 1872a, S. 137-138: „So remarkable a distinction certainly appears to imply a difference of race, and Dr. Thurnam is disposed to refer the Dolichocephalic people to the Neolithic Age, the Brachycephalic to that of Bronze. [...] [B]ut it must be remarked [...] that even if the Bronze Age indicates the immigration of a new race into Western Europe, they would probably not exterminate the earlier inhabitants, but would at any rate spare the young women, so that $[. .$.$] it would be very$ unsafe to speculate on the character of the population during the Bronze Age".

101 Thurnams Tabelle nach Lubbock (1872a, S. 137): ,

Skulls Dolichocephalic Orthocephalic Brachycephalic 63-73. $\quad$ 74-79. 80-89.

$\begin{array}{lrrrr}\text { Long Barrows } & 67 & 55 & 12 & 0 \\ \text { Round Barrows } & 70 & 0 & 26 & 44 \text { “. }\end{array}$

102 Lubbock 1862a, S. 48: „We have seen evidences of a gradual progress in civilization, and improvement in the arts, an increase in the domestic animals, and proofs at last of the existence of an extended commerce. We found the country inhabited only by rude savages and we leave it the seat of a powerful nation". 
ropa zwischen Autochthonen und eingewanderten Asiaten angenommen hatte. Und deshalb beschrieb hier er die Ablösung der Stein- durch die Bronzezeit als einen kontinuierlichen sozialen Wandel:

„So bedeutende Veränderungen vollziehen sich nicht an einem Tag, der Fortschritt des menschlichen Verstandes ist langsam und anhand des langsamen Wachstums menschlichen Wissens und menschlicher Macht können wir [...] eine Vorstellung gewinnen, wie fern der Tag ihres Beginns gewesen sein muß“. ${ }^{103}$

Lubbock argumentierte im Bewußtsein eines erweiterten Verständnisses des Alters der Menschheit. ${ }^{104}$ Er schilderte die Prozesse sozialer Veränderung als stetige, aber langsam ablaufende soziale Evolution und betrachtete diese durchweg als einen sozialen Fortschritt, der von rohen Wilden bis zu einer mächtigen Nation verlaufen sei. Außerdem verband er diese Entwicklung mit Veränderungen im Verstand der einzelnen Menschen. Gerade hierin, so Lubbock, sei die Ursache für die sich nur langsam vollziehende soziale Wandlung zu sehen.

Auch wenn Lubbock an dieser Stelle soziale Evolution als lokale und emergente Entwicklung diskutierte und offenbar keine Veranlassung hatte, somatische Merkmale als Indizien verschiedener Rassen aufzurufen, hatte er die Rassenlogik nicht aufgegeben. Sie erweist sich vielmehr als elementarer Bestandteil seiner Vorstellung sozialer Evolution. Zu dieser Rassenlogik Lubbocks zählte auch, daß er Huxleys Ausführungen über die Schädel aus Engis und dem Neandertal in seiner Diskussion über prähistorische Europäer aufgriff. ${ }^{105}$ Aus der von Huxley diagnostizierten Verteilung dolichokephalischer und brachykephalischer Schädel folgerte er, daß „Europa selbst in dieser frühen Epoche bereits

103 Lubbock 1862a, S. 48 und (wortidentisch) Lubbock 1872a, S. 221: „Changes so important as these are not effected in a day; the progress of the human mind is but slow; and the gradual additions to human knowledge and power $[\ldots]$ enable us to form some idea how distant must be the date of their commencement".

104 Die Betonung einer großen zeitlichen Ausdehnung der Vorgeschichte bildet ein immer wiederkehrendes Motiv bei Lubbock (vgl. auch Lubbock (1873) „Existence of Men in the Miocene“. In: Nature 7, S. 401, S. 401).

105 Vgl. Lubbock (1864) „Cave-Man”. In: Natural History Review 4, 407428, S. 427-428. In Lubbocks Aufzeichnungen findet sich ein systematischer Ansatz zur Zuordnung von Schädelformen zu vermeintlich primitiven Gesellschaften erst 1868 (vgl. Lubbock Papers, MS 684 LUA 15 Savages, S. 27). In Pre-historic Times (1865) ergänzte Lubbock die Überlegungen aus seinem Aufsatz „Cave-Man“ (1864) zur Zivilisation der vorgeschichtlichen Höhlenbewohner in Europa durch kraniometrische Daten ihrer Schädel. 
von mehr als einer Rasse besiedelt war". ${ }^{106}$ Lubbock deutete die verschiedenen Schädel als Merkmale distinkter Rassen und stellte sich deren friedliche Koexistenz über Generationen vor. Seine Vermutung eines Rassenkampfes in Nordosteuropa war folglich ein Sonderfall, der allein durch das Indiz der Griffgröße der Bronzeschwerter geschaffen wurde.

\section{Evolution und Degeneration}

Seit der Entdeckung Amerikas waren Spekulationen über den Ursprung der Menschheit von den Bildern der vermeintlich Wilden der neuen Welt beeinflußt. Doch die europäische Vorstellung der präkolumbianischen Gesellschaften war nicht einheitlich. Vielmehr war sie von einer Ambivalenz der hier unterstellten, primitiven Wildheit auf der einen und den steinernen Monumenten Meso- und Südamerikas auf der anderen Seite geprägt, die als Hinterlassenschaften untergegangener Hochkulturen gedeutet wurden. Im Kontext der revolutionären Entwicklungen der europäischen Archäologie forderte die Klärung dieser Ambivalenz Archäologen und Anthropologen gleichermaßen heraus. Britische Archäologen wie Daniel Wilson begannen deshalb sogar, selbst in Amerika $\mathrm{zu}$ forschen. ${ }^{107}$ Lubbock schaltete sich in die damalige Debatte ein und meinte, daß vor allem die Ergebnisse der nordamerikanischen Archäologie eine Modifikation der europäischen Periodisierung von Stein-, Bronze- und Eisenzeit erforderlich gemacht hätten:

„Zur Zeit der Entdeckung Amerikas [...] waren die mächtigen Nationen Zentralamerikas in der Bronzezeit, während die Nordamerikaner sich in einem $\mathrm{Zu}-$ stand befanden, für den wir in Europa nur spärliche Spuren finden - nämlich die Kupferzeit"“. ${ }^{108}$

106 Lubbock 1872a, S. 340: „It would appear then that, even at this early period, Europe was already occupied by more than one race of man".

107 Mit dem Verhältnis von Wilson zu Lubbock und anderen Paläo-Anthropologen und Archäologen im viktorianischen England setzt sich Alice B. Kehoe auseinander. Sie ist allerdings in erster Linie daran interessiert, für Wilson den Platz in der Disziplinengeschichte der Archäologie zu behaupten, der ihm von der Praxis der sog. Whig-History verweigert worden sei, jener positivistischen Form der Geschichtsschreibung, die nur diejenigen berücksichtigt, die zum immer noch gültigen Wissenshaushalt einer Disziplin beigetragen haben (vgl. Alice B. Kehoe (1991) „The Invention of Prehistory“. In: Current Anthropology 32, S. 467-476, S. 468).

108 Lubbock (1863) „North American Archæology“. In: Natural History Review 3, S. 1-30, S. 3: „At the time of the discovery of America [...] [t]he powerful nations of Central America were [...] in the age of Bronze, while the North Americans were in a condition of which we find in Europe but scanty traces - namely, in the age of Copper". 
Er verwendete hier die Epochen nicht mehr nur, um eine zeitliche $\mathrm{Ab}$ folge $\mathrm{zu}$ bestimmen, sondern auch um rezente gesellschaftliche Entwicklungszustände zu beschreiben. Mit dieser Überlegung vollzog er Huxleys Vergleich des Australiers mit dem Neandertaler auf ethnologischer Ebene nach - mit dem Unterschied, daß er den amerikanischen Gesellschaften nicht das Fehlen jeglicher Entwicklung, sondern bloß eine beträchtlich langsamere Entwicklung als den Europäern zuschrieb. Die Amerikaner hätte kaum die Steinzeit verlassen. Insbesondere nicht, da sie Lubbock zufolge das Kupfer nicht durch Gußverfahren, sondern durch Hämmern in die gewünschte Form gebracht:

„Sie lebten in einer Steinzeit, da sie das Kupfer nicht wie ein Metall, sondern wie Stein behandelten. Dieser Zwischenzustand zwischen einer Steinzeit und einer Eisenzeit ist höchst interessant “. ${ }^{109}$

Lubbock konstruierte hier zwar eine kulturelle Aufwärtsentwicklung, bei der die bloße Kenntnis der Existenz des Metalls seiner Verarbeitung in Schmelzprozessen vorausgegangen sein soll. Doch bei seiner Bestimmung einer Zwischenstufe zwischen Stein- und Eisenzeit erwies sich allein seine Verwendung der prähistorischen Epochen als flexibel. Hingegen wurden die hier klassifizierten Wilden auf eine Steinzeit fixiert, ungeachtet des Umstands, daß sie Metalle verarbeiteten. Die flexible Handhabung seines prähistorischen Epochensystems zeigt, wie sehr für Lubbock die Gewißheit, daß die nordamerikanischen Wilden in keiner der Bronzezeit vergleichbaren Epoche lebten, einen robusten Wissensbestand darstellte, der nicht erst aus der Anwendung des Epochensystems heraus generiert wurde, sondern auf einem rassistischen Dünkel beruhte, der durch Lubbocks wissenschaftliche Ergebnisse nicht zu erschüttern war.

Die amerikanische Archäologie war neben vermeintlicher Belege für eine kupferverarbeitenden Steinzeit in der damaligen Debatte über soziale Evolution auch deshalb wichtig, weil sie sich mit den Überresten vergangener Kulturen in Lateinamerika befaßte. Für die kontroverse Frage, ob soziale Entwicklung vorwiegend progressiv oder degenerativ verlaufe, waren diese Überreste wichtiges Referenzmaterial. Sie wurden in der Regel als Indiz degenerativer Verläufe sozialer Entwicklung gedeutet. Um diese Ansicht zu entkräften, kombinierte Lubbock die Methodologie einer rein archäologischen Periodisierung mit einem Ver-

109 Lubbock 1872a, S. 254: ,they may in one sense be said to have been in an age of Stone, since they used the copper, not as metal, but as Stone. This intermediate condition between an age of Stone and one of metal is most interesting“. 
gleich kultureller Unterschiede. Dabei zog er nicht nur Werkzeuge und Artefakte, sondern auch die Entwicklung von Agrartechniken in Betracht:

„wir scheinen Anzeichen für vier lange Perioden zu haben:

1. Jene, in der die amerikanischen Stämme, nach ursprünglicher Barbarei, ein Wissen von Landwirtschaft und die Fähigkeit zur Assoziation ausbildeten.

2. Jene, in der die Wallanlagen errichtet und andere große Arbeiten bewältigt wurden.

3. Das Alter der Gartenbeete, die zumindest in einigen der Wallanlagen existierten. [...]

Und 4. Die Periode, in der der Mensch in die Barbarei zurückfiel und die Gebiete, die zuerst bewaldet, dann (vielleicht) heilige Anlagen und danach kultiviertes Land waren, wieder zu Wald wurden“. ${ }^{110}$

Lubbock beschrieb so Aufstieg und Niedergang der amerikanischen Gesellschaften in einem großen Erzählrahmen und griff damit der $\mathrm{Ar}$ gumentation der späteren Theorien von der zyklischen Entwicklung von Kulturen vor, wie sie Ende des neunzehnten Jahrhunderts von Arnold Toynbee oder Oswald Spengler entworfen wurden. ${ }^{111}$ Dabei berief er sich nicht mehr auf den Unterschied zwischen den zuvor zugeschriebenen Perioden von Bronze- und Kupferzeit und vernachlässigte ebenso die damit einhergehenden Hinweise auf die geographische Verteilung verschiedener Gesellschaftstypen. Er versuchte, die archäologischen Hinweise auf frühere Hochkulturen mit dem tradierten Bild der amerikanischen Barbarei zu vereinen und konstruierte dafür eine Phase der Degeneration, die er allerdings nicht in einen Zusammenhang mit dem

110 Lubbock 1863, S. 25: ,we appear to have indications of four long periods.

1. That in which, from an original barbarism, the American tribes developed a knowledge of agriculture and a power of combination.

2 . That in which the mounds were erected and other great works undertaken.

3. The age of the ,garden beds,' which occupy some at least of the mounds. [...]

And 4 . The period in which man relapsed into barbarism, and the spots which had been first forest, then (perhaps) sacred monuments, and thirdly cultivated ground; relapsed into forest once more“. Als ,garden beds" bezeichnet Lubbock die Anlage auf Beeten in Bezirken, die als heilig gegolten haben sollen. Das Zeitalter dieser Beetanlagen interpretiert er deshalb dahingehend, daß diese Orte also bereits ihren Status als heilige Stellen verloren haben müssen, da sonst ihre profane Nutzung nicht möglich gewesen wäre.

111 Vgl. Priester 2003, S. 207. 
Einfluß der Europäer brachte, ${ }^{112}$ sondern als Schlußakkord eines autonomen Spannungsbogens der amerikanischen Vorgeschichte selbst behandelte.

Dieser Entwicklungsverlauf steht im Widerspruch zu Lubbocks vehementem Einsatz für eine grundsätzlich progressiv ausgerichteten Verlauf sozialer Evolution, wie etwa in seiner Auseinandersetzung mit dem Duke of Argyll. ${ }^{113}$ Die seiner evolutionären Ethnologie ansonsten immanente Fortschrittsannahme konnte Lubbock hier nicht durchhalten. Die steinernen Monumente vergangener Gesellschaften in Lateinamerika und die stereotypisierte Vorstellung der Primitivität seiner zeitgenössischen indigenen Bevölkerung veranlaßten ihn, hier sein Fortschrittsmodell durch eine abschließende Phase des Niedergangs zu erweitern. Zwar spekulierte er über die Gründe für diese Degeneration und hielt vernichtende Kriege für wahrscheinlich, doch stellte er an keiner Stelle Überlegungen an, welchen Einfluß die europäische Landnahme in Amerika auf diesen Prozeß gehabt haben könnte. Lubbocks Überzeugung von Degeneration und Niedergang der lateinamerikanischen Hochkulturen war gewissermaßen in Stein gehauen.

Gleichwohl er am Beispiel des Übergangs von Stein- und Bronzezeit in Nordeuropa von einem Verdrängungskampf ausging, in dem die überlegene Gesellschaft überlebte, zog er einen vergleichbaren Prozeß, ausgelöst durch den Kolonialismus nicht in Betracht. Er wollte vor allem vermeiden, daß die hier für ihn evidenten degenerativen Momente als Belege für die Degenerationshypothese verwendet werden könnten, die von den Evolutionisten als hartnäckiger Überrest des Monogenismus betrachtet wurde. Deshalb ging es ihm darum, die Degeneration nur als letzte Phase einer grundsätzlich progressiven sozialen Entwicklung darzustellen.

\section{Evolution und Vergleichende Methode}

In Pre-historic Times bekannte sich Lubbock 1865 ausdrücklich zur Darwinschen Lehre und legte nahe, diese auch für die ethnologische Interpretation kulturellen Fortschritts heranzuziehen:

„Das große Prinzip der natürlichen Auslese, das bei Tieren den Körper beeinflußt und wenig Auswirkungen auf den Verstand zu haben scheint,

112 Vgl. Hund 1999, S. 46-53.

113 Hierhinter steht kein konzeptioneller Wandel in Lubbocks Ethnologie, denn er hatte die Argumentation, die er erstmals in einem Aufsatz von 1863 entwickelte, in Pre-historic Times übernommen und auch in späteren, ansonsten stark überarbeiteten Auflagen, unverändert gelassen. 
beeinflußt beim Menschen den Verstand und hat wenig Auswirkungen auf den Körper. Bei den ersten führt es hauptsächlich zur Bewahrung des Lebens, beim zweiten zur Verbesserung des Ver-standes und folglich zu vermehrtem Glück. Es stellt, in den Worten Herbert Spencers, ,einen beständigen Fortschritt hin zu [...] einem vollständigeren Leben" sicher". ${ }^{114}$

Er brachte bei der Anwendung der Darwinschen Lehre auch Spencer ins Spiel. Spencer habe den Prozeß, Darwin die Mechanik beschrieben. Bei seinen ethnologischen und archäologischen Arbeiten stützte sich Lubbock zwar beständig auf das Konzept sozialen Fortschritts. Die von ihm aufgestellte Behauptung, daß das von Darwin entdeckte Prinzip der natürliche Auslese den Verstand verbessere, beschäftigte ihn hingegen weniger. ${ }^{115}$ Hier brachte er die seinem Verständnis sozialer Evolution immanente Forschrittslogik auf den Punkt, auf der er eine für die Ethnologie lange Zeit bedeutende Konzeption fußen ließ: Die vergleichenden Methode (comparative method). ${ }^{116}$

Der vollständige Titel seines Buches Pre-historic Times as Illustrated by Ancient Remains and the Manners and Customs of Modern Savages von 1865 drückt als griffige Formel der komparativen Methode ein Programm aus, das letztlich die Operationalisierung eines traditionellen Gedankens war. Stocking erklärt, daß Lubbock in der Tradition eines damals verbreiteten Ansatzes der Ethnographie arbeitete, der den Wilden tierische Umgangsformen und Religionslosigkeit attestierte und sie für das Ebenbild vergangener Gesellschaftsformen hielt. ${ }^{117}$ Lubbock selbst beschrieb die Grundannahme seiner vergleichenden Verfahrensweise folgendermaßen:

114 Lubbock 1872a, S. 602: „The great principle of natural selection, which in animals affects the body and seems to have little influence on the mind, in man affects the mind and has little influence on the body. In the first it tends mainly to the preservation of life; in the second to the improvement of the mind, and consequently to the increase of happiness. It ensures, in the words of Mr. Herbert Spencer, ,a constant progress towards $[\ldots]$ a more complete life “".

115 Lubbocks theoretische Anleihen bei der Entwicklung seines Verständnisses sozialer Evolution verdeutlichen, daß eine solche Theorie im viktorianischen England ohne Spencer kaum denkbar gewesen war. Die Einschätzungen Van Ripers und Mark Pattons, Lubbock habe bei seiner Theorie sozialer Evolution durch und durch darwinistisch argumentiert, erweisen sich deshalb als eine vereinfachende Identifikation von Darwinismus und Evolutionismus, die andere Theorieelemente im Evolutionismus, wie etwa Spencers Beitrag, übersieht (vgl. Van Riper 1993, S. 218; Mark Patton (im Erscheinen) Kap. 5).

116 Vgl. Stocking 1987, S. 152.

117 Vgl. Stocking 1987, S. 153: „,manners beastly; religion none““; „Lubbock carried his cultural values emblazoned on his scientific standard“. 
„Vieles war über unsere [europäischen, T.G.] fossilen Dickhäuter von jenen Arten zu erfahren, die immer noch Teile Asiens und Afrikas besiedeln, [...] und auf die gleiche Weise müssen wir, wenn wir die vorzeitlichen Artefakte Europas eindeutig verstehen wollen, sie mit den einfachen Gebrauchsgegenständen und Waffen vergleichen, die immer noch oder bis vor kurzem von den wilden Rassen in anderen Teilen der Welt verwendet wurden. In der Tat sind der Van Dimaner und der Südamerikaner für den Altertumsforscher das, was für den Geologen das Opossum und das Faultier sind“. 118

Lubbock ging davon aus, daß die zeitgenössischen Wilden so lebten, wie die prähistorischen Gesellschaften in Europa. Er schlug vor, sich diesen Umstand bei der archäologischen und prähistorischen Forschung zu Nutzen zu machen und die vermeintlich Wilden als Anschauungsobjekte zu betrachten. Bei der Rekonstruktion der sozialen Entwicklung vertraute er einem tradierten Topos des rassistischen Diskurses, der die vermeintlich primitive Gesellschaften für geschichtslos hielt und ihnen jegliche Entwicklung absprach. ${ }^{119}$ Besonders die Van Diemaner, also die für ausgestorben gehaltenen Tasmanier, und die Feuerländer zählten im europäischen Diskurs über die Wilden zu den primitivsten Gesellschaften. Bei ihnen erwartete Lubbock, die größte Annäherung an den Nullpunkt der sozialen Entwicklung vorzufinden.

Franz Boas zufolge stand die vergleichende Methode in unmittelbarem Zusammenhang mit der Theorie sozialer Evolution, da der Vergleich eine Vergleichbarkeit voraussetze, die nur dann gegeben sei, wenn identische Entwicklungsverläufe unterstellt würden. ${ }^{120}$ Die vergleichende Methode schöpfte ihre Plausibilität nicht allein aus der Übertragung einer verbreiteten Haltung in eine wissenschaftliche Methodologie. Dazu trug auch die nicht minder verbreitete Ansicht bei, die sogenannten Primitiven verhielten sich wie Kinder. Hierbei handelt es sich um einen im damaligen europäischen Denken fest etablierten Topos. Auch Lubbock stützte sich auf eine derartige Infantilisierung der Wilden, wenn er etwa die Errichtung von Dolmen oder anderen Mega-

118 Lubbock 1872a, S. 427-428: „Much light is thrown on our fossil pachyderms, for instance, by the species which still inhabit some parts of Asia and Africa; [...] and in the same manner, if we wish clearly to understand the antiquities of Europe, we must compare them with the rude implements and weapons still, or until lately, used by the savage races in other parts of the world. In fact, the Van Dimaner and South American are to the antiquary what the opossum and the sloth are to the geologist".

119 Vgl. Meek 1976, S. 5-36.

120 Vgl. Franz Boas (1982b) „The Limitations of the Comparative Method in Anthropology“. In: Ders.: Race,Language and Culture. S. 270-280, S. 270-280. 
lithgräbern im kindlichen Spiel mit Bauklötzen wiederfand, ${ }^{121}$ oder die soziale Entwicklungsstufe der Primitivität mit dem Kindesalter parallelisierte:

„das Leben jedes Individuums ist eine Miniatur der Geschichte der Rasse und die graduelle Entwicklung des Kindes illustriert die der Art. Daher die Bedeutung der Ähnlichkeit zwischen Wilden und Kindern“. ${ }^{122}$

Hiermit betonte Lubbock die progressive Tendenz der sozialen Entwicklung, denn mit der Degenerationshypothese wäre die Theorie von der Spiegelung der Ontogenese in der Phylogenese, auf die sich die Infantilisierung der vermeintlich Wilden stützte, nicht vereinbar. ${ }^{123}$ Auf diese Weise parallelisierte er die soziale Differenz mit der biologischen Entwicklung und erklärte sie so für unaufhebbar. Die Entwicklungsfähigkeit wurde den vermeintlich Primitiven so nur in dem Maße zugestanden, als es einem individuellen Alterungsprozeß in den Dimensionen der Menschheitsgeschichte entspräche, sie wurde ihnen faktisch abgesprochen.

Hatte Lubbock bei seiner Diskussion von Bronze- oder Eisenzeitkulturen vor allem Technikeinsatz, Innovation und Landwirtschaft in Betracht gezogen, so nahmen diese Aspekte bei seiner Diskussion zeitgenössischer Wilder keine erklärungsmächtige Position mehr ein.

„Zweifelsohne markiert der Besitz von Eisen einen großen Fortschritt in der Zivilisation. Dennoch ist der Prozeß sehr kleinschrittig, und so gibt es Nationen, die, auch wenn sie im Besitz von metallenen Gegenständen sind, nur wenig aus dem Zustand der Barbarei herausgetreten sind. So gehörten die Hottentotten, die grundsätzlich mit der Herstellung von Eisen vertraut waren und die in großer Zahl Schafe und Rinder besaßen, dennoch in vieler Hinsicht zu den verabscheuungswürdigsten Wilden“. ${ }^{124}$

121 Vgl. Lubbock 1872a, S. 129.

122 Lubbock 1872a, S. 570: ,the life of each individual is an epitome of the history of the race, and the gradual development of the child illustrates that of the species. Hence the importance of the similarity between savages and children".

123 Vgl. allgemein Gould 1977.

124 Lubbock 1872a, S. 430: „No doubt the possession of iron generally marks a great advance in civilization; still the process is very gradual, and there are some nations which, though provided with metal implements, are nevertheless but little removed from a state of barbarism. Thus the Hottentots, who were generally [...] acquainted [...] with the manufacture of iron, and who possessed large numbers of sheep and cattle, were yet in many respects among the most disgusting of savages“. 
Zwar registrierte er, daß die sogenannten Hottentotten Kenntnisse der Metallverarbeitung besaßen, doch er maß diesem Kriterium keine Bedeutung bei ihrer Einordnung in die evolutionäre Rangordnung zivilisatorischen Fortschritts bei. Trotz ihres auch nach seinen Maßstäben evidenten technischen Fortschritts, rechnete er sie zu den primitivsten Gesellschaften. Dies ist bemerkenswert, da derartige materielle Errungenschaften gerade die Grundlage der Unterscheidung von Stein-, Bronzeoder Eisenzeit bildeten.

Lubbock setzte sich über die von ihm noch selbst verfeinerte Epocheneinteilung der Vorgeschichte hinweg. Obschon er durch die komparative Methode und ihren Vergleich mit vermeintlichen zeitgenössischen Wilden Erkenntnisse über die prähistorischen Gesellschaften zu generieren dachte, und obschon er an anderer Stelle die Australier als eine Steinzeitgesellschaft darstellte (vgl. Abb. 8), sah er an dieser Stelle davon ab, die vorgeschichtliche Periodisierung auf die zeitgenössischen Gesellschaften anzuwenden.

Abb. 8. Lubbock: Parallelisierung von australischer und vorgeschichtlicher Kultur. ${ }^{125}$

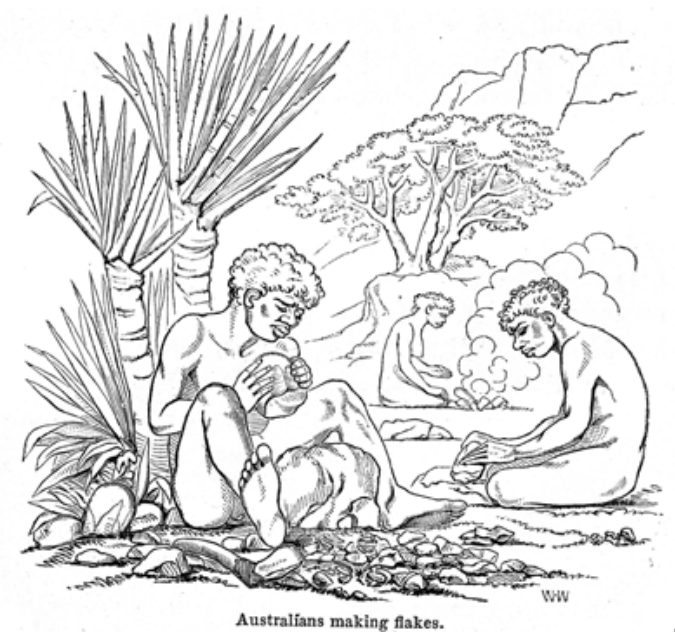

Dies ist nur dadurch zu erklären, daß er die sogenannten Hottentotten für eine derart primitive Gesellschaft hielt, daß er ihnen den Fortschrittsnachweis der Eisenzeitlichkeit nicht zubilligen wollte. Sie galten im neunzehnten Jahrhundert als eine der primitivsten Gesellschaften über-

125 Abb. 7: „Australians making flakes“. In: Lubbock 1872a, S. 88. 
haupt. Ihre Eisenverarbeitung wie auch die Kupferverarbeitung in der vermeintlichen nordamerikanischen Steinzeit reichte für Lubbock nicht aus, um einen sozialen Fortschritt zu diagnostizieren. Die Modifikationen und Wechsel seiner Methodologie waren erforderlich gewordenen, um eine fortgesetzte Zuschreibung der Primitivität dieser Gesellschaften gewährleisten zu können.

Die Erklärung, bei den sogenannten Hottentotten handele es sich um ,verabscheuungswürdige Wilde', koppelte an einen chauvinistisch aufgeladenen Diskurs über die Lebensweisen der als primitiv stilisierten Gesellschaften an. Er speiste sich aus Reiseberichten, die regelmäßig von ästhetischem und rassistischem Dünkel geprägt waren. Auch Lubbock rekurrierte auf diese amateurethnographischen Quellen und stellte die sogenannten Wilden, ihre Ernährung oder ihre Behausungen als „dreckig“, „,stinkende Kadaver“, ,,abstoßend“ oder ungewaschen dar. ${ }^{126}$ Er übernahm diese Darstellungen ebenso wie die grausamer Bräuche, Kinds- und Elternmordes oder Kannibalismus mit dem expliziten Hinweis, sich nur zuverlässiger Quellen bedient zu haben. ${ }^{127}$ Und er verwendete dieses Material in methodischer Hinsicht konsequent zur Rekonstruktion prähistorischer Lebensweisen in Europa:

„Wenn nicht zu den niedrigsten, zählen die Feuerländer mit Sicherheit zu den miserabelsten Beispielen der menschlichen Rasse, und die Bräuche dieser Menschen sind aufgrund ihrer wahrscheinlichen Ähnlichkeit mit denen der dänischen Muschelhaufen-Erbauer von besonderem Interesse“. ${ }^{28}$

Nachdem Lubbock größtmöglichen Ekel bei seinen zeitgenössischen Lesern hervorgerufen hatte, verlangte er ihnen nun die Einsicht ab, in den Feuerländern das Ebenbild der eigenen Ahnen zu erkennen. Er unterstrich den langen Weg des zivilisatorischen Fortschritts, der Innovati-

126 Vgl. Lubbock 1872a, S. 439: „As other natives arrive they ,fairly eat their way into the whale, and you see them climbing in and about the stinking carcase, [...] rubbed from head to toe in stinking blubber"“; „The snow-houses [...] gradually become very filthy. [...] ,In every direction round the huts $[\ldots]$ were lying innumerable bones of walruses and seals $[\ldots]$ on many of which a part of the putrid flesh still remaining sent forth the most offensive effluvia““ (ebd. S. 494); „They are excessively dirty [...] they never dream of washing" (ebd. 513).

127 Vgl. Lubbock 1872a, S. 583.

128 Lubbock 1872a, S. 543, S. 548-549: ,If not the lowest, the Fuegian certainly appear to be among the most miserable specimens of the human race, and the habits of this people are of especial interest from their probable similarity to those of the ancient Danish shellmound builders"; „The works of art found in the Dordogne caves are little ruder than those of the Esquimaux or the North American Indians“. 
onsschübe nicht nur in technischer, sondern auch in kultureller Hinsicht bedingt habe. Daß es sich hierbei um verschiedene Stufen eines progressiven und nicht eines degenerativen Prozesses handele, machte Lubbock im Anschluß an den Vergleich von Feuerländern und dänischer Steinzeit, von Eskimo und Höhlenmensch deutlich. Alle vier genannten Gesellschaften oder Gesellschaftsformen repräsentierten für ihn eine frühe Stufe des Zivilisationsprozesses. Und selbst diese eine Stufe weise in Abhängigkeit von natürlichen äußeren Umständen höchst unterschiedliche soziale Formen und Phänomene auf.

„Die Zivilisation der Steinzeit weicht nicht nur graduell, sondern in ihrer Art ab, sie variiert mit Klima, Vegetation, Nahrung etc. Daher ist es unstrittig, zumindest für jene, die an die Einheit der Menschheit glauben - daß die gegenwärtigen Bräuche der wilden Rassen nicht für eine exakte Wiedergabe der Charaktereigenschaften des ersten Menschen gehalten werden können, sondern daß auch sie von äußeren Umständen abhängen“. ${ }^{129}$

Lubbock führte etwaige Unterschiede zwischen prähistorischen und modernen Wilden auf die Anpassung an verschiedene Umweltbedingungen zurück. Dennoch gestand er den zeitgenössischen Wilden keine eigene Entwicklungsgeschichte $\mathrm{zu}$, sondern plazierte sie entwicklungsgeschichtlich auf der Stufe der ersten Menschen.

\section{Evolution familiärer Beziehungen}

Den methodischen Gedanken, einen zivilisatorischen Fortschritt am Wandel des Geschlechterverhältnisses abzulesen, legte Lubbock ausführlich in Origin of Civilization and the Primitive Condition of Man (1870) dar. Er erklärte, daß sowohl die Ehe als auch Vater-Kind-Beziehungen keineswegs universelle Erscheinungen seien, und glaubte, daß dies auch für den Gefühlshaushalt gelte:

129 Lubbock 1872a, S. 550: „The civilization, moreover, of the Stone Age differs not only in degree, but also in kind, varying according to the climate, vegetation, food, etc.; from which it becomes evident - at least to all those who believe in the unity of the human race - that the present habits of savage races are not to be regarded as representing exactly those which characterized the first men, but as depending also on external conditions“. 
„Die niedrigsten Rassen haben keine Institutionen der Heirat, wahre Liebe ist bei ihnen unbekannt, und die Ehe ist in ihren niedrigsten Zuständen keineswegs eine Sache von Zuneigung und Partnerschaft" . ${ }^{130}$

Für die familiären Strukturen solcher Gesellschaften verwendete Lubbock den Begriff der „Gemeinschaftsehe“, mit dem er ein Element der Regellosigkeit in der Paarbildung hervorheben wollte. ${ }^{131}$ Den Ausgangspunkt für eine soziale Evolution von Familienstrukturen sah er in Gesellschaften wie den Andamanen, Buschmännern, Hottentotten oder den Australiern abgebildet, als angeblich niedrigste Rassen repräsentierten sie eine soziale Verfassung, bei der die soziale Position der Frauen, die willkürlichen Gewaltexzessen ausgesetzt gewesen seien, als höchst erbärmlich galt. ${ }^{132}$ Aus den ihm vorliegenden Schilderungen dieser Gesellschaften schloß er, daß die Beziehung zwischen Frauen und Männern für lange Zeit ein Gewaltverhältnis gewesen sein müsse. ${ }^{133}$ Frauen seien in der Regel entführt und in die Ehe gezwungen worden. Der Verlauf der sozialen Evolution habe deutliche Veränderungen im Verhältnis der Geschlechter mit sich gebracht, die deshalb von einer ,graduellen Entwicklung“ gekennzeichnet wären. ${ }^{134}$ Wenn „Gemeinschaften größer und zivilisierter werden“, würde die Entführung von Frauen „umständlich und zuletzt unmöglich“. ${ }^{135}$ Der Brauch sei deshalb in eine nur noch sym-

130 Lubbock (1870a) The Origin of Civilisation and the Primitive Condition of Man. Mental and Social Condition of Savages. London: Longmans, Green, S. 58: „The lowest races have no institution of marriage; true love is almost unknown among them; and marriage in its lowest phases, is by no means a matter of affection and companionship".

131 Lubbock 1870, S. 69: „Communal Marriage“. Lubbock sah sich in der Annahme einer derartigen Gemeinschafts-Ehe als ,primitive condition of man" durch Bachofen, McLennan und Morgan bestätigt (vgl. ebd. S. 77; Johann Jakob Bachofen, 1815-1887, schweizer Anthropologe, Hauptwerk: Das Mutterrecht, 1861; John McLennan, 1827-1881, schottischer Ethnologe, Hauptwerk: Primitive Marriage: An Enquiry into the Origin of the Form of Capture in Marriage Ceremonies, 1865; Lewis Henry Morgan, 1818-1881, amerikanischer Anthropologe, Hauptwerk: Systems of Consanguinity and Affinity of the Human Family, 1871). Allerdings widersprach er ihren Darstellungen des weiteren Verlaufs sozialer Entwicklung. So bestritt er, daß die Phase des Mutterrechtes, wie sie von Bachofen postuliert wurde, relevante Verbreitung gehabt habe (vgl. ebd. S. 78). Bei McLennan bezweifelte er dessen Abfolge von Hetärie über Polyandrie, Endogamie und Exogamie, und erklärte, McLennan hätte sich nicht auf repräsentative Fakten gestützt (ebd., vgl. S. 80-81).

132 Vgl. Lubbock 1870, S. 58, S. 60, S. 69, S. 70.

133 Vgl. Lubbock 1870, S. 86.

134 Lubbock 1870, S. 69: „gradual development“.

135 Lubbock 1870, S. 87: ,as communities become larger and more civilized, the actual ,capture" became inconvenient, and at last impossible“. 
bolische Form überführt worden. Lubbock faßte diese Veränderungen der familiären Strukturen folgendermaßen zusammen:

„Eine Beziehung ist zuerst nicht eine Angelegenheit des Blutes, sondern der Stammesorganisation. In der zweiten Phase wird sie durch die Mutter hergestellt, in der dritten durch den Vater und erst in der vierten Phase konstituiert sich die Idee der Familie, wie sie unter uns üblich ist“ ${ }^{\text {. }}{ }^{136}$

Die so gezeichnete Entwicklung beschrieb er als das Produkt sozialen Wachstums und zunehmender Zivilisation. Lubbock rekonstruierte den Anfangspunkt der sozialen Evolution aus dem von rassistischen Überzeichnungen geprägten ethnographischen Material. Diese aus christlichkonservativer Sicht skandalöse Entsublimierung war der Auslöser für den Konflikt mit dem Duke of Argyll und Lubbock führte ihn stellvertretend für die erste Generation der evolutionären Ethnologen.

Dabei legte er darauf Wert, diese soziale Evolution als von den Umweltbedingungen determiniert und nicht als voluntaristisch darzustellen. Dies zeigt seine Darstellung der Beziehungen der Kinder zu ihren Eltern, und hier vor allem der zum Vater. Lubbock unterstellte bei manchen wilden Gesellschaften losere emotionale Bindungen zwischen den Generationen und führte dies auf ein üppiges Nahrungsangebot zurück. Diese Darstellung beruhte auf der stillschweigend gesetzten Norm der monogamen, europäischen Familie, der gegenüber die Familienstrukturen der angeblich Wilden als ,rückständig“ galten. ${ }^{137}$ Beispielsweise wären Kinder auf Hawaii aus diesem Grund weniger an ihre Eltern als an die Gruppe der Dorfbewohner gebunden:

„Ich denke es gibt Gründe in den sozialen Bräuchen dieser Inselbewohner, die die Persistenz dieser archaischen Struktur erklären. Wegen des milden Klimas und dem reichhaltigen Nahrungsangebot werden Kinder schnell unabhängig“. 138

136 Lubbock (1872c) „On the Development of Relationships“. In: Journal of the Anthropological Institute of Great Britain and Ireland 1, S. 1-29, S. 25: ,relationship is, at first, a matter, not of blood, but of tribal organization; $[\ldots]$ it is, in the second place, traced through the mother; in the third, through the father: and [...] only in the fourth stage is the idea of family constituted as among ourselves".

137 Lubbock 1870, S. 70: „backwardness“.

138 Lubbock 1870, S. 74: „There are, I think, reasons in the social habits of these islanders which go far to explain the persistence of this archaic nomenclature. From the mildness of the climate and the abundance of food, children soon become independent". 
Lubbocks Modell einer evolutionären Entwicklung familiärer Beziehungen beschrieb den Charakter einer universell gültigen Entwicklung und interpretierte die regionalen Unterschiede als Einflüsse der Umweltbedingungen. Hier ist aber auch interessant, daß er die in seinen Augen loseren Familienzusammenhänge der Hawaiianer damit begründete, daß ein äußerer, klimatischer Zwang zu engeren Beziehungen nicht gegeben sei. Doch da er selbst die enge familiäre Beziehung als Ausdruck zivilisatorischer Leistung schätzte, kann dies nur bedeuten, daß er bei den vermeintlich primitiven Gesellschaften grundsätzlich die sozialen Kohäsionskräfte erst im Entstehen sah. Und dort, wo äußere Umstände dies nicht erforderlich sei, verlangsame oder erstarre die soziale Entwicklung. Hiermit hatte Lubbock auf eine mit dem Evolutionsparadigma kompatible Erklärung für den vermeintlichen Stillstand der sozialen Evolution konstruiert. Er stellte, entsprechend dem naturwissenschaftlichen Adaptionsmodell, soziale Veränderungen als die Erfüllung von äußeren Zwängen dar.

Eine parallele Entwicklung machte er auch für andere Aspekte des gesellschaftlichen Lebens geltend, wie zum Beispiel für die Entwicklung der Religion, deren Verlauf von der primitiven Religionslosigkeit über Fetischismus, Totemismus, Idolatrie bis hin zur einer Stufe führte, auf der erstmals Moral mit Religion verbunden würde. ${ }^{139}$ Nach Lubbock verlief die soziale Evolution also immer von einem sozialen Nullpunkt $\mathrm{zu}$ jenem Stadium der Vergesellschaftung, das durch die europäischen Gesellschaften abgebildet wurde. Bei aller Betonung und Überzeichnung der Unterschiede, hob er dennoch hervor, daß die Gemeinsamkeit aller Gesellschaften darin bestünde, daß sie den Kern einer Idee der Geschlechterbeziehung teilten, der bei der Evolution zwischen den sozialen „Extremen einer Serie“ von Entwicklungszuständen nur verschiedene Formen ausbilden würde. ${ }^{140}$

\section{Evolutionärer Rassenbegriff}

Wie bei den meisten seiner Zeitgenossen fand der Begriff ,Rasse“ auch bei Lubbock, der mal von der menschlichen Rasse, ein anderes mal von menschlichen Rassen schrieb, keine stringente Verwendung. In dieser begrifflichen Unschärfe spiegelt sich die Problematik des durch den Po-

139 Vgl. Lubbock 1870, S. 136-137.

140 Vgl. Lubbock 1872c, S. 9: „Hence, we see that not only do the ideas of the several relationships, among the lower races of men, differ from ours; but the idea of relationship, as a whole, is, so to say, embryonic, and subsidiary to that of the tribe“. Sie bildeten ,the extremes of a series". 
lygenismus besetzten und dadurch für viele diskreditierten Begriff ,Rasse'. Wie Huxley galt auch Lubbock der Begriff in den sechziger Jahren des neunzehnten Jahrhunderts offenbar als belastet. Hiermit erklärt sich, warum er häufig ,Volk‘ oder ,Bevölkerung ' als begriffliche Alternativen bevorzugte.

Dennoch sind wesentliche Elemente einer kohärenten Definition des Begriffs ,Rasse“ bei Lubbock bereits vorhanden. ${ }^{141}$ Rasse stellte er im biologischen Sinne als eine lokale Variation dar, die, da ihre wesentlichen körperlichen Merkmale vererbbar seien, ein Kontinuum von Generationen ausbildeten. Er entwickelte einen Rassenbegriff, der auf die Mechanik der Anpassung an die Umweltbedingungen in physischer Hinsicht rekurrierte, dieser aber in kultureller Hinsicht keine Wirkungsmächtigkeit zugestand. Dies wurde deutlich, wenn er die kulturellen Eigenschaften von Rassen auf verschiedenen Zivilisationsstufen miteinander verglich: „Verschiedene Rassen auf gleichen Stufen der Zivilisation haben oftmals mehr Ähnlichkeiten als die gleiche Rasse auf verschiedenen Stufen in ihrer Geschichte“. ${ }^{142}$ Die kulturelle Entwicklung nahm in dieser Argumentation eine von den rassischen Eigenschaften unabhängige Entwicklung an.

Zum Rassendiskurs des neunzehnten Jahrhunderts zählte auch der Topos der aussterbenden Rassen. Lubbock war sich der gravierenden Einschnitte in der Lebensweise der autochthonen Einwohner der kolonisierten Länder sehr wohl bewußt. Er zitierte Berichte, aus denen die Gewißheit sprach, daß die importierte Fauna und Flora der einheimischen überlegen sein müsse, da sie diese rapide verdränge. Das gleiche gelte für die Menschen:

„Die Maoris haben ein melancholisches Sprichwort, daß die Maoris wegen des weißen Manns verschwinden, genau so wie die Ratte des weißen Manns die eingeborene Ratte vernichtet, die europäische Fliege die Maori-Fliege vertreibt und der Klee den neuseeländischen Farn tötet“ ${ }^{143}$

Trotzdem ging er, wie auch bei seiner Diskussion der amerikanischen Gesellschaften zu sehen war, von einem immanenten, selbst-initiierten

141 Den Begriff „Race“ verwendete Lubbock darüber hinaus synonym und alternierend mit „People“ (vgl. Lubbock 1872c, S. 19).

142 Lubbock 1870, S. 9: ,[D]ifferent races in similar stages of development often present more features of resemblance to one another than the same race does to itself in different stages of its history".

143 Lubbock 1868a, S. 5: „The Maoris have a melancholy proverb that the Maoris disappear before the white man, just as the white man's rat destroys the native rat, the European fly drives away the Maori fly, and the clover kills the New Zealand fern". 
Prozeß des Niedergangs bei einigen der sogenannten primitiven Rassen aus. Mit dieser Mutmaßung versuchte er all jene Fälle zu erklären, bei denen die Hinweise auf den von ihm generell angenommenen sozialen Fortschritt zu schwach waren. Gerade in solchen Fällen stellte er den Zusammenhang mit der Kolonisation nicht her. Wenn ihm die verheerende Wirkung eingeschleppter Krankheiten vielleicht nicht bekannt gewesen war, hätte er doch berücksichtigen können, daß regelmäßig die Einheimischen von Siedlern vertrieben und mitunter auch in großer Zahl dahingemordet wurden, weshalb sich ihr vermeintliches Aussterben im kolonialen Kontext bisweilen als bewußte Ausrottung darstellte. Lubbock erklärte, daß das Aussterben auf ein defizitäres Entwicklungsvermögen zurückzuführen sei und nahm an, ein Potential zum sozialen Fortschritt sei nicht allen Rassen gegeben:

„Ich meine natürlich nicht, daß jede Rasse notwendigerweise fortschreitet: im Gegenteil, die meisten der niedrigeren bleiben annähernd unverändert, und es gibt ohne Zweifel Fälle, in denen Nationen zurückfielen. Aber es scheint eine fast unabänderliche Regel zu sein, daß solche Rassen aussterben [...], auf der anderen Seite nehmen die sich verbessernden Nationen an Zahl zu, so daß sie stets auf die weniger fortschrittlichen Rassen übergreifen“. ${ }^{144}$

Selbst die Einsicht, daß die ,fortgeschrittenen Rassen ‘ beständig an Zahl zunähmen und andere Länder eroberten, hinderte Lubbock nicht daran, das Aussterben mancher Rassen auf ein Entwicklungsdefizit zurückzuführen. Zwar war sein Verständnis sozialer Evolution in der Tradition der Aufklärung progressivistisch konzipiert, doch wird hier deutlich, daß diese Tradition nur bei einer Hauptlinie sozialer Entwicklung gepflegt wurde, die er problemlos mit degenerativen Entwicklungen kombinieren konnte.

\section{Fazit}

Lubbock hatte seine ethnologische Forschung gewissermaßen aus den prähistorischen Problemstellungen heraus entwickelt. Dies wird vor allem an der von ihm in die ethnologische Forschung integrierten vergleichenden Methode deutlich. Deren Gebrauchwert realisierte sich aber nur, wenn von vergleichbaren Entwicklungszuständen bei den zeitge-

144 Lubbock 1870, S. 366: „I do not of course mean that every race is necessarily advancing: on the contrary, most of the lower ones are almost stationary; and there are, no doubt, cases in which nations have fallen back; but it seems an almost invariable rule that such races are dying out [...]; on the other hand, improving nations increase in numbers, so that they always encroach on less progressive races“. 
nössischen Wilden und den prähistorischen Europäern ausgegangen wurde. Sein Verständnis sozialer Entwicklung war daher in ihrer Grundstruktur progressivistisch. Seine komparative Methode ersetzte den hypothetischen Wilden der Aufklärungsanthropologie durch den empirischen Wilden, der zu jener Zeit im Begriff war, zum Gegenstand wissenschaftlicher Beschreibungen zu werden. Zwar war deshalb, wie Christopher Chippindale schreibt, bei Lubbock der Evolutionsgedanke vom Fortschrittsdenken geprägt, doch diese Feststellung gilt nicht uneingeschränkt. ${ }^{145}$ Lubbock kalkulierte, ungeachtet seiner fundamentalen Kritik an der Degenerationshypothese und ungeachtet der einen progressiven sozialen Entwicklungsverlauf voraussetzenden vergleichenden Methode, auch mit der Möglichkeit degenerativer Entwicklungen.

Hierbei handelte es sich um weit mehr als um bloße Sonderfälle. Indem Lubbock von etwaigen externen Einflüssen wie der kolonialen Landnahme durch die Europäer absah, konstruierte er diesen Niedergang gewissermaßen als einen schicksalhaften Schlußakt der sozialen Evolution dieser Gesellschaften. Entwicklungsstillstände und Degenerationsprozesse würden zum Aussterben einzelner Rassen führen. Lubbock Vorstellung sozialer Evolution setzte sich folglich aus progressiven Entwicklungen auf der einen und degenerativen auf der anderen Seite zusammen.

Rassen stellten für Lubbock regionale Vererbungskontinuen dar, deren Qualitäten als Trägerbasen der kulturellen Entwicklung über die Fähigkeiten, im Kampf ums Überleben bestehen zu können, entschieden. Seine Diskussion ihrer physische Grundlage lehnte sich oftmals an die Beweisführungen der physischen Anthropologie an. Für ihn wogen dabei taxonomisch-statische Erklärungen schwerer als evolutionäre. Dies zeigte sich bei seiner Idee eines prähistorischen Rassenkampfes zwischen steinzeitlichen Europäern und bronzezeitlichen Asiaten genauso wie bei seiner Diskussion vorgeschichtlicher Schädel in Europa.

Das modernisierende Element der Rassentheorie Lubbocks lag in erster Linie in ihrer Verbindung zur expandierten archäologischen Zeitrechung und in ihrer Kombination von progressiver und degenerativer Entwicklung. Wie seine Auseinandersetzung mit dem Monogenismus verdeutlichte, lehnte er dessen universelle Deutung der Menschheitsgeschichte als Degenerationsprozeß ab. Soziale Strukturen und Institutionen, so Lubbock, wären von den Menschen geschaffen und in einem evolutionären Prozeß permanenter Veränderung ausgesetzt: „Für den

145 Vgl. Christopher Chippindale (1989) „,Social Archaeology“ in the Nineteenth Century: Is It Right to Look for Modern Ideas in Old Places?“. In: Andrew L. Christenson (Hrsg.): Tracing Archaeology's Past. The Historiography of Archaeology. Carbondale, Ill., S. 21-33, S. 30. 
Anhänger der Evolution muß es eine Zeit gegeben haben, in der sie allmählich zu existieren begann“. ${ }^{146} \mathrm{Da}$ er dennoch in seiner grundsätzlich progressivistischen Konzeption die Möglichkeit degenerativer Entwicklungsvorgänge integrierte, zeigt, daß sich seine Theorie sozialer Evolution aus den dogmatischen Koordinaten der alten Anthropologie bereits befreit und ein neues Bündel prinzipieller Mechanismen als ihr treibendes Moment installiert hatte: Anpassung, Selektion und Überlebenskampf bewirkten entweder einen Fortschritt oder einen Niedergang.

Die durch Lubbocks Theorie bedingten Veränderungen des Blicks auf die Erkenntnisobjekte der damaligen Ethnologie, auf die vermeintlichen Wilden, nahm sich kaum weniger dramatisch aus: Sie wurden durch die konsequente Anwendung der vergleichenden Methode zu zeitgenössischen Zeugen einer steinzeitlichen Lebensweise. Daran änderten auch Kulturtechniken nichts, die nach Lubbocks Verständnis nicht als steinzeitlich hätten gelten dürfen. Da die Epocheneinteilung, die er aus einem vorgeschichtlichen Forschungskontext in einen ethnologischen übertrug, bei seiner Diskussion der zeitgenössischen Wilden recht flexibel Verwendung fand, liegt der Schluß nahe, daß die wesentlichsten Fixpunkte seiner Ethnologie die Zuschreibungen von Zivilisiertheit und Primitivität waren. Sie waren seiner Forschung vorgeschaltet. Seine Ethnologie zielte deshalb letztlich auf ihre Rationalisierung, auf eine zeitgemäße Begründung tradierter Topoi des europäischen Rassendiskurses.

\section{4 „From the smallest and rudest up to the largest and most civilized". Rasse und soziale Evolution bei Herbert Spencer}

Im Unterschied zu seinen X-Club-Mitstreitern hatte sich Herbert Spencer mit der Frage der sozialen Entwicklung schon lange, bevor er in den sechziger Jahren des neunzehnten Jahrhunderts eine Theorie organischer Evolution entwarf, befaßt. Soziale Evolution und Soziologie gehörten bei ihm zueinander, die soziale Evolution war für ihn der Gegenstand der Soziologie - und den ersten Entwurf einer Wissenschaft des Sozialen legte er in Social Statics 1851 vor. Doch erst in den siebziger Jahren folgten seine soziologischen Hauptwerke, The Study of Sociology und Principles of Sociology. Der als darwinianische Revolution bezeichnete

146 Lubbock (1911) Marriage, Totemism and Religion. An Answer to Critics. London: Longmans, Green \& Co, S. 138: „Hence to the believers in evolution there must have been a time when it gradually came into existence“". 
Umbruch in den Wissenschaften fiel also zwischen seine soziologischen Arbeiten - und er bedingte eine signifikante Verschiebung seines Ansatzes.

In Social Statics hatte Spencer seine in den Jahren zuvor entstandene, liberale Kritik am Wohlfahrtsstaat noch in den Denktraditionen Thomas Malthus' geübt, diese Position aber um ein - von der schottischen Moralphilosophie entlehntes - Verständnis progressiver sozialer Entwicklung ergänzt. ${ }^{147} \mathrm{Er}$ argumentierte in Social Statics insofern teleologisch, als daß er von einer fortschreitenden Entwicklung hin zum einem idealen sozialen Zustand ausging. ${ }^{148}$ Diese soziale Entwicklung illustrierte er anhand von Berichten über zeitgenössische Wilde und stellte hierfür die „nackten, unbehausten Wilden“ den „Shakespeares und Newtons eines zivilisierten Zustandes" gegenüber. ${ }^{149}$ Zwischen ihnen lägen unzählige Unterschiedsgrade, sowohl physische wie mentale:

„Die Unterschiede zwischen den Rassen in Form, Farbe und Gesichtszügen sind nicht größer als die Unterschiede ihrer moralischen und intellektuellen Qualitäten. Die Überlegenheit der Sehstärke die einen Buschmann befähigt, mit dem bloßen Auge weiter zu sehen, als ein Europäer mit einem Fernrohr, entspricht völlig der höheren Perfektion des intellektuellen Blickes des Europäers. [...] Jedes Zeitalter, jede Nation, jedes Klima zeigt eine modifizierte menschliche Form". ${ }^{150}$

Die äußeren Unterschiede zwischen den Menschen seien Ausdruck der Entwicklung unter dem Einfluß verschiedener Umweltbedingungen. Spencer wandte diese akklimatisierungstheoretische Überlegung auch auf die Interpretation unterstellter Unterschiede der Denk- und Perzeptionsleistungen an. Jedem Gesellschaftszustand entspräche nicht nur ein besonderer Phänotyp, sondern auch eine jeweilige psychische Disposi-

147 Vgl. Adam Ferguson (1767) An Essay on the History of Civil Society. Edinburgh.

148 Vgl. Robert G. Perrin (1976) „Herbert Spencer's Four Theories of Social Evolution“. In: American Journal of Sociology, Nr. 81, S. 1339-1359, S. 1342-1343; Peel 1971, S. 101.

149 Spencer 1851, S. 33: „Between the naked houseless savage, and the Shakespeares and Newtons of a civilized state".

150 Spencer 1851, S. 33-34: „The contrasts of races in form, colour, and feature, are not greater than the contrasts in their moral and intellectual qualities. That superiority of sight which enables a Bushman to see further with the naked eye than a European with a telescope, is fully paralleled by the European's more perfect intellectual vision [...] Every age, every nation, every climate, exhibits a modified form of humanity“. 
tion. ${ }^{151}$ Spencer stellte die soziale Struktur als eine Funktion solch individueller Eigenschaften dar: „So gegensätzlich wie ihre Bestandteile sind, müssen sich primitive und fortgeschrittene Gemeinschaften essentiell in den Prinzipien ihrer Struktur unterscheiden“. ${ }^{152}$ Die Voraussetzung zum zivilisierten Dasein müßte in den Individuen erfüllt sein. Spencers frühe Rassentheorie basierte nicht nur auf einer progressivistischen Entwicklungstheorie, sondern auch auf dieser hypothetischen Verbindung psychischer und sozialer Eigenschaften.

\section{Naturalisierung sozialer Differenz}

Spencer vollzog in den fünfziger Jahren des neunzehnten Jahrhunderts einen scientific turn, der unmittelbare Auswirkungen auf seine Theorie sozialer Entwicklung und auf seine Rassentheorie hatte. ${ }^{153}$ Nun entwickelte er im Kontext dieser naturwissenschaftlichen Orientierung eine Begründung sozialer Ungleichheiten, die auf quantifizierte körperliche Unterschiede rekurrierte. Eine kraniometrische Meßreihe entspreche den sozialen Unterschieden zwischen Rassen. Dafür brachte Spencer die Hierarchie der Gehirnvolumina mit einer Wertigkeitsskala der zivilisatorischen Leistungen in Übereinstimmung:

„Die mittleren Kapazitäten der Krania in den Hauptunterteilungen der Art wurden wie folgt festgestellt -

$\begin{array}{cccc}\text { Beim Australier } & \ldots & 75 & \text { Kubikzoll } \\ \text { African } & \ldots & 82 & " \\ \text { Malayan } & \ldots & 86 & " \\ \text { Englishman } & \ldots & 96 & "\end{array}$

Sie zeigen im Laufe des Fortschritts eine Zunahme vom wilden Zustand zu unserer gegenwärtigen Phase der Zivilisation, die sich auf annähernd 30 Prozent der ursprünglichen Größe beläuft" ${ }^{154}$

151 Vgl. Spencer 1851, S. 411. Indianer, deren Leben von der Jagd geprägt sei, wären deshalb ebenso grausam zueinander wie zu dem von ihnen erlegten Wild. Vgl. La Vergata 1995, S. 199; Wiltshire 1978, S. 200.

152 Spencer 1851, S. 419: „Contrasted as are their units, primitive communities and advanced ones must essentially differ in the principles of their structure".

153 Vgl. Burrow 1970, S. 188.

154 Spencer 1852a, S. 498: ,The mean capacities of the crania in the leading divisions of the species have been found to be -

In the Australian $\quad \ldots \quad 75$ cubic inches

African

Malayan

Englishman

82

$\cdots-82$

$\begin{array}{lll}\cdots & 86 & \\ \cdots & 96 & \end{array}$ 
Spencer war überzeugt, daß diese Vergleichsreihe „,menschlichen Fortschritt" darstelle, denn das Hirnvolumen steige vom Australier über den Afrikaner und den Malayen bis zum Engländer stetig an. Daß zugleich die kulturelle Leistung eine entsprechende Steigerungsreihe aufweise, setzte Spencer hierbei voraus. Er folgerte, daß im Lauf der Entwicklung der Menschheit „eine Vergrößerung der Nervenzentren“ stattgefunden habe. ${ }^{155}$ Damit plazierte er diese Bevölkerungen auf einer Entwicklungsachse, die er zwischen Primitivität und Zivilisation konstruierte. Mit dieser Überlegung hatte Spencer allerdings nur eine traditionelle Vermutung über die Abfolge sozialer Entwicklung, zu deren Maßstab die europäische Zivilisation erhoben wurde, mit der Vorstellung proportionalen Hirnwachstums kombiniert.

Das Moment des Fortschritts, der sich in der Zunahme des Kranialvolumens ausdrücke, kombinierte Spencer mit der malthusianischen Theorie der Ressourcenknappheit. Es würden, so Spencer, ,letztlich nur jene überleben, die sich unter ihr entwickeln,“, jene aber, die übrig blieben, „um die Rasse fortzuführen, [...] sind die Auslese ihrer Generation“. ${ }^{156}$ Die Zunahme der Hirnmasse deutete Spencer also als das Ergebnis eines Überlebenskampfes, bei dem die Entwicklungsfähigkeit des Einzelnen das Überleben sichern würde. Einen funktionalen Zusammenhang für diese Korrelation sollte Spencer wenig später nachschieben.

\section{Evolution als theoretische Rationalisierung}

Spencer baute neben dem Gehirnvolumen auch Campers Gesichtswinkel als Unterscheidungskriterium in seine Rassentheorie ein. Sein Ausgangspunkt war dessen ästhetische Dimension, die einen vorstehenden Kiefer als häßlich und animalisch apostrophierte. Er erklärte:

,[D]er vorstehende Kiefer, charakteristisch für die niederen menschlichen Rassen, [...] wird [...] bei der Gattung der Säugetiere grundsätzlich mit entsprechendem Mangel an Intelligenz assoziiert. In Übereinstimung mit dem Gesetz, nach dem die Organe sich in Proportion zu ihrem Gebrauch entwickeln, sind die Kiefer relativ groß, wenn sie viel beansprucht werden; und sie

showing an increase in the course of the advance from the savage state to our present phase of civilization, amounting to nearly 30 per cent on the original size".

155 Spencer 1852a, S. 498: „,human progress“, S. 497: „enlargement of the nervous centres“.

156 Spencer 1852a, S. 499: „only those who do advance under it eventually survive“, S. 500: ,those left behind to continue the race [...] are the select of their generation“. 
verkleinern sich, wenn ihre Beanspruchungen weniger zahlreich und anstrengend werden. [...] Vom Zustand des Buschmanns aufwärts hat es eine graduelle Zunahme der Komplexität unserer Werkzeuge gegeben. [...] Deshalb setzten sich die Zunahme des Gehirns und gleichzeitige Rückbildung des Kiefers während des Fortschritts der Menschheit von der Barbarei zur Zivilisation fort". 157

Spencer bediente sich hier des traditionellen Topos vom Zusammenhang zwischen Gesichtswinkel und Intelligenz. Das Verhältnis der Gesichtspartien zu einander sei durch adaptive Prozesse bestimmt. Der Gebrauch von Werkzeugen stimuliere das Wachstum des Gehirns und gemeinsam mit dem verminderten Gebrauch des Beißapparates würde so eine Veränderung der Gesichtsproportionen herbeigeführt. ${ }^{158}$ Er führte die Physiognomie folglich über einen Adaptionsmechanismus auf sozial determiniertes Verhalten zurück: Veränderungen der Kulturtechniken hätten die Physiognomie der Menschen beeinflußt. Weil er das Einverständnis voraussetzten konnte, daß die sogenannten Buschmänner nur über kleine Hirne verfügten, erklärte er, daß solche Wilde den ersten Schritt „,während des Aufstiegs der Menschheit von der Barbarei zur Zivilisation“ darstellten. ${ }^{159}$

Spencer teilte die Einschätzung vieler zeitgenössischer Europäer, daß die sogenannten Buschmänner zu den primitivsten Gesellschaften rechneten. Durch seine kausale Verbindung einer kulturellen Entwicklung mit einer Hierarchie der Kranialvolumina entwickelte er den Kern einer Theorie sozialer Evolution, die von einer Prägung der somatischen Entwicklung durch die kulturelle Entwicklung ausging. Damit ging er über die bestehende Korrelationsvermutung hinaus, stellte die Entwicklung der Physiognomie als eine Funktion der sozialen Entwicklung dar und baute sein Rassenverständnis auf dem Primat dieser kulturellen Entwicklung auf.

157 Spencer (1854) „Personal Beauty“. In: [The Leader 15.April, 13.Mai, S. 356-357, S. 451-452] Essays. Bd. 3, S. 387-399, S. 389: ,it is a fact that prominence of jaw is associated in the mammalia generally with comparative lack of intelligence. [...] In conformity with the law that organs develop in proportion as they are exercised, the jaws are relatively large where the demands made on them are great; and diminish in size as their functions become less numerous and less onerous [...] From the bushman state upwards, there has been a gradual increase in the complexity of our appliances. [...] Thus that simultaneous protrusion of the brain and recession of the jaws [...] have continued during the advance of Humanity from barbarism to civilization".

158 Vgl. Spencer 1854, S. 390.

159 Spencer 1854, S. 390: ,during the advance of Humanity from barbarism to civilization". 


\section{Evolution der Intelligenz}

Die Bedeutung, die Spencer dem Gehirn in seiner Theorie sozialer Evolution beimaß, beruhte vor allem auf seinem individualistischen Ansatz, denn er betonte das Primat der individuellen Entwicklung bei jeder Diskussion gesellschaftlicher Entwicklung. Zudem war er früh durch die Phrenologie beeinflußt gewesen, jener Wissenschaft, die versuchte, die psychische Disposition eines Menschen an der Form des Schädels abzulesen. ${ }^{160}$ Spencer hatte in jungen Jahren selbst Schädel vermessen, sich jedoch später kritisch von diesem Verfahren distanziert. ${ }^{161}$ Zwar hielt er - wie die Phrenologen - das Gehirn für das Organ des Verstands, doch die Entwicklung des Verstands beschrieb er unabhängig von der des Gehirns, die er vor allem als eine Massenzunahme betrachtete. Die Evolution der Intelligenz beruhe auf ihrer graduellen und progressiven Entwicklung. Durch sie unterschied Spencer Rassen auf verschiedenen Entwicklungsstufen:

„Wenn wir vom fortgeschrittenen Mann der Wissenschaft, der seine Untersuchungen unter vollständiger Kenntnis der von ihm [...] eingesetzten Prozesse betreibt, hinunter gehen zum Mann der gewöhnlichen Bildung, der vernünftig und verständlich argumentiert [...] wenn wir weiter zu den minderwertigen menschlichen Rassen hinabsinken, die nicht zum Denken angeregt werden können, die komplexe Ideen nicht begreifen können und deren Zahlenverständnis kaum über das des Hundes hinausgeht, wenn wir als nächstes die Primaten nehmen, deren Handlungen fast so rational sind wie die von Schuljungen [...], und wenn wir zuletzt erkennen, daß jede der hier aufgeführten Phasen der Intelligenz in die angrenzenden durch unzählige unendlich kleine Modifikationen übergeht, sollten wir begreifen, daß keine deutliche Trennung zwischen den Erscheinungen des Verstandes und denen des Lebens im Allgemeinen festgestellt werden kann“ “ ${ }^{162}$

160 Vgl. Robert M. Young (1985c) „The role of psychology in the nineteenth-century evolutionary debate“. In: Ders. (Hrsg.): Darwin's Metaphor. S. 56-78, S. 76; allgemein John van Wyhe (2003) Phrenology and the Origins of Victorian Scientific Naturalism. Aldershot: Ashgate; David de Giustino (1975) Conquest of Mind: Phrenology, and Victorian Social Thought. London: Croom Helm.

161 Vgl. Spencer 1904b, Bd. 1, S. 200-203; Spencer (1846) „On a Proposed Cephalograph“. In: Ders. (1904a), Bd. 1, S. 540-543.

162 Spencer 1855, S. 349-350: „If from the advanced man of science, pursuing his inquiries with a full understanding of the $[\ldots]$ processes he employs, we descend to the man of ordinary education, who reasons well and comprehensively [...] if, again, we sink to the inferior human races, who cannot be induced to think, who cannot take in the ideas of any complexity, and whose conceptions of number scarcely transcend those of the dog; if we take next the higher quadrumana, hosts of whose 
Spencer zeichnete ein Spektrum der Intelligenzverteilung, das Gesellschaften wie Berufsstände umfaßte. Er extrapolierte dieses angenommene Intelligenzgefälle über den Menschen hinaus bis hin zu den einfachsten Lebensformen, die noch über ein Sensorium für die Reize der Umgebung verfügten. So konstruierte er eine vollständig naturalisierte Vorstellung von Intelligenz.

Er behandelte Intelligenz als Mittel der Anpassung eines Organismus an seine Umwelt. Dabei unterstellte er die Vererbbarkeit der Intelligenz selbst, ,erbliche Weitergabe“ gelte „,beim Menschen nicht nur für physische, sondern auch für psychische Eigenschaften“. ${ }^{163}$ Wenn sich ein Verhalten verstetige, dann würde auch die dahinterliegende psychische Disposition verstetigt und als Anlage vererbt. ${ }^{164}$

Deshalb basiere „reflexives und instinktives“ Verhalten nicht auf individuellen Erfahrungen, sondern auf „den Erfahrungen der Rasse von Organismen, die ihre Vorfahren bilden“. ${ }^{165}$ Spencer hatte hiermit die von ihm grundsätzlich abgelehnte Hypothese der Experience-Theorie, nach der Verhalten vor allem auf Erlerntem basiere, vom Individuum auf die Rasse verschoben. ${ }^{166}$ Hierdurch konnte er den zuvor konstruierten Entwicklungsverlauf der Intelligenz mit der evolutionären Modifikation der Schädelprofile sinnhaft verbinden, wobei beide Diskurse im Konzept der Rasse zusammenfielen. ${ }^{167}$ Durch diese Konstruktion einer

actions are quite as rational as those of school-boys [...]; and if, finally, we perceive that each of the phases of intelligence here instanced, shades off into the adjacent ones by modifications too numerous to specify, too minute to describe, we shall in some measure realize the fact, that no definite separation can be effected between the phenomena of mind and those of vitality in general".

163 Spencer 1855, S. 526: „Hereditary transmission [...] applies not only to physical but to psychical peculiarities".

164 Vgl. Spencer 1855, S. 526.

165 Spencer 1855, S. 526: „Though it is manifest that reflex and instinctive sequences are not determined by the experiences of the individual organism manifesting them; yet there still remains the hypothesis that they are determined by the experiences of the race of organisms forming its ancestry".

166 Vgl. Robert M. Young (1990) Mind, Brain and Adaptation in the Nineteenth Century. Cerebral localization and its biological context from Gall to Ferrier. New York, Oxford: Oxford University Press, S. 173 und 178.

167 Rick Rylance registriert zwar, daß Spencer die psychologische Diskussion mit der Konstruktion des Intelligenzkontinuums auf die Ebene der Rasse verlagerte (vgl. Rylance 2000. S. 215-216). Doch wenn er den evolutionären Biologismus und die Mechanik der Vererbung erworbener Eigenschaften bei Spencer nur dafür verantwortlich macht, daß seine „,sozialen und politischen Ideen [...] zum Teil als Konsequenz, von einem nicht völlig untypischen viktorianischen Rassismus durchsetzt wa- 
Inkorporierung von Erfahrungen, die den Reflex- und Instinkthaushalt einer Rasse bestimmen würde, war Spencer gezwungen, einen vor allem auf Wiederholung basierenden Selektionsmechanismus zu entwerfen, der diese historische Sedimentierung plausibilisieren sollte.

,[D]as Gehirn repräsentiert eine unermeßliche Zahl von Erfahrung, die im Laufe der Evolution des Lebens im Allgemeinen gemacht worden sind: die gleichmäßigsten und häufigsten wurden erfolgreich vermacht $[\ldots]$, und haben sich so zu der hohen Intelligenz summiert, [...] die mit minimalen Ergänzungen erneut an folgende Generationen vermacht wird. Und so kommt es, daß die Europäer zwanzig bis dreißig Kubikzoll mehr Gehirn als die Papuans haben. [...] So kommt es, daß aus Wilden [...] am Ende unsere Newtons und Shakespeares werden“. 168

Der Motor der Entwicklung des Kranialvolumens war für ihn die Anhäufung von wiederholten Erfahrungen. Der Zuwachs von Erfahrung bedingte, so Spencer, einen Zuwachs an Gehirnmasse. Beide, kulturelle Prägung und Hirnmasse, setzte er zudem mit dem zivilisatorischen Fortschritt von Primitivität zu Zivilisiertheit in Beziehung. Sein Rassenkonzept schuf so eine Entwicklungstrias von Soma, Psyche und Kultur.

\section{„Large-brained Europeans“}

In Principles of Biology entwickelte Spencer einen weiteren Wirkungszusammenhang von Schädelmaß und Zivilisationsgrad. Ausgehend von der Vermutung, ein Organismus könne nur eine begrenzte Menge von Energie an seine Funktionen verteilen, konstruierte er einen Gegensatz

ren" (vgl. ebd. S. 221: "his social and political ideas [...] which, partly as a consequence, were tainted by a not wholly untypical Victorian racism"), dann übergeht er Spencers Konstruktion des Zusammenhangs von Psyche, Hirn und zivilisatorischer Leistung, die durchaus ein Novum in der damaligen Psychologie wie auch im damaligen Rassendiskurs darstellte.

168 Spencer 1855, S. 583: ,the brain represents an infinitude of experiences received during the evolution of life in general: the most uniform and frequent of which, have been successively bequeathed, [...] and have thus slowly amounted to that high intelligence [...] which, with minute additions is bequeaths to future generations. And thus it happens that the European comes to have from twenty to thirty cubic inches more brain than the Papuan. [...] Thus it happens that out of savages [...] come at length our Newtons and Shakespeares". 
von Individuation und Reproduktion. ${ }^{169}$ Diese Gegensatzvermutung führte er in einen Vergleich zwischen den Rassen ein.

Zwar stünde die Fruchtbarkeit in der Energieökonomie des Körpers grundsätzlich in einem reziproken Verhältnis zur körperlichen und geistigen Leistung. Die vermeintlich primitiven Gesellschaften hätten jedoch niedrigere Geburtenraten, obwohl von ihnen angenommen wurde, daß sie weniger intellektuelle Leistungen erbrächten. Ihre niedrigen Geburtenraten erklärte Spencer deshalb dadurch, daß sie dauerhaft unterernährt seien und sich für den bloßen Lebenserhalt beständig verausgaben müßten. ${ }^{170}$ Hingegen brächte der Regelfall der sozialen Evolution, und den hielt er bei der progressiven Entwicklung der zivilisierten Gesellschaften für gegeben, einerseits individuelles Wachstum, höhere individuelle Komplexität und gesteigerte individuelle Aktivität; andererseits aber sinkende Fertilitätskennziffern hervor. Daraus ergab sich für Spencer, daß zwischen primitiven und zivilisierten Rassen der Unterschied im Kranialvolumen beständig zunehme:

„Der künftige Prozeß der Zivilisation, den der nie ruhende Bevölkerungsdruck produzieren muß, wird durch steigende Individuations-Kosten begleitet werden, sowohl in Struktur als in Funktion; and vor allem in nervlicher Struktur und Funktion. Der friedliche ,struggle for existence " in immer dichter und komplizierter werdenden Gesellschaften muß als Begleiterscheinung eine $\mathrm{Zu}$ nahme an Masse, Komplexität und Aktivität der großen Nervenzentren mit sich bringen. [...] Bereits jetzt ist das Gehirn des zivilisierten Menschen um annähernd 30 Prozent größer als das Hirn des Wilden“. ${ }^{171}$

Spencer betrachtete die Gesellschaft als die soziale Umwelt für den einzelnen Menschen und nahm an, daß sich das Gehirn in einem adaptiven

169 Vgl. Cynthia Eagle Russett (1989) Sexual Science. The Victorian Construction of Womanhood. Cambridge, Mass.: Harvard University Press, S. 118.

170 Vgl. Spencer 1883a, Bd. 2, S. 487-488: „Australians, Fuegians, and sundry races that might be named as having low rates of multiplication, are obviously underfed. [...] In quality as well as in quantity, their feeding is bad. [...] Further, to uncivilized men supplies of food come very irregularly. [...] The chase is very laborious".

171 Spencer 1883a, Bd. 2, S. 501-502: „The future process of civilization which the neverceasing pressure of population must produce, will be accompanied by an enhanced cost of Individuation, both in structure and in function; and most especially in nervous structure and function. The peaceful struggle for existence in societies ever growing more crowded and complicated, must have for its concomitant an increase of the great nervous centres in mass, in complexity, in activity. [...] Already, the brain of the civilized man is larger by nearly 30 per cent than the brain of the savage“. 
Prozeß an die sozialen Umweltbedingungen anpasse. Der Bevölkerungsdruck fungiere als Motor der zivilisatorischen Entwicklung, er erfordere immer mehr technische Errungenschaften: „Jede industrielle Verbesserung [...] benötigt [eine] höhere Form menschlichen Seins, sie in die Praxis umzusetzen“. ${ }^{172}$ Aus dieser Innovativität begünstigenden Selektion resultierte nach Spencer eine höhere Entwicklung sowie eine gesteigerte Aktivität des Nervensystems der zivilisierten Rassen, was letztlich zum „großhirnigen Europäer“ führe. ${ }^{173} \mathrm{Er}$ attestierte den Wilden eine bessere Sinneswahrnehmung aber eine geringere Intelligenz als den Zivilisierten. Diese Annahme entwickelte er vor dem Hintergrund seiner Hypothese der körperlichen Energiebilanz zu einem sich wechselseitig bedingenden Zusammenspiel: „In dem Maße, in dem die mentalen Energien in ruheloser Wahrnehmung aufgehen, können sie nicht in bewußtem Denken aufgehen“. ${ }^{174}$

Greene hat zwar erkannt, daß Spencers Verbindung von somatischer und kultureller Entwicklung auf der Hypothese basiere, Gehirnstruktur wie mentale Prozesse wären gleichermaßen Produkte der Lebensweise einer Rasse. ${ }^{175}$ Doch der Umstand, daß Spencer neben den Regelfall progressiver Evolution alternativ die Stagnation in der Evolution gestellt hatte, und deshalb von einer sich weitenden Differenzierung somatischer Unterschiede ausgehen konnte, ist von nicht minderer Tragweite für seine Rassentheorie, insbesondere in Hinblick auf die Prognosen zukünftiger sozialer Entwicklungen.

\section{„Out of adjustment“. Rassenmischung}

Die Verkörperlichung sozialer Unterschiede zwischen den Rassen spielte auch bei Spencers Diskussion eines anderen Topos eine zentrale Rolle, dem der Rassenmischung. Für Spencer war die Frage der Rassenmischung grundsätzlich eher marginal. In seiner Theorie sozialer Evolution war für sie keine tragende Funktion vorgesehen. Deshalb befaßte er sich nur an wenigen Stellen mit ihr. Wie selbstverständlich ging er davon aus, daß die Europäer ein Gemisch von Rassen darstellten: „Alle zivilisierten Rassen, und wahrscheinlich auch die unzivilisierten, sind

172 Spencer 1883a, Bd. 2, S. 499: „Every industrial improvement [...] demands that higher form of humanity to carry it into practice“".

173 Spencer 1883a, Bd. 2, S. 503: „large-brained European“.

174 Spencer (1883b) The Principles of Sociology [Bd. 1876], New York: Appleton, Bd. 1, S. 79: „In proportion as the mental energies go out in restless perception, they cannot go out in deliberate thought“". Vgl. Greene 1969, S. 435. 
gemischten Ursprungs“. ${ }^{176}$ Vor dem Hintergrund der Siedlungsgeschichte der Britischen Inseln war die Annahme, die zivilisierten Gesellschaften seien das Resultat einer gelungenen Rassenmischung, durchaus diskurskompatibel. ${ }^{177}$ Allerdings fügte Spencer hinzu, könnten Rassenmischungen auch sehr instabile Gebilde sein:

„Mischungen von verschiedenen Rassen des Menschen [...] können sich nicht als eigenständige Varietät erhalten, sie sterben aus, wenn sie sich nicht mit den Originalen kreuzen. [...] Wenn es stimmt, daß ein Organismus, der von zwei ungleichen Organismen produziert wird, nicht ein Mittel zwischen ihnen ist, sondern eine Mischung von Teilen des einen mit Teilen des anderen [...], dann wird deutlich, daß in Abhängigkeit davon, ob der Unterschied zwischen den Eltern-Organismen größer oder kleiner ist, die Defekte der Koordinierung beim Abkömmling größer oder kleiner ausfallen“. ${ }^{178}$

Die Stabilität einer Mischung hänge also vom Grad einer nicht näher bestimmten Affinität zwischen den beiden gemischten Rassen ab. Auch wenn er Rassenmischung für allgegenwärtig hielt, hatte Spencer so ein Kriterium der qualitativen Differenzierung an der Hand.

Eine Ursache für diese variierende Kompatibilität sah Spencer darin, daß die Menschen von den Bedingungen ihres Habitats geprägt seien, an das sie sich angepaßt hätten. Bei der Verbindung mit Menschen, die an andere Umweltbedingungen angepaßt seien, käme es zu einem Konflikt zwischen ererbten „Tendenzen zu verschiedenen Gesellschaftstypen“. ${ }^{179}$ Die so entstandene „Mischrasse“ („half-caste“) sei deshalb weder für den einen noch für den anderen ererbten Set ,,angepaßt“ (,fit““). ${ }^{180}$ Derar-

176 Spencer 1854, S. 394: „All the civilized races, and probably also the uncivilized ones, are of mixed origin“.

177 Vgl. Spencer 1854, S. 399.

178 Spencer 1854, S. 398: ,[M]ixtures of different races of man [...] cannot maintain themselves as separate varieties; [they] die out unless there is intermarriage with the originals. [...] For if it be true that an organism produced by two unlike organisms is not a mean between them, but a mixture of parts of the one with parts of the other [...] then it becomes manifest that in proportion as the difference between the parent organisms is greater or less, the defects of co-ordination in the offspring will be greater or less".

179 Spencer 1883 b, Bd. 1, S. 572: „, tendencies towards different social types“.

180 Spencer 1883b, Bd. 1, S. 572: „,half-caste“, „, not fitted for either“. Diesen Gedanken, den er in den sechziger Jahren erstmals entwickelte, griff er später wieder auf: „Some facts seem to show that mixture of human races extremely unlike, produce a worthless type of mind - a mind fitted neither for the kind of life led by the higher of the two races, not for that led by the lower - a mind out of adjustment to all conditions of life“" 
tige ,Mischlinge“ wären außerstande, einen neuen sozialen Typ hervorzubringen.

Diese Rassenmischungstheorie veranlaßte Spencer, einigen Offiziellen Japans den Ratschlag zu erteilen, von Heiraten zwischen Europäern und Japanern zur Aufbesserung des Erbguts abzusehen. Die Japaner führten zu jener Zeit eine Diskussion über die Möglichkeiten, die wirtschaftliche Distanz zu Europa und Nordamerika zu verringern. ${ }^{181}$ Spencer teilte die Einschätzung der Japaner, die sich offenkundig für eine schwächere Rasse als die Europäer hielten. „Halten Sie sich andere Rassen möglichst vom Leibe“, lautete seine Empfehlung, „keine weiteren Privilegien sollten Menschen anderer Rassen, und besonders Menschen der stärkeren Rassen, zugebilligt werden“. ${ }^{182}$ Rassenmischung erörterte Spencer folglich immer vor dem Hintergrund einer biologischen oder psychischen Differenz, die in seiner Evolutionslogik zugleich als Ausdruck einer diskrepanten Entwicklung galt.

\section{Soziologie sozialer Evolution}

Die Untersuchung von Geschichte, Strukturen und Bedingungen der sozialen Evolution war für Spencer die Aufgabe der Soziologie. Sie habe

„beginnend mit Menschentypen, die nur kleine und unzusammenhängende soziale Aggregate bilden, zu zeigen, in welcher Weise die individuellen intellektuellen und emotionalen Eigenschaften weitere Aggregation verhindern. Sie hat zu erklären, wie kleine Veränderungen der individuellen Natur, die aus veränderten Lebensumständen entstehen, etwas größere Aggregate ermöglichen. [...] Unter den Gesellschaften aller Kategorien und Größen, von den kleinsten und wildesten hoch bis zu den größten und zivilisiertesten, muß sie feststellen, welche Züge sie gemeinsam haben, bestimmt durch die den Menschen gemeinsamen Züge; welche weniger generellen Züge, die verschiedene Gruppen von Gesellschaften unterscheiden, von den Zügen, die die verschiedenen Rassen charakterisieren, herrühren; und welche Besonderheiten in jeder Gesellschaft auf die Besonderheiten ihrer Mitglieder zurückzuführen sind. In

(Spencer (1876) ,The Comparative Psychology of Man”. In: [Mind 1, S. 7-20] Essays. Bd. 1, S. 351-370, S. 359).

181 Vgl. Hund 2006, S. 59-60; Ruth Benedict (1935) The Chrysanthemum and the Sword. Patterns of Japanese Culture. Boston: Mifflin, S. 80ff.

182 Spencer an Kentaro Kaneko, 26. August 1892. In: Duncan 1908, S. 323: „,keep other races at arm's length as much as possible“; S. 321: „No further privileges should be allowed to people of other races, and especially to people of the more powerful races“. Peel schreibt in völliger Verkennung der rassistischen Logik von einem brauchbaren Rat (Peel 1971, S. 233: „his advice was very sound“). 
jedem Fall hat sie das Wachstum, die Entwicklung, die Struktur und die Funktionen des sozialen Aggregats zum Gegenstand“. ${ }^{183}$

Spencer setzte hier die Parameter seiner soziologischen Agenda. Seine Soziologie war auf den Vergleich von Gesellschaften angelegt und zielte auf die Beschreibung der sozialen Evolution. Die verlaufe grundsätzlich als ein paralleler Wachstums- und Zivilisationsprozeß. Er differenzierte hierbei seine bereits in Social Statics entwickelte individualistische Interpretation der Eigenschaften einer Gesellschaft als Funktion der Eigenschaften der Gesellschaftsmitglieder. Zwar ging er auch hier davon aus, daß die „Eigenschaften der Einheiten [...] die des Aggregats“ bestimmten, unterschied dabei jedoch nur zwischen individuellen und rassentypischen Eigenschaften. ${ }^{184}$ Die rassischen Merkmalen wären nicht nur für die verschiedenen Ausprägungen sozialer Strukturen verantwortlich, sondern auch dafür, daß sich manche Gesellschaften nicht weiter entwickelten. In den rassebedingten Eigenschaften der Individuen vermutete er die Ursachen für die durch die soziale Evolution geschaffene und sich weitende soziale Distanz zwischen primitiven und zivilisierten Gesellschaften.

Doch Spencer grenzte seine Theorie sozialer Evolution bewußt von Vorstellungen einer linearen historischen Entwicklung der Gesellschaften ab. Gerade weil er soziale Entwicklung als eine beständige Zunahme von Komplexität und Größe des sozialen Aggregats, als eine Entwicklung von Primitivität zu Zivilisiertheit beschrieb, mußte er den Unter-

183 Spencer 1899, S. 47: „Beginning with types of men who form but small and incoherent social aggregates, such a science has to show in what ways the individual qualities, intellectual and emotional, negative further aggregation. It has to explain how slight modifications of individual nature, arising under modified conditions of life, make somewhat larger aggregates possible. [...] Among societies of all orders and sizes, from the smallest and rudest up to the largest and most civilized, it has to ascertain what traits there are in common, determined by the common traits of human beings; what less-general traits, distinguishing certain groups of societies, result from traits distinguishing certain races of men; and what peculiarities in each society are traceable to the peculiarities of its members. In every case it has for its subject-matter the growth, development, structure, and functions of the social aggregate".

184 Spencer (1899) The Study of Sociology [1873], New York: Appleton, S. 47. ,the properties of the units determine the properties of the aggregate"; vgl. Burrow 1970, S. 199-200. John Offer ist auf diesen rassentheoretischen Aspekt nicht eingegangen, er diskutiert zwar Spencers Versuch, die menschliche Natur dem sozialen Sein zugrunde zu legen, übersieht dabei aber, daß Spencer dies nicht nur auf der individuellen, sondern auf der Rassenebene unternahm (vgl. Offer 1980, S. 137). 
schied zu progressivistischen Interpretationen hervorheben. Es wäre ein Irrtum anzunehmen,

„daß die verschiedenen Gesellschafts-Formen, wie sie bei wilden und zivilisierten Gesellschaften überall auf dem Globus gefunden werden, nichts weiter seien als verschiedene Stufen der Evolution einer Form; die Wahrheit ist eher, daß soziale Typen, wie die Typen der individuellen Organismen, keine Serie bilden, sondern ausschließlich als divergente und abermals-divergente Gruppen zu klassifizieren sind“. ${ }^{185}$

Spencers Evolutionsmodell sah keinen linearen Fortschrittsautomatismus vor, sondern entwarf das Bild eines verzweigten genealogischen Arrangements. ${ }^{186}$ Dabei könnten Entwicklungen ebensogut progressiv verlaufen oder als Veränderungen ohne Zugewinn an Nutzen auftreten. Trotz dieses Ausschlusses eines Automatismus blieb die Möglichkeit des Fortschritts selbst aber unberührt. Spencer, schreibt Bowler,

„,konnte die vorherrschende Ansicht nicht ablegen, daß einige Rassen anderen überlegen wären, aber er hat darauf bestanden, daß kulturelle und rassische Unterschiede nicht als eine einfache lineare Hierarchie ausgedrückt werden können. In einem System verzweigter Entwicklung sind Unterschiede nicht notwendig Zeichen von Über- oder Unterlegenheit" ". ${ }^{187}$

Bowler behandelt den Aspekt der rassenhierarchischen Ordnung bei Spencer zum einen als ein kulturelles Einsprengsel in dessen Denken, das letztlich im Widerspruch $\mathrm{zu}$ seinem sozialevolutionären Modell stünde. Zum anderen nimmt er an, daß Spencers Modell universeller Evolution keine eindeutige Wertung von Gesellschaften zuließe. Doch eine solche Einschätzung übergeht den Umstand, daß Spencer hier bildlich betrachtet - zwei Folien übereinander legte. Auf der einen Folie befand sich eine hierarchische Ordnung von Gesellschaften. Sie beruhte

185 Spencer 1899, S. 300: ,that the different forms of society presented by savage and civilized races all over the globe, are but different stages in the evolution of one form: the truth being rather, that social types, like types of individual organisms, do not form a series, but are classifiable only in divergent and re-divergent groups".

186 Peel (1971, S. 157) hebt dabei noch einmal den Unterschied hervor, daß dies eine dem Kettenmodell Linnés etwa völlig entgegengesetztes Vorstellung sei.

187 Bowler 1987, S. 54: „Spencer could not escape the prevailing view that some races were superior to others, but he was prepared to insist that cultural and racial differences cannot be expressed in a simple linear hierarchy. In a system of branching development, differences are not necessarily a sign of superiority or inferiority". 
auf einheitlichen Beurteilungskriterien, die an den Gesellschaften jeweils ihre Größe und ihre arbeitsteilige Differenzierung ablasen und die die Aufwärtsentwicklung von primitiven zu zivilisierten Gesellschaften beschrieben. Auf der anderen Folie befand sich das Modell verzweigter sozialer Entwicklungen. Die Richtung dieser Entwicklungen machte Spencer von der Anpassung abhängig. ${ }^{188}$ Welche Richtung sie auch immer nehme, mit einer in seinen Augen objektiven Einordnung von Gesellschaften in eine hierarchisierende Grobstruktur zwischen den Eckpunkten ,primitiv“ und ,zivilisiert' war dieses evolutionäre Modell durchaus kompatibel.

Diese duale Struktur von divergenter sozialer Evolution und hierarchischer Ordnung der Gesellschaften prägte Spencers weiteres soziologisches Programm. Die Ausführung seiner soziologischen Agenda hatte Spencer seit der Mitte der sechziger Jahre verfolgt. Um die Verbindungslinien der sozialen Evolution und ihre Entwicklungsrichtungen rekonstruieren zu können, legte er eine umfangreiche Sammlung ethnologischer Daten an. Hieraus entstanden die großformatigen Folianten der Descriptive Sociology. Spencer verstand sie vor allem als Vorstudien zu den Principles of Sociology, doch heute erlauben sie einen von keiner Theorie verbauten Einblick in die Logik seiner Soziologie. ${ }^{189}$ Ihre Struktur folgte dem etablierten Wertigkeitsgefälle der Rassen, denn der Grad der Zivilisiertheit war ihr Ordnungskriterium für die behandelten Gesell-

188 David Wiltshire hat zwar erkannt, daß nach Spencer die Anpassung an verschiedene Umweltbedingungen zu sehr verschiedenen sozialen Strukturen führte, doch daß Spencer hier auch degenerative Prozesse unterstellte und soziale Evolution nicht stringent progressivistisch faßte, problematisierte Wiltshire nicht (vgl. Wiltshire 1978, S. 201).

189 Unter Spencers Regie wurden nur acht Bände veröffentlicht, weitere neun gaben die Herbert Spencer Trustees nach seinem Tod zwischen 1910 und 1934 heraus. Vgl. Spencer: Descriptive Sociology. 8 Bde., Williams and Norgate, London 1873-1881: 1. English, 1873; 2. Ancient Mexicans, Central Americans, Chibchas, and Ancient Peruvians, 1874; 3. Lowest Races, Negritto Races, and Malayo-Polynesian Races. 1874; 4. African Races, 1875; 5. Asiatic Races 1876; 6. American Races, 1878; 7. Hebrews and Phoenicians, 1880; 8. French, 1881. Schon Ernest Barker hatte 1915 geschrieben: „As it is, we must consider him as a brilliant generalizer from imperfect data which he had never really thought together into a unity. That is why the study of his ,sources" matters more for the understanding of Spencer than it does for the study of most other thinkers" (Ernest Barker (1915) Political Thought in England. From Herbert Spencer to the Present Day. London: Williams and Norgate, S. 96). Doch Barkers Hinweis wurde überhört und Spencers Datenmaterial, sowohl in den Principles of Sociology, als auch in den Bänden der Descriptive Sociology, keiner kritischen Untersuchung unterzogen. 
schaften. ${ }^{190}$ Spencer wollte eine systematische Beschreibung der „Institutionen und Aktionen von Gesellschaften verschiedenen Typs und in verschiedenen Stadien der Evolution" liefern, ohne die eine Soziologie nicht möglich sei. ${ }^{191}$ Er entwarf zu diesem Zweck eine Standard-Tabelle nach folgendem Muster (vgl. Abb. 9):

\section{Abb. 9. Descriptive Sociology: Spencers Schema zur Analyse sozialer}

\section{Phänomene}

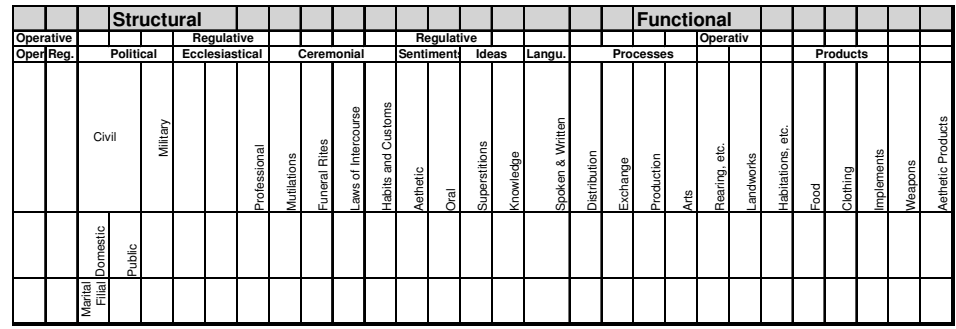

In jeweils einer Tabelle behandelte er eine Rasse. Einer jeden Tabelle stellte Spencer eine kurze Charakterisierung der natürlichen Umweltbedingungen, wie Klima, Relief, Vegetation und Tierwelt, eine skizzenhafte Darstellung der sozialen Umgebung und schließlich noch drei Absätze zur jeweils physischen, mentalen und intellektuellen Charakterisierung der Rasse voran. Diese Charakterisierungen hatten er und seine Mitarbeiter aus einer Unmenge von Dokumenten extrahiert. Der Textfundus bestand aus Amateurschilderungen, Reiseberichten und Darstellungen von damals anerkannten Ethnographen. ${ }^{192}$ Carneiro und Perrin schätzen die Descriptive Sociology als die „erste systematische Sammlung komparativer ethnographischer Fakten" ein, die als Material-

190 Diese Hierarchisierung wurde schon im Titel der einzelnen Bände angekündigt, von denen sich manche mit „niedrigen Rassen“, manche bloß mit „Rassen“ ohne wertenden Zusatz und zuletzt, in Europa angekommen, sich mit Gesellschaften ohne den Begriff ,Rassen ' befaßten. Hier kam erneut die Logik der Rassenmischung zum Tragen, die den Status ,Rasse“ allein bei den vermeintlich primitiven Gesellschaft erfüllt sah und die zivilisierten Gesellschaften als gelungene Rassenmischungen betrachtete.

191 Spencer 1874, S. i: ,definite accounts of the institutions and actions of societies of various types, and in various stages of evolution".

192 Auf diesen Charakter der Quellen hat auch John Haller (1971, S. 128129) hingewiesen. 
sammlung mit Referenzcharakter von Spencers Zeitgenossen verwendet wurden. $^{193}$

Spencer war aufmerksam genug, eine grundsätzliche Problematik seines Materials wahrzunehmen. Er gab unumwunden zu, daß bei geringem Sprachvermögen der Reisenden Verständigungsprobleme unvermeidbar waren, die für die Überlieferung nicht folgenlos gewesen sein dürften, und wies sogar darauf hin, daß die Quellen durchaus widersprüchlich oder unzulänglich sein könnten. ${ }^{194}$ Dennoch baute er keine methodologischen Zweifel in seine Behandlung des Materials ein. Außerdem war die reine Zahl der zusammengetragenen Aussagen mitunter so gering, daß Spencer auch nicht auf einen Nivellierungseffekt hätte spekulieren können. ${ }^{195}$

Der von ihm besonders betonte Gebrauchswert der tabellarischen Aufbereitung sollte sich, so seine Vorstellung, bei einem Vergleich von mehreren Gesellschaften realisieren. ${ }^{196}$ In dieser Hoffnung drückt sich Spencers Gesellschaftsverständnis aus. Er glaubte durch die aus ihrem setting losgelösten Bruchstücke soziale Sachverhalte rekonstruieren und zueinander ins Verhältnis setzen zu können. Er verglich in den Principles of Sociology dann soziale Tatbestände einerseits zwischen den vermeintlich zivilisierten und primitiven Gesellschaften und andererseits über Epochen hinweg bis hin zur europäischen oder lateinamerikanischen Antike. Erst durch dieses Verfahren wurde die soziale Komplexität derart reduziert und auf die eine Dimension des jeweiligen Beob-

193 Carneiro, Perrin 2002, S. 240; vgl. bspw. Augustus Henry Lane Fox (1878) „Observations on Mr Man's collection of Andamanese and Nicobarese Objects“. In: Journal of the Anthropological Institute 7, S. 434451, S. 434.

194 Vgl. Spencer 1883b, Bd. 1, S. 363: „Unfortunately, in most vocabularies of the uncivilized, travellers have given us only such equivalents for our words as they contain: taking no note of those words we possess for which they have no equivalents"; Boas 1914, S. 114; Spencer 1883b, Bd. 1, S. 554.

195 Über die Feuerländer etwa speiste sich Spencers Sammlung aus insgesamt nur sieben Quellen: James Cook: First Voyage (1786); Adolf Bastian: Der Mensch in der Geschichte (1860); Charles Darwin: Voyage of Beagle (1839); Admiral Fitzroy: Voyages of the Adventure and Beagle (1839); Snow: A Two Years' Cruise off Tierra del Fuego, \&c. (1861); Charles Wilkes: United States Exploring Expedition (1844); James Weddell: Voyage towards the South Pole (1827).

196 Darin sieht auch Jonathan Turner den Wert der Descriptive Sociology (vgl. Jonathan H. Turner (1985) Herbert Spencer: A Renewed Appreciation. Beverly Hills, London: Sage, S. 95-102). 
achter und Berichterstatters eingeschränkt, daß das Material zur Dokumentation sozialer Evolution handhabbar wurde. ${ }^{197}$

\section{"Primitive Conditions“. Rasse und Soziale Evolution}

Spencer bezeichnete die soziale Evolution auch als überorganische (,superorganic“) Evolution. ${ }^{198}$ Sie folge aber nicht nur in ihrer Logik der organischen Evolution, insofern sie etwa auf den gleichen Mechanismen beruhe. Die Verbindung zwischen organischer und super-organischer Evolution stellte sich bei Spencer enger dar. Es handelte sich nicht um eine analoge Übertragung der Wirkungsweisen, sondern um eine Verlängerung: ,Wenn es Evolution gegeben hat, dann muß ihre hier als super-organische unterschiedene Form durch nicht mehr wahrnehmbar kleine Schritte aus dem Organischen hervorgegangen sein““. ${ }^{199}$

Hatte Huxley den Menschen anatomisch in die Natur eingegliedert, so konstruierte Spencer die soziale Evolution und damit die Gesellschaft als Verlängerung der organischen Evolution und der Natur. Wie die organische Evolution von den Umweltbedingungen der Organismen und die individuelle psychische Entwicklung nach Spencer von der sozialen Umwelt abhängig wäre, so diskutierte er auch den Einfluß von Umweltfaktoren auf die soziale Evolution.

Bei der Umwelt einer Gesellschaft unterschied er dabei äußere und innere Natur. Bei der äußeren Natur berücksichtigte er Faktoren wie Klima, Relief, Fauna und Flora. Sie würden über das Verhalten und die

197 Carneiro und Perrin erklären die einseitige Datenlage damit, daß Spencer soziale Evolution vom ihrem Anbeginn an skizzieren wollte (Carneiro, Perrin 2002, S. 248: „,because Spencer was, after all, trying to trace the evolution of social institutions from their beginnings"). Doch Spencers auffällige Nichtberücksichtigung zeitgenössischer Gesellschaften ist damit keineswegs begründet. Vor allem hatte Spencer die soziale Evolution ja gar nicht nur anhand der sogenannten Primitiven und der antiken Gesellschaften rekonstruiert. Weil sie diese Problematik der Materialsammlung Spencers nicht erfaßt haben, übersehen Carneiro und Perrin einerseits die Unzulänglichkeit des Materials selbst und andererseits deren billigende Inkaufnahme Spencers. Jonathan Turner wiederum erkennt zwar die Problematik der Daten, die Spencer zur Verfügung standen, nimmt aber dennoch an, daß es ihm gelungen sei, ein überzeugendes Modell sozialer Evolution zu entwerfen. Dieses Modell habe er von Prinzipien deduziert, die von nachfolgenden Soziologen aufgegeben worden seien (vgl. Turner 1985, S. 104).

198 Spencer 1883 b, Bd. 1, S. 3.

199 Spencer 1883b, Bd. 1, S. 4: „If there has been Evolution, that form of it here distinguished as super-organic must have come by insensible steps out of the organic". 
körperliche Anpassung direkten Einfluß auf die sozialen Strukturen nehmen. So hätten etwa die Wilden größere Verdauungstrakte als die ,Zivilisierten“, da sie nur unregelmäßig Nahrung aufnehmen könnten. Doch dieses - aus Hungersymptomen herbeikonstruierte - Merkmal galt Spencer nicht einfach als ein Adaptionsergebnis. Er hielt es für den Ausweis der Primitivität, denn ,eine solche abdominale Entwicklung wie bei den Akka in fast affenartigem Grad, ist ein Körpermerkmal des primitiven Menschen, das durch primitive Lebensumstände notwendig gemacht wurde". ${ }^{200}$ Aber auch das soziale Leben sei durch die klimatischen Bedingungen determiniert, insofern es „durch bestimmte Extreme der Hitze und der Kälte beschränkt" würde. ${ }^{201}$ Zwar könnten Menschen in extrem unwirtlichen Klimaten leben,

„wo aber [...] die notwendige Temperatur für die lebenswichtigen Funktionen des Menschen nur mit Schwierigkeiten aufrechterhalten werden kann, ist soziale Evolution nicht möglich. [...] Die großen physischen Kosten des individuellen Lebens, begrenzen indirekt die Vermehrung der Individuen und bringen die soziale Evolution zum Stillstand“. ${ }^{202}$

Er griff also auf seine alte Behauptung zurück, die Wilden - und wie viele seiner Zeitgenossen hielt er insbesondere Feuerländer, Australier und Buschmänner für die primitivsten Wilden - hätten sich nicht oder kaum entwickelt. Hatte er vormals anhand des Gehirnvolumens und des Gesichtswinkels ihre Primitivität und Entwicklungslosigkeit abgeleitet, so führte er hier eine Begründung für den physischen Ausdruck der sozialen Distanz zwischen Zivilisierten und Primitiven ein: Die Umweltbedingungen hätten bei ihnen die soziale Evolution und damit auch die Entwicklung bestimmter Kulturtechniken verhindert, woraus die signifikanten Schädelproportionen und, vermittelt über die geringere Denkleistung, ein kleineres Gehirn resultierte. Deshalb lebten die Feuerländer, so Spencer,

200 Spencer 1883b, Bd. 1, S. 47: ,such an abdominal development as the Akka show in a degree almost ape-like, is a trait of primitive man necessitated by primitive conditions".

201 Spencer 1883 b, Bd. 1, S. 17: ,social life [...] is restricted by certain extremes of cold and heat".

202 Spencer 1883b, Bd. 1, S. 18: „But where [...] the temperature which man's vital functions require can be maintained with difficulty, social evolution is not possible [...] This great physiological cost of individual life, indirectly checking the multiplication of individuals, arrests social evolution“. 
„annähernd unbekleidet in einer Region von Stürmen, die ihre elenden Unterkünfte aus Stöcken und Gras nicht abschirmen. Diese Wesen, die als kaum menschlich in ihrem Aussehen beschrieben werden und über kaum mehr Nahrung als Fisch und Weichtiere verfügen, haben derartige Schwierigkeiten, die vitale Balance [...] zu erhalten, daß der Überschuß für die individuelle Entwicklung eng begrenzt ist, und folglich auch der Überschuß für die Zeugung und Aufzucht neuer Individuen. Daher bleibt die Anzahl zu klein, um irgend etwas jenseits des beginnenden sozialen Seins aufzuweisen“. 203

Spencer selbst hatte nun in der Descriptive Sociology Passagen über die Feuerländer zitiert, denen diese Zusammenfassung widersprach. So war dort ebenso von „Wigwams“ oder „Hütten“ als wohl robusteren Behausungen zu lesen wie von vielfältigerer Ernährung, auch gab es Berichte, die sich nicht in despektierlichen Beschreibungen ihres Äußeren ergingen. ${ }^{204}$ Er verarbeitete also dieses von ihm in Descriptive Sociology aufwendig aufbereite Material selektiv und stützte sich nur auf jene Berichte, die die Feuerländer als besonders primitiv erscheinen ließen. Es ist offensichtlich, daß Spencer von einer differenzierteren Diskussion der Darstellungen absah, da er ohnehin annahm, daß in bestimmten Regionen eben keine wahrnehmbaren sozialen Entwicklungen möglich seien. Er ging von einem wirkungsmächtigen Zusammenhang zwischen Umwelt und Zivilisationsgrad aus. Dabei stand ganz offenkundig der Zivilisationsgrad der Feuerländer selbst nicht zur Disposition. Deshalb erklärte er, die üppige Vegetation sei ein Hemmnis für ihre evolutionäre Entwicklung gewesen. ${ }^{205}$

Bemerkenswert an seiner Diskussion des Einflusses externer Faktoren auf die soziale Evolution ist der Umstand, daß er sich fast ausschließlich mit Evolutionshemmnissen befaßte und weder bei der Diskussion der äußeren noch der der inneren Natur die Wirkungsweise jener

203 Spencer 1883b, Bd. 1, S. 18: „Living nearly unclothed in a region of storms, which their wretched dwellings of sticks and grass do not exclude, and having little food but fish and mollusks, these beings, described as scarcely human in appearance, have such difficulty in preserving the vital balance [...], that the surplus for individual development is narrowly restricted, and, consequently, the surplus for producing and rearing new individuals. Hence the numbers remain too small for exhibiting anything beyond incipient social existence."

204 Vgl. Spencer (1874) Descriptive Sociology or Groups of Sociological Facts. Types of Lowest Races, Negritto Races, and Malayo-Polynesian Races. London: Williams and Norgate, S. 6 (,Wigwams“, „huts“, „,get birds“, ,gather shell-fish, dive for sea-eggs"); zur Beschreibung der äuBeren Erscheinung vgl. ebd. S. 1.

205 Vgl. Spencer 1883b, Bd. 1, S. 31: „luxuriance of vegetation is in some cases a hindrance to progress“. 
Faktoren dargelegte, die die soziale Evolution begünstigt haben könnten. Nicht anders als bei Huxley war auch Spencers Versuch, soziale Evolution zu plausibilisieren, ein Diskurs über die vermeintlich Wilden.

\section{Exkurs. Spencers Theorie sozialer Evolution}

Spencer untersuchte soziale Evolution anhand sozialer Institutionen wie Familie, Religion, Politik, Beruf oder Wirtschaft. In all diesen Formen sozialer Institutionenbildung analysierte er die gleiche soziale Entwicklung, die er in den Koordinaten von Wachstum und struktureller sowie funktionaler Differenzierung über verschiedene Stufen des sozialen Prozesses hinweg verfolgte. Durch die Einführung dieser analytischen Begriffe wird Spencer in der Geschichte der Soziologie ebenso für die komplexitätsbedingte Differenzierung von Struktur und Funktion hervorgehoben, wie auch für seine Unterscheidung von Wachstum, also die Zunahme an Größe. ${ }^{206}$ Andreski schreibt, daß Spencer mit dem Kriterium der strukturellen Komplexität das alte Stufenmodell gesellschaftlicher Entwicklung grundsätzlich novelliert habe. ${ }^{207}$

Auf dieser theoretischen Grundlage war es ihm möglich, den Wachstumsgrad sozialer Gebilde in vier Stufen zu unterteilen: einfache, zusammengesetzte, doppelt-zusammengesetze und dreifach-zusammengesetzte Gesellschaften. Größere Gesellschaften könnten nach Spencer nicht allein aus kleinen sozialen Verbänden erwachsen, ihre Entstehung bedürfte immer auch des Zusammenschlusses von verschiedenen, zunächst kleinen, dann immer größeren Gesellschaften. ${ }^{208}$

Die Entwicklung sozialer Kohäsion und die Entwicklung einer sozialen Differenzierung waren bei Spencer untrennbar. Zunächst existierten

206 Vgl. Talcott Parsons (1962) „Introduction“. In: Herbert Spencer: The Study of Sociology. Michigan: Ann Arbor Press, S. v-x, S. vii; Robert L. Carneiro (1967b) The Evolution of Society. Selections from Herbert Spencer's „Principles of Sociology“. Chicago: University of Chicago Press, S. xxxvi; Ronald Fletcher (1972) The Making of Sociology. A Study of Sociological Theory. Vol. 1. Beginnings and Foundations. London: Nelson.

207 Vgl. Stanislav Andreski (1969) „Introduction“. In: Ders. (Hrsg.): Herbert Spencer. Principles of Sociology. London: Macmillan, S. ix-xxxvi, S. xix

208 Vgl. Jay Rumney (1965) Herbert Spencer's Sociology. New York: Atherton, S. 241-266; Spencer 1883b, Bd. 1, S. 549ff; Ferdinand Tönnies (2000) „Herbert Spencers soziologisches Werk“. In: Lars Clausen (Hrsg.): Ferdinand Tönnies Gesamtausgabe. Berlin: De Gruyter, Bd. 15, S. 131-165, S. 157. 
nur „kopflose Haufen, völlig unregiert [und] zusammenhangslos“. ${ }^{209}$ Doch wenn diese Horden sich zu sozialen Aggregaten von hundert oder mehr Individuen auswüchsen, entstünden auch Formen von lenkenden Autoritäten und mithin die erste Stufe sozialer Differenzierung. ${ }^{210}$ Die zweite Stufe dieser sozialen Differenzierung beschrieb Spencer als verstetigte Etablierung einer herrschenden Klasse, ,eine Teilung zwischen regulativen und operativen Teilen““. ${ }^{211}$ Aus dieser primären politischen Differenzierung in Herrscher und Beherrschte entstünde mit wachsender Größe der Gesellschaft ein komplexes System unterschiedlicher Machtniveaus. Die politische Differenzierung wurde bei Spencer von einer ökonomischen begleitet.

„Wenn wir von den niedrigen Stämmen, gänzlich ohne soziale Unterscheidung, zu den Stämmen unmittelbar über ihnen gehen, finden wir Klassen von Herren und Sklaven. [...] [Z]usammen mit der Einführung der Landwirtschaft wird diese Differenzierung deutlicher. [...] Eine Gesellschaft, die derart aus zwei mit einander in Kontakt stehenden Schichten zusammengesetzt ist, wird durch das Aufkommen von Rängen in jeder Schicht komplexer“" ${ }^{212}$

Zwischen diesen ursprünglichen Klassen seien nun sukzessive drei Systeme der Vermittlung entstanden, die sozialen Systeme der Güterfertigung, der Infrastruktur und der Politik. ${ }^{213}$ Da Spencer in erster Linie die Entwicklung dieser Systeme auf der Basis einer Analogiebildung zur vermuteten Entwicklung zwischen verschiedenen Organismen zu rekonstruieren versuchte, stellte er keine analytische Verbindung zwischen ihnen her. So blieben sie als separate Entitäten stehen, deren Verbindung und Entwicklung über die Klammer der sozialen Evolution hergeleitet wurde.

209 Spencer 1883b, Bd. 1, S. 472: „headless clusters, wholly ungoverned [...] incoherent".

210 Vgl. Spencer 1883b, Bd. 1, S. 472.

211 Spencer 1883b, Bd. 1, S. 472: „Soon after it there frequently comes another, tending to form a division between regulative and operative parts. In the lowest tribes this is rudely represented only by the contrast of status between the sexes".

212 Spencer 1883b, Bd. 1, S. 492-493: „When from low tribes entirely undifferentiated, we pass to tribes next above them, we find classes of masters and slaves [...]. [A]long with establishment of the agricultural state, the differentiation grows more appreciable. [...] A society thus composed of two strata in contact, complicates by the rise of grades within each stratum“.

213 Vgl. Spencer 1883b, Bd. 1, S. 498ff. Spencer nennt diese Systeme „,sustaining system”, ,distributing system” und ,regulating system“. 
Neben der mehrstufigen Unterteilung der Gesellschaften nach ihrem Kompositionsgrad führte Spencer auch eine generelle, idealtypische Unterscheidung von militanten oder industriellen Gesellschaften ein. ${ }^{214}$ Damit löste er den Prozeß der sozialen Evolution allerdings aus dem naturhaften Kampf ums Überleben heraus. Spencer verwendete mit dem Gegensatzpaar industriell-militant eine Dichotomie, die bereits von liberalen Philosophen wie Thomas Paine, John S. Mill oder Henry Thomas Buckle vorgedacht wurde. ${ }^{215}$ Sie betrachteten Krieg und Handel als diametralen Gegensatz. Spencer projizierte nun diesen Gegensatz auf die zivilisierten Europäer und die unzivilisierten Wilden. Als militanten Gesellschaftstypus bezeichnete er Gesellschaften, die nach militärischen Strukturen hierarchisiert wären. ${ }^{216}$ Dieser Gesellschaftstyp sei für primitive Gesellschaften ebenso wie für sogenannte halb-zivilisierte und eine große Zahl der als zivilisiert angesehenen Gesellschaften charakteristisch. Die Militarisierung erfasse nicht nur die Politik, sondern alle Bereiche des gesellschaftlichen Lebens:

„Diese Struktur wiederholt sich in den anderen sozialen Arrangements. Es gibt präzise Gradierungen des Ranges in der Gemeinschaft und vollständige Unterwerfung eines jeden Ranges unter den Rang darüber“. 217

Eine industrielle Gesellschaft zeichne sich demgegenüber nicht allein durch politische Strukturen oder das Volumen der gewerblichen Produktion aus, sondern durch das Maß der Kooperation in der Produktion. $^{218}$ Deshalb unterschied Spencer zwei Formen des industriellen Typs, eine archaische und eine moderne Ausprägung. Er begrenzte den archaischen industriellen Typ auf vermeintlich primitive Gesellschaften, die auf einer freiwilligen Unterwerfung unter ein von den Erfahrensten gebildetes Regime beruhten. ${ }^{219}$ Diese Gesellschaften wären in ihrem Wachstum und ihrer Entwicklung begrenzt, da eine dafür notwendige ,Zweifach-Zusammensetzung' die - gewaltsame - Inkorporierung anderer Gesellschaften zur Bedingung habe. Darum sei der militante Gesellschaftstypus eine notwendige Zwischenstufe der sozialen Evolution. Die

214 Vgl. Spencer 1883b, Bd. 1, S. 556; Peel 1971, S. 192f; Haines 1988, S. 1213.

215 Vgl. Peel 1972, S. xxxii.

216 Spencer 1883b, Bd. 1, S. 557: ,the militant type is one in which the army is the nation mobilized while the nation is the quiescent army".

217 Spencer 1883b, Bd. 1, S. 558: „This structure repeats itself in the accompanying social arrangements. There are precise gradations of rank in the community and complete submission of each rank to the ranks above it".

218 Vgl. Spencer 1883b, Bd. 2, S. 604.

219 Vgl. Spencer 1883b, Bd. 1, S. 564. 
moderne Form der industriellen Gesellschaft zeichnete sich für Spencer durch die funktionale Differenzierung und die soziale Kohäsion aus. ${ }^{220}$

Für Peel war das Besondere bei Spencer, daß er „,eine zweistufige Charakterisierung der jüngeren Vergangenheit in ein Muster für die allgemeine soziale Evolution verwandelte", und dabei die ökonomische Entwicklung Englands auf die Zivilisationsgeschichte extrapoliert habe. $^{221}$ Peel übergeht allerdings Spencers Differenzierung zwischen der archaischen und der modernen Ausprägung des industriellen Gesellschaftstyps. Spencer hatte keinen uniformen Entwicklungsgang vom militanten zum industriellen Typ skizziert. Dies zeigt sich nicht nur an seiner Konstruktion der archaischen industriellen, oder besser nicht-militanten Gesellschaften, sondern auch daran, daß er etlichen zeitgenössischen europäischen Staaten, bedingt durch internationale Konflikte, einen Rückfall in autoritäre, militante Ordnungen attestierte, wie dem napoleonischen Frankreich oder dem Deutschland Bismarcks. ${ }^{222}$ Seine Gesellschaftstypologie verband Spencer aber nicht mehr mit seiner grundsätzlichen Annahme, daß die soziale Struktur von den Eigenschaften der Mitglieder einer Gesellschaft bestimmt wäre. Denn dieser Prämisse laufen Annahmen wie die eines Rückfalls industrieller Staaten in militante Strukturen zuwider.

\section{Survival of the fittest}

Bei Spencer übernahm der Mechanismus des Überlebens des am besten Angepaßten, des survival of the fittest, eine zentrale Funktion. Die Vorstellung von der sozialen Evolution als Ausdruck eines Prozesses der Anpassung an die Umwelt unterstellte eine Dimension von Verteilungsund Verdrängungskämpfen. Sie verstand Spencer als Motor einer nicht endenden, wechselseitigen Perfektionierung, denn „Krieg zwischen den

220 Nach Peter J. Bowlers Einschätzung war es paradox, daß ausgerechnet Spencer, der „Hauptvertreter des liberalen Individualismus [...] die Identifikation jeder Rasse als einer evolutionären Einheit mit einem jeweiligen besonderen Charakter und Entwicklungsniveau ermöglichte“ (Peter J. Bowler (1995) „Herbert Spencers Idee der Evolution und ihre Rezeption“. In: Eve-Marie Engels: Die Rezeption von Evolutionstheorien im 19. Jahrhundert. Frankfurt: Suhrkamp, S. 309-325, S. 322). Doch wie hier zu sehen ist, war Spencers Liberalismus logisch mit seiner Vorstellung einer Evolution zwischen verschiedenen Zivilisationsstufen und diesen zugeordneten Rassen verbunden.

221 Peel 1971, S. 198: „Spencer's peculiarity was that he took a two-stage characterization of recent history and turned it into a pattern for general social evolution".

222 Vgl. Spencer 1883b, Bd. 1, S. 579-581. 
Menschen, wie Krieg zwischen Tieren, hat einen großen Anteil an der Anhebung ihrer Strukturen auf eine höhere Stufe“. ${ }^{223}$

Spencer hatte mit der ,Anhebung der Strukturen' auch die individuelle, körperliche Verfassung im Sinn. Der Kampf ums Überleben hatte bei ihm, der sowohl von der Anpassung eines Organismus an die Umwelt als auch von der Vererbbarkeit erworbener Eigenschaften ausging, einen beschleunigenden Effekt auf die ,Anhebung der Strukturen'. Doch Spencer sah den Effekt solcher kriegerischen Auseinandersetzungen nicht nur in einer individuellen Perfektionierung. Genauso ging er von einer Ausmerze der Schwachen aus:

„,der Effekt der beständigen Ausrottung derjenigen Rassen, die [...] am wenigsten geeignet waren, mit den gegebenen Umweltbedingungen umzugehen. Das Abtöten von vergleichsweise schwächlichen Stämmen oder von Stämmen, denen es an Ausdauer, Courage, Scharfsinn oder Kooperationsvermögen vergleichsweise mangelte, muß zu einer andauernden Erhaltung und zu gelegentlichem Anwachsen der lebenserhaltenden Kräfte des Menschen führen“. ${ }^{224}$

Hier bewegte sich Spencer im Kontext des damals aktuellen Diskurses über die aussterbenden Rassen. ${ }^{225}$ Dabei kam er der Wahrheit des aktiven Ausmerzens der Eingeborenen durch europäische Siedler erheblich näher als die meisten seiner Zeitgenossen, die diesen Vorgang euphemistisch als ein natürliches und schicksalhaftes Dahinsterben betrachteten, unter ihnen auch Lubbock. Er hingegen erklärte freimütig, daß es sich bei solchen Vorgängen um eine Ausrottung jener handele, die sich an die veränderten sozialen Umweltbedingungen nur ungenügend hätten anpassen können.

Den Mechanismus der Anpassung als treibendes Element der sozialen Evolution hatte Spencer um die Dimension der Anpassung an die verschärften Bedingungen des Kriegs ergänzt. Doch neben die so bewirkte Perfektionierung, die sowohl auf individueller wie sozialer Ebene wirke, stellte Spencer einen Mechanismus der Ausmerze, des Unterge-

223 Spencer 1899, S. 174: „Warfare among men, like warfare among animals, has had a large share in raising their organizations to a higher state".

224 Spencer 1899, S. 175: ,the effect of continually extirpating races, which [...] were least fitted to cope with the conditions of existence they were subject to. The killing-off of relatively-feeble tribes, or tribes relatively wanting in endurance, or courage, or sagacity, or power of co-operation, must have tended ever to maintain, and occasionally to increase, the amounts of life-preserving powers possessed by men“.

225 Vgl. allgemein Patrick Brantlinger (2003) Dark Vanishings. Discourse on the Extinction of Primitive Races, 1800-1930. Ithaca, London: Cornell University Press. 
hens der Nichtangepaßten (,unfit'). Soziale Evolution wird in Spencers Sichtweise gewissermaßen von einem Rückstoßverfahren angetrieben, sie sondere beständig Schwache aus und treibe so die progressive Evolution der Angepaßten voran. Zwar würden im Verlauf fortschreitender sozialer Evolution die militaristischen Strukturen einer Gesellschaft durch eine industrielle Organisation abgelöst. Doch die Überwindung der Militanz in höheren Gesellschaftsformen bedeute nicht, daß in ihnen der Ausrottungsprozeß der Schwächsten ausgesetzt sei. Er würde bloß auf eine andere Ebene verlagert und

„weiter im industriellen Krieg fortgesetzt - in einem Wettbewerb der Gesellschaften, bei dem sich die physisch, emotional und intellektuell Besten am weitesten ausbreiten und die am wenigsten Befähigten schrittweise verschwinden lassen“. 226

Der soziale Strukturwandel von der militaristischen zur industriellen Gesellschaft löste bei Spencer zunächst einmal eine semantischen Wechsel aus, nicht mehr ,Ausrotten“ und ,Abtöten“ sei das Schicksal der Schwachen in der industriellen Gesellschaft, sondern ihr ,Verschwinden'. Darin sah er allerdings nicht nur eine Folge, sondern eine Funktion des allgemeinen gesellschaftlichen Fortschritts:

„Wenn der Kampf ums Überleben als Krieg zwischen den Gesellschaften aufgehört hat und nur noch der industrielle Kampf ums Überleben bleibt, können letztlich nur jene Gesellschaften überleben und sich verbreiten, die die größte Zahl der besten Individuen hervorbringt, Individuen, die am besten an das Leben im industriellen Staat angepaßt sind“. ${ }^{227}$

An dieser Stelle verband sich bei Spencer die Vermutung einer Ausmerze der schwachen Gesellschaften mit einer Behauptung der erforderlichen Perfektionierung der Menschen in einer Gesellschaft. Einerseits mag diese blutrünstig anmutende Passage angesichts der entschiedenen Kritik am Imperialismus überraschen, die er bereits in Social Statics ge-

226 Spencer 1899, S. 180: ,the purifying process, continuing to be an important one, remains to be carried on by industrial war - by a competition of societies during which the best, physically, emotionally, and intellectually, spread most, and leave the least capable to disappear gradually“.

227 Spencer 1883b, Bd. 2, S. 610: „For when the struggle for existence between societies by war has ceased, there remains only the industrial struggle for existence, the final survival and spread must be on the part of those societies which produce the largest number of best individuals individuals best adapted for life in the industrial state“. 
übt und die er bis an sein Lebensende vertreten hatte. ${ }^{228}$ Doch er war vor allem an der Freiheit der Kolonisten und ihrer Unabhängigkeit von den Direktiven einer zentralen Administration interessiert, die koloniale Landnahme selbst stellte er nicht in Frage. Andererseits ist hervorzuheben, daß Spencer zwar, wie es heißt, sozialdarwinistisch argumentierte, er aber gerade nicht die aktive Verbesserung des Erbmaterials durch bevölkerungspolitische Maßnahmen forderte, wie es die Eugenik jener Jahre tat.

\section{Fortschritt oder Degeneration}

Die Annahme, daß die vermeintlich primitiven Rassen Produkte degenerativer Prozesse seien, war lange Zeit eines der Kernargumente des Monogenismus. Im Unterschied zu Lubbock schien die Degenerationshypothese für Spencer kein ernstzunehmendes Problem darzustellen, denn er hing seine Erörterungen zu der hier grundsätzlich zur Disposition stehenden Einschätzung der Hauptrichtung der sozialen Entwicklung an der Feststellung auf, daß im Diskurs eine naiv-teleologischer Fortschrittsautomatismus vorherrsche:

„Evolution wird gewöhnlich so verstanden, daß sie überall eine intrinsische Tendenz zur Verbesserung impliziere. Dies ist eine irrtümliches Verständnis. Sie ist grundsätzlich von einem Zusammenspiel innerer und äußerer Faktoren bestimmt. Es bedingt Veränderungen, bis ein Gleichgewicht erreicht ist [...]. Aber daraus folgt bei weitem nicht, daß eine solche Veränderung einen Schritt in der Evolution konstituiert. Normalerweise resultieren daraus weder Fortschritt noch Rückschritt". 229

Spencer machte diese universellen Gesetzmäßigkeit der Evolution auch für die soziale Evolution geltend. Zu anpassungsbedingtem Wandel käme es auch bei fluchtbedingter Erschließung neuer Lebensräume, ein

228 Vgl. Spencer 1851, S. 367-369; Spencer an Moncrue D. Conway, 17. Juli 1898. In: Duncan 1908, S. 410; Spencer (1902) „Imperialism and Slavery“. In: Herbert Spencer (Hrsg.): Facts and Comments. New York: Appleton, S. 157-171; Carneiro 1981, S. 179.

229 Spencer 1883b, Bd. 1, S. 95: „Evolution is commonly conceived to imply in everything an intrinsic tendency to become something higher. This is an erroneous conception of it. In all cases it is determined by the co-operation of inner and outer factors. This co-operation works changes until there is reached an equilibrium [...]. But it by no means follows that this change constitutes a step in evolution. Usually, neither advance nor recession results". 
Wandel, der nicht notwendigerweise Fortschritt impliziere. ${ }^{230}$ Waren es doch die ,entwickelteren Gesellschaften, die die weniger entwickelten Gesellschaften in unvorteilhafte Lebensräume verdrängen, und ihnen derart Verminderung an Zahl, Niedergang der Struktur oder beides aufbürden““. ${ }^{231}$ Die hier beschriebene Degeneration müsse also als das Produkt eines - erzwungenen - Anpassungsprozesses an unvorteilhafte Umweltbedingungen verstanden werden.

Das im Kontext seiner Formel des ,Survival of the fittest“ entstandene ,Rückstoßprinzip“ der sozialen Evolution verknüpfte Spencer hier mit dem Diskurs über Degeneration, denn er trennte soziale Entwicklungen in zwei Richtungen auf. Hatte er zuvor den vom sozialen Fortschritt ausgestoßenen Individuen beziehungsweise Gesellschaften Entwicklungslosigkeit attestiert, so ging er jetzt nicht von ihrem statischen $\mathrm{Zu}$ stand, sondern ihrer Degeneration aus. Den vormals als „Auswurf der Evolution“, („Outcasts of evolution“) in den Worten John Hallers, beschriebenen Gesellschaften wurde derart eine evolutionäre Entwicklung zugeschrieben, die auf der gleichen Mechanik beruhte, wie der soziale Fortschritt anderer Gesellschaften: Überlebenskampf, Anpassung und Auslese. So führte Spencer ,Primitivität' exklusiv auf Regression zurück und ,Zivilisiertheit‘ exklusiv auf Fortschritt:

„[D]ie meisten der Stämme, die als die niedrigsten bekannt sind, zeigen einige soziale Eigenschaften, die nicht durch gegenwärtig wirkenden Ursachen, sondern durch Umstände verursacht wurden, die während vergangener sozialer Zustände wirkten, die höher waren als der gegenwärtige“. 232

Mit der Integration des Degenerationskonzeptes vollzog Spencer eine elementare theoretische Wende, die in bemerkenswerter zeitlicher Nähe $\mathrm{zu}$ den Entwicklungen im anthropologischen Diskurs und zu den Entwicklungen in der Theoriebildung bei seinen Mitstreitern im X-Club stand, etwa Huxleys Dynamisierung der persistenten Urstämme. Vor allem Lubbock dürfte ihm vorexerziert haben, daß soziale Evolution durchaus progressive und degenerative Entwicklungsrichtungen erklären könne.

230 Vgl. Spencer 1883b, Bd. 1, S. 96: „But this change does not necessarily imply advance".

231 Spencer 1883b, Bd. 1, S. 97: „The more-evolved societies drive the lessevolved societies into unfavourable habitats; and so entail on them decrease of size, or decay of structure, or both".

232 Spencer 1883b, Bd. 1, S. 98: ,,most of the tribes known as lowest, exhibit some social phenomena which are due, not to causes now operating, but to causes that operated during past social states higher than the present". 
Es liegt nahe, daß es Spencer aufgrund der Entspannung im rassentheoretischen und anthropologischen Diskurs in der Folgezeit leichter fiel, auch den Niederschlag degenerativer Effekte eines evolutionären Überlebenskampfes und evolutionärer Prozesse der Auslese und Anpassung zu erörtern und für die Erklärung der sozialen Differenz nutzbar zu machen. Diese Wende bedeutete auch, daß Spencer die Determination des Gehirns durch die sozialen Strukturen, die er in seinen frühen Entwürfen zur sozialen Evolution noch in den Mittelpunkt seiner Begründung der sozialen Unterschiede zwischen den vermeintlich Primitiven und Zivilisierten gestellt hatte, kaum noch betonte. Die soziale Differenz konnte er offenbar in seinen Augen plausibler unter Heranziehung degenerativer Momente erklären.

Weil die Zuschreibungen von Zivilisiertheit und Primitivität selbst nicht durch seine Überlegungen einer Neuordnung oder Modifikation ausgesetzt werden sollten, führte die Einbindung degenerativer Prozesse in sein Modell sozialer Evolution auch nicht dazu, daß dadurch die soziale Distanz zwischen den als zivilisiert beziehungsweise als primitiv apostrophierten Gesellschaften ausgeweitet wurde. Allerdings wirkte sich diese Kombination gegenläufiger Entwicklungen auf die Prognose der weiteren sozialen Evolution aus. Durch diese Degenerationsvermutung wird den Wilden auch für die Zukunft jegliches Potential progressiv-evolutionärer Entwicklung abgesprochen. Ihr Schicksal des ,Verschwindens“, wie Spencer das ,Abtöten“ euphemisierte, war für ihn damit besiegelt.

\section{Fazit}

In den fünfziger Jahren entwickelte Spencer seine Theorie sozialer Evolution in der diskursiven Schnittmenge von tradiertem Fortschrittsdenken und moderner Naturwissenschaft. Der Ausgangspunkt seiner sozial-evolutionären und anthropologischen Überlegungen war die traditionsreiche Korrelationsvermutung von Rasse und Gehirnvolumen, die er als Ausdruck sozialer Evolution verstand. Doch weil die zeitgenössischen Debatten der Anthropologie keine überzeugenden Konzepte bieten konnten, arbeitete Spencer in den Folgejahren an einer kausalen Erklärung dieser Korrelation, an deren Faktizität für ihn folglich kein Zweifel bestand.

In seinen frühen Entwürfen zur sozialen Evolution aus den sechziger Jahren des neunzehnten Jahrhunderts biologisierte Spencer das Soziale, indem er soziale Strukturen aus der somatischen wie psychischen Beschaffenheit der Individuen ableitete. Diese Ableitung war nicht nur für seine Konzeption der Soziologie entscheidend, sondern zeigt zugleich, 
daß er hier auf in seinen Augen gesicherte Wissensbestände zurückgriff, die sich allerdings auch aus stereotypisierten Bildern vor allem vermeintlich Primitiver zusammensetzten.

Die Biologisierung bei Spencer basierte vor allem auf der Konstruktion eines kausalen Zusammenhangs zwischen der Sozialstruktur und dem Gehirn. Allerdings konstruierte er einen bidirektionalen Wirkungszusammenhang: Neben der Erklärung, daß die Struktur einer Gesellschaft von den Eigenschaften ihrer Mitglieder abhinge, ging er auch davon aus, daß die Kulturtätigkeit selbst das Wachstum des Hirns und damit die Physiognomie beeinflusse. Hier galt also ein Primat des Sozialen.

Spencer drehte die traditionelle Vorstellung, nach der das Gehirn Intellekt und kulturelle Leistung bestimmte, aber keineswegs vollständig um. Er ging von einer zirkulären Wechselwirkung zwischen den beiden Faktoren aus, wobei er das Gehirnvolumen sukzessive zu einem Indikator des Zivilisationsgrades reduzierte. Die soziale Evolution lief in Spencers Modell eben nicht nur in sozialen Institutionen ab, wie in der Sekundärliteratur grundsätzlich angenommen wird, sondern auch in den Körpern der Mitglieder einer Gesellschaft, die selbst Bedingungen und Objekte beständiger evolutionärer Prozesse seien. ${ }^{233}$

Spencer hatte nicht nur einen kausalen Zusammenhang zwischen somatischen und sozialen Unterschieden unterstellt, er hielt die psychischen Eigenschaften der Menschen, ihre Intelligenz und psychischen Prädispositionen für vererbbar. Hierin liegt der Kern seiner Rassentheorie. Im Unterschied zu vorevolutionstheoretischen Ansätzen, die Körperunterschiede nur taxonomisch verstanden und die soziale Entwicklung rein kulturell begriffen, konstruierte Spencer eine Theorie sozialer Evolution, die ganz wesentlich auf evolutionsbedingten Veränderungen der physischen Eigenschaften der Individuen und der Rassen basierte.

Doch in seinen späteren Ansätzen trat diese Betonung der Korrelation von Gehirnvolumen und Intelligenz in den Hintergrund. Dafür kam in seinen soziologischen Hauptschriften der frühen siebziger Jahre, in The Study of Sociology und im ersten Band der Principles of Sociology, die evolutionäre Mechanik des Überlebenskampfes und der Anpassung zum Tragen. Sie führte zu einer Akzentverschiebung, bei der Spencer seine Erklärung sozialer Unterschiede zwischen den Rassen durch die Degeneration der vermeintlich Primitiven zu erhärten versuchte. Des-

233 Perrin bspw. nimmt an, daß Spencers soziale Evolution erstens zu einem idealen sozialen Zustand tendiere, zweitens in einer funktionalen Differenzierung bestehe, drittens durch zunehmende Arbeitsteilung bestimmt sei und viertens Arten von Gesellschaften (,Species of Societies“) hervorbringe (vgl. Perrin 1976, S. 1353). 
halb ist für das Verständnis der Spencerschen Theorie sozialer Evolution sein Gebrauch von Fortschritt und Retrogression entscheidend.

$\mathrm{Daß}$ er beide Mechanismen vorhielt, wurde in der Spencerforschung kaum zur Kenntnis genommen. Dabei fußte auch seine Annahme einer Degeneration auf einem Adaptionsprozeß und war deshalb integraler Bestandteil seines Evolutionskonzeptes. Zudem wurde beständig übersehen, daß er für die zivilisierten Gesellschaften wie selbstverständlich eine progressive Entwicklung unterstellte, sich aber auf die Annahme einer regressiven Entwicklung als Erklärung für die vermeintliche Primitivität der Wilden stützte.

Der unterschiedliche Umgang, den Spencer mit diesen gegensätzlichen Entwicklungsrichtungen pflegte, tritt bei einer Untersuchung seiner Argumentation über Rassenunterschiede deutlich hervor. Zwar haben Robert Perrin und Valerie Haines erkannt, daß nach Spencer „Arten von Gesellschaften" durch die Anpassung an verschiedene Umweltkontexte entstünden. ${ }^{234}$ Daß er deshalb auch degenerative Entwicklungen annehmen konnte, ohne in einen Widerspruch mit seinem Schema evolutionärer Entwicklung zu geraten, ist dabei aber nicht berücksichtigt worden. Das gilt auch für Peel, der Spencers Definition sozialer Evolution für progressiv und tendenziell teleologisch hält. ${ }^{235}$ Er stellt zwar fest, daß Spencers zentraler Mechanismus die „Anpassung an den sozialen $\mathrm{Zu}$ stand" war, und nimmt dessen alternative Formen der Anpassung an verschiedene soziale Zustände zur Kenntnis, die eigentlich von den Umweltbedingungen bestimmt wären. ${ }^{236}$ Doch gerade wegen dieser Abhängigkeit von den Umweltfaktoren ordnet Peel dieses duale Entwicklungsmodell bei Spencer einem globalen, progressiven Entwicklungsmodell unter, indem er behauptet, Spencer selbst sei hier widersprüchlich gewesen und habe seine Perspektive von der einzelnen, partikularen Gesellschaft zu einer gedachten, idealisierten sozialen Entwicklung verschoben. ${ }^{237}$

234 Perrin 1976, S. 1342: „,species of societies“; vgl. Haines 1988, S. 1210.

235 Vgl. La Vergata 1995, S. 212; Haines 1988, S. 1203.

236 Peel 1971, S. 155: ,adaptation to the social state“.

237 Vgl. Peel 1971, S. 154-155: ,The use of the word ,adaptation“ to cover both this long-term continual approximation of mankind to an unrealized perfection and the perpetual adjustment to variable preent conditions in Lamarckian biology is very misleading. Spencer's usage is not quite consistent here, since he also speaks of man becoming adapted to a less perfect state of society [...]. To take society as part, as adaptation implies, is to make its progress contingent on persistently favourable conditions in the nonsocial environment. [...] But adaptation to the social is state is essentially a secular process which is immanent in society itself, and like all such processes conceals teleology“. 
Spencer selbst hat die Grundlage für eine derartige Lesart seines Werkes geliefert, indem er in programmatischen Erklärungen zu seinem Modell soziale Entwicklung mehrfach strikt progressivistisch skizziert hatte. Diesen Widerspruch durch ein Primat allgemeiner theoretischer Aussagen zu klären, übersieht die bewußt differenzierende Verteilung von Fortschritt und Degeneration und von Zivilisation und Primitivität. Er lieferte wegen der Entwicklung seiner Argumentation Anhaltspunkte für verschiedene Interpretationen.

Spencer hatte die Degenerationshypothese nicht von Beginn an in seine Konzeption sozialer Evolution integriert. Lange Zeit war er davon ausgegangen, daß die fortschreitende soziale Evolution der im Überlebenskampf Überlegenen die Schwachen als Auswurf zurückließe. Erst später hatte er diese Vorstellung dahingehend modifiziert, daß er nun von einer durch den Überlebenskampf ausgelösten Degenerierung der Unterlegenen ausging. Da Spencer wie seine Mitstreiter seine Theorien im Rahmen fixer Zuschreibungen von Primitivität und Zivilisiertheit entwickelte, änderte sich durch diese konzeptionelle Modifikation der Befund sozialer Distanz nicht.

Allerdings änderte sich dadurch die Diagnose künftiger Entwicklungen und der zukünftigen Lage der vermeintlichen Wilden. Fortschreitende Degeneration würde unweigerlich in ihr Aussterben münden. Die Rolle des Überlebenskampfes betonte dabei allerdings den gewissermaßen soziogenen Charakter dieses Aussterbens, da er nicht als naturhafter Vorgang geschildert wurde. Das heißt im Umkehrschluß, daß ohne den Einfluß der Europäer oder anderer übermächtiger Invasoren die vermeintlich Degenerierten, also sogenannte Primitive wie Feuerländer, Buschmänner oder Australier durchaus weiter existieren und überleben würden. Spencer ging es nicht um die Erklärung eines naturhaften Degenerierens und Aussterbens, sondern um die Betonung der jeweiligen Anpassung einer Gesellschaft an ihre Umweltbedingungen.

Obwohl er in Social Statics noch von einem teleologischen Verlauf der sozialen Entwicklung ausgegangen war, legte er diese traditionelle Überzeugung im Zuge seines scientific turns ab. Der Verlauf sozialer Evolution war in Spencers späteren Schriften ausschließlich durch die theoretischen Grundbausteine der Evolution determiniert, Überlebenskampf, Adaption und Selektion. Diese evolutionstheoretische Transformation der Rassentheorien in Spencers Schriften bewirkte allerdings nur eine radikale Neuschreibung der Erklärung sozialer Unterschiede, sie änderte hingegen nichts an ihrer Darstellung: Wilde blieben Wilde, Zivilisierte blieben Zivilisierte. Diese Zuschreibungen stellten den apriorischen Rahmen der Erklärung sozialer Evolution dar, sie bildeten den rassistischen Kerngehalt auch der evolutionären Rassentheorie Spencers 
und blieben deshalb von ihrer Modernisierung unberührt, deren Erkenntnisziel die Verläufe und Gesetzmäßigkeiten der sozialen Evolution waren.

\subsection{Zusammenfassung}

Die rassentheoretischen Ansätze der X-Club-Akteure unterschieden sich in mehrfacher Hinsicht voneinander. Sie arbeiteten mit unterschiedlichen Methodologien und waren unterschiedlich tief in die wissenschaftlichen Kontroversen ihrer Disziplinen involviert. Gemeinsam war ihren Ansätzen hingegen der Versuch, eine evolutionäre Sichtweise auf die Fragestellungen der menschlichen Entwicklung und evolutionäre Erklärungen der sozialen Unterschiede zwischen den Rassen zu entwickeln. Dabei gingen sie von gleichen apriorisch gesetzten Annahmen aus, denn sie teilten die im rassistischen Diskurs gesetzten Zuschreibungen von Primitivität und Zivilisiertheit. Unter vier Aspekten werden die rassentheoretischen Ansätze Huxleys, Busks, Lubbocks und Spencers im folgenden zusammenfaßt, in Hinblick auf ihre Methodologien, auf ihr Konzept sozialer Evolution, auf ihren Rassenbegriff und schließlich im Hinblick auf die Dimension der Modernisierung von Rassentheorien.

\section{Methodologien}

Die anthropologische und sozialevolutionäre Theoriebildung der XClub-Akteure läßt sich zwei Methodologien zuordnen: zum einen der physischen Anthropologie und Anthropometrie, mit der vor allem Busk und Huxley arbeiteten, und zum anderen der ethnologischen oder kulturanthropologischen Forschung, in deren Kontext sich Spencer und Lubbock bewegten. Dennoch gab es häufig Überschneidungen, die mehr als nur argumentative Anleihen waren, denn alle vier gingen von einer determinierenden Verbindung von Gehirn, Verstand und Kultur aus. Deshalb beriefen sich Lubbock und Spencer auf die Ergebnisse der Kraniometrie bei ihrer Interpretation sozialer Unterschiede, wie sich umgekehrt Busk und Huxley auf die Überlieferung sozialer Unterschiede stützten, um ihre physischen Messungen plausibel zu machen und mit sozialem Sinn aufzuladen.

Diese methodischen Überschneidungen dokumentieren die gemeinsame materielle Basis, auf der ihre evolutionären Theorien über die 
Menschrassen entstanden. ${ }^{238} \mathrm{Zu}$ dieser Basis rechneten auch die tradierten und stereotypen Vorstellungen und Bilder, die von den vermeintlich Wilden existierten. Bei ihnen nahmen Gesellschaften wie Australier, 'Buschmänner' oder Feuerländer die Position der primitivsten Wilden ein, deren geringer Entwicklungsstand oder gar Degenrationszustand entweder über die Physiognomie oder über die Kulturtechniken hergeleitet wurde. Dabei stützten sie sich auch auf mitunter widersprüchliches Quellenmaterial. Allerdings setzten sie, im Gegensatz zu manch traditionellem Monogenisten, weder die vermeintlich Wilden, noch den Neandertaler als missing link zu den Primaten ein. ${ }^{239}$

\section{Theorien}

Huxleys Konzept der persistenten Modifikationen verlagerte die Entstehung stabiler Rassen oder Modifikationen als Anpassung an die Umweltbedingungen in eine ferne Vorzeit. Die geographische Isolation habe dann früh distinkte Typen hervorgebracht. Huxley sprach bestimmten Gesellschaften - wie beispielsweise den Australiern - eine Geschichte oder Entwicklung ab, hob im Gegensatz den zivilisatorischen Fortschritt zentraleuropäischer Gesellschaften hervor und unterstellte eine Entwicklung des Gesichtswinkels von Prognatismus zu Orthognatismus.

Lubbock befaßte sich mit kulturellen Ausdrucksformen sozialer Evolution. Er ging zum einen von der Möglichkeit sozialer Entwicklungsprozesse aus, die über bestimmte Stufen verliefen und so den Vergleich zwischen verschiedenen Gesellschaften ermöglichten. Doch obschon die vergleichende Methode auf der Vorstellung uniformer sozialer Entwicklungen basierte, hatte Lubbock seine Theorie sozialer Evolution nicht als selbst-induzierten, von Umwelteinflüssen unberührten Entwicklungsprozeß konzipiert. Vielmehr ging er davon aus, daß die soziale Evolution Ausdruck von Anpassung an die natürlich wie die soziale Umwelt, von Selektion und Überlebenskämpfen sei. Auch wenn er in

238 Da Busk keine Theorie sozialer Evolution entworfen hatte, sondern in seinem Werk nur Fragmente einer entsprechenden, stillschweigenden Vermutung aufscheinen, wird er an dieser Stelle nicht berücksichtigt.

239 Peter Bowlers Aussage, daß die evolutionären Anthropologen die Wilden als missing link eingesetzt hätten, stimmt zumindest für die evolutionären Anthropologen des X-Clubs nicht. Sie wiesen gerade diese Annahme traditioneller Monogenisten zurück (vgl. Bowler 1989, S. 106: „The most primitive savages became, in effect, the ,missing links' in human evolution, only one step higher than the ape-like Neanderthals. Evolutionism did not create this sense of a racial hierarchy, of course, but it provided a convenient justification for attitudes that had already emerged as a consequence of white imperialism“, vgl. auch Kap. 3.2.1). 
Abgrenzung von monogenistischen Degenerationshypothesen ein in seinen Grundzügen progressives Entwicklungsmodell entwarf, umfaßte es aufgrund der evolutionären Mechanik auch degenerative Entwicklungen.

Spencers frühes Verständnis sozialer Evolution beruhte vor allem auf einer immanenten Fortschrittsvermutung und einer kausalen Verbindung zwischen Gehirnvolumen und Kulturleistung, die aus der Annahme abgeleitet wurde, daß die Entwicklung von Gehirn und Intelligenz von der begrenzten Energie eines Körpers abhinge, durch die Lebensweise der Wilden jedoch gehemmt sei. Als Lamarckist ging er von der Stärkung eines Organs durch seinen Gebrauch und von der Vererbbarkeit erworbener Eigenschaften aus. In späteren Ansätzen entwickelte Spencer ein komplexeres Bild sozialer Evolution, bei dem er der Degeneration der vermeintlich Wilden große Bedeutung zuschrieb. Hierin führte er vor allem die Umwelt als determinierenden Faktor der sozialen Entwicklung an. $\mathrm{Zu}$ den Umweltfaktoren rechnete er auch andere Gesellschaften. Die durch sie konstituierte soziale Umwelt war von Überlebenskampf, Verdrängung, Anpassung und Selektion geprägt. Soziale Evolution hatte Spencer so vollständig unter Verwendung der Kombination evolutionärer Mechanismen konzipiert und damit den impliziten Fortschrittsautomatismus seiner alten Ansätze eliminiert.

Den Ansätzen Spencers und Lubbocks war in Hinblick auf ihre Konzeption sozialer Evolution gemein, daß sie degenerative und progressive Elemente kombinierten, die vormals noch als sich ausschließende, wissenschaftliche Glaubenssätze gegeneinander standen. ${ }^{240}$ Beide zielten mit dieser gegenüber alten Ansätzen modifizierten Vorstellung auf eine plausiblere Erklärung sozialer Unterschiede zwischen vermeintlich Primitiven und Zivilisierten ab. Von dem Erklärungsbedarf solcher Differenzen gingen auch die physischen Anthropologen Huxley und Busk aus. Für sie standen sozialen Unterschiede zwischen Rassen selbst nicht zur Diskussion, sollten aber durch anthropometrische Befunde erklärt werden.

240 Dieser Umstand wurde in der Geschichte der Evolutionstheorien bislang nicht zur Kenntnis genommen, vgl. bspw. Robert A. Nisbet (1969) Social Change and History. Aspects of the Western Theory of Development. London u.a.: Oxford University Press; Mandelbaum 1971; Bowler 1988; Young 1990. 


\section{Rassenbegriff}

Die Unschärfe des Begriffs ,Rasse', die in den Werken der X-Club-Akteure immer wieder auffällig war, ist der deutlichste Hinweis darauf, daß es sich bei ihm um alles andere als eine rein naturwissenschaftlich konzipierte Kategorie handelte. Daran hatte auch Buffons Definition des Unterschiedes zwischen Art und Rasse nichts geändert, auf der sich der Versuch gründete, die anthropologische Verwendung des Begriffs Rasse naturwissenschaftlich aufzuwerten. Zur Mitte des neunzehnten Jahrhunderts hatte der Begriff dann im viktorianischen Anthropologiediskurs erheblich an Gebrauchswert verloren. Huxley hatte ihn für viele Jahre durch den Begriff der ,Typen“ ersetzt, ebenso vermied Lubbock seinen systematischen Gebrauch. Daß sich Evolutionstheoretiker am Ende der Phase intensiver wissenschaftspolitischer Auseinandersetzungen den Begriff ,Rasse“ wieder aneignen konnten, zeigt Darwins Descent of Man. Darwin erklärte darin, daß die Menschen zwar eher in „Unterarten“ (,sub-species“) unterteilt werden sollten, doch sei ,Rasse“ ein etablierter Begriff, weshalb er ihn der Verständlichkeit wegen auch gebrauchen wollte. $^{241}$

Die Evolutionstheoretiker des X-Clubs verstanden Rassen als regionale Vererbungseinheiten. Veränderungen im Phänotyp wurden, wie bei der organischen Evolution, als Indikatoren eines Anpassungsprozesses an die Umweltbedingungen betrachtet. Darüber hinaus bedachten weder der lamarckistische Spencer noch die als Darwinianer angesehenen Lubbock, Huxley oder Busk andere Faktoren der Veränderung des Phänotyps. Wie sich schon bei Darwin die Vererbungsproblematik mit der Formel ,like begets like ' und der Mutationsannahme einer ,Abstammung mit Modifikationen“ (,descent with modification“) erschöpfte, so auch bei den Evolutionstheoretikern des X-Clubs. Die von Francis Galton bereits Mitte der sechziger Jahre des neunzehnten Jahrhunderts angestoßene Diskussion der zur Eugenik führenden Vererbungstheorien spielte für sie keine oder nur eine marginale Rolle.

Das gilt auch für die Diskussion der Rassenmischung. Nicht nur Huxley baute seine anthropologische Typologie der persistenten Variationen auf der Grundannahme der Isolation auf. Auch Lubbock und Spencer arbeiteten stillschweigend mit dieser Annahme, weshalb die Mischung von vermeintlichen Rassen bei ihnen zum Sonder- oder Ausnahmefall der sozialen Evolution wurde. Huxley und Spencer hielten die Mischung vermeintlich affiner Rassen dabei für eine Voraussetzung des kulturellen Fortschritts der großen europäischen Nationalstaaten. Auf

241 Darwin 1998b, S. 182. 
der anderen Seite war Spencer auch davon überzeugt, daß in besonderen Fällen Rassenmischung eine degeneratives Potential berge, da die Anpassungsfähigkeit nicht mehr gewährleistet sei. Doch eine Dramatisierung der Rassenmischung, wie sie den Rassendiskurs gegen Ende des neunzehnten und Anfang des zwanzigsten Jahrhunderts kennzeichnete, war den Evolutionstheoretikern des X-Clubs noch fremd.

Ihre Rassenkonzepte basierten auf einer Reihe etablierter Standards des rassistischen Diskurses im damaligen Europa. Dazu zählen nicht nur zahllose Invektiven und Stereotype über die vermeintlich Primitiven, die oftmals aus ethnographischen Schilderungen stammten und an deren Faktizität für sie kein Zweifel bestand. Dazu zählt ferner die Vorstellung einer meßtechnisch erfaßbaren, somatischen Essenz der Rasse und ihrer Korrelation mit einer spezifischen Kulturbefähigung. Dazu rechnen aber vor allem die Extreme der selbstzugeschriebenen Zivilisation und der fremdzugeschriebenen Primitivität. Diese beiden Zentralkategorien bildeten in ihrer Polarität den sozialen und rassistischen Gehalt der evolutionstheoretischen Rassentheorien. Daß diese Zuschreibungen als Fixpunkte der Rassentheorien fungierten, verdeutlicht, daß sie den Überlegungen der Evolutionstheoretiker vorgeschaltet waren und nicht selbst zum Erkenntnisziel gehörten.

Dies zeigt sich auch daran, daß die X-Club-Theoretiker an der Primitivität von Australiern, Feuerländern oder sogenannten Buschmännern auch dann keine Zweifel aufkommen ließen, wenn sie bei ihnen Kulturtechniken diskutierten, die mit ihrem Kategoriensystem nicht in Einklang gebracht werden konnten. Die evolutionären Rassentheorien zielten auf eine neue Rationalität der Rassen - nicht auf eine Relativierung der sozialen Aussagekraft der Rassenkonzepte in Hinblick auf Ungleichheitsbegründung und Unwertigkeitskonstruktionen. Diese neue Rationalität drückte sich auch in der Form aus, in der der Diskurs über die aussterbenden Rassen aufgegriffen wurde. Hatten die Philanthropen der Aboriginal Protection Society deren Schicksal noch auf einerseits ein unterstelltes Phlegma, aber andererseits auch auf die hemmungslose Landnahme der Europäer zurückgeführt - und deshalb zu Schutzmaßnahmen aufgerufen -, so konstatierte die neue Rationalität ungerührt das Verschwinden der dem Untergang geweihten Gesellschaften, die sich im Überlebenskampf als die Schwächeren erwiesen hätten. 


\section{Paradigmawechsel und Modernisierung}

Die evolutionären Rassentheorien der X-Clubs-Theoretiker fielen mit ihren Modernisierungsbestrebungen zusammen. Doch angesichts der vom evolutionären Rassenbegriff fortgeschriebenen rassentheoretischen Altbestände stellt sich die Frage nach der Reichweite des evolutionstheoretischen Paradigmawechsels und nach seiner Wechselwirkung mit den Modernisierungsbestrebungen der Akteure des X-Clubs.

In methodischer Hinsicht ging die Etablierung der evolutionären Rassentheorien mit einer Standardisierung von anthropometrischen Meßverfahren und mit der systematisierten Erfassung ethnographischen Materials einher. Die Evolutionstheoretiker des X-Clubs arbeiteten auf verschiedene Weisen an der Verwissenschaftlichung anthropologischer und ethnologischer Methodologien. Sie konnten bereits mit einer erheblich ausgeweiteten Zeitspanne kalkulieren, innerhalb derer die soziale Entwicklung sich vollzogen haben müsse.

Da der Fundus der Reiseliteratur nicht nur an Umfang enorm zugenommen hatte - das Genre selbst begann sich nach ethnographischen Gesichtspunkten zu organisieren und zunehmend wechselseitige Bezugnahmen, Vergleiche, Kritiken und Falsifikationen zu praktizieren -, konstruierten sich die Evolutionstheoretiker, im Unterschied zu früheren Theoretikern der sozialen Entwicklung, nicht einen hypothetischen Wilden als Ausgangspunkt der sozialen Evolution, sondern meinten, in den ethnographischen Schilderungen einem empirischen Wilden zu begegnen, der Zeugnis über den Ausgangspunkt sozialer Evolution ablegen würde.

Neben der generellen Säkularisierungswirkung der Evolutionstheorien bestand für die Rassentheorien der wesentlichste theoretische Modernisierungsschub in der Überwindung der tradierten Interpretationsmuster des Monogenismus und Polygenismus. Mit der Konsolidierung der Annahme eines gemeinsamen Ursprungs der Menschheit überwanden die Evolutionstheoretiker des X-Clubs die polygenistische Position in der Anthropologie, die alle Unterschiede auf verschiedene Ursprünge der vermeintlichen Rassen zurückzuführen versuchte. Entgegen dem noch von den traditionellen Monogenisten angenommenen linearen Modell sozialer Entwicklung entwarfen sie eine verzweigte Genealogie der Rassen. Regionale Anpassungen hätten jeweils spezifische phänotypische Ausprägungen und soziale Formationen evoziert. Der monogenistischen Degenerationshypothese begegneten sie durch eine Kombination der degenerativen Entwicklungsannahme mit der von der Aufklärung herrührenden Vorstellung progressiver Entwicklung. Hierbei veränderten beide Entwicklungsannahmen ihre Profile. Die soziale Entwicklung 
wurde nun nicht mehr voluntaristisch oder teleologisch gedeutet. Sie wurde zu einer Funktion der evolutionären Mechanismen Bevölkerungsdruck, Adaption, Selektion und Überlebenskampf. Als Resultate des Zusammenspiels dieser Faktoren galten dabei degenerative Entwicklungen ebenso wie sozialer Fortschritt.

Da die evolutionären Rassentheorien auf eine Erklärung der sozialen Ungleichheit zwischen Primitivität und Zivilisiertheit abzielten, diese Zuschreibungen selbst aber nicht in Frage stellten, folgte aus ihr keine Veränderung in der Darstellung der sozialen Distanz. Die Modernisierung war auf eine evolutionstheoretische Rationalisierung der Erklärung von Entwicklungen und genealogischen Zusammenhängen zwischen den Rassen begrenzt. Allerdings, und dies zeigt sich am evolutionstheoretischen Beitrag zum Diskurs über die aussterbenden Rassen, hatte sie einen erheblichen Einfluß auf die Diagnose zukünftiger Entwicklungen. Unter evolutionstheoretischen Gesichtspunkten war das Schicksal des Aussterbens all jener Gesellschaften besiegelt, deren Degeneration aus einer Anpassung an immer widrigere Lebensbedingungen resultierte, in die sie als Unterlegene im Kampf ums Überleben vertrieben worden seien. Diesem Befund schloß sich auch Huxley an, der 1894 erklärte, daß die Wilden ihre zivilisatorischen Pflichten nicht erfüllt hätten, die darin bestünde, ,sich zu erhalten und sich zu verbessern“. ${ }^{242}$ Verstärkt durch die gleichzeitig implizierte Verkörperlichung der sozialen Differenz im Kranialvolumen, bestand für die Wilden in den Augen der Evolutionstheoretiker keine Chance auf Verbesserung ihrer Lage und mithin keine Überlebensperspektive.

242 Huxley (1894) „Evolution and Ethics. Prolegomena“. In: Collected Essays. Bd. 9, S. 1-45, S. 44: „That which lies before the human race is a constant struggle to maintain and improve“; vgl. Helfand 1977, S. 162163. 


\section{Schluß. Theoretischer und institutioneller Wandel in Anthropologie und Rassentheorien}

„Diese Feuerländer in den Kanus waren fast nackt, eine ausgewachsene Frau sogar vollständig. [...] Diese armen Teufel waren in ihrem Wachstum verkümmert, ihre abscheulichen Gesichter mit weißer Farbe beschmiert, ihre Haut dreckig und schmierig, ihre Haare verfilzt, ihre Stimmen dissonant, ihre Gesten grob und würdelos. Angesichts solcher Menschen kann man kaum glauben, daß es sich um Mitgeschöpfe handelt, die in derselben Welt leben“ (Charles Darwin: Voyage of the Beagle. 1839). ${ }^{1}$

„Es kann kaum einen Zweifel daran geben, daß wir von Barbaren abstammen. Ich werde nie meine Verwunderung vergessen, als ich das erste Mal eine Gruppe von Feuerländern an einer wilden und zerklüfteten Küste erblickte, denn mir schoß es durch den Kopf - so waren unsere Vorfahren“ (Charles Darwin: Descent of Man. 1871). ${ }^{2}$

1 Darwin 1989, S. 177-178: ,[T]hese Fuegians in the canoe were quite naked, and even one full-grown woman was absolutely so. [...] These poor wretches were stunted in their growth, their hideous faces bedaubed with white paint, their skins filthy and greasy, their hair entangled, their voices discordant, their gestures violent and without dignity. Viewing such men, one can hardly make oneself belief they are fellow-creatures, and inhabitants of the same world".

2 Darwin 1998b, S. 642: „There can hardly be any doubt that we are descended from barbarians. The astonishment which I felt on the first seeing of a party of Fuegians on a wild and broken shore will never be forgotten by me, for the reflection at once rushed into my mind - such were our ancestors". 
Zwischen diesen beiden Betrachtungen Darwins über die Feuerländer liegen mehr als dreißig Jahre - und die sogenannte darwinianische Revolution. Durch sie wurde der Abstammungsgedanke fest in der Anthropologie und im rassentheoretischen Diskurs verankert. Aus den bemitleidenswerten Mitgeschöpfen von einst waren die Ebenbilder der eigenen Vorfahren geworden. Ein statisch-taxonomisches Menschenbild war durch ein dynamisch-genealogisches abgelöst, das voluntaristische Fortschrittsmodell der Aufklärung durch die Vorstellung einer von der evolutionären Mechanik angetriebenen Entwicklung ersetzt worden.

Den Wandel in der viktorianischen Anthropologie in den Jahren nach 1859 als einen Paradigmawechsel im weitesten Sinne zu betrachten, bot sich bei der vorliegenden Untersuchung - auch angesichts der eingangs diskutierten Unschärfen dieses Begriffs in der Kuhnschen Konzeption - aus guten Gründen an. Wie in den Naturwissenschaften hatte sich in Anthropologie und Rassentheorien ein grundlegender Wandel der wissenschaftlichen Wissensproduktion vollzogen, der auf der Evolutionstheorie und der neuen Archäologie aufbaute. Der Umstand, daß Darwin sich des gravierenden Unterschieds zwischen seinen beiden Betrachtungen über die Feuerländer gar nicht bewußt war, unterstreicht die Nachhaltigkeit dieses wissenschaftlichen Wandels - denn Wissenschaften tendieren dazu ihre Geschichte umzuschreiben, so daß Brüche und ehemalige vermeintliche Irrtümer kaschiert werden. Der Paradigmawechsel vollzog sich über eine Auseinandersetzung zwischen Vertretern der alten und der neuen Ansätze. Die Evolutionstheoretiker agierten dabei als kompakte pressure group und lieferten sich Kontroversen mit Vertretern des Kreationismus, Degenerationismus, Poly- oder Monogenismus.

Ihre gemeinsame Basis - bestehend aus der Überzeugung einer natürlichen Entstehung des Lebens, eines beständigen Mangels, eines Kampfs ums Überleben und einer natürlichen Auslese, die zusammengenommen im Postulat generell progressiver Entwicklung mündeten war allgemein und flexibel genug, um selbst so verschiedene Ansätze wie die Spencers, Darwins oder Huxleys zu einen. Doch zu dieser Einheit trugen ganz wesentlich auch soziale und politische Interessen bei, berufliche Aspirationen und eine liberale Gesellschaftsauffassung. Durch ihre Berücksichtigung ließ sich die Analyse der sozialen Natur des Paradigmawechsels über die ihm unmittelbar zugrundeliegenden Auseinandersetzungen zwischen konkurrierenden Fraktionen der scientific community hinausverfolgen - und im gesellschaftlichen Kontext einbetten.

Doch beim Paradigmawechsel in den Rassentheorien handelte es sich nur partiell um eine veränderte Sichtweise auf die Erkenntnisob- 
jekte der Rassentheorien, auf die Menschen und die Rassen, in denen sie kategorisiert wurden: Die evolutionären Rassentheorien schrieben den kaum modifizierten Stereotypenhaushalt über die vermeintlichen Wilden fort.

\section{Paradigmawechsel in Naturwissenschaft und Anthropologie}

Die verschiedenen Dimensionen des Paradigmawechsels in den Rassentheorien und seine unterschiedlichen Reichweiten in der Mitte des neunzehnten Jahrhunderts erschlossen sich erst durch die miteinander verknüpfte Analysen einerseits der sozialen Prozesse des, science in the making ' und andererseits der Transformation inhaltlicher und theoretischer Konzeptionen. So wurde deutlich, daß die evolutionären Rassentheorien keinesfalls durch einen disziplinenexternen Zugriff bereits etablierter Anthropologen auf neueste naturwissenschaftliche Erkenntnisse entstanden, etwa um den Fortbestand einer rassentheoretischen Absicherung politischer Argumentationen zu gewährleisten. Vielmehr wurde der evolutionstheoretische Wandel in der Anthropologie maßgeblich von den Naturwissenschaftlern des X-Clubs initiiert.

Sie hatten erkannt, daß die evolutionstheoretische Bestimmung der Stellung des Menschen in der Natur ebenso wie die Begründung seiner physischen und sozialen Variabilität eine Vorbedingung für die erfolgreiche Etablierung des Evolutionsparadigmas war. Nicht weil sich das Evolutionsparadigma im naturwissenschaftlichen Diskurs als erfolgreich erwiesen und öffentliche Diskurshoheit erlangt hatte, war seine Anwendung im Kontext von Rassentheorien und Anthropologie möglich oder gar nötig geworden. Vielmehr verhielt es sich umgekehrt: Gerade die Erklärung der Abstammung der Menschen und ihrer Unterschiede war der Prüfstein für naturwissenschaftliche Ordnungssysteme und für jegliche Theorie über die Entstehung des Lebens. Die Durchsetzung evolutionärer Rassentheorien war deshalb integraler Bestandteil der Etablierung des Evolutionsparadigmas in den Naturwissenschaften. Die Revolution in den viktorianischen Naturwissenschaften wurde über die Grenzen ihrer Disziplinen hinausgetragen und eine ihrer entscheidenden Schlachten auf dem Territorium der Anthropologie ausgefochten.

Obschon die Anthropologie noch um ihre Akzeptanz als wissenschaftliche Disziplin ringen mußte, hielt die scientific community ihre Erkenntnisziele selbst für relevant, dies galt vor allem für die Fragen zu Abkunft und Verschiedenheit der Menschen. Diese ambivalente Situation, verstärkt noch durch eine elementare Krisenhaftigkeit der Disziplin, führte den Evolutionstheoretikern die Notwendigkeit ihrer Interven- 
tion in der Anthropologie vor Augen. Hier massierte der X-Club in den sechziger Jahren seine Kräfte ganz besonders. Auf sein Eingreifen ist die Etablierung des Evolutionsparadigmas in Rassentheorien und Anthropologie zurückzuführen. So war die Etablierung der Evolutionslehre in den Naturwissenschaften mit ihrer Einführung in Anthropologie und Rassentheorien nicht nur diskursiv, sondern unmittelbar über die Akteure des X-Clubs verbunden.

\section{Die Kampagnen des X-Clubs}

Der Zusammenhalt des X-Clubs basierte auf geteilten Erfahrungen und kompatiblen Aspirationen seiner Mitglieder, die in der Mehrzahl eine wissenschaftliche Laufbahn ansteuerten und sich zunächst mit großen Schwierigkeiten bei der Realisierung dieser Berufsperspektive konfrontiert sahen. Die Evolutionslehre war für sie vor diesem Hintergrund in mehrfacher Hinsicht von Interesse. Zum einen vermochte sie Antworten auf Fragen zu geben, die weder die bis dahin etablierten Ordnungssysteme der Natur, etwa Linnés oder Buffons Theorien, noch entwicklungstheoretische Ansätze wie der Lamarcks hatten geben können. Zum anderen versprach sie einen wissenschaftspolitischen Effekt. Sie stellte einen Hebel für die Modernisierung des Wissenschaftsbetriebes in Hinblick auf seine Professionalisierung und die Institutionalisierung von Disziplinen dar. Die Etablierung der Evolutionslehre in den Naturwissenschaften trug wesentlich dazu bei, die Dominanz des konservativen und klerikal geprägten ,Oxbridge“ in den Wissenschaften zu untergraben und Vertreter der alten Lehren in Einfluß und Bedeutung zu marginalisieren.

Der theoretische Wandel wurde deshalb von einem sozialen Umwandlungsprozeß der scientific community begleitet. Er war eingebettet in einen Modernisierungsprozeß des Wissenschaftsbetriebs, der sich auf institutioneller Ebene durch Gründungen von Universitäten, Instituten und Studiengängen sowie die Schaffung eines wissenschaftlichen Berufsstandes und auf methodischer Ebene durch die Verständigung auf Wissenschaftsstandards, Evidenzkriterien und Lehrcurricula vollzog. Auch an diesem Prozeß waren die Mitglieder des X-Clubs an zentraler Stelle beteiligt, und sie beförderten ihn durch eine Reihe von wissenschaftspolitischen Initiativen.

Zwar war Darwin selbst im Origin of Species einer Diskussion der Konsequenzen seiner Theorie für die Betrachtung des Menschen ausgewichen, dennoch konzentrierten sich die Debatten um sein Werk schon 
wenige Monate nach dessen Erscheinen auf eben jene brisante Problematik, und seine Lehre wurde als ,Affentheorie“ diffamiert.

In diese Skandalisierung griff zuerst Huxley ein. Er entwarf in seiner Kritik an Wilberforce und Owen eine Theorie der evolutionären Verbindung des Menschen zu den Primaten, in der er zugleich Rassen als verschiedene evolutive Entwicklungszustände konstruierte. So operationalisierte er gewissermaßen die ,Affentheorie"-Schmähungen und intervenierte zugleich in den Diskurs der Rassentheorien. Der X-Club arbeitete in der Folge entlang einer sich entwickelnden, evolutionstheoretischen Forschungsagenda.

Lubbock war zunächst in die archäologischen Debatten um die Einteilung und Identifikation prähistorischer Epochen involviert. Dabei war er maßgeblich an einer systematischen Erfassung der vorgeschichtlichen Artefakte beteiligt und stritt für die Anerkennung der neuen archäologischen Zeitrechnung. Für Theorien sozialer Evolution bereiteten diese Debatten den Boden, denn erst auf der Grundlage einer erheblich ausgeweiteten Zeitrechnung konnten sie ihre Erklärung der evolutiven Ausdifferenzierung sowohl der physischen Merkmale der Menschen als auch der sozialen Formationen plausibel machen.

Spencers Beitrag bestand im wesentlichen in seiner Theorie sozialer Evolution, die in ihrer sozialpolitischen Perspektive als Sozialdarwinismus interpretiert wurde und die in ihrer globalen Perspektive der gesellschaftlichen Entwicklung und der Vergesellschaftung des menschlichen Seins den Charakter einer evolutionären Rassentheorie hatte. ,Rasse war bei Spencer ein zentrales Konzept der Theorie sozialer Evolution, das die soziale Entwicklung kausal mit einer unterstellten somatischen Entwicklung verklammerte. Mit seiner derart biologisch erweiterten Theorie sozialer Evolution hatte Spencer das vorevolutionstheoretische Modell sozialer Entwicklung überholt und durch ein Modell ersetzt, das anschlußfähig an die naturwissenschaftlichen Evolutionstheorien war.

Bei der Intervention des X-Clubs in den Konflikt zwischen der Ethnological Society und der Anthropological Society treten der politische oder normative Charakter der Wissensproduktion und deren soziale Seite am deutlichsten zutage. In diesem Kontroversen zeigt sich, daß wissenschaftliche Wissensproduktion nicht nur soziale Aspekte hat, sondern ein immanent sozialer Prozeß ist. Hier ging es nicht nur um die Problematik des Polygenismus und die Frage der politischen Implikationen der Anthropologie und ihrer Reputation. In dieser Auseinandersetzung konnte auch die Institutionalisierungsstrategie des X-Clubs beobachtet werden, mit der die Etablierung einer evolutionstheoretischen Anthropologie verfolgt wurde und die den Kulminationspunkt der wissenschaftspolitischen Aktivitäten des X-Clubs darstellte. Sie endete 
mit der erfolgreichen Vereinigung der beiden rivalisierenden Gesellschaften zum Anthropological Institute, für dessen Agenda der evolutionstheoretische Zuschnitt durch strategische Besetzungen zentraler Positionen auf längere Sicht sichergestellt wurde. Dem X-Club gelang es so, eine evolutionstheoretische Hegemonie innerhalb der viktorianischen Anthropologie herzustellen. Zugleich wurde die Reputation der evolutionstheoretischen Anthropologie durch die hier programmatisch praktizierte Trennung von Wissenschaft und Politik abgesichert. Gerade der politische Einwand, den konservative Kreise gegen die Evolutionstheorie im Allgemeinen vorbrachten, erzwang diese ostentative Trennung und Reklamierung einer distinkten Systemrationalität für die Anthropologie. Die Institutionalisierung einer evolutionstheoretischen Anthropologie rechnet aus diesem Grund zu den zentralen Modernisierungsbestrebungen des X-Clubs und war seinem Einfluß innerhalb der scientific community nachhaltig förderlich.

Die Kampagnen der X-Club-Mitglieder waren nicht nur entscheidende wissenschaftspolitische Voraussetzungen für die Etablierung der Evolutionslehre im Diskurs der Rassentheorien. Sie waren zugleich Taktgeber für die Entwicklung ihrer eigenen rassentheoretischen Ansätze. Die erwiesen sich als äußerst dynamisch und veränderten sich in den Jahren nach Darwins Origin of Species erheblich. Ihre Prägung durch die Entwicklung der wissenschaftspolitischen Auseinandersetzungen des X-Clubs im Feld der Rassentheorien wird besonders bei Huxley deutlich. Huxley entwarf in der Frühphase der Auseinandersetzung mit der Anthropological Society ein recht statisches Konzept persistenter Rassen-Typen, das er erst dynamisierte, als sich der Erfolg des X-Clubs in dieser Auseinandersetzung abzeichnete. Auch bei Spencer drückt sich der Einfluß der wissenschaftlichen Kontroversen in seiner Verwendung der Degenerationsvermutung aus. Während er ursprünglich von einem tendenziell sogar teleologischen Modell progressiver sozialer Entwicklung ausgegangen war, hatte er ab den siebziger Jahren des neunzehnten Jahrhunderts seine Erklärung der sozialen Distanz zwischen vermeintlich Primitiven und Zivilisierten vorbehaltlos auch auf degenerative Entwicklungen aufgebaut. Dies war ihm nur möglich, weil letztlich durch Lubbocks Kontroverse mit dem Duke of Argyll die monogenistische Degenerationshypothese demontiert worden war. Das politisch wie theoretisch entschärfte Theoriefragment der Degeneration konnte Spencer dann problemlos in seine Konzeption sozialer Evolution integrieren.

Die Bedeutung des X-Clubs für seine Mitglieder schwand mit dem einsetzenden wissenschaftspolitischen und persönlichen Erfolg, seine Rolle hing also zu einem großen Teil von seiner Funktion ab, individuelle, aber dennoch kompatible Interessen zu realisieren. Und der Zeit- 
punkt, von dem an der Bedeutungsverlust des Klubs zu verzeichnen ist, verdeutlicht, daß seine Kampagnen in der Anthropologie den Höhepunkt seines Wirkens markierten.

\section{Evolutionäre Rassentheorien}

Ungeachtet ihrer Verschiedenheiten waren die Ansätze der Evolutionisten des X-Clubs komplementär. In der Summe entstand ein rationalisiertes evolutionstheoretisches Rassenverständnis, in dem von einer kausalen Verbindung von kulturellen und körperlichen Eigenschaften und ihrer evolutionären Entwicklung ausgegangen wurde. Dieses Rassenverständnis zeichnete sich durch vier Annahmen aus:

Erstens: Der Mensch ist ein Primat. Auf unterschiedlichen Wegen argumentierten die Evolutionstheoretiker des X-Clubs, daß der Mensch weder das Produkt einer göttlichen Schöpfung sei noch innerhalb des taxonomischen Ordnungssystems der Natur eine Sonderstellung einnehme. Huxley etwa trat jeglichem Versuch entgegen, über die Heranziehung anatomischer Merkmale den Menschen in einer gesonderten Klasse der Lebewesen einzuordnen. Zwar insistierte er auf signifikante Unterschiede im anatomischen Aufbau des Menschen und der Menschenaffen. Doch da er Darwins Vermutung nicht teilte, daß in der Natur keine sprunghaften Entwicklungen vorkämen, waren diese Unterschiede kein Grund für eine taxonomische Trennung zwischen Mensch und Menschaffen. Für Huxley bestand die Essenz des Menschseins in der Sprachbefähigung.

Auch Spencer schloß eine Sonderschöpfung des Menschen explizit aus und postulierte ein psychisches Kontinuum. Der Mensch stünde am Ende einer Entwicklung beständiger Intelligenzzunahme. Intelligenz hielt er für einen entscheidenden Faktor bei der Anpassung eines Organismus an seine Umwelt. Da er Gesellschaft als soziale Umwelt des Menschen verstand, sah er sich weder zu einer qualitativen Differenzierung von Intelligenz noch zu einer Diskussion ihrer Realisierung im gesellschaftlichen Kontext gezwungen. Von einem ähnlichen Intelligenzkontinuum ging auch Lubbock in seinen späteren Untersuchungen der sozialen Insekten aus. Beide schalteten von einer universellen auf eine differenzierte Betrachtung des Menschen um und konstruierten ein Intelligenzgefälle zwischen den Rassen. Die evolutionäre Naturalisierung des Menschen dachte deshalb gleich eine Erklärung der sozialen Ungleichheit mit, die auf der Annahme unterschiedlicher Entwicklungsgrade fußte. Die soziale Ungleichheit war durch den Stereotypenhaushalt des europäischen Diskurses über die vermeintlich Wilden aufgela- 
den, der auch für die Evolutionstheoretiker einen stabilen Wissensbestand darstellte.

Zweitens: Die Menschenrassen hätten einen gemeinsamen Ursprung. Die soziale Differenz ging nach Vorstellung der Evolutionisten aus einer Entwicklung von einem gemeinsamen Ausgangspunkt hervor. Diese Annahme lag Lubbocks und Spencers Konzepten der komparativen Methode zugrunde. Beide bauten ihre Modelle sozialer Evolution auf der Annahme auf, daß die sogenannten primitiven zeitgenössischen Gesellschaften einen frühen, wenn nicht den ersten Entwicklungszustand der Menschheit in ihrer kulturellen und zivilisatorischen Entwicklung abbildeten. Lubbocks Rekonstruktion prähistorischer Gesellschaften beruhte ebenso auf der Annahme einer Entwicklung der Menschheit aus einem gemeinsamen Ursprung heraus, wie Spencers Theorie sozialer Evolution, die die sozialen Unterschiede zwischen den Gesellschaften für einen Ausdruck ihrer Anpassung an verschiedene Umweltbedingungen hielt und als Modell für die soziale Evolution eine baumartig verzweigte Struktur vorschlug.

Huxley betonte die gemeinsame Abstammung der Menschheit bei seiner Diskussion anatomischer Vergleichsreihen. Er hatte zur Widerlegung der Behauptung Owens, der Mensch bilde aufgrund seiner anatomischen Besonderheiten eine eigene Klasse, Ähnlichkeiten zwischen Mensch und Primaten betont und darüber hinaus eine evolutionäre Entwicklung der Schädelform und des Gehirnvolumens vom Australier beziehungsweise vom sogenannten Buschmann bis hin zu den Europäern angenommen.

Drittens: Somatische und kulturelle Evolution seien über das Gehirn verbunden. Die Konzepte sozialer Evolution der X-Club-Akteure gingen von der Verbindung einer somatischen mit einer sozialen oder kulturellen Entwicklung aus, auch wenn sie den Prozeß der sozialen Evolution aus verschiedenen wissenschaftlichen Perspektiven konstruierten. Als Bindeglied zwischen diesen beiden Entwicklungen fungiert das Gehirn, das als materielle Substanz des Verstandes galt. Der Verstand wiederum wurde als Vorbedingung für Intelligenz und Kulturbefähigung angesehen. An das Gehirn als ihr Organ gekoppelt, wurden Verstand und Kulturbefähigung zu quantifizierbaren Größen, die als direkt abhängig vom meßbaren Gehirnvolumen behandelt wurden. Zudem gingen die Theoretiker sozialer Evolution davon aus, daß das Gehirn nicht individuell in Masse oder Volumen variiere, sondern daß signifikante Unterschiede zwischen Rassen festzustellen seien.

Diese Biologisierung der sozialen und kulturellen Ungleichheit wurde bei Spencer um eine weitere Komponente ergänzt. Er ging nicht mehr nur von einer Determinierung der kulturellen Leistung durch das Volu- 
men oder die Masse des Gehirns aus, sondern nahm vielmehr an, daß das Wachstum des Gehirns selbst durch die Erfordernisse des sozialen Seins und die Komplexitätszunahme der Gesellschaften stimuliert worden sei. Folglich konstruierte Spencer eine wechselseitige Determinierung von Zivilisation und Gehirnwachstum.

Zwar verstanden die Evolutionstheoretiker des X-Clubs Rassen als regional herausgebildete Vererbungseinheiten mit charakteristischen phänotypischen Eigenschaften, die durch Anpassung an die Umweltbedingungen entstanden seien. Aber diese über die Zuschreibung von distinkten somatischen Eigenschaften konstruierten Rassen wurden darüber in eine zivilisatorische Hierarchie gebracht, daß die angeblichen körperlichen Eigenschaften mit den angeblichen kulturellen verklammert wurden. Diese Hierarchisierung war eine Grundkonstante des europäischen Rassendiskurses. Doch die anthropologischen Rassentheorien des achtzehnten und neunzehnten Jahrhunderts waren in die Krise geraten, weil sie keine falsifikationsresistenten Nachweise für die Korrelation von sozialen und körperlichen Eigenschaften erbringen konnten. Aus einem andauernden Plausibilisierungsdruck waren so Rassentheorien entstanden, die sich auf die unterschiedlichsten Körpermerkmale beriefen und sich nicht im mindesten über Zahl, Beziehung und Merkmale der von ihnen konstruierten Menschenrassen einig wurden.

Auch die Rassentheorien Spencers, Huxleys und Lubbocks zielten mehr oder weniger explizit auf eine Erklärung der kulturellen und sozialen Differenz unter Berufung auf entsprechende körperliche Unterschiede. Sie schrieben einerseits tradierte Bilder und Vorstellungen über die Primitivität vermeintlicher Rassen fort, andererseits unterlegten sie diesen Bildern jene neue Rationalität, durch die solche Fortschreibung überhaupt erst möglich wurde.

Viertens: Die evolutionäre Entwicklung verlaufe sowohl progressiv als auch degenerativ. Die Evolutionstheorien des neunzehnten Jahrhunderts operierten grundsätzlich mit einem Modell progressiver, wenn auch explizit anti-teleologischer Entwicklung der Organismen. Dieser Gedanke, der durchaus an das Denken der Aufklärung anschloß, strukturierte auch die Vorstellung von den Verläufen der sozialen Evolution. Die physischen Anthropologen des X-Clubs etwa skizzierten die Evolution des Menschen als eine Zunahme von Hirnvolumen und eine Veränderung der Schädelproportionen mit entsprechend zunehmender Zivilisationsbefähigung. Spencer und Lubbock, die ohnehin bei der Beschreibung der sozialen Entwicklung ansetzten, explizierten ihre progressive Konzeption sozialer Entwicklung.

Lubbock stellte die generelle soziale Entwicklung als eine über bestimmte Kulturstufen verlaufende Entwicklung dar, die er als einen auf- 
steigenden Zivilisationsprozeß begriff. Dieser Entwicklungsgedanke lag auch seiner Unterteilung von Paläolithikum und Neolithikum zugrunde, die er vor allem aufgrund einer festgestellten Verfeinerung der Bearbeitungstechniken vorgenommen hatte. Spencer skizzierte eine progressive Entwicklung der Evolution sowohl in kultureller wie auch in somatischer Hinsicht. Er stellte die soziale Evolution als eine Zunahme an Komplexität und funktionaler wie struktureller Differenzierung der Gesellschaft dar, die mit der Zunahme ihrer Größe einherginge.

Doch neben dieser progressiven Generallinie räumten Spencer und Lubbock auch degenerativen Prozessen erhebliche Bedeutung ein. Die Lebensweise der vermeintlich primitiven Gesellschaften erklärten sie oftmals durch die Annahme kulturellen Niedergangs. Während Lubbock diesen Niedergang als Schlußpunkt eines zunächst fortschrittlichen Entwicklungsverlaufs skizzierte, stellte Spencer ihn als Resultat der Kernmechanismen der Evolutionstheorie dar: In permanenten Überlebenskämpfen würden die Schwächeren in immer widrigere Umweltbedingungen gezwungen, wo sie durch Anpassung sukzessive degenerierten.

Beide, Spencer wie Lubbock, erklärten so die soziale Distanz zwischen den vermeintlich Primitiven und Zivilisierten mit einer Kombination von degenerativen und progressiven Prozessen. Aufgrund des apriorischen Charakters der Zuschreibungen von Primitivität und Zivilisiertheit hatte dieser Befund zunächst keine Auswirkung auf die soziale Distanz zwischen vermeintlich primitiven und zivilisierten Gesellschaften. Allerdings änderte sich durch ihn der Blick auf die Zukunft der primitiven Gesellschaften. Der Topos der aussterbenden Rassen war bereits fest im europäischen Rassendiskurs verankert. Doch was bis dahin im Kontext philanthropischer Debatten über Schutzmaßnahmen und Zivilisierungspotentiale erörtert wurde, erhielt nun eine nüchterne Wende. Das schicksalhafte Aussterben der Wilden wurde, insbesondere vor dem Hintergrund einer neuen und erheblich ausgedehnten Zeitrechnung und des in Jahrzehntausenden verknöcherten Entwicklungsdefizits für unabwendbar gehalten. Dem evolutionstheoretischen Verständnis galt es als natürlich bedingt, da der Überlebenskampf als intersozialer Konflikt selbst naturalisiert wurde.

\section{Paradigmawechsel und Modernisierung der Rassentheorien}

Die differenzierte Betrachtung der Reichweite des evolutionstheoretischen Paradigmawechsels in den Rassentheorien zeigt, daß er sich auf verschiedenen Ebenen asymmetrisch vollzog und unterschiedlich ak- 
zentuiert mit Elementen der wissenschaftlichen Modernisierung verband:

Auf der sozialen Ebene des Wissenschaftsbetriebes drückte er sich in erster Linie in der institutionellen Marginalisierung der Vertreter des Monogenismus und des Polygenismus im anthropologischen Diskurs aus. Dies war das offenkundigste Ziel der Kampagnen des X-Clubs. Da die Anthropologie in der Mitte des neunzehnten Jahrhunderts noch nicht universitär etabliert war, blieb der anthropologische Diskurs auf die Ethnological Society und die Anthropological Society begrenzt. Die Intervention des X-Clubs in deren Konflikt setzte somit im Zentrum der viktorianischen Anthropologie an. Die Etablierung einer evolutionstheoretischen Diskurshoheit wurde ab 1871 durch die Besetzung der Schlüsselpositionen des Anthropological Institutes mit führenden Evolutionstheoretikern abgesichert. Danach nahmen die vormals bedeutenden Repräsentanten einer monogenistischen oder polygenistischen Anthropologie nur noch in begrenztem Umfang am anthropologischen Diskurs teil.

$\mathrm{Zu}$ den modernisierenden Elementen im Sinne einer Rationalisierung der Wissenschaften muß auch der Gestus der Entpolitisierung der Rassentheorien gezählt werden. Die Markierung der Areale ihrer wissenschaftlichen Wissensproduktion war für die Anerkennung der Anthropologie innerhalb der scientific community ebenso entscheidend wie die Überwindung des Schismas von Ethnological Society und Anthropological Society. Die Evolutionstheoretiker des X-Clubs betonten die Unabhängigkeit ihrer Rassentheorien von den politischen Debatten ihrer Zeit und versuchten damit, ihren wissenschaftlichen Charakter zu unterstreichen. Traditionelle Rassentheorien waren explizit mit politischen Positionen verknüpft. Der Monogenismus stand in der Tradition der Emanzipationsbewegung, während der Polygenismus oft als Legitimationsgerüst der Sklaverei verwendet wurde. Die evolutionären Rassentheoretiker betrieben hingegen eine intensive Grenzziehungsarbeit zwischen wissenschaftlicher Wissensproduktion und politischen, als nichtwissenschaftlich verstandenen Diskursen. Die von ihnen betriebene Ausgrenzung von Monogenisten und Polygenisten zielte deshalb auf die Diskreditierung ihrer politischen Polisitionen zur Sklaverei und zur rechtlichen Stellung der ehemaligen Sklaven in den Kronkolonien.

Auf der methodologischen Ebene wurde der Paradigmawechsel von der Einführung neuer Meßverfahren und der Verständigung auf Evidenzkriterien begleitet, wie sie durch Huxleys Kombination verschiedener kraniometrischer Maße, durch Busks Meßtabellen oder durch Lubbocks vergleichende Methode initiiert wurde oder zumindest werden sollte. $\mathrm{Zu}$ dieser methodologischen Modernisierung rechnet weiter der Versuch, durch den Einsatz von Kartographie und Photographie die Da- 
tenbasis der Rassentheorien solider auszubauen. Spencer versuchte die Problematik einer uneinheitlichen und unvollständigen empirischen Basis mit seiner ethnologischen Datensammlung Descriptive Sociology zu überwinden.

Auf der theoretischen Ebene vollzog sich der Paradigmawechsel als Rationalisierung des Rassendiskurses. Durch die Evolutionstheorien wurde eine vereinheitlichte Sichtweise etabliert. Die evolutionären Rassentheorien ersetzten die bis dahin dominierenden Interpretationsschemata von Monogenismus und Polygenismus und führten eine neue, evolutionäre Rationalität in den Rassendiskurs ein. Sie bestritten gleichermaßen die Kernannahmen des Monogenismus und des Polygenismus. Dabei setzten sie vor allem an den schon offenkundig gewordenen Schwachstellen dieser traditionellen Theorien an. Die monogenistische Akklimatisierungstheorie war bereits diskreditiert worden. Die andere Kernannahme des Monogenismus, sein grundsätzlich auf Degeneration beruhendes Verständnis gesellschaftlicher Entwicklung, war mit dem durch Industrialisierung und Technisierung sowie imperiale Expansion angetriebenen Fortschrittsdiskurs nicht mehr vereinbar. Auf der anderen Seite hatte der die Rassen als statische Einheiten behandelnde Polygenismus mit dieser statischen Konzeption den Anschluß an die Entwicklungen im naturwissenschaftlichen Diskurs verloren.

Der evolutionstheoretische Paradigmawechsel in den Rassentheorien bedeutete auch, daß die treibenden Kräfte der sozialen Entwicklung naturalisiert wurden. Soziale Entwicklung wurde ihrer teleologischen und ihrer voluntaristischen Dimensionen entkleidet. An deren Stelle setzten die evolutionären Rassentheorien die Mechanismen des Überlebenskampfes, der Auslese und der Anpassung und schufen so eine Vereinheitlichung ihrer Erklärungsstrukturen: Progressive wie degenerative Entwicklungen würden durch die selben Faktoren bedingt.

Auf der Ebene der Erkenntnisobjekte führte der Paradigmawechsel hingegen zu keiner substanziell veränderten Sichtweise. Zwar hatte sich nach der Logik der vergleichenden Methode die Vorstellung etabliert, daß in den zeitgenössischen Wilden die Lebensweise der eigenen Vorfahren sichtbar würde. Das Beispiel Darwins legt diese Veränderung offen. Ebenfalls rechnet zur evolutionstheoretischen Wende der Rassentheorien das neu gewonnene Verständnis des Alters der Menschheit, mit dem zwischen den der Steinzeit zugerechneten, zeitgenössischen Wilden und den Zivilisierten eine in Jahrzehntausenden gemessene Entwicklung eingeschoben werden konnte. Doch darüber hinaus folgten die Darstellungen der Menschen und der Rassen traditionellen Mustern.

Abgesehen von tradierten Stereotypen über die vermeintlich Primitiven änderte der evolutionstheoretische Paradigmawechsel auch nichts an 
der Polarität der Zuschreibung von Primitivität und Zivilisiertheit und ihrer Hierarchisierung. Mehr noch. Die Evolutionstheoretiker des XClubs griffen $\mathrm{zu}$ Methodenwechseln oder strapazierten die von ihnen ansonsten vehement eingeforderte methodische Stringenz, um die rassistische Zuschreibung von Primitivität auch dann durchhalten zu können, wenn die von ihnen wahrgenommenen Sachverhalte eigentlich eine andere Interpretation verlangten. Dies wird beispielsweise bei Busks Annahme einer vermeintlichen Rassenmischung in China, Lubbocks Vermutung eines Rassenkampfes im steinzeitlichen Skandinavien, Huxleys Modellierung eines australischen Schädels, seiner Überzeugung vom Kulturimport bei vermeintlich primitiven Insulanern oder bei Spencers selektivem Umgang mit dem von ihm zusammengetragenen Datenmaterial deutlich. An solchen Verfahrensweisen wird ersichtlich, daß die Zuschreibungen von Primitivität und Zivilisiertheit den anthropologischen und ethnologischen Forschungsprozessen der Evolutionstheoretiker des X-Clubs vorgeschaltet waren, sie gehörten zu jenen Wissensbeständen, die grundsätzlich nicht zur Disposition standen, und deren Aufrechterhaltung wesentlich zum Agendasetting ihrer Arbeiten beitrugen.

Der Paradigmawechsel beschränkte sich auf dieser Ebene folglich auf die naturwissenschaftliche Rationalisierung eines Wissensbestands, der älter als die evolutionären Rassentheorien war: Die des kulturalistischen Rassismus, dessen stereotypisierenden Bilder der vermeintlich Wilden von den Evolutionstheoretikern des X-Clubs und vielen Zeitgenossen für realitätsgetreue Darstellungen gehalten wurden. Eine Reihe von Altbeständen der vorevolutionären Rassentheorien konnte mehr oder weniger problemlos in die evolutionären Rassentheorien integriert werden. Die rassistischen Topoi zeichneten sich dabei durch eine hohe Beständigkeit aus. Inmitten der epistemologischen und ontologischen Turbulenzen einer wissenschaftlichen Revolution, inmitten der wissenschaftsinternen Umbrüche bestehender Orientierungen erwiesen sie sich als erstaunlich veränderungsresistent.

Der evolutionstheoretische Paradigmawechsel führte zwar zu einer elementar veränderten Sicht auf den Menschen, doch die Sicht auf die Menschen wurde hiervon kaum beeinflußt. Dies lag vor allem an der Persistenz und Akzeptanz des Rassismus, denn die analytische Sicht auf die Menschen lag in den Hoheitsgebieten eines im Kern kulturalistischen Rassismus, der den evolutionstheoretischen Paradigmawechsel und die von ihm induzierte Modernisierung der Rassentheorien unbeschadet überstand - und mehr noch, der durch eine robuste wissenschaftliche Absicherung gestärkt aus ihr hervorgehen konnte.

Die begrenzte Reichweite des evolutionstheoretischen Transformation der Rassentheorien, der Umstand, daß ihr rassistischer Kerngehalt 
unbeschadet blieb, war zugleich die Bedingung für ihre Modernisierung. Durch sie wurden Restbestände alter theoretischer Orientierungen ausgeräumt und Widersprüche bereinigt, die zwischen den traditionellen Ansätzen bestanden. Durch sie erhielten sich die Rassentheorien ihre Anschlußfähigkeit an den naturwissenschaftlichen Theoriebestand, der für sie als Legitimationsressource existentiell war. Erst durch diese Modernisierungsleistung konnten die evolutionären Rassentheorien ihren Siegeszug in der zweiten Hälfte des neunzehnten Jahrhundert und noch darüber hinaus antreten. 


\section{Anhang}

\section{A Tabellen}

Anthropologie in führenden viktorianischen Journalen

Tabelle 1. Anteile naturwissenschaftlicher und anthropologischer Beiträge, 1861-1865.

\begin{tabular}{|c|c|c|c|c|c|c|}
\hline Journal & Beiträge & 1861 & 1862 & 1863 & 1864 & 1865 \\
\hline \multirow[t]{2}{*}{ Natural History Review } & total & 21 & 23 & 19 & 13 & 9 \\
\hline & naturwissenschaftlich & 21 & 23 & 19 & 13 & 9 \\
\hline davon & anthropologisch & 3 & 5 & 4 & 5 & 2 \\
\hline \multirow[t]{2}{*}{ London Review } & total & 41 & 37 & 39 & 36 & 38 \\
\hline & naturwissenschaftlich & 1 & 2 & 2 & 2 & 1 \\
\hline davon & anthropologisch & 1 & 2 & 1 & 1 & 0 \\
\hline \multirow[t]{2}{*}{ Westminster Review } & total & 36 & 38 & 38 & 37 & 33 \\
\hline & naturwissenschaftlich & 1 & 0 & 3 & 3 & 2 \\
\hline davon & anthropologisch & 1 & 0 & 2 & 2 & 1 \\
\hline \multirow[t]{2}{*}{ Quarterly Review } & total & 33 & 32 & 25 & 33 & 37 \\
\hline & naturwissenschaftlich & 2 & 0 & 3 & 1 & 2 \\
\hline davon & anthropologisch & 1 & 0 & 2 & 0 & 0 \\
\hline \multirow[t]{2}{*}{ Cornhill Magazine } & total & 109 & 109 & 110 & 109 & 94 \\
\hline & naturwissenschaftlich & 1 & 3 & 4 & 0 & 0 \\
\hline davon & anthropologisch & 0 & 3 & 3 & 0 & 0 \\
\hline \multirow[t]{2}{*}{ Fraser's Magazine } & total & 118 & 113 & 112 & 106 & 108 \\
\hline & naturwissenschaftlich & 2 & 2 & 2 & 0 & 0 \\
\hline davon & anthropologisch & 1 & 0 & 1 & 0 & 0 \\
\hline
\end{tabular}

Tabelle 1 zeigt die Verteilung naturwissenschaftlicher Beiträge in den bedeutendsten Magazinen im Vergleich zum Natural History Review in den Jahren seines Erscheinens. Sie zeigt die Anteile der im weitesten Sinne anthropologisch relevanten Aufsätze und Beiträge (ausgenommen reine Buchbesprechungen) an den der Summe der naturwissenschaftli- 
chen Beiträge. Hierbei wurden auch Aufsätze berücksichtigt, die sich mit Fragen der Psychologie beschäftigten. Rein politisch argumentierende Aufsätze fanden keine Berücksichtigung. Die Tabelle zeigt, daß der Natural History Review in der Zeit, in der er vom X-Club herausgegeben wurde, für den Diskurs der scientific community ein wichtiges Forum darstellte und zugleich anthropologischen Fragen mehr Raum bot als andere Journale seiner Zeit, ausgenommen natürlich jene Magazine, die von der Anthropological Society oder von der Ethnological Society herausgegeben wurden.

\section{B Abkürzungen}

AP: $\quad$ British Library: Avebury Papers

CCD: $\quad$ Frederick Burkhardt, Sydney Smith (Hrsg.): The Corre spondence of Charles Darwin. Cambridge 1985ff

CE: $\quad$ Thomas Henry Huxley: Collected Essays, 8 Bde. London 1893-1894

Essays: $\quad$ Herbert Spencer: Essays, Scientific, Political, and Speculative, 3 Bde., New York 1901

HP: $\quad$ Imperial College: Huxley Papers

HSP: University of London: Athenaeum Collection, Herbert Spencer Papers

JAI: Journal of the Anthropological Institute

JAS: Journal of the Anthropological Society of London

JES: $\quad$ Journal of the Ethnological Society of London

JTAH: Journal of Thomas Archer Hirst, The Royal Institution

LLTHH: $\quad$ Leonard Huxley: Life and Letters of Thomas Henry Huxley. 2 Bde. London 1900

NHR: $\quad$ Natural History Review

RAI: Archives of the Royal Anthropological Institute of Great Britain and Northern Ireland.

SM: $\quad$ The Scientific Memoirs of Thomas Henry Huxley, 5 Bde. London 1898-1903 


\section{Literatur}

\section{Archive}

Athenaeum Collection, Herbert Spencer Papers, Library, University of London.

Avebury Papers, British Library, London.

Busk Papers, Royal College of Surgeons of London.

Huxley Papers, Imperial College, London.

Lubbock Papers, Library of the Royal Society.

Council Minutes Book, Ethnological Society of London, Archives of the Royal Anthropological Institute.

Anthropological Society of London, Council Minutes, Archives of the Royal Anthropological Institute.

\section{Primärquellen: Schriften des X-Clubs}

Busk, George; G. Budd (1838) „Report of twenty cases of malignant cholera that occurred in the Seamen's Hospital, Dreadnought, between the 8th and 28th of October, 1837“. In: Medico-Chirurgical Transactions 21, S. 152186.

Busk, George; Hugh Falconer (1863) „An account of the proceedings of the late conference held in France to enquire into the circumstances attending the reported discovery of a Human Jaw in the gravel at Moulin-Quignon, near Abbeville...". In: Natural History Review 3, S. 423-462.

- (1865) „On the Fossil Contents of the Genista Cave, Gibraltar“. In: Quarterly Journal Geological Society 21, 364-370.

Busk, George (1861a) „On the Crania of the Most Ancient Races of Man. By Professor D. Schaaffhausen, of Bonn. (From Müller's Archiv, 1858, pp. 453). With Remarks, and original Figures, taken from a Cast of the Neanderthal Cranium“. In: Natural History Review 1, S. 172-176.

- (1861b) „Observations on a systematic Mode of Craniometry“. In: Transactions of the Ethnological Society 1, S. 341-348.

— (1866a) „An Account of the Discovery of a Human Skeleton beneath a Bed of Peat on the Coast of Cheshire“. In: Transactions of the Ethnological Society 4 , S. 101-104.

- (1866b) „Description of two Andamanese Skulls“. In: Transactions of the Ethnological Society 4, S. 205-211.

- (1868) „Description of an Aino Skull“. In: Transactions of the Ethnological Society 6, S. 109-111.

— (1870a) „On the Discovery of Platycnemic Men in Denbingshire“. In: Journal of the Ethnological Society 2, S. 450-468. 
- (1870b) „Description of and Remarks upon an Ancient Calvaria from China, which has been supposed to be that of Confucius“. In: Journal of the Ethnological Society 2, S. 73-81.

— (1873) „Man in the Settle Cave“. In: Nature 9, S 70.

- (1874a) „Description of a Samoiede Skull in the Museum of the Royal College of Surgeons“. In: Journal of the Anthropological Institute 3, S. 494497.

- (1874b) „Note on a Ready Method of Measuring the Cubic Capacity of Skulls“. In: Journal of the Anthropological Institute 3, S. 200-204.

- (1874c) „Notice of a Human Fibula of Unusual Form, discovered in the Victoria Cave, near Settle, in Yorkshire“. In: Journal of the Anthropological Institute 3, S. 392-395.

- (1874d) „Remarks on a Collection of 150 Ancient Peruvian Skulls, presented to the Anthropological Institute by T. J. Hutchinson, H. M. Consul at Callao". In: Journal of the Anthropological Institute 3, S. 86-94.

- (1875) „The President's Address“. In: Journal of the Anthropological Institute 4, S. 476-502.

- (1879-80) „Notes on the Collection of Bones from Caves in Borneo, Referred to in Mr. Everett's Report on the Exploration of the Bornean Caves in 1878-9“. In: Proceedings of the Royal Society of London 30, S. 319-321.

Huxley, Thomas Henry (1850) „Notes on Medusæ and Polypes“. In: Annals and Magazine of Natural History 6, S. 66-67.

- (1852) „Upon Animal Individuality“. In: [Proceedings of the Royal Institution of London 1, 1852, S. 184-189] The Scientific Memoirs of Thomas Henry Huxley, Bd. 1, S. 146-151.

- (1853) „On the Morphology of the Cephalous Mollusca as Illustrated by the Anatomy of Certain Heteropoda and Pteropoda Collected During the Voyage of H.M.S. ,Rattlesnake' in 1846-50“. In: [Philosophical Transactions of the Royal Society 1, 1853, S. 29-66] The Scientific Memoirs of Thomas Henry Huxley, Bd. 1, S. 52-93.

- (1854) „Vestiges of the Natural History of Creation“. In: [The British and Foreign Medico-Chirurgical Review 13, 1854, S. 425-439] The Scientific Memoirs of Thomas Henry Huxley Bd. 5, S. 1-19.

- (1859a) „Time and Life: Mr. Darwin’s ,Origin of Species““. In: Macmillan's Magazine 1, S. 142-148.

- (1859b) „The Darwinian Hypothesis“. In: [The Times, 26. Dezember] Collected Essays, Bd. 2, S. 1-21.

— [anon.] (1860a) „The Origin of Species“. In: [Westminster Review 17 (n.s.), S. 541-570] Collected Essays, Bd. 2, S. 22-79.

- (1860b) „On Species and Races, and Their Origin“ [Proceedings of the Royal Institution 3, 1858-1862, S. 195-200 und Annual Magazine of Natu- 
ral History 5, S. 344-346] The Scientific Memoirs of Thomas Henry Huxley, Bd. 2, S. 388-394.

- (1861a) „Man and the Apes“. In: The Athenaeum, 27. März und 21. Sept., S. 433, S. 498.

- (1861b) „On the Relation of Man to the Lower Animals“. In: [Ursprünglich: „On the Zoological Relations of Man with the Lower Animals“. In: Natural History Review (n.s.) 1, S. 67-84] Collected Essays, Bd. 7, S. 77-156.

- (1862a) „Geological Contemporaneity“. In: [Quarterly Journal of the Geological Society 18, S. 40-54] Collected Essays, Bd. 8, S. 272-304.

- (1862b) „A Lecture on the Fossil Remains of Man, delivered at the Royal Institution, Feb. $7^{\text {th }} 1862^{\prime \prime}$. In: The Lancet, 15. Februar, S. 166-167.

- (1862c) „The Brain of Man and Apes“. In: Medical Times and Gazette, 25. Oktober, S. 449.

- (1862d) „On Some Fossil Remains of Man“. In: [Proceedings of the Royal Institution of Great Britain 3, 1858-62, S. 420-422] Collected Essays, Bd. 7, S. 157-208.

- (1863a) „On Our Knowledge of the Causes of the Phenomena of Organic Nature (Six Lectures to Working Men)“. In: Collected Essays, Bd. 2, S. 307-475.

- (1863b) Evidence as to Man's Place in Nature. London: Williams and Norgate.

- (1864a) Lectures on the Elements of Comparative Anatomy. London: Churchill and Sons.

- (1864b) „Further Remarks Upon the Human Remains from the Neanderthal“. In: [Natural History Review n.s. 4, S. 429-446] The Scientific Memoirs of Thomas Henry Huxley, Bd. 2, S. 573-590.

- (1865a) „On the Methods and Results of Ethnology“. In: [Fortnightly Review 1, S. 257-277] Collected Essays, Bd. 7, S. 209-252.

- (1865b) „Emancipation - Black and White“. In: [The Reader 5, 1865, S. 561-562)] Collected Essays, Bd. 3, S. 60-75.

- (1866a) „Notes upon the Human Remains from Keiss“. In: Samuel Laing: Pre-Historic Remains of Caithness. London, Williams and Norgate, S. 83160.

— (1866b) „Letter on Jamaica Committee“. In: Pall Mall Gazette 4, 31. Oktober, S. 3.

- (1867) „On Two Widely Contrasted Forms of the Human Cranium“. In: [Journal of Anatomy and Physiology 1, S. 66-70] The Scientific Memoirs of Thomas Henry Huxley, Bd. 3, S. 214-230.

- (1868) „On the Animals Which Are Most Nearly Intermediate between Birds and Reptiles“. In: [Geological Magazine 5, S. 357-363] The Scientific Memoirs of Thomas Henry Huxley, Bd. 3, S. 303-313. 
— (1869a) „On the Ethnology and Archæology of India“. In: [The Journal of the Ethnological Society of London, n.s. 1, S. 89-93] The Scientific Memoirs of Thomas Henry Huxley, Bd. 3, S. 427-431.

- (1869b) „On the Ethnology and Archæology of North America“. In: [The Journal of the Ethnological Society of London, n.s. 1, S. 218-221] The Scientific Memoirs of Thomas Henry Huxley, Bd. 3, S. 432-435.

— (1870a) „The Forefathers of the English People“. In: Nature 1, S. 514-515.

- (1870b) „On the Ethnology of Britain”. In: [Journal of the Ethnological Society of London, n.s. 2, S. 382-384] The Scientific Memoirs of Thomas Henry Huxley, Bd. 3, S. 551-553.

- (1870c) „On the Geographical Distribution of the Chief Modifications of Mankind“. In: [Journal of the Ethnological Society of London n.s. 2, S. 404-412] The Scientific Memoirs of Thomas Henry Huxley, Bd. 3, S. 564571.

- (1890) „Autobiography“. In: [L. Engel (Hrsg.): From Handel to Halle: Biographical Sketches with Autobiographies of Professor Huxley and Professor Herkomer. 1890] Collected Essays, Bd. 1, S. 1-17.

— (1893-94) Collected Essays. London: Macmillan.

— (1894) „Professor Tyndall“. In: The Nineteenth Century 35, S. 1-11.

- (1894) „Evolution and Ethics. Prolegomena“. In: Collected Essays. Bd. 9, S. 1-45.

- (1898-1903) The Scientific Memoirs of Thomas Henry Huxley. Ed. by Michael Foster and E. Ray Lankaster. London: Macmillan.

Lubbock, John (1853a) „Description of a New Genus of Calanidae“. In: The Annals and Magazine of Natural History 11, S. 25.

- (1853b) „On two new Subgenera of Calanida“. In: The Annals and Magazine of Natural History 11, S. 202-209.

- (1857) „Description of eight new species of Entomostraca found at Weymouth". In: The Annals and Magazine of Natural History 20, S. 401-410.

- (1860) „On the Distribution of the Trachea in Insects“. In: Transactions of the Linnean Society 23, S. 23-50.

- (1861) „The Kjökkenmöddings: Recent Geologico-Archæological Researches in Denmark". In: Natural History Review 1, S. 489-504.

- (1862a) „On the Ancient Lake-Habitations of Switzerland“. In: Natural History Review 2, S. 26-52.

— (1862b) „On two Aquatic Hymenoptera“. In: Report British Association 32, S. 110.

— (1863) „North American Archæology“. In: Natural History Review 3, S. 130.

— (1864) „Cave-Man“. In: Natural History Review 4, 407-428.

- (1865) „On Mr. Bateman's Researches in Ancient British Tumuli“. In: Transactions of the Ethnological Society of London. n.s. 3, S. 307-321. 
— (1866) „On the Development of Chloëon (Ephemera) dimidiatum. Part II“. In: Transactions of the Linnean Society 25, S. 477-491.

- (1867) „Address delivered to the Section of ,Primæval Antiquities' at the London Meeting of the Archaeological Institute, July 1866“. In: Archaeological Journal of London 23, S. 190-211.

- (1868a) „The Early Condition of Man“. In: Anthropological Review 6, S. 121.

- (1868b) „Stone Implements from the Cape“. In: Journal of the Ethnological Society of London, n.s. 1, S. 51-53.

- (1870a) The Origin of Civilisation and the Primitive Condition of Man. Mental and Social Condition of Savages. London: Longmans, Green.

- (1870b) „On the Primitive Condition of Man - Part 2“. In: The Origin of Civilisation and the Primitive Condition of Man, Mental and Social Condition of Savages. New York: Appleton, S. 325-362.

- (1872a) Pre-historic Times: As Illustrated by Ancient Remains, and the Manners and Customs of Modern Savages. [1865] London: Williams \& Norgate.

- (1872b) „Note on Some Stone Implements from Africa and Syria“. In: Journal of the Anthropological Institute 1, xcii-xcvii.

— (1872c) „On the Development of Relationships“. In: Journal of the Anthropological Institute of Great Britain and Ireland 1, S. 1-29.

— (1873) „Existence of Men in the Miocene“. In: Nature 7, S. 401.

- (1874) On the Origin and Metamorphoses of Insects. London: Macmillan.

- (1875) „Notes on the Discovery of Stone Implements in Egypt“. In: Journal of the Anthropological Institute 4, S. 215-222.

— (1881) „Note on a Stone Implement of Palaeolithic Type found in Algeria“. In: Journal of the Anthropological Institute 10, S. 316-319.

- (1882) Ants, Bees, and Wasps. London: Kegan Paul.

- (1911) Marriage, Totemism and Religion. An Answer to Critics. London: Longmans, Green \& Co.

— (1966) Essays \& Addresses. 1900-1903. [1903] Freeport NY: Books for Libraries.

Spencer, Herbert (1836) „Poor Laws: Reply to ,T.W.S.““. In: The Bath and West of England Magazine 3, S. 81-83.

- (1846) „On a Proposed Cephalograph“. In: Ders.: Autobiography. Bd. 1, S. 540-543.

- (1851) Social Statics: or, the Conditions Essential to Human Happiness Specified and the First of them Developed. London: Chapman.

- (1852a) „A Theory of Population. Deduced from Animal Fertility“. In: The Westminster Review, New Series 1, S. 468-501.

- (1852b) „The Development Hypothesis“. In: [The Leader 3 (20. März), S. 280-281] Essays. Bd. 1, S. 1-7. 
— (1854) „Personal Beauty“. In: [The Leader 15.April, 13.Mai, S. 356-357, S. 451-452] Essays. Bd. 3, S. 387-399.

- (1855) The Principles of Psychology. London: Longmans.

- (1857a) „Progress: Its Law and Cause“. In: [Westminster Review 67] Essays. Bd. 1, S. 8-62.

- (1857b) „Transcendental Physiology“. In: [,,The Ultimate Law of Physiology”. In: National Review 5, S. 332-355] Essays. Bd. 1, S. 63-107.

- (1874) Descriptive Sociology or Groups of Sociological Facts. Types of Lowest Races, Negritto Races, and Malayo-Polynesian Races London: Williams and Norgate.

— (1876) „The Comparative Psychology of Man“. In: [Mind 1, S. 7-20] Essays. Bd. 1, S. 351-370.

- (1883a) The Principles of Biology. [Bd. 1: 1864, Bd. 2: 1867] New York: Appleton.

- (1883b) The Principles of Sociology. [Bd. 1: 1876, Bd. 2: 1879, Bd. 3: 1883] New York: Appleton.

- (1899) The Study of Sociology. [1873] New York: Appleton.

- (1901) Essays: Scientific, Political, and Speculative. New York: Appleton.

- (1902) „Imperialism and Slavery“. In: Herbert Spencer (Hrsg.): Facts and Comments. New York: Appleton, S. 157-171.

— (1904a) First Principles. [1864] New York: Appleton.

— (1904b) An Autobiography. London: Williams \& Norgate.

— (1908) „The Filiation of Ideas“. In: Duncan: Spencer. S. 533-576.

- (1994) „The Proper Sphere of Government”. In: [The Nonconformist 2 und 3, 1842-43] John Offer (Hrsg.): Herbert Spencer: Political Writings. Cambridge: Cambridge University Press, S. 3-57.

\section{Weitere Primärquellen}

Anderson, Joseph (1866) „On Human Remains at Keiss“. In: Journal of the Anthropological Society 4, S. clii-clvi.

Anon. (1863) „On the Relation of Man to the Lower Animals“. In: Anthropological Review 1, S. 107-117.

Beddoe, John (1866) „On the Head-Forms of the West of England“. In: Memoirs of the Anthropological Society 2, S. 348-357.

Blake, Charles Carter (1861) „On the Occurrence of Human Remains Contemporaneous with those of Extinct Animals“. In: The Geologist 4, S. 365.

- (1862) „On the Cranium of the Most Ancient Races of Man“. In: The Geologist 5, S. 206.

- (1863a) „Professor Huxley on Man's Place in Nature“. In: Edinburgh Review 117, S. 541-569. 
— [alias Anthropos] (1863b) „Man and Beast“. In: Anthropological Review 1, S. 153-162.

- (1864a) „On the alleged Peculiar Characters, and Assumed Antiquity of the Human Cranium from the Neanderthal". In: Journal of the Anthropological Society 2, S. cxxxix-clvii.

- (1864b) ,Report on the Anthropological Papers read at the Newcastle Meeting of the British Association for the Advancement of Science, in August and September, 1863“. In: Journal of the Anthropological Society 2, S. ivi.

- (1865) „Report on the Anthropological Papers read at the Bath Meeting of the British Association for the Advancement of Science, September 1864". In: Journal of the Anthropological Society 3, S. ii-vi.

- (1866) „On Certain „Simious“ Skulls with Especial Reference to a Skull from Louth in Ireland“. In: Memoirs of the Anthropological Society 2, S. 74-81.

- (1867) „Report on the Anthropological Papers read at the Nottingham Meeting of the British Association for the Advancement of Science, 1866“. In: Journal of the Anthropological Society 5, S. iv-viii.

Bory de Saint Vincent, Jean Baptiste (1827) „Orang“. In: Dictionnaire classique de l'histoire naturelle, Paris, Bd. 12, S. 261-285.

Burke, Luke (1865) In: Ethnological Journal, S. 4-5.

Campbell, George, Duke of Argyll (1867) The Reign of Law. London: Strahan.

- (1869) Primeval Man. An Examination of Some Recent Speculations. New York: George Routledge.

Camper, Petrus (1782) Natuurkundige Verhandelingen over den Orang Outang; en eenige andere Aap-soorten. Over den Rhinoceros met den Dubbelen Horen; en over het Rendier. Amsterdam: Meijer en Warnars.

Crawfurd, John (1861a) „On the Aryan or Indo-Germanic Theory“. In: Transactions of the Ethnological Society of London 1, S. 268-286.

- (1861b) „On the Classification of the Races of Man“. In: Transactions of the Ethnological Society of London 1, S. 354-378.

- (1865) „On Language as a Test of the Races of Man“. In: Transactions of the Ethnological Society of London 3. S. 1-9.

Cull, Richard (1851) „Remarks on the nature, objects, and evidences of ethnological science“. In: Journal of the Ethnological Society 3, S. 102-111.

Darwin, Charles (1989) Voyage of the Beagle. [1839] London: Penguin.

- (1998a) On the Origin of Species by Means of Natural Selection or, the Preservation of Favoured in the Struggle for Life. [1859] Ware: Wandsworth.

— (1998b) The Descent of Man and Selection in Relation to Sex. [1874] New York: Prometheus Books. 
Davis, Joseph Barnard (1863) „The Neanderthal Skull: Its Peculiar Conformation explained Anatomically“. In: Memoirs of the Anthropological Society 1, S. 281-295.

- (1864) The Neanderthal Skull: Its Peculiar Conformation explained Anatomically. London.

Ethnological Society of London (1850) „Regulations“. London: Ethnological Society.

Ferguson, Adam (1767) An Essay on the History of Civil Society. Edinburgh.

Flower, William Henry (1862) „On the Posterior Lobes of the Cerebrum of the Quadrumana“. In: Philosophical Transactions of the Royal Society of London, Biology 152, S. 185-201.

- (1863) „On the Brain of the Siamang“. In: Natural History Review 3, S. 279-287.

Hunt, James (1862) „On Ethno-Climatology; or, the Acclimatization of Man“. In: Report of the $31^{\text {st }}$ Meeting of the BAAS, Manchester 1861. London, S. 129-150.

- (1863) „On the Negro's Place in Nature“. In: Memoirs Read Before the Anthropological Society of London 1, S. 1-60.

- (1866a) „On the Application of the Principle of Natural Selection to Anthropology“. In: Anthropological Review 4, S. 320-340.

- (1866b) „On the Keiss Graves“. In: Journal of the Anthropological Society 4 , S. clxiii-clxx.

- (1866c) „Address delivered at the third anniversary meeting of the Anthropological Society of London“. In: Journal of the Anthropological Society 4, S. lix-lxxxi.

- (1866d) „On the Application of the Principle of Natural Selection to Anthropology“. In: Anthropological Review 4, S. 320-340.

- (1867) „Address to the Anthropological Society“. In: Journal of the Anthropological Society 5, S. xlvi-lxx.

— (1868) „Presidential Address“. In: Anthropological Review 6, S. 72-79.

King, Richard (1844) „Address to the Ethnological Society of London“. In: Journal of the Ethnological Society 2, S. 9-40.

King, William (1864) „The Reputed Fossil Man of the Neanderthal“. In: Quarterly Journal of Science 1, S. 88-97.

Knox, Robert (1850) The Races of Man. A Fragment. Philadelphia: Lea, Blachard.

- (1863) „Ethnological Inquiries and Observations“. In: Anthropological Review 1, S. 246-270.

Kolk, Schroder van den, Willem Vrolik (1862) „Note sur l'encéphale de l'orang utang“. In: Natural History Review 2, S. 111-117. 
Lane Fox, Augustus Henry (1878) „Observations on Mr Man’s collection of Andamanese and Nicobarese Objects“. In: Journal of the Anthropological Institute 7, S. 434-451.

Lyell, Charles (1914) On the Geological Evidence of the Antiquity of Man. [1863] London: Dent.

Mackintosh, D. (1866) „Comparative Anthropology of England and Wales“. In: Anthropological Review 4, S. 1-21.

Malthus, Thomas Robert (1890) An Essay on the Principle of Population or a View of its Past and Present Effects on Human Happiness. [1803] London: Johnson.

Marshall, John (1861) „On the Brain of a Young Chimpanzee“. In: Natural History Review 1, S. 296-315.

Mayer, Johann Friedrich Carl (1864) „Ueber die fossilen Ueberreste eines menschlichen Schädels und Skelettes in einer Felsenhöhle des Düssel- oder Neander-Thales“. In: Archiv für Anatomie,Physiologie und wiss. Medi$\operatorname{cin} 1$, S. 1-26.

Morton, Samuel George (1839) Crania Americana, or, a comparative view of the skulls of various aboriginal nations of North and South America. Philadelphia: Pennington.

Owen, H. Burnard (1865) „Missionary Successes and Negro Converts“. In: Anthropological Review 3, S. clxxxiv-ccxlvi.

Owen, Richard (1830) „On the Anatomy of the Orang Outang (Simia satyrus, L. “". In: Proceedings of the Committee of Science and Correspondence of the Zoological Society 1, S. 4-5, S. 9-10, S. 28-29, S. 67-72.

- (1835) „On the Osteology of the Chimpanzee and Orang Utan“. In: Transactions of the Zoological Society 1, S. 343-379.

- (1849) „Osteological Contributions to the Natural History of the Chimpanzees (Troglodytes, Geoffroy), including the description of the Skull of a large species (Troglodytes Gorilla, Savage) discovered by Thomas S. Savage, M.D., in the Gaboon country, West Africa“. In: Transactions of the Zoological Society of London 3, S. 381-422.

- (1855) „On the Anthropoid Apes, and their relations to Man“. In: Proceedings of the Royal Institution 2, S. 26-41.

- (1858) „On the Characters, Principles of Division, and Primary Groups of the Class Mammalia“. In: Journal of the Proceedings of the Linnean Society of London 2, S. 1-37.

- (1860a) „On the Cerebral System of Classification of the Mammalia“. In: Proceedings of the Royal Institution 3, S. 174-189.

- (1860b) „Darwin on the Origin of Species“. In: Edinburgh Review, April, S. 487-532.

- (1860c) ,Report on a Series of Skulls of various Tribes of Mankind inhabiting Nepal, collected, and presented to the British Museum, by Bryan H. 
Hodgson, esq., late resident in Nepal, \&c. \&c.“. In: Report of the $29^{\text {th }}$ Meeting of the British Association for the Advancement of Science. S. 95103.

- (1861a) „Origin of Species“. In: Natural History - Zoology. The Year Book of Facts, S. 203.

- (1866) „Contribution to the Natural History of the Anthropoid Apes. No. VIII. On the External Characters of the Gorilla (Troglodytes Gorilla)“. In: Transactions of the Zoological Society of London 5, S. 243-283.

Petrie, George (1866) „Letter on Human Remains from Keiss“. In: Journal of the Anthropological Society 4, S. cl-clii.

Prichard, James Cowles (1813) Researches into the Physical History of Man. London: Arch.

- (1848) „On the Relations of Ethnology to Other Branches of Knowledge“. In: Journal of the Ethnological Society of London 1, S. 301-329.

Reade, W. Winwood (1865) „Efforts of Missionaries among Savages“. In: Anthropological Review 3, S. clxiii-clxxxiii.

Rolleston, George (1861) „On the Affinities of the Brain of the Orang Utang“. In: Natural History Review 1, S. 210-217.

Schaaffhausen, Hermann (1856) „Über Beständigkeit und Umwandlung der Arten“. In: Verhandlungen des Naturhistorischen Vereins der Preußischen Rheinlande und Westphalens 10, S. 420-451.

— (1858) „Zur Kenntnis des ältesten Rassenschädel“. In: Archiv Verbindung mehrerer Gelehrten, S. 453-488.

- (1861) „On the Crania of the Most Ancient Races of Man“. In: Natural History Review 1, S. 155-172.

- (1868) „Darwinism and Anthropology“. In: Journal of the Anthropological Society 6, S. cviii-cxvii.

Shearer, Robert L. (1866) „On the Human Remains at Keiss“. In: Journal of the Anthropological Society 4, S. clvii-clxiii.

Soemmering, Samuel Thomas (1785) Ueber die körperliche Verschiedenheit des Negers vom Europäer. Frankfurt, Mainz: Warrentrapp, Wenner.

Thurnam, Joseph, John Barnard Davis (1856) Crania Britannica. Delineations and Descriptions of the Skulls of the Aboriginal and Early Inhabitants of the British Islands. London: Selbstverlag.

- (1864) „On the Two Principal Forms of Ancient British and Gaulish Skulls“. In: Memoirs of the Anthropological Society 1, S. 120-168.

Tiedemann, Frederick (1836) „On the Brain of a Negro, Compared with That of the European and the Orang-Utang“. In: Philosophical Transactions of the Royal Society of London 126, S. 497-527.

Tyson, Edward (1699) Orang-Outang: Or the Anatomy of a Pygmie Compared with That of a Monkey, an Ape, and a Man. London: Bennet, Brown. 
Wallace, Alfred Russel (1864) „The Origin of Human Races and the Antiquity of Man deduced from the theory of ,Natural Selection““. In: Anthropological Review 2, S. clviii-clxxxvii.

Whately, Richard (1832) Introductory Lectures on Political Economy. London: Parker.

Wilberforce, Samuel (1860) „On the Origin of Species, by means of Natural Selection; or the Preservation of Favoured Races in the Struggle for Life. By Charles Darwin, M.A., F.R.S. London 1860“. In: Quarterly Review 102, S. 225-264.

\section{Zeitschriften}

Anthropological Review.

The Athenaeum.

The Geologist.

Journal of the Anthropological Society.

Journal of the Ethnological Society of London.

Memoirs Read Before the Anthropological Society of London.

Natural History Review.

Nature.

Pall Mall Gazette.

Philosophical Transactions of the Royal Society of London, Biology.

Quarterly Journal of the Geological Society.

Quarterly Review.

The Reader.

The Times.

Transactions of the Ethnological Society of London.

Transactions of the Zoological Society of London.

Westminster Review.

\section{Sekundärliteratur}

Addinall, Peter (1991) Philosophy and Biblical Interpretation: A Study in Nineteenth-Century Conflict. Cambridge: Cambridge University Press.

Albee, Ernest (1957) A History of English Utilitarianism. London: Allen and Unwin.

Albritton, Claude C., Jr. (1980) The Abyss of Time, Changing Conceptions of the Earth's Antiquity After theSixteenth Century. San Francisco: Freeman, Cooper.

Altholz, Joseph L. (1980) „The Huxley-Wilberforce Debate revisited“. In: Journal of the History of Medicine and Allied Sciences 35, S. 313-316. 
- (1994) Anatomy of a Controversy: The Debate over „Essays and Reviews“ 1860-1864. Aldershot: Scholar Press.

Anderson, R. D. (1995) Universities and elites in Britain since 1800. Cambridge: Cambridge University Press.

Andersson, Gunnar (1988) Kritik und Wissenschaftsgeschiche. Kuhns, Lakatos' und Feyerabends Kritik des kritischen Rationalismus. Tübingen: Mohr.

Andreski, Stanislav (1969) „Introduction“. In: Ders. (Hrsg.): Herbert Spencer. Principles of Sociology. London: Macmillan, S. ix-xxxvi.

- (1971) Herbert Spencer: Structure, Function, and Evolution. London: Joseph.

Anon. (1901) „Busk, George (1807-1886)“. In: Dictionary of National Biography. Supplement 1, London: Smith and Elder, S. 357-358.

Anstey, Roger (1980) „The pattern of British abolitionism in the eighteenth and nineteenth centuries“. In: Roger Anstey, Christine Bolt, Symour Drescher (Hrsg.): Anti-slavery, religion and reform. Folkstone: Dawson, S. $19-42$.

Ashforth, Albert (1969) Thomas Henry Huxley. New York: Twayne.

Augstein, Hannah Franziska (1996) „Introduction“. In: Dies.: Race. The Origin of an Idea, 1760-1850. Bristol: Toemmes, S. ix-xxxiii.

- (1999) James Cowles Prichard's Anthropology: Remaking the Science of Man in Early Nineteenth-Century Britain. Amsterdam etc.: Rodopi.

Bannister, Robert C. (1979) Social Darwinism, Science and Myth in AngloAmerican Social Thought. Philadelphia: Temple University Press.

Banton, Michael (1967) Race Relations. London: Tavistock.

- (1998) Racial Theories. Cambridge: Cambridge University Press.

Barber, Bernard (1973) „Der Widerstand von Wissenschaftlern gegen wissenschaftliche Entdeckungen“. In: Peter Weingart (Hrsg.): Wissenschaftssoziologie I. Wissenschaftliche Entwicklung als sozialer Prozeß. Frankfurt: Athenäum, S. 205-221.

Barkan, Elazar (1996) The Retreat of Scientific Racism. Changing Concepts of Race in Britain and the United States Between the World Wars. Cambridge: Cambridge University Press.

Barker, Ernest (1915) Political Thought in England. From Herbert Spencer to the Present Day. London: Williams and Norgate.

- (1946) British Universities. London: Longmans, Green.

Barnes, Barry (1974) T. S. Kuhn and Social Science. London, Basingstoke: Macmillan.

- (2003) „Thomas Kuhn and the Problem of Social Order in Science“. In: Thomas Nickles (Hrsg.) Thomas Kuhn. Cambridge: Cambridge University Press, S. 122-141. 
Barnes, Barry, David Bloor, John Henry (1996) Scientific Knowledge. A Sociological Analysis. London: Athlone.

Barsch, Achim, Peter M. Hejl (2000) „Zur Verweltlichung und Pluralisierung des Menschenbildes im 19. Jahrhundert: Einleitung“. In: Dies. (Hrsg.): Menschenbilder. Zur Pluralisierung der Vorstellung von der menschlichen Natur (1850-1914). Frankfurt: Suhrkamp, S. 7-90.

Barton, Ruth (1983) „Evolution: The Whitworth Gun in Huxley's War for the Liberation of Science from Theology“. In: David Roger Oldroyd, Ian Langham: The Wider Domain of Evolutionary Thought. Dordrecht u.a.: Reidel, S. 261-286.

- (1990) „,An Influential Set of Chaps““. In: British Journal for the History of Science 23, S. 53-81.

- (1998a) ,Just before Nature: The Purposes of Science and the Purposes of Popularization in some English Popular Science Journals of the 1860s”. In: Annals of Science 55, S. 1-33.

- (1998b) „,Huxley, Lubbock, and Half a Dozen Others“. Professionals and Gentlemen in the Formation of the X-Club, 1851 - 1864“. In: Isis 89, S. 410-444.

— (2004) „Lubbock, Sir John, Lord Avebury (1834-1913)“. In: Bernard Lightman (Hrsg.): The Dictionary of Nineteenth-Century British Scientists. Bristol: Thoemmes.

Bassalla, George, William Coleman, Robert H. Kargon (1970) „Introduction“. In: Dies. (Hrsg.): Victorian Science. A Self-Portrait from the Presidential Addresses of the British Association for the Advancement of Science. Garden City, New York: Doubleday, S. 3-21.

Beckett, James Camlin (1982) Geschichte Irlands. Stuttgart: Kröner.

Benton, Ted (1982) „Social Darwinism and Socialist Darwinism in Germany: 1860 to $1900 “$ “. In: Rivista di Filosofia 73, S. 79-121.

Benedict, Ruth (1935) The Chrysanthemum and the Sword. Patterns of Japanese Culture. Boston: Mifflin.

Bernasconi, Robert (2001) „Who invented the Concept of Race? Kant's Role in the Enlightenment Construction of Race“. In: Ders.: (Hrsg.): Race. Oxford: Basil Blackwell, S. 11-36.

Best, Geoffrey (1990) Mid-Victorian Britain 1851-75. London: Fontana Press.

Bibby, Cyril (1958) „Thomas Henry Huxley and University Development“. In: Victorian Studies 2, S. 97-116.

- (1972) Scientist Extraordinary. The Life and Scientific Work of Thomas Henry Huxley, 1825-1895. Oxford: Pergamon Press.

Bibby, Geoffrey (1960) Faustkeil und Bronzeschwert. Frühzeitforschung in Nordeuropa. Berlin, Darmstadt, Wien: Dt. Buchgemeinschaft. 
Biddiss, Michael D. (1976) „The Politics of Anatomy: Dr. Robert Knox and Victorian Racism“. In: Proceedings of the Royal Society, Medicine 69, S. 245-250.

Birx, H. James (1998) „Introduction“. In: Charles Darwin: The Descent of Man and Selection in Relation to Sex. $\left[1874^{2}\right]$ New York: Prometheus Books, S. ix-xxviii.

Blackburn, Robin (2000) The Overthrow of Colonial Slavery, 1776-1848. London, New York: Verso.

Block, Ed Jr. (1986) „T. H. Huxley's Rhetoric and the Popularization of Victorian Scientific Ideas: 1854-1874“. In: Victorian Studies 30, S. 363-386.

Bloxam, George W. (1893) Index to the Publications of the Anthropological Institute of Great Britain and Northern Ireland [1843-1891]. London: The Anthropological Institute.

Boas, Franz (1914) Kultur und Rasse. Leipzig: Veit.

— (1982a) „Evolution or Diffusion?“ In: Ders.: Race, Language and Culture. [1940] Chicago: University of Chicago Press, S. 290-294.

- (1982b) „The Limitations of the Comparative Method in Anthropology“. In: Ders.: Race,Language and Culture. S. 270-280.

- (1982c) „The Methods of Ethnology“. In: Ders.: Race, Language and Culture. S. 281-289.

Boas Hall, Marie (1984) All Scientists Now. The Royal Society in the nineteenth century. Cambridge: Cambridge University Press.

Bock, Kenneth (1980) Human Nature and History. A Response to Sociobiology. New York: Columbia University Press.

Bolt, Christine (1971) Victorian Attitudes to Race. London: Routledge and Paul.

Bowler, Peter J. (1975) „,The Changing Meaning of „Evolution““. In: Journal for the History of Ideas 36, S. 95-114.

- (1987) Theories of Human Evolution: A Century of Debate, 1844-1944. Oxford: Basil Blackwell.

- (1988) The Non-Darwinian Revolution. Re-Interpreting a Historical Myth. Baltimore: Johns Hopkins University Press.

- (1989) The Invention of Progress: The Victorians and the Past. Oxford: Basil Blackwell.

— (1995) „Herbert Spencers Idee der Evolution und ihre Rezeption“. In: EveMarie Engels: Die Rezeption von Evolutionstheorien im 19. Jahrhundert. Frankfurt: Suhrkamp, S. 309-325.

- (1997) „Thomas Henry Huxley and the Reconstruction of Life's Ancestry“. In: Alan P. Barr (Hrsg.): Thomas Henry Huxley's Place in Science and Letters: Centenary Essays. Athens, Georgia: University of Georgia Press, S. 119-139. 
— (2005) „Revisiting the Eclipse of Darwinism“. In: Journal of the History of Biology 38, S. 19-32.

Boylan, Patrick J. (1979) „The controversy of the Moulin-Quignon jaw: the role of Hugh Falconer“. In: Ludmilla J. Jordanova, Roy S. Porter: Images of the Earth. Essays in the History of the Environmental Sciences. Chalfont St. Giles: British Society for the History of Science, S. 171-199.

Brantlinger, Patrick (1997) „Thomas Henry Huxley and the Imperial Archive“. In: Alan P. Barr (Hrsg.): Thomas Henry Huxley's Place in Science and Letters: Centenary Essays. Athens, Georgia: University of Georgia Press, S. 259-276.

- (2003) Dark Vanishings. Discourse on the Extinction of Primitive Races, 1800-1930. Ithaca, London: Cornell University Press.

Brock, W. H., R. M. MacLeod (1979) „The Scientists' Declaration: Reflexions on Science and Belief in the Wake of Essays and Reviews, 1864-5“. In: British Journal for the History of Science 9, S. 39-66.

Brock, W. H. (1980) „The Development of Commercial Science Journals in Victorian Britain“. In: Arthur Jack Meadows (Hrsg.): Development of Science Publishing in Europe. Amsterdam u.a.: Elsevier, S. 95-122.

Burkhardt, Frederick, Sydney Smith (Hrsg.) (1985ff) The Correspondence of Charles Darwin. Cambridge: Cambridge University Press.

Burkhardt, Frederick H. (2001) „Darwin and the Copley Medal“. In: Proceedings of the American Philosophical Society 145, S. 510-518.

Burkhardt, Richard W. (1977) The Spirit of System: Lamarck and Evolutionary Biology, Cambridge, Mass.: Harvard University Press.

Bürger, Willy (1956) Johann Carl Fuhlrott. Der Entdecker des Neandertalmenschen. Wuppertal: Abendland Verlag.

Burrow, John W. (1963) „Evolution and Anthropology in the 1860's: The Anthropological Society of London, 1863-71“. In: Victorian Studies 7, S. 137-154.

- (1970) Evolution and Society. A Study in Victorian Social Theory. Cambridge: Cambridge University Press.

Campbell, Bernard (1956) „The Centenary of Neanderthal Man“. In: Man 56, S. 156-158.

Carneiro, Robert L. (1967a) „Editor's Introduction“. In: Ders. (Hrsg.): The Evolution of Society. Selections from Herbert Spencer's „,Principles of Sociology “. Chicago: University of Chicago Press, S. ix-lvii.

- (1967b) The Evolution of Society. Selections from Herbert Spencer's „Principles of Sociology“. Chicago: University of Chicago Press.

- (1981) „Herbert Spencer as an Anthropologist“. In: The Journal of Libertarian Studies 5, S. 153-210.

- (2003) Evolutionism in Cultural Anthropology: A Critical History. Boulder, Colorado: Westview Press. 
Carneiro, Robert L.; Robert G. Perrin (2002) „Herbert Spencer's Principles of Sociology: A Centennial Retrospective and Appraisal“. In: Annals of Science 59, S. 221-261.

Carrier, Martin (2006) Wissenschaftstheorie zur Einführung. Hamburg: Junius. Caudill, Edward (1994) „The Bishop-Eaters: The Publicity Campaign for Darwin and the Origin of Species“. In: Journal of the History of Ideas 55, S. 441-460.

Cazamian, Louis (1973) The Social Novel in England 1830-1850. London, Boston: Routledge and Kegan Paul.

Chippindale, Christopher (1989) „,Social Archaeology“ in the Nineteenth Century: Is It Right to Look for Modern Ideas in Old Places?“. In: Andrew L. Christenson (Hrsg.): Tracing Archaeology's Past. The Historiography of Archaeology. Carbondale, Ill., S. 21-33.

Clark, Graham (1972) Aspects of Prehistory. Berkeley: University of California Press.

Clark, J. F. M. (1997) „,The ants were duly visited': making sense of John Lubbock, scientific naturalism and the senses of social insects". In: British Journal for the History of Science 30, S. 151-176.

— (1998) „John Lubbock and mental evolution“. In: Endeavour 22, S. 44-47.

Clegg, Stewart R. (1994) „Max Weber and contgemporary sociology of organisations". In: Larry J. Ray; Michael Reed (Hrsg.): Organizing Modernity. New Weberian Perspectives on Work, Organization and Society. London, New York: Routledge, S. 46-80.

Cockshut, A. O. J. (1964) The Unbelievers. English Agnostic Thought, 18401890. London: Collins.

Cook, G. C. (1997) „George Busk FRS (1807-1886), nineteenth-century polymath: surgeon, parasitologist, zoologist and palaeontologist“. In: Journal of Medical Biography 5, S. 88-101.

Daniel, Glyn (1952) A Hundred Years of Archaeology. London: Duckworth.

Davies, Rupert E. (1963) Methodism. Harmondsworth, London: Penguin.

De Giustino, David (1975) Conquest of Mind: Phrenology, and Victorian Social Thought. London: Croom Helm.

Desmond, Adrian (1982) Archetypes and Ancestors. Palaeontology in Victorian London, 1850-1875. London: Blond, Briggs.

- (1989) The Politics of Evolution. Morphology, Medicine, and Reform in Radical London. Chicago: University of Chicago Press.

- (1998) Huxley. From Devil's Disciple to Evolution's High Priest. Harmondsworth, London: Penguin.

- (2001) „,Redefining the X Axis: ,Professionals, "Amateurs“ and the Making of Mid-Victorian Biology - A Progress Report“. In: Journal of the History of Biology 34, S. 3-50.

Desmond, Adrian; James Moore (1994) Darwin. Reinbek: Rowohlt. 
Di Gregorio, Mario A. (1982) „The Dinosaur Connection: A Reinterpretation of T.H. Huxley's Evolutionary View“. In: Journal of the History of Biology 15 , S. 397-418.

- (1984) Thomas Henry Huxley's Place in Natural Science. New Haven, London: Yale University Press.

Dockrill, D. W. (1971) “T. H. Huxley and the Meaning of ,Agnosticism““. In: Theology 74, S. 461-477.

Dougherty, Frank W. P. (1990) „Christoph Meiners und Johann Friedrich Blumenbach im Streit um den Begriff der Menschenrasse“. In: Gunter Mann, Franz Dumont (Hrsg.): Die Natur des Menschen. Probleme der Physischen Anthropologie und Rassenkunde (1750-1850). Stuttgart, New York: Fischer, S. 89-111.

Duncan, David (1908) Life and Letters of Herbert Spencer. London: Methuen. Elliot, Hugh Samuel Roger (1917) Herbert Spencer. London: Constable.

Endrade, E. N. da C. (1960) A Brief History of the Royal Society. London: The Royal Society.

Eng, Erling (1978) „Thomas Henry Huxley’s Understanding of ,Evolution““. In: History of Science 16, S. 291-303.

Fleck, Lugwig (1980) Entstehung und Entwicklung einer wissenschaftlichen Tatsache. Einführung in die Lehre vom Denkstil und Denkkollektiv. Frankfurt: Suhrkamp.

Fletcher, Ronald (1972) The Making of Sociology. A Study of Sociological Theory. Vol. 1. Beginnings and Foundations. London: Nelson.

Fiske, John (1894) Edward Livingston Youmans. Interpreter of Science for the People. New York: Appleton.

Forgan, Sophie; Graeme Gooday (1997) „Constructing South Kensington: the buildings and politics of T. H. Huxley's working environment“. In: British Journal for the History of Science 29, S. 435-468.

Freeland, Guy (1983) „Evolutionism and Arch(a)eology“. In: David Roger Oldroyd, Ian Langham: The Wider Domain of Evolutionary Thought. Dordrecht u.a.: Reidel, S. 175-219.

Fuller, Steve (1988) Social Epistemology. Bloomington: Indiana University Press.

- (2000) Thomas Kuhn. A Philosophical History for Our Times. Chicago, London: University of Chicago Press.

- (2003) Kuhn vs Popper. Cambridge: Icon Books.

Gamerschlag, Kurt (1978) Sir Walter Scott und die Waverley Novels. Darmstadt: Wissenschaftliche Buchgesellschaft.

Garner, Steve (2004) Racism in the Irish Experience. London: Pluto Press.

Gillespie, Neal C. (1977) „The Duke of Argyll, Evolutionary Anthropology, and the Art of Scientific Controversy“. In: Isis 68, S. 40-54. 
Goldman, Alvin I. (1999) Knowledge in a Social World. Oxford: Clarendon Press.

Goldman, Irving (1959) „Evolution and Anthropology“. In: Victorian Studies 3, S. 55-75.

Gould, Stephen J. (1977) Phylogeny and Ontogeny. Cambridge, Mass.: Harvard University Press.

- (1981) The Mismeasure of Man. New York: Norton.

- (1998) „A Seahorse for All Races“. In: Ders.: Leonardo's Mountain of Claims and the Diet of Worms. London: Jonathan Cape, S. 119-140.

Grant Duff, Ursula (1924) The Life Work of Lord Avebury (Sir John Lubbock) 1834-1913. London: Watts.

Graves, Joseph L. (2002) The Emperor's New Clothes. Biological Theories at the Millennium. New Brunswick: Rutgers University Press.

Gray, Tim S. (1996) Political Philosophy of Herbert Spencer. Aldershot: Avebury.

Greene, John C. (1969) „Biology and Social Theory in the Nineteenth Century: Auguste Comte and Herbert Spencer“. In: Marshall Clagett (Hrsg.): Critical Problems in the History of Science. Madison, Milw., London: University of Wisconsin Press, S. 419-446.

- (1981a) „The Kuhnian Paradigm and the Darwinian Revolution in Natural History“. In: Ders.: Science, Ideology, and World View. Essays in the History of Evolutionary Ideas. Berkeley: University of California Press, S. 3059.

- (1981b) „Darwin as a Social Evolutionist“. In: Ders.: Science, Ideology, and Worldview. Essays in the History of Evolutionary Ideas. S. 95-127.

— (1981c) „Darwinism as a World View“. In: Ders. (Hrsg.) Science, Ideology, and World View. Essays in the History of Evolutionary Ideas. S.128-157.

- (1981d) „From Huxley to Huxley: Transformations in the Darwinian Credo“. In: Ders. (Hrsg.) Science, Ideology, and World View. Essays in the History of Evolutionary Ideas. S.158-193.

Griffith, Belver C.; Nicholas C. Mullins (1974) „Kohärente soziale Gruppen im wissenschaftlichen Wandel“". In: Peter Weingart (Hrsg.): Wissenschaftssoziologie II. Determinanten wissenschaftlicher Entwicklung. Frankfurt: Athenäum, S.223-238.

Gross, Charles G. (1999) „The Hippocampus Minor and Man’s Place in Nature: A Case Study in the Social Construction of Neuroanatomy“. In: Ders.: Brain, Vision, Memory. Tales in the History of Neuroscience. Cambridge, Mass.: Harvard University Press, S. 137-178.

Gruber, Jacob W. (1948) „The Neanderthal Controversy: Nineteenth-Century Version“. In: The Scientific Monthly 67, S. 436-439.

Hacking, Ian (1981) „Introduction“. In: Ders. (Hrsg.): Scientific Revolutions. Oxford: Oxford University Press, S. 1-5. 
- (1993) „Working in a New World: The Taxonomic Solution“. In: Paul Horwich (Hrsg.) Thomas Kuhn and the Nature of Science. Cambridge. Mass.: MIT Press, S. 275-310.

Hall, Catherine (2000) „The nation within and without“. In: Catherine Hall, Keith McClelland, Jane Rendall: Defining the Victorian Nation. Class, Race, Gender and the Reform Act of 1867. Cambridge u.a.: Cambridge University Press, S. 179-233.

Haller, John S. (1970) „The Species Problem: Nineteenth-Century Concepts of Racial Inferiority in the Origin of Man Controversy“. In: American Anthropologist 172, S. 1319-1329.

- (1971) Outcasts from Evolution. Scientific Attitudes of Racial Inferiority, 1859-1900. Urbana, Chicago, London: Southern Illinois University Press.

Halliday, R. J. (2000) „Social Darwinism: A Definition“ [1971]. In: John Offer (Hrsg.): Herbert Spencer: Critical Assessments of Leading Sociologists. London, New York: Routledge, Band 2, S. 133-148.

Haines, Valerie A. (1988) „Is Spencer's Theory an Evolutionary Theory?“. In: American Journal of Sociology 93, S. 1200-1223.

- (1991) „Spencer, Darwin, and the Question of Reciprocal Influence“: In: Journal of the History of Biology 24, S. 409-431.

- (1997) „Spencer and His Critics“. In Charles Camic (Hrsg.): Reclaiming the Sociological Classics: The State of Scholarship. New York: Blackwell, S. 81-111.

Harris, Marvin (1969) The Rise of Anthropological Theory. A History of Theories of Cultures. London: Routledge, Kegan Paul.

Harrison, Andrew John (1988) Scientific Naturalists and the government of the Royal Society. 1850-1900. Unveröffentlichte PhD-Thesis, Milton Keynes: Open University.

Harte, Negley (1986) The University of London. 1836-1986. London: Athlone.

Hawkins, Mike (1997) Social Darwinism in European and American thought, 1860-1945. Nature as model and nature as threat. Cambridge: Cambridge University Press.

Helfand, Michael S. (1977) „T. H. Huxley’s ,Evolution and Ethics‘: The Politics of Evolution and the Evolution of Politics“. In: Victorian Studies 20, S. 159-177.

Himmelfarb, Gertrude (1959) Darwin and the Darwinian Revolution. London: Chatto and Windus.

- (1968) Victorian Minds. London: Weidenfeld, Nicolson.

Hofstadter, Richard (1955) Social Darwinism in American Thought. Boston: Beacon Press.

Howarth, O. J. R. (1922) The British Association for the Advancement of Science - a Retrospect 1831-1931. London: The Association. 
Hoßfeld, Uwe (2005) Geschichte der biologischen Anthropologie in Deutschland. Stuttgart: Steiner.

Hoyningen-Huene, Paul (1989) Die Wissenschaftsphilosophie Thomas S. Kuhns. Rekonstruktion und Grundlagenprobleme. Braunschweig, Wiesbaden: Vieweg.

- (2001) „Thomas S. Kuhn 1922-96“. In: International Encyclopedia of the Social \& Behavioral Sciences, Bd. 12, Amsterdam: Elsevier, S. 81718176.

Hund, Wulf D. (1999) Rassismus. Die soziale Konstruktion natürlicher Ungleichheit. Münster: Westfälisches Dampfboot.

— (2003) „Inclusion and Exclusion“. In: Wiener Zeitschrift zur Geschichte der Neuzeit 3, S. 6-19.

- (2006) Negative Vergesellschaftung. Dimensionen der Rassismusanalyse. Münster: Westfälisches Dampfboot.

Hutchinson, Horace G. (1914) Life of Sir John Lubbock, Lord Avebury. 2 Bde. London: Macmillan.

Huxley, Julian (Hrsg.) (1936) T. H. Huxley's Diary of the Voyage of H.M.S. Rattlesnake. Garden City, New York: Doubleday, Doran.

Huxley, Leonard (1900) Life and Letters of Thomas Henry Huxley. 2 Bde. London: Macmillan.

- (1921) Life and Letters of Sir Joseph Dalton Hooker. 2. Bde. London: Macmillan.

Irvine, William (1960) Thomas Henry Huxley. London: Longmans, Green.

- (1963) Apes, Angels, and Victorians. Darwin, Huxley, and Evolution. New York: Time.

Jensen, J. Vernon (1970) „The X-Club Fraternity of Victorian Scientists“. In: British Journal for the History of Science 5, S. 63-72.

— (1981) „Tyndall's Role in the ,X Club““. In: W. H. Brock, N. D. McMillan, R. C. Mollan: John Tyndall. Essays on a Natural Philosopher. Dublin: Royal Society, S. 157-168.

— (1988) „Return to the Wilberforce-Huxley Debate“. In: British Journal for the History of Science 21, S. 161-179.

- (1991) Thomas Henry Huxley: Communicating for Science. Newark: University of Delaware Press.

Jones, Greta (1980) Social Darwinism and English Thought. Brighton: Harvester Press.

Jordanova, Ludmilla (1989) „Nature's powers: A reading of Lamarck's distinction between creation and production“. In: James R. Moore (Hrsg.): History, Humanity, and Evolution: Essays for John C. Greene. Cambridge: Cambridge University Press, S. 71-98.

Kehoe, Alice B. (1991) „The Invention of Prehistory“. In: Current Anthropology 32 , S. 467-476. 
Keith, Arthur (1911) „The Early History of the Gibraltar Cranium“. In: Nature 87, S. 313-314.

— (1934) „65. Centenary of the Birth of Lord Avebury“. In: Man 34, S. 49-51.

Kennedy, James G. (1978) Herbert Spencer. Boston: Twayne.

Kettler, David (1965) The Social and Political Thought of Adam Ferguson. Ohio: Ohio State University Press.

King, M. D. (1974) „Vernunft, Tradition und Fortschrittlichkeit der Wissenschaft“. In: Peter Weingart (Hrsg.): Wissenschaftssoziologie II. Determinanten wissenschaftlicher Entwicklung. Frankfurt: Athenäum, S. 39-75.

Kitcher, Philip (1993) The Advancement of Science. Science without Legend, Objectivity without Illusions. New York, Oxford: Oxford Univeristy Press.

Krohn, Wolfgang (1976) „Zur soziologischen Interpretation der neuzeitlichen Wissenschaft“. In: Edgar Zilsel: Die sozialen Ursprünge der neuzeitlichen Wissenschaft. Frankfurt: Suhrkamp, S. 7-43.

Kuhn, Thomas S. (1978a) „Die grundlegende Spannung: Tradition und Neuerung in der wissenschaftlichen Forschung“. In: Ders. Die Entstehung des Neuen. Studien zur Struktur der Wissenschaftsgeschichte. Frankfurt: Suhrkamp, S. 308-326.

- (1978b) "Neue Überlegungen zum Begriff des Paradigma". In: Ders. Die Entstehung des Neuen. Studien zur Struktur der Wissenschaftsgeschichte. Frankfurt: Suhrkamp, S. 389-420.

- (1996) The Structure of Scientific Revolutions. Chicago, London: University of Chicago Press.

Kuper, Adam (1988) The Invention of Primitive Society: Transformations of an Illusion. London: Routledge.

— (1997) „On Human Nature: Darwin and the Anthropologists“. In: Mikuláš Teich, Roy Porter, Bo Gustavson (Hrsg.): Nature and Society in Historical Context. Cambridge: Cambridge University Press, S. 274-290.

Lakatos, Imre (1970) „Falsifikation and the Methodology of Scientific Research Programmes“. In: Ders., Alan Musgrave (Hrsg.) Criticism and the Growth of Knowledge. Cambridge: Cambridge University Press, S. 91195.

Latour, Bruno, Steve Woolgar (1986) Laboratory Life. The Construction of Scientific Facts. Princeton: Princeton University Press.

La Vergata, Antonello (1995) „Herbert Spencer: Biology, Sociology, and Cosmic Evolution“. In: Maasen, Mendelsohn, Weingart: Biology as Society, Society as Biology. S. 193-229.

Leeds, Anthony (1988) „Darwinian and ,Darwinian' Evolutionism in the Study of Society and Culture“. In: Thomas F. Glick (Hrsg.): The Comparative Reception of Darwinism. Chicago: University of Chicago Press, S. 437477. 
Levine, George (1990) „Scientific Discourse as an Alternative to Faith“. In: Richard J. Helmstadter, Bernhard Lightman (Hrsg.): Victorian Faith in Crisis. Essays on Continuity and Change in Nineteenth-Century Religious Belief. Stanford, Cal.: Stanford University Press, S. 225-261.

Lightman, Bernhard (1987) The Origins of Agnosticism. Baltimore: John Hopkins University Press.

Lilienthal, Georg (1990) „Samuel Thomas Soemmering und seine Vorstellung über Rassenunterschiede“. In: Gunter Mann, Franz Dumont (Hrsg.): Die Natur des Menschen. Probleme der physischen Anthropologie und Rassenkunde. Stutgart: Fischer, S. 31-55.

Lorimer, Douglas A. (1978) Colour, Class and Victorians: English Attitudes to the Negro in the Mid-Nineteenth Century. Leicester: Leicester University Press.

- (1988) „Theoretical Racism in Late-Victorian Anthropology, 1870-1900“. In: Victorian Studies 32, S. 405-430.

- (1996) „Race, science and culture: historical continuities and discontinuities, 1850-1914“. In: Shearer West (Hrsg.): The Victorians and Race. Aldershot, Scolar Press, S. 12-33.

- (1997) „Science and the Secularization of Victorian Images of Race“. In: Bernhard Lightman (Hrsg.): Victorian Science in Context. Chicago: University of Chicago Press, S. 213-235.

Lovejoy, Arthur O. (1936) The Great Chain of Being. The Study of an History of an Idea. Cambridge Mass.: Harvard University Press.

Lucas, J. R. (1979) „Wilberforce and Huxley: A Legendary Encounter“. In: The Historical Journal 22, S. 313-330.

Luhmann, Niklas (1969) Soziologische Aufklärung. Aufsätze zur Theorie sozialer Systeme. Köln, Opladen: Westdeutscher Verlag.

- (1991) Die Wissenschaft der Gesellschaft. Frankfurt: Suhrkamp.

Luyendijk-Elshout, Antonie M. (1989) „Petrus Camper als antropoloog“. In: J. Schuller tot Persum-Meijer, W.R.H. Koops (Hrsg.): Petrus Camper (17221789): onderzoeker van nature. Groningen: Universiteitsmuseum, S. 5772.

Lyons, Henry (1944) The Royal Society 1660-1940. A History of its Administration under its Charters. Cambridge: Cambridge University Press.

Lyons, Sherrie Lynne (1999) Thomas Henry Huxley: The Evolution of a Scientist. New York: Prometheus Books.

Maasen, Sabine, Everett Mendelsohn, Peter Weingart (1995) „Metaphors: Is there a bridge over troubled waters?". In: Dies. (Hrsg.): Biology as Society, Society as Biology: Metaphors. Yearbook of the Sociology of the Sciences. Dordrecht u.a.: Kluwer, S. 1-8. 
MacLeod, Roy M. (1969) „The X-Club. A Social Network of Science in LateVictorian England“. In: Notes and Records of the Royal Society of London 24, S. 305-322.

- (1971) „The Support of Victorian Science: The endowment of Research Movement in Great Britain, 1868-1900“. In: Minerva 9, S. 197-230.

- (1980) „Evolutionism, Internationalism and Commercial Enterprise in Science: The International Scientific Series 1871-1910“. In: A. J. Meadows: Development of Science Publishing. Amsterdam u.a.: Elsevier, S. 63-93.

MacRae, Donald (1969) „Introduction“. In: Ders. (Hrsg.) Herbert Spencer: The Man Versus The State. Harmondsworth: Penguin, S. 7-54.

Mair, Lucy (1965) An Introduction to Social Anthropology. Oxford: Clarendon.

Mallet, Sir Bernhard (1924) „Political and Economic“. In: Grant Duff: The Life-Work of Lord Avebury. S. 35-66.

Mandelbaum, Maurice (1971) History, Man, \& Reason. A Study in NineteenthCentury Thought. Baltimore: Johns Hopkins University Press.

Masterman, Margaret (1970) „The Nature of a Paradigm“. In: Imre Lakatos, Alan Musgrave (Hrsg.) Criticism and the Growth of Knowledge. Cambridge: Cambridge University Press, S. 68-76.

Mayr, Ernst (1972) „Lamarck Revisited“. In: Journal of the History of Biology 5, S. 55-94.

Meacham, Standish (1970) Lord Bishop. The Life of Samuel Wilberforce, 1805-1873. Cambridge, Mass.: Harvard University Press.

Meadows, Arthur Jack (1980) „Access to the Results of Scientific Research: Developments in Victorian Britain“. In: Ders.: Development of Science Publishing. Amsterdam: Elsevier, S. 43-62.

Meek, Ronald L. (1976) Social science and the ignoble savage. Cambridge: Cambridge University Press.

Meijer, Miriam Claude (1999) Race and Aesthetics in the anthropology of Petrus Camper (1722-1789). Amsterdam, u.a.: Rodopi.

Merton, Robert K (1996) „The Rise of Modern Science“. In: Piotr Sztompka (Hrsg.): Robert K. Merton. On Social Structure and Science. Chicago, London: University of Chicago Press, S. 223-240.

Miles, Robert (1989) Racism. London u.a.: Routledge.

Millar, Ronald (1974) The Piltdown Man. A Case of Archaeological Fraud. St Albans: Paladin.

Mills, Charles W. (1997) The Racial Contract. Ithaca, London: Cornell University Press.

Mineka, Francis E., Dwight N. Lindley (Hrsg.) (1972) The Later Letters of John Stuart Mill, 1849-1873. Toronto, London: University of Toronto Press. 
Montagu, Ashley (1972) Statement on Race. An Annotated Elaboration and Expostion of the Four Statements on Race Issued by the United Nations Educational, Scientific, and Cultural Organization. Oxford: Oxford University Press.

Moore, James (1991) „Deconstructing Darwinism: The Politics of Evolution in the 1860s“. In: Journal of the History of Biology 24, S. 353-408.

Morrell, Jack; Arnold Thackray (1981) Gentlemen of Science. Early Years of the British Association for the Advancement of Science. Oxford: Clarendon.

Morris, Jan (1998) Heaven's Command: An Imperial Progress. London: Faber and Faber.

Morrow, John (1999) „Introduction“. In: Ders. (Hrsg.): Young England: The New Generation: A Selection of Primary Texts. London: Continuum, S. 128.

Mosse, George (1978) Toward the Final Solution. A History of European Racism. New York: Fertig.

Mühlmann, Wilhelm (1968) Geschichte der Anthropologie. Bonn: Athenaeum.

Mullins, Nicholas C. (1973) Theories and Theory Groups in Contemporary American Sociology. New York: Harper and Row.

Murphee, Idus L. (1961) „The Evolutionary Anthropologists: The Progress of Mankind. The Concepts of Progress and Culture in the Thought of John Lubbock, Edward B. Tylor, and Lewis H. Morgan“. In: Proceedings of the American Philosophical Society 105, S. 265-300.

Niel, Fernand (1977) Auf den Spuren der Großen Steine. Stonehenge, Carnac und die Megalithen. München: List.

Nisbet, Robert A. (1969) Social Change and History. Aspects of the Western Theory of Development. London u.a.: Oxford University Press.

- (1970) The Sociological Tradition. London: Heinemann.

Oehler-Klein, Sigrid (1998) „Einleitung“. In: Dies. (Hrsg.): Samuel Thomas Soemmering. Anthropologie: Über die körperliche Verschiedenheit des Negers vom Europäer (1785). Stuttgart, New York: Fischer, S. 89-142.

Offer, John (1980) „Interpreting Spencer“. In: Sociology 14, S. 131-140.

— (1994) „Introduction“. In: John Offer (Hrsg.): Herbert Spencer. Political Writings. Cambridge: Cambridge University Press, S. vii-xxxix.

Orange, A. D. (1981) „The Beginnings of the British Association, 1831-1851“. In: Roy MacLeod, Peter Collins (Hrsg.): The Parliament of Science. Northwood, Midx.: Science Reviews, S. 43-64.

Owen, Janet (1999) „The Collections Sir John Lubbock, The First Lord Avebury (1834-1913). ,An Open Book? ““. In: Journal of Material Culture 4, S. 283-302. 
- (2000) The Collecting Activities of Sir John Lubbock (1834-1913). Unveröffentlichte Ph.D. Thesis, Durham: University of Durham.

Owen, Rev. Richard (1894) The Life of Richard Owen. London: John Murray.

Parsons, Talcott (1962) „Introduction“. In: Herbert Spencer: The Study of Sociology. Michigan: Ann Arbor Press, S. v-x.

- (1968) The Structure of Social Action. A Study in Social Theory with Special Reference to a Group of Recent European Writers. New York: Free Press.

Patton, Mark (im Erscheinen) Science Politics and Business in the Work of Sir John Lubbock.

Peel, J. D. Y. (1971) Herbert Spencer. The Evolution of an Evolutionist. New York: Basic Books.

— (1972) „Introduction“. In: J.D.Y. Peel (Hrsg.): Herbert Spencer on Social Evolution. Selected Writings. Chicago: University of Chicago Press, S. viili.

Penniman, Thomas Kenneth (1974) A Hundred Years of Anthropology. New York: Morrow.

Perrin, Robert G. (1976) „Herbert Spencer’s Four Theories of Social Evolution“. In: American Journal of Sociology, Nr. 81, S. 1339-1359.

- (1993) Herbert Spencer. A Primary and Secondary Bibliography. New York: Garland.

Priester, Karin (2003) Rassismus. Eine Sozialgeschichte. Leipzig: Reclam.

Pumphrey, R. (1958) „The Forgotten Man - Sir John Lubbock, F.R.S.“. In: Notes and Records of the Royal Society of London 13, S. 49-58.

Rae, Isobel (1964) Knox: The Anatomist. Edinburgh, London: Oliver and Boyd.

Rainger, Ronald (1978) „Race, Politics, and Science: The Anthropological Society of London in the 1860s“. In: Victorian Studies 22, S. 51-70.

Reader, John (1981) Missing Links. The hunt for earliest man. Boston, Toronto: Little, Brown.

Rehbock, Philip F. (1983) The Philosophical Naturalists. Themes in Early Nineteenth-Century British Biology. London: University of Wisconsin Press.

Reining, Conrad C. (1962) „A Lost Period of Applied Anthropology“. In: American Anthropologist 64, S. 593-600.

Richards, Evelleen (1989) „Huxley and woman's place in science: The ,woman question" and the control of Victorian anthropology“. In: James R. Moore (Hrsg.): History, Humanity, and Evolution: Essays for John C. Greene. Cambridge: Cambridge University Press, 1989, S. 253-284.

Richards, Robert John (1987) Darwin and the Emergence of Evolutionary Theories of Mind and Behavior. Chicago: University of Chicago Press. 
- (1992) The Meaning of Evolution: The Morphological Construction and Ideological Reconstruction of Darwin's Theory. Chicago: University of Chicago Press.

Rodden, Judith (1981) „The development of the Three Age System: Archaeology's first paradigm”. In: Glyn Daniel (Hrsg.): Towards a History of Archaeology. Being the Papers Read at the First Conference on the History of Archaeology in Aarhus, 29 August - 2 September 1978. London: Thames, Hudson, S. 51-68.

Romanes, George J. (1882) „Ants, Bees, and Wasps“. In: Nature 26, S. 121123.

Roos, David A. (1981) „The ,Aims and Intentions“ of Nature“. In: James Paradis, T. Postlewait (Hrsg.): Victorian Science and Victorian Values: Literary Perspectives. New York: New York Academy of Science, S. 159180.

Rumney, Jay (1965) Herbert Spencer's Sociology. New York: Atherton.

Rupke, Nicolaas A. (1993) „Richard Owen’s Archetype“. In: Isis 84, S. 231251.

- (1994) Richard Owen. Victorian Naturalist. New Haven, London: Yale University Press.

Ruse, Michael (1979) The Darwinian Revolution. Science Red in Tooth and Claw. Chicago, London: Chicago University Press.

— (1982) „Social Darwinism: Two Sources“. In: Rivista di Filosofia 73, S. 36-52.

- (1997) „Thomas Henry Huxley and the Status of Evolution as Science“. In: Alan P. Barr (Hrsg.): Thomas Henry Huxley's Place in Science and Letters. Athens, Georgia: University of Georgia Press, S. 140-158.

- (2001) Mystery of Mysteries: is evolution a social construction? Cambridge, Mass.: Harvard University Press.

- (2005) „The Darwinian Revolution, as seen in 1979 and as seen TwentyFive Years Later in 2004“. In: Journal of the History of Biology 38, S. 317.

Russell, Colin Archibald (1996) Edward Frankland: chemistry, controversy, and conspiracy in Victorian England. Cambridge: Cambridge University Press.

Russett, Cynthia Eagle (1989) Sexual Science. The Victorian Construction of Womanhood. Cambridge, Mass.: Harvard University Press.

Rylance, Rick (2000) Victorian Psychology and British Culture, 1850-1880. Oxford: Oxford University Press.

Sanderson, Stephen K. (1990) Social Evolutionism. A Critical History. London: Basil Blackwood. 
Schaffer, Simon (1989) „The nebular hypothesis and the science of progress“. In: James R. Moore (Hrsg.): History, humanity, and evolution. Essays for John C. Greene. Cambridge: Cambridge University Press, S. 131-164.

Schwartz, Joel S. (1997) „,A Good Impudent Faith in My Own Star“. Thomas Henry Huxley's Odyssey in the South Seas“. In: Alan P. Barr (Hrsg.): Thomas Henry Huxley's Place in Science and Letters:Centenary Essays. Athens, Georgia: University of Georgia Press, S. 67-94.

Schweber, Sylvan S. (1980) „Darwin and the Political Economists: Divergence of Character“. In: Journal of the History of Biology 13, S. 195-289.

Semmel, Bernard (1962) The Governor Eyre Controversy. London: Macgibbon, Kee.

Shapin, Steven (1996) The Scientific Revolution. Chicago, London: University of Chicago Press.

Shapin, Steven; Arnold Thackray (1974) „Prosopography as a Research Tool in History of Science: The British Scientific Community 1700-1900“. In: History of Science 7, S. 1-28.

Shapin, Steven; Barry Barnes (1979) „Darwin and Social Darwinism: Purity and History”. In: Dies. (Hrsg.): Normal Order: Historical Studies of Scientific Culture. Beverly Hills: Sage, S. 125-142.

Shapiro, Harry L. (1959) „The History and Development of Physical Anthropology“. In: American Anthropologist 61, S. 371-379.

Shea, Victor, William Whitla (Hrsg.) (2000) Essays and Reviews: The 1860 Text and its Reading. Charlottesville: University of Virginia Press.

Smocovitis, Vassiliki Betty (2005) ,„It Ain’t Over ,til it's Over': Rethinking the Darwinian Revolution“. In: Journal of the History of Biology 38, S. 3349.

Spencer, Frank (1994) „Some Notes on the Attempt to Apply Photography to Anthopometry during the Second Half of the Nineteenth Century“. In: Elizabeth Edwards (Hrsg.): Anthropology and Photography 1860-1920. New Haven: Yale University Press, S. 99-107.

Stepan, Nancy (1982) Idea of Race in Science. Great Britain 1800-1960. Houndsmill, London: Macmillan.

Stichweh, Rudolf (1984) Zur Entstehung des modernen Systems wissenschaftlicher Disziplinen. Frankfurt: Suhrkamp.

- (1988) „Differenzierung des Wissenschaftssystems“. In: Renate Mayntz (Hrsg.): Differenzierung und Verselbständigung: zur Entwicklung gesellschaftlicher Teilsysteme. Frankfurt u.a.: Campus, S. 45-115.

Stocking, George W. (1968a) „French Anthropology in 1800“. In: Ders. (Hrsg.): Race, Culture and Evolution. Essays in the History of Anthropology. New York: Free Press, S. 13-41.

- (1968b) „The Persistence of Polygenist Thought in Post-Darwinian Anthropology“. In: Ders. (Hrsg.): Race, Culture and Evolution. S. 42-68. 
- (1971) „What's in a Name? The Origins of the Royal Anthropological Institute (1837-71)“. In: Man. The Journal of the Royal Anthropological Institute. New Series 6, S. 369-390.

- (1973) „From Chronology to Ethnology. James Cowles Prichard and British Anthropology 1800-1850“. In: James Cowles Prichard: Researches into the Physical History of Man. Chicago: University of Chicago Press, S. ixcx.

- (1987) Victorian Anthropology. New York: Free Press.

- (2001) Delimiting Anthropology: Occasional Essays and Reflections. Madison, Wisc.: University of Wisconsin Press.

Stringer, Christopher, Clive Gamble (1993) In Search of the Neanderthals. Solving the Puzzle of Human Origins. New York, Thames and Hudson.

Sutter, Alex (1989) „Kant und die ,Wilden“. Zum impliziten Rassismus in der Kantischen Geschichtsphilosophie“. In: Prima Philosophia 2, S. 241-265.

Symondson, Anthony (1970) The Victorian Crisis of Faith. London: Society for Promoting Christian Knowledge.

Tax, Sol (1964) „The Setting of the Science of Man“. In: Ders. (Hrsg.): Horizons of Anthropology. London: Allen and Unwin, S. 15-24.

Taylor, Michael W. (1992) Men versus the State. Oxford: Clarendon.

Thomson, J. Arthur (1924) „Zoology (Animal Behaviour)“. In: Grant Duff: The Life-Work of Lord Avebury. S. 115-156.

Tillett, Alfred W. (1939) Herbert Spencer Betrayed. London: King \& Sons.

Tönnies, Ferdinand (2000) „Herbert Spencers soziologisches Werk“. In: Lars Clausen (Hrsg.): Ferdinand Tönnies Gesamtausgabe. Berlin: De Gruyter, Bd. 15, S. 131-165.

Trautmann, Thomas (1987) Lewis Henry Morgan and the Invention of Kinship. Berkeley: University of California Press.

Trinkaus, Eric; Pat Shipman (1994) The Neanderthals: Changing the Image of Mankind. London: Pimlico.

Turner, Frank M. (1974) Between Science and Religion: The Reaction to Scientific Naturalism in Late Victorian England. New Haven, Conn.: Yale University Press.

Turner, Jonathan H. (1985) Herbert Spencer: A Renewed Appreciation. Beverly Hills, London: Sage.

Van Riper, A. Bowdoin (1993) Men Among the Mammoths. Victorian Science and the Discovery of Human Prehistory. Chicago: University of Chicago Press.

Van Wyhe, John (2003) Phrenology and the Origins of Victorian Scientific Naturalism. Aldershot: Ashgate.

Vogt, Markus (1997) Sozialdarwinismus. Wissenschaftstheorie, politische und theologisch-ethische Aspekte der Evolutionstheorie. Freiburg: Herder. 
Ward, Humphrey (1926) History of the Athenaum. 1824-1925. London: Athenaeum.

Webb, Beatrice (1926) My Apprenticeship. London: Longmans, Green.

Weber, Max (1988) „Wissenschaft als Beruf“ [1919]. In: Johannes Winckelmann (Hrsg.): Max Weber. Gesammelte Aufsätze zur Wissenschaftslehre. Tübingen: Mohr, S. 586-613.

Weingart, Peter (1974a) „Wissenschaftlicher Wandel als Institutionalisierungsstrategie“. In: Ders. (Hrsg.): Wissenschaftssoziologie II. Determinanten wissenschaftlicher Entwicklung. Frankfurt: Athenäum, S. 11-35.

- (1974b) „On a sociological theory of scientific change“. In: Richard Whitley (Hrsg.): Social Processes of Scientific Development. London: Routledge, S. 45-68.

- (1976) Wissensproduktion und soziale Struktur. Frankfurt: Suhrkamp.

— (1983) „Verwissenschaftlichung der Gesellschaft - Politisierung der Wissenschaft“" In: Zeitschrift für Soziologie 12, S. 225-241.

— (2003) Wissenschaftssoziologie. Bielefeld: Transcript.

Weingart, Peter; Jürgen Kroll; Kurt Bayertz (1996) Rasse, Blut und Gene. Geschichte der Eugenik und Rassenhygiene in Deutschland. Frankfurt: Suhrkamp.

Welsh, Alexander (1968) The Hero of the Waverley Novels. New York: Athenaeum.

White, Paul (2003) Thomas Huxley: Making the ,Man of Science‘. Cambridge: Cambridge University Press.

Wilberforce, Reginald G. (1881) Life of Samuel Wilberforce. Bishop of Oxford and Winchester. London: Murray.

Williams, Elizabeth A. (1985) „Anthropological Institutions in Nineteenth-Century France“. Isis 76, S. 331-348

Williams, Raymond (2000) „Social Darwinism“ [1973]. In: Offer: Herbert Spencer. Critical Assessments. London, New York: Routledge, Bd. 2, S. 186-197.

Wilson, L. G. (1972) Charles Lyell. The Years to 1841: The Revolution in Geology. New Haven, Conn.: Yale University Press.

Wiltshire, David (1978) The Social and Political Thought of Herbert Spencer. Oxford: Oxford University Press.

Winant, Howard (2002) Racial Conditions. Politics, Theory, Comparisons. Minneapolis, London: University of Minnesota Press.

Winch, Donald (1987) Malthus. Oxford: Oxford University Press.

Winckelmann, Johannes (1980) „Die Herkunft von Max Webers ,Entzauberungs'-Konzeption. Zugleich ein Beitrag zu der Frage, wie gut wir das Werk Max Webers kennen können“. In: Kölner Zeitschrift für Soziologie und Sozialpsychologie 32, S. 12-53. 
Wood, B. A. (1979) „The ,Neanderthals' of the College of Surgeons“. In: Annals of the Royal College of Surgeons 61, S. 385-389.

Woodward, Sir Llewellyn (1962) The Age of Reform, 1815-1870. Oxford: Clarendon Press.

Woolgar, Steve (1993) Science. The Very Idea. London: Routledge.

Young, Robert M. (1985a) „Malthus and the evolutionists: the common context of biological and social theory“. In: Ders. (Hrsg.): Darwin's Metaphor. Cambridge: Cambridge University Press, S. 23-55.

- (1985b) „The Impact of Darwin on Conventional Thought“. In: Ders. (Hrsg.): Darwin's Metaphor. S. 1-22.

- $(1985 \mathrm{c})$,The role of psychology in the nineteenth-century evolutionary debate“. In: Ders. (Hrsg.): Darwin's Metaphor. S. 56-78.

- (1990) Mind, Brain and Adaptation in the Nineteenth Century. Cerebral localization and its biological context from Gall to Ferrier. New York, Oxford: Oxford University Press.

Zängl-Kumpf, Ursula (1990) Hermann Schaaffhausen (1816-1893). Die Entwicklung einer neuen physischen Anthropologie im 19. Jahrhundert. Frankfurt: R. G. Fischer.

Zilsel, Edgar (1976) Die sozialen Ursprünge der neuzeitlichen Wissenschaft. Frankfurt: Suhrkamp.

\section{Internetquellen}

Blinderman, Charles, James Paradis: „Huxley Files“. http://aleph0.clarku.edu /huxley/index.html (letzter Zugriff Dezember 2005).

Brooke, John: „Lecture at Queen's Lecture Theatre, Emmanuel College, Cambridge, 26. 02. 2001“. www.st-edmunds.cam.ac.uk/cis/brooke/lecture1 .html (letzter Zugriff Dezember 2005).

Numbers, Ronald L.: ,„,The Most Important Biblical Discovery of Our Time“: William Henry Green and the Demise of Ussher's Chronology“. In: Church History 69, 2000: www.wls.wels.net/conted/Science/ussher.pdf (letzter Zugriff: Dezember 2005).

Rammert, Werner (1999) „Weder festes Faktum noch kontingentes Konstrukt: Natur als historisches Resultat experimenteller Interaktivität zwischen menschlicher und nicht-menschlicher Natur". In: IWT-Paper 23 - Workshop „Die Natur der Natur“. S. 184-205. http://uni-bielefeld.de/iwt/general/iwtpapers/rammert.pdf (letzter Zugriff: Dezember 2005). 


\section{WULF D. HUND}

\section{Nachwort: Evolution und Extinktion. Die darwinistische Modernisierung des}

\section{Rassismus}

$\mathrm{Da}$ es schließlich nur noch Weiße geben würde, gehörte schon früh zu den Phantasmagorien des modernen Rassismus. Zwar stellten aufgeklärte Denker wie der Marquis de Condorcet den ,Wilden“ aller Kontinente anheim, sich als „Schüler“ der Europäer unter deren Anleitung auf den Weg der Zivilisation zu machen. Für den Fall mangelnder Gelehrigkeit kalkulierte er indessen die Möglichkeit ihres Verschwindens ein. ${ }^{1}$ Bereits Immanuel Kant war sich zumindest hinsichtlich der nordamerikanischen Indianer sicher, daß sie nur noch ,eine halb erloschene Lebenskraft" hätten. Gelegentlich beschlich ihn aber auch eine deutlich weiterreichende Vorstellung und schlug sich in der Notiz nieder, „[a]lle $[\mathrm{R}]$ acen $w[\ddot{u}]$ rden ausgerottet werden, [...] nur nicht die der Weissen“. ${ }^{2}$

Die Indianer hielt auch Georg Wilhelm Friedrich Hegel für ,ein verschwindendes schwaches Geschlecht“, das am „Hauche der europäi-

1 Condorcet [d. i. Marie-Jean-Antoine-Nicolas Caritat, Marquis de Condorcet]: Entwurf einer historischen Darstellung der Fortschritte des menschlichen Geistes. Hrsg. v. Wilhelm Alf. Frankfurt: Suhrkamp 1976, S. 197.

2 Immanuel Kant: „Von den verschiedenen Rassen der Menschen“. In: ders., Werke in sechs Bänden. Hrsg. v. Wilhelm Weischedel. Darmstadt: Wissenschaftliche Buchgesellschaft 1983. Bd. 6, S. 22 (Lebenskraft) u. ders., ,[Reflexionen zur Anthropologie]“. In: Kant's gesammelte Schriften. Hrsg. v. d. Königl. Preuß. Akad. d. Wissenschaften. Bd. XV. Berlin, Leipzig: Reimer 1923, S. 895 (ausgerottet). 
schen Thätigkeit untergegangen“"wäre. ${ }^{3}$ Er und Kant hatten solche Vorstellung nicht erfunden. Sie faßten nur als allgemeines Gesetz der Weltgeschichte, was sich amerikanischen Kolonisten in interessierter Verkehrung der Tatsachen zur Legitimation ihrer Politik der Enteignung und Vertreibung ausgedacht und nicht selten voll hinterhältiger Anteilnahme formuliert hatten. Den Kriegsminister der Vereinigten Staaten, Henry Knox, „schmerzt[e] der Gedanke“, daß in den von Europäern besiedelten und kultivierten Staaten der Ostküste „alle Indianerstämme“ wegen mangelnder Jagdmöglichkeiten ,ausgelöscht wurden“. Präsident Andrew Jackson befielen „traurige Gedanken“ angesichts der historischen Mission seines Landes, zu der es gehörte, ,über die Gräber untergegangener Völker zu schreiten“. Der Anwalt Thomas Farnham registrierte die „traurige Tatsache“, daß die „Gebeine der Indianer [...] den Boden düngen“ müßten, „,bevor der Pflug des zivilisierten Menschen ihn erschließen" könnte. Und Benjamin Lincoln, General der Revolutionsarmee, befürchtete, daß ihre "ganze Rasse ausgelöscht" werden würde, falls die „Wilden [...] nicht zur Zivilisierung taugen“" sollten. ${ }^{4}$

Schließlich beschwor James Fenimore Cooper das ,inevitable fate of all these people, who disappear before the advances [...] of civilization" und setzte dem Letzten Mohikaner ein verlogenes Denkmal. ${ }^{5}$ Das war 1826. Kurz vor Ende des Jahrhunderts ließ Joseph Conrad den ideologischen Code derlei literarischer Verbrämungen des europäischen Kolonialismus außer acht. In seiner 1899 erschienenen Novelle Heart of Darkness spielte er seinem Icherzähler Marlow mitten im Urwald des Kongos den von Kurtz, dem Repräsentanten des Imperialismus, geschriebenen Bericht für die International Society for the Suppression of Savage Customs in die Hände. Dort wurde in heroischen Phrasen die zivilisatorische Sendung der Weißen beschworen, der es obliegen sollte, das Schicksal der Wilden zum Guten zu wenden. Wie das geschehen würde, blieb allerdings im Dunkeln. Nur ein später hinzugefügter Satz

3 Georg Wilhelm Friedrich Hegel: System der Philosophie. Dritter Teil. Die Philosophie des Geistes. In: ders., Sämtliche Werke. Jubiläumsausgabe in zwanzig Bänden, einer Hegel-Monographie und einem Hegel-Lexikon. Hrsg. v. Hermann Glockner. Stuttgart-Bad Cannstatt: Fromann 1927 1940, Bd. 10, S. 78 (Geschlecht) u. ders., Vorlesungen über die Philosophie der Geschichte. In: ders., Sämtliche Werke, a. a. O., Bd. 11, S. 123 (Thätigkeit).

4 Vgl. Roy Harvey Pearce: Rot und Weiß. Die Erfindung des Indianers durch die Zivilisation. Stuttgart: Klett-Cotta 1993, S. 89 (Knox), 90 (Jackson), 101 (Farnham), 106 (Lincoln).

5 James Fenimore Cooper: The Last of the Mohicans. London etc.: Penguin 1994, S. VII. 
am Ende des Textes ließ sich als methodischer Hinweis interpretieren: „Exterminate all the brutes! “6

Zwischen die Veröffentlichung beider Texten fiel 1859 das Erscheinen von Charles Darwins On the Origin of Species. In der Einleitung stellte der Verfasser einen engen Zusammenhang her zwischen dem „Struggle for Existence“, dadurch bedingter „Natural Selection“ auf der einen und „Extiction“ auf der anderen Seite und der „,doctrine of Malthus, applied to the whole animal and vegetable kingdoms“". ${ }^{7}$ Der Text selbst vermied aus strategischen Gründen die Beschäftigung mit der Spezies Mensch und ihren angeblichen, zu diesem Zeitpunkt überwiegend Rassen genannten Varietäten. Doch war Darwin selbst „,a Social Darwinist", ,sought to apply evolutionary theory to mental and social phenomena" ${ }^{\text {"8 }}$ und machte davon weitreichenden Gebrauch. Er ging davon aus, daß "[a]t some future period [...] the civilised races of man will almost certainly exterminate and replace throughout the world the savage races"9. Und nachdem die Türkei durch den Berliner Vertrag Gebiete im Kaukasus und weite Teile des Balkans und schließlich auch noch Tunesien an Frankreich und Ägypten an England verloren hatte, meinte er, ,[t]he more civilized so-called Caucasian races have beaten the Turkish hollow in the struggle for existence“. ${ }^{10}$

Von den australischen Aborigines glaubte Charles Darwin, daß sie wahrscheinlich aussterben müßten, während Walter Baldwin Spencer und Francis James Gillen davon bereits so überzeugt waren, daß sie nur noch forderten, ihnen den ,path to final extinction“ so angenehm wie möglich zu machen. In den Vereinigten Staaten wurden nach dem Bürgerkrieg Prognosen zu den Überlebensmöglichkeiten der ehemaligen

6 Joseph Conrad: Heart of Darkness. Hrsg. v. Robert Kimbrough. 3. Aufl. New York etc.: Norton. Chinua Achebe und andere haben darauf hingewiesen, daß Conrads Kritik imperialistischer Politik selbst nicht frei von Rassismus ist. Sein Beitrag „An Image of Africa: Racism in Conrad's Heart of Darkness“ ist in der zitierten Ausgabe der Novelle dokumentiert - vgl. a. a. O., S. $251 \mathrm{ff}$.

7 Charles Darwin: On the Origin of Species by Means of Natural Selection, or the Preservation of Favoured Races in the Struggle for Life. London: John Murray 1859, S. 4f.

8 Mike Hawkins: Social Darwinism in European and American Thought, 1860 - 1945. Nature as Model and Nature as Threat. Cambridge etc.: Cambridge University Press 1997, S. 35f.

9 Charles Darwin: The Descent of Man, and Selection in Relation to Sex. 2 Bde. London: John Murray 1871, Bd. 1, S. 201.

10 Charles Darwin: (Brief an William Graham vom 3. Juli 1881). In: The Life and Letters of Charles Darwin, Including an Autobiographical Chapter. Hrsg. v. Francis Darwin. 3 Bde. London: John Murray 1887. Bd. 1, S. 316. 
Sklaven darwinistisch verbrämt und liefen darauf hinaus, daß ihr „lack of fitness“ im „struggle for existence“ zu ihrem Verschwinden führen müßte. ${ }^{11}$

Gelegentlich verstanden die europäischen Kolonisten die vermeintlich sozialen Implikationen der Evolutionstheorie auch als unmittelbare Gebrauchsanweisung. Ihre Veröffentlichung fiel mitten in die Zeit der neuseeländischen Kolonialkriege. ${ }^{12} 1863$ schrieb das Southern Monthly Magazine aus Auckland, man könnte zu Darwin stehen wie man wollte, aber "no one will be disposed to deny the existence of that struggle for life which he describes, or that a weak and ill-furnished race will necessarily have to give way before one which is strong and highly endowed". Im selben Jahr schloß sich Arthur Samuel Atkinson der Siedlermiliz der Taranaki Volunteers an, nachdem er Darwin gelesen und seinem Tagebuch anvertraut hatte, der Kampf gegen die Maoris wäre seine „scientific duty“. 1867 behauptete die Lyttelton Times aus Christchurch unter der Schlagzeilte „Mr Darwin at the Antipodes“, selbst bei den indigenen Neuseeländern wäre die Einsicht in ihr Aussterben mittlerweile zum Sprichwort geworden: „As the white man's rat has driven away the native rat, $[\ldots]$, so will the Maori disappear before the white man himself". 13

Diese angebliche Einsicht der Wilden in die Mission der Zivilisierten unterschied den darwinistischen Auslöschungsdiskurs von seinen Vorläufern. Denn diese Mission hatte jetzt eine naturgeschichtliche Dimension, der sich auch diejenigen, die durch sie hinweggerafft wurden, nicht verschließen können sollten. Ihr Verschwinden mußte deswegen

11 Vgl. zu Australien Russell McGregor: Imagined Destinies. Aboriginal Australians and the Doomed Race Theory, 1880-1939. Carlton South: Melbourne University Press 1997, S. 51 (Darwin) u. S. 53 (Spencer, Gillen); zu den USA siehe Audrey Smedley: Race in North America. Origin and Evolution of a Worldview. Boulder: Westview Press 1999, S. 238; der Statistiker Frederick L. Hoffmann behauptete in einem viel zitierten Werk nicht nur, "the time will come [...] when the negro, like the Indian, will be a vanishing race", sondern beanspruchte auch, dies mathematisch nachgewiesen zu haben - vgl. George M. Fredrickson: The Black Image in the White Mind. The Debate on Afro-American Character and Destiny, 1817-1914. New Ed. Hanover: Wesleyan University Press 1987, S. 250 .

12 Vgl. James Belich: The New Zealand Wars and the Victorian Interpretation of Racial Conflict. Auckland etc.: Penguin 1998 u. Peter Maxwell: Frontier. The Battle for the North Island of New Zealand, 1860-1872. Überarb. Aufl. Auckland: Celebrity Books 2005.

13 Vgl. John Stenhouse: Darwinism in New Zealand, 1859-1900. In: Disseminating Darwinism. The Role of Place, Race, Religion, and Gender. Hrsg. v. Ronald L. Numbers, John Stenhouse. Cambridge etc.: Cambridge University Press 1999, S. 83f. 
nicht bedauert werden. Es ließ sich sogar deistisch als eine der vielen Windungen des Flusses des Lebens durch die Zeit lesen, der die Fortschrittsvorstellung der Geschichtsphilosophie in sich aufgenommen hatte und deswegen auch in der Evolutionstheorie wundersamer Weise nach oben floß. ${ }^{14}$ Die toten Maori würden in ihren europäischen Exterminatoren weiterleben. Der Konflikt zwischen Lederstrumpf und Herrn Kurtz war gelöst. Das schlechte Gewissen der Aufklärung war so überflüssig geworden wie die genozidale Mordbereitschaft des Imperialismus. Dessen Politik konnte sich auf eine entmoralisierte Version der schon vorhandenen „fantasy of auto-genocide“"15 stützen. Die Wilden wie die Zivilisierten vollzogen lediglich das Gesetz der Natur.

Thomas Gondermanns Studie zeigt, daß diese Entwicklung weder zufällig noch wider Willen verlief. Sie verdankte sich nicht dem Zufall, weil die Vertreter der Evolutionstheorie sich das Feld der Anthropologie gezielt als Ort für die zu erwartende Schlacht um Ideen und Einfluß aussuchten und ihre Auseinandersetzung mit den traditionellen Vertretern der Wissenschaftsgemeinschaft sozial absicherten und politisch umsetzten. Und sie verlief nicht wider Willen, weil die Propagandisten des Evolutionskonzepts keinen Widerspruch zu den kulturalistischen Überlegenheitsansprüchen des traditionellen Rassismus äußerten, sondern diesen durch deren naturwissenschaftliche Unterfütterung aus einer krisenhaften Situation befreiten und ihm neues Gewicht verliehen.

14 Vgl. Charles Darwin: On the Origin of Species, a. a. O., S. 487f.: „When I view all beings not as special creations, but as the lineal descendants of some few beings which lived long before the first bed of the Silurian system was deposited, they seem to me to become ennobled. Judging from the past, we may safely infer that not one living species will transmit its unaltered likeness to a distant futurity. And of the species now living very few will transmit progeny of any kind to a far distant futurity; for the manner in which all organic beings are grouped, shows that the greater number of species of each genus, and all the species of many genera, have left no descendants, but have become utterly extinct. We can so far take a prophetic glance into futurity as to foretel that it will be the common and widely-spread species, belonging to the larger and dominant groups, which will ultimately prevail and procreate new and dominant species. As all the living forms of life are the lineal descendants of those which lived long before the Silurian epoch, we may feel certain that the ordinary succession by generation has never once been broken, and that no cataclysm has desolated the whole world. Hence we may look with some confidence to a secure future of equally inappreciable length. And as natural selection works solely by and for the good of each being, all corporeal and mental endowments will tend to progress towards perfection".

15 Patrick Brantlinger: Dark Vanishings. Discourse on the Extinction of Primitive Races, 1800-1830. Ithaca etc.: Cornell University Press 2003, S. 2. 
Die Vermittlung dazu führender Formen sozialen Handelns mit der Verknüpfung wissensorientierter und legitimatorischer Erkenntnismuster unterzieht Gondermann einer innovativen Analyse, die Wissenschaftssoziologie und Ideologiekritik verbindet. Sie bezieht sich auf einen Umbruch der Wissenschaften, dessen Protagonisten sich im X-Club genannten informellen Kreis die soziale Basis für ihre wissenschaftspolitischen Ambitionen geschaffen hatten. Zu deren Verwirklichung scheuten sie vor spektakulären öffentlichen Debatten nicht zurück. Gleichzeitig versuchten sie erfolgreich, im Wissenschaftsbetrieb institutionellen Einfluß zu erlangen. Dazu benutzten sie die Rassentheorien als Instrument der ideologischen Auseinandersetzung.

Die Mitglieder des von Thomas Henry Huxley so genannten ,Scientific Young England' waren sich der Bedeutung der Öffentlichkeitsarbeit wie der Eroberung institutioneller Positionen für ihre Konfrontationsstrategie gegenüber den alten gentlemen scientists sehr wohl bewußt. Sie verstanden den X-Club deswegen durchaus als freundschaftlichen Kreis von ,Strippenziehern“ und ihre geselligen Zusammenkünfte als Bekräftigung der sich selbst zugemessenen intellektuellen Bedeutung wie des daraus abgeleiteten Anspruchs auf wissenschaftliche Entscheidungsmacht. Die in der Diskussion der Bedeutung des Klubs vertretenen gegensätzlichen Auffassungen, er wäre entweder reiner Freundschaftskreis oder bloßes Instrument gezielter Einflußnahme gewesen, erscheinen demgegenüber soziologisch einseitig. Die Klubmitglieder waren viel zu unterschiedlich und individualistisch, um sich der Disziplin einer Schaltzentrale der Macht zu unterwerfen. Ihre gleichgerichteten Interessen in einer konkreten wissenschaftspolitischen Konfliktsituation erlaubten ihnen aber genau jene persönlichen Engagements, deren Summe sogar der eine oder andere unter ihnen als ,konzertierte Aktion“ betrachtete.

Damit verbunden war die Bereitschaft zu einer weichen Interpretation durchaus nicht einheitlicher Auffassungen des neuen Evolutionsparadigmas, die sowohl von außen durch den Druck der Konfrontation, als auch von innen durch die freundschaftlichen Beziehungen, nicht zuletzt aber auch durch der Geschichte des Evolutionsdenkens immanente Faktoren gefördert wurde. Sie verdeutlicht der Verfasser anhand der Evolutionsauffassungen Charles Darwins und Herbert Spencers und der Rezeption der Evolutionstheorie durch Huxley und John Lubbock. Dabei spielten die malthusianischen, teleologischen und politischen Elemente des Darwinismus eine bedeutsame Rolle, weil sie erlaubten, ihn in Verbindung mit der sozialen Evolutionsvorstellung des Spencerismus zu bringen und als ,Weltbild“ zu betrachten, das sich gegenüber inneren theoretischen Widersprüchen nicht zuletzt deswegen nachgiebig zeigte, 
weil es nach außen hin als politisches ,Sturmgeschütz‘ eingesetzt werden konnte.

Die Mitglieder des X-Clubs bedienten sich seiner in einer Reihe öffentlichkeitswirksamer Kampagnen zur Marginalisierung nichtevolutionärer Konzeptionen. Dazu gehörten unter anderem die Kontroversen Huxleys, die ihm nicht umsonst den Titel ,Darwin's Bulldog' und die Rolle des evolutionstheoretischen Aufreißers eintrugen. Im Disput mit Bischof Wilberforce behauptete der schneidige Evolutionstheoretiker, seinem klerikalen Gegner auf die Frage, ob er einen Affen lieber zum Großvater oder zur Großmutter hätte, geantwortet zu haben, in jedem Fall lieber von einem Affen als einem Ignoranten abstammen zu wollen. In der Auseinandersetzung mit dem herausragenden Repräsentanten der alten Naturwissenschaften, Richard Owen, startete Huxley eine regelrechte Kampagne, deren Ziel es war, diesen wissenschaftlich zu diskreditieren. Dabei versuchte er nicht nur, ihm Irrtümer nachzuweisen, sondern bezichtigte ihn auch der Fälschung von Daten. Offensichtlich handelte es sich hier nicht nur um den Sieg der besseren Argumente, sondern um die Ausschaltung eines als hinderlich betrachteten wissenschaftlichen Kontrahenten.

Mit der Aufmerksamkeit erzeugenden Skandalisierung ging in diesem Fall bereits jene Rationalisierung einher, für die die Rassenfrage von besonderer Bedeutung wurde und die in Debatten um die Einordnung des Neandertalers und das Verhältnis von Evolution und Degeneration zum Ausdruck kam. Die Evolutionstheoretiker versuchten sich dabei erfolgreich sowohl gegenüber den Polygenetikern wie den alten Monogenetikern zu positionieren. Sie konnten mit ihrer Vorstellung eines Entwicklungskontinuums sowohl die Spekulationen um ein vorsintflutliches missing link wie um vergleichsweise junge Überreste eines pathologisch deformierten Menschen zurückweisen. Gleichzeitig fanden sie nichts dabei, eine enge Verwandtschaft zwischen den Schädeln der prähistorischen Neandertaler und den Schädeln rezenter, aber als primitiv angesehener Menschenrassen anzunehmen. Auf diese Weise schienen sich gleich mehrere Probleme, bei deren Behandlung die Rassenwissenschaften sich festgefahren hatten, elegant lösen zu lassen. Rassen konnten in das biologische Entwicklungsdenken einbezogen und damit gleichzeitig ihre gemeinsame Abkunft wie ihre gewaltige Distanz betont werden, was den Konflikt zwischen Monogenetikern und Polygenetikern tendenziell entschärfte.

Für die Mitglieder des X-Clubs war das der Ansatzpunkt für die Institutionalisierung einer evolutionstheoretisch reformierten Anthropologie durch eine konzertierte Aktion. Thomas Gondermann zeichnet überzeugend nach, daß die Übernahme der Ethnological Society durch die 
Evolutionstheoretiker erfolgte, weil sie sich nicht auf öffentliche Auseinandersetzungen verlassen, sondern ihr Konzept auch institutionell verankern und dadurch einen Brückenkopf für seine schnellere Verbreitung schaffen wollten. Ihre intensive Beschäftigung mit der Rassentheorie entsprang nicht zuletzt diesem politischen Motiv, das mit der Gründung des Anthropological Institutes von einem Erfolg gekrönt wurde, der den Mitgliedern des X-Clubs wichtige Schlüsselpositionen im Wissenschaftsbetrieb einbrachte.

Die bis heute strapazierte Trope von der nebensächlichen Kontamination des Evolutionsdenkens durch Elemente des zeitgenössischen Rassismus erweist sich gegenüber der detaillierten und gründlichen Argumentation der vorliegenden Studie schon deswegen als Bestandteil der auch außerhalb der Wissenschaftsforschung gepflegten Methode marginalisierenden Beschweigens. Tatsächlich unterschlägt sie damit aber auch die Rolle der Evolutionstheoretiker bei der fatalen Modernisierung des Rassismus.

An ihr beteiligten sich mehrere Mitglieder des X-Clubs. George Busk konzentrierte sich dabei zwar weitgehend auf Messungen und ihre tabellarische Erfassung. Gleichwohl wurde in seiner Beschreibung der ,Neger' deutlich, daß sich für ihn deren Entwicklungspotential in den Anstrengungen der Menschwerdung erschöpft und sie als geschichtslose und kulturlose Wesen zurückgelassen hatte, deren Zukunft ungewiß war. Überlegungen zum Aussterben niederer Rassen existieren auch in der Rassentheorie John Lubbocks. Er ging davon aus, daß die meisten ihm als niedrig geltenden Rassen praktisch kein Entwicklungspotential hätten und verband diese Vorstellung mit der ,almost invariable rule that such races are dying out". ${ }^{16}$ Zum neuen evolutionären Denken gehörte offensichtlich nicht nur, daß es die große Kette der Wesen in ein Fließdiagramm der Entwicklung des Lebens verwandelte, sondern nicht minder, daß mit der Aufgabe des Bildes der Kette das Verschwinden einzelner ihrer vorher für unabdingbar gehaltener Glieder verbunden war. Die Entstehung der Arten umfaßte die Möglichkeit ihres Aussterbens, das die Evolutionstheoretiker für angeblich primitive Menschenrassen nicht ausschlossen.

Diese Vorstellung prägte auch die Rassentheorie Thomas Henry Huxleys. ${ }^{17}$ In einer Bewertung des Kolonialismus als globaler Gärtnerei

16 John Lubbock: The Origin of Civilisation and the Primitive Condition of Man. Mental and Social Condition of Savages. London: Longmans, Green 1870, S. 366.

17 Vgl. Patrick Brantlinger: Dark Vanishings, a. a. O., der S. 174 über Huxleys Anstrengungen zum ,mapping and measurement of all the races of the world' schreibt: „The ethnological map of human races would, of course, 
machte er dabei durch eine bezeichnende Auslassung den politischen Hintergrund solchen Aussterbens deutlich. Dazu ließ er ein Schiff mit englischen Kolonisten nach Tasmanien fahren, um dort Vegetation und Tierwelt auf den neuesten Stand zu bringen. Bereits dort lebende Menschen wurden dabei gar nicht erwähnt und der Genozid an den Tasmaniern konnte stillschweigend übergangen werden. Sie tauchten nur symbolisch als ihre eigenen Widergänger auf und dienten als Drohbild gegenüber den Siedlern aller Kolonien, die ihre historische Aufgabe nicht ernst genug nehmen sollten. ${ }^{18}$

Herbert Spencer äußerte sich entschieden unverblümter. Für ihn war der „effect of continually extirpating races“ Bestandteil der natürlichen wie der sozialen Entwicklung. Durch die Betonung der sozialen Evolution machte er den Entwicklungsabstand zwischen zivilisierten und primitiven Rassen zu einer perennierenden und zunehmenden Größe, die

also be a hierarchy, and it would help in the general process of eradicating savagery, if not the savages themselves".

18 Vgl. Thomas Henry Huxley: „Evolution and Ethics - Prolegomena“. In: ders., Collected Essays. 9 Bde. London: Macmillan 1893/94. Bd. IX, S. 16f.: „The process of colonization presents analogies to the formation of a garden which are highly instructive. Suppose a shipload of English colonists sent to form a settlement, in such a country as Tasmania was in the middle of the last century. On landing, they find themselves in the midst of a state of nature, widely different from that left behind them in everything but the most general physical conditions. The common plants, the common birds and quadrupeds, are as totally distinct as the men from anything to be seen on the side of the globe from which they come. The colonists proceed to put an end to this state of things over as large an area as they desire to occupy. They clear away the native vegetation, extirpate or drive out the animal population, so far as may be necessary, and take measures to defend themselves from the re-immigration of either. In their place, they introduce English grain and fruit trees; English dogs, sheep, cattle, horses; and English men; in fact, they set up a new Flora and Fauna and a new variety of mankind, within the old state of nature. Their farms and pastures represent a garden on a great scale, and themselves the gardeners who have to keep it up, in watchful antagonism to the old regime. Considered as a whole, the colony is a composite unit introduced into the old state of nature; and, thenceforward, a competitor in the struggle for existence, to conquer or be vanquished. Under the conditions supposed, there is no doubt of the result, if the work of the colonists be carried out energetically and with intelligent combination of all their forces. On the other hand, if they are slothful, stupid, and careless; or if they waste their energies in contests with one another, the chances are that the old state of nature will have the best of it. The native savage will destroy the immigrant civilized man; of the English animals and plants some will be extirpated by their indigenous rivals, others will pass into the feral state and themselves become components of the state of nature. In a few decades, all other traces of the settlement will have vanished". 
sich aus dem Zusammenspiel von Kulturentwicklung und Gehirnwachstum speiste. Im Verlauf der Evolution sollte es dazu geführt haben, daß die mittlere Schädelkapazität von den Australiern über Afrikaner und Asiaten bis zu den Europäern um nahezu dreißig Prozent zugenommen hätte. Das Fortschreiten der Zivilisation könnte deswegen letztlich nur vom ,large-brained European“ besorgt werden. ${ }^{19}$

Der Rassismus der evolutionären Rassentheorien zeigte sich hier auf seine krasseste Weise. Denn er schrieb gleichzeitig die traditionelle Rassenhierarchie fort und stellte die Existenz der als niedrig eingestuften Rassen zur Disposition. Aus den benachteiligten oder bestraften Kindern Gottes der Monogenisten und den von unterschiedlichen Umwelten verschieden geprägten menschlichen Arten der Polygenisten waren Außenseiter der Evolution geworden. Ihnen gegenüber stellte das evolutionistische Rassenverständnis ein theoretisches Totschlagargument zur Verfügung.

Vor diesem Hintergrund kommt Thomas Gondermann hinsichtlich der das evolutionäre Rassenverständnis zusammenfassenden zentralen Ergebnisse seiner Studie zu eindeutigen Schlußfolgerungen. Die von ihm dabei im einzelnen angeführten Punkte beziehen sich auf a) die Behandlung des Menschen als Teil der Natur, b) das Bestehen auf einem gemeinsamen Ursprung der Menschheit, c) die Vermittlung körperlicher und kultureller Evolution mit Hilfe des Gehirns, das als Organ des Verstandes galt und d) die Vermittlung von Progression und Degeneration in der Ausrichtung der evolutionären Entwicklung.

Schon der erste dieser Punkte enthielt neben seiner Zurückweisung religiöser Elemente ein erhebliches rassistisches Potential. Die Einmottung der großen Kette der Wesen mit ihren distinkten Merkmalen machte zwar die traditionelle Suche nach dem missing link zwischen Affen und Menschen und die damit verbundenen pornographischen Phantasien über sexuelle Beziehungen zwischen Affen und Afrikanern hinfällig. In dem sich auftuenden Kontinuum der Evolution blieb aber unendlicher Raum zur Distanzierung der primitiven von den entwickelten Rassen, mit der erstere entweder an die Menschenaffen oder die Neandertaler angenähert werden konnten.

Die Perspektive des zweiten Punktes wurde damit relativ. Zwar wies man die Spekulationen der Polygenetiker zurück. Aber für ihre Zurechnung zur ungeteilten Menschheit bekamen die sogenannten niederen Rassen eine Quittung präsentiert, die sie entwicklungsgeschichtlich in die Vorzeit abschob und zu lebenden Fossilen machte. Sie galten als

19 Herbert Spencer: The Study of Sociology. New York etc.: Appleton 1899, S. 175 (extirpating) u. ders.: The Principles of Biology. 2 Bde. New York: Appleton 1883, Bd. 2, S. 503 (large-brained). 
häßlich bis auf die Knochen, sollten widerliche Sitten haben und stinken. Während die polygenetischen Wilden immerhin eine Daseinsberechtigung als Sklaven hatten, wurde den evolutionären Wilden beschieden, $\mathrm{da} ß$ sie aussterben müßten.

Der dritte Punkt sah daher konsequenterweise Spencers ,großhirnige' Europäer über Huxleys ,prognathische“ Verwandtschaft triumphieren. Deren verknöcherte Unterentwicklung markierte die Perspektivlosigkeit jener, deren kleinen Gehirnen das Potential für eine am europäischen Beispiel orientierte Entwicklung nicht zugetraut wurde.

Der vierte Punkt schrieb nicht nur die hierarchische Perspektive aller Rassentheorien fort. An die Stelle der ambivalenten Vorstellungen der Aufklärung, in denen sich Perfektibilität und Primitivität verbanden, trat eine im Verlauf der Evolution wachsende Kluft zwischen den Zivilisierten und denen, die es zu keiner nennenswerten Kultur haben sollten, sondern als geschichtslose Kreaturen galten. Der schon von den Aufklärern überwiegend bei den Weißen vermutete Beruf zum Fortschritt wurde so zur Gewißheit. Für diejenigen, die ihn angeblich verfehlt hatten, gabt es angesichts der ihrer Körperlichkeit eingeschriebenen Unterentwicklung keine zweite Chance.

Im Ergebnis zeigten sich die evolutionären Rassentheorien als conditio sine qua non eines Fortbestehens des wissenschaftlichen Rassismus. Das Verdienst der Studie Thomas Gondermanns liegt nicht zuletzt darin, überzeugend herausgearbeitet zu haben, daß und wie in Prozesse der institutionellen und theoretischen Modernisierung der Wissenschaften alltägliches wie theoretisches Wissen aus den ideologischen Beständen des traditionellen Rassismus einging. Es führte dazu, daß dessen diskriminierender Gehalt den evolutionstheoretischen Paradigmawechsel nicht nur unbeschadet überstehen, sondern sogar gestärkt aus ihm hervorgehen konnte. 


\section{Science Studies}

Sabine Maasen

Wissenssoziologie

(2., komplett überarbeitete

Auflage)

Juli 2007, ca. 120 Seiten,

kart., ca. $12,80 €$,

ISBN: 978-3-89942-421-8

Martin Carrier,

Johannes Roggenhofer (Hg.)

Wandel oder Niedergang?

Die Rolle der Intellektuellen in der Wissensgesellschaft

Juni 2007, ca. 175 Seiten,

kart., ca. $17,80 €$,

ISBN: 978-3-89942-584-0

Thomas Gondermann

\section{Evolution und Rasse}

Theoretischer und institu-

tioneller Wandel in der

viktorianischen Anthropologie

April 2007, 324 Seiten,

kart., $32,80 €$,

ISBN: 978-3-89942-663-2

Tatjana Zimenkova

Die Praxis der Soziologie:

Ausbildung, Wissenschaft,

\section{Beratung}

Eine professionstheoretische

Untersuchung

April 2007, 324 Seiten,

kart., 31,80 €,

ISBN: 978-3-89942-519-2
Carsten von Wissel

Hochschule als

Organisationsproblem

Neue Modi universitärer

Selbstbeschreibung in

Deutschland

April 2007, 352 Seiten,

kart., 32,80 €,

ISBN: 978-3-89942-650-2

Jörg Potthast

Die Bodenhaftung der

Netzwerkgesellschaft

Eine Ethnografie von Pannen an Großflughäfen

März 2007, 230 Seiten,

kart., $25,80 €$,

ISBN: $978-3-89942-649-6$

Christine Hanke

Zwischen Auflösung und

Fixierung

Zur Konstitution von 'Rasse

und 'Geschlecht in der

physischen Anthropologie

um 1900

März 2007, 298 Seiten,

kart., $29,80 €$,

ISBN: $978-3-89942-626-7$

Reinhard Heil,

Andreas Kaminski,

Marcus Stippak,

Alexander Unger,

Marc Ziegler (Hg.)

Tensions and Convergences

Technological and Aesthetic

Transformations of Society

März 2007, 366 Seiten,

kart., $33,80 €$,

ISBN: $978-3-89942-518-5$

Leseproben und weitere Informationen finden Sie unter: www.transcript-verlag.de 


\section{Science Studies}

Sebastian Linke

Darwins Erben in den Medien

Eine wissenschafts- und

mediensoziologische Fallstudie

zur Renaissance der

Soziobiologie

Januar 2007, 262 Seiten,

kart., $26,80 €$,

ISBN: 978-3-89942-542-0

Martin Voss,

Birgit Peuker (Hg.)

Verschwindet die Natur?

Die Akteur-Netzwerk-Theorie in der umweltsoziologischen

Diskussion

2006, 264 Seiten,

kart., $25,80 €$,

ISBN: $978-3-89942-528-4$

Wolf-Andreas Liebert,

Marc-Denis Weitze (Hg.)

Kontroversen als Schlüssel

zur Wissenschaft?

Wissenskulturen in

sprachlicher Interaktion

2006, 214 Seiten,

kart., $24,80 €$,

ISBN: 978-3-89942-448-5

Andréa Belliger,

David J. Krieger (Hg.)

ANThology

Ein einführendes Handbuch

zur Akteur-Netzwerk-Theorie

2006, 584 Seiten,

kart., $29,80 €$,

ISBN: 978-3-89942-479-9
Heide Volkening

Am Rand der Autobiographie

Ghostwriting - Signatur -

Geschlecht

2006, 262 Seiten,

kart., $27,80 €$,

ISBN: $978-3-89942-375-4$

Natàlia Cantó Milà

A Sociological Theory of Value

Georg Simmel's Sociological

Relationism

2005, 242 Seiten,

kart., $28,80 €$,

ISBN: 978-3-89942-373-0

Anja Frohnen

Diversity in Action

Multinationalität in globalen

Unternehmen am Beispiel Ford

2005, 246 Seiten,

kart., $25,80 €$,

ISBN: $978-3-89942-377-8$

Markus Buschhaus

Über den Körper

im Bilde sein

Eine Medienarchäologie

anatomischen Wissens

2005, 356 Seiten,

kart., zahlr. Abb., $28,80 €$,

ISBN: 978-3-89942-370-9

Peter Weingart

Wissenschaftssoziologie

2003, 172 Seiten,

kart., $13,80 €$,

ISBN: 978-3-933127-37-2

Leseproben und weitere Informationen finden Sie unter: www.transcript-verlag.de 